\title{
Design de interação para TV Digital: convergência das mídias e o Sistema Brasileiro de TV Digital
}

Tese de doutorado apresentada à Faculdade de Arquitetura e Urbanismo da Universidade de São Paulo para obtenção do título de

Doutor em Arquitetura e Urbanismo

Área de concentração: Design e Arquitetura Orientador: Prof. Dr. Carlos Roberto Zibel Costa 
Autorizo a reprodução e divulgação total ou parcial deste trabalho, por qualquer meio convencional ou eletrônico, para fins de estudo e pesquisa, desde que citada a fonte.

E-mail: joaopaulos@usp.br

Schlittler Silva, João Paulo Amaral

S344d Design de interação para TV Digital: convergência das mídias e o Sistema Brasileiro de TV Digital / João Paulo Amaral Schlittler Silva. --São Paulo, 2011. 320 p. : il.

Tese (Doutorado - Área de Concentração: Design e Arquitetura) - FAUUSP.

Orientador: Carlos Roberto Zibel Costa

1.Design gráfico 2.Televisão interativa 3.Interface homemcomputador 4.Multimídia interativa 5.Interação usuário-computador I.Título 
Para Orest Woronewych, mentor de uma geração pioneira em design digital (In memoriam) 
O presente trabalho foi produzido com o apoio do UOL (www.uol.com.br), através do programa UOL Bolsa Pesquisa, Processo Número 20100211131900.

Trabalho produzido com apoio do programa Rumos Itaú Cultural Arte Cibernética. 


\section{Agradecimentos}

Agradeço a ajuda inestimável de todos que colaboraram

para a elaboração desta tese:

(em ordem alfabética)

Aline Marques

Almir Almas

Ana Maria Amaral

André Tanaka

André Toral

Andrés Colpa

Anna Van Steen

Aracy Amaral

Beatriz Di Giorgi

Carlos Zibel

Dan Sullivan

Edla Van Steen

Fernando Scavone

Gilberto Schlittler

Luis Fernando Angerami

Meire Assami

Natalia Helena

Paula Pinto e Silva

Priscila Farias

Thais Waisman 



\section{Resumo}

O Sistema Brasileiro de TV Digital (SBTVD), adotado como padrão de TV Digital no Brasil, traz consigo a alta resolução de imagens, mais canais, a transmissão para receptores móveis e a promessa de interatividade. Concomitantemente à sua implantação, vemos o crescimento da base de usuários do serviço móvel pessoal, assim como um aumento substancial dos usuários de redes sociais e da internet acessando mídias como TV, música, publicações e conteúdo gerado por usuários.

As mídias digitais interativas criaram uma demanda pelo design de interfaces facilitadoras da interação entre máquinas, usuários e o acesso, busca e distribuição de conteúdo midiático. Designers gráficos antes dedicados a mídias específicas como a TV, cinema e publicações impressas têm migrado para plataformas digitais, contribuindo para o design de mundos virtuais e a interação homem-computador.

Com a convergência da TV Digital com outras mídias, designers de interfaces devem considerar a ubiquidade de dispositivos móveis inteligentes presentes no mesmo ambiente da TV, criando assim uma experiência em que os usuários podem interagir com múltiplas telas e plataformas. É cada vez mais comum celulares e outros aparelhos portáteis estarem conectados à internet, e que podem servir como canal de retorno e tela secundária, expandindo a interface do usuário e facilitando a interação com a TV.

Diversos motivos como a ausência de um canal de retorno e a disponibilidade limitada do middleware Ginga em conversores e receptores de TV Digital têm atrasado o lançamento de serviços interativos para o SBTVD. Ao transferir o paradigma da interatividade de um modelo de distribuição vertical para um ambiente conectado, no qual usuários e telespectadores podem compartilhar sua experiência em múltiplas telas e dispositivos, é possível conceber uma nova forma de interação com a TV Digital.

Esta tese pesquisa avanços no design de interfaces, tecnologia da TV Digital e novas mídias de modo a subsidiar o design de experiência do usuário da TV Digital. Partindo do conteúdo audiovisual e digital da Copa do Mundo de 2010, propõe-se o design de uma interface que integra um smartphone com um receptor de TV Digital como síntese de um modelo de interação com a TV para a Copa de 2014. 

While Brazil has adopted SBTVD as its Digital Television standard, providing higher resolution, multiple channel feeds, mobile television and the promise of interactivity, there has been an explosive growth of the cell phone user base, as well as a dramatic increase in the usage of social networks and services on the internet that provide access to digital media such as TV, music, publishing and user generated content.

The emergence of digital media has created a demand for the design of humancomputer interfaces allowing the interaction between users, searching, publishing and retrieving media content. Graphic designers once working on specific medias such as print, film and television have migrated to digital platforms becoming more and more involved in the design of virtual worlds and human computer interaction.

As Digital TV converges with other media, user interface designers should consider the ubiquity of digital devices in the same room as an HDTV receiver, creating an experience where users can fluidly interact with multiple platforms and screens. Increasingly smartphones and other devices are connected to the internet, thus providing both a data return path and a secondary display that can extend the user interface enhancing the interaction with the TV.

For several reasons, such as the lack of a return path and limited availability of Ginga middleware in converter boxes and digital sets, the launch of Interactive TV services has had a slow start in Brazil. By shifting the paradigm of interactivity from a vertical distribution model to a connected environment where users and viewers can share their experiences using multiple screens and devices, it is possible to design a new way to experience and interact with Digital TV.

This thesis researches developments in interface design, digital TV technology and new media in order to subsidize the design of an interactive TV user experience. Drawing on audiovisual media and interactive content of the 2010 FIFA World Cup, the design of a user interface that integrates a smartphone with a DTV Receiver proposes a DTV interaction model for the 2014 World Cup. 



\section{Lista de Figuras}

\section{Capítulo 1}

1.1: $\quad$ Esquema representando o método adotado na pesquisa

\section{Capítulo 2}

2.1: Instruções para construir um kit receptor Baird de televisão em 1930

2.2: Wega Stereo Set by Verner Panton, 1963

2.3: Anúncio da Volkswagen do Brasil, 2009

2.4: As Profissões do Design da Experiência 52

2.5: $\quad$ Primeiro mouse, $1963-1964$

2.6: Engelbart apresentando o oN-line System em 1968

2.7: Desenho esquemático do Dynabook de Alan Kay 57

2.8: Interface do Xerox Star System, 1981

2.9: Um dos anúncios publicados pela Apple ao lançar o Macintosh, 1984

2.10: Reconstrução do esboço original de Tim Mott 61

2.11: Escala do público em relação às diversas mídias audiovisuais 67

2.12: Billboard - Painel desenvolvido por Muriel Cooper no VLW-MIT 71

2.13: Interface Gráfica 3-D "Financial Viewpoints” de Lisa Strausfeld do VLW - MIT 72

2.14: Interfaces sensíveis ao toque do iPhone 76

2.15: Myron Kruger - Videoplace 1998

2.16. Head Tracking utilizando um "hack" do controlador do Wii 79

2.17: Desenvolvimento de um “app” para iPhone 82

2.18: Interface de um celular projetada na palma da mão 83

2.19: Diagrama dos elementos da Experiência do Usuário 84

2.20: Interface do usuário e suas intersecções com áreas afins 85

2.21: Modelo de Ciclo de Vida de Software em Cascata 92

2.22: Diagrama representando o Modelo de Ciclo de Vida de Software em Espiral 92 


\section{Capítulo 3}

3.1: $\quad$ Mapa dos padrões de TV Digital Terrestre - 2010

3.2: $\quad$ As camadas e os módulos de um sistema de TV Digital 111

3.3: O equipamento receptor de TV Digital 112

3.4: Comparação da resolução e aspecto da imagem na TV Digital 114

3.5: Padrões de resolução de imagem na TV Digital 115

3.6: Transmissão Multiplex em diversas resoluções em um canal DTV de 6MHz 117

3.7: Hardware, Middleware e Software na TV Digital 118

3.8: $\quad$ Entradas e saídas de um STB 118

3.9: $\quad$ EPG desenvolvido pela NDS para HDTV 138

3.10: Guia de programação da SKY em HDTV 138

3.11. EPG HD da TV Guide 139

3.12: UK Sky - "Who wants to be a millionaire?" 139

3.13: Channel 4 UK (Open TV) - "Big Brother” Interativo 140

3.14: Serviço de T-Commerce da "Domino’s Pizza” no STB Tivo 140

3.15: Campanha de publicidade interativa "Caso Bourne" veículada na Espanha 142

3.16: Portal de serviços do Canal SAT - Canal + Technologies 142

3.17: Página de vídeos do site do New York Times 145

3.18: Comparação da distribuição de TV: OTT - IETV 148

3.19: Escala de um aparelho Apple TV 150

3.20: Menu do YouTube na Apple TV 150

3.21: D-Link Boxee Box 152

3.22: Slingbox $\quad 152$

3.23: Set-top Box e controle remoto Roku 152

3.24: Página do site You Tube 154

3.25: Menu prinicipal da Google TV 155

3.26: Glee - Série de TV da FOX no site de vídeos Hulu 156

3.27: Yahoo Widgets para IETV 157

3.28: Página de vídeos da globo.com 159 
3.30: Protótipo de Interação com a Social TV 161

3.31: Celulares com TV Digital: Nokia Operator, Samsung Star TV e LG Scarlet II 162

3.32: $\quad$ EPG da Yahoo Entertainment 164

3.33: Telas do Superguia Fingertips para o iPhone 164

3.34: Telas do EPG da Uverse para o iPad 165

3.35: H-Design e Sony Research Labs US Surf-Space 169

3.36: Menu de sistema com opções de fonte em um STB da NDS 173

3.37: Exemplo da interface de um EPG em um PDA 175

3.38: Widgets Adobe Nitro 176

3.39: Widget da AOL - Adobe Nitro 177

3.40: Yahoo Widgets para o Flickr e Previsão do tempo 178

3.41: Controle Remoto - Zenith Space Commander 178

3.42: Os seis controles remotos necessários para operar o Home Theater de Norman 179

3.43: Menus do software de controle remoto NoviiRemote para celulares Symbian $\quad 180$

3.44: Controle Remoto Fios para celulares Android Symbian 181

3.45: Controle Remoto Re para iPhone e iPod Touch 182

3.46: iPhone com acessório L5 Remote 183

3.47: Controlador do player no Iphone 183

3.48: Iphone com acessório RedEye, emulando controle remoto em tela touch screen 184

3.49: Menus emulando controle remoto do STB da Verizon Fios em um iPhone 185

3.50: $\quad$ SlingPlayer iPhone App 185

3.51: Controle Remoto Logitech Harmony 1100

3.52: Controle remoto MCC AVL300 da Monster Cable 187

3.53: Controle remoto Wii Remote 188

3.54: Menus do Looking Local no Wii Internet Channel 188

3.55: Widget do Twitter para Looking Local 189

3.56: Microsoft Project Natal/Kinect 189

3.57: Play Station Motion Controller 190 


\section{Capítulo 4}

4.1: Interface do Programa iTunes 204

4.2: Frame da transmissão da rede de TV CNN e do website CNN.com 211

\section{Capítulo 5}

5.1: $\quad$ Transmissão do jogo da Copa no canal Sport TV 238

5.2: Anúncio de TV portátil integrada a um GPS veicular 239

5.3: $\quad$ Caderno Especial Copa 2010 do jornal O Estado de S. Paulo 242

5.4: $\quad$ Regras - Caderno Copa 2010 - Folha de S.Paulo 243

5.5: Infográfico Caderno Copa 2010 - Folha de São Paulo 244

5.6: “Os Estádios da Copa”, jornal Destak 244

5.7: Jornal 3-D, MTV na Rua 245

5.8: Revista Veja "Interativa” Edição Especial da Copa do Mundo 2010

5.9: $\quad$ Revista Placar - Edição Especial da Copa do Mundo 2010

5.10: Transmissão da Copa do Mundo 2010 em HDTV na Rede Globo 247

5.11: Tira-Teima da Rede Globo 248

5.12: EPG da operadora de TV a cabo NET durante o jogo EUA e Gana 248

5.13: Miniguia e sinopse do EPG da NET em SDTV 249

5.14: Interatividade com Ginga na Copa do Mundo disponível na TV LH45 da LG 249

5.15: Detalhe da aplicação da Band para Copa $2010 \quad 250$

5.16: Home page do site New York Times durante o jogo EUA vs. Gana 251

5.17: Infográfico Interativo - Escalação e lances - EUA vs. Gana Copa 2010

5.18: Home page da UOL durante o jogo EUA vs. Gana 253

5.19: Lances e estatísticas do jogo EUA x Gana no site da UOL 254

5.20: UOL Copa do Mundo 2010 - Gols 3-D 254

5.21: Aplicativo de notícias da Copa para celular do UOL 255

5.22: Home page do Estadao.com.br durante o jogo EUA e Gana na Copa de $2010 \quad 255$

5.23: Home page da Placar Online durante a Copa de $2010 \quad 256$ 
5.24: Página principal do Globoesporte.com durante a Copa de 2010

5.25: Página de lances em tempo real no Globoesporte.com, Copa de 2010

5.26: Página principal da versão interativa da revista Veja na Copa de 2010

5.27: “Galeria do Penta” na versão interativa da revista Veja na Copa de 2010

5.28: Anúncio no site da LG do celular GM600 com TV Digital e Ginga

5.29: Aplicativo Central Copa da TV Globo para iPhones

5.30: Copa do Mundo 2010 - Finger Tips

5.31: Menu horizontal do aplicativo Copa do Mundo 2010 - Finger Tips

5.32: South Africa Tracker 2010 - Mubaloo

5.33: App Placar UOL para iPhone

5.34: App do site livescore.com para iPhone

\section{Capítulo 6}

6.1: Conteúdos adaptados para diversos formatos

6.2: Distribuição de conteúdo digital em múltiplas plataformas

6.3: Redes e mídias físicas para a distribuição de conteúdo digital

6.4: Classificação "material” da Copa do Mundo FIFA

6.5: Convergência como representação virtual de um evento esportivo

6.6: Universo de conteúdo de um jogo de futebol ao vivo

6.7: Conexões TV - Controle

6.8: "Questões Práticas de Projeto"

6.9: Escala relativa das telas de plataformas digitais

6.10: "A Nova TV"

6.11: Fluxograma de escolha de programação

6.12: Gráfico representando o fluxo de uma sequência operacional

6.13: Concepção inicial do controle em um celular

6.14: Gabarito para desenho de interface do iPhone

6.15: Croquis representando layouts da interface de um EPG no iPhone 
6.16: Storyboard de interação do controle remoto com a TV Digital no modo EPG

6.17: Aplicativo de controle remoto para TV Digital

6.18: Tela como cursor e teclas de atalho no controle remoto

6.19: Guia de programação para TV Digital em um iPhone

6.20: Integração de guia de programação para TV Digital em um iPhone com um EPG 297

6.21: Tela de diálogo da interface de um EPG em um iPhone

6.22: Tela de escolha de ângulos em uma transmissão multicâmera 298

6.23: Tela de opções de áudio 299

6.24: Menu que permite visualizar passes durante uma partida na Copa do Mundo 299

6.25: Tela de visualização de lances durante uma partida de futebol 300

6.26: Aplicativo de Rede Social para Celular sincronizado com widget para IETV 301

6.27: Sobreposição na tela das informações de um jogador

\section{Lista de Tabelas}

Tabela 2.1 Modelo de Alan Kay em A Personal View, 1990

Tabela 3.1: Especificações técnicas do padrão ISDB-TB 109

Tabela 6.1: Menu de Seleção de Fontes em um sistema de TV Digital 285 


\section{Lista de Siglas}

ACM - Association for Computing Machinery

ANATEL - Agência Nacional de Telecomunicações

API - Application Programming Interface

APP - Application Software

ARIB - Association of Radio Industries and Business

ARC - Augmentatin Research Center

ARG - Alternate Reality Games

ATSC - Advanced Television Systems Committee

BCI - Brain Computer Interfaces

BML - Broadcast Markup Language

CATV - Cable TV

CDMA - Code Division Multiple Access

CODEC - Codificador/Decodificador

CPU - Central Processing Unit

CRM - Customer Relationship Management

DASE - Digital Television Applications Software Environment

DTH - Direct to Home

DTMB - Digital Terrestrial Multimedia Broadcast

DTV - Digital Television

DVB - Digital Video Broadcast Group

DVD - Digital Video Disc

DVI - Digital Video Interface

DVR - Digital Video Recorder

ETSI - European Telecommunications Standards Institute

FCC - Federal Communications Comission

FUNTTEL - Fundo para o Desenvolvimento Tecnológico de Telecomunicações

FSN - Full Service Network

GEM - Globally Executable MHP

GUI - Graphical User Interface

HD - Hard Drive

HDTV - High Definition TV

HTML - Hypertext Markup Language

IBOPE - Instituto Brasileiro de Opinião Pública e Estatística 
IHC - Interação Humano-Computador

IPTV - Internet Protocol TV

ISDB - Integrated Services Digital Broadcast

ITU - International Telecommunications Union

ITV - Interactive Television

LCD - Liquid Cristal Display

LDTV - Low Definition Television

LED - Light Emitting Diode

MHP - Multimedia Home Platform

MPEG - Moving Picture Experts Group

NAB - National Association of Broadcasters

NUI - Natural User Interface

PC - Personal Computer

PTPTV - Peer to Peer TV

PVR - Personal Video Recorder

RAD - Rapid Applications Development

RAM - Random Access Memory

ROM - Read Only Memory

RUP - Rational Unified Process

SBTVD - Sistema Brasileiro de TV Digital

SDTV - Standard Definition Television

SIGCHI - Special Interest Group on Computer Human Interaction

SMS - Short Message Service

STB - Set-Top Box

RF - Radio Frequency

TUI - Tangible User Interface

TVDI - Televisão Digital Interativa

WIFI - Wireless Fidelity

WiMAX - Worldwide Interoperability for Microwave Access

WIMP - Window Icon Menu Pointing Device

WYSIWYG - What You See Is What You Get

WWW - World Wide Web

XML - Extensible Markup Language

XP - Extreme Programming 
Resumo 7

Abstract .9

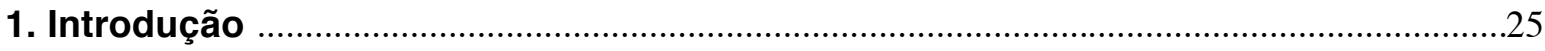

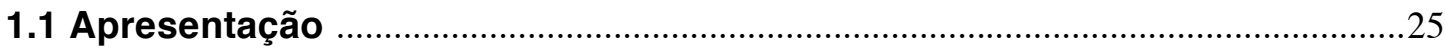

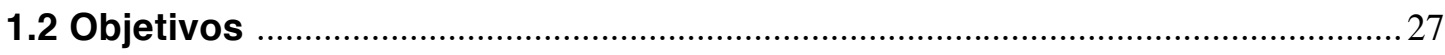

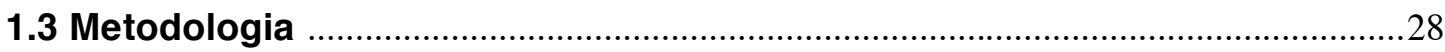

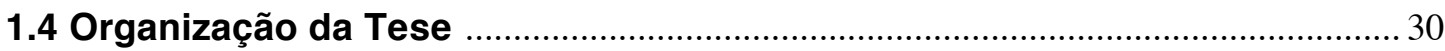

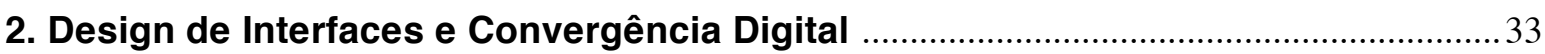

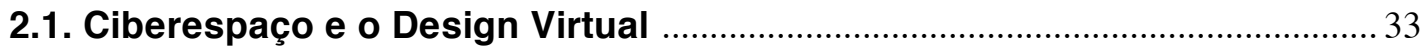

2.1.1 Introdução - Ciberespaço e espaços virtuais.....................................33

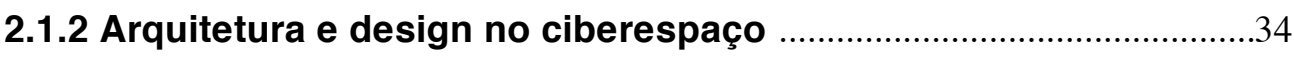

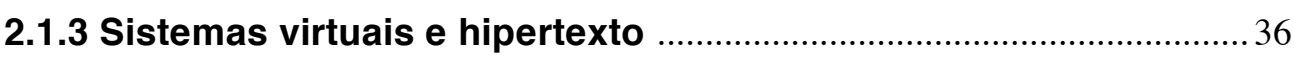

2.2. Design de interfaces e Design da Interação ..................................................... 37

2.2.1 Interação homem-máquina e homem-computador ..........................40

2.2.2 Interfaces analógicas e interfaces digitais .......................................42

2.2.3 Metáforas e a linguagem das interfaces .........................................47

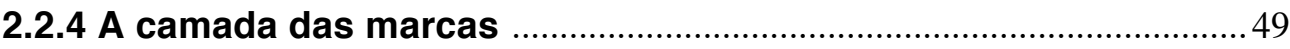

2.2.5 Áreas de interesse no Design de Interfaces para TVDI ............... 50

2.3. Pioneiros em Design de Interfaces Gráficas ………...................................... 53

2.3.1 Doug Engelbart - Aumentando o intelecto humano ..................... 53

2.3.2 Alan Kay - Interface do Usuário, sua visão pessoal ......................56

2.3.3 A metáfora do Desktop ...................................................................... 59

2.3.4 Brenda Laurel - Computadores como teatro ................................... 63

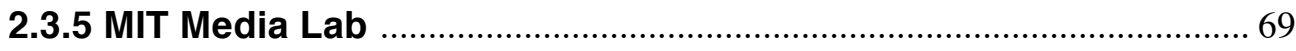

2.3.6 Bill Moggridge - IDEO ………..........................................................

2.4. Novas Tendências em Design de Interfaces ……….....................................

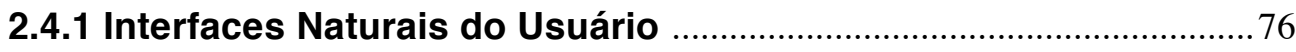

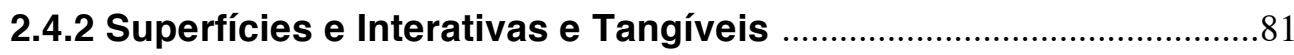

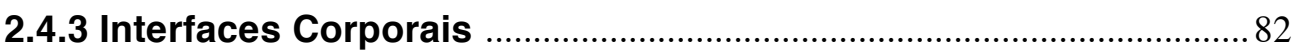

2.5. A Prática do Design da Interação Humano-Computador ...............................83 
2.5.1 Design da Experiência do Usuário .83

2.5.2 Princípios do Design e Usabilidade ................................................. 87

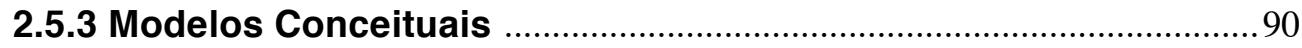

2.5.4 Processos do Desenvolvimento de Software ................................. 91

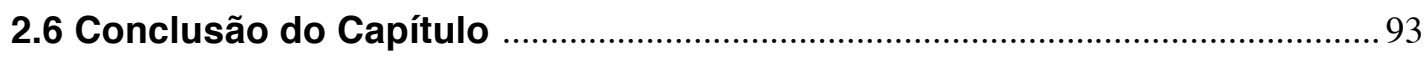

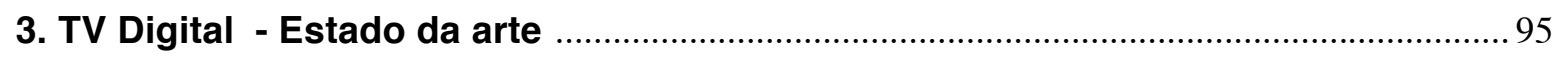

3.1 TV Digital - Definição, padrões e sistemas ......................................................95

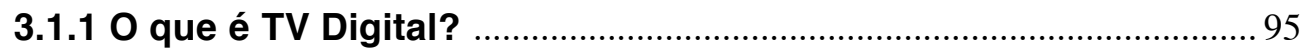

3.1.2 Padrões e Sistemas de TV Digital no Mundo .................................. 106

3.1.3 Sistema Brasileiro de TV Digital - SBTVD ........................................109

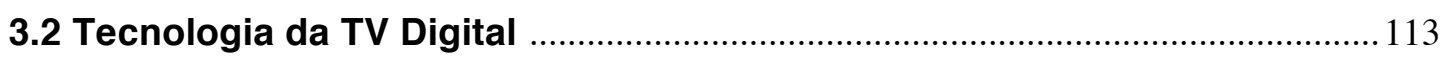

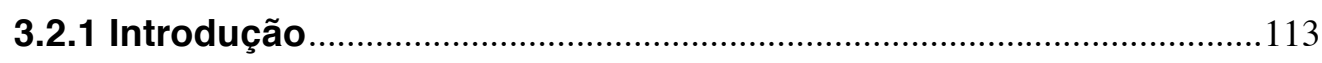

3.2.2 Resolução e métodos de compressão de vídeo................................113

3.2.3 Receptores e conversores para a TV Digital ................................... 117

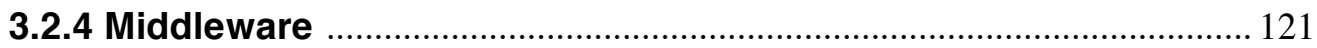

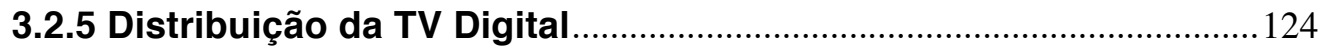

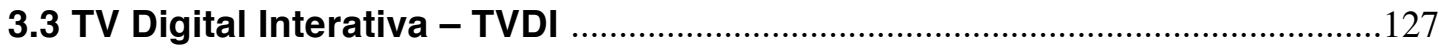

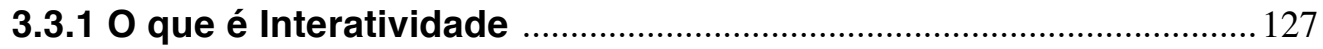

3.3.2 Histórico da TV Digital Interativa ..................................................... 132

3.3.3 Tipos de Interatividade na TV Digital ................................................. 133

3.3.4 Serviços Interativos na TV Digital ....................................................137

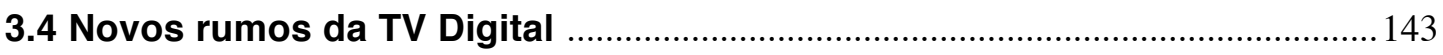

3.4.1 Convergência das mídias e dispositivos audiovisuais ................. 143

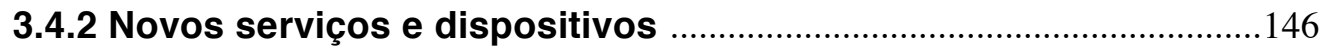

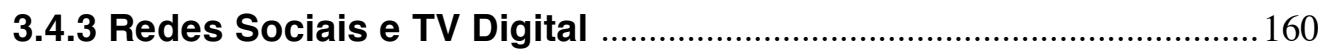

3.4.4 Integração com dispositivos móveis ................................................. 162

3.5 Design de Interfaces para TV Digital Interativa …........................................... 165

3.5.1 Design para TVDI - Disciplinas convergentes ……........................ 165

3.5.2 Design de Interfaces Gráficas - GUI ................................................ 168

3.5.3. Novas Direções em Design para TVDI ...........................................173

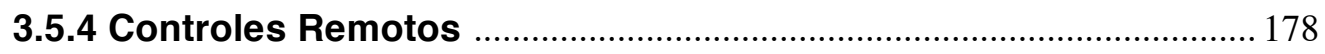

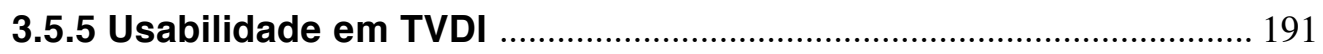

3.5.6 Processo de produção de software para a TVDI ............................. 194

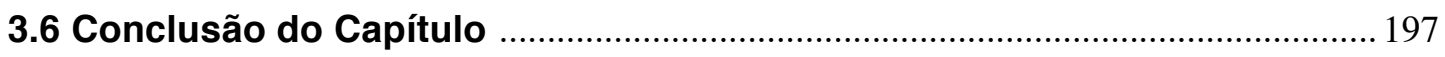


4. Design para Mídias Convergentes - Interação e Identidade 199

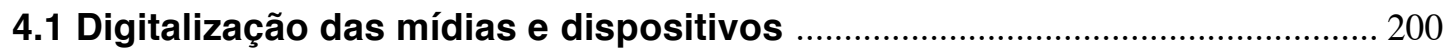

4.1.1 Produção e distribuição de mídias não lineares ……………...........200

4.1.2 A música como precursora do audiovisual ..................................... 200

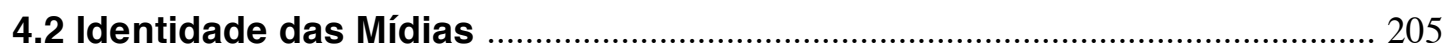

4.2.1 Especificidade dos aparelhos midiáticos ....................................... 205

4.2.2 Materialidade das mídias ..................................................................... 206

4.2.3 Representação e metáforas da TV ................................................... 207

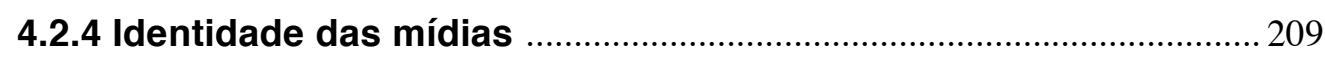

4.3 Definindo a experiência de assistir a TV .......................................................... 211

4.3.1 HDTV e percepção de resolução ....................................................... 213

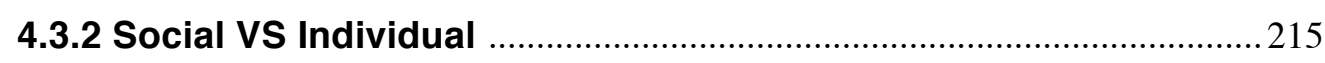

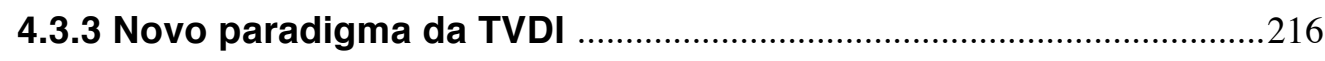

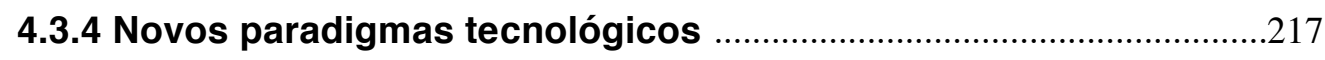

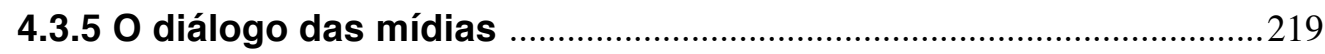

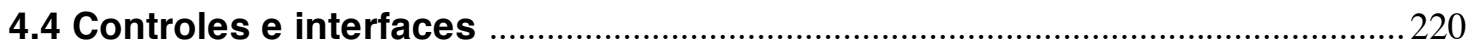

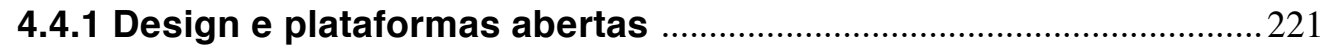

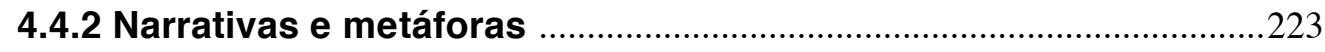

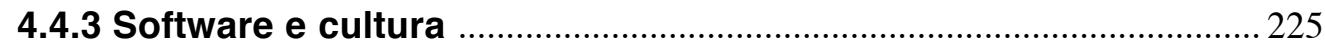

4.5 Design como facilitador do diálogo entre as mídias …...................................227

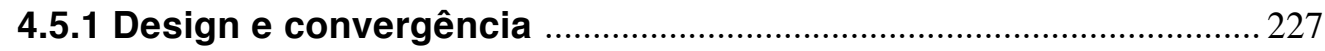

4.5.2 Design e dispositivos móveis ........................................................228

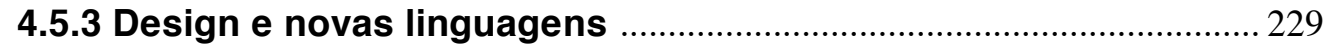

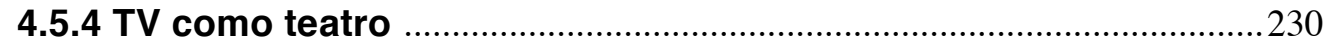

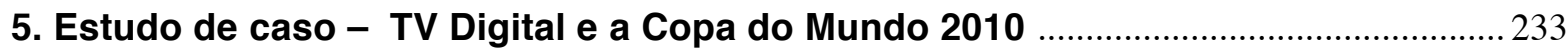

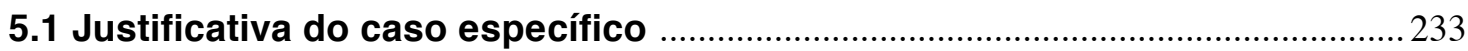

5.1.1 Estudo de Caso: Copa do Mundo - FIFA ……...................................233

5.1.2 Copa de 2010 e convergência ...........................................................234

5.1.3 Novo comportamento do Telespectador ......................................... 237

5.1.4 Classificação de Conteúdo Mediático ............................................... 240

5.2 Levantamento de conteúdo em diversas mídias - Copa de 2010 ................. 241

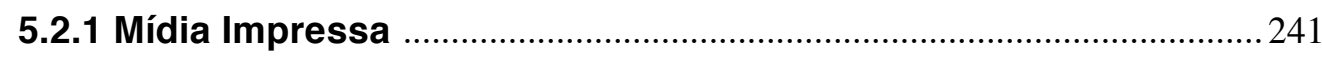

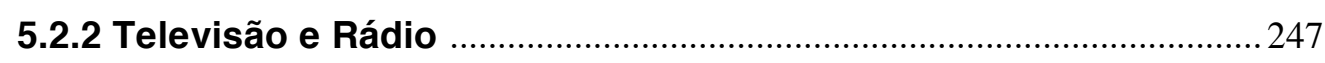

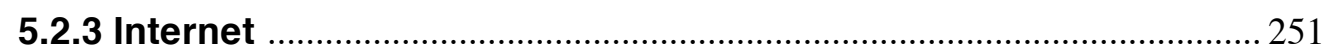




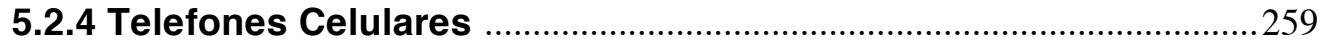

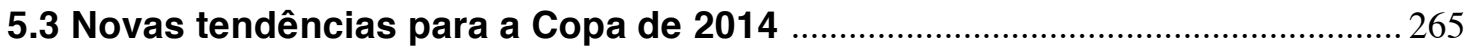

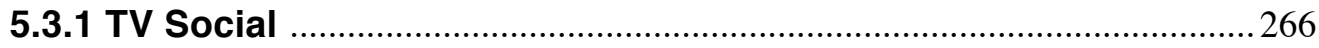

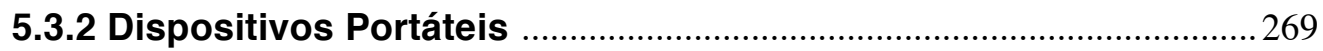

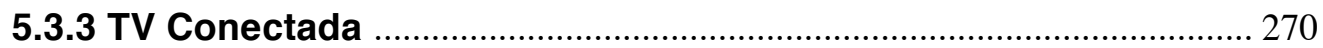

6 . Projeto de Interfaces - TV Digital na Copa do Mundo 2014 ................................... 273

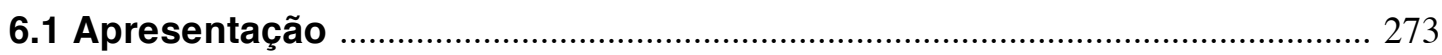

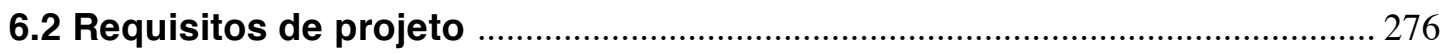

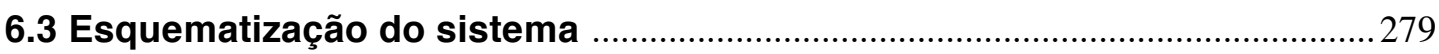

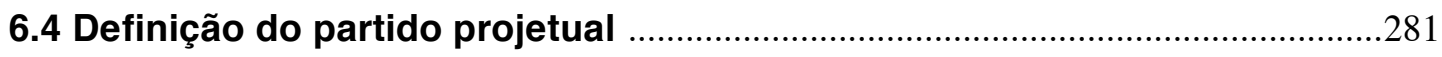

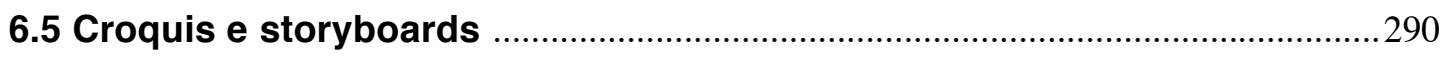

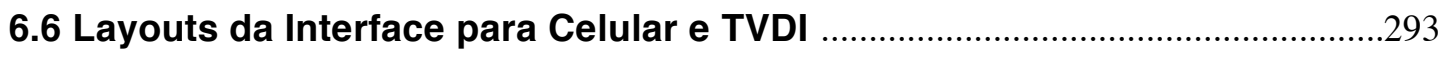

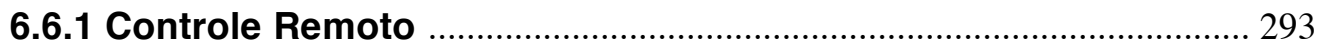

6.6.2 Guia Eletrônico de Programação - EPG ………………………........29

6.6.3 Aplicativos para a Copa do Mundo de Futebol ...............................298

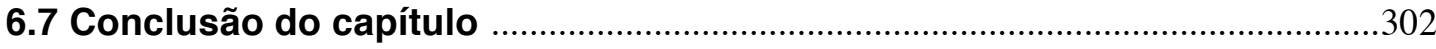

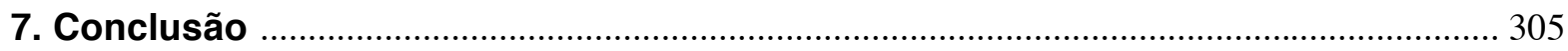

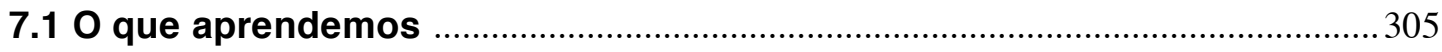

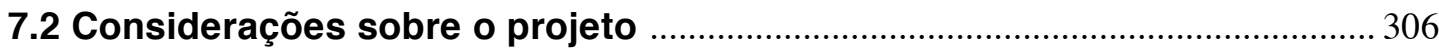

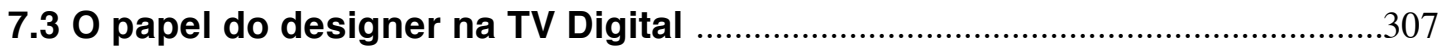

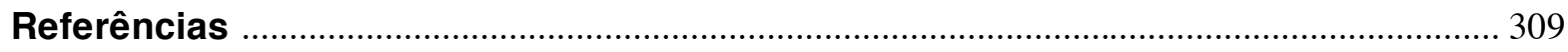

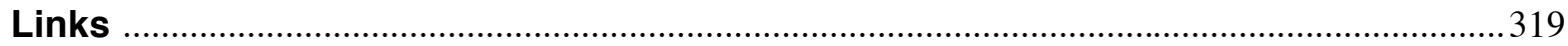




\section{Notação}

Termos em inglês de uso corrente foram padronizados sem itálico. Os itálicos são utilizados apenas para destaques, ou nomes de livros, jornais, revistas, etc.

Termos como TV, Web, Celular, Internet, Smartphones e Games quando se referem a "mídia", estão grafados com a primeira letra maiúscula. 



\section{Introdução}

"O Design pode fazer uma contribuição importante para a TV Digital Interativa".

\subsection{Apresentação}

Esta tese tem como objeto de estudo o Design de Interação para o Sistema Brasileiro de TV Digital (SBTVD), não pelo fato de ser uma plataforma tecnológica que tem apoio das emissoras de TV e do governo, mas sim por representar uma janela aberta sobre uma realidade aumentada, virtualizada e conectada, passível de ser traduzida em formato compreensível pelos brasileiros. Estamos falando da tecnologia como mídia, como espaço social, um ambiente onde se pode participar, trabalhar, aprender e se divertir.

Até os anos 1990, a penetração da telefonia fixa foi bastante lenta no país, mas em contrapartida o crescimento da telefonia móvel tem sido explosivo ${ }^{1}$, atingindo 191 milhões de celulares habilitados em 2010, aproximadamente uma linha por habitante. O índice de analfabetismo no Brasil em 2009 era próximo a 10\% dos brasileiros com mais de 15 anos, ainda abaixo do aceitável ${ }^{2}$, o que torna o relacionamento de nossa população com a palavra escrita bastante deficitário. Essa seria uma das possíveis explicações da preferência dos brasileiros pelos meios audiovisuais. Hoje vivemos em uma sociedade permeada por mídias

\footnotetext{
${ }^{1}$ Segundo dados da Anatel, o total de serviços móveis habilitados no Brasil chegou a 191 milhões em setembro de 2010. "Número de celulares no Brasil supera os 191 milhões", O Estado de S. Paulo, 22 de outubro de 2010. Disponível em: <http://economia.estadao.com.br/noticias/negocios+servicos,numero-de-celulares-no-brasilsupera-os-191-milhoes, $40059,0 . \mathrm{htm}>$. Acesso em: 5/2/2011.

${ }^{2}$ Segundo pesquisa do IBGE, a taxa de analfabetismo no Brasil em pessoas maiores de 15 anos era de $9,7 \%$ em 2009. “Analfabetos ainda somam 14,1 milhões de pessoas, segundo PNAD 2009”, O Estado de S. Paulo, 8 de setembro de 2010. Disponível em: <http://www.estadao.com.br/noticias/vidae, analfabetos-ainda-somam-141milhoes-de-pessoas-segundo-pnad-2009,606716,0.htm > . Acesso em: 5/2/2011.
} 
eletrônicas, onde a televisão tem um forte apelo, mas, em contrapartida, temos um compromisso mínimo com as estruturas literárias.

A TV Digital já está sendo transmitida em diversas capitais brasileiras e segundo o cronograma oficial deverá estar disponível em todo o território nacional até $2016^{3}$. Sua implantação ocorre concomitantemente ao crescimento da telefonia celular e ao acesso à internet no país. A introdução de novas tecnologias de telecomunicação tem consequências na educação, no cotidiano familiar, na forma como trabalhamos e nos relacionamos em sociedade, com o governo e o resto do mundo. O Sistema Brasileiro de TV Digital foi concebido não só como substituto da TV analógica, mas como um meio de inclusão digital que permitisse o acesso à internet e contribuísse para a convergência das tecnologias de comunicação (BRASIL, 2003) ${ }^{4}$.

A digitalização das mídias audiovisuais, permitindo sua ampla distribuição na internet, proporcionou uma interatividade mais avançada do que a prevista nos sistemas de TV Digital. A internet tornou-se uma enorme biblioteca audiovisual, ora de forma aberta como no You Tube, ora em serviços por assinatura como Apple TV e Net Flix. Hoje o tráfego de vídeo já representa metade do tráfego total de dados na internet (ANDERSON, 2010).

Enquanto a TV Digital interativa ainda engatinha no Brasil, vemos o crescimento de novas formas de interatividade como o compartilhamento de vídeos na internet, muitos gerados pelos usuários que os publicam em sites, blogs e redes sociais. Somam-se ainda canais alternativos de distribuição de vídeos pessoais como a telefonia celular, que tem o potencial de democratizar a produção audiovisual.

O foco inicial desta pesquisa era o design de interfaces gráficas para TV Digital utilizando especificamente a tecnologia da TV Digital terrestre definida pelo SBTVD, sendo que os desafios deste design seriam determinados pelas limitações impostas pelo sistema. No entanto, a convergência das mídias digitais casou impacto na comunicação audiovisual de tal forma que foi necessário acomodar esta pesquisa a essas transformações.

\footnotetext{
${ }^{3}$ Segundo o cronograma oficial de implantação do SBTVD, publicado no site www.dtv.org.br

${ }^{4}$ Conforme o Decreto n. 4.901, de 26 de novembro de 2003. Institui o Sistema Brasileiro de Televisão Digital SBTVD, e dá outras providências. Ministério Das Comunicações; Casa Civil Da Presidência Da República.
} 
Este cenário levou-me a repensar o que é TV Digital. A ubiquidade de dispositivos inteligentes móveis e computadores conectados em redes aliados ao fácil acesso a conteúdo digital transformam a TV, que deixa assim de ser apenas um receptor de imagens e sons. A TV de alta definição (HDTV) permite ao espectador uma experiência que se aproxima do cinema, enquanto assistir TV ainda é uma atividade primordialmente coletiva, inserida no espaço doméstico ou público. Como é cada vez mais comum nos conectarmos com várias mídias simultaneamente, é necessário repensar a interatividade na TV.

No início da pesquisa, comecei a questionar a viabilidade de utilização do controle remoto tradicional como forma primordial de comando que permite ao usuário interagir com a TV. Diante dos avanços e do crescimento da telefonia celular, passei a investigar como esta plataforma poderia convergir com a TV Digital e incorporar vantagens de cada uma delas com o objetivo de facilitar a interatividade. Partindo do estudo de tecnologias que emergiram na Copa do Mundo da FIFA de 2010 e incorporando conclusões do levantamento sobre Design de Interação e a tecnologia da TV Digital, busquei uma solução prática ao apresentar o design de uma interface que integra a TV Digital com celulares e a internet, servindo não só como forma de comando facilitador da interatividade, mas também como ponto de acesso a serviços e conteúdos que tendem a convergir na Copa de 2014.

Ao estudar o design de interação homem-máquina, evidenciou-se a transformação do uso do computador como simples ferramenta em uma nova mídia apropriada a nossa sociedade, que cada vez mais vive entre o real e o virtual. A capacitação de designers, em disciplinas como: arquitetura da informação, design visual, design de interfaces e de interação é fundamental para que eles possam exercer o papel de facilitadores da interatividade na TV Digital.

\subsection{Objetivos}

O objetivo geral desta pesquisa é a importância da contribuição que o design pode oferecer para uma melhor usabilidade das interfaces que facilitam a interatividade na TV Digital. O objetivo específico é desenvolver um modelo de interface integrando o conteúdo da TV e da internet, de modo que este possa ser acessado tanto em monitores de alta definição como em dispositivos inteligentes móveis, proporcionando ao usuário uma experiência 
consistente entre as diversas plataformas ao optar pelo suporte mais apropriado para cada atividade.

Considerando as especificações do SBTVD e a base de computadores e celulares conectados à internet, é possível desenvolver uma única interface para assistir TV utilizando múltiplas telas, tendo como objetivo facilitar o acesso a conteúdos audiovisuais de diferentes plataformas digitais.

\subsection{Metodologia}

A metodologia adotada nesta tese está representada no esquema seguinte, onde demonstro os passos utilizados para apresentar soluções às questões levantadas na pesquisa. $\mathrm{O}$ método corresponde a uma sequência que envolve pesquisa e subsequentemente a articulação e o encadeamento de ideias, que, como veremos mais adiante, irão definir os capítulos da tese.

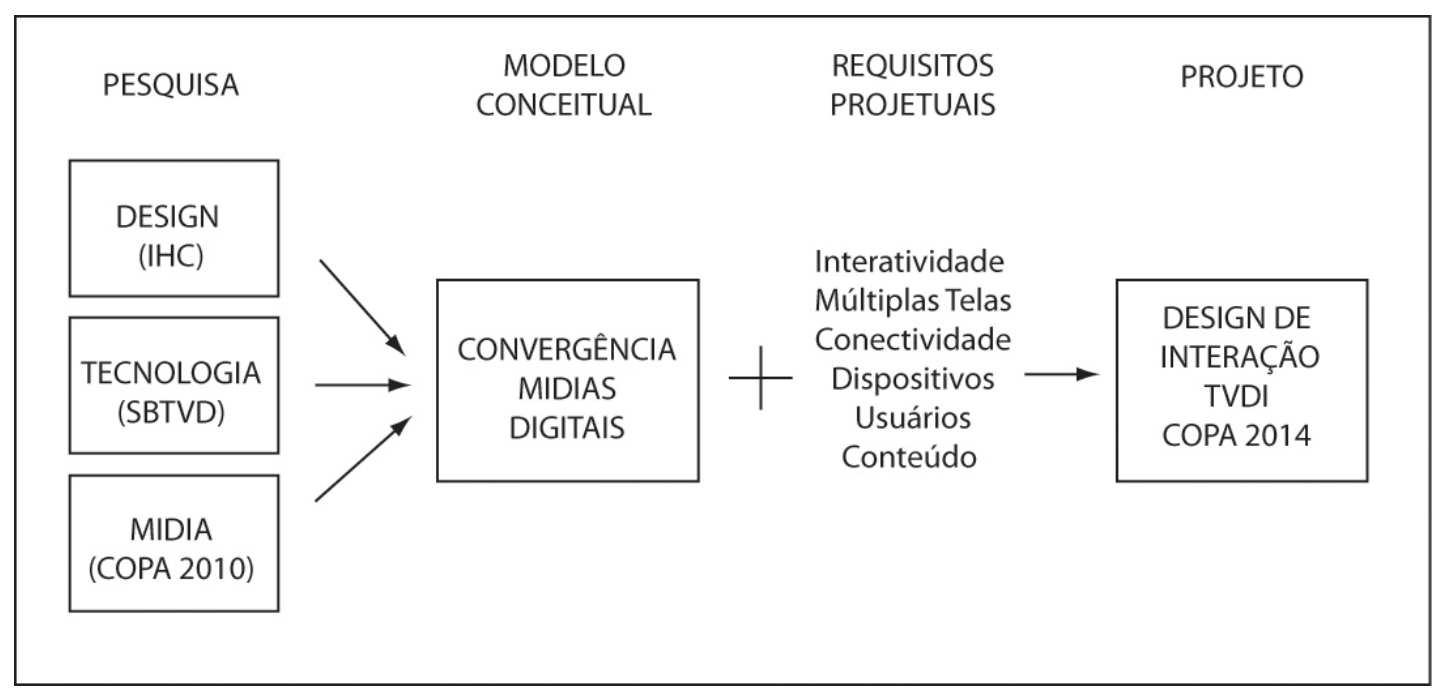

Fig. 1.1: Esquema representando o método adotado na pesquisa.

Os passos tomados foram:

\subsubsection{Problema}

Definição do problema diante da constatação de que há um interesse limitado pela interatividade com a TV Digital:

- A interatividade na TV Digital é limitada devido à dificuldade de utilização das interfaces desenvolvidas atualmente? 
- Qual a importância do design do controle remoto para a usabilidade destas interfaces?

- Outros fatores como a implementação de um canal de retorno pode incentivar o desenvolvimento de programas interativos para TV Digital?

\subsubsection{Levantamento - Quadro de Referência}

De modo a estabelecer um quadro de referência teórico e prático, foi realizado um levantamento das principais pesquisas, teóricas e tecnológicas, nas áreas de:

a) Design de interfaces e interação homem-computador

b) Tecnologia da TV Digital: SBTVD e convergência

\subsubsection{Modelo Conceitual}

Fundamentado nas pesquisas realizadas, proponho um modelo conceitual em que argumento a importância da inserção da TV Digital em um cenário de convergência das mídias digitais.

\subsubsection{Estudo de Caso}

Com o objetivo de definir os requisitos de um projeto de design de interação que responda as questões levantadas inicialmente e tendo em vista o modelo conceitual do estudo, a Copa do Mundo de 2010 na TV e em outras mídias é o tema escolhido como estudo de caso. Durante o evento, foram registrados e colhidos exemplos de sua presença em diversas mídias. Entre os motivos de escolha do tema, destacam-se sua importância como um exemplo global da inovação tecnológica na TV e por ser emblemática do telespectador brasileiro.

\subsubsection{Design de Interação}

Levando em conta os requisitos definidos no estudo de caso, o projeto de design de interação tem como objetivo demonstrar uma proposta de experiência do usuário para TV 
Digital interativa. O design de uma interface para múltiplas telas em dispositivos conectados busca responder de forma prática as questões levantadas na pesquisa.

\subsection{Organização da Tese}

Antes de iniciar a redação da tese, organizei o conteúdo de cada capítulo procurando resumir em uma frase a ideia que o representasse de modo a desencadear um pensamento lógico entre eles. A tese está organizada em sete capítulos, cuja descrição está precedida pelas seguintes frases geradoras.

\subsubsection{Capítulo 1 - Introdução}

"O Design pode fazer uma contribuição importante para a TV Digital Interativa".

Apresentação da TV Digital no Brasil, os objetivos, o método de pesquisa e a forma como a tese está organizada.

\subsubsection{Capítulo 2 - Design de Interfaces e Convergência Digital}

"O novo paradigma da TV estabelece-se no contexto da convergência das mídias digitais, abrindo um novo campo de design”.

Quadro de referência teórico que introduz o conceito de ciberespaço como novo espaço de atuação do design, as novas mídias e levantamento do estado da arte em Design da interação homem-computador, e aponta exemplos e pesquisas relacionadas ao design digital.

\subsubsection{Capítulo 3 - Tecnologia da TV Digital Interativa}

"No entanto, o design para TVDI deve libertar-se do paradigma da TV Expandida". 
Levantamento do estado da arte da TV Digital, definindo seus padrões e sistemas. Detalhamento de aspectos como a alta definição, serviços como guias de programação e design para TV Digital interativa. No final do capítulo, há um compêndio de tecnologias emergentes como TV conectada e TV social que estão reconfigurando o campo. Podemos considerar este como o quadro de referência prático.

\subsubsection{Capítulo 4 - Design - Interação e Identidade das Mídias}

"Neste cenário o design de interfaces para TVDI deve facilitar o diálogo entre as mídias".

Articulação conceitual de ideias que surgiram a partir do levantamento realizado no capítulo anterior.

\subsubsection{Capítulo 5 - Estudo de caso - TV Digital e a Copa do Mundo 2010}

"Partindo de um exemplo de conteúdo distribuído em diversas mídias, podese demonstrar a contribuição do design de interfaces para a TV Digital em um cenário de convergência".

Definição do conteúdo e requisitos projetuais do caso específico de estudo: a Copa do Mundo FIFA 2010. Levantamento de conteúdo do evento em diversas mídias e perspectivas midiáticas para a de Copa 2014.

\subsubsection{Capítulo 6 - Projeto de Interfaces - TV Digital na Copa do Mundo 2014}

"Uma solução é a integração de dispositivos móveis inteligentes com a TV Digital".

Processo de trabalho e apresentação das interfaces gráficas de um projeto de Design de Interação propondo controles em múltiplas telas e mídias para a Copa do Mundo de 2014. O projeto pretende demonstrar como celulares, smartphones, tablets e PDAs podem ser utilizados como extensão do conteúdo e da funcionalidade da TV. Mais especificamente:

-Utilização do dispositivo como controle remoto. 
-Extensão da interface de conteúdo interativo ao dispositivo.

-Utilização do dispositivo como canal de retorno.

-Transmissão de TV para o dispositivo.

-Dispositivo como extensão da experiência televisiva.

\subsubsection{Capítulo 7 - Conclusão}

"Desta forma o design poder facilitar a experiência da TVDI em um cenário de convergência".

Análise crítica do projeto e sugestões de encaminhamento futuro. 
Capítulo 2

\section{Design de Interfaces e Convergência Digital}

"O novo paradigma da TV estabelece-se no contexto da convergência das mídias digitais, abrindo um novo campo de design”.

\subsection{Ciberespaço e o Design Virtual}

\subsubsection{Introdução - Ciberespaço e espaços virtuais}

Em seu livro City of Bits, William Mitchell (1995), professor de arquitetura e diretor da Escola de Arquitetura e Urbanismo do Massachussets Institute of Technology (MIT), reimagina a arquitetura e o urbanismo no contexto de suas observações. Ele começa o livro relatando suas observações sobre trabalhadores saindo das bocas de lobo das cidades americanas na década de 1990, “eles não estavam consertando os esgotos ou linhas de gás, estavam puxando vidro" (MITCHELL, 1995, p. 3); em outras palavras, eles estavam instalando fibra ótica. Na verdade, o que estava sendo construído era a rede de telecomunicação em banda larga; Mitchell nota: “assim como o Barão Haussmann impôs uma rede de boulevards cortando as vielas de Paris, estes trabalhadores estavam instalando a Infobahn" (MITCHELL, 1995, p. 3), reconfigurando as relações de espaço tempo, de uma forma invisível aos nossos olhos, mas na realidade instalando a infraestrutura do ciberespaço.

O termo "ciberespaço" foi cunhado pelo escritor de ficção científica William Gibson (1983), que prevê um mundo pós-industrial de pura informação, onde as construções são substituídas por um não espaço. Um autor fundamental para a compreensão do ciberespaço é Michael Benedikt, professor de arquitetura na Universidade do Texas, em Austin. Em seu livro Cyberspace: First Steps, Benedikt (1991) e David Thomas (um dos colaboradores desse livro) trabalham com base na obra de Michel Serres, autor de Language and Space: From 
Oedipus to Zola onde teoriza que: O espaço euclidiano define uma cultura e sua aparência através de junções e encruzilhadas - culturas e indivíduos são constituídos de junções de espaços sociais mais ou menos fluidos sempre compreendidos dentro de uma estrutura social e cultural (SERRES apud BENEDIKT, 1991).

O modelo euclidiano sobrevive em razão da problemática de visualização da informação, ao passo que o projeto da arquitetura no final do século XX está permeado de significação, criando espaços carregados de informação (BENEDIKT, 1991), definindo o posicionamento do arquiteto que passa a ser cada vez mais conceitual, culminando nas tendências desconstrutivistas do final do milênio. Marcos Novak em Liquid Architectures for Cyberspace define as interfaces gráficas tradicionais como externas; já no ciberespaço, podemos navegar o espaço virtual "internamente" sem a limitação de símbolos e convenções gráficas (NOVAK, 1991).

\subsubsection{Arquitetura e design no ciberespaço}

Na virada do milênio, o mundo contemporâneo deparou-se com transformações radicais do capitalismo e de seus ideais democráticos - um mundo que na superfície parece muito similar ao mundo moderno que se estabeleceu durante o século XX, onde o capitalismo ainda divide espaço com ditaduras, culturas tribais, subdesenvolvimento, diferenças religiosas e violência. Mas por trás de tudo isso uma grande revolução está em curso, a ubiquidade da cultura digital, a informatização de diversos aspectos do dia a dia e as redes de computadores são catalisadores desta transformação, evidenciada na cultura globalizada e na sociedade conectada na qual vivemos.

Computadores conectados a redes de informação têm permeado cada vez mais nossas vidas. É difícil pensar em algum aspecto do nosso cotidiano que não dependa destas novas tecnologias digitais, sejam livrarias, escolas, bancos, exames médicos, companhias aéreas ou órgãos do governo. A tecnologia da informação modificou radicalmente a forma como nos comunicamos, trabalhamos, nos divertimos e nos transportamos. Não faz muito tempo as vanguardas artísticas e a arquitetônicas discutiam como a revolução industrial, as máquinas, as revoluções sociais e culturais definiram a cultura moderna. Hoje nossa cultura e sociedade estão sendo definidas pelas tecnologias da informação. 
Os valores do modernismo, levados ao extremo com o pós-modernismo, eventualmente foram exauridos ao encontrar um ponto de resistência ou de esgotamento de possibilidades que poderíamos definir como "hiper-modernismo" ou o final do pósmodernismo, como sugere Kazys Varnelis (2008), professor da Escola de Arquitetura de Columbia University, que define este novo ciclo como Network Culture (Cultura de Rede). Jameson (1991) insere o pós-modernismo na sociedade pós-industrial definida por David Bell, enquanto Varnelis (2008) situa a Cultura de Rede no contexto de uma nova ordem global definida por Antonio Negri e Michael Hardt em Empire (2000), onde defendem que na virada do milênio novas estruturas de poder transnacionais regem uma economia globalizada, sucedendo a sociedade pós-industrial. Embora ainda não compreendamos plenamente as consequências destas mudanças, é impossível negar que elas estão ocorrendo.

No universo da arquitetura e do design, pode parecer que pouco mudou na superfície, mas as mudanças são maiores do que parecem, não simplesmente porque hoje se pode projetar e visualizar um edifício ou um objeto utilizando programas de modelagem 3-D, ou porque, devido às novas tecnologias, houve avanços nos processos de produção e construção, mas sim e muito mais em razão dos espaços virtuais, da comunicação em redes ou das transações digitais que passaram a fazer parte intrínseca de nossas vidas. Ir ao banco hoje significa sacar dinheiro nos caixas eletrônicos, ou simplesmente fazer uma transferência utilizando o web-banking.

Os arquitetos do século XX, ao projetar agências de bancos, buscavam valorizar a imagem de solidez da instituição, seja na semelhança com templos, como se vê na arquitetura neoclássica de Nova York do início do século XX, ou na solidez do concreto-armado das agências bancárias do Brasil nos anos de 1970. Hoje, os negócios bancários ocorrem principalmente através da internet, baseados na premissa de que o site é seguro. O espaço construído das agências bancárias têm pouca importância no nosso relacionamento bancário. Para realizar transações financeiras, interagimos com uma imagem representada na tela de um computador, acreditando que a instituição e a rede por trás do site acessado são sólidas e funcionais. Assim como um arquiteto precisava definir as áreas de uma agência a serem ocupadas pelos caixas, gerência, caixa-forte e os acessos entre elas, um site também precisa ser "navegado", o usuário tem de saber chegar em um local determinado, alguns abertos ao público, outros restritos e mais seguros; é necessário saber orientar-se nesse espaço, voltar ao mesmo lugar, identificar-se e assim por diante. 


\subsubsection{Sistemas virtuais e hipertexto}

William Gibson, autor do bestseller de ficção científica dos anos de 1980 Neuromancer, já vislumbrava o universo que estamos vivendo hoje. Gibson introduz o termo “ciberespaço" em Neuromancer (1983), onde Case, o personagem principal, é uma espécie de cowboy futurista que vive entre o real e o virtual rompendo as barreiras entre os dois. Esse personagem serviu como inspiração para o filme Matrix dos irmãos Wachovsky. Pierre Lévy (1997), em seu texto The Art and Architecture of Cyberspace, descreve como a arte está transformando-se em um ambiente fluido, dinâmico e em constante mutação, um plano semiótico "des-territorializado" em que o "artista" e o "receptor" se unem em um jogo consensual na formação, execução e interpretação da arte. As noções de autoria, segundo Lévy, estão sendo reconsideradas na sociedade contemporânea, o que está levando-nos a transformações culturais, em uma sociedade conectada por redes eletrônicas em que os cidadãos participam coletivamente da criação de novos códigos e linguagem.

Outro conceito de extrema importância nesta sociedade digitalizada e conectada é a do "rizoma" do filósofo Gilles Deleuze (1976). "Rizoma" é um sistema de ramificações tubulares (raízes) em que um ponto pode sempre estar conectado a outro ou a outros pontos. Deleuze utiliza o conceito de "rizoma" como modelo de conectividade em sistemas de ideias, já os cientistas da computação utilizam modelos semelhantes ao conceber redes. Nos anos de 1960, Ted Nelson, um dos pensadores pioneiros do universo cibernético, concebeu sistemas de computadores em que textos eram entre si conectados ${ }^{5}$ (links), os quais denominou "hipertextos" (NELSON, 1981). Segundo Nelson, hipertextos transcendem os limites da textualidade impressa em uma folha de papel. Douglas Engelbart apresenta uma aplicação prática do hipertexto na demonstração que realizou do NLS em 1968, um sistema de computadores conectados em rede que permitia que pessoas em localizações remotas trabalhassem colaborativamente (MOGGRIDGE, 2007).

Tanto as ideias de Ted Nelson como as de Douglas Engelbart surgiram a partir de um importante artigo de Vannevar Bush, publicado em 1945 na revista Atlantic Monthly. Nesse artigo, intitulado "As We may Think", Bush propõe o desenvolvimento de um sistema de arquivamento e recuperação de dados, o Memex, que possibilitaria uma forma de memória coletiva acessível por todos (BUSH, 1945). Segundo George Landow, o hipertexto permite a

\footnotetext{
${ }^{5}$ Nelson desenvolve um sistema hipertextual em seu projeto Xanadu em seu livro Litrary Machines (1981)
} 
utilização do computador para transcender as qualidades lineares e fixas do texto tradicional escrito (LANDOW in LANDOW;DELANY, 1991). Um hipertexto pode ser lido e composto de forma não sequencial, tem uma estrutura variável formada por "blocos de texto que Barthes define como a lexia ${ }^{6}$ - e de links eletrônicos que os unem" (LANDOW in LANDOW;DELANY,1991).

William Burroughs, em The Cut-Up Method of Bryan Gysin, propõe escrever um texto e depois recortá-lo para reorganizar continuamente sua composição, gerando uma obra não estática que pode ser consumida de diversas formas (BURROUGHS, 1978). Jean Baudrillard elabora suas ideias com base na obsessão da nossa sociedade por simulacros, que, segundo ele, seriam imagens que sustentam valores e metáforas permitindo a explosão da sociedade de consumo (BAUDRILLARD, 1973). Com um ponto de vista mais pragmático, Donald Norman (1988), em The Psychology of Everyday Things, diz que: "O design de uma interface inteligente deve começar com a análise do que uma pessoa está tentando fazer, ao invés de uma metáfora ou noção do que deve ser exibido na tela.” (NORMAN, 1988).

\subsection{Design de interfaces e Design da Interação}

O livro Designing Interactions, de Bill Moggridge (2007), apresenta um extenso panorama do Design de Interação em artigos e entrevistas com os principais expoentes do campo. A obra conta com um prefácio de Gillian Grampton Smith, professora que montou o primeiro curso de Design da Interação no Royal College of Arts na Inglaterra, com o objetivo de ensinar artistas e designers a aplicarem seus conhecimentos no projeto de produtos e sistemas interativos. Smith busca responder a questão: "O que é Design de Interação", sem limitar-se a buscar resolver unicamente as questões de usabilidade, preocupando-se com aspectos mais subjetivos ao levantar questões acerca da linguagem da interatividade (SMITH in MOGGRIDGE, 2007).

Eu acredito que o design de interação está em uma fase equivalente aos primeiros anos do cinema. Até o momento ainda não temos uma linguagem totalmente desenvolvida que seja única à tecnologia interativa. Portanto nos baseamos na linguagem de modos criativos prévios. Ajuda categorizar estas

\footnotetext{
${ }^{6}$ Esses "blocos" de texto são equivalentes às "Lexias", elementos que compõem a textualidade ideal descrita por Roland Barthes em S/Z (1970).
} 
linguagens de acordo com suas "dimensões": 1-D, 2-D, 3-D e 4-D. (SMITH in MOGGRIDGE, 2007, p. xvii) ${ }^{7}$.

Smith (in MOGGRIDGE, 2007) categoriza as dimensões da linguagem como:

- A linguagem 1-D inclui as palavras e a poesia.

- As linguagens 2-D, que podem ser adotadas pelo design da interação, incluem a pintura, tipografia, diagramas e ícones.

- As linguagens 3-D são as de formas físicas, esculturais.

- A $4^{\text {a }}$ dimensão é o tempo, as linguagens 4-D incluem som, cinema e animação.

No entanto, depois de passarmos vinte anos partindo de linguagens expressivas existentes, precisamos agora desenvolver uma linguagem independente de interação com "sistemas e dispositivos inteligentes", uma linguagem apropriada (verdadeira) ao meio dos computadores, redes e telecomunicações. Em termos de psicologia da percepção estamos começando a compreender os limites funcionais da interação entre pessoas e dispositivos ou sistemas: velocidade de resposta, fala, ou capacidade de comunicação de uma tela pequena. Mas no nível simbólico de humor ou significado, de sociabilidade e civilidade, ainda não alcançamos a inovação de tirar o fôlego, a sutileza e certeza intuitiva da linguagem da montagem de Eisenstein. ${ }^{8}$ (SMITH in MOGGRIDGE, 2007, p. xix).

O Design de Interação, assim como a arquitetura, busca soluções para a engenharia levando em conta o que querem os seres humanos dentro das limitações da tecnologia e do espaço. O designer que projeta espaços virtuais não deve somente buscar a forma mais

\footnotetext{
${ }^{7}$ Tradução minha de: "I believe that interaction design is still in the equivalent of the early stages of cinema.As yet, we have no fully developed language unique to interactive technology. So we are still drawing on the language of previous creative modes. It may help to categorize these languages according to their "dimensions":1-D,2-D,3-D, and 4-D."

${ }^{8}$ Tradução minha de Gillian Grampton Smith, prefácio de Bill MOGGRIDGE, Designing Interactions, Cambridge, MIT Press, 2007: "However, after twenty years of drawing on existing expressive languages, we now need to develop an independent language of interaction with "smart systems and devices, a language true to the medium of computation, networks, and telecommunications. In terms of perceptual psychology, we're starting to understand the functional limits of interaction between people and devices or systems: speed of response, say, or the communicative capacity of a small screen. But at the symbolic level of mood and meaning, of sociability and civility, we haven't quite achieved the breathtaking innovativeness, the subtlety and intuitive 'rightness', of Eisenstein's language of montage."
} 
eficiente de introduzir uma tecnologia assumindo que os seres humanos se adaptem a ela. $\mathrm{Na}$ arquitetura e no desenho industrial, a ergonomia é a ciência que estuda os fatores humanos no desenvolvimento de um produto; no desenvolvimento de softwares e sistemas digitais, a usabilidade é a ciência correlata que estuda como se pode facilitar a interação dos seres humanos com os computadores e torná-los mais amigáveis e mais acessíveis aos usuários.

Os computadores são vistos pela maioria das pessoas como ferramentas que estendem a capacidade dos seres humanos. Brenda Laurel e Alan Kay ${ }^{9}$ discutem se eles são apenas isso, ideias que serão detalhadas mais adiante neste capítulo. Doug Engelbart, considerado o inventor do mouse e de modos colaborativos de utilizar computadores, enxergava a informática como uma forma de aumentar a capacidade intelectual dos seres humanos, do mesmo modo como as ferramentas e outras máquinas tiveram esse papel durante séculos, permitindo ao homem domesticar animais, dominar a natureza, aperfeiçoar a agricultura, navegar, atravessar mares, guerrear, voar e conquistar o espaço. Engelbart, em seu texto Augmenting Human Intelect (1962) ${ }^{10}$, descreve como o homem passa a ter desafios cada vez mais complexos e passa a depender de ferramentas que podem resolvê-las. Engelbart sugere que os computadores são a forma pela qual o homem irá "aumentar" a sua capacidade intelectual de modo que possa equacionar problemas complexos.

A pesquisa desenvolvida por Muriel Cooper, diretora do Visible Language Workshop, do MIT Media Lab, define o caminho a ser percorrido no futuro por designers de interfaces. Algumas semanas antes de falecer, em 1994, concedeu uma entrevista para a revista ID (International Design, setembro de 1994). Nesse artigo, Nicholas Negroponte (diretor do MIT Media Lab e autor do livro Ser Digital (1997)) define o trabalho de Muriel em duas palavras: "Beyond Windows" ou “Além do Windows". Negroponte explica: "Cooper destrói os planos de retângulos sobrepostos ao introduzir a ideia de um universo galáctico.” (NEGROPONTE apud ABRAMS, 1994).

Todos esses pesquisadores atuam na área do Design de Interação HomemComputador (IHC) ou Human Computer Interaction (HCI). Assim com na arquitetura, no

\footnotetext{
9 Tanto Brenda Laurel em Computers as Theater e Alan Kay em A Personal View propõem pensarmos o computador como uma mídia. Ambos trabalharam no laboratório Xerox Parc na Califórnia nos anos de 1970 desenvolvendo interfaces gráficas; essas pesquisas influenciaram o sistema operacional do microcomputador Macintosh, lançado em 1984.

${ }^{10}$ Douglas C. Engelbart, Augmenting Human Intellect: A Conceptual Framework, 1962.
} 
design da interação não basta compreender a tecnologia e a engenharia por trás dos sistemas, é necessário levar em conta os aspectos humanos: os processos de cognição, de organização social e códigos culturais, permitindo que os homens consigam utilizar os computadores, onipresentes em nossas vidas. Mais importante, esses designers são inventores que, ao inovar, buscam quebrar paradigmas, permitindo-nos explorar novos mundos ou aumentar os limites do mundo em que vivemos.

Vemos que o papel do designer passa a ser redefinido com essas transformações. É possível hoje criar mundos inteiramente virtuais, nos quais podemos habitar através da mediação das interfaces gráficas. E, embora esses espaços devam ser compreendidos e consumidos pelos seres humanos, esses mundos não precisam necessariamente espelhar o mundo real, o que, como projetistas, talvez seja nosso primeiro ímpeto criativo. Por exemplo, a interface do computador Macintosh utiliza uma lixeira para eliminarmos coisas indesejadas, textos aparecem como documentos e são guardados em pastas e estas podem estar empilhadas ou organizadas em fichários. Mas nada impede que elas estejam em dois lugares ao mesmo tempo, que a cópia e o original sejam a mesma coisa.

Por que precisamos utilizar a metáfora de uma lixeira para jogar fora um documento? É necessário representar um documento como uma folha de papel? Não estamos perdendo algo com a tradução simbólica, será que as próximas gerações de usuários de computador não acharão mais lógico lidar simplesmente com arquivos e diretórios em vez de lidar com uma simbologia que no futuro possivelmente irá remeter a coisas obsoletas e talvez extintas?

\subsubsection{Interação homem-máquina e homem-computador}

O homem, ao projetar máquinas, inventa sistemas complexos a serem utilizados por outros seres humanos, que não precisam necessariamente compreender completamente esses sistemas para utilizá-los. Um dos exemplos a que costumo recorrer ao explicar o conceito de interface para pessoas que não têm familiaridade com computadores é a ideia de interface entre uma pessoa e um automóvel.

Automóveis são sistemas complexos: motor, chassis, carroceria, sistemas elétrico e eletrônico. Além disto, dirigir um automóvel requer habilidades motoras e a compreensão de regras e convenções. No entanto, o motorista não precisa estar ciente de todo o processo e sim se concentrar em suas ações e reações. Por meio de um volante poderá operar as rodas, o 
acelerador permite que aumente a velocidade, mas não necessariamente precisa saber que essa ação causa a queima de mais combustível, embora hoje em dia essa informação, devido a questões ecológicas que afetam nosso planeta, passe a incorporar a interface do homem com o automóvel, como é o caso do design do painel do Toyota Prius elétrico e do novo Fiat Economy Flex nacional. As marchas do carro, compreendidas como posições de uma alavanca, na prática permitem mudar a relação de engrenagens (fato evidente no câmbio de uma bicicleta de dez marchas), mas ao utilizar a interface com o "câmbio" o que importa para o motorista de um veículo é a informação da posição da alavanca da marcha (às vezes representadas por um gráfico) ou, no caso de um carro automático, indicado por um aviso luminoso no painel.

As convenções ditadas por questões de segurança no trânsito nos impõem a necessidade de controlar a velocidade do veículo. Esta é traduzida por um velocímetro e apresentada gráfica e dinamicamente no painel do veículo. O automóvel necessita de uma manutenção programada, como no caso da troca de óleo, e nos baseamos no odômetro e um adesivo colado no retrovisor para monitorar esse aspecto. Ao dirigir, nos comunicamos com os outros motoristas através de sinais: a parte traseira do veículo é sinalizada por luzes vermelhas, que mudam de intensidade ao diminuirmos a velocidade. Se resolvermos andar de marcha a ré, a luz vermelha na traseira do veículo transforma-se em branca, avisando da inversão do sentido de rolagem do veículo; se decidimos realizar uma conversão, acionamos uma seta amarela intermitente sinalizando a direção em que esta se realizará, e ao completála, desvirando o volante, a seta automaticamente desliga no final da manobra.Vemos então que existe uma linguagem estabelecida entre o motorista, o seu veículo e outros motoristas.

O homem necessita de alguma forma de se comunicar com a máquina, por exemplo, no caso de um veículo, dando instruções de partida, velocidade, direção através de uma interface composta de um volante, pedais, alavancas e botões. Faz isso após aprender comandá-los de modo a controlar o veículo. Em um segundo momento, é necessário interagir com outros motoristas e seguir regras de condução do veículo de forma que ele não se choque com outro, sendo às vezes necessário se comunicar com outros motoristas, o que é feito por meio de sinais preestabelecidos, alguns reconhecidos internacionalmente, como o sinal de seta; em outros casos, há códigos de certos grupos, como entre os motoristas de caminhão, ou mesmo culturais, como no caso do brasileiro, que costuma "piscar" o farol alto para "informar" outros motoristas. 
O automóvel é uma máquina representativa do mundo moderno e do mundo construído nele representado. Javier Royo (2008), ao definir o ciberespaço em seu livro Design Digital, utiliza a classificação do filósofo contemporâneo espanhol Javier Echeverria, que em seu livro Cosmopolitas Domésticos ${ }^{11}$ propõe a divisão da realidade em três meios (ECHEVERRÍA apud ROYO, 2008):

1 - natureza-corpo

2 - cidade-sociedade

3 - telecomunicações-rede

Vemos que o modernismo é emblemático do segundo meio, culminando com as grandes metrópoles: no primeiro meio, o homem desenvolve a linguagem para comunicar-se com outros e organiza-se em clãs, inicialmente coletando ou caçando para sobreviver. Segundo Royo (2008), “como os sistemas de comunicação do meio natural são baseados na fala não há necessidade de Design”.

Já ao se organizar em sociedade, os códigos necessários para o homem comunicar-se tornam-se cada vez mais complexos e precisam ser padronizados, como é o caso da escrita. Com a organização social, o homem cria ferramentas e estruturas e, consequentemente, informações são atreladas a estes inventos. Portanto, em paralelo ao mundo construído, passamos a ter uma camada cultural de conhecimento - códigos que permitem a reprodução e o desenvolvimento das capacidades humanas. Essa informação é registrada seja em texto, passada oralmente ou representada em desenhos e planos que simbolizam e sistematizam processos. Vemos aí o início do design da informação: cidades passam a ser planejadas, organizadas em forma de grade, logradouros podem ser identificados e tabulados, uma infraestrutura que culmina com o modernismo.

\subsubsection{Interfaces analógicas e interfaces digitais}

Como vimos anteriormente, a interação do homem com o automóvel é um bom exemplo de utilização de interfaces da sociedade moderna, pois assim como a língua, escrita

\footnotetext{
${ }^{11}$ Javier Echeverría, Cosmopolitas domésticos, Barcelona: Anagrama, 1995. Javier Royo, Design Digital, São Paulo, Rosari, 2007.
} 
ou vestimentas, as interfaces são códigos que utilizamos para interagir com a sociedade e o meio construído, mesmo que não estejamos cientes do que sejam ou compreendamos o que é uma interface, como ocorre no caso do automóvel. O homem moderno tem criado interfaces cada vez mais complexas para interagir com seus inventos. O rádio é controlado por botões, mas para operá-lo devemos compreender que ao mudar a frequência sintonizamos outra estação e que elas são representadas por números que podem ser memorizados para que sejam sintonizadas em um outro momento. No mundo construído, as interfaces geralmente causam uma reação direta para cada ação física ou para cada objeto de controle. Por exemplo, ao girar o botão de volume, há um aumento da intensidade do som saindo do alto-falante ou ao pedalar uma bicicleta a força de nossas pernas é transferida para a roda, permitindo o deslocamento.

No caso dos equipamentos mecânicos, nos quais ocorre uma reação direta e imediata, é mais fácil para o homem compreender a interface como uma ferramenta. Tomemos o exemplo de uma máquina de escrever: ao pressionar uma tecla, a letra referente a ela é impressa na máquina, mas essa máquina já pressupõe o conhecimento de um código, neste caso a escrita. Já um telégrafo requer que o operador conheça previamente o código Morse e compreenda seus princípios; no caso, uma cartela impressa como o código serve de referência para o operador que não tenha memorizado o código. Ao buscarmos uma estação no rádio, nos referimos a uma lista de estações representadas numericamente, neste caso o design de informação deve estar integrado no desenho do produto, no caso o dial do receptor de rádio.

Ao projetarmos objetos cada vez mais complexos, vemos a necessidade da identificação de partes e controles e a criação de manuais de instruções. Isso é especialmente significativo no caso de aparelhos eletrônicos. É interessante notar como isso pode evoluir de várias formas, principalmente na introdução de uma nova tecnologia: nos anos de 1930, os primeiros aparelhos receptores mecânicos de TV a serem comercializados nos EUA eram kits que vinham acompanhados de manuais detalhados ${ }^{12}$, direcionados a entusiastas e exigiam um alto grau de conhecimento técnico para serem montados. Vimos o mesmo caso se repetir quando os computadores pessoais foram introduzidos nos anos de 1970. Além de uma certa facilidade do usuário com a configuração do sistema, os primeiros computadores exigiam o conhecimento da linguagem de programação da máquina.

\footnotetext{
12 O livreto Hollis Baird The Romance and Reality of Television, produzido em 1930 pela Shortwave and Television Corporation - Station W1XAV - Boston, Mass. - USA.
} 

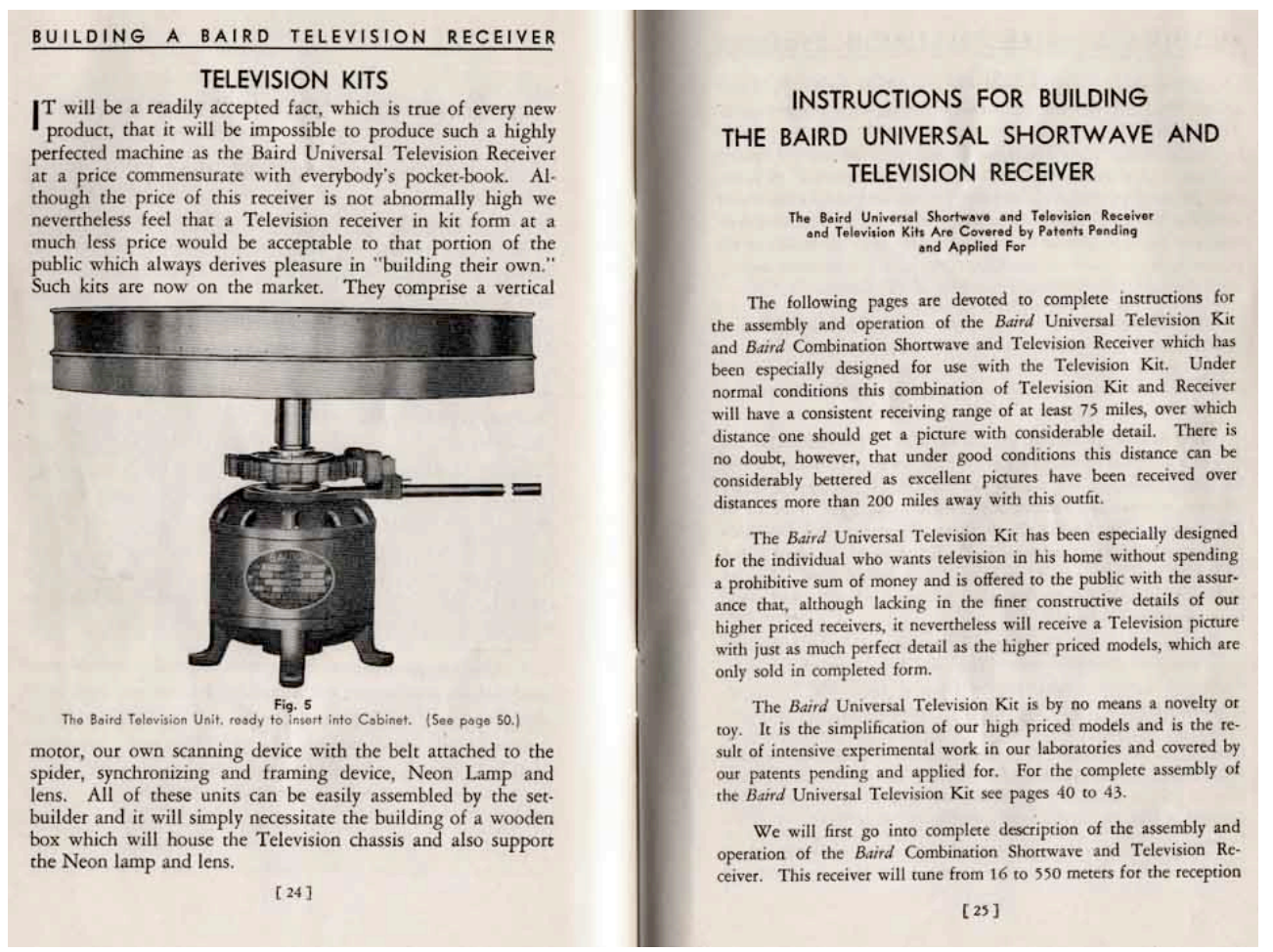

Fig. 2.1: Instruções para construir um kit receptor Baird de televisão em 1930 Fonte: http://www.tvhistory.tv

Objetos eletrônicos, assim como tem sido com outras ferramentas no passado, passam a ser extensões do homem; mas, com o desenvolvimento da indústria eletrônica, o design de interfaces passa de uma fase em que o usuário deve entender o funcionamento da máquina para uma fase na qual se deve facilitar a utilização do equipamento, surgindo então os princípios de "usabilidade", ciência oriunda da ergonomia. Ao considerarem a usabilidade de um produto, os engenheiros e designers passam a adequar a funcionalidade dos equipamentos ao ser humano ao invés de fazer com que estes se adaptem à máquina. Mesmo assim, certas regras e convenções devem ser aceitas em princípio. É interessante observar o interesse do ser humano por jogos e a relação dos jogos com suas regras e a disseminação destas em paralelo com o desenvolvimento de inventos.

O que há de particular com os objetos eletrônicos é que, mesmo no caso das tecnologias analógicas, a compreensão do funcionamento da máquina é cada vez mais abstrato, pelo menos para a maioria dos que a utilizam. Então o que prevalece é a necessidade de compreensão do sistema em que o equipamento se encaixa e as operações que devem ser 
realizadas para conseguir um dado objetivo. Por exemplo, para falar ao telefone, dirigimos a voz a um bocal (microfone) e escutamos a voz da pessoa do outro lado através de um pequeno alto-falante que colocamos ao ouvido; temos então uma conversa semiparticular com um receptor que transmite remotamente e está conectado conosco através de um par de fios de cobre (hoje sem fio em muitos casos).

Inicialmente não é necessário aprender a falar para se comunicar ao telefone, nem compreender a tecnologia, devemos apenas nos adaptar a um novo hábito de comunicação. Com a evolução da tecnologia, esta torna-se mais complexa. No início, ao se fazer uma ligação, havia um(a) operador(a) que realizava fisicamente a conexão de uma linha com a outra em uma central telefônica; com o surgimento das centrais mecânicas, essa função passa a ser realizada pelo usuário, que utiliza um disco para entrar com os dados da conexão a ser realizada. Com o número de assinantes crescendo, torna-se necessária a compilação, edição e a distribuição de listas telefônicas que passam a integrar esse sistema, adicionando uma camada de informação. Hoje, a lista de telefones está integrada aos nossos aparelhos, sendo possível guardá-la na memória do telefone. Com a iminente proliferação de telefones conectados à internet, será possível acessar listagens do mundo inteiro diretamente do aparelho.

Vemos que, embora os sistemas tenham se tornado mais complexos, em muitos casos, como no da TV, foi necessária a integração de diversas funcionalidades em um sistema: câmera, transmissor, antena, aparelho receptor etc. No início, os aparelhos utilizados na comunicação eletrônica tinham uma única função: um telefone servia para a comunicação de voz entre duas pessoas, um telégrafo para enviar sinais codificados, um fac-símile para transmitir imagens e assim por diante. Com o passar do tempo, ficou cada vez mais comum objetos integrarem diversas funcionalidades: os primeiros receptores de televisão integraram um receptor de imagens a um rádio; o automóvel passou a incorporar um rádio em seu painel; nos anos de 1970, tornou comum a produção de aparelhos 3 em 1 que consistiam em uma combinação de toca-discos, rádio e toca-fitas. Hoje, vemos a combinação de diversas funcionalidades em um único objeto que não representam necessariamente sua função: um celular pode funcionar perfeitamente como uma câmera, mas não se assemelha em nada com a noção estabelecida do que uma máquina fotográfica deva parecer. Portanto, hoje a forma de um objeto pode não representar sua função, embora seja perfeitamente capaz de realizar funções diversas. 


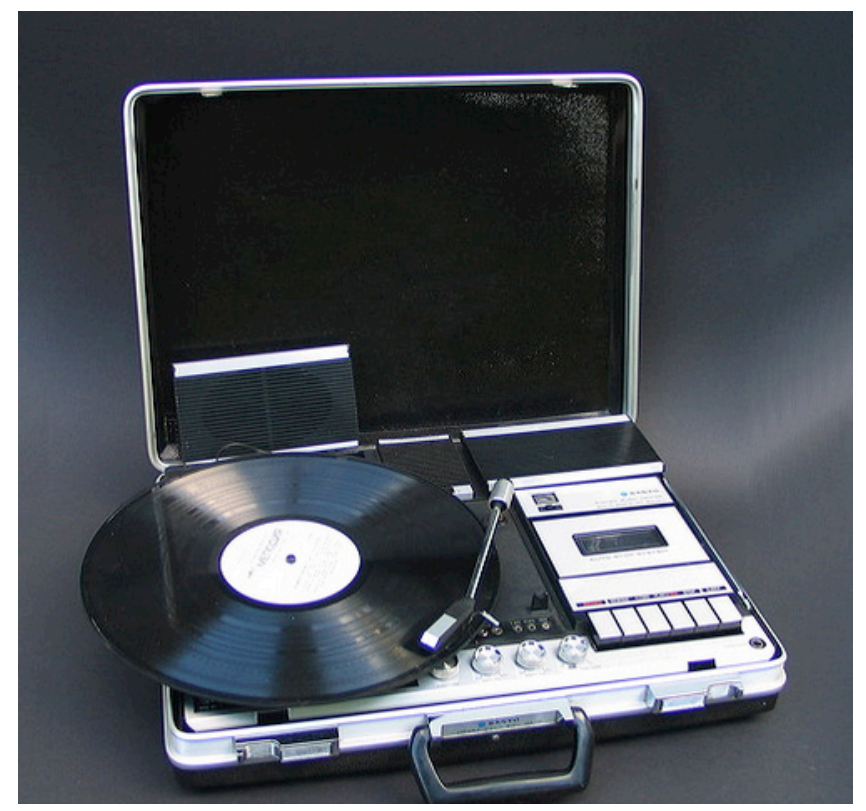

Fig. 2.2 Wega Stereo Set by Verner Panton, 1963

Fonte: http://www.soundmuseum.com

Com a digitalização, as funções de um aparelho, a forma de evidenciá-las deve sobrepor-se, através de camadas visuais ou da temporalidade da representação da informação. Isso se dá principalmente por meio das interfaces gráficas. Mas, antes de entrarmos neste assunto, vamos voltar brevemente às interfaces dos primeiros aparelhos eletrônicos: em alguns casos, as funções não eram evidentes fisicamente, como no caso de localizar uma música em um tocador de fita cassete; para se localizar uma música em um disco long play, era possível visualizar a faixa por indicações nos sulcos do vinil, estando o disco em movimento bastava abaixar o braço da vitrola para reproduzi-la. Já no caso de uma fita cassete, é necessário acionar o comando de reprodução ou de avanço rápido para localizar uma música; uma operação até então bastante simples se torna bastante complexa, para não dizer suscetível a uma imprecisão.

Se por um lado a fita cassete adicionava novas facilidades à reprodução de música gravada, com a possibilidade de compilar uma coleção individual de música e a facilidade de mobilidade do equipamento, ela passa a exigir o desenvolvimento de uma interface indireta, em que as operações são representadas por símbolos - reprodução, gravação, pausar, parar e retroceder - que identificam teclas que, de outro modo, são idênticas e acionam o mecanismo interno de modo diferente. Por exemplo, a combinação da tecla de reprodução com a de avanço rápido possibilita a reprodução de modo rápido da música. Neste caso, vemos duas inovações: a utilização de símbolos abstratos (setas e cores) representando funções físicas e a 
utilização de indicadores de status e indexação, no caso o estado do botão (pressionado ou não) indicando o estado da função, enquanto uma janela no cartucho da fita permite observar quão próximo se está do início ou final da fita.

Assim como o rádio necessita da representação numérica da frequência sendo sintonizada em um dial para que o ouvinte encontre uma estação, os aparelhos de fita cassete utilizam símbolos para representar funções para localizar uma música. Se em ambos os casos esta simbologia tem uma relação direta com funções mecânicas dos aparelhos, no caso da fita cassete o som está gravado magneticamente na fita e não é visível aos nossos olhos (embora haja uma alteração física do substrato) e, portanto, é necessária a utilização de uma interface para determinar o início de uma música.

Com a digitalização, passamos a ter que representar funções utilizando metáforas de processos e objetos existentes ou conhecidos pelos usuários, pois não há necessariamente uma ação e reação física ao se realizar uma tarefa. Por exemplo: ao executarmos uma música em um iPod ou um aparelho de MP3 (tocadores digitais de música), acionamos a tecla Play (>) simbolizada por um ícone que representa o avanço de uma fita gravada e que nos induz a pensar que algo se movimenta, mas, na realidade, nada está tocando, o que esta ocorrendo é que a informação digitalizada daquele som está sendo acessada e uma ordem é enviada para que ele seja modulado em frequências elétricas que irão chegar a um fone de ouvido; a única coisa que se move na realidade é a membrana do fone de ouvido, que ao vibrar movimenta o ar e consequentemente nossos tímpanos.

\subsubsection{Metáforas e a linguagem das interfaces}

Hoje nos encontramos em um estágio em que projetamos interfaces que na maioria dos casos utilizam metáforas representando objetos, funções e tarefas do mundo construído. Mas, se considerarmos que estamos vivendo em uma sociedade onde grande parte de nossas atividades são realizadas em redes de telecomunicação, ou seja, no ciberespaço, percebemos que há um esforço desnecessário aplicado à tradução do mundo construído para o mundo virtual.

Vamos tomar o exemplo de uma máquina de escrever: desde criança aprendemos a desenhar as letras de nosso alfabeto utilizando um lápis ou uma caneta, e com isso conseguimos expressar-nos com a palavra escrita; agora, se queremos apresentar um trabalho 
finalizado, uniformizado e facilmente reproduzível procuramos digitalizar o texto, seja em uma máquina de escrever ou um processador de texto, casos em que utilizamos a mão de uma forma totalmente diferente, pois a máquina realiza a tarefa de desenhar as letras; para isso temos que conhecer a posição dos caracteres em um teclado - QWERTY -, e esta interface tem uma reação imediata ao nosso comando (input), ou seja, é uma interface WYSIWYG ${ }^{13}$. Já um programa gráfico de desenho em um computador, como o Paint ou Photoshop, utiliza um lápis ou papel para facilitar a ação de algo que simula essa ferramenta, mas que no fundo é totalmente diferente, pois sabemos que a utilização dessas metáforas é completamente redundante, tornando os programas cada vez mais pesados.

Estudantes de cinema podem nunca ter visto um filme ser editado da forma analógica em uma Moviola, uma máquina onde se carregam rolos de película que são cortados e colados fisicamente, mas montam seus filmes em programas de edição que utilizam o símbolo de uma lâmina para realizar um corte no "ponto de edição" e os "rolos" são representados e organizados em tiras, como era feito anteriormente. No entanto, esse processo é bastante confuso para quem não passou pela experiência anterior: isto é, se o objetivo é selecionar trechos de um filme e conectá-los (isto ainda considerando que se pretende realizar uma montagem de modo linear), talvez faça mais sentido realizar a tarefa através de alguma outra forma de indexação e conexão dos elementos físicos. Como essas interfaces foram projetadas em um primeiro momento para substituírem os equipamentos existentes e serem utilizadas pelos técnicos já familiarizados com estes, elas acabam simulando processos completos, mas que no final tornam a tarefa bastante ineficiente, para não dizer confusa para quem não tem essa bagagem (e não precisa dela).

Não estou dizendo que a linguagem, a gramática da montagem de um filme ou da escritura de um texto deve ser ignorada ou reinventada, pelo contrário, o foco de atenção de um desenvolvedor de uma interface ou de um programa de computador deve ser exatamente a essência, mas deve no futuro libertar-se das limitações fisíco-mecânicas dos processos atuais. Estes, por sua vez, também devem ser preservados pois geram "ruídos" particulares no meio e podem ser incorporados a qualquer momento como um elemento de linguagem, mas não como um "ruído" que interfira na funcionalidade do processo.

\footnotetext{
${ }^{13}$ WYSIWYG é o acrônimo de What you see is what you get, significando que há uma resposta direta do computador ao input do usuário.
} 


\subsubsection{A camada das marcas}

No pós-modernismo, vemos a sociedade de consumo criar uma nova camada entre o homem e o meio construído, as máquinas e os objetos. Segundo Guy Debord (1967) ${ }^{14}$, a marca e atributos de marketing adicionaram aspectos não funcionais como o desejo, a obsolescência e as tendências da moda aos produtos construídos. O design de uma interface vem imbuído dos valores da marca e às vezes pode ser construído completamente por ela. Vejamos o caso de uma loja virtual: se considerarmos a comparação entre duas empresas tomando por exemplo uma empresa sólida e preestabelecida no mundo real, como por exemplo a Livraria Cultura ou a Barnes \& Noble, nos EUA, e outra empresa cujo site é bem desenhado, é funcional e entrega o que promete, como por exemplo a Amazon ou o site de vendas Submarino. Estas empresas virtuais, embora nunca visitadas fisicamente pelos seus clientes e sem referenciais históricos, hoje recebem a confiança de seus clientes baseada na sua representação gráfica, na funcionalidade de sua arquitetura de navegação, na segurança de seus sistemas de cobrança e principalmente no seu histórico documentado por seus clientes e divulgado na internet.

Mesmo em relação ao design do produto em si, muita coisa mudou na sociedade pósmoderna. Um carro não é mais apenas um transporte, mas uma experiência em si, um símbolo de status ou um estilo com o qual o consumidor se identifica; acessórios, detalhes que nada tem a ver com a funcionalidade do automóvel, servem como atrativos para um consumidor escolher um determinado modelo ou marca. Se observarmos os anúncios de automóveis, podemos notar que se tem dado cada vez mais importância ao conforto no interior do veículo, aos acessórios, entretenimento ao incorporar tocadores de música digital e DVDs, sistema de informação como GPS que auxiliam na navegação e computadores de bordo que auxiliam no comando do veículo, cores e detalhes e uma infinidade de modelos que tornam o veículo atrativo para grupos diversos. Há carros para mulheres, jovens, idosos, rebeldes, comportados ou aventureiros, mas em comparação pouca importância é dada a características do veículo como autonomia de rodagem, manutenção, emissão de gases.

\footnotetext{
${ }^{14}$ Guy Debord, La société du spectacle, 1967, tradução em inglês The Society of the Spectacle, Zone Books, 1995.
} 


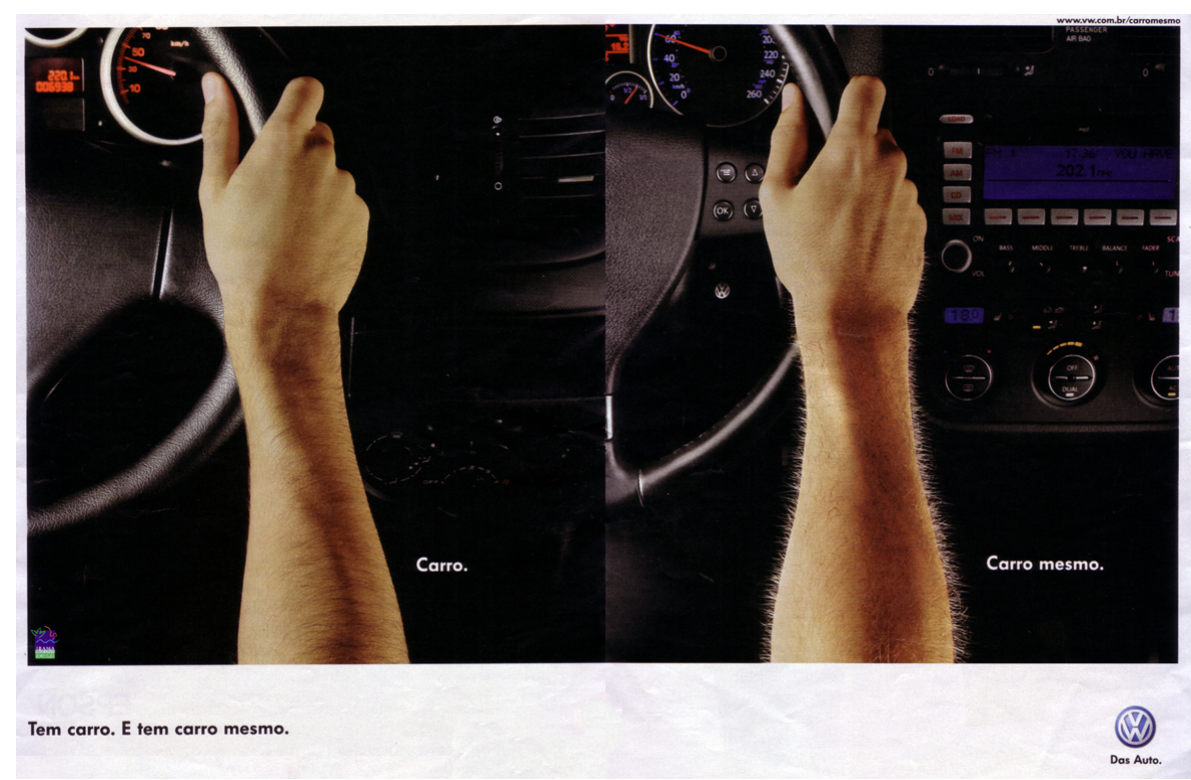

Fig. 2.3: Anúncio da Volkswagen do Brasil

Fonte: Revista Veja, março de 2009

\subsection{5 Áreas de interesse no Design de Interfaces para TVDI}

Diversas pesquisas em interfaces para Televisão Digital Interativa - TVDI que apresento neste capítulo se fixam em um design determinado pelas especificações dos sistemas de TV Digital. Como veremos com mais detalhes no capítulo 4, na convergência digital um novo paradigma se estabelece na TV Digital, trazendo para o designer atuante nesta nova mídia, o desafio de incorporar diversas competências em seu trabalho. Três áreas do design já estabelecidas são especialmente relevantes como base para o Design de Interfaces para TV Digital. Estas áreas de interesse específico são:

a) Design de Interfaces Analógicas. Design de interfaces aplicadas ao design de produto (desenho industrial) de equipamentos de escritório e de produção e recepção audiovisual: telefone, telégrafo, rádio, calculadoras, videogames etc. Esses produtos estão sendo incorporados no repertório visual e funcional da TV Digital, já que com a convergência dos meios passa a ser possível realizar diversas dessas funções na TV e muitos desses aparelhos servem como base para o desenvolvimento de interfaces na computação. 
b) Design de Interfaces Digitais. São as interfaces aplicadas à computação: é a principal área de conhecimento a ser pesquisada, tanto os seus aspectos históricos, como os princípios estabelecidos na prática atual. Os principais expoentes da área também merecem uma especial atenção, assim como pesquisas inovadoras e novas tecnologias que têm sido introduzidas. A área de videogames, tradicionalmente pouco estudada tanto em IHC como no campo do audiovisual, tem aberto novas possibilidades e tem se tornado presente no cotidiano das gerações mais novas.

c) Design Televisual ou Design em movimento. Designers atuando na TV têm dominado as ferramentas de representação gráfica e animação nas emissoras de televisão. O campo que surgiu do encontro do design gráfico com animação tem seus pioneiros no cinema. Com a explosão da TV a cabo e a necessidade de identificação das emissoras, tem crescido em um mercado cada vez mais competitivo, e é responsável em grande parte por criar o imaginário e o ambiente da TV. Hoje, esta área de atuação também é conhecida como motion graphics e não se limita mais ao meio televisivo, tendo encontrado aplicações em painéis eletrônicos instalados em aeroportos, lojas, cinemas e sistemas de transporte público.

\section{Design da Experiência}

Designers têm atuado no campo do design das mídias digitais em diversas capacidades: design de produto, interfaces gráficas, motion graphics, interação. Inicialmente essas competências têm sido bem delimitadas; a crescente complexidade dos sistemas e produtos digitais resultante da pervasividade computacional e ubiquidade de dispositivos digitais têm ofuscado os limites dessas especialidades (PINHEIRO, 2007). Richard Grefé (2000) introduziu a disciplina de experience design como um novo campo de Design na AIGA (American Instirute of Graphic Arts) que emerge das necessidades de comunicação da economia de rede (VARNELIS). Segundo Grefé, o esquema do designer Clement Mok, no qual se mapeiam as profissões envolvidas nas mídias analógicas e digitais aplicadas ao design da comunicação e o design do produto, revela os desafios de definir uma "profissão" que atenda aos requisitos desta nova economia (GREFÉ, 2000). 
O design da experência, como uma disciplina, envolve as habilidades que no passado eram associadas a profissões distintas, é um exemplo dos desafios da produção coletiva e multidisciplinar da nova economia. As profissões destacadas neste diagrama estão ativamente envolvidas no novo campo do design da experiência. ${ }^{15}$ (MOK apud GREFÉ, 2000, p. 7).

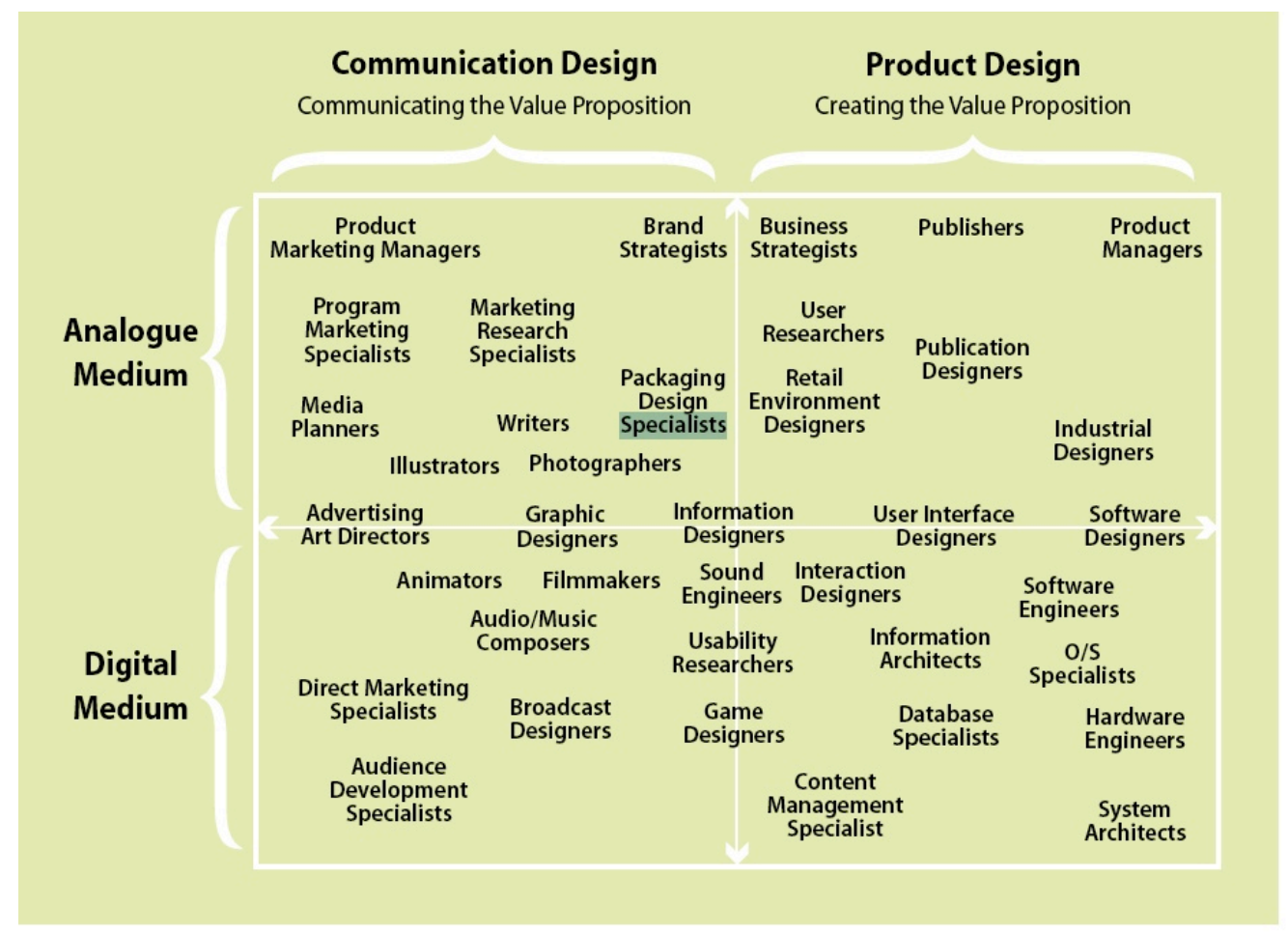

Design: Clement Mok, Sapient

Fig. 2.4: As Profissões do Design da Experiência

Fonte: Gain AIGA Journal for the Network Economy, vol. 1, n. 1, 2000.

No capítulo 4, irei contextualizar o design para TV Digital dentro de um cenário de convergência das mídias no qual o design tem um papel central na identidade destas. Neste cenário, o design passa a ser multidisciplinar e cada vez mais centrado na informação. As pesquisas que têm sido desenvolvidas desde os anos de 1960 em design de interação são pouco conhecidas por designers gráficos e de produto e fundamentais como base no desenvolvimento de produtos e serviços digitais.

\footnotetext{
${ }^{15}$ Tradução minha de: "Experience design, as a discipline, involves the skills associated in the past with many discrete professions. In this respect, it is an exemplar of the team oriented, cross-disciplinary challenges of the new economy. The highlighted professions in this diagram are actively involved in the new field of experience design and are welcome participants in AIGA Experience Design.” (GREEFÉ, 2000).
} 


\subsection{Pioneiros em Design de Interfaces Gráficas}

Apresento aqui um quadro de referência teórico do design de interfaces gráficas e as novas mídias. Este estudo expõe a síntese das ideias e algumas citações de autores considerados fundamentais na área.

Designing Interactions, editado por Bill Moggridge, conta com a introdução de Gillian Grampton Smith e acompanha um DVD de entrevistas com vários dos designers e autores que participam do livro. Além de Moggridge e Smith, neste trabalho apresento as ideias de Alan Kay, Doug Engelbart, Larry Tesler e John Maeda contidas em entrevistas, artigos e livros. Dou especial atenção às pesquisas do laboratório Xerox Parc, onde se originou a interface gráfica dos computadores pessoais tal como a conhecemos hoje, e ao trabalho desenvolvido por Brenda Laurel tanto no seu livro The Art of Human Computer Interface Design (1990), que foi um marco ao coletar textos, pesquisas e discutir interfaces que operam através de metáforas e símbolos, como também em Computers as Theater, em que traça um paralelo entre o de design de interface e a representação teatral. Em relação às novas direções que o design de interação tem tomado, a revista Interactions, publicada pela SIGCHI (Special Interest Group Computer Human Interaction) da ACM (Association for Computer Machinery), é uma referência fundamental para manter-se atualizado.

\subsubsection{Doug Engelbart - Aumentando o intelecto humano}

Douglas C. Engelbart é considerado o inventor do mouse. Bill Moggridge relata que, ao entrevistá-lo sobre o seu invento, Engelbart conta que estava entediado em uma conferência e observava um aparato de medir superfícies curvas que utilizava duas roldanas em eixos opostos; a partir dessa observação, esboçou algumas ideias em que um mecanismo poderia dimensionar a distância no eixo leste-oeste e norte-sul, assim concebendo o mouse (MOGGRIDGE, 2007, p. 17). No início dos anos de 1960, Engelbart obteve financiamento para pesquisar formas de interagir e selecionar objetos na tela do computador, trabalhando com o designer Bill English no Stanford Research Center, nos EUA.

Englebart e English iniciaram a pesquisa utilizando inventos disponíveis na época, como o light-pen e track ball, e foi aí que resgataram esboços que haviam feito anteriormente, culminando na invenção do primeiro mouse. Ao ser testado por usuários sem experiência com computadores, o mouse provou ser o mais intuitivo dos inventos, pois permitia maior 
naturalidade na interação com a tela do que um teclado. Esses testes foram inovadores porque nesse período ainda não existia a disciplina de "fatores humanos" na computação. Somente mais tarde, quando Stu Card desenvolve os menus "pull down" é que sistematicamente passam a testar a interação dos usuários com os computadores.

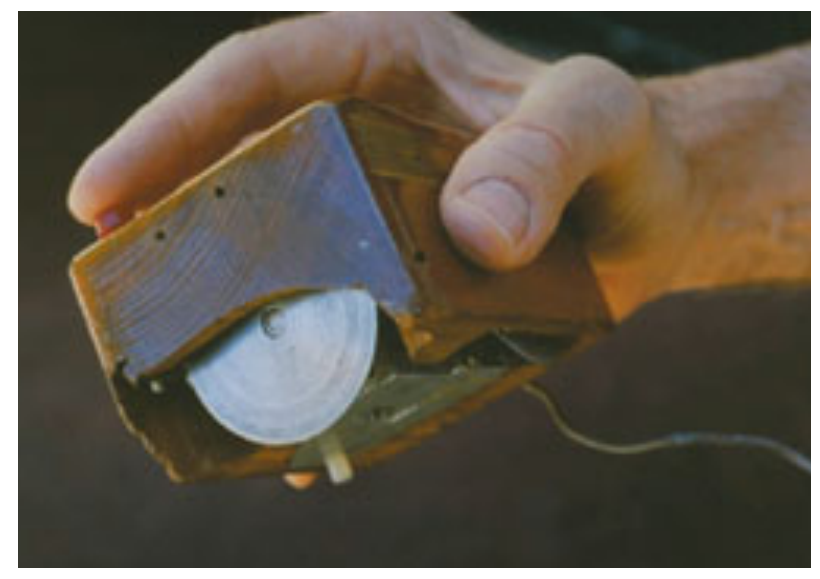

Fig 2.5: Primeiro mouse, $1963-1964$

Fonte: Designing Interactions

Engelbart cita a influência do "Memex" de Vannevar Bush, uma máquina que permitiria incrementar a memória dos seres humanos. O interesse pelas ideias de Bush leva-o a dedicar-se exclusivamente à pesquisa de um sistema que pudesse aumentar a capacidade humana de processar e armazenar informação e utilizá-la no seu dia a dia no Augmentation Research Center (ARC), laboratório onde desenvolveu o “oN-line System” (NLS). Em 1968, realizou uma demonstração desse sistema que permitia pessoas conectadas remotamente a interagir com um computador através de uma interface gráfica e um mouse. Muitos acreditam que esse demo tenha "mudado o mundo" (MOGGRIDGE, 2007). Em um dos artigos publicados sobre as pesquisas desenvolvidas no $\mathrm{ARC}$, Engelbart define quatro áreas em que o intelecto humano pode ser "aumentado":

1. Artefatos - Objetos físicos projetados para oferecer conforto aos homens, a manipulação de coisas ou materiais, e a manipulação de símbolos.

2. Linguagem - a forma como indivíduos classificam (traduzem) retratos de seu próprio universo em conceitos que suas mentes utilizam para modelar o mundo, e símbolos que anexam a estes conceitos e utilizam conscientemente para manipular os conceitos ("pensar")

3. Metodologia - os métodos, procedimentos e estratégias com as quais um indivíduo organiza suas atividades centralizadas em meta (resolução de problemas). 
4. Treinamento - o condicionamento necessário para um indivíduo aumentar suas capacidades nas áreas 1, 2 e 3 de modo que sejam operacionalmente efetivas.

Portanto o sistema que pretendemos melhorar pode ser visualizado como um ser humano treinado, junto com seu artefatos, linguagem e metodologia. $\mathrm{O}$ novo sistema explícito que contemplamos incorporará como artefatos os computadores, o armazenamento de informações controlados por computadores e a manipulação de informação e dispositivos para visualização de informações. Os aspectos deste quadro de referência conceitual que discutimos aqui são primariamente aqueles relacionados à habilidade individual de se fazer um uso significativo deste equipamento em um sistema integrado. (ENGLEBART, 1962 apud MOGGRIDGE, 2007, p. 32) ${ }^{16}$.

No demo do "oN-line System" na "Fall Joint Computer Conference" de 1968, Engelbart apresenta em tempo real a possibilidade de interação de usuários de dois computadores remotos, de menus gráficos hierárquicos e diversas inovações, como a possibilidade de selecionar links, visualizar a informação de modos diferentes e outras que foram incorporadas nos computadores que hoje utilizamos diariamente.

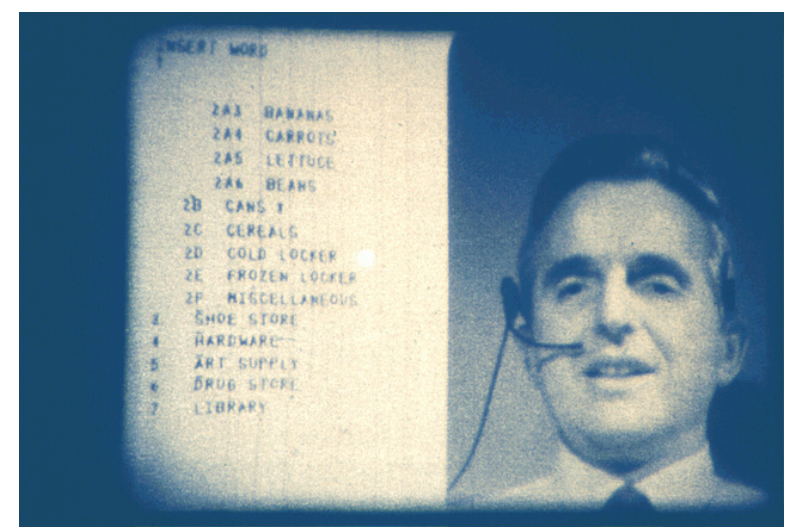

Fig. 2.6: Engelbart apresentando o oN-line System em 1968 Fonte: New Media Reader

\footnotetext{
${ }^{16}$ Tradução minha de: Douglas C. Engelbart, Augmenting Human Intellect, 1962.

“(1) Artifacts - physical objects designed to provide for human comfort, for the manipulation of things or materials, and for the manipulation of symbols.

(2) Language - the way in which the individual parcels out the picture of his world into the concepts that his mind uses to model that world, and the symbols that he attaches to those concepts and uses in consciously manipulating the concepts ('thinking').

(3) Methodology the methods, procedures, strategies, etc., with which an individual organizes his goal_entered (problem-solving) activity.

(4) Training - the conditioning needed by the human being to bring his skills in using Means 1, 2, and 3 to the point where they are operationally effective.

The system we want to improve can thus be visualized as a trained human being together with his artifacts, language, and methodology. The explicit new system we contemplate will involve as artifacts computers, and computer-controlled information-storage, information-handling, and information-display devices. The aspects of the conceptual framework that are discussed here are primarily those relating to the human being's ability to make significant use of such equipment in an integrated system.
} 
Em seu artigo "Augmenting the Human Intellect", publicado em 1962, Engelbart define que "Aumentar o Intelecto Humano significa aumentar a capacidade de o ser humano lidar com uma situação ou problema complexo" e estabelece os motivos de suas pesquisas ao afirmar que "A população humana e sua produção aumentam consideravelmente, mas a complexidade de seus problemas ainda aumenta mais rapidamente e a urgência destes problemas é cada vez maior." E apresenta um quadro de referência conceitual no qual sugere hierarquias de processos, pequenos passos que as pessoas podem usar para resolver problemas complexos, sínteses de nossas capacidades para resolver problemas complexos (ENGELBART, 1962).

Tecnologias existentes ou do futuro próximo podem certamente prover aos profissionais solucionadores de problemas as ferramentas necessárias para duplicar e rearranjar texto diante de seus próprios olhos, rapidamente e com o mínimo de esforço humano. Este aparente pequeno avanço pode resultar em mudanças radicais no repertório de hierarquias de um indivíduo, o que representaria um grande ganho na eficácia de modo geral." (ENGELBART, 1962, p. 12)..$^{17}$

\subsubsection{Alan Kay - Interface do Usuário, sua visão pessoal}

Alan Kay é um norte-americano conhecido pelo seu trabalho pioneiro em programação orientada por objetos, design de interface gráficas com "múltiplas janelas" e a invenção do Dynabook, predecessor do laptop. Em seu texto User Interface: A Personal View (KAY, 1990), descreve essas pesquisas e como seu trabalho foi influenciado pela leitura da obra Marshall McLuhan e pelos estudos de psicologia cognitiva conduzidos por Seymour Papert (1980).

Com um grande interesse em computação pelo que se denominava "ergonomia" na Europa ou "Fatores Humanos" nos EUA, passou a incorporar em sua pesquisa ideias de McLuhan apos a leitura de Understanding Media (McLUHAN, 1964), quando descobriu que a coisa mais importante sobre qualquer meio de comunicação é "recuperar a mensagem" em que o receptor tenha o meio internalizado de modo que se subtraia o meio e só reste a mensagem. Ele conclui que o computador é um meio e que, assim como ocorreu com a

\footnotetext{
${ }^{17}$ Tradução minha de: "Existing, or near-future, technology could certainly provide our professional problemsolvers with the artifacts they need to have for duplicating and rearranging text before their eyes, quickly and with a minimum of human effort. Even ao apparently minor an advance could yield total changes in an individual's repertoire hierarchy that would represent a great increase in over-all effectiveness." (ENGELBART, 1962, p. 12).
} 
introdução do livro na Idade Média, através dele haverá uma transformação nos padrões de raciocínio daqueles que são letrados.

Em 1968, estava desenvolvendo a ideia de um computador do tamanho de um livro de anotações que ele chamou de Dynabook, "capturando a metáfora de McLuhan no silício que estava por vir". Nesse, período conhece o trabalho de Seymour Pappert, que estava desenvolvendo a linguagem LOGO de programação para crianças ou pessoas que não tinham conhecimento de computação. Pappert aplica as teorias de Jean Piaget nessa linguagem de programação. O Dynabook veio a ser o que hoje conhecemos como computador Laptop ou Tablet PC, mas seu projeto original tinha como objetivo ampliar o acesso das crianças às mídias digitais, embora também pudesse ser utilizado por um adulto.

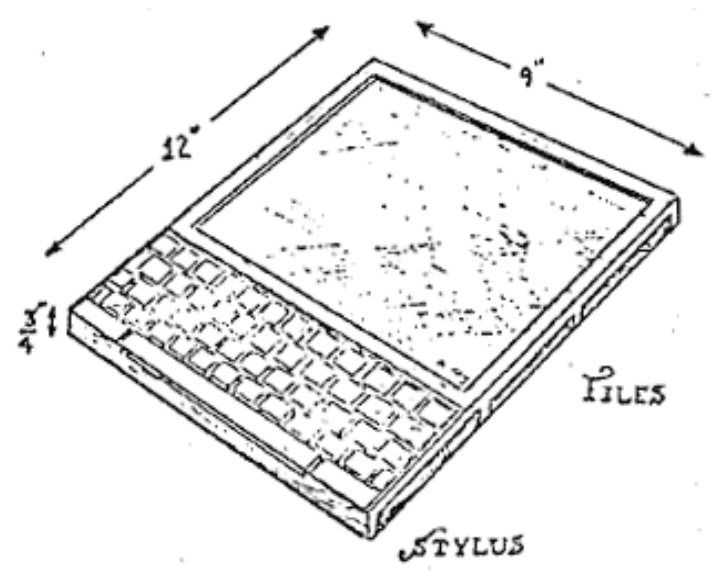

Fig 2.7: Desenho esquemático do Dynabook de Alan Kay Fonte: Wikipedia

Kay pessoalmente não encontra aplicação prática nas teorias de Piaget, mas é bastante influenciado pelo trabalho de Jerome Brunner Towards a Theory of Instruction (1966), que segundo ele encontrou uma forma bastante poderosa de aplicar as teorias de cognição de Piaget ao decompor a capacidade humana de aprendizado nas seguintes mentalidades:

\section{-Cinestésica}

-Icônica

-Intuitiva 
Kay afirma que as interfaces homem-máquina são como aprender, portanto devem basear seu desenvolvimento em teorias de cognição humana. Em A Personal View, Alan Kay apresenta um modelo das funções de cada mentalidade:

$\begin{array}{ll}\text { “representativa } & \text { conhecer onde se está situado, manipular } \\ \text { icônica } & \text { reconhecer, comparar, configurar, concretizar } \\ \text { simbólica } & \text { juntar longos encadeamentos do raciocínio, abstrato" }\end{array}$

A partir do que concebeu o mote:

“Fazendo com Imagens produz Símbolos”18 (KAY, 1990, p.196).

Segundo Kay, sua afirmação implica que se deve começar da forma concreta "Fazendo com Imagens" e ser levado ao mais abstrato "produzindo Símbolos".

Essas ideias são postas em prática no projeto FLEX que desenvolviam no Xerox Parc. FLEX era uma pequena máquina com um display de LCD plano e uma tablet como dispositivo de entrada que usava caneta para apontar os objetos. Como o display do FLEX era bastante reduzido, a solução foi utilizar na interface múltiplas janelas sobrepostas umas sobres as outras (já no NLS havia múltiplos painéis).

Aqui vemos o modelo onde Kay aplica as teorias de Brunner na interface desse projeto (KAY, 1990, p. 197):

\begin{tabular}{llll}
\hline FAZER & mouse & $\begin{array}{l}\text { representativo } \\
\text { situado, manipular }\end{array}$ & conhecer onde se está \\
Com & ícones, janelas & icônico & $\begin{array}{l}\text { reconhecer, comparar } \\
\text { configurar,concreto concretizar/ }\end{array}$ \\
SMAGENS & Smalltalk*19 & simbólico & $\begin{array}{l}\text { juntar longos encadeamentos do } \\
\text { raciocínio, abstrato }\end{array}$ \\
\hline
\end{tabular}

Tabela 2.1: Modelo de Alan Kay em A Personal View, 1990

\footnotetext{
${ }^{18}$ Tradução minha de: "Doing with Images makes Symbols”.

19 "Smalltalk" é uma linguagem de programação orientada por objetos.
} 
Segundo Kay, a obra de Pappert convenceu-o de que:

É preferível aprender algo cinestesicamente, depois iconicamente, e finalmente o conhecimento intuitivo estará implantado de modo a permitir que os poderosos processos simbólicos, embora menos vividos, entrem em ação com força total." $(\mathrm{KAY}, 1990)^{20}$.

\subsubsection{A metáfora do Desktop}

Os projetos desenvolvidos pelo laboratório Xerox Parc culminaram em 1981 no lançamento comercial pela Xerox do sistema Star, considerado uma "revolução no design de interfaces para computadores pessoais" (PREECE et al., 2005, p. 53). O Star combinava inovações do Alto como um display com uma resolução que permitia exibir imagens gráficas e a linguagem Smalltalk de Alan Kay. O sistema não teve um bom desempenho de vendas; quando de seu lançamento, a Xerox realizou estudos de mercado que sugeriam que o seu público-alvo pagaria mais pela tecnologia incorporada no sistema, no entanto este mesmo público acabou optando por pagar menos pela interface inferior do IBM PC lançado pouco depois (MOGGRIDGE, 2007).

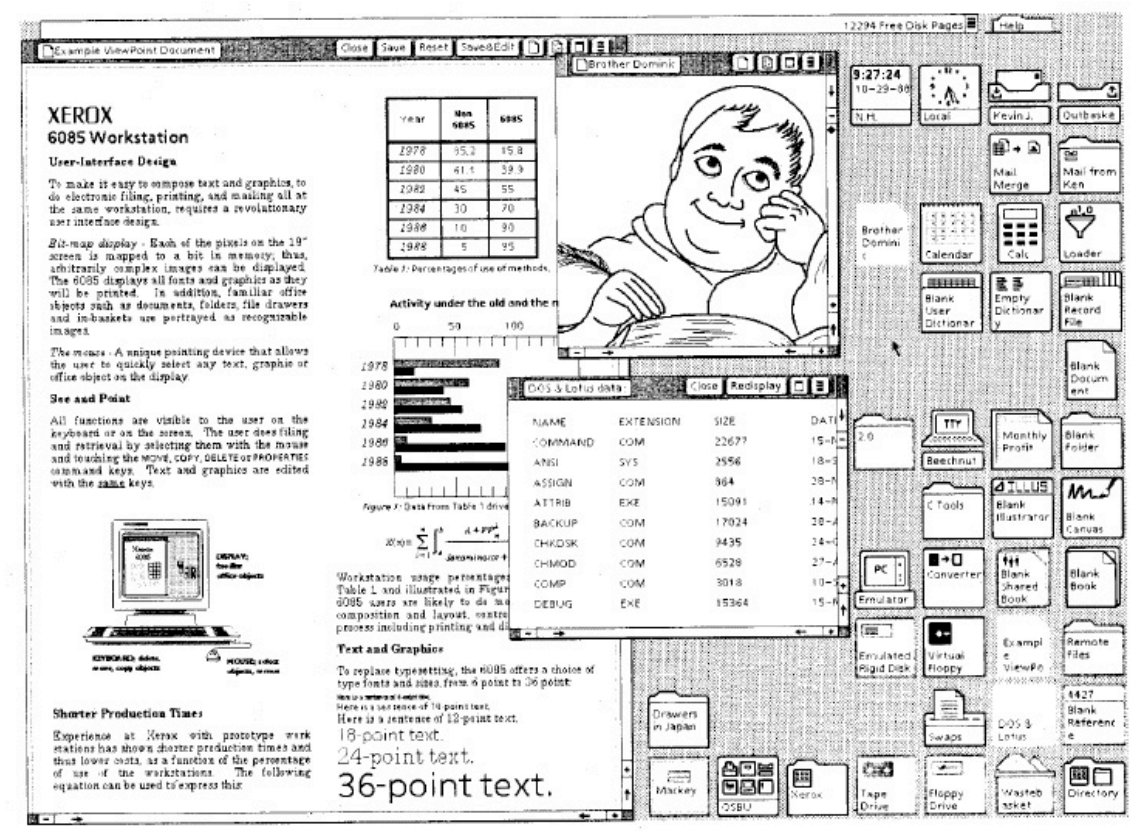

Fig. 2.8: Interface do Xerox Star System, 1981

Fonte: http://www.digibarn.com/friends/curbow/star/retrospect/

\footnotetext{
${ }^{20}$ Tradução minha de: "It's best to learn something kinesthetically, then iconically, and finally the intuitive knowledge will be in place that will allow the powerful but less vivid symbolic processes to work at their strongest."
} 
Steve Jobs, em visita ao laboratório da Xerox, interessou-se pelo Smalltalk, trazendo Alan Kay para a Apple para incorporar as pesquisas da Palo Alto em seus computadores, culminando com o lançamento do Macintosh em 1984, com o slogan "The computer for the rest of us (o computador para o resto de nós)" (JOHNSON, 2001). Eventualmente muitas das ideias do sistema Star implementadas no sistema operacional do Apple Macintosh foram “adaptadas” no Microsoft Windows para utilização nos computadores PCs, que ironicamente tiveram um papel no fracasso comercial do Star. A introdução do Macintosh, ao popularizar as interfaces gráficas, tornou os computadores pessoais mais amigáveis e acessíveis.

com uma metáfora do desktop inventiva, fascinante, que introduziu na imaginação popular quase todos os elementos da interface atual: menus, ícones, pastas e lixeiras. Mais de uma década depois, ela continua sendo o padrão pelo qual todas as interfaces são julgadas. Pode-se dizer com segurança que todos os aperfeiçoamentos de interfaces feitos desde então são meras variações em torno desse tema origina (JOHNSON, 2001, p. 41).

\section{Apple introduces Macintosh. The computer for the bemused, confused and intimidated.}

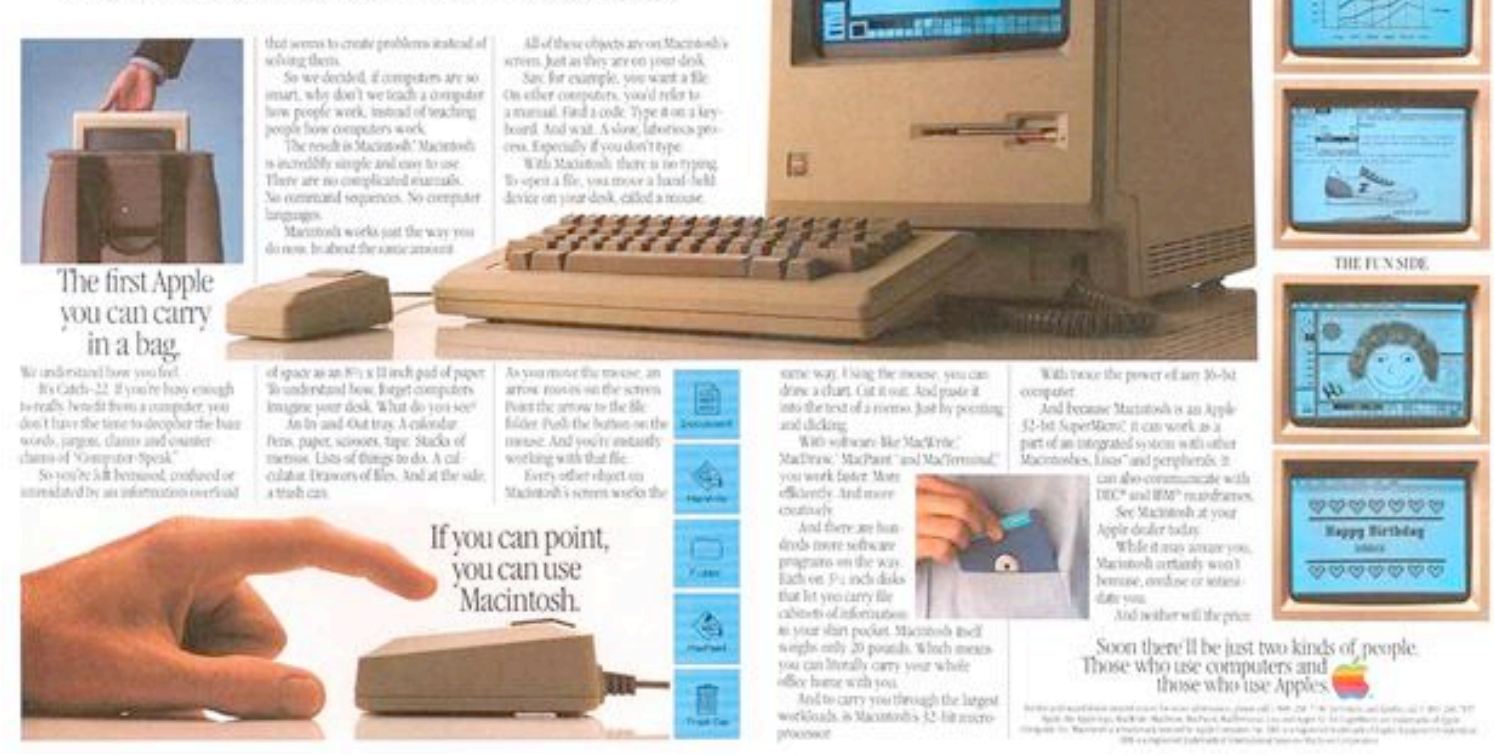

Fig. 2.9: Um dos anúncios publicados pela Apple ao lançar o Macintosh, 1984

Fonte: http://www.vhml.org/theses/nannip/HCI_final.htm 


\section{Apple Computer, o Macintosh e a interação humano-computador}

Um das características mais marcantes da interface do Macintosh é a metáfora do "Desktop", que pode ser traduzido como "escrivaninha". Ela surgiu da necessidade de como pensar em uma interface onde o usuário pudesse realizar ações em documentos e arquivos como arquivá-los o renomeá-los de uma forma externa ao invés de realizá-las internamente nas próprias páginas ou texto do arquivo. Essa metáfora tem sua origem no laboratório de pesquisa da Xerox, quando Tim Mott, obcecado por resolver esse problema, começou a rabiscar em um guardanapo um esquema de um escritório onde seria possível mover documentos que seriam arrastados de um lugar para outro através de ícones representando gabinetes de fichários, um impressora e uma lixeira. O desenho ainda incluía relógios e cestas para guardar documentos que seriam arquivados posteriormente. Esse esquema tornou-se o precursor da metáfora do "Desktop" que conhecemos até hoje.

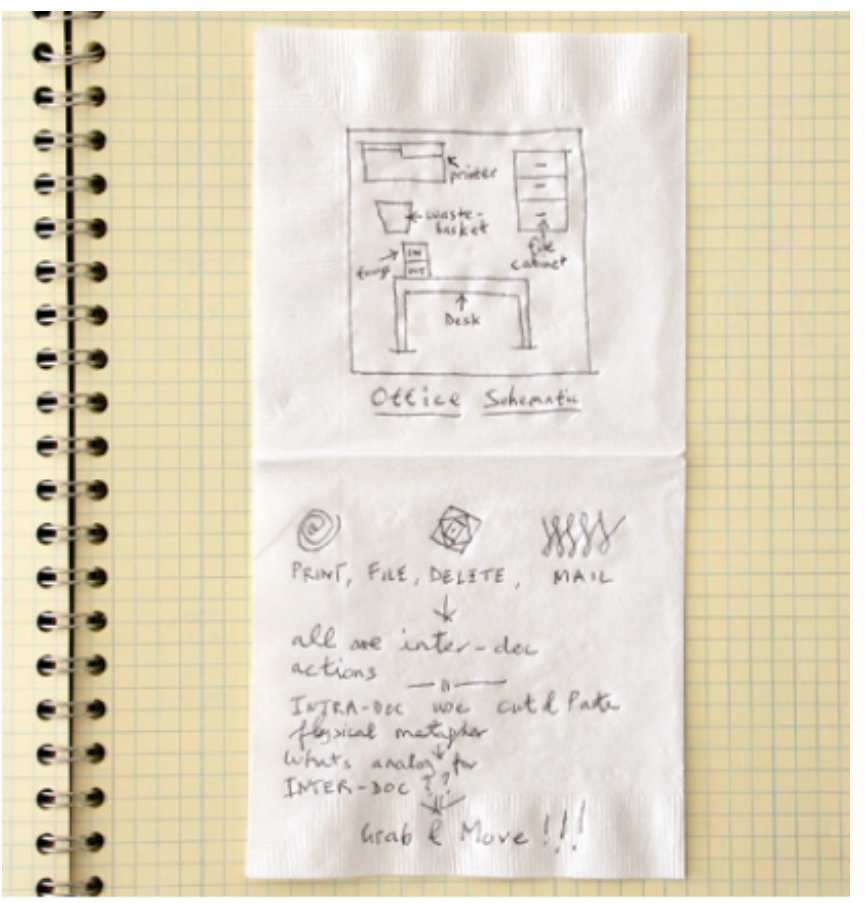

Fig. 2.10: Reconstrução do esboço original de Tim Mott quando concebeu a metáfora do "Desktop" da Apple Fonte: Designing Interactions (2006) 
Pesquisadores da Xerox Parc como Larry Tesler e Alan Kay integraram o laboratório de pesquisa Advanced Technology Group (ATG) da Apple Computer, e junto com Bill Atkinson, Larry Tesler entre outros desenvolveram os elementos que integram a interface dos computadores Macintosh e programas como Mac Paint, Hypercard e Quickdraw, que permitiam explorar as vantagens do novo sistema operacional. Nesse mesmo período, no final do anos de 1980, Joy Mountford, que liderava o Human Interface Group da Apple, propôs um curso de treinamento em design de interfaces para os funcionários da empresa. $\mathrm{O}$ projeto cresceu e transformou-se em um livro editado por Brenda Laurel que reúne textos de integrantes da equipe de desenvolvimento de produtos e interface da Apple e pontos de vista externos à empresa, tendo contribuições de Donald Norman, Ted Nelson e Nicholas Negroponte. A publicação desse livro é um marco no sentido que amplifica o envolvimento de profissionais de diversas áreas no desenvolvimento de computadores e o uso que se pode fazer deles.

\section{Janelas, menus, ícones etc.}

As interfaces WIMP (Window, icon, menu, pointing device), compostas de janelas, ícones, menus e dispositivos de seleção de objetos na tela, foram concebidas inicialmente na Xerox Parc e popularizadas com a introdução do Macintosh. Esse estilo de interação que se tornou bastante comum nas interfaces gráficas foi incrementado por pesquisadores que atuaram na Apple, como Larry Tesler, Joy Mountford e Bill Atkinson.

Larry Tesler trabalhou na Apple nos anos de 1980, e a ênfase do seu trabalho era desenvolver softwares que fossem simples e de fácil utilização. Tesler acreditava que a melhor forma de se criar um programa era com a participação dos usuários, e assim desenvolveu técnicas para observar como as pessoas realizavam tarefas, desse modo criando programas que permitissem que as pessoas se familiarizassem facilmente com novas tecnologias. No período em que trabalhava na Apple, ele inventou o "cut and paste", permitindo mover "pedaços" de informações dentro de um aplicativo e entre aplicativos distintos; criou também caixas de diálogo editáveis que permitiam ao usuário "responder" ao computador de uma forma mais coloquial. Defensor da teoria que a tecnologia deve ser simplificada, Tesler concentrou a funcionalidade do mouse em um único botão. Na entrevista 
encontrada no DVD que acompanha o livro Designing Interactions ${ }^{21}$, Tesler relata que, quando trabalhava com Bill Atkinson no desenvolvimento do sistema operacional do novo computador Lisa da Apple (predecessor do Macintosh), Atkinson concebeu e programou toda a estrutura de menus "pull down" em uma única noite.

Joy Mountford, originalmente da Inglaterra, foi residir nos EUA ao receber uma bolsa de estudos para realizar pesquisas em Psicologia da Engenharia de como pilotos interagiam com os complexos controles de aeronaves e de como os simuladores de voo poderiam auxiliar no treinamento dos pilotos. Nos EUA, começou sua carreira na Honeywell projetando controles e displays para aviões militares e o Space Shuttle e mais tarde criou e administrou o Human Interface Group na Apple. Em sua entrevista no DVD de Designing Interactions ${ }^{22}$, Joy Mountford (2007) descreve como ela e seu colega Mike Mills desenvolveram o que chamavam de ícones dinâmicos, mais tarde vindo a se consolidar como o formato Quicktime, permitindo visualizar vídeos no computador. Quando apresentou o Quicktime Player ao vicepresidente de engenharia da Apple, ouviu dele: “agora eu vejo como minha avó irá se interessar por computadores"; até então, Mountford nunca havia pensado na possibilidade de sua própria avó usar um computador, mas nesse momento sua percepção de como as pessoas poderiam usar um computador mudou completamente.

Os vídeos apareciam na tela como imagens estáticas; um dos problemas era fazer que os usuários soubessem que essas imagens poderiam estar em movimento, o que foi resolvido com um controlador bastante simples que permitia que as pessoas reproduzissem, pausassem, retrocedessem ou avançassem o vídeo, sons e animações. Esse tipo de controlador hoje é utilizado pela maioria dos formatos de vídeo digital, como o Quicktime, Real-player, Windows media e Flash video. Estes hoje se tornaram bastante familiares entre o público em geral com a popularização de sites de vídeo na internet, como o You Tube.

\subsubsection{Brenda Laurel - Computadores como teatro}

Apelidada de "diva digital", por participar do universo do teatro simultaneamente ao

\footnotetext{
${ }^{21}$ Entrevista de Larry Tesler em: Bill Moggridge, Designing Interactions, Cambridge, MIT Press, 2007.

${ }^{22}$ Joy Mountford entrevistada em: Bill Moggridge,Designing Interactions, Cambridge, MIT Press, 2007.
} 
da computação, Brenda Laurel tem demonstrado para engenheiros e designers como pensar nas pessoas que utilizam os computadores e usar a interpretação teatral no design de interfaces (MOGGRIDGE, 2007). Seu segundo livro, Computers as Theater, foi publicado em 1993. Laurel define Computers as Theater como "Uma teoria dramática da atividade homem-computador". Embora esse livro tenha quase vinte anos, suas ideias inovadoras para a época têm ganhado um interesse renovado nos últimos anos, e uma de suas frases mais célebres que sintetiza suas teorias é: "Pense no computador não como um ferramenta e sim como uma mídia."23 (LAUREL, 1993, p. 126 ).

Donald Norman, em sua introdução de Computers as Theater (LAUREL, 1991), afirma que os estudiosos do campo de interação homem-máquina talvez se desapontassem com o livro, pois ele não contemplava estudos controlados e sim estudava "personagens" e "pontos de vista". Norman defende que os "engenheiros devem voltar a se concentrar na engenharia e que para desenvolver novas tecnologias, eles devem dar espaço para uma nova geração de indivíduos criativos associados com disciplinas poesia, literatura e direção teatral”. E pergunta (referindo-se a Laurel): "Quem melhor conhece as interações humanas do que um dramaturgo?" (NORMAN in LAUREL, 1993).

Norman levanta o fato de que novas tecnologias estão em toda parte, nos rodeiam, tomam conta do dia a dia, desde os caixas eletrônicos, passando por DVDs até os fornos de micro-ondas. Uma das questões chaves destas novas tecnologias é a "interatividade", que é comum a todos, pois elas podem ajudar-nos a interagir melhor com outras pessoas, com sistemas, com as próprias máquinas. Mas a tecnologia tem sido criada apenas por "tecnologistas", que enfatizam cada vez mais os aspectos "tecnológicos" das máquinas que eles criam, obrigando-nos a aprender como operar, a cada vez mais um aspecto da máquina, assimilar uma nova tecnologia e decorar suas instruções. Norman pergunta se esses inventores não parariam um instante para pensar sobre o "prazer" ou a "experiência" resultante da utilização de uma tecnologia. Segundo Brenda Laurel, em 1993 pouco havia mudado nas regras do Design de Interfaces, que eram até então:

-Projetar objetos e ambientes consistentes.

${ }^{23}$ Tradução minha de: “Think of the computer, not as a tool, but as a medium”, Brenda Laurel em Computers as Theatre, 1993. 
-Desenvolver uma metáfora para a ação, ferramentas e ações de modo a fazer com que todas as atividades sejam consistentes com esta metáfora.

-Pensar no computador como uma ferramenta.” (LAUREL, 1993, cap. 5).

Laurel formula novas regras como contraponto às estabelecidas:

-Focar em desenhar a ação. O design de objetos e personagens são subsidiários a este objetivo central.

-Metáforas na interface têm uma utilidade limitada. O que você ganha agora pode lhe custar caro mais tarde.

-Pense no computador não como uma ferramenta, e sim como um mídia."

(LAUREL, 1993, cap. 5).

Segundo Norman, as "antigas" regras faziam sentido, no contexto da escala mais restrita vigente na época, mas que, no futuro, um pensamento mais amplo como o de Brenda Laurel seria mais coerente, pois ela se preocupava com a experiência total, e se novas tecnologias iriam enriquecer nossas experiências, essas tecnologias precisariam ser construídas com uma visão global. A visão dominante vigente no período era a de pensar a computação interativa como um "aplicativo + interface", no entanto há uma diferença conceitual entre um aplicativo que tem funcionalidades específicas para atingir um determinado objetivo e uma interface que representa essa funcionalidade para as pessoas (LAUREL, 1993).

Um aplicativo serve para resolver uma funcionalidade específica e a interface é a coisa que permite a mediação entre nós e o funcionamento interno de máquina. Esta interface é tipicamente projetada por último, depois do aplicativo ser totalmente concebido e talvez até implementado, ela é anexada a um pacote pré-existente de "funcionalidade" servindo como superfície de contato. (LAUREL, 1993).

Essa "superfície de contato", particularmente a interface do computador Macintosh, depende de tal maneira do uso de metáforas que a torna inquestionável, como se fosse uma "Ideologia Metafórica" que chega ao extremo de representar coisas que não fazem nenhum sentido, como no caso da metáfora de uma escrivaninha, em que, ao colocar uma folha de 
papel em cima de uma pasta, esta a "engole" (NELSON, 1990). A partir das ideias de Donald Norman em The Psychology of Everyday Things, onde defende que as metáforas têm suas limitações como facilitadoras de ações, ao dizer que "O design de uma interface eficiente deve começar com a análise do que uma pessoa está tentando fazer, ao invés de uma metáfora ou noção do que deve ser exibido na tela" (NORMAN, 1988), Laurel propõe pensar na interface como uma "arena" na qual os papéis são interpretados por seres humanos e máquinas. Desse modo, múltiplos agentes representam ações em sua integralidade, o que segundo a autora é precisamente a definição do teatro.

O termo "Manipulação Direta" de objetos nas interfaces gráficas de computadores foi introduzido por Ben Shneiderman, da Universidade de Maryland em 1983, e o conceito é baseado em teorias advindas da psicologia que formulam que as pessoas podem relacionar-se com objetos em mundos virtuais tendo por base o conhecimento desses objetos no mundo real. "O critério da manipulação direta, é a representação contínua de objetos e interesses e ações rápidas, incrementais e irreversíveis, causando um impacto visual imediato nos objetos em si” (SHNEIDERMAN, 1983).

Para Laurel, a representação gráfica é fundamental no design de interfaces, assim como a cenografia é fundamental no teatro. O designer gráfico, ao representar objetos em uma interface, passa a atuar como um cenógrafo. Ao criar um contexto para as ações que podem ser aplicadas a um objeto, projeta-se o comportamento destes, por exemplo: ao clicar em uma porta, o usuário desencadeia uma ação em que ela se abre ou fecha. No teatro, o iluminador, trabalhando junto com o cenógrafo, utiliza elementos como cor, intensidade e direção para destacar uma ação. Eles estão empregando metáforas de modo a amplificar determinadas ações em uma cena (LAUREL, 1993).

O designer que atua nas mídias audiovisuais deve preocupar-se com a escala relativa entre a tela e o usuário. No caso do computador, a escala é individual; já a televisão, estando situada na sala, apresenta uma escala familiar e o cinema cria um ambiente público. A seguinte ilustração apresenta as questões de escala em diversas mídias audiovisuais: 


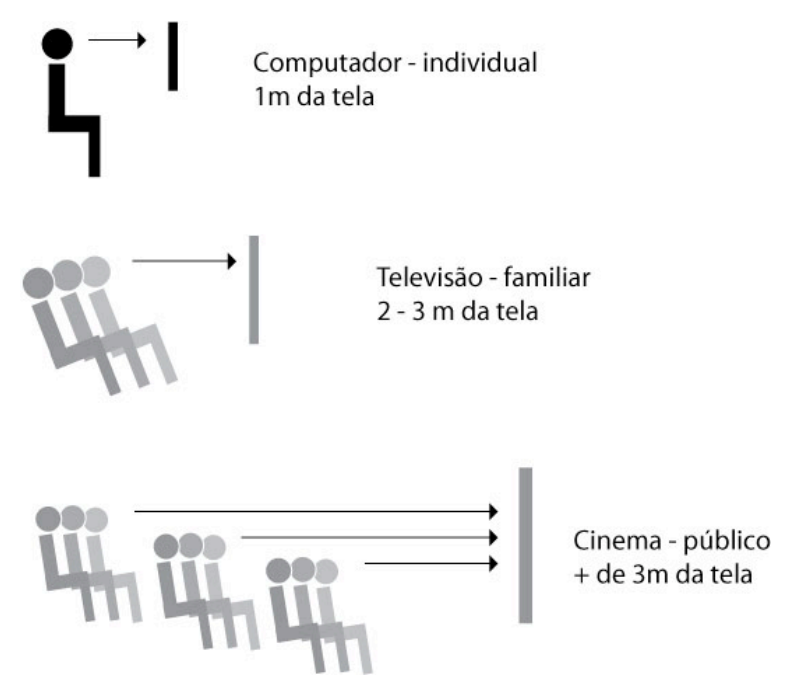

Fig 2.11: Escala do público em relação às diversas mídias audiovisuais. Ilustração do autor adaptada de Laurel (1993)

O teatro tem uma escala equivalente à do cinema, no entanto o público do teatro dá retorno ao ator, o que não ocorre no cinema. Em ambos os casos, "O público não tem noção dos aspectos técnicos, ou melhor, se desliga dele assim como no cinema nos abstraímos do projetor" (LAUREL, 1993). Já os computadores permitem o retorno do usuário à máquina e às pessoas conectadas às máquinas, mas como suas interfaces são demasiadamente presentes, elas não possibilitam o nível de abstração dos aspectos técnicos, como ocorre no cinema e no teatro.

Laurel apresenta a ideia de que no teatro, onde o público é participativo, este gera ruído e passa a ser ator. Na sua visão teatral da atividade homem-computador, o palco é um mundo virtual, povoado por agentes tanto humanos como gerados por computadores. No teatro, o maquinário das coxias apoia a representação enquanto "por trás" das telas dos computadores reside uma "magia técnica" do software. Em ambos os casos, a natureza da mágica, seja ela realizada por software ou mecanismos, não tem importância para o público (ou usuário). O valor está no que resulta no palco. Em outras palavras, "representação é tudo que há” (LAUREL, 1993).

As atividades computacionais são classificadas por Laurel como produtivas, citando o exemplo das calculadoras ou experienciais, como ocorre nos games. Nas atividades produtivas, os aspectos técnicos da engenharia do software são mais evidentes, ao passo que nas experienciais passamos a abstraí-las A história do cinema ilustra a transição de uma disciplina da engenharia que, ao desenvolver uma linguagem própria, passa a ser uma forma 
de expressão artística. A visão humanista da computação proposta por Laurel é fundamentada nos seis elementos da estrutura dramática da Poética de Aristóteles, e segundo a autora as semelhanças das atividades das atividades homem-computador com a dramaturgia permitem utilizar a relação entre os "seis elementos" como base para a análise do design da interação do homem com computadores. Segundo Laurel (1993), os seis elementos da Poética são estruturados hierarquicamente da seguinte forma:

\section{$A c ̧ \tilde{a} o$ \\ Personagem \\ Pensamento \\ Linguagem}

\section{Melodia}

Atuação

Cada elemento é uma causa formal na sequência, desde a "Ação" até a "Atuação" e no sentido inverso uma causa material.

Aristóteles define o "espetáculo" como o elemento fundamental da dramaturgia, ou seja, tudo o que é visto, e o teatro tradicional considera primordialmente os sentidos da audição e da visão, levando Laurel a constatar que "o espetáculo é tudo o que se vê e se ouve". Ao seguir a lógica da estrutura proposta por Aristóteles, os sentidos tradicionalmente considerados pelo teatro clássico, Laurel propõe um modelo no qual replica essa estrutura nos computadores, já que ambos trabalham de forma similar com os sentidos. Na estrutura proposta por Laurel, os elementos são transpostos para o universo da computação da seguinte forma:

A ação, sendo representada como um todo, é definida pela colaboração do usuário e do sistema. No teatro teoricamente ela é a mesma em cada apresentação, na computação ela pode variar em cada sessão.

Os personagens, assim como no teatro, são compostos de traços e predisposições inferidos por padrões escolhidos pelo agente, mas na computação incluem agentes humanos e computacionais. 
O pensamento é um processo internalizado que leva a escolhas como cognição, emoção e razão, e pode incluir processos originados pelo computador ou pelo ser humano.

A linguagem, que no teatro vem de uma seleção de palavras, na computação inclui signos verbais, visuais, auditivos e outros fenômenos não verbais.

A melodia, que se expressa no teatro como padrões sonoros especificamente da fala, na computação estende-se ao prazer na percepção dos sentidos.

O espetáculo ou atuação, ou tudo que é visto no teatro, são as dimensões sensitivas da ação sendo representada: visual, auditiva, cinestésica e tátil, entre outras.

A pesquisa de Laurel tem uma importância significativa no estudo do design de interefaces para a TV Digital ao trazer à tona os aspectos humanos na computação. A TV, sendo uma mídia do entretenimento, assim como o cinema, possibilita a imersão de seu público ao abstrair os aspectos tecnológicos. A teoria da atuação teatral na computação proposta por Laurel abre caminhos para o desenvolvimento de conteúdos interativos para as mídias audiovisuais que podem ter superfícies de contato mais transparentes entre o homem e as máquinas midiáticas.

\subsubsection{MIT Media Lab}

O MIT Media Lab foi fundado por Nicholas Negroponte em $1985^{24}$ como um laboratório de vanguarda no Massachussets Institute of Technology, "utilizando tecnologias que facilitassem a 'revolução digital' e incrementassem a expressão humana" (MIT, 2010) para realizar pesquisas consideradas inovadoras que iam desde cognição e aprendizado, a música eletrônica e holografia. Na década seguinte, o laboratório quebrou diversos paradigmas da computação, ao incorporar "os bits digitais aos "átomos do mundo físico", com pesquisas como computação incorporadas, comunicação "viral”, máquinas com "senso comum” e novas formas de expressão artística (MIT, 2010). Nesta sessão, destaco as

\footnotetext{
${ }^{24}$ Tradução minha de: "at the vanguard of the technology that enabled the 'digital revolution' and enhanced human expression", em: MIT Media Lab - Mission and History, disponível em: <http://www.media.mit.edu/about/mission-history>, acesso em: 21/12/2010.
} 
pesquisas de Muriel Cooper e de John Maeda, no final deste capítulo incluo novos avanços no design de interface a partir do conceito de Interfaces Tangíveis desenvolvido por Hiroshi Ishi, e no capítulo 4 as ideias de Negroponte servem como fundamento importante para conceitos que irão nortear esta tese.

\section{Visible Language Workshop}

Muriel Cooper é uma personalidade pouco conhecida, embora as pesquisas desenvolvidas por ela no Massachussets Institute of Technology (MIT) tenham influenciado as novas fronteiras no campo de interfaces gráficas. Diretora do Visible Language Workshop (VLW) no Media Lab do MIT, Cooper faleceu em 1994, pouco depois de uma série de entrevistas com Janet Abrams que foram publicadas em uma matéria na revista International Design $(I D)^{25}$. Nessa matéria, um dos poucos documentos encontrados sobre sua pesquisa, Abrams relata que, logo após Cooper apresentar as pesquisas do VLW na conferência TED5 em Monterey, CA (1994), Bill Gates da Microsoft pediu pessoalmente uma cópia da apresentação.

Bill Mitchell, diretor na época da Escola de Arquitetura do MIT, nessa mesma matéria descreve a contribuição de Muriel Cooper:

Acho que ela era foi a primeira designer gráfica a realizar verdadeiras e profundas explorações das novas possibilidades em mídias eletrônicas - coisas como texto 3-D. Ela não via a tecnologia da computação gráfica apenas como uma nova ferramenta para realizar tarefas de design gráfico. Ela compreendeu desde o princípio que o mundo digital abria uma série de questões e problemas, e ela queria compreender os problemas de uma forma profunda e rigorosa.

Segundo Abrams (1994), até a realização de sua conferência na TED5, seus colegas diminuíam a importância do trabalho dela. Ela não só era uma das poucas mulheres em um universo dominado por homens, mas era uma das poucas pessoas que tinha uma linha mais humanista naquela geração do Media Lab do MIT. Assim como Marvin Minsky e Seymour

\footnotetext{
${ }^{25}$ Janet Abrams, “Muriel Cooper's Visible Wisdom”, ID Magazine, September-October, 1994.
} 
Pappert, que também integravam o MIT Media Lab, Cooper não programava, mas concebia estruturas complexas segundo sua própria lógica. Ron MacNeil, um físico e fotógrafo com quem montou o VLW, comenta a este respeito: "Como ela era uma pensadora completamente original, ela se negava a aprender a simbologia de outro, era um anátema para ela" (ABRAMS, 1994).
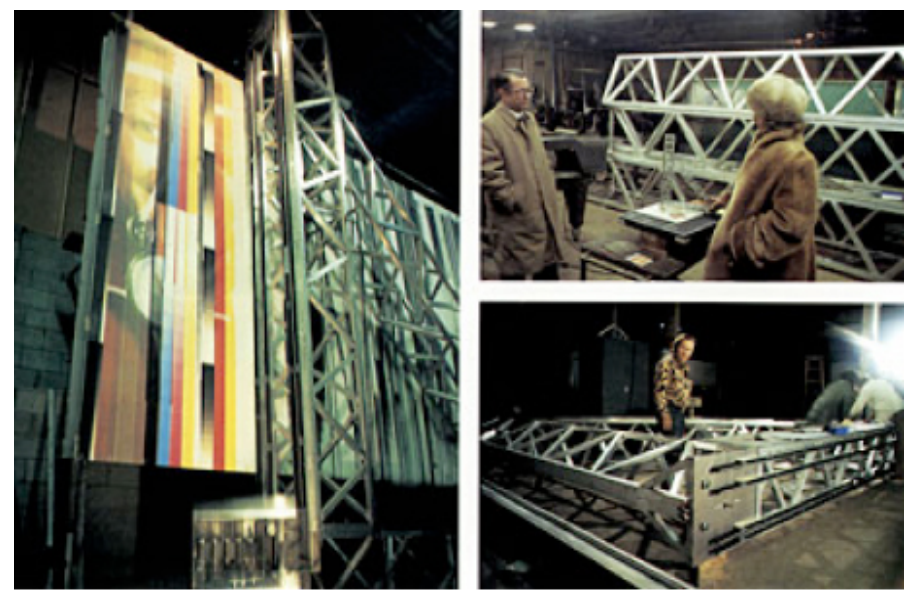

Fig 2.12: Painel - Billboard desenvolvido por Muriel Cooper no Visible Language Workshop do MIT

Fonte: www.aiga.org

Com a parceria e o conhecimento de Mac Neil, ambos desenvolveram pesquisas inéditas no VLW que tiveram um grande impulso com a chegada de computadores Reality Engine da Silicon Graphics; essas máquinas permitiam a manipulação espacial de tipografia anti-aliased no computador. Até então as máquinas não tinham a capacidade de gerar uma saída visual que preservasse a integridade das formas tipográficas ao serem manipuladas em um espaço tridimensional. Muriel Cooper fazia questão de sempre ter em seu time alguém com experiência em animação, pois além de seu rigor tipográfico e suas experiências em visualização espacial, a compreensão das possibilidades oferecidas pela animação eram para ela cruciais para o futuro do texto na computação.

A pesquisa das interfaces espaciais de Muriel Cooper foi utilizada como referência para as interfaces utilizadas pelo ator Tom Cruise no filme de ficção científica Minority Report, filme no qual existe um sistema de navegação no tempo e no espaço que se dá através da manipulação de dados utilizando gestos. 


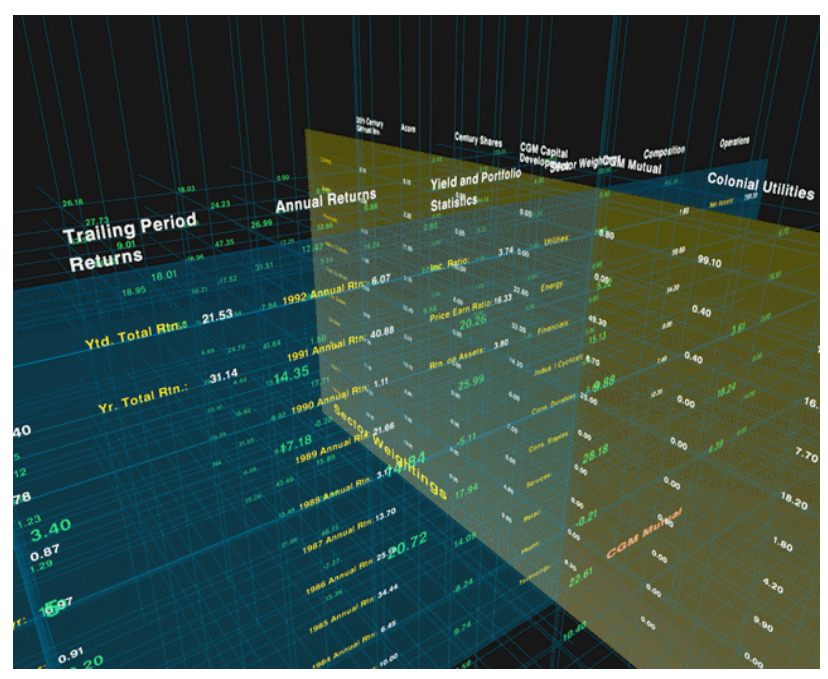

Fig. 2.13: Interface Gráfica 3-D "Financial Viewpoints" de Lisa Strausfeld do Visible Language Workshop - MIT.

Fonte: www.inventinginteractive.com

Cooper, em sua entrevista, declara para Abrams:

A mídia eletrônica é maleável, a mídia impressa é rígida... Acho que não tenho certeza se o meio impresso é verdadeiramente linear: é algo como um meio simultâneo. O que os designers sabem é como controlar a atenção da percepção, como apresentar informação de uma forma que lhe ajuda a encontrar o que você precisa, ou que eles pensam que você precisa. Informação só é útil quando ela pode ser compreendida. ${ }^{26}$ (COOPER apud ABRAMS, 1994).

Abrams elabora sobre isso:

A prática do design gráfico, durante séculos, tem se concentrado na organização de informação no território estático. Como demonstra a história do design gráfico, já é difícil o domínio de duas dimensões. Agora designers se deparam com informações que estão além de seu controle imediato e final. Isto é, eles devem encontrar formas de criar hierarquias inteligíveis para administrar um material do qual não se pode mais ter a expectativa de que ele irá ficar parado, fixo em um local - e portanto, de alguma forma, seu significado passa a ser mutável dependendo de onde é posicionado em uma superfície.(ABRAMS, 1994).

\footnotetext{
${ }^{26}$ Tradução minha de "Electronic is malleable. Print is rigid," she told me, then backtracked in characteristic fashion. "I guess I'm never sure that print is truly linear: it's more a simultaneous medium. Designers know a lot about how to control perception, how to present information in some way that helps you find what you need, or what it is they think you nee. Information is only useful when it can be understood."
} 
Esta é uma questão fundamental que já era confrontada por designers pioneiros nos meios eletrônicos, como no caso da televisão, em que o controle final de sua produção passava por diretores, técnicos e toda a cadeia de produção, em que todos têm a possibilidade de manipular a saída visual, e hoje se radicalizou com o design de páginas para a Web, onde até o usuário final pode alterar a forma de visualização da informação gráfica em sua tela.

\section{John Maeda - Design by Numbers}

John Maeda hoje é presidente da Rhode Island School of Design (RISD), uma das escolas mais importantes de Design dos EUA. Maeda foi professor do MIT durante doze anos na área de Artes Midiáticas e Ciências. No MIT, foi diretor associado de Pesquisa do MIT Media Lab, onde seu trabalho foi pioneiro em incorporar a sensibilidade dos artistas gráficos na programação e computação gráfica. Maeda acredita que software é demasiadamente caro e complexo hoje em dia, e propõe que os designers aprendam a escrever seus próprios programas. Em seu livro Design by Numbers (1999), Maeda ensina como designers podem utilizar a programação para criar imagens gráficas sem depender de softwares escritos por outros, de modo que o designer possa expressar-se de uma forma mais direta sem a interferência do software e dos métodos dos autores dos softwares. Maeda em The Laws of Simplicity (2006) estabelece dez princípios com o objetivo de simplificar a disciplina do Design. Estes princípios são:

\section{Dez Leis:}

1. Reduzir: Redução consciente (planejada).

2. Organizar: Onde fazemos que um sistema composto de muitos elementos aparente ter menos.

3. Tempo: Economizar tempo dá a sensação de simplicidade.

4. Aprender: O conhecimento torna tudo mais fácil.

5. Diferenças: Complexidade e simplicidade são mutuamente dependentes.

6. Contexto: O que habita a periferia da simplicidade não é periférico.

7. Emoção: Mais emoções é melhor do que menos emoções.

8. Confiança: "Em simplicidade nós confiamos" (do Inglês "In simplicity we trust", um trocadilho com os dizeres nas notas de dólar "In God we trust").

9. Fracasso: Algumas coisas nunca podem ser simplificadas. 
10. A única: Subtraia o óbvio, adicione o que tem significado.

$$
(\text { MAEDA, 2006, p. ix })^{27}
$$

Em The Laws of Simplicity (2006), Maeda descreve o projeto do iPod, no qual os designers da Apple foram eliminando componentes, resultando em uma interface com pouquíssimos botões; no caso ele se refere ao projeto original do iPod, que consistia em um disco sensível ao toque e um único botão central. Com exceção de uma trava do aparelho, todos os comandos do iPod são realizados utilizando um disco e o botão. Para Maeda, esse projeto sintetiza as leis da simplicidade.

\subsubsection{Bill Moggridge - IDEO}

Bill Moggridge é fundador da IDEO, uma das empresas de design mais bem-sucedidas no mundo e uma das primeiras a integrar o design de software e hardware na prática do desenho industrial. Bill Moggridge é o autor e editor do livro Designing Interactions (2007), ao qual me referi diversas vezes neste capítulo; a obra reúne artigos de sua autoria e entrevistas com alguns dos mais importantes designers atuantes no campo do Design da Interação. Moggridge atualmente leciona no Programa de Design da Universidade de Stanford nos EUA.

$\mathrm{Na}$ introdução do livro, conta duas histórias pessoais de como passou a se interessar por Design de Interação. Uma delas relata as dificuldades que teve em operar o primeiro relógio digital com o qual teve contato: para acertar as horas no relógio, era necessário pressionar os botões em sequências que não faziam o menor sentido, sendo extremamente difícil e frustrante realizar uma tarefa bastante simples, como era o caso do relógio de pulso

\footnotetext{
27 Tradução minha de “Ten Laws of Simplicity”, de John Maeda (2006)

"Law 1: Reduce -The Simplest way to achieve simplicity is through thoughtful reduction

Law 2: Organize-Organization makes a system of many appear fewer

Law 3: Time-Savings in time feel like simplicity

Law 4: Learn- Knowledge makes everything simpler

Law 5: Differences-Simplicity and complexity need each other

Law 6: Context- What lies in the periphery of simplicity is definitely not peripheral

Law 7: Emotion-More emotions are better than less

Law 8: Trust-In simplicity we trust

Law 9: Failure-Some things can never be made simple

Law 10: The One-Simplicity is about subtracting the obvious, and adding the meaningful"
} 
analógico. A segunda história é sobre o design de um dos primeiros laptops na sua empresa, a IDEO; quando finalmente o produto estava pronto, sentia-se bastante orgulhoso com o resultado e, ao experimentar o produto, começou a utilizar o software (que não foi projetado pela IDEO), ficando totalmente imerso no programa; foi quando percebeu que o design de computadores e dispositivos digitais envolve necessariamente o Design da Interface do Software e da interação com a máquina, pois só assim se poderia projetar a experiência total do produto. Em seu livro, Bill Moggridge cita David Liddle, da Interval Research, que define três fases na introdução de uma nova tecnologia (MOGGRIDGE, 2007, p. 245):

1. Entusiasta - Que não se importa com as dificuldades impostas por novas tecnologias.

2. Profissional - Que normalmente utiliza mas não adquire o equipamento e prefere que permaneça difícil de se utilizar.

3. Consumidor - Quando a tecnologia passa a ser menos importante do que ela pode fazer por ele.

Considero essa classificação bastante oportuna ao pensarmos na introdução da TV Digital, pois podemos ver que aspectos diferentes da tecnologia se encaixam em fases distintas neste primeiro momento.

\subsection{Novas Tendências em Design de Interfaces}

Nos últimos anos, novas formas de interfaces têm se popularizado. As razões para isso são: os avanços tecnológicos na indústria da computação, com o desenvolvimento de processadores mais rápidos e mais baratos e a disseminação de dispositivos móveis inteligentes; pesquisas no design de interfaces utilizando superfícies tangíveis ou gestos; interfaces ditas naturais que têm encontrado aplicações no mercado em aparelhos celulares, videogames e tablets, como as telas "multi-touch" e o "two finger pinch zoom".

As Interfaces Naturais do Usuário: Natural User Interfaces (NUI) e Interfaces Tangíveis do Usuário: Tangible User Interfaces (TUI), introduzidas recentemente, prometem possibilitar uma interação mais intuitiva entre homem e computadores do que as Interfaces Gráficas do Usuário - Graphical User Interfaces (GUI), que se tornaram comuns nos dispositivos digitais. 


\subsubsection{Interfaces Naturais do Usuário}

As interfaces gráficas baseadas no modelo WIMP desenvolvidas pelo laboratório Xerox Parc em Palo, na Califórnia, sempre incorporaram a manipulação direta da informação de alguma forma (JORDÀ et al., 2010); a ideia por trás da manipulação direta é que o usuário possa manipular objetos de forma que faça uma associação com o mundo real, mas o mouse e o controle remoto limitavam de certo modo essa interação. As interfaces WIMP popularizaram-se com o sistema operacional da Apple Macintosh lançado em 1984 e posteriormente com o Windows, e embora tenham passado por diversas atualizações, essencialmente pouco mudaram desde então. No entanto, pesquisas e experimentos de videoartistas durante os anos de 1980 e 1990 abriram caminho para as interfaces ditas naturais.

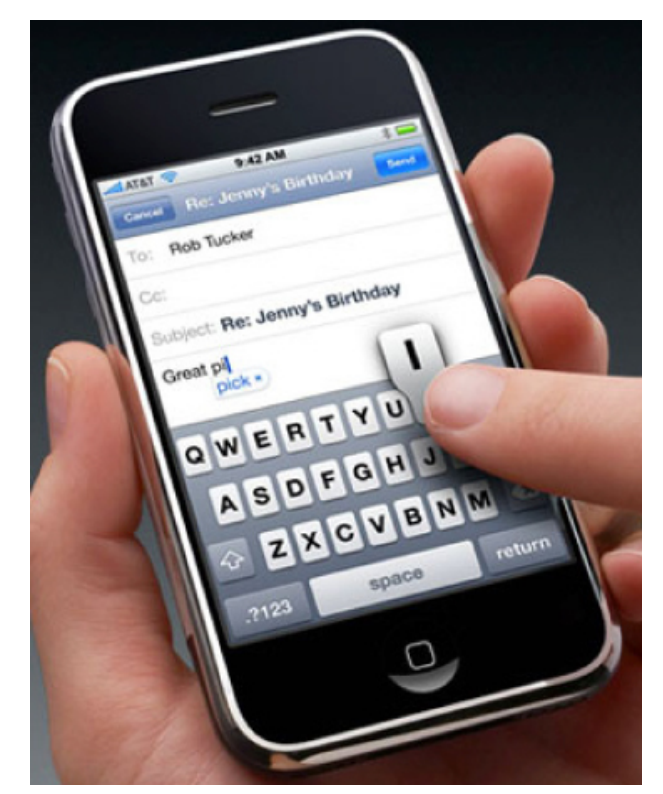

Fig. 2.14: Interfaces sensíveis ao toque do iPhone Fonte: www .apple.com

\section{Myron Kruger}

Myron Kruger é um videoartista pioneiro em arte interativa e realidade virtual, seu trabalho pode ser considerado predecessor das interfaces naturais que vemos emergindo recentemente. Em um texto na exposição "Touchware”, realizada na Siggraph em 1998, Kruger diz que desde 1969 ele tem como objetivo fazer que a interatividade se transforme em 
uma forma de arte em oposição em fazer arte, que é interativa. Insatisfeito com a limitação da interação homem-máquina a um homem sentado à frente de um computador tocando em uma máquina com os dedos ou movendo um "stylus" sobre um "tablet", ele passa a pesquisar formas mais interessantes de o homem relacionar-se com as máquinas, e o resultado dessa pesquisa é a criação de uma ambiente virtual que responde às ações do participante e oferece uma resposta audiovisual.

Esses conceitos são colocados em prática no projeto "Videoplace", apresentado originalmente no Milwaukee Art Museum em 1975 e posteriormente aperfeiçoado e apresentando em diversas edições da Siggraph. "Videoplace" é uma evolução dos projetos GLOWFLOW, META PLAY e PSYCHICSPACE e tem como proposta sugerir uma nova mídia artística que permita a interação em tempo real utilizando sensores, telas e sistemas de controle; esses ambientes não são limitados à expressão estética, mas podem ter aplicações em diversos campos com uma nova forma de comunicação em que duas pessoas podem encontrar-se visualmente de uma forma muito mais rica do que em um videofone (KRUGER, 1998). Em 1983, publica O livro Artificial Reality, termo que utiliza para descrever os ambientes de realidade virtual que desenvolve.

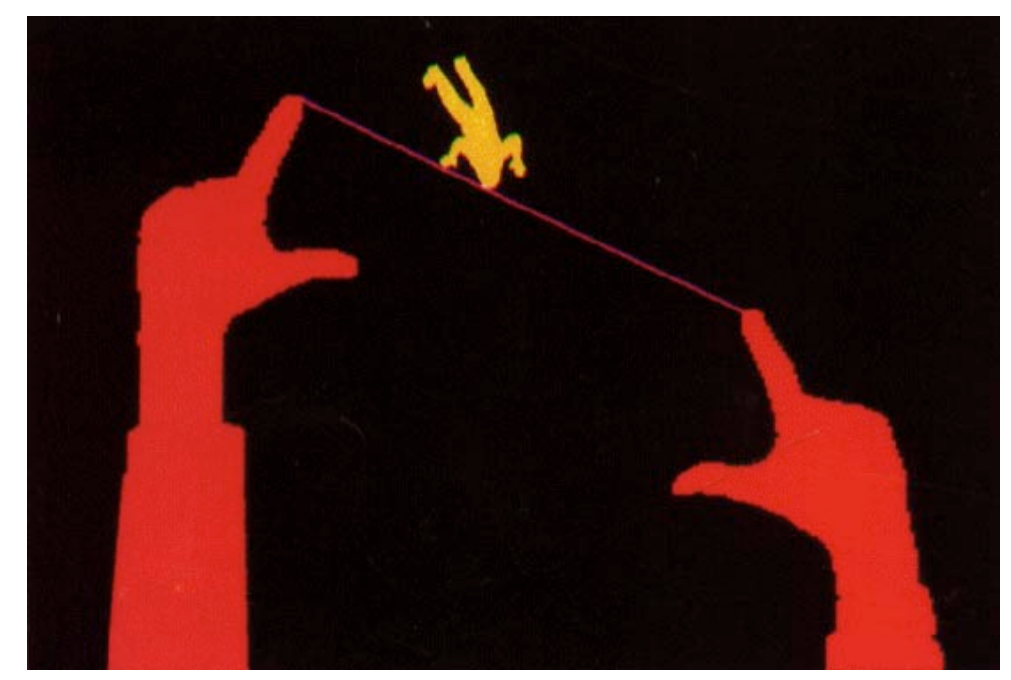

Fig. 2.15: Myron Kruger - Videoplace, 1998

Fonte: www.inventinginteractive.com 


\section{Interfaces por Gestos}

As interfaces que utilizam gestos ou "naturais", no entanto, apresentam diversos .problemas, como apontam Nielsen e Norman (2010) no artigo "Gestural Interfaces: A Step Backward in Usability", publicado na revista Interactions da ACM. Nele, os autores criticam as interfaces de uma série de dispositivos, entre eles as do iPhone da Apple e smartphones utilizando o sistema operacional Android, afirmando que elas esquecem por completo regras já estabelecidas de usabilidade, o que deixa os usuários completamente confusos, pois por mais que essas interfaces naturais sejam intuitivas, muitos aspectos são baseados em abstrações ou convenções que devem ser preestabelecidas e aprendidas, mas que acabam sendo reinventadas por cada fabricante ou desenvolvedor (NORMAN; NIELSEN, 2010).

Segundo Norman e Nielsen, há princípios fundamentais do design para interação que são completamente independentes da tecnologia; são eles:

-Visibilidade (ou percepção de significantes)

\section{-Feedback}

-Consistência

-Operações não destrutivas (undo)

-Descobrimento - Todas as operações podem ser descobertas pela exploração sistemática dos menus

-Escalabilidade - A operação deve funcionar em diversos tamanhos de telas das pequenas as grandes.

-Confiabiliadade - As operações devem funcionar: ponto final.

(NORMAN;NIELSEN, 2010, p. 47)

Esses princípios estão gradualmente desaparecendo do arsenal de ferramentas dos designers de interfaces e sendo substituídos pelo que Norman e Nielsen consideram "guidelines estranhos" da Apple, do Google e da Microsoft.

Embora essa crítica seja bastante relevante, a realidade é que nos últimos anos as interfaces dos computadores têm se transformado em diversos aspectos. Em um artigo de autoria de Johnny Chung Lee intitulado "In Search of Natural Gesture", publicado na revista XRDS (Summer 2010) da ACM, Lee (2010) afirma que o hardware dedicado à interface do 
computador com os homens tem determinado a forma de diversos dispositivos computacionais da atualidade. (CHUNG, 2010)

Em outras palavras, conforme o tamanho do processador diminui, a interface acaba dominando a forma do dispositivo, como no caso de um laptop reduzido a tela e um teclado e mais recentemente os smartphones com tela touch screen ou tablets como o iPad ou Kindle, que tem forma determinada pelo tamanho da tela, que serve tanto como monitor como meio de entrada de dados.

Johnny Lee Chung, pesquisador do Microsoft Applied Sciences Group, tornou-se bastante conhecido pelos seus vídeos no You Tube Wii Hack (2008), onde demonstra aplicações alternativas para o controle remoto do vide ogame Wii da Nintendo. Nesses vídeos ele demonstra como é possível utilizar um controle remoto que custa aproximadamente US\$40 em um caneta virtual que permite escrever em um quadro branco (white board) e como transformar o controle em um mecanismo de "head tracking", permitindo acompanhar o movimento da cabeça de um usuário que navega em um “display” de Realidade Virtual

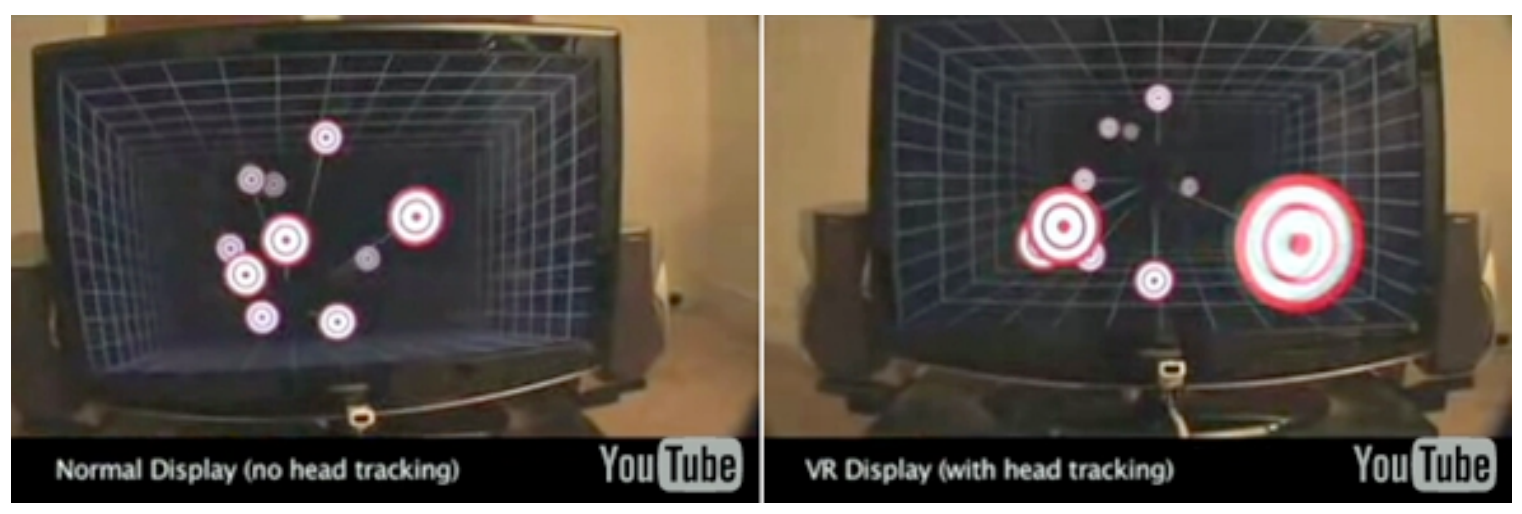

Fig. 2.16. Head Tracking utilizando um "hack" do controlador do Wii - Johnny Lee Chung Fonte: www.youtube.com

Nesse artigo em que fala das interfaces ditas naturais, Chung as denomina "Natural Gesture User Interfaces” (NUI) , que seriam uma evolução das GUIs, não se limitando apenas à representação e manipulação de objetos em uma tela através de metáforas gráficas. Segundo Chung (2010), as NUI são altamente intuitivas e tornam-se efetivamente invisíveis ao usuário ao realizar uma tarefa; essas interfaces ditas naturais podem ser uma solução ao problema levantado por Dan Norman (2000) quando afirma que "O verdadeiro problema de uma interface é que ela é uma interface": "The real problem with the interface is that it is an 
interface. Interfaces get in the way. I don't want to focus my energies on an interface. I want to focus on the job." (NORMAN, 2000, p. 219).

Diante desse problema da interferência da interface na comunicação do homem com o computador, faz uma correlação com a comunicação humana; Chung propõe que para a interação de um homem com um sistema interativo ter a mesma fluidez que a comunicação humana ele deve compreender nossos gestos.

Gesto e velocidade caminham juntos na comunicação humana-humana e será apropriado ter isto em mente no design de qualquer sistema interativo pretendendo prover um nível similar de fluidez. ${ }^{28}$ (CHUNG, 2010).

Segundo Chung, "O suprimento de informação nos últimos anos tem ultrapassado a habilidade de muitas pessoas absorverem-nas". Isso acaba ocasionando uma demanda de performance e consequentemente uma redução de custo, tornando economicamente viável produzir computadores com específicos em vez de computadores mais potentes com diversas funções, por exemplo um dispositivo digital projetado especificamente para exibir filmes ou um outro que serve para tocar música. Essa é uma posição bastante interessante, pois vai na contramão da tendência de se concentrarem diversas funções em um único aparelho, como no caso de smartphones; isso tem uma consequência para as interfaces, pois elas podem ter um fim específico.

Gestos podem ser definidos como o movimento físico das mãos, braços, face e corpo com a intenção de transmitir informação e significado, e podem ser percebidos como uma forma natural de interação e transmitir informação, mas gestos também podem ser percebidos como imprecisos e não autorreveladores e mesmo pouco ergonômicos (VATAVU et al., 2005). Gestos articulados sozinhos no espaço são pouco naturais e o reconhecimento destes enfrenta dificuldades similares às encontradas nos sistemas de reconhecimento de voz (CHUNG, 2010). (Jean Luc Nespoulos, 1986 in CHUNG, 2010) propõe três classes de gestos comunicativos de uso comum:

\footnotetext{
${ }^{28}$ Tradução minha de: "Gesture and speed go hand in hand in daily human-to-human communication and it will be appropriate for any interactive system that attempts to provide a similar level of fluidity to be designed with that in mind." (CHUNG, 2010).
} 
Mimético - São os mais comuns, sendo utilizados usualmente em uma cultura (VATAVU et al., 2005), e descrevem a forma e o comportamento de um objeto (CHUNG, 2010).

Deictic - Ocorrem dentro de um contexto, por exemplo no caso de uma explicação ao apontar para o objeto da conversa ou apontar em uma direção. Estes incluem os gestos específicos que apontam a um objeto em particular, gestos genéricos que apontam a uma classe de objetos e gestos de indicação de funções que apontam a um objeto simultaneamente indicando uma ação.

Arbitrário - Sinais que aprendemos em uma cultura, como os do juiz de futebol ou do guarda de trânsito, são gestos pouco comuns que devemos aprender.

Gestos podem ser muito úteis para selecionar e apontar para objetos, mas além das questões de imprecisão e de interpretação dos gestos um outro problema que encontramos ao utilizar gestos para interagir com espaços virtuais é a questão de repertório de gestos, quais são apropriados para um fim específico, quais são realmente naturais e fazem parte de uma cultura e quais vale a pena aprender.

\subsubsection{Superfícies e Interativas e Tangíveis}

Hiroshi Ishii, pesquisador do MIT Media Lab, cunhou o termo TUI - "Tangible User Interfaces” (Interfaces Tangíveis do Usuário) em 1997, sua proposta era de integrar a computação com objetos físicos de modo a "aumentar" o mundo fisíco real, permitindo que o usuário pudesse literalmente manipular dados com as mãos (JORDÁ et al., 2010). Outro pioneiro no campo é Bill Buxton, hoje conhecido por suas propostas de prototipagem de programas de computadores utilizando papel e lápis. Em 1984, começa a pesquisar comandos multi-touch e bimanual, desenvolvendo protótipos, junto com os estudantes de doutorado Fitzmaurice e Ishii; em 1995, apresentam o Active Desk, uma superfície de trabalho que combina uma câmera sensor e um projetor criando um ambiente de trabalho digital multiusuário.

O Reactables é um outro projeto de interface colaborativa que permite que diversos usuários manipulem objetos em uma mesa e que, de acordo a forma, posição e movimento destes, controlem as frequências de sons. Utilizado em performances musicais inclusive pela 
artista Bjork em sua turnê de 2007-8, o Reactables foi desenvolvido na Universidade Pompeu Fabra, em Barcelona, no ano de 2003.

Esses projetos de pesquisa têm aberto novos horizontes para a indústria em produtos como Apple Iphone e Microsoft Surface, que trazem para o mercado essas novas formas de interação. No vídeo iPhone User Interface Design ${ }^{29}$, podemos acompanhar o desenvolvimento de alguns aplicativos que integram o sistema operacional do iPhone. Interessante notar que logo no início do vídeo apresentado por funcionários da Apple eles afirmam que o processo de desenvolvimento de um aplicativo para o iPhone requer a dedicação de no mínimo $60 \%$ do tempo do projeto ao design da interface, versus $5 \%$ que é o usual na indústria de software. Em outra parte desse vídeo, mostram como os aplicativos de sucesso para o iPhone são resolvidos inteiramente no papel utilizando lápis e templates de papelão como os da figura ao lado, e só depois dessas "iterações" com papel é que a interface passa a ser detalhada em um programa gráfico no computador.

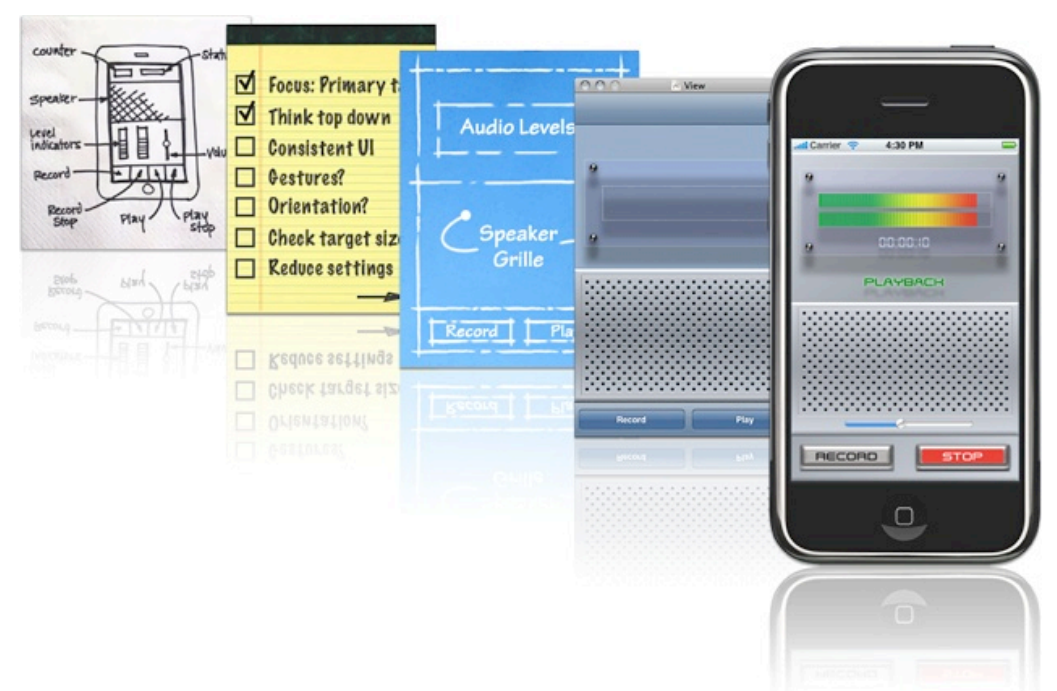

Fig. 2.17: Desenvolvimento de um “app” para iPhone

Fonte: www.apple.com

\subsubsection{Interfaces Corporais}

Desney Tan, Dan Morris e Scott Saponas têm desenvolvido pesquisas em interfaces que integram o computador com músculos, de modo que não seja necessária a manipulação

\footnotetext{
${ }^{29}$ iPhone User Interface Design em iPhone Development Essential Videos. Disponível em: $<$ http://developer.apple.com/library/ios/\#documentation/userexperience/conceptual/mobilehig/Introduction/Intro duction.html>. Acesso em: 21/12/2010.
} 
de "transducers" físicos (TAN et al., 2010). Um exemplo prático é a proposta de um celular em que a interface é projetada na palma da mão utilizando um microprojetor, e o movimento dos dedos é captado por uma pulseira no braço que recebe os impulsos elétricos das fibras musculares em sensor eletromiográfico EMG; esse tipo de dispositivo permite que diversas superfícies sejam utilizadas como "display" e o controle é realizado sem a necessidade de um dispositivo de comando específico.

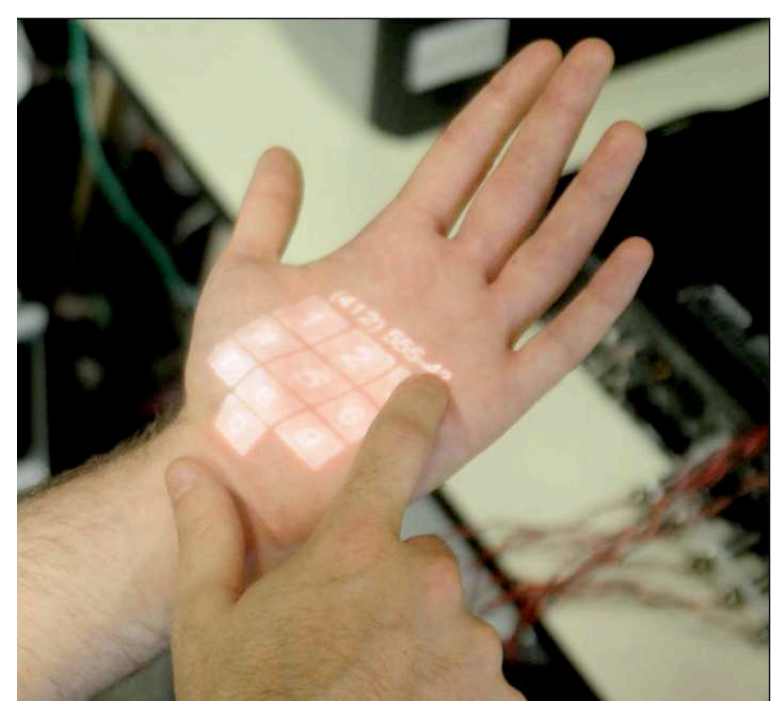

Fig. 2.18: Interface de um celular projetada na palma da mão Fonte : Revista XRDS - ACM

A fronteira extrema do desenvolvimento de interfaces é a das interfaces cérebrocomputador (Brain-Computer Interfaces - BCI), que pode ser tão radical como a vivida pelos personagens de Neuromancer (GIBSON), que implantam microprocessadores no cérebro possibilitando interagir como espaços virtuais a sistemas que utilizam sensores de eletroencéfalogramas para captar impulsos elétricos cerebrais, permitindo realizar tarefas virtuais sem a manipulação física no mundo real (PECK et al., 2010).

\subsection{A Prática do Design da Interação Humano-Computador}

\subsubsection{Design da Experiência do Usuário}

O Design de IHC - Interação Humano-Computador é uma prática multidisciplinar em que atuam diversos profissionais. Até o início dos anos de 1990, o foco do IHC eram usuários 
individuais; com o crescimento das atividades computacionais conduzidas em rede por múltiplos indivíduos, a cooperação de diversos especialistas passou a ser uma prática comum (PREECE, 2002). Na segunda metade dos anos 2000, tem se disseminado a utilização do termo "Experiência do Usuário" (UX), em referência a uma gama de aspectos perceptuais e práticos realizados na utilização de produtos e serviços digitais. O termo foi popularizado por Don Norman em 1993 ao adotar o título de "User Experience Architect" no período em que trabalhou na Apple Computer (KNEMEYER;SVOBODA, 2007). Jesse Garrett, em The Elements of User Experience (Os Elementos da Experiência do Usuário), define a "experiência do usuário" como a forma "como um produto se comporta e como é utilizado no mundo real" (apud BARROS, 2009); o modelo de Garrett é representado de forma sintética neste diagrama:

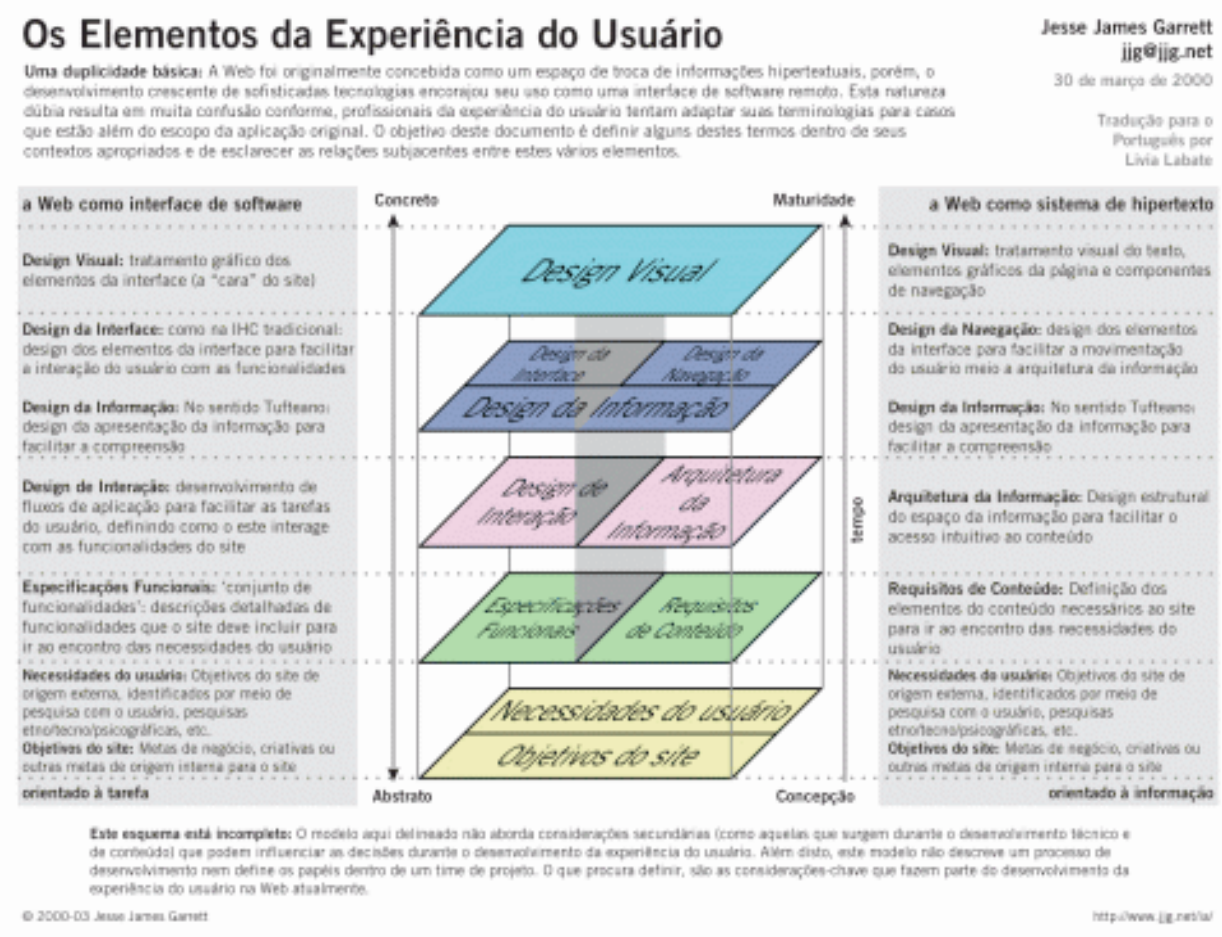

Figura 2.19: Diagrama dos elementos da Experiência do Usuário

Fonte: http://www.congressoebai.org/wp-content/uploads/Diagrama_Garrett.gif

Com a popularização do conceito da Experiência do Usuário, consolida-se a visão de que o design de produtos e serviços digitais é uma prática multidisciplinar que integra a contribuição de diversas especialidades como: Design de Interação, Design Visual, Design de Interface Gráficas, Desenho Industrial, Engenharia da Usabilidade, Arquitetura da Informação, Design da Experiência. A articulação dessas disciplinas no projeto de um 
produto contextualiza os parâmetros tecnológicos, aspectos mercadológicos, as necessidades funcionais e expectativas do usuário, possibilitando uma visão holística em seu desenvolvimento. A formalização da funcionalidade de um produto passa a incorporar aspectos subjetivos como os emocionais e lúdicos e que tradicionalmente eram excluídos do processo projetual, e que muitas vezes podem definir o seu sucesso ou fracasso do ponto de vista do usuário.

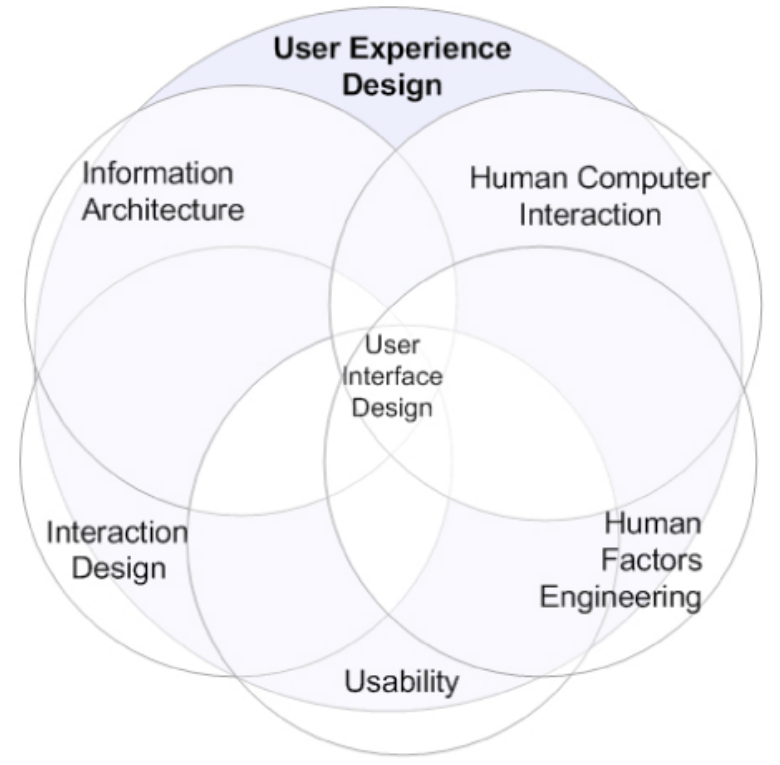

Figura 2.20: Interface do usuário e suas intersecções com áreas afins. Fonte: www.montparnas.com

Por sua vez, Preece, Sharpe e Rogers (2002) reconhecem a importância da colaboração multidisciplinar dos profissionais atuando no Design de Interação e apresentam a experiência do usuário como uma de suas principais metas. Em sua obra, que tem servido como importante referência para os estudantes e profissionais do campo, as metas decorrentes da experiência do usuário são incorporadas em um processo de um modo bastante linear e baseadas fundamentalmente em atender o cronograma e as necessidades funcionais. Segundo os autores, as atividades básicas deste processo são:

1. Identificar necessidades e estabelecer requisitos.

2. Desenvolver "designs" alternativos que preencham estes requisitos.

3. Construir versões interativas dos "designs", de maneira que possam ser comunicados e analisados. 
4. Avaliar o que está sendo construído durante o processo.

(PREECE et al., 2002, p. 33).

Parte desse processo é compreender as necessidades dos usuários para atender as duas principais metas do Design da Interação, que segundo os autores são:

1. Metas de Usabilidade

“Ser eficaz no uso (eficácia)

Ser eficiente no uso (eficiência)

Ser segura no uso (segurança)

Ser de boa utilidade (utilidade)

Ser fácil de aprender (learnability)

Ser fácil de lembrar como se usa (memorability)" (PREECE, 2002, p. 36).

2. Metas decorrentes da Experiência do Usuário

Criação de sistemas que sejam:

- satisfatórios

- agradáveis

- divertidos

- interessantes

- úteis

- motivadores

- esteticamente apreciáveis

- incentivadores de criatividade

- compensadores

- emocionalmente adequados (PREECE, 2002, p. 40). 


\subsubsection{Princípios do Design e Usabilidade}

Donald Norman é reconhecido como um dos principais críticos da usabilidade de produtos digitais; em seu livro Design of Everyday Things, Norman descreve os princípios do design que devem ser considerados no design de um produto (NORMAN, 1988 apud PREECE, 2002) $)^{30}$. Os principais conceitos são:

\section{- Visibilidade}

As ações que um usuário pode realizar em um sistema devem estar visíveis de modo que possa acessá-las com facilidade; por exemplo, se um item de menu em um website não estiver visível, é provável que o usuário não o encontre e portanto não acesse com facilidade as informações pertencentes a esse item.

\section{- Feedback}

Refere-se ao retorno ao usuário da ação que este realizou, de modo que ele perceba o efeito de sua ação em um sistema ou objeto. Este retorno pode ser visual, sonoro ou tátil. Por exemplo, ao realizarmos uma ligação telefônica, um tom sonoro nos dá o feedback de que a ligação está sendo efetuada.

\section{- Restrições (Constraints)}

As restrições têm o objetivo de evitar que o usuário realize alguma interação com o sistema que não seja apropriada em determinado momento. Norman (NORMAN, 2000) as classifica em restrições fisícas, lógicas e culturais; um exemplo de restrição física é a encontrada nos diversos formatos de conectores de cabos, impedindo que o usuário insira um cabo incorretamente em um terminal incompatível com este.

\section{- Mapeamento (Mapping)}

Preece (2005) descreve o mapeamento como relação dos controles e seus efeitos no mundo; um exemplo de um bom mapeamento são as teclas de cursores em um controle remoto ou teclado de computador, onde as setas indicam a posição do movimento desejado e são posicionadas de acordo.

\footnotetext{
${ }^{30}$ O site Usabilidade-Brasil tem uma sessão onde há um levantamento dos Princípios de Design de Norman que apresenta exemplos concretos de sua aplicação no design de interfaces e produtos. Disponível em: $<$ http://usabilidade-brasil.com/?p=34>.
} 


\section{- Consistência}

Refere-se à semelhança dos elementos dentro de uma interface ou entre diversas interfaces para realizar operações semelhantes. Por exemplo, os sinais de trânsito que indicam que se pode prosseguir devem consistentemente utilizar a cor verde, enquanto a cor vermelha significa que se deve parar.

\section{- Capacidades Percebidas (Affordances)}

Affordance é como percebemos a capacidade de um determinado objeto. Norman apresenta o exemplo das portas em que o formato da maçaneta indica a forma de abri-las; um outro exemplo são as alças das malas ou sacolas que fazem o usuário perceber a forma como deve carregá-las.

\section{Heurísticas na Avaliação da Usabilidade}

Quando os princípios de design são utilizados na prática, eles geralmente são referidos como heurísticas $^{31}$, ao passo que utilizar os princípios da usabilidade para avaliar um projeto de design da interação é chamado de avaliação heurística. Este tipo de avaliação, que tem sido popularmente utilizado para a avaliação de protótipos e sistemas existentes, baseia-se nos dez princípios de usabilidade desenvolvidos por Jakob Nielsen (2001) (apud PREECE, 2002).

A avaliação heurística é um método da engenharia da usabilidade para encontrar problemas no design da interface do usuário de modo que possam ser considerados como parte de um processo de design iterativo. A avaliação heurística compreende ter um pequeno grupo de avaliadores julgarem uma interface e julgarem sua concordância com princípios reconhecidos da usabilidade (as "heurísticas").$^{32}$ (NORMAN;NIELSEN, 2010).

\footnotetext{
31 Segundo a definição do Dicionário Houaiss (p. 1017), "Heurística" significa: "arte de inventar, de fazer descobertas"; no mesmo verbete, seu significado na pedagogia é: "Método educacional que consiste em fazer descobrir pelo aluno o que lhe quer ensinar".

32 Tradução minha da definição publicada no site de Jakob Nielsen, www.useit.com: "Heuristic evaluation (Nielsen and Molich, 1990; Nielsen 1994) is a usability engineering method for finding the usability problems in a user interface design so that they can be attended to as part of an iterative design process. Heuristic evaluation involves having a small set of evaluators examine the interface and judge its compliance with recognized usability principles (the 'heuristics')." Disponível em: <http://www.useit.com/papers/heuristic/>. Acesso em: 29/11/2010.
} 
Segundo Nielsen, os dez princípios para o design de interfaces aqui apresentados são denominados de "heurísticas", por serem aproximações e não regras específicas da usabilidade ${ }^{33}$.

As Dez Heurísticas da Usabilidade de Nielsen (1994):

\section{Visibilidade do status do sistema:}

O sistema deve sempre manter os usuários informados sobre o que está acontecendo através de feedback apropriado, em um tempo razoável.

\section{Compatibilidade entre sistema e mundo real:}

O sistema deve utilizar a linguagem do usuário, com palavras, frases e conceitos familiares para ele, ao invés de termos específicos de sistemas. Seguir convenções do mundo real, fazendo que a informação apareça em uma ordem lógica e natural.

\section{Controle e liberdade para o usuário:}

Estão relacionados à situação em que os usuários frequentemente escolhem as funções do sistema por engano e então necessitam de "uma saída de emergência" claramente definida para sair do estado não desejado sem ter de percorrer um longo diálogo, ou seja, é necessário suporte a undo e redo.

\section{Consistência e padrões:}

Referem-se ao fato de que os usuários não deveriam ter acesso a diferentes situações, palavras ou ações representando a mesma coisa. A interface deve ter convenções não ambíguas.

\section{Prevenção de erros:}

Os erros são as principais fontes de frustração, ineficiência e ineficácia durante a utilização do sistema.

\section{Reconhecimento em lugar de lembrança:}

Tornar objetos, ações, opções visíveis e coerentes. O usuário não deve ter de lembrar informações de uma parte do diálogo para outra. Instruções para o uso do sistema devem estar visíveis ou facilmente acessíveis.

\section{Flexibilidade e eficiência de uso:}

A ineficiência nas tarefas pode reduzir a eficácia do usuário e causar-lhes frustração. O sistema deve ser adequado tanto para usuários inexperientes quanto para usuários experientes.

\section{Projeto minimalista e estético:}

\footnotetext{
${ }^{33}$ Tradução de Jair Cavalcanti Leite, publicada em http://www.dimap.ufrn.br/ jair/. Acesso em: 30/11/2010.
} 
Os diálogos não devem conter informações irrelevantes ou raramente necessárias.

Cada unidade extra de informação em um diálogo compete com unidades relevantes e diminui sua visibilidade relativa.

\section{Auxiliar os usuários a reconhecer, diagnosticar e recuperar erros:}

Mensagens de erro devem ser expressas em linguagem natural (sem códigos), indicando precisamente o erro e sugerindo uma solução.

\section{Ajuda e documentação:}

Mesmo que seja melhor que o sistema possa ser usado sem documentação, pode ser necessário fornecer ajuda e documentação. Tais informações devem ser fáceis de encontrar, ser centradas na tarefa do usuário, listar passos concretos a serem seguidos e não ser muito grandes. A ajuda deve estar facilmente acessível e on-line. (NIELSEN, 1994).

\subsubsection{Modelos Conceituais}

Um método utilizado por designers da interação no desenvolvimento de um projeto é a elaboração de modelos conceituais do usuário de modo que se possa visualizar o produto. Este modelo é definido por Preece (2002) como:

Uma descrição do sistema proposto - em termos de um conjunto de ideias e conceitos integrados a respeito do que ele deve fazer, de como deve se comportar e como o que se deve parecer - que seja compreendida pelos usuários da mesma maneira pretendida. (PREECE et al., 2005, p. 61).

Os modelos conceituais podem ser baseados em atividades; Preece (2005) classifica estes modelos em:

1. Instrucional - Em que o usuário dá instruções ao sistema relativas às tarefas que gostaria de realizar, como é o caso das interfaces que utilizam linhas de comando.

2. Conversacional - No qual o usuário conversa com o sistema, como é o caso dos sistemas automáticos de voz ou menus que apresentam opções que devem ser respondidas pelo usuário.

3. Manipulação e Navegação - Em que se manipulam objetos em espaços virtuais, como as interfaces de manipulação direta (SCHNEIDERMAN, 1983) como a do Apple Macintosh. 
4. Exploração e Pesquisa - Como é o caso dos navegadores da internet, em que o usuário pode ir através de links e conhecimentos preexistentes de mídias como jornais e revistas.

Outros modelos conceituais podem ser baseados em objetos ou metáforas, nos quais se desenvolve uma interface que simula objetos reais e as interações são baseadas no conhecimento e nos conceitos desses objetos com os quais já estamos familiarizados.

\subsubsection{Processos do Desenvolvimento de Software}

\section{Modelos de Processo}

A indústria de software tem aplicado diversos modelos de processos no desenvolvimento de software, modelos esses que têm sido estudados pela engenharia de software e normatizados, de modo que a produção de software em uma escala industrial seja realizada dentro de padrões de qualidade e entregue dentro de prazos previstos. Entre as normas existentes atualmente estão a ISO 12207, CMMI e MPS-BR (Melhoria de Processos de Software Brasileiro), voltadas à realidade do mercado no Brasil (FILGUEIRAS et al., 2006). Essas normas buscam sistematizar processos e metodologias utilizados pela indústria de software, que buscam estruturar o ciclo de projetos de sistemas interativos e que são fundamentais no processo do Design de Interação. Os métodos tradicionais têm sido considerados extremamente formais e substituídos por modelos mais ágeis (MOREIRA; CASTRO, 2007). Dentre os modelos e processos mais comumente utilizados atualmente encontramos:

\section{Modelos de Ciclo de Vida}

A engenharia de software tem utilizado o termo "modelo de ciclo de vida" (Lifecycle Models) para definir um modelo que capta uma série de atividades e como estas se relacionam entre si (PREECE et al., 2005). Os modelos de Ciclo de Vida mais conhecidos são o Modelo em Cascata e o Modelo em Espiral. 
O Modelo em Cascata (Waterfall), também conhecido como o modelo Clássico, apresenta uma sequência a ser seguida rigorosamente, em que cada etapa deve ser cumprida e aprovada antes de seguir a próxima etapa. Este modelo é considerado bastante desatualizado, por ser bastante linear e não adotar em sua filosofia a ideia de iteração, revisões e o feedback dos usuários, nem a incorporação de novas fases no processo. (PREECE, 2005; MOREIRA;CASTRO, 2007)

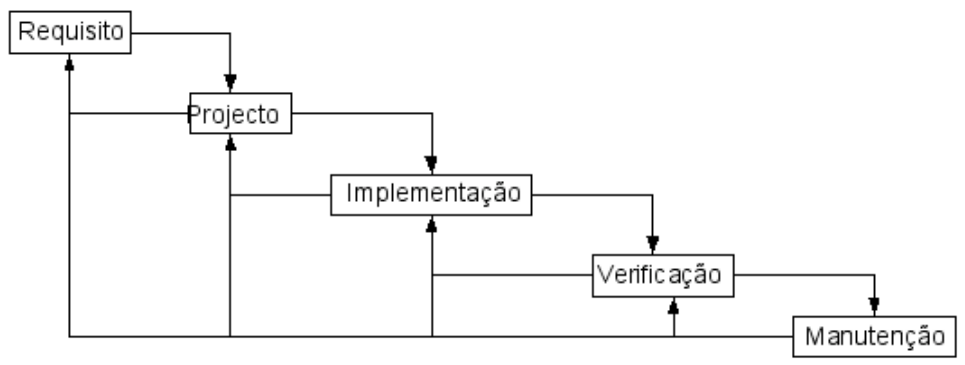

FIg. 2.21: Modelo de Ciclo de Vida de Software em Cascata Fonte: http://wiki.portugal-a-programar.org/

O Modelo em Espiral, proposto originalmente por Barry Boehm em 1988 (apud PREECE, 2005), é uma evolução do modelo cascata que incorpora iterações advindas da análise de riscos e alternativas de design advindas da prototipagem. Embora as iterações previstas neste modelo não previam originalmente as contribuições dos usuários, o modelo tem sido adaptado para incorpora-las.

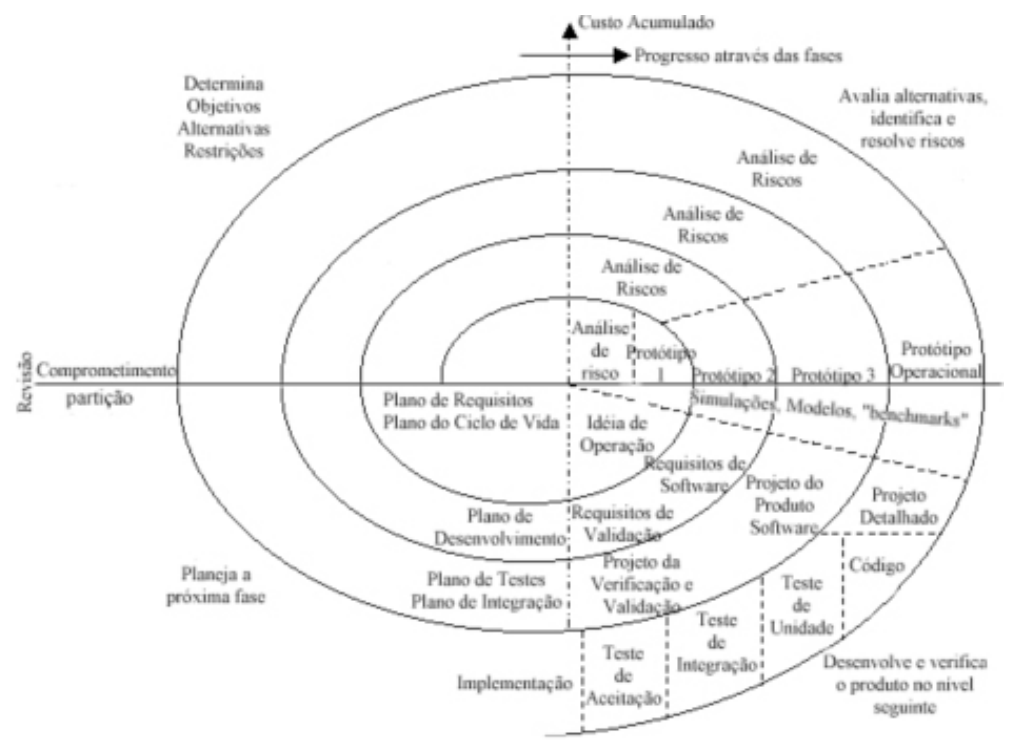

Fig. 2.22: Diagrama representando o Modelo de Ciclo de Vida de Software em Espiral. Fonte: http://voat.com.br/rdal/?tag=cascata 


\section{Processos Iterativos}

As iterações incorporadas inicialmente no modelo em espiral com o objetivo de atender as demandas dos clientes, e posteriormente reconhecer a importância das avaliações realizadas com os usuários, abriram caminho para os processos iterativos. Entre os processos iterativos mais conhecidos destacam-se o Rapid Applications Development (RAD), Rational Unified Process (RUP) - desenvolvido pela Rational Software Corporation. Os processos iterativos surgiram da necessidade de limitar a duração dos ciclos de desenvolvimento e de incorporar uma visão centrada no usuário nas diversas fases do processo. Mais recentemente tem se adotado o termo "Metodologias Ágeis" por especialistas que passaram a compartilhar métodos de desenvolvimento de software através da Aliança Ágil ${ }^{34}$; os valores propagados por esta aliança estão declarados no "Manifesto Ágil” publicado no site da Aliança:

Indivíduos e interações mais que processos e ferramentas

Software em funcionamento mais que documentação abrangente

Colaboração com o cliente mais que negociação de contratos

Responder a mudanças mais que seguir um plano (http://www.agilemanifesto.org/iso/ptbr/)

Os processos ágeis têm sido adotados por empresas de software de pequeno e médio porte, valorizam a desburocratização e a comunicação face a face entre os indivíduos envolvidos no processo. Uma das "metodologias ágeis" mais conhecidas é a Extreme Programming (XP), uma das "principais diferenças da XP em relação às outras metodologias são feedback constante e abordagem incremental" (MOREIRA;CASTRO, 2007).

\subsection{Conclusão do Capítulo}

Até agora vimos como os computadores, as redes de comunicação digitais e os softwares promoveram o surgimento de novas mídias digitais e como as interfaces entre os homens e os computadores se estabelecem como elementos formativos de uma nova linguagem. Com ela surgem novos códigos, vocabulários e processos particulares a estas

34 http://www.agilealliance.org/ 
mídias e que estão em constante evolução. Computadores e dispositivos digitais não são mais considerados apenas um equipamento de escritório, fazem parte de diversos aspectos de nosso dia a dia, em particular no que se refere à forma como nos comunicamos. A mídia eletrônica deixa de ser primordialmente unidirecional e com a digitalização da TV, a mais importante mídia eletrônica do século XX, está iniciando um processo de transformação com vastas consequências, desde sua recepção e seus aspectos técnicos à forma como iremos experienciála, que inclui a temporalidade, a interatividade, a mobilidade e novas formas de produção.

Com isso, as pesquisas no campo do design de interação têm uma importância ainda pouco explorada no design e na produção de programas e sistemas para a TV Digital, que ainda na sua infância está buscando a definição de sua identidade e linguagem. Interfaces por gestos, a linguagem metafórica, a comunicação entre dispositivos e a não linearidade certamente irão fazer parte do repertório do design para a TV Digital.

\section{No próximo capítulo}

No próximo capítulo, faço um levantamento da tecnologia e dos sistemas de TV Digital que estão sendo introduzidos no Brasil e no mundo e as transformações que estão ocorrendo na TV Digital, que mal foi introduzida e já está redefinindo-se em função dos avanços tecnológicos no campo da computação e comunicação digital, caracterizando um cenário de convergência das mídias em que a TV inevitavelmente está inserida. 
Capítulo 3

\section{TV Digital - Estado da arte}

"No entanto, o design para TVDI deve libertar-se do paradigma da TV Expandida".

\subsection{TV Digital - Definição, padrões e sistemas}

\subsubsection{O que é TV Digital, ou o que é percebido como TV Digital?}

O Sistema Brasileiro de TV Digital (SBTVD) está gradativamente substituindo a TV analógica convencional no Brasil. Enquanto ocorre a implantação deste novo sistema, que se iniciou em 2007 e está sendo realizado de forma gradativa, começando pelas principais capitais até chegar a todos os municípios brasileiros em $2016^{35}$, receberemos simultaneamente o sinal de TV digital e o analógico no padrão $\mathrm{PAL}_{-\mathrm{M}^{36}}$, quando então se prevê o encerramento da transmissão de TV analógica.

Como veremos nos exemplos apontados a seguir, a maioria das definições da TV digital descrevem-na como uma tecnologia que permite a produção e transmissão da TV utilizando sinais digitais, trazendo como consequência: a melhoria da qualidade do som e imagem, mais canais, novos serviços e aplicativos interativos. A Cartilha da TV Digital, publicada pelo CREA de Minas Gerais (SOUZA et al., 2007), começa com a seguinte

\footnotetext{
${ }^{35}$ http://www.dtv.org.br/index.php/onde-ja-tem-tv-digital/evolucao-da-tv-digital/

${ }^{36}$ O sistema de TV analógico PAL-M, adotado no Brasil nos anos 1970, é derivado do sistema PAL europeu semelhante a outros sistemas de TV analógicos como o NTSC norte-americano quanto ao aspecto de imagem $3 \times 4$, o espaço de cor RGB e o fato de a imagem ser composta por campos entrelaçados. As linhas que compõem a imagem da TV analógica são entrelaçadas, isto é, as linhas ímpares ou as pares alternam-se na tela da TV, mas a nossa retina registra uma imagem única devido à velocidade com a qual elas se desenrolam. Isso faz que a resolução efetiva seja metade do número de linhas. No sistema PAL-M são transmitidas 525 linhas de vídeo a $60 \mathrm{~Hz}$ e 30 quadros por segundo, enquanto no sistema PAL Europeu são transmitidas 625 linhas.
} 
definição:“A televisão digital (TVD) é um sistema tecnológico que permite transmitir e receber o sinal de televisão em formato digital.”( (SOUZA et al., 2007, p. 7).

Ao dirigir-se à categoria dos engenheiros, na simpliciade dessa definição, Souza busca estabelecer um parâmetro estritamente técnico antes de analisar as consequências da introdução desta tecnologia.

No site DTV.org.br, publicado pelo Fórum SBTVD $^{37}$ com o objetivo de esclarecer o público em geral sobre a implantação da TV Digital no Brasil, encontramos orientações de como receber a TV Digital, notícias, perguntas e respostas frequentes, entre outras informações sobre o assunto. Eles apresentam a seguinte definição:

O que é TV Digital? É uma nova tecnologia de transmissão de sinais de televisão, que proporcionará gratuitamente ao telespectador melhor qualidade de imagens e sons e uma série de novos benefícios, tais como ver televisão quando em deslocamento e interagir com os programas. (DTV, $2010)^{38}$.

Neste caso, já vemos uma referência às consequências da digitalização buscando promover a adoção da TV Digital. Já o site da Fundação de Proteção e Defesa do Consumidor (PROCON) de São Paulo ${ }^{39}$ apresenta uma definição similar à do Fórum SBTVD:

É uma nova tecnologia de transmissão dos sinais de televisão, com melhoria na qualidade da imagem e do som. Através dessa nova tecnologia, também será possível a interatividade entre o consumidor e a emissora, ou seja, o consumidor poderá ter acesso a informações sobre a programação e outros serviços oferecidos pelas emissoras, através de comandos disponíveis nos novos aparelhos. (PROCON, 2007).

Mas o órgão de proteção ao consumidor logo avisa que "O consumidor terá até o ano de 2016 para se preparar e se equipar para utilizar a nova tecnologia. O consumidor não deve ter pressa e procurar entender como funcionará o novo sistema antes de ir às

\footnotetext{
${ }^{37}$ O fórum SBTVD é uma organização sem fins lucrativos da qual participam empresas públicas e privadas, emissoras de TV, institutos de pesquisa e universidades. O Fórum SBTVD é composto por quatro módulos: Mercado, Promoção, Propriedade Intelectual, Promoção e Técnico. O endereço do site é www.forumsbtvd.org.br, uma referência importante para os profissionais da TV digital no Brasil, já que nele podem ser encontradas as normas completas da TV Digital publicadas pela ABNT acompanhada a implantação da TV Digital no país.

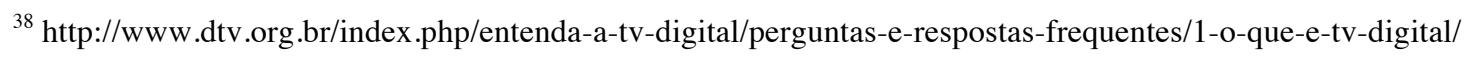

${ }^{39}$ http://www.procon.sp.gov.br/pdf/OrientaTvDigital.pdf
} 
compras."(PROCON, 2007). Subentende-se que a tecnologia e os produtos no mercado ainda estão em desenvolvimento, assim sendo o consumidor deve refletir se este é o momento adequado para realizar o investimento necessário para adotar esta nova tecnologia.

Embora se sustente que as inovações decorrentes do processo de digitalização da TV irão transformar a experiência do telespectador, como vemos na definição publicada pelo Federal Communications Comission $(\mathrm{FCC})^{40}$, em seu site dtv.gov:

A TV Digital (DTV) é uma avançada tecnologia de transmissão que tem transformado sua experiência ao assistir televisão. DTV tem possibilitado às emissoras oferecerem uma TV com melhor qualidade de imagem e som. Ela também oferece múltiplas opções de programação, chamadas de multicasting, e capacidades interativas. (DTV, 2010) ${ }^{41}$.

A Agência Nacional de Telecomunicações (ANATEL), o órgão regulador das telecomunicações no Brasil, estabeleceu em 1999 um termo de cooperação técnica com o instituto de pesquisa $\mathrm{CPqD}^{42}$ na realização de pesquisas para o desenvolvimento do SBTVD, “dando início ao processo de avaliação técnica e econômica para a tomada de decisão quanto ao padrão de transmissão digital a ser aplicado no Brasil ao Serviço de Radiodifusão de Sons e Imagens". (OLIVEIRA; CARVALHO; JÚNIOR, 2006). Um documento publicado pelo $\mathrm{CPqD}$ sobre o histórico SBTVD reforça as vantagens proporcionadas pela tecnologia da TV Digital:

\footnotetext{
${ }^{40}$ O Federal Communications Comission - FCC é o órgão regulador da área de telecomunicações e radiodifusão nos Estados Unidos.

${ }^{41}$ Tradução minha de: "Digital Television (DTV) is an advanced broadcasting technology that has transformed your television viewing experience. DTV has enabled broadcasters to offer television with better picture and sound quality. It also offers multiple programming choices, called multicasting, and interactive capabilities." Disponível em: <http://www.dtv.gov/whatisdtv.html>. Acesso em: 03/12/2010.

42 “A escolha do CPqD para a prestação desses serviços considerou não apenas o histórico de serviços prestados à Agência e às empresas operadoras da antiga Telebrás, mas o elevado domínio técnico das tecnologias de compressão digital de sons e imagens." (BORDIM et al., 2006).

Segundo o próprio site do instituto CPqD: "O CPqD foi criado em 1976 como Centro de Pesquisa e Desenvolvimento da Telebrás, empresa estatal que detinha o monopólio dos serviços públicos de telecomunicações no Brasil. Desde então, ocupa posto de vanguarda tecnológica, sintonizado com o futuro e antecipando-se às necessidades de uma sociedade que se modifica e evolui em alta velocidade. Em 1998, com a privatização do sistema Telebrás, o CPqD tornou-se uma fundação de direito privado, ampliando a sua atuação, tanto no escopo como na abrangência do mercado.” Em: http://www.cpqd.com.br/o-cpqd/historico.html.
} 
A TV Digital não deve ser vista apenas como uma evolução tecnológica da televisão. Trata-se de uma nova plataforma de comunicação baseada em tecnologia digital para a transmissão de sinais. Esta tecnologia proporciona ganhos em termos de qualidade de vídeo e áudio, aumento da oferta de programas televisivos e novas possibilidades de serviços e aplicações. $(\mathrm{CPqD}, 2010)^{43}$.

Esse documento reflete as mesmas justificativas apresentadas na "Minuta de Exposição de motivos da TV Digital” (BRASIL, 2003), pelo ministro Miro Teixeira em 2003 à presidência da República durante o debate sobre a definição do SBTVD .

6. De maneira bastante sucinta, a adoção da tecnologia digital é capaz de oferecer os seguintes benefícios para a sociedade, no geral, e para os usuários, em particular:

a) novas ferramentas tecnológicas de comunicação para serem utilizadas em políticas públicas de inclusão social e digital;

b) novos serviços e aplicações de telecomunicações, principalmente aqueles baseados em interatividade;

c) possibilidade de uma mesma exploradora de serviço de radiodifusão de sons e imagens ofertar um conjunto maior e diversificado de programas televisivos simultâneos; e

d) melhor qualidade de vídeo e de áudio. ${ }^{44}$

Vemos que as vantagens da digitalização da TV apresentadas hoje pelo CPqD tanto como as apresentadas pelo Ministério das Comunicações em 2003 enfatizam os aspectos inovadores das transformações tese decorrentes da adoção da tecnologia digital na TV e como isto irá definir novas plataformas e serviços de telecomunicações.

5. O que caracteriza a digitalização do serviço de radiodifusão de sons e imagens é que os sinais transmitidos podem ser submetidos a uma ampla gama de processamentos digitais, conferindo ao serviço características não apenas vantajosas, mas também inovadoras, quando comparadas àquelas que são suportadas pelas tecnologias de transmissão e de processamento analógico. Mais ainda, outros sinais, que não apenas os de vídeo e de áudio, podem ser transmitidos pelo mesmo canal, abrindo possibilidades quanto à oferta de novos serviços de telecomunicações. (BRASIL, 2003).

\footnotetext{
${ }^{43} \mathrm{http} / / /$ sbtvd.cpqd.com.br/?obj=historico\&mtd=texto\&item $=1$.

44 "Minuta de Exposição de Motivos da TV Digital" - Proposta em debate em 25/6/2003. Brasília, junho de 2003. Disponível em: <http://www.mc.gov.br/tv-digital>.
} 
Do ponto de vista do consumidor, essas transformações têm sido muito mais "evolucionárias do que revolucionárias" (MORRIS; SMITH-CHAIGNEAU, 2005). A melhoria da qualidade da transmissão e do som e a alta resolução de imagens a princípio não têm tido grande impacto na percepção dos telespectadores a ponto de fazê-los migrar em massa para a TV Digital ${ }^{45}$ (MORRIS; SMITH-CHAIGNEAU, 2005). Com isso tem sido criada a expectativa de que novos produtos e serviços interativos irão atrair os telespectadores a adotar a tecnologia, no entanto a incorporação desses serviços tem sido bastante lenta. Nos EUA, onde tem se dado prioridade à TV de Alta Definição (HDTV) e há uma grande penetração da TV a cabo, a migração para receptores de TV Digital durante o período de transição foi inferior às expectativas da indústria (LU, 2005).

Na Europa, onde há um histórico de sucesso de serviços interativos na TV como o videotexto, o legado de receptores e Set-Top-Boxes (STBs) analógicos e a dominância de middleware proprietário nos STBs dos serviços pagos têm retardado a adoção do middleware Multimedia Home Platform (MHP) em alguns mercados (MORRIS;SMITH-CHAIGNEAU, 2005).

No Brasil, a demora da incorporação do Ginga, middleware aberto do SBTVD nos receptores de TV Digital entre outros fatores têm frustrado as expectativas de que a interatividade iria impulsionar a migração para a TV Digital.

A TV Digital pode ser compreendida como um processo de digitalização da Mídia TV que traz como consequência o florescimento (amadurecimento) de uma nova mídia. No entanto, as transformações que têm sido decorrentes desse processo não têm alterado o que concebemos como TV, em parte pela dominância das formas tradicionais de conteúdo audiovisual, mesmo que distribuídos em novas mídias, e também pelo interesse da indústria de comunicação de massa, em particular as emissoras de TV, em direcionar o desenvolvimento das novas tecnologias em modelos que mantêm os seus modelos de negócio. Essa resistência é similar à que ocorreu com a indústria fonográfica com o advento dos arquivos MP3 e dos serviços de compartilhamento como o Napster.

\footnotetext{
45 "To the layman, however, DTV can be a little confusing. During a demonstration of DVB-T SDTV at the 2000 International Broadcasting Convention in Amsterdam, visitors asked one of the authors whether the pictures they were looking at were 'high definition'. From questions like this, it is obvious that their main understanding of DTV was the format and not the technical details. Why the confusion? In this case, the content they were seeing was an SDTV picture being displayed on some of the first 16:9 plasma TVs on the market. Visitors - not even average consumers, but visitors to a broadcasting-related trade show - assumed that this new plasma display meant high-definition signals.” (MORRIS;SMITH-CHAIGNEAU, 2005).
} 
Os novos serviços e aplicativos interativos que estão sendo utilizados pelas emissoras e a indústria eletrônica como forma de justificar os investimentos no setor, tanto por parte do governo como dos consumidores, têm em sua maioria o objetivo de expandir (realçar) e facilitar o acesso às formas existentes de conteúdo, como é o caso dos guias de programação, um maior número de canais (multiplexing), a TV Expandida ou mesmo o comércio eletrônico e a publicidade interativa. Grosso modo, a tecnologia sendo padronizada nos sistemas de TV Digital enfatiza os processos de produção e distribuição já estabelecidos pelas emissoras e produtoras de conteúdo, de modo a não ameaçar interesses e mercados já estabelecidos.

No entanto, a convergência das mídia tem facilitado a introdução de formas inovadoras e interativas de se assistir a filmes e vídeos, utilizando a internet e redes de celulares cada vez mais rápidas como meio de distribuição. Serviços como Internet Protocol TV (IPTV), sites de compartilhamento de vídeos como Vimeo e You Tube, redes sociais, entre outros, têm sido responsáveis pelo aumento exponencial do tráfego de vídeos na internet (ANDERSEN, 2010). A popularização dessas novas formas de se assistir televisão tem ameaçado a soberania de grupos tradicionais de mídia como as emissoras de TV, operadoras de TV a cabo (CATV) e satélite Direct to Home (DTH).

Em meados dos anos 1990, quando FCC que estava prestes a aprovar o padrão de TV digital norte-americano, a indústria de computação e do cinema organizou-se através do Americans for Better Digital TV ${ }^{46}$, um comitê ad-hoc liderado por Bill Gates para contestar as decisões que estavam sendo tomadas pelos conselheiros do FCC. Essas demandas levaram Reed E. Hundt, presidente do FCC, a manifestar seu desagrado sobre a decisão de aprovar o padrão de TV Digital que atendia aos interesses do lobby da Grand Alliance ${ }^{47}$, uma invenção da indústria do Broadcast, cujo único interesse era obter o espectro gratuitamente (CARUSO, 1996). “A Grande Aliança foi uma criação da indústria da televisão, cujo principal objetivo era

\footnotetext{
46 “Americans for Better Digital TV, a sort of ad hoc committee comprised of various computer, entertainment and consumer interest groups and corporations recently coalesced under the leadership of Microsoft and Bill Gates. This loosely banded group disagrees on several specific points - or rather doesn't necessarily agree on everything - but has united in an effort to alter the proposed standard or stop it altogether." (KAVANAGH, 1996).
}

47 "The Grand Alliance, a cross-industry coalition consisting of Lucent Technologies, General Instrument, MIT, Philips, Thomson, Zenith and the David Sarnoff Research Center. Over the past decade, these companies worked first individually, then together in the formation of the proposed new standard for digital television." (KAVANAGH, 2006). 
garantir que obtivessem o espectro de graça", diz Hundt. "Não é largamente anunciado desta forma, mas é minha opinião." (CARUSO, 1996). ${ }^{48}$

Um artigo do New York Times retrata Hundt cada vez mais cético com a indústria da TV, buscando um bom motivo para frear o processo de aprovação do padrão de TV Digital nos EUA ao dar cada vez mais crédito às objeções pessoais de Steven Spielberg e Bill Gates. Hundt teria afirmado que "Não é um consenso da indústria se só as redes de TV estão de acordo." (DONNELLY, 1996). ${ }^{49}$

A definição de Sivaldo Pereira da Silva da TV Digital é mais abrangente que a da indústria da TV:

A TV digital e seus antecedentes - a TV a cabo/satélite - estão inseridos dentro do que pode ser chamado de "sistemas emergentes de mídia digital": um conjunto de dispositivos de comunicação e seus modelos de serviços que possuem outro design tecnológico e, consequentemente, sustentam potencialidades para outro modo de relação com o usuário, quando comparamos ao modelo analógico anterior. Isto traz novas características para a comunicação mediada em larga escala e muda, de modo substancial, as relações no interior desses processos comunicativos. (SILVA, 2009, p. 20).

Atualmente vemos novos grandes grupos se fortalecendo na nova economia da informação e passando a competir com os players do mercado de televisão, independentemente de terem espectro ou operarem em padrões horizontais. A introdução de seus serviços e produtos como a Google TV e a Apple TV e a integração de widgets da Yahoo e do Facebook em televisores capazes de serem conectados diretamente à internet demonstram como essas empresas tem dado a volta por cima dos padrões de TV Digital ao distribuírem soluções que, embora sejam proprietárias, têm uma compatibilidade com uma base significativa de computadores conectados em rede. É claro que esta solução vertical,

\footnotetext{
${ }^{48}$ Tradução minha de: "The Grand Alliance was a creation of the broadcasting industry, the primary purpose of which was to make sure they could get the spectrum" for free, says Mr. Hundt. "It's not widely reported that way, but that's my opinion." (CARUSO, 1996).

${ }^{49}$ Tradução minha de: "It's not an industry consensus if only broadcasters and manufacturers agree." (DONNELLY, 1996) em "Determining the Next U.S. Television Standard, David Donnelly, Ph.D., New Telecom Quarterly 3Q96 Austin
} 
como é o caso da Apple, tem o objetivo de dominar a distribuição de filmes e programas de TV de modo a sustentar os produtos eletrônicos da empresa. No caso da Google, ela tem feito parcerias com fabricantes de hardware, elegendo o sistema operacional Android, que tem sido incorporado a televisores que podem ser conectados à internet, em clara oposição à Apple.

Como sabemos por experiência de cada um (tem se tornado um prática comum), as soluções da indústria da computação exigem constantes atualizações de software, que por sua vez demandam cada vez mais do hardware, exigindo processadores mais rápidos, fazendo com que o consumidor acabe trocando de hardware. Por ocasião do debate sobre a definição do sistema de TV Digital nos EUA, em contraponto à posição da indústria da computação, Edward Fritts, presidente da National Association of Broadcasters (NAB), coloca a seguinte posição.

Esta tentativa na $11^{\text {a }}$ hora do Bill Gates e de alguns fabricantes de computadores de derrubar este padrão é em seu próprio interesse. Consumidores querem a certeza de TV gratuita. Eles não querem ser forçados a comprar computadores a cada ano somente para assistirem a seus programas favoritos, e eles não querem ficar pensando se seus computadores vão travar no meio do noticiário. (KAVANAGH, 1996). 50

Efetivamente o que tem acontecido é que, com a digitalização, a indústria eletroeletrônica, ao fabricar os aparelhos de TV Digital, não tem escapado do modus operandi da indústria de computação. No Brasil, no período que antecedeu a decisão do padrão de TV Digital, os aparelhos de TV de tela plana e alta definição não possuíam um conversor integrado, só recentemente e em parte por força de lei é que passaram a ser comercializados desta forma. No caso do Middleware GINGA, que possibilitaria a interatividade, a situação é ainda mais complicada; existem até o momento dois receptores (Sony e LG) com o Middleware integrado na TV disponível no mercado brasileiro, sendo que é difícil prever qual será a forma de atualização do hardware e software nestas TVs. A outra opção é a aquisição de um conversor externo que, para que esteja dentro de uma faixa de preço accessível,

\footnotetext{
${ }^{50}$ Tradução minha de: "On the other side of the issue, National Association of Broadcasters President/CEO Edward O. Fritts says the following: "This 11th-hour attempt by Bill Gates and a few computer companies to scuttle this standard is anti-competitive and self-serving. Consumers want the certainty of free TV. They don't want to be forced to buy new computers and software every year just to watch their favorite TV programs, and they don't want to be left wondering if their computers will crash in the middle of the evening news. That could happen if computers ultimately become the delivery vehicle for American television."
} 
provavelmente terá uma baixa capacidade de processamento, o que inevitavelmente irá levar o consumidor a realizar um upgrade quando serviços interativos se tornarem mais comuns, replicando os problemas da indústria de software mencionados anteriormente.

A questão do canal de retorno que permite a interatividade plena ainda é uma incógnita; os conversores (STBs) preveem a possibilidade de utilização de diversos canais como WiMAx, CDMA, linhas telefônicas, TV a cabo (ZIMMERMAN, 2007) ${ }^{51}$, mas não há um consenso, deixando o consumidor no mínimo confuso. A limitação do retorno acaba por estimular a produção de conteúdo interativo com interatividade local como os já citados; com o crescimento da internet no Brasil e principalmente das redes sociais, inclusive em camadas sociais mais populares, a ausência desse tipo de interatividade que só é possível com o canal de retorno provavelmente irá frustrar o telespectador que busca a interatividade na TV. Em contrapartida, o Brasil viu um crescimento exponencial do número de linhas de celulares nos últimos anos, chegando a cerca 200 milhões no ano de 2010, o que equivale, grosso modo, a uma linha por habitante. Uma vez que as tecnologias de rede dos celulares têm evoluído, ao passo que os preços de acesso a redes de dados têm decaído (embora sejam bastante caras), é possível conceber que este seja uma forma de canal de retorno não só pela viabilidade tecnológica e econômica que pode estabelecer-se, mas também pelos aspectos culturais do telefone, que é uma mídia de comunicação bidirecional por natureza e assim poderá ser assimilado mais facilmente pelo usuário.

\section{Características da TV Digital}

As principais características da TV Digital são:

1. Digitalização do sinal.

2. Múltiplas resoluções de imagem.

3. Múltiplos canais de áudio.

4. Interatividade.

\footnotetext{
${ }^{51}$ Filipe Zimermann, Canal de Retorno em TV Digital: técnicas e abordagens para a efetivação da interatividade televisiva. Monografi, Departamento de Informática e Estatística, Universidade Federal de Santa Catarina (UFSC), Florianópolis, SC, 2007. Orientador: Mario Antonio Ribeiro.
} 
No caso do Brasil, o padrão SBTVD-T permite a recepção móvel, como nos meios de transporte ou em receptores portáteis como celular. A legislação também prevê o acesso à internet, cuja implementação ainda depende de uma definição do canal de retorno (REGIS; FECHINE, 2006).

Essas características são possíveis através de hardware e Middleware. No caso do hardware, refiro-me a monitores que permitem exibir as imagens e os sons transmitidos em diversas qualidades e que tenham a capacidade de processar o sinal digital. Para que haja compatibilidade entre os diversos tipos de dados que trafegam na TV Digital, os sistemas buscam padronizar uma camada comum entre o hardware encontrado nos aparelhos de diversos fabricantes e o sinal sendo transmitido e o aplicativos que serão utilizados na TV e que rodam ou em terminal de acesso na TV.

A TV Digital pode englobar desde imagens em alta definição ou standard, como imagens em resoluções mais baixas, apropriadas para a visualização em um celular. Isso é possível porque a TV Digital, em vez de transmitir imagens moduladas em tempo real, consiste na transmissão de dados modulados em uma faixa de frequência alocada para esse fim. Esses dados não precisam necessariamente representar a codificação audiovisual de um programa de TV, podem também incluir outros sons, imagens, textos, programas de computador, informação e mesmo outros vídeos que são digitalizados e transmitidos pelos canais de dados que acompanham a transmissão da TV Digital. Esses dados, ao serem decodificados através de um Middleware instalado na receptor ou conversor de TV Digital, permitem a interatividade do telespectador ao acesso a serviços interativos, aplicativos computacionais, jogos eletrônicos e gravação de programas. Mais adiante serão apresentados mais detalhes sobre os tipos de interatividade na TV Digital.

Uma das características mais divulgadas da TV Digital é a possibilidade de transmitir imagens com qualidade superior à da TV Analógica, passando a ser conhecida como High Definition TV (HDTV), por possuir alta definição. Mas receber um sinal de TV Digital não significa necessariamente que a imagem seja em HDTV, pois ainda é comum que a captação de programas seja realizada em resolução standard (equivalente à da TV Analógica) e transmitida em HDTV.

A TV Digital possibilita a transmissão de dois ou mais canais de áudio, podendo ser mono, estéreo ou multicanal, como utilizado no esquema Surround 5.1 (no qual uma combinação de diversos canais permite tornar o som especial). Os múltiplos canais de áudio 
também permitem recursos adicionais de áudio como escolher idiomas em um filme, destacar instrumentos em um concerto, várias locuções em jogos de futebol entre outros.

Um aparelho de TV Digital deve ter a capacidade de processar os dados que recebe e transformá-los em sons e imagens, exibi-los em uma tela e permitir algum tipo de interatividade. Essencialmente é um computador com a funcionalidade dedicada a receber e exibir sinais de TV. Se considerarmos que os computadores pessoais (PCs) podem ser equipados com uma placa receptora de TV Digital e conectados à mesma tela e aos altofalantes de uma TV HD, transformando-os efetivamente numa TV, é possível questionar: em que sentido a TV Digital é diferente de um computador? Ocorre que existe uma diferença perceptual entre esses dois modos de recepção definida por serem mediados por dispositivos diferentes (que serão discutidos mais detidamente no capítulo 4).

Se abstrairmos todos os detalhes técnicos e nos concentrarmos na forma de assistir ou usar o computador e a TV, vemos que ao utilizarmos dispositivos digitais o que define a mídia é a postura do usuário e não o dispositivo propriamente dito. Até recentemente era comum pensarmos em ações distintas: assistir à TV e usar o computador, mas hoje podemos fazer os dois, acessar a internet e jogar games em uma TV ou assistir filmes em um computador. Com a proliferação de monitores de alta resolução, está tornando-se cada vez mais viável utilizar uma TV como um monitor de computador, possibilitando realizar tarefas que faríamos em um computador em um aparelho de TV.

A funcionalidade de um aparelho de TV analógico estava limitado a pouco mais do que a possibilidade de mudar de canal e regular o volume, mas recentemente as TVs passaram a incorporar entradas e saídas de vídeo, o que expandiu sua funcionalidade e permitiu que fossem utilizadas para assistir DVDs, jogar videogames entre outras atividades. A TV Digital integra essas novas funcionalidades na TV; em princípio, elas seriam incorporadas no aparelho, mas na maioria dos casos ainda depende da configuração de um set-top box (STB), um receptor externo que possibilita que o aparelho de TV (que não deixa de ser um simples monitor) receba o sinal digital.

A TV Digital vem substituir uma TV Analógica que em parte já está digitalizada, ou seja, assistimos programação digital em um aparelho analógico, e o inverso também é verdadeiro, pois podemos sintonizar um canal analógico ou conectar um aparelho de VHS em um aparelho de TV Digital. Inevitavelmente, a digitalização acaba por gerar sistemas bastante 
complexos, em oposição à experiência passiva da TV, que era bastante simples do ponto de vista do usuário.

Para o usuário, podemos generalizar que essas são especificidades de um mesmo invento, que é a TV Analógica, que, como outros meios de comunicação, requerem uma série de convenções de modo a garantir efetivamente a comunicação entre o transmissor e o receptor. Independentemente do sistema de TV, se tomarmos uma posição bastante simplista a configuração da TV é muito similar em todos os sistemas analógicos: uma antena, um circuito receptor de TV, um monitor de vídeo, um alto-falante e algum método de operar certas funções do aparelho.

Com isso chegamos à conclusão que a definição de TV Digital deveria ser mais abrangente, já que ela pode representar várias coisas: um padrão de transmissão de televisão através de um sinal digital, a produção de programas de TV utilizando equipamentos digitais, a recepção da TV utilizando dispositivos inteligentes móveis, assistir conteúdo audiovisual disponível na internet, filmes sob demanda em um avião, hotel, ou mesmo um canal de vídeo acessado em um videogame.

As soluções que fazem parte dos sistemas de TV Digital são, em sua maioria, consideradas horizontais, por terem como objetivo a recepção gratuita do sinal de TV Digital sendo transmitida no ar, de modo que há uma padronização dos aparelhos e settop boxes. No caso das soluções verticais, como aquelas utilizadas pelas operadoras de DTH e serviços com Apple TV e Google TV, a tecnologia tanto do hardware como o middleware são soluções proprietárias nas quais o consumidor deve adquirir o equipamento dedicado ao serviço. (SMITH-CHAIGNEAU, 2005).

\subsubsection{Padrões e Sistemas de TV Digital no Mundo}

Assim como na TV Analógica, diversos padrões de TV Digital foram adotados no mundo. Os principais padrões em uso são: O Digital Video Broadcast Group (DVB), europeu; o Advanced Television Systems Committee (ATSC), norte-americano; o Integrated Services Digital Broadcast (ISDB), desenvolvido no Japão; o Sistema Brasileiro de TV Digital (SBTVD) derivado do ISDB, implantado no Brasil; e o Digital Terrestrial Multimedia Broadcast (DTMB), recentemente adotado pela China. Esses padrões eventualmente foram 
adotados por outros países além daqueles para os quais foram desenvolvidos. A distribuição global dos padrões em 2010 pode ser vista no diagrama abaixo:

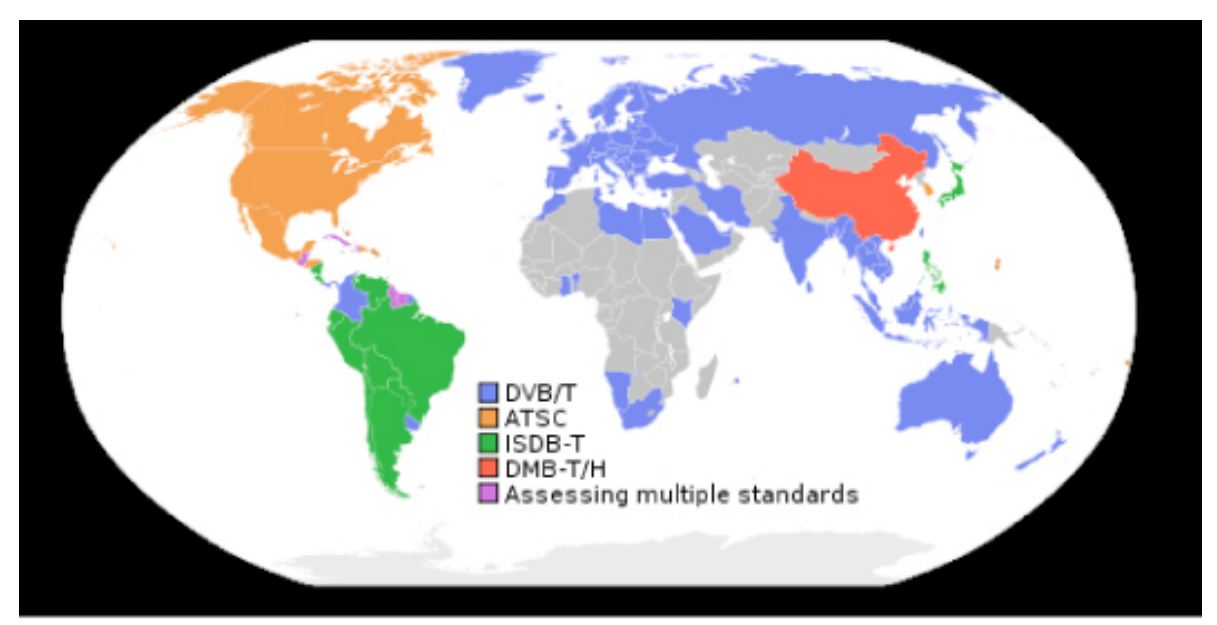

Fig. 3.1: Mapa dos padrões de TV Digital Terrestre 2010 Fonte: Wikipedia

DVB - A Europa foi pioneira na adoção de um padrão de TV Digital (GAWLINSKY, 2003), com o Digital Video Broadcasting (DVB), padrão que possui a especificação de um middleware, o Multimedia Home Platform (MHP), possibilitando que aplicativos interativos desenvolvidos por provedores de conteúdos diferentes rodem em receptores e STB's de diversos fabricantes (DVB PROJECT, 2000). Esses serviços interativos tornaram-se bastante comuns na Europa desde o final dos anos 1990, e diversos exemplos são apresentados mais adiante neste capítulo. O padrão DVB também foi adotado pela maioria dos países da América Central e do Sul, em vários paises do continente africano, no sul da Ásia e na Austrália.

ATSC - O padrão American Televison Standards Committee (ATSC) foi desenvolvido no início da década de 1990 por um consórcio Grand Alliance formado por empresas de telecomunicações e da indústria eletrônica. Este padrão substituiu o padrão analógico norteamericano NTSC. Desde 12 de junho de 2009, todas as emissoras de TV nos EUA passaram a transmitir digitalmente no padrão ATSC. O formato privilegia a TV de alta definição (FERNANDES; LEMOS; ELIAS, 2004) e tem havido pouco interesse por interatividade na TV, embora haja bastante integração dos canais de TV com sites das emissoras na internet. 
Como grande parte do país assina TV a cabo ou via satélite, muitos não perceberam a mudança, pois não dependiam da transmissão terrestre para receber um sinal digital. $\mathrm{O}$ site www.dtv.gov esclarece dúvidas sobre a transição para TV Digital.

ISDB - Embora o Japão tenha sido um dos pioneiros na transmissão da TV em Alta definição, no formato 16:9 nos anos 1980 (PEREIRA; BEZERRA, 2008), a transmissão de vídeo HDTV, originalmente analógica, utilizava o padrão Muse "Hi-vision", que foi substituído pelo padrão atual de TV Digital no Japão, o Integrated Services Digital Broadcast (ISDB), mantido pelo Association of Radio Industries and Business (ARIB), órgão normatizador da indústria de radiodifusão no Japão. No Brasil, adotamos um padrão derivado do ISDB, o ISDB-T como padrão de transmissão para o SBTVD.

DTMB - O sistema Digital Terrestrial Multimedia Broadcast (DTMB), adotado na China, é o mais recente padrão de TV Digital adotado no mundo, fato que traz algumas vantagens, pois a incorporação de novos avanços em codificação de dados faz com que seja um dos mais avançados do mundo. O padrão cobre tanto receptores fixos como móveis, mesmo que estejam em alta velocidade, e é bem menos suscetível a interferências que os padrões implantados anteriormente (KARAMCHEDU, 2009). O padrão DTMB foi adotado em Hong Kong e Macau e tem sido considerado para ser adotado pela Venezuela (SONG, 2008).

SBTVD - No Brasil, o Sistema Brasileiro de TV Digital (SBTVD) foi adotado em 2006 (CRUZ, 2008). Hoje as principais redes de TV já transmitem sua programação em HDTV digitalmente em algumas capitais e alguns testes de programas interativos têm sido realizados. Gradativamente este padrão irá substituir o padrão PAL-M analógico ainda em uso na maioria dos receptores de TV no país. Como padrão de transmissão terrestre do SBTVD, foi adotado o padrão ISDB-TB (SOUZA et al., 2007) sendo que TB é a abreviatura de Terrestre Brasileiro, permitindo várias resoluções de compressão de vídeo e utiliza o middleware Ginga desenvolvido em universidades brasileiras. A tabela abaixo sintetiza as características do sistema: 


\begin{tabular}{|l|l|}
\hline \multicolumn{2}{|c|}{ Especificações técnicas do padrão ISDB-TB } \\
\hline Aplicações & EPG, t-GOV, t-COM, Internet \\
\hline Middleware & Ginga \\
\hline Compressão de áudio & MPEG-4 AAC 2.0 ,5.1 canais \\
\hline Compressão de vídeo & $\begin{array}{l}\text { MPEG-4 H.264 } \\
\text { HDTV/1080i (1920 colunas por } 1080 \text { linhas entrelaçadas, 16:9) }\end{array}$ \\
\hline SDTV/480p (720 colunas por 480 linhas progressivas, 4:3) \\
LDTV/1SEG (320 colunas por 240 linhas, 4:3)
\end{tabular}

Tabela 3.1: Especificações técnicas do padrão ISDB-TB

Fonte: Wikipedia

\subsubsection{Sistema Brasileiro de TV Digital - SBTVD}

\section{Introdução}

Em 2003, foi assinado um decreto presidencial instituindo o Sistema Brasileiro de TV Digital (SBTVD), com o objetivo de estabelecer o padrão de TV Digital a ser adotado no país, a forma de exploração do serviço de TV Digital e o prazo do início das transmissões de TV Digital no Brasil. Foram realizadas pesquisas para o desenvolvimento do SBTVD em três áreas: tecnologia, regulamentação e conteúdo, inicialmente financiadas com recursos provenientes do Fundo para o Desenvolvimento Tecnológico de Telecomunicações (FUNTTEL).

Os principais focos do debate em torno da implantação da TV Digital no Brasil giraram em torno da definição das caracteristícas ou vantagens do sistema mais adequadas 
para impulsionar o desenvolvimento da TV Digital no país. Do ponto de vista dos telespectadores, espera-se que os consumidores sejam exigentes quanto aos recursos e serviços disponíveis no novo sistema, devido ao custo que eles irão ter para fazer um upgrade ou receber os novos serviços.

Em junho de 2006, definiu-se a escolha do padrão japonês ISDB-T como base para o desenvolvimento da TV Digital no Brasil, e que ficou também conhecido como ISDB-TB. Em novembro de 2006, foi instaurado o Fórum do Sistema Brasileiro de TV Digital, do qual participaram representantes da indústria, universidades, institutos de pesquisa e do governo, com o objetivo de assessorar o comitê de desenvolvimento da TV Digital (Fórum SBTVD 2010). Em dezembro de 2007, ocorreram em São Paulo as primeiras transmissões de TV Digital no Brasil, em seguida outras cidades passaram a realizar transmissão de TV Digital, de acordo com um cronograma que define que em um período de dez anos todos os municípios brasileiros que irão receber o sinal da TV Digital. Segundo o cronograma do governo, em 29 de Junho de 2016 irão ser encerradas as transmissões da TV analógica no Brasil (DTV.ORG, 2010). Após a adoção do SBTVD no Brasil, outros países da América do Sul anunciaram interesse em adotar o padrão brasileiro.

Para receber o sinal de TV Digital, os telespectadores terão que comprar uma caixa receptora conversora para que os aparelhos atuais sejam capazes de receber o sinal, ou comprar um aparelho de TV com um receptor digital incorporado no aparelho. A maioria das TVs digitais que incoporam um receptor de TV digital são os de HDTV com monitor de tela plana de cristal líquido (LCD), plasma ou diodo emissor de luz (LED) e com resolução mais alta (Full HDTV 1920x1280). Estes, inicialmente, mais caros que os analógicos, estavam fora do alcance da maior parte da população. Com o início da produção em escala, o custo destes aparelhos está se reduzindo gradativamente.

Do ponto de vista dos produtores de conteúdo, a produção de vídeo em alta resolução deverá ser muito cara no início e inacessível para várias emissoras, principalmente as dos mercados menores. Assim sendo, espera-se que, durante a primeira década após a introdução da TV Digital no país, a maior parte da programação ainda seja transmitida em resolução standard, equivalente à atual no sistema analógico (640x480 pixels ou 720x486 no sistema digital). 


\section{Tecnologia do SBTVD}

A Cartilha da TV Digital (SOUZA et al., 2007), publicada pelo CREA de Minas Gerais em 2007 sob coordenação do engenheiro Anivaldo Matias de Souza, explica com razoável profundidade técnica e de forma bastante clara como funciona a TV Digital sendo implantada no Brasil. A seguir, transcrevo alguns trechos que considero relevantes.

A respeito da transmissão da TV Digital, segundo a cartilha, o SBTVD prevê a transmissão e recepção de TV Digital por satélite (TVD-S), por cabo ótico e coaxial (TVD-C) ou pelas frequências hertzianas atmosféricas (TVD-T, de "terrestre") e possui cinco camadas software: modulação (8-VSB e COFDM), transmissão (MPEG-2), compressão de áudio e vídeo, middleware (DAS, MHP, ARIB e Ginga) e aplicativos (EPG, T-Commerce, T-Gov, internet, serviços etc.) . Como vemos no esquema abaixo:

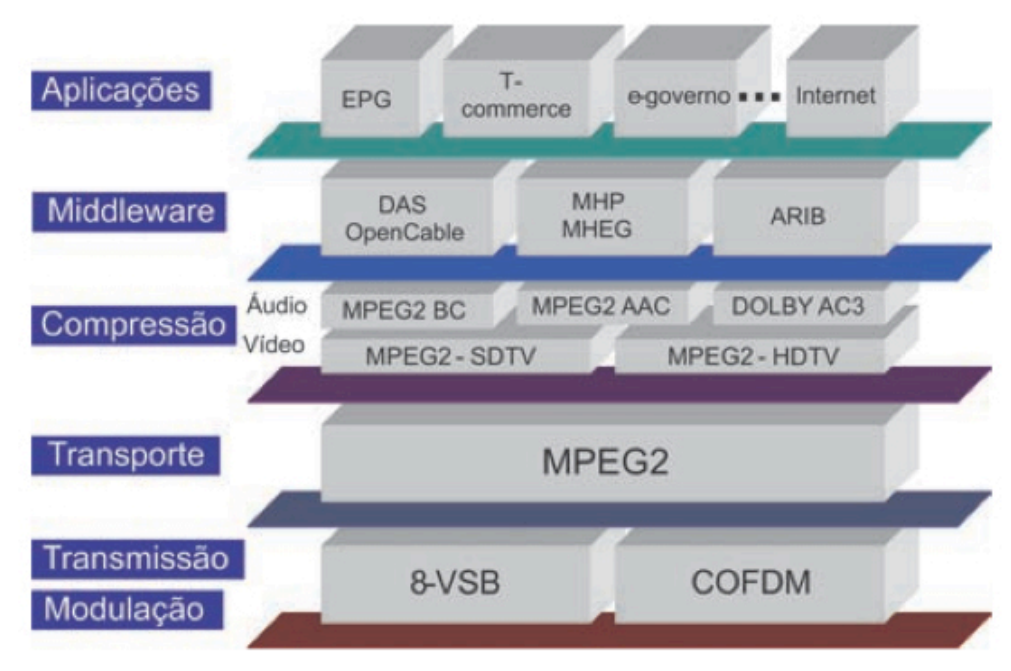

Fig. 3.2: As camadas e os módulos de um sistema de TV Digital.

Fonte: Cartilha da TV Digital - CREA-MG

A modulação 8-VSB é adotada pelo ATSC estadunidense, enquanto que o COFDM é adotado pelo DVB e pelo ISDB. Os três sistemas adotam o MPEG-2, podendo agora evoluir para o MPEG-4. Na compressão de áudio, o sistema estadunidense adota o Dolby e os outros dois, diferentes versões do MPEG. Para cada sistema, foi desenvolvido um middleware apropriado: DAS para o ATSC, MHP ou MHEG para o DVB e Arib para o ISDB. O Brasil deverá adotar o Ginga, da PUC-Rio/UFPb. Acima do middleware, encontram-se os aplicativos (guias de programação, jogos, acesso a extras, serviços etc.). (SOUZA, 2007). 
Com a pressão das emissoras em razão dos longos prazos de desenvolvimento de um chip nacional, o governo brasileiro incorporou o padrão ISDB no Sistema Brasileiro de TV Digital (SOUZA, 2007). No entanto, diversas pesquisas visando desenvolver tecnologia nacional de DTV estavam em curso (e várias continuam em desenvolvimento) em muitos centros de pesquisa no Brasil, como na Universidade de São Paulo, Universidade Federal da Paraíba e na PUC-Rio.

O governo viu-se obrigado a adotar o ISDB mas a realidade brasileira deulhe uma oportunidade para aproveitar alguma coisa da pesquisa acadêmica: o middleware. Do ponto de vista industrial, a incorporação do middleware ao sistema é relativamente simples. Além disso, o Ginga, nome do módulo desenvolvido pelos pesquisadores da PUC-Rio e da UFPb, é realmente muito bom e completamente adequado às condições socioambientais do país e aos objetivos da política governamental. (SOUZA, 2007).

A seguir reproduzo, dessa mesma publicação, um esquema que demonstra o funcionamento do receptor do SBTVD-T, que pode tanto estar incorporado ao aparelho televisor com estar em uma caixa conversora, o STB.

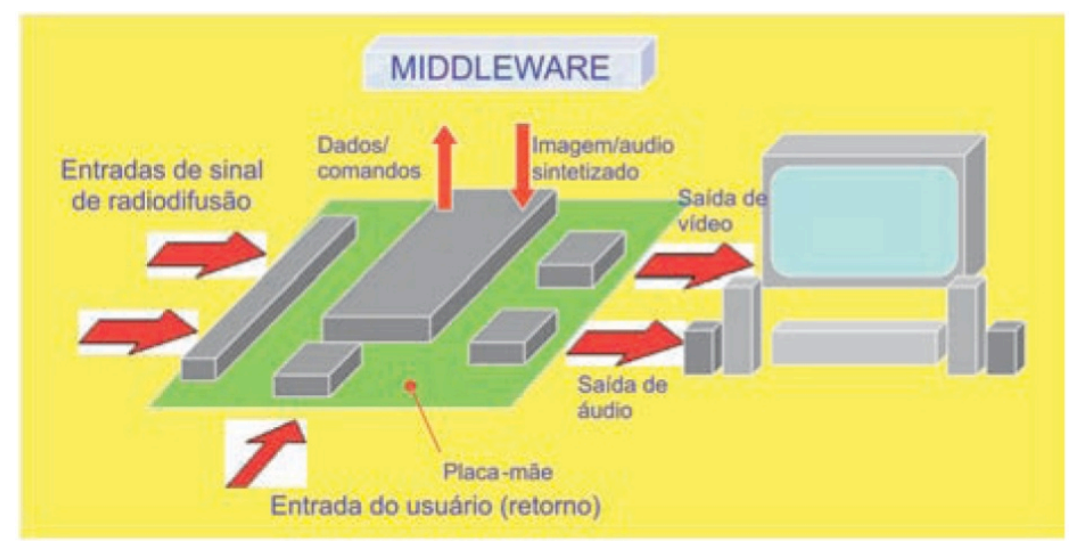

Fig. 3.3: O equipamento receptor de TV Digital

Fonte: Cartilha da TV Digital - CREA-MG

O receptor de TVD constitui-se basicamente de uma placa-mãe com um conjunto de circuitos integrados. Esta placa pode vir acondicionada num pequeno equipamento conversor, separado do monitor de vídeo, ou dentro do gabinete da TV. (SOUZA, 2007). 


\subsection{Tecnologia da TV Digital}

\subsubsection{Introdução}

Diversos aspectos tecnológicos se aplicam aos vários sistemas de DTV, sendo que algumas funcionalidades podem variar em cada sistema, como a forma de modulação, transmissão e compressão utilizada. O ideal é que haja interoperabilidade entre os sistemas. Nos padrões analógicos, era suficiente transcodificar os programas de um sistema para outro, como de NTSC para PAL-M. Nos sistemas digitais, ou o terminal de acesso é capaz de interpretar o Codificador/Decodificador (CODEC) de vídeo, ou é necessário realizar a conversão do CODEC em uma outra plataforma antes de realizar a transmissão do sinal digital. Um dos maiores problemas de compatibilidade entre sistemas de TV Digital refere-se aos aspectos interativos da programação e da execução de aplicativos e games que podem ser transmitidos no canal de dados. A adoção de um middleware nos sistemas de TV Digital tem como objetivo prover uma camada comum que permita interoperabilidade entre os diversos componentes do sistema. Aqui destaco aspectos da tecnologia que são relevantes para diversos sistemas de TV Digital.

\subsubsection{Resolução e métodos de compressão de vídeo}

A TV Digital pode utilizar diversas resoluções de vídeo, de modo a apresentar uma qualidade mais alta ou mais baixa da imagem na tela. A resolução do vídeo pode ser: de baixa resolução e pequenas dimensões para visualização em celulares e outros dispositivos portáteis; resolução padrão ou standard, cuja qualidade é muito próxima da resolução de imagem da TV Analógica, sendo apropriada para exibição em um parque estabelecido de receptores de TV analógica e outros monitores com resolução equivalente; e a alta resolução (HDTV), cuja resolução de até 1080 linhas e o aspecto de tela mais largo tem a proporção 16:9. Recentemente têm sido lançado aparelhos de TV 3-D que permitem visualizar programas de TV em três dimensões, utilizando óculos especiais que permitem "juntar" a imagem captada por duas câmeras. 


\section{Resolução de Vídeo}

Utilizamos a seguinte classificação de resolução de vídeo na TV Digital:

Low Definition Television - LDTV, vídeo de baixa resolução, até 320x240, é utilizado em celulares e outros dispositivos móveis; também é uma resolução de vídeo comumente utilizada em web sites.

Standard Definition Television - SDTV, possibilita a transmissão de programas na resolução de vídeo padrão, com $720 \times 480$ pixels e aspecto $3 \times 4$, e é equivalente ao formato de TV analógico atual. Embora o aspecto mais comum nesta resolução seja 3x4, é possível em alguns casos se utilizar o aspecto widescreen 16x9, como nos DVDs que usam a mesma resolução de vídeo com um aspecto de pixel mais distorcido. Importante notar que na resolução standard da TV Analógica o escaneamento entrelaçado (interlaced) reduz ainda mais a resolução efetiva desses monitores, ao passo que os monitores de alta resolução podem utilizar o escaneamento progressivo (progressive scan). Entretanto, imagens de escaneamento entrelaçado, quando exibidos em monitores de escaneamento progressivo, podem causar "artifacts" (distorções).

High Definition Television - HDTV, possibilita a transmissão de vídeo em alta definição. A resolução pode ser de 1280x720 ou 1920x1280 pixels (Full HD); em ambos os casos, o aspecto de tela 16x9, conhecido como widescreen, aproxima-se das películas cinematográficas e é utilizado em DVDs e na produção digital de filmes.

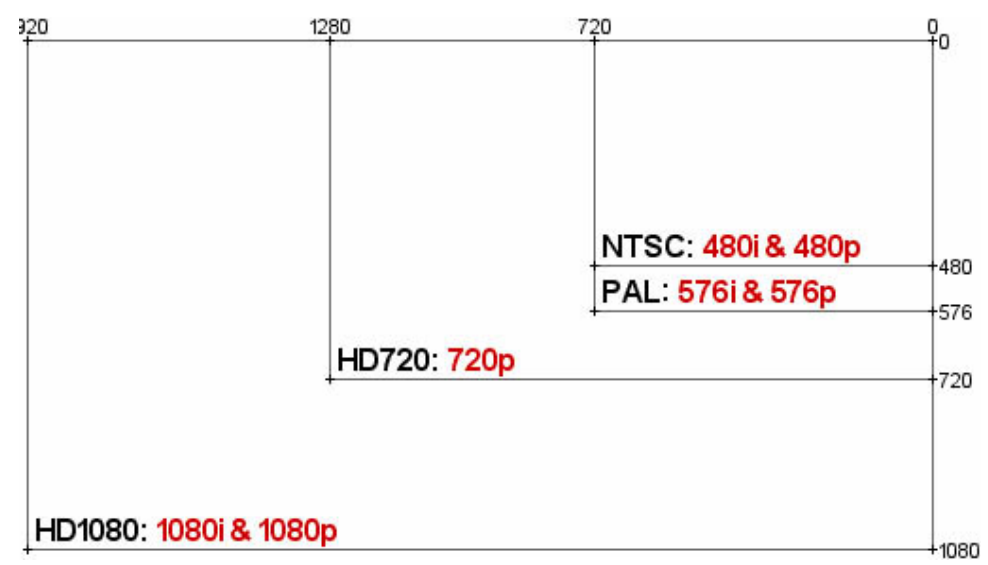

Fig. 3.4: Comparação da resolução e aspecto da imagem na TV Digital Fonte: http://www.tamblue.com/page/2/ 


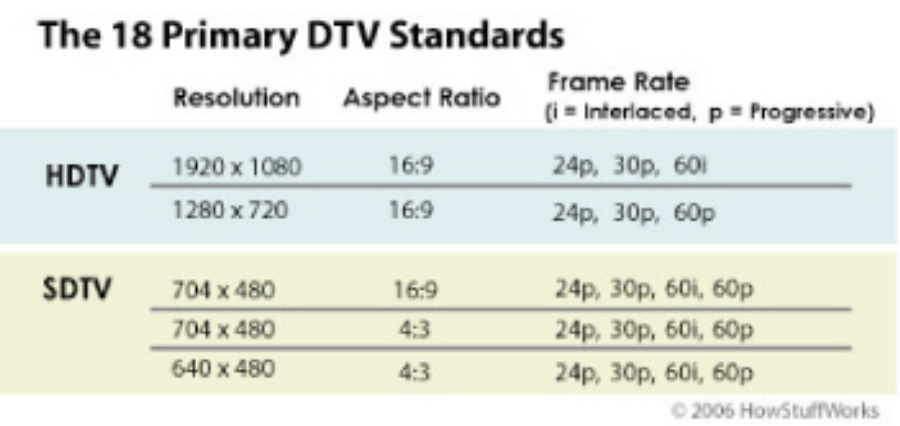

Fig. 3.5: Padrões de resolução de imagem na TV Digital Fonte: http://electronics.howstuffworks.com/hdtv2.htm

\section{TV de Alta Definição - HDTV}

High Definition Television (HDTV) é a denominação geral de serviços de TV em alta resolução, a qual não precisa ser necessariamente digital, como foi o caso do Japão, pioneiro na transmissão de HDTV. O formato HDTV utiliza o aspecto de tela 16x9, mais próximo da "janela" da maioria dos filmes captados em película, possibilitando uma reprodução mais fiel do enquadramento dos filmes produzidos para o cinema. O padrão HDTV contempla a resolução 1920x1080 pixels ou 1080 linhas horizontais e uma versão com qualidade intermediária com 1280x720 linhas, que permite compatibilidade com equipamentos de vídeo digital no formato DV com 720 linhas. Este formato também é conhecido com High Definition Vídeo (HDV) e utiliza pixels "não quadrados" ou "anamórficos" e uma compressão maior do que o "Full HDTV".

A imagem de HDTV pode ser formada por 24 ou 30 quadros progressivos por segundo (24p e 30p), sendo que a imagem em $24 \mathrm{p}$ se aproxima bastante da imagem cinematográfica. Os aparelhos de TV em alta definição podem exibir as "linhas" de modo progressivo (progressive scan), entrelaçado (interlaced) ou ambos; no caso da imagem entrelaçada, temos 60 linhas ou 60i. Uma observação é que o formato SDTV também permite a exibição de imagens no aspecto 16x9 tanto progressivo como entrelaçado, o que já é suportado pelo padrão de Digital Video Disc (DVD) convencional. 


\section{Compressão de vídeo e Multicasting}

A compressão MPEG-4 ${ }^{52}$ adotada no Brasil permite reduzir o tamanho dos dados do vídeo, sendo transmitido de modo que possa distribuir até oito canais de vídeo em resolução padrão SDTV ou um programa em HDTV em um canal de TV Digital de 6MHz. A compressão também permite escalabilidade do vídeo para recepção em aparelhos móveis em uma banda ainda menor. Multicasting possibilita a transmissão de vários canais de vídeo em diversas resoluções em um único canal de TV Digital. Como a frequência alocada para cada emissora transmitir HDTV comporta um canal de HDTV na sua resolução mais alta e com o desenvolvimento dos padrões de compressão de áudio e vídeo, é possível utilizar a largura de banda (Bandwidth) disponível para transmitir vários canais de vídeo em resolução padrão ou dois canais em HDTV em resolução mais baixa (utilizando uma taxa de compressão mais alta). Essa técnica é denominada Multicasting, que vem das palavras Multiplexing, tecnologia que permite a compressão e distribuição de vários canais de vídeo em uma única faixa de frequência, e Broadcasting. Os dois esquemas a seguir demonstram como uma emissora pode utilizar o mesmo espectro alocado para ela na TV Digital para transmitir programas com resoluções diversas.

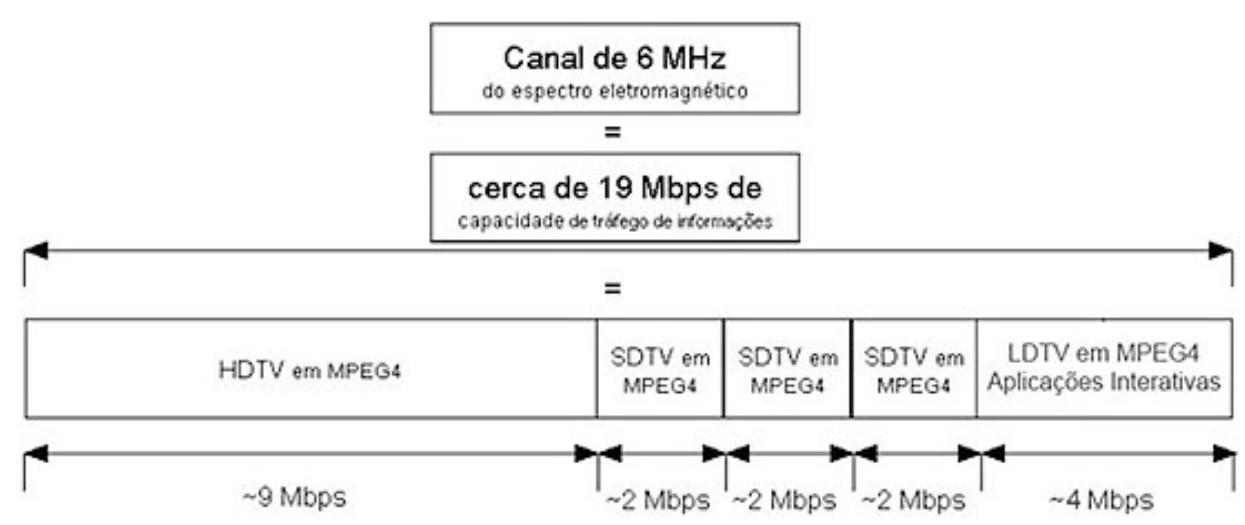

\footnotetext{
52 O MPEG Sistema define formatos e protocolos para montagem de pacotes para transmissão de fluxos elementares multiplexados. Os fluxos elementares transportam streams de vídeo, áudio ou dados. Porém, a escolha deste padrão, apesar de importante, representa apenas a ponta de um iceberg, pois, segundo a ABERT/SET, o impacto da escolha representa menos de $4 \%$ do custo dos aparelhos receptores, e se dá apenas sobre os equipamentos moduladores e demoduladores no conjunto de equipamentos das estações transmissoras e retransmissoras (CPqD, 2001 apud FERNANDES; LEMOS; ELIAS, 2004).
} 


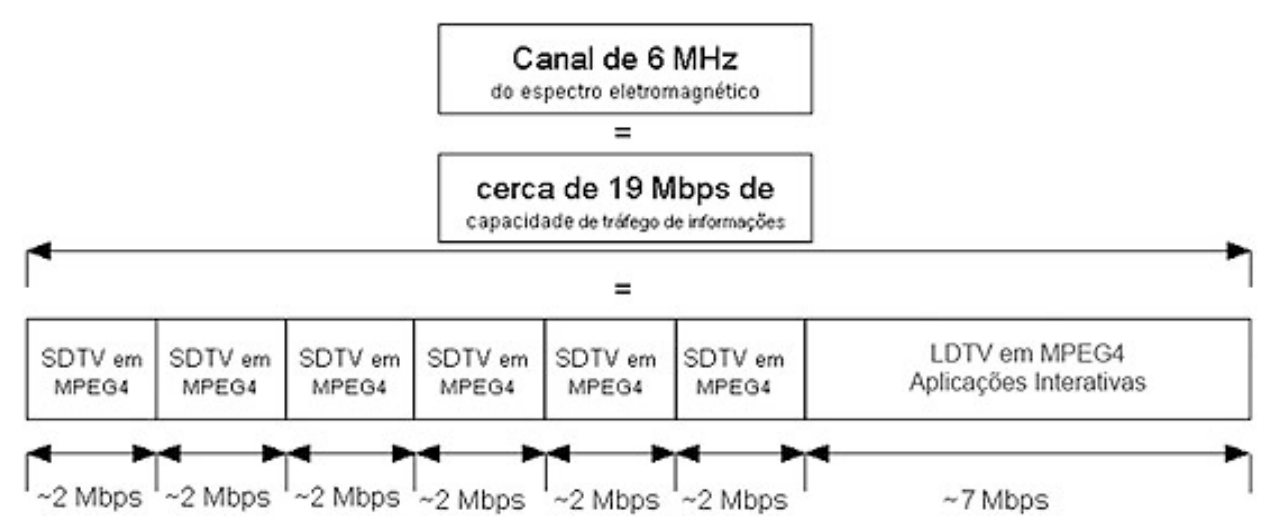

Fig. 3.6: Transmissão Multiplex em diversas resoluções em um canal de 6MHz de TV Digital Fonte: www.via.multimidia.nom.br

\section{TV 3-D}

Em 2010, no Consumer Electronic Show em Las Vegas, EUA, fabricantes da indústria eletrônica como a Sony, Samsung e LG apresentaram novos aparelhos de TV 3-D. A maioria ainda utiliza óculos para que a imagem seja vista em três dimensões pelo telespectador (CAPANEMA, 2010), mas alguns fabricantes introduziram modelos que não necessitam de óculos para reproduzir o efeito esteroscópico. Nesse mesmo ano, foram realizados vários testes de transmissão de TV 3-D no Brasil, tanto em circuito fechado, como na TV aberta e a cabo (JOVANELI, 2010).

\subsubsection{Receptores e conversores para a TV Digital (STBs)}

Para que os dados transmitidos no sinal da TV Digital sejam decodificados, é necessária a utilização de um receptor, o conversor digital conectado a um monitor. Esse receptor pode ser incorporado nos aparelhos de TV Digital ou conectado externamente a um aparelho de TV analógico ou digital, como no caso da TV a cabo. A recepção da TV Digital depende da integração de componentes de hardware, middleware e software.

Segue um esquema adaptado de Gawlinsky (2003) demonstrando como estão relacionados o hardware, o middleware e o software na TV Digital: 


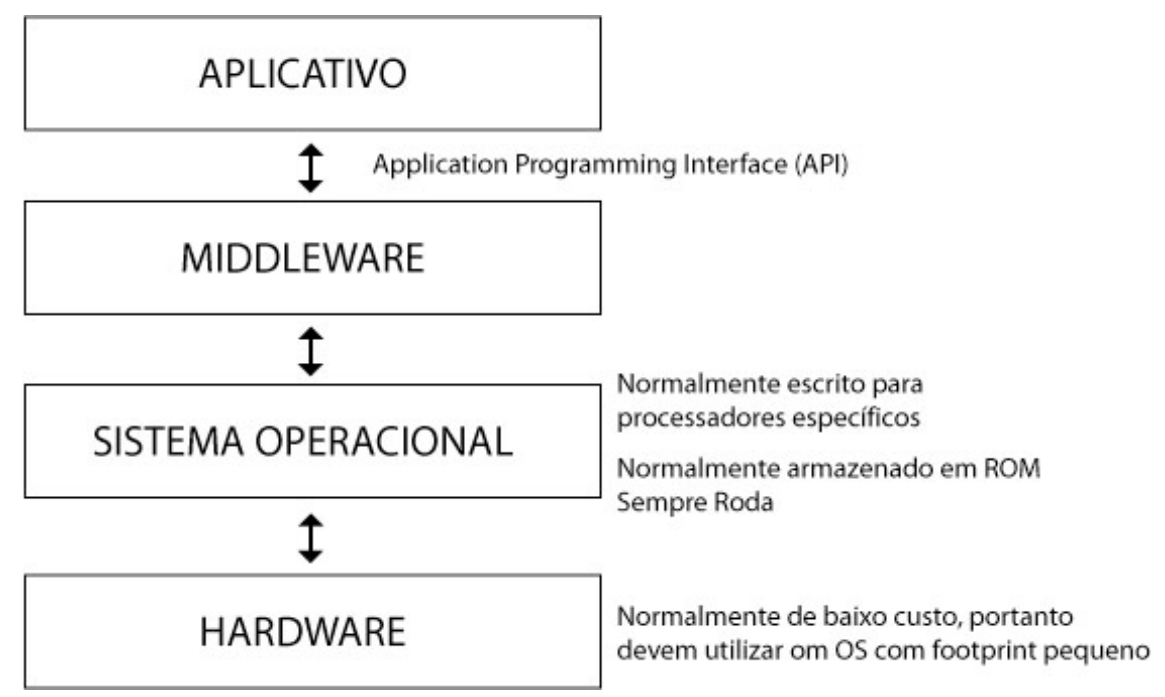

Fig. 3.7: Hardware, Middleware e Software na TV Digital Fonte: Gawlinksy, 2004

\section{Set-top Boxes - STB}

O Set-top Box (STB) é como denominamos genericamente uma caixa que pode ser colocada "em cima" de um aparelho de TV expandindo sua funcionalidade. No início, essas caixas eram dedicadas a uma função, começando com os conversores de UHF, passando pelos primeiros conversores de TV a cabo que e de satélite que com o tempo passaram a incluir cada vez mais funcionalidades. Hoje dentro destas caixas estão pequenos computadores, com discos rígidos, memória e programas, assim como diversos tipos de entradas e saída de áudio.

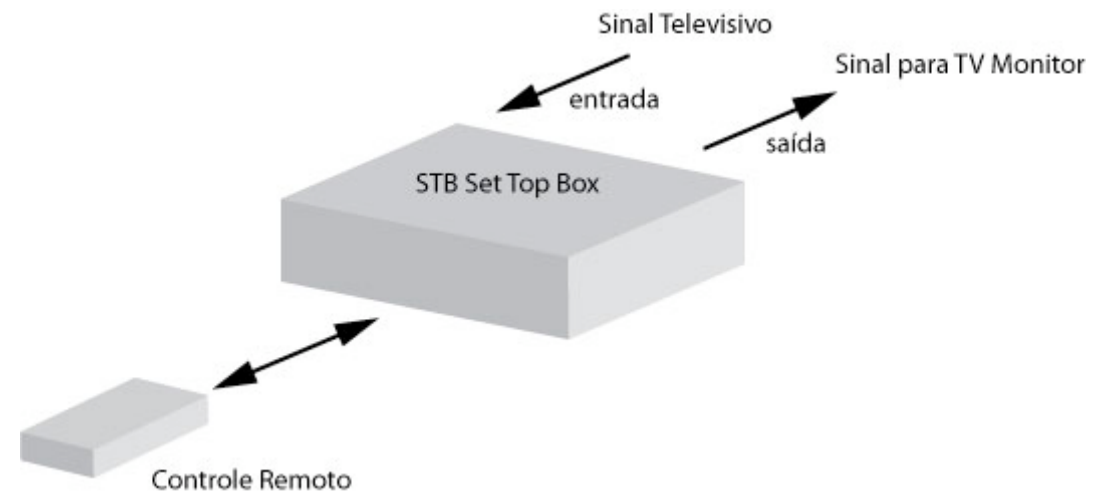

Fig 3.8: Entradas e saídas de um STB

No Brasil, a especificação do SBTVD refere-se ao Set-Top Box como terminal de acesso, o aparelho receptor e conversor facilitando a transição da TV analógica para a TV Digital e também permitindo a interatividade. A pesquisa de referência do terminal de acesso 
(BECKER, 2005) para o SBTVD foi desenvolvido pelo Laboratório de Sistemas Integráveis da Escola Politécnica da USP (LSI-USP) sob a coordenação de Marcelo Knörich Zuffo e Domingos Kiriakos Stavridis e contou com a colaboração de outros centros de pesquisa como o Mackenzie, UFPB, UFRN, PUC-RIO, USP/São Carlos e as empresas SM Microeletronics, Intel, IPV6, Superwaba, Gradiente, Samsung e Instituto Casablanca (Consórcio TARSBTVD).

\section{Hardware, Middleware e Software}

Os STBs normalmente são equipados com hardware de baixo custo, portanto devem utilizar um sistema operacional (OS) bastante leve. Como nem todos os fornecedores de caixas de TV Digital usam o mesmo hardware e OS, a solução encontrada foi a utilização de um middleware que, através do Application Programming Interface (API) permite dialogar com o software os programas e aplicativos de diversas maneiras; os aplicativos podem ser um Guia Eletrônico de Programação (EPG), conteúdo interativo de um programa ou gerenciador de filmes arquivados no DVR (GAWLINSKY, 2003).

\section{Componentes do Set-top Box}

O hardware encontrado dentro dos Set-top Boxes é composto de diversos componentes que possibilitam realizar as funções da TV Digital e "rodar" o middleware e consequentemente os aplicativos. Segundo Gawlinsky (2003), os principais componentes dos STBs são:

Sintonizador - Separa as frequências de radio em canais particulares de informação.

Demodulador - Controla os pulsos e fluxo de dados digitais.

Demultiplexador - Converte o código binário separando vídeo, áudio e dados.

Acesso Condicional - Determina pacotes de canais assinados ou bloqueados, lida também com criptografia.

Placa de Vídeo e Placa de Áudio - Saídas de imagem e som. A saída de vídeo pode ser em Vídeo Composto, Vídeo Componente, Digital Video Interface (DVI) ou Rádio Frequência (RF), o áudio pode ser composto ou digital. 
CPU - Acessa o processador gráfico, a memória, administra os componentes e roda programas.

RAM e ROM - Algumas caixas possuem capacidades adicionais de armazenamento de dados utilizando por exemplo discos rígidos, permitindo gravar programas, pausá-los ou armazenar videogames.

Smartcard - Guarda informações do assinante que são utilizados pelo sistema de acesso condicional.

Modems - Os modems são utilizados como canal de retorno, ou podem permitir o acesso à internet utilizando a infraestrutura de um sistema de TV a cabo.

- Convencional - $56 \mathrm{Kbps}$

- Cable Modem 1,5 a 30 Mbps $^{53}$

- ADSL 128 Kbps a 3 Mbps

Interfaces Fisícas - Permitem estender a funcionalidade a outros dispositivos (aparelhos). As caixas (STBs) normalmente incluem as interfaces:

- Paralela IEEE 1284 e Serial RS232

- USB (Universal Serial Bus)

- IEEE 1394 (Firewire) com alta taxa de transferência de dados.

- PCMIA

- Base T-Ethernet

- Bluetooth

\footnotetext{
53 Teoricamente é possível chegar a $30 \mathrm{Mbps}$, mas na prática os assinantes “utilizam” em média 1,5 Mbps (GAWLINSKY, 2003).
} 
Controle Remoto - Permite o controle das operações básicas do STB e navegar as interfaces dos softwares instalados no STBs e a interação com aplicativos e programas interativos.

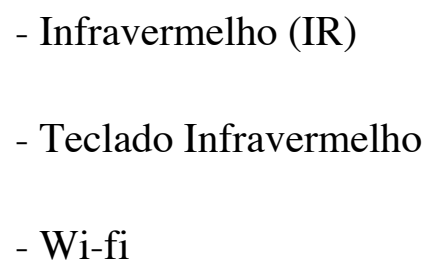

Canal de Retorno - Uma conexão de linha discada até uma conexão de banda larga (como o DSL) permitem o retorno de dados, desde texto a vídeos em qualidade broadcast. A desvantagem é que vários podem requisitar a mesma informação ao mesmo tempo, congestionando a rede.

\subsubsection{Middleware}

Os fabricantes de STBs podem adotar diferentes arquiteturas de hardware e sistemas operacionais, e para evitar que as aplicações devam ser reescritas para cada hardware e sistema operacional, optou-se por prover uma API genérica possibilitando a portabilidade das aplicações. O middleware é uma camada de software que fica entre o sistema operacional e os aplicativos (BRENNAND; LEMOS, 2007).

O objetivo do middleware é oferecer um serviço padronizado às aplicações, escondendo as especificidades e heterogeneidades das camadas de hardware e sistema operacional, que dão suporte às facilidades básicas de codificação, transporte e modulação de um sistema de TV Digital. (BRENNAND;LEMOS, 2007, p. 129).

A portabilidade das aplicações é essencial para estimular o desenvolvimento de aplicações para a TV Digital em um sistema horizontal, que, caso contrário, seria inviável economicamente caso não houvesse compatibilidade dos aplicativos com os aparelhos de diversos fabricantes.

O middleware comunica-se com o sistema operacional de uma forma controlada, reduzindo as possibilidades de "crash". Além disso, padroniza os comandos e ferramentas de programação. Como a linguagem é consistente, o programador não precisa testar como o aplicativo irá funcionar em uma caixa específica ou em diversas configurações de hardware. 
Alguns exemplos de sistemas de middleware proprietário são: Open TV, TV Navigator, Microsoft TV, Liberate (GAWLINSKY, 2003).

O método de comunicação dos aplicativos com o middleware é a Application Programming Interface (API). Alguns utilizam APIs baseados em linguagens de computação como Java ou C, permitindo desenvolver programas que serão utilizados pelo telespectador (como EPG, e-mail, games). Alguns middlewares permitem que o programador utilize uma “máquina virtual”, possibilitando que o programado "visualize" como seu programa irá rodar no STB que utiliza o middleware.

\section{Middleware nos diversos sistemas de TV Digital}

Cada sistema de TV digital tem adotado um middleware próprio; recentemente tem havido uma preocupação em buscar a compatibilidade e portabilidade de programas interativos de um sistema para outro. Uma proposta é o Globally Executable MHP (GEM), permitindo a execução global de aplicações (MORRIS;SMITH-CHAIGNEAU, 2005).

\section{DVB-MHP}

Os membros do grupo DVB perceberam que seria necessário encontrar uma forma de padronizar uma estrutura para o software, middleware e suas APIs de modo que se criassem serviços interativos interoperáveis. Para isso criaram a especificação Digital Video Broadcasting - Multimedia Home Platform (DVB- MHP).

O MHP define uma interface genérica entre as aplicações e o set-top Box (hardware e sistema operacional), no qual as aplicações são executadas. Além disso, o MHP define o modelo e o ciclo de vida das aplicações, como também os protocolos e os mecanismos de transmissão de dados em ambientes de televisão interativa e pseudointerativa. (BRENNAND;LEMOS, 2007, p. 136).

\section{DASE}

Nos EUA, a ATSC adotou seu próprio padrão de middleware: o Digital Television Applications Software Environment (DASE), que permite a programação de conteúdo e aplicativos. As aplicações do DASE adotam linguagens procedurais como o Java TV e 
declarativas, que suportam a execução de aplicações na linguagem Hyper Text Markup Language (HTML) (BRENNAND; LEMOS, 2007) e têm questões de interoperabilidade que foram mais bem resolvidas no MHP.

\section{ARIB}

O padrão ISDB adota o middleware ARIB (Association of Radio Industries and Business). O modelo de programação do ARIB é baseado na linguagem declarativa Broadcast Markup Language (BML), que por sua vez é baseada na Extensible Markup Language (XML).

\section{GINGA}

O SBTVD, ao adotar o padrão ISDB-T para a transmissão e modulação, optou por especificar um middleware nacional, o Ginga, uma camada intermediária de software (middleware) que possibilita desenvolver aplicações interativas para a TV Digital. O middleware GINGA é resultado de pesquisas da Pontifícia Universidade Católica do Rio de Janeiro (PUC-Rio) e da Universidade Federal da Paraíba (UFPB), incorporando tecnologia nacional que tornou o middleware adequado à realidade brasileira enquanto mantém especificações de ponta em TV Digital Interativa (TVDI) (MONTEZ; BECKER, 2005).

O Ginga utiliza dois ambientes de programação: um declarativo, o Ginga-NCL, e outro procedural, o Ginga-J, baseado na API do Java, que se comunicam através de um centro comum a ambos, permitindo a escolha do ambiente de programação mais adequado. No Portal do Software Público do Brasileiro (http://www.softwarepublico.gov.br), é possível baixar a documentação, exemplos e emuladores para a programação em Ginga. No site é possível baixar o programa de autoração Composer, que permite criar programas interativos em um ambiente gráfico que não requer conhecimentos de programação. O emulador GingaNCL permite visualizar em um PC os programas sendo desenvolvidos e o NCL-Eclipse, uma ferramenta de autoração textual. Uma outra fonte de informação para programação em Ginga é o livro Programando em NCL 3.0: desenvolvimento de aplicações para o middleware Ginga, dos professores Luiz Fernando Gomes Soares e Simone Diniz Junqueira Barbosa da Puc-Rio. 


\subsubsection{Distribuição da TV Digital}

A TV Digital pode ser transmitida por cabo, via satélite ou por redes terrestres, cada sistema de transmissão tem suas particularidades e vantagens. O sinal da TV, ao ser digitalizado, é codificado pelo MPEG encoder em um único fluxo elementar contendo uma unidade de conteúdo de áudio e vídeo (MORRIS;SMITH-CHAIGNEAU, 2005). O fluxo de transporte pode, também, conter diversos canais de $\mathrm{DTV}^{54}$, como vimos quando foi apresentado o conceito de Multiplexing. Uma vez que o fluxo de dados está codificado, ele poderá ser transmitido. "A última etapa do processo é a modulação: converter o fluxo de bits digitais em uma onda analógica transmissível” (MORRIS;SMITH-CHAIGNEAU, 2005). Cada sistema de TV Digital pode ter um esquema próprio de modulação, mas em todos os casos de distribuição, seja terrestre, por cabo ou satélite, os dados são modulados dentro de uma frequência do espectro analógico; a exceção é a distribuição por IPTV, em que os dados são distribuídos pela internet.

A transmissão pode ser unidirecional, através de um canal broadcast Forward Path, ou bidirecional (GAWLINSKI, 2003); neste caso a comunicação interativa se dá através de um canal de retorno. No caso da transmissão unidirecional, é possível que haja interatividade do telespectador, quando dizemos que a interatividade é local. Normalmente dois tipos de dados são transmitidos, um aplicativo como por exemplo o EPG (que também pode ter componentes residentes no STB), e os dados utilizados pelo aplicativo como fotos, textos e gráficos.

\section{TV Digital Terrestre}

Mesmo com o início da transmissão de TV Digital, pouca gente sabe que apenas com um receptor de TV Digital, ou uma caixa conversora e uma antena é possível receber em casa o sinal da TV Digital terrestre gratuitamente. Além da falta de uma divulgação mais eficiente por meios oficiais, uma possível explicação para a desinformação ou desinteresse da

\footnotetext{
54 “ In the context of DTV, an MPEG program may also be known as a 'service' or a 'channel', but all of these terms mean the same thing."(MORRIS, SMITH-CHAIGNEAU, 2005)
} 
população é uma questão perceptual ${ }^{55}$. Outra explicação é a falta de aplicativos e interesse pela interatividade.

A transmissão terrestre da TV Digital é bastante robusta, os dados digitais são modulados em ondas de rádio, e não há perda na recepção como no caso de fantasmas encontrados na TV Analógica. Através de técnicas de compressão de vídeo como as padronizadas pelo MPEG-2 e MPEG-4 (a última sendo implementada no ISDB), um volume maior de dados audiovisuais pode ser transmitido na mesma banda. A TV Digital terrestre pode ser recebida por dispositivos móveis como celulares e dispositivos móveis, e a TV Digital móvel também pode ser recebida por veículos e meios de transporte como ônibus, táxis e trens.

\section{TV Digital via Cabo}

A televisão a cabo (CATV), é um sistema de distribuição de programas de televisão, rádio e dados através de cabos coaxiais fixos, em vez de se transmitir o sinal via antenas de rádio (televisão aberta). A maioria dos sistemas de TV a cabo são serviços por assinatura como NET e TVA em São Paulo, mas existem também serviços comunitários de TV a cabo. Geralmente os canais na TV a cabo são recebidos em um local central e distribuídos aos assinantes do sistema utilizando uma rede de fibra ótica e cabos coaxiais. A TV a cabo originalmente analógico permite hoje a transmissão de TV digital utilizando a mesma infraestrutura de cabos e fibras ao utilizar um conversor digital. As operadoras de TV a cabo recebem o sinal digital das emissoras e o retransmitem para os assinantes, que podem utilizar um STB analógico ou digital (SDTV ou HDTV).

\section{TV Digital via Satélite - DTH}

DTH é a abreviação em inglês de Direct to home que quer dizer "direto para casa". A transmissão DTH é realizada via satélite, e o sinal de TV pode ser recebido em casa por meio de pequenas antenas em forma de disco. No Brasil, conhecemos este serviço pelas operadoras

\footnotetext{
${ }^{55}$ Uma matéria publicada recentemente no site da revista New Scientist descreve a pesquisa de Lidwien van de Wijngaert (2009), da Universidade de Twent, na Holanda, que realizou testes com espectadores de TV que eram levados a acreditar, por meio de cartazes fixados na sala, que estavam assistindo TV de Alta Definição (HDTV). Na realidade, o que assistiam no aparelho de HDTV no formato 16x9 era um sinal de resolução padrão (SDTV), mas acreditavam que assistiam uma TV de alta definição.
} 
de TV por assinatura como a SKY e Direct TV. Antes do início das transmissões terrestres de TV Digital, as operadoras de DTH já estavam transmitindo o sinal digital na resolução SDTV para os seus assinantes utilizando plataformas proprietárias. Com o crescimento da produção em HDTV e a oferta de canais de TV Digital transmitindo em HDTV, as operadoras de DTH passaram a oferecer canais em HD na sua grade de programação.

\section{IPTV}

Em vez de utilizar métodos dedicados à transmissão do sinal de TV como frequências de rádio, sinal via satélite ou TV a cabo, um outro sistema através do qual se pode distribuir a TV digital é a Internet Protocol Television (IPTV). Com a arquitetura de rede comutada utilizando o protocolo da internet é possível prover um serviço de TV Digital aproveitando a infraestrutura da internet (I.T.U., 2008). Existem várias modalidades de IPTV:

- TV ao Vivo, em que é possível ajustar a banda de dados enviadas à velocidade da rede, de modo a transmitir TV com qualidade broadcast $(720$ x 480) Standard Definition TV (SDTV) utilizando o backbone da internet.

- Vídeo sob demanda, como é o caso da Apple TV, onde é possível "baixar" filmes e programas de TV.

- Programação Destemporalizada, Time Shifted TV, em que a grade de programação de um canal esta disponível em horários diferentes.

Um serviço de IPTV não deve ser confundido com sites da World Wide Web (WWW) que oferecem serviços multimídia como o You Tube e o Net Flix. Existe uma regulamentação específica e normatização da distribuição de IPTV, por órgãos reguladores como a European Telecommunications Standards Institute (ETSI). A forma de implementação do IPTV é preferencialmente através de redes de alta velocidade dedicadas a uma base de assinantes que tem acesso a estes serviços utilizando Set-top Boxes (STBs), caixas conversoras que de modo geral utilizam acesso condicional e tecnologias proprietárias. Existem vários serviços de IPTV em funcionamento como Imagenio, nome comercial da IPTV da Telefónica da Espanha, um serviço de televisão sobre ADSL. Empresas como Verizon, AT\&T Alcatel Lucent, NEC, Thomson, Ericson atuam na área e recentemente tem havido um crescimento das operadoras de IPTV, sobretudo na Ásia. 


\subsection{TV Digital Interativa - TVDI}

\subsubsection{O que é Interatividade}

Na nossa sociedade contemporânea, o termo interatividade tem sido utilizado como um atributo positivo nas mais diversas áreas, não só na indústria eletrônica, mas na educação, no entretenimento e mesmo na arquitetura. O dicionário Houaiss define "interação" como: "influência mútua de órgãos ou organismos inter-relacionados; ação mútua ou compartilhada entre dois ou mais corpos ou organismos"(HOUAISS, 2010). Como vemos, a interatividade pressupõe uma ação mútua, seja com outros seres humanos, objetos ou sistemas. Embora o ser humano tenha sempre "interagido" entre si, com as suas ferramentas e com o seu meio, a interatividade tem ganhado uma importância significativa com o advento das mídias eletrônicas e dos computadores.

A telefonia, por exemplo, sempre foi interativa no sentido em que há um diálogo, mas os meios de comunicação eletrônica como o rádio e a TV passaram a exacerbar o aspecto ativo do transmissor e passivo do receptor na comunicação. Mesmo os jornais e revistas são mais interativos não só porque o leitor pode folhear as páginas, arrancar folhas ou ler na ordem que quiser, mas também porque o leitor pode enviar cartas, ler editoriais de autores diferentes e tem um distanciamento um pouco maior da mídia do que as mídias eletrônicas, em que o processo de recepção é muito mais eficiente. Com o advento dos computadores, temos duas forças opostas neste sentido: por um lado, os programas e sistemas computacionais eram extremamente cartesianos, e a utilização deles pressupunha o aprendizado de uma sequência de operações e linguagens específicas que só poderiam ser desenroladas de uma única forma, caso contrário os sistemas não compreenderiam nossas instruções e vice-versa; por outro lado, as interfaces centradas no usuário, o conceito de hipertexto e as redes de comunicação passam a possibilitar um tipo de interação com computadores que nunca havia ocorrido com outras máquinas criadas pelo homem.

As redes de computadores, da mesma forma que tornam cada vez mais forte a sociedade do controle, onde todos os nossos movimentos e informações podem ser controlados, permitem a comunicação eletrônica bidirecional, com a qual se tornou mais fácil para indivíduos se expressarem e terem uma repercussão que pode competir com as grandes mídias. Estas, por sua vez, ao perceberem isso, abrem um espaço de interação de modo a garantir o domínio de seus canais de comunicação. Essas transformações afetaram inicialmente as mídias impressas (jornal, revistas), depois as sonoras (rádio, música) e com a 
viabilização tecnológica da distribuição digital das mídias audiovisuais a interatividade tem se tornado uma preocupação da indústria de televisão e cinema, tanto pelos aspectos territoriais e de direitos autorais como na criação e linguagem. É o caso, por exemplo, da indústria de games, que é uma mídia essencialmente interativa (ao menos nos aspectos operacionais) e que tem se tornado um sério competidor do cinema mainstream. Sivaldo Silva (2008) ilustra como a televisão tem encarado a interatividade:

Se interatividade nunca foi um aspecto central na história da indústria televisiva, tal temática vem ganhando força nas últimas décadas e se transformou em uma das principais promessas no atual processo de estruturação da TV digital no Brasil e no mundo. Ser interativo passou a ser uma qualidade em si, às vezes, utilizada como um sinônimo de "democrático". Porém, o que nem sempre está evidente é que o tipo de interação está sendo implantada, para que fins e como a noção de interatividade pode ser, inclusive, não democrática, a depender do modo como será configurada no design tecnológico de mídias emergentes como a TV digital. (SILVA, 2009, p. 14) ${ }^{56}$.

Segundo Silva (2008), a televisão é um meio de comunicação top-down (de cima para baixo) e a participação nunca teve um papel muito importante, mas com a interatividade entrando em cena ela irá buscar formas de realizá-la dentro dos modelos de sua indústria. Vemos que a interatividade pode ter diversas conotações dependendo dos valores que estão embutidos nos interesses de quem a promove. Silva (2008) apresenta a seguinte categorização de valores relativos à interatividade:

a) Interatividade enquanto valor mercadológico: quando a interatividade é tratada como um distintivo agregado a objetos, produtos e lugares capazes de receber algum tipo de estímulo do consumidor e propiciar algum tipo de resposta subsequente (brinquedos interativos, museus interativos, livros interativos etc.).

b) Interatividade enquanto valor tecnológico: quando é tratada como uma qualidade técnica avançada, agregada principalmente a aparelhos digitais do tipo "autômatos", programados para receber inputs e produzir outputs de dados ou ações em sua relação com o usuário ou com outras máquinas (computadores, softwares, aparelhos eletrônicos etc.).

c) Interatividade enquanto valor político: quando o adjetivo interativo aparece como uma qualidade positiva de algo ou alguém capaz de propiciar 
trocas de informação de modo mais ou menos horizontal (governo interativo; programa de auditório interativo; peça de teatro interativa etc.).

E conclui que essas noções de interatividade sustentam problemas teóricos pragmáticos e éticos que distorcem ou mesmo esvaziam a noção de interatividade:

Do ponto-de-vista teórico, é preciso tornar claro que a relação entre interatividade e comunicação se dá dentro de um debate conceitual, onde existe uma noção que requer precisão conceitual, do contrário, o termo perde o seu valor e passa a ter um significado vazio (porque pode é usado aleatoriamente).

Do ponto de vista pragmático, interatividade ocorre em diversos graus, podendo haver níveis irrisórios ou, inversamente, níveis elevados de interação, com efeitos e resultados distintos.

E, por fim, do ponto de vista ético, interatividade não é uma qualidade em si, está sujeita a valores e princípios sociais externos ao seu campo e que delimitam a sua valoração, podendo haver inclusive tipos e formas de interatividade negativas.

Vemos uma banalização pelas mídias de massa do que definimos como interatividade, ao se criarem sistemas interativos em que as interações de uma das partes não têm consequências para as outras, o que é reforçado por esta definição de interatividade.

Brennand \& Lemos destacam a definição de interatividade a partir do conceito de Habermas (1987): Habermas entende o processo de interatividade como uma orientação racional da ação por meio do critério da coordenação comunicativa da ação. Não se pode considerar a presença ou não de interatividade pela análise de uma determinada atividade racional de um sujeito isolado... A interatividade é uma prática da argumentação que permite continuar a ação comunicativa quando há desacordos. A argumentação é um tipo de discurso, pelo qual os participantes tematizam exigências de validade contestadas e tentam resgatá-las ou criticá-las. (BRENNAND; LEMOS, 2007, p. 78 (Apud FEITOSA; ALVES; NUNES FILHO, 2009, p. 136).

Na conferência TED USP $^{57}$ realizada na Faculdade de Arquitetura e Urbanismo da Universidade de São Paulo (FAUUSP) em 2010, Demi Getschko, um dos pioneiros da internet no Brasil, comentou que os livros nasceram proibidos e passaram a ser livres, já a internet nasceu livre e passou a ser cada vez mais controlada. Esta dubiedade relaciona-se

\footnotetext{
${ }^{57}$ http://www.tedxusp.com.br. Acesso em: 20/12/2010.
} 
com as questões da interaividade de acabei de levantar, pois em um meio como a internet, que com suas ramificações permite a interatividade dos que estão conectados, dependendo dos valores atribuídos às ações e a formas de acesso ao sistema, essa interatividade pode ter seu conceito alterado. E, por sua vez, os livros, que com a digitalização são passíveis de fugir de qualquer meio de controle eletrônico, ganham um novo significado como forma de liberdade de experessão e de interatividade no sentido apresentado por Habermas, de que é possível haver desacordos na comunicação.

\section{Interatividade na TV Digital do Brasil}

No Brasil, a TV Digital ainda está presente em uma minoria dos lares, pois mesmo aqueles que possuem aparelhos de HDTV não necessariamente recebem o sinal de TV Digital. Nos EUA, foi bastante lenta a migração dos consumidores norte-americanos para a TV Digital (LU, 2005); em junho de 2009, esgotou-se nos EUA o prazo para transição para TV Digital, mas uma grande parcela dos lares não a havia adquirido (grande parte dos telespectadores nesse país recebe TV via cabo ou satélite, o que explica em parte o reduzido interesse em adquirir um receptor digital). Discute-se qual a motivação para a população migrar para a TV Digital; uma delas seria o interesse por uma maior resolução da imagem com a TV de alta definição (HDTV), o outro motivo seria a TV Digital interativa. Como, ao que parece, a primeira razão não foi suficiente para atrair a população a adotar a TV Digital, há um aumento das expectativa de que a interatividade será o Killer Application $^{58}$ da TV Digital. Em 2010, o governo brasileiro começou a tomar algumas medidas de modo que a interatividade passe a ser um recurso obrigatório ${ }^{59}$.

\footnotetext{
${ }^{58}$ Killer Application é um termo da indústria da computação que pode ser traduzido como “Aplicativo Matador”, ou seja, um programa ou serviço que faça com que uma nova tecnologia tenha sucesso junto ao público consumidor.

59 “TV Digital: governo quer interatividade como recurso obrigatório”. IDG Now! Circuito de Luca.

“A partir da nossa ação, a indústria começou a se mexer. As reuniões começaram a acontecer”, diz André Barbosa, assessor especial da Casa Civil. Segundo ele, a capacidade de interatividade passará a ser exigida pelo governo de forma mais enfática, para conversores fixos embutidos nos televisores e também nos externos. "Pensamos em tornar a interatividade um recurso obrigatório. É claro que não vamos fazer isso de afogadilho. A proposta passará por uma consulta pública...", diz ele, lembrando que o PPB dos conversores populares já é um instrumento à disposição do governo para incentivar a interatividade. Outro é a rede pública de tv digital, onde começarão a surgir serviços de T-gov, muitos deles já adaptados para rodar bem também em televisores de CRT, sem problemas de interface comuns aos aplicativos desenvolvidos para televisores de alta definição. E onde todos os envolvidos na cadeia produtiva poderão investigar que modelos de negócio de interatividade vão
} 
A mesma lógica tem sido aplicada na fase inicial de implantação das possibilidades de interação digital no SBTVD. Do ponto de vista pragmático, nenhum nível de interatividade digital foi inserida no design técnico dos set-top boxes lançados do final de 2007. Isto ocorreu devido a uma ausência de pressão governamental para que sistemas já desenvolvidos por pesquisadores brasileiros (como o middleware GINGA) fossem obrigatoriamente incorporados pela indústria, conforme havia sido anunciado anteriormente12. Pelo menos a curto prazo, não haverá interatividade de fato na TV digital, devendo ser implantada posteriormente. (SILVA, 2009, p. 23).

A TV Digital Interativa, TVDI, também é conhecida como ITV, abreviação de Interactive Television. Neste trabalho irei detalhar aspectos técnicos da TV Digital Interativa como tem sido introduzida pela indústria da TV, usando como referência principal o livro Interactive Television Production, de Mark Gawlinsky (2003). Duas importantes fontes de referência são o site Broadband Bananas ${ }^{60}$ (Loucos por Banda Larga), que tem dado cada vez mais cobertura ao IPTV e ITVT Interactive TV Today ${ }^{61}$, site fundado por Tracy Swedlow, uma das principais interlocutoras da interatividade na TV Digital nos EUA. Swedlow publica semanalmente o ITV News, que apresenta os principais lançamentos e novidades do setor.

Na TV Digital, além de o sinal de vídeo e áudio poderem ser digitalizados em formatos e resoluções diferentes, o sinal da TV Digital pode incluir também um fluxo de dados sendo transmitido junto com o fluxo de audiovisual, dados esses que podem ser aplicativos ou arquivos de textos, imagens, sons e vídeos. O receptor de TV Digital pode ter aplicativos residentes que utilizam esses dados ou executar os aplicativos sendo transmitidos junto com a programação ou sob demanda. A execução desses aplicativos permite a interatividade do telespectador ${ }^{62}$ com a TV e a utilização de serviços integrados ao STB como o guia de programação, gravação de programas, acesso à internet e informações. Os aplicativos também podem ser incorporados na programação da TV, e ser sincronizados com a transmissão ou independentes dela, como é caso dos videogames.

pegar." http://idgnow.uol.com.br/blog/circuito/2010/10/29/tv-digital-governo-quer-interatividade-como-recursoobrigatorio/

\footnotetext{
${ }^{60} \mathrm{http}: / / \mathrm{www} \cdot$ broadbandbananas.com

${ }^{61} \mathrm{http}: / / \mathrm{www}$. itvt.com

${ }^{62} \mathrm{Na}$ TV Digital, o "telespectador" passa a ser ativo ou um usuário de modo geral. Utilizo o termo telespectador mas, quando no contexto da interação do telespectador com os aplicativos da TV Digital, refiro-me a ele como usuário.
} 
A interatividade pode ser local, ou seja, limitada à capacidade do usuário de acessar e navegar informações que estão sendo "transmitidas" junto com o fluxo de dados do programa, como também pode ser plena, e neste caso é necessário que haja um canal de retorno que possibilite o envio e troca bidirecional de informações do telespectador com a emissora ou operadora de TV. No caso em que a interatividade possibilite a interação na TV com outros usuários, a TV deixa de ser uma forma de comunicação simplex (uni-direcional) e passa ser duplex (bi-direcional), com consequências bastante interessantes para o futuro da TV.

\subsubsection{Histórico da TV Digital Interativa}

"Winky Dinky and You”, de 1950, é considerado um dos primeiros programas interativos da televisão (GAWLINSKY, 2003; LU, 2006); neste programa infantil de uma rede de televisão norte-americana, era possível pedir pelo correio um kit composto de uma película plástica que era fixado na tela por eletrostática e um jogo de canetas coloridas com as quais se podia desenhar sobre a película. Telespectadores mirins podiam interagir com os personagens por exemplo desenhando uma ponte quando havia um rio, ajudando-os a atravessar. O programa foi cancelado em parte porque havia reclamações de que as crianças começaram a desenhar diretamente sobre a tela da TV.

Em 1992, a TV Globo lança o programa "Você Decide" (TEIXEIRA, 2008), onde o público podia votar no seu final favorito para o programa através de uma central telefônica. Já nos meados da década de 1990, Dan Sullivan, pesquisador e professor do Interactive Telecommunications Program (ITP), em Nova York, dirigia um programa em um canal de acesso público na Manhattan Cable TV, principal operadora de TV a cabo de Nova York. No período realizava meu mestrado nessa escola e acompanhei de perto a produção deste programa, o "YORB - Electronic Neighbourhood", no qual era possível habitar um bairro virtual e interagir com outros telespectadores ao se controlar uma espécie de Avatar utilizando o teclado de um telefone fixo comum.

Nos anos 1990, a Time Warner, nos EUA, monta o Full Service Network (FSN), um sistema de TV a cabo em Orlando, Flórida, que utilizava fibra ótica e STBs com chips da Silicon Graphics, e permitia assistir filmes sob demanda e outras formas de interatividade. O projeto acabou custando caro demais (HUDGINS, 2005); em entrevista com Jim Luddngton, especulava-se que os STBs estavam custando em torno de US3000,00 cada, mas que seria 
possível que o custo chegasse a US\$300, o que não foi possível na época e acabou sendo abandonado, como ocorreu com o Qube, outra experiência da Time Warner (LU, 2003). Com intuito de desenvolver a produção de programas para a TV Interativa, o AFI (American Film Institute) criou um workshop patrocinado por diversas empresas em que a cada ano um programa era desenvolvido para plataformas de TV interativa como OPEN, Microsoft TV e Liberate. Na Europa, no final da década e início dos anos 2000, emissoras como BBC, MTV Europe, CANAL +, BSkyB começaram a desenvolver programas interativos compatíveis com a plataforma MHP (Multimedia Home Platorm). Hoje há uma variedade de programas interativos sendo transmitidos no sistema DVB (Digital Vídeo Broadcast) europeu.

\section{Novas direções da TVDI}

Com a TV Digital vem a interatividade, e quando falamos em TV Interativa (ITV), geralmente estamos referindo-nos à interatividade possível nos sistemas de TV Digital (DTV), que é bem mais limitada do que em sites na internet banda larga, que integram vídeo digital, animação e aplicativos conectados em rede, permitindo outros tipos de interatividade. Com a convergência das mídias, diversas formas de distribuição permitem receber a TV Digital, como serviços de IPTV, sites como o YouTube na internet e aplicativos no celular e outros dispositivos móveis. A interatividade destas novas formas de exibição não estão limitadas ao controle remoto e podem apontar para novos caminhos a serem incorporados na TV Digital.

\subsubsection{Tipos de Interatividade na TV Digital}

O livro Interactive Television Production, de Mark Gawlinsky (2003), é considerado uma das principais referências para produtores de ITV ou TV Digital Interativa. Gawlinsky foi diretor de produção da BBC Resources, a produtora interna da British Broadcasting Corporation (BBC) na Inglaterra e seu livro apresenta de uma forma bastante prática a tecnologia das ferramentas e dos métodos de produção de programas para a TV Digital Interativa, focando principalmente no padrão europeu MHP, onde já se estabeleceu um mercado de TV Digital interativa. Esse livro é uma excelente fonte de referência para produtores, designers, roteiristas e outros que pretendem produzir conteúdo para a TV Digital. 
Os tipos de interatividade estudadas no livro de Gawlinsky são limitadas às que são exibidas em um monitor de TV e não de um computador; hoje, com o avanço dos monitores HDTV (em muitos caso de varredura progressiva), talvez essa limitação se torne um pouco rígida e poderíamos incluir qualquer forma de se assistir TV em que haja uma certa distância entre o telespectador e a tela (como em uma sala ou no quarto na cama). O STB, conversor que permite assistir o sinal da TV Digital em uma TV comum, é na verdade um computador dedicado rodando um sistema operacional limitado às funcionalidades especificadas pela TV Digital.

Gawlinsky, em seu livro, utiliza a taxonomia da Microsoft TV(2003) para classificar os tipos de TV Digital Interativa:

-Televisão Expandida ${ }^{63}$ - Enhanced Television - O programa de TV é "enriquecido" com conteúdo interativo em uma camada de dados transmitida junto com o sinal de áudio e vídeo.

-Internet na Televisão - Internet on Television - Quando a internet pode acessada em um aparelho de televisão, como é o caso da "Web TV".

-Televisão Pessoal - Personal Television - A TV personalizada sob demanda. You Tube e TIVO são formas de assistir televisão de forma personalizada.

-Televisão Conectada - Connected Television - A TV conectada em que os usuários podem transmitir conteúdo.

Quanto à interatividade, o Centro de Pesquisa Henley Centre (GAWLINSKY, 2003), define as categorias de interatividade na TV como sendo:

- Interatividade na Distribuição, em que o telespectador interage e controla a recepção do conteúdo; a funcionalidade neste caso é similar ao Personal Video Recorder (PVR), no qual se pode "gravar" um programa para ser assistido posteriormente.

\footnotetext{
${ }^{63}$ Gil Barros, em sua dissertação de mestrado, sugere o termo Televisão Expandida como tradução de Enhanced TV.
} 
- Interatividade da Informação - Quamdo o telespectador pode acessar diversos tipos de informação, como jogar um game na TV, encomendar uma pizza ou verificar a previsão do tempo.

- Interatividade Participativa - Neste caso os telespectadores podem selecionar opções durante um programa ou comercial, como a capacidade de escolher o ângulo da câmera em um jogo de futebol.

Montez e Becker (2005) partem da classificação de André Lemos (LEMOS, 1997 apud MONTEZ;BECKER, 2005) para propor novas classes de interatividade na TV:

Se utilizarmos a ideia com enfoque na televisão (LEMOS, 1997) classifica a interatividade nesse meio em cinco níveis de interação baseados na evolução tecnológica dessa mídia.

Nível 0: é o estágio em que a televisão expõe imagens em preto e branco e dispõe de um ou dois canais. A ação do espectador resume-se a ligar e desligar o aparelho, regular volume, brilho ou contraste e trocar de um canal para outro.

Nível 1: a televisão ganha cores, maior número de emissoras e controle remoto - o zapping vem anteceder a navegação contemporânea na web. Ele facilita o controle que o telespectador tem sobre o aparelho, mas, ao mesmo tempo, o prende ainda mais à televisão.

Nível 2: alguns equipamentos periféricos vêm acoplar-se à televisão, como o videocassete, as câmeras portáteis e os jogos eletrônicos. O telespectador ganha novas tecnologias para apropriar-se do objeto televisão, podendo agora também ver vídeos e jogar, e das emissões, podendo gravar programas e vê-los ou revê-los quando quiser.

Nível 3: já aparecem sinais de interatividade de características digitais. O telespectador pode então interferir no conteúdo a partir de telefones (como no programa "Você Decide" da Rede Globo de Televisão) por fax ou correio eletrônico.

Nível 4: é o estágio da chamada televisão interativa em que se pode participar do conteúdo a partir da rede telemática em tempo real, escolhendo ângulos de câmera, diferentes encaminhamentos das informações etc. Apesar dessa definição de Lemos, no nível 4 o telespectador ainda não tem controle total sobre a programação. Ele apenas reage a impulsos e caminhos predefinidos pelo transmissor. Isso ainda não é TV interativa, pois contradiz a característica do "não default", definida por (LIPPMAN, 1998). No estágio 4, a TV ainda é reativa, sendo necessários pelo menos mais 3 níveis de interatividade para torná-la pró-ativa, como vimos no conceito de (REISMAN, 2002).

Para isso, propomos neste livro mais três níveis: 
Nível 5: o telespectador pode ter uma presença mais efetiva no conteúdo, saindo da restrição de apenas escolher as opções definidas pelo transmissor. Passa a existir a opção de participar da programação enviando vídeo de baixa qualidade, que pode ser originado por intermédio de uma webcam ou filmadora analógica. Para isso, torna-se necessário um canal de retorno ligando o telespectador à emissora, chamado de canal de interação.

Nível 6: a largura de banda desse canal aumenta, oferecendo a possibilidade de envio de vídeo de alta qualidade, semelhante ao transmitido pela emissora. Dessa forma, a interatividade chega a um nível muito superior a simples reatividade, como caracterizado no nível quatro (LEMOS, 1997).

Nível 7: neste nível, a interatividade plena é atingida. O telespectador passa a se confundir com o transmissor, podendo gerar conteúdo. Esse nível é semelhante ao que acontece na internet hoje, onde qualquer pessoa pode publicar um site, bastando ter as ferramentas adequadas. $\mathrm{O}$ telespectador pode produzir programas e enviá-los à emissora, rompendo o monopólio da produção e veiculação das tradicionais redes de televisão que conhecemos hoje. (MONTEZ; BECKER, 2005, p. 54).

Morris e Smith-Chaigneau (2005) classificam os tipos de interatividade na TV como:

Enhanced (Expandida) - Como encontrada nos guias de programação de feeds de notícias, onde a interação ocorre somente entre o usuário e o aparelho receptor, utilizando dados enviados ao receptor de modo que não há necessidade de comunicação com a emissora.

Interativa - Que se refere a aplicações específicas entre o usuário e a emissora ou provedor de conteúdo utilizando um canal de retorno, como no caso de quizzes, chats, cotações. Este tipo de interatividade pode utilizar um canal de retorno proprietário ou não como no caso de uma conexão IP.

Internet TV - Onde a interação pode ocorrer entre o usuário e emissora ou um servidor na internet, neste caso se utiliza um IP padrão na internet e uma banda maior do que o canal de retorno alocado nas categorias anteriores, possibilitando também o envio de vídeos em ambas as direções.

\subsubsection{Serviços Interativos na TV Digital}

Os países europeus atualmente utilizam o sistema Digital Vídeo Broadcast (DVB) de TV Digital, sistema que oferece diversos serviços interativos na plataforma Multimedia Home 
Platform (MHP). Existem vários exemplos de aplicativos interativos desenvolvidos para a plataforma MHP, cujas características são muito próximas do que é possível como middleware Ginga do SBTVD.

A TV Digital interativa possibilita uma variedade de serviços interativos como o acesso a internet, governo eletrônico (T-Gov), compras (T-Commerce) ou educativos (TLearning). Assim como na internet tem se denominado os serviços eletrônicos com a inicial "E”, como em "E-Commerce", "E-Learning”, na TV Digital tem se incorporado a letra "T" antes do nome do serviço em inglês para designá-lo. No site www.broadbandbanas.com temos exemplos de vários desses serviços disponíveis principalmente na Europa em DVBMHP e na Ásia através das operadoras de IPTV. Acredita-se que esses serviços de TV digital estarão disponíveis no Brasil, com a introdução do middlware Ginga; seguem alguns exemplos:

\section{EPG - Guias Eletrônicos de Programação}

Um dos principais serviços da TV interativa é o Electronic Programming Guide (EPG) ou Guia Eletrônico de Programação. O EPG é um aplicativo, presente em praticamente todos os sistemas de TV Digital, que permite navegar a grade de programação dos canais disponíveis e acessar uma sinopse onde se pode obter mais informações sobre um determinado filme. Outras funções do EPG incluem salvar lembretes e realizar controle de conteúdo por idade. Nos modelos mais avançados, equipados com um PVR (Personal Video Recorder), pode-se agendar a gravação de programas. Esses aplicativos que costumam ser residentes nos STBs também servem como portal de entrada das operadoras para a programação e outros serviços oferecidos. Os EPGs podem ser organizados em um mosaico, como é o caso da Sky e TVA, em listas como na NET ou em forma de tabela refletindo a grade de programação. 


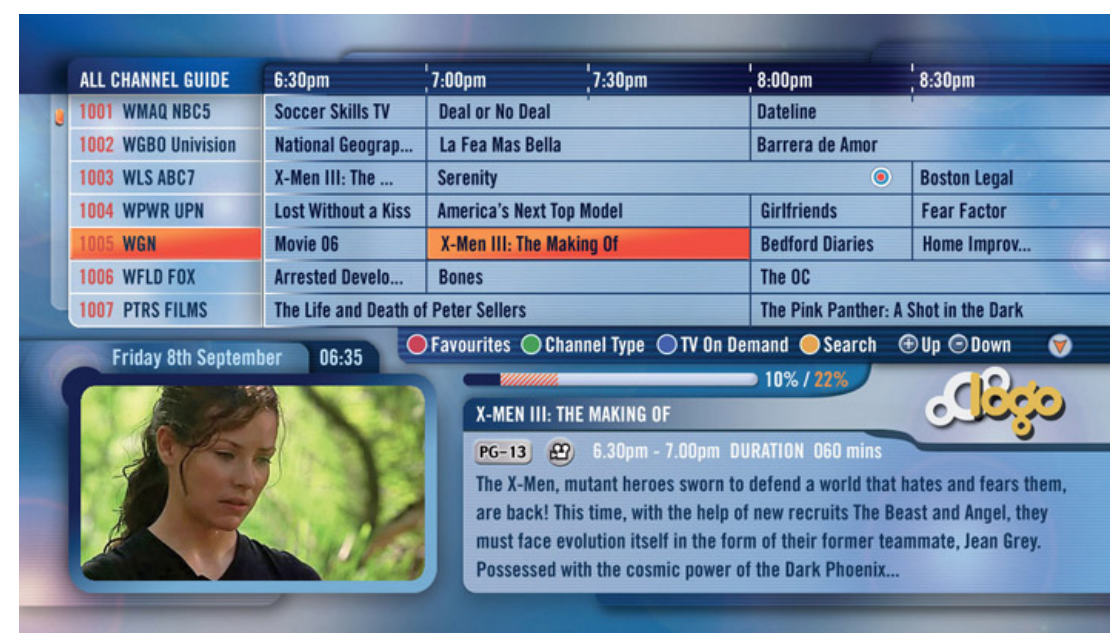

Figura 3.9: EPG desenvolvido pela NDS para HDTV

Fonte: http://www.nds.com/solutions/epgs.php

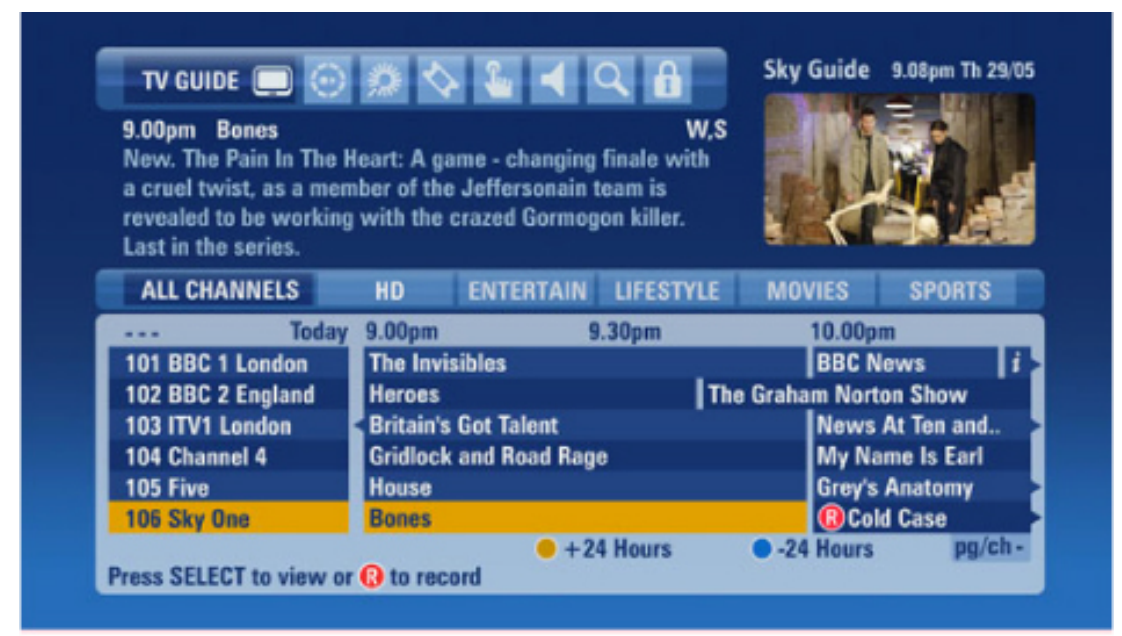

Figura 3.10: Guia de programação da SKY em HDTV

Fonte: http://www.hdtvuk.tv/2008/05/sky_shows_off_i.html

A revista $T V$ Guide estabeleceu-se como a principal fonte de informação dos horários e sinopses de programas de TV nos EUA nos anos 1970. Nos anos 1980, começou a oferecer um canal de programação, o Prevue Channel, para operadoras de TV a cabo e mais recentemente para TV Digital. A TV Guide, que foi adquirida pela ROVI (http://www.rovicorp.com), licencia seu banco de dados e EPGs para diversos fabircantes, operadoras de TV a cabo e registrou diversas patentes de seus EPGs, o que tem sido disputado por diversas empresas como a Virgin e Toshiba ${ }^{64}$.

\footnotetext{
${ }^{64}$ Virgin wins Gemstar patent case on programme guide 27 November 2009. http://informitv.com/news/2009/11/27/virginwinsgemstar/
} 


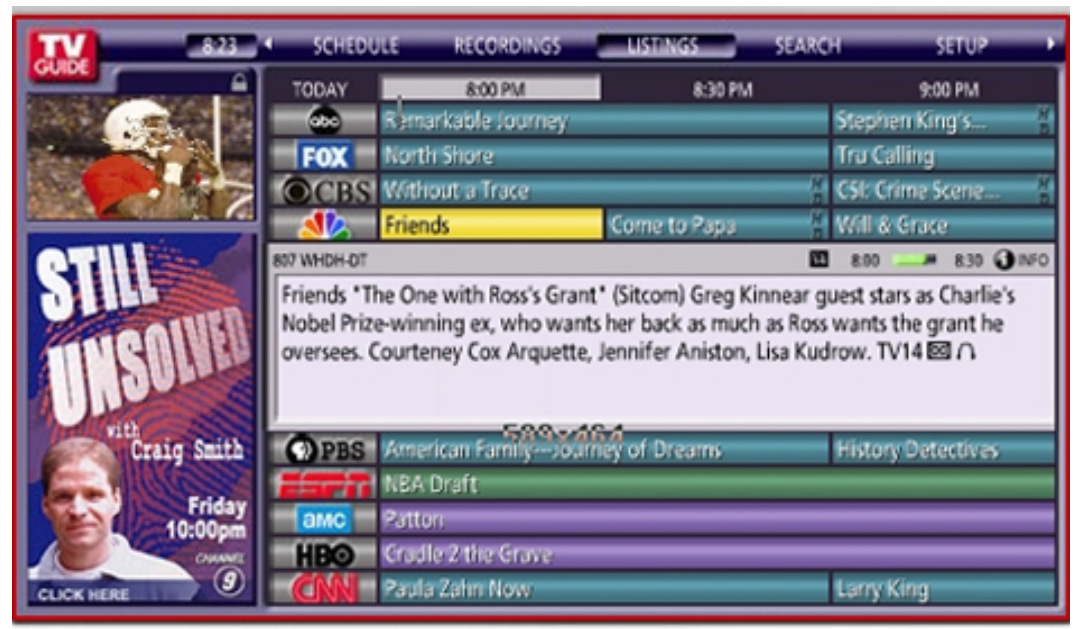

Fig. 3.11. EPG HD da TV Guide

Fonte: www.rovi.com

\section{TV Expandida}

A ideia por trás da TV Expandida (Enhanced TV) é a de enviar conteúdo complementar ao programa junto à camada de dados; este conteúdo pode ser síncrono ou assíncrono. No Reino Unido, onde estes serviços são bastante comuns, a BBC refere-se a eles como Red Button, e tem se convencionado que, ao aparecer na tela um símbolo representando um botão vermelho, é possível acessar o conteúdo interativo que acompanha o programa ao se pressionar o botão vermelho do controle remoto. De modo geral, a Enhanced TV funciona como uma camada em cima do vídeo, não interrompendo a programação nem a obstruindo; e permite obter informações adicionais ao programa ao interagir com ele, por exemplo no caso de um jogo de futebol, em que é possível escolher o ângulo de visão. Seguem alguns exemplos e interfaces para TV Expandida.

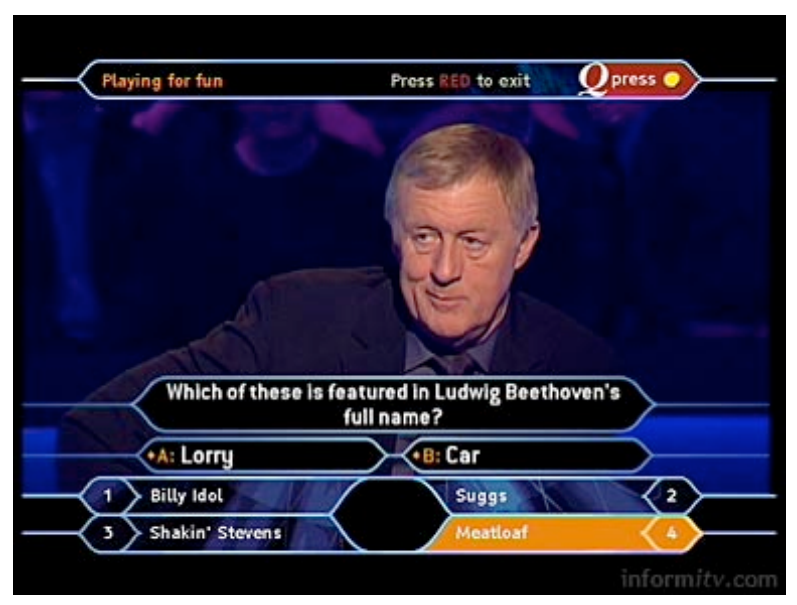

Fig. 3.12: UK Sky - "Who wants to be a millionaire?" Fonte: http://informitv.com/images 


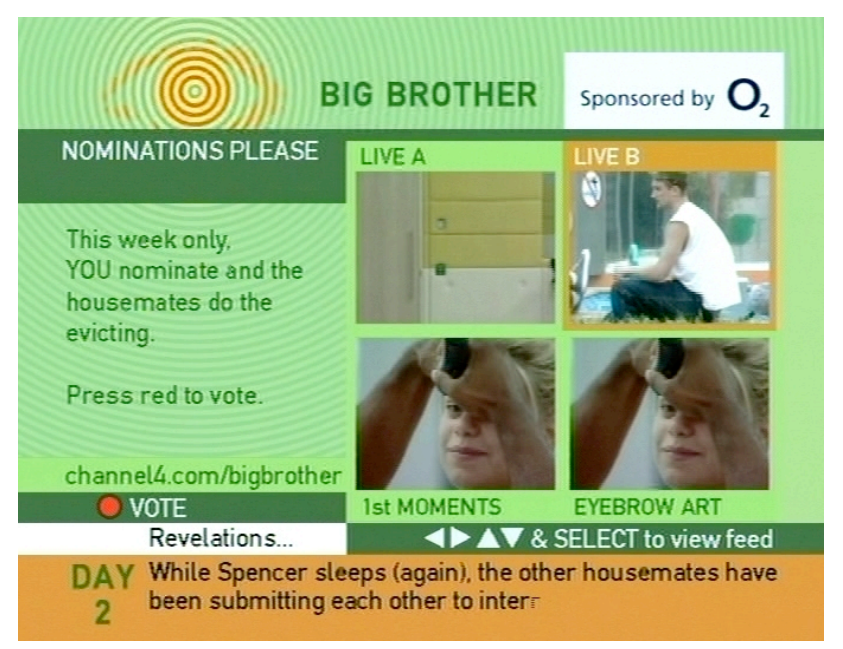

Fig. 3.13: Channel 4 UK (Open TV) - "Big Brother" Interativo Fonte: http://informitv.com/images

\section{T-Commerce}

Uma das possibilidades de exploração comercial da TV interativa é a do comércio eletrônico, que tem sido apelidado de T-Commerce. O exemplo mais comum é o do anúncio de pizza: ao assistir ao anúncio de uma pizzaria, o telespectador pode acionar o controle remoto e acessar um servidor permitindo-o encomendar uma pizza; essa operação pode ser realizada utilizando um cartão de crédito ou, no caso da TV por assinatura, pode ser cobrado na fatura do assinante. Paralelamente ao T-Commerce se abre uma série de possibilidades para a publicidade, onde podem ser enviados metadados junto com os comerciais, permitindo ao telespectador obter mais informações sobre um produto, cadastrar-se em promoções e assim por diante.

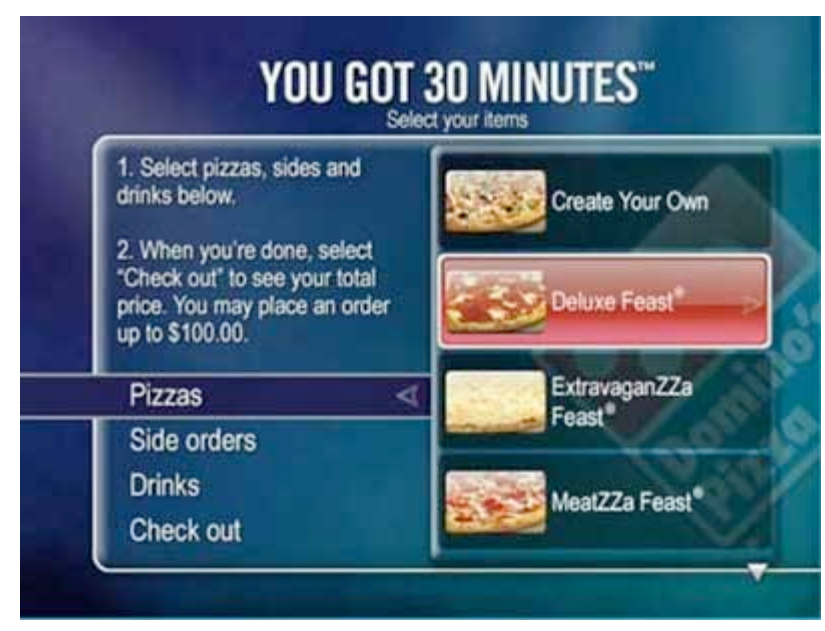

Fig. 3.14: Serviço de T-Commerce da "Domino’s Pizza" no STB Tivo Fonte: www adage.com 


\section{T-Banking}

O T-Banking é a versão para a TV do que conhecemos na internet como web banking, ou seja, a possibilidade de realizar transações bancárias eletronicamente na TV. Muitos bancos brasileiros já portaram estes serviços para celulares, e é só uma questão de tempo para que disponibilizem o serviço para a plataforma da TV Digital.

\section{T- Learning}

A interatividade e os computadores conectados em rede têm aberto muitas possibilidades no ensino a distância. Aliados à programação educativa na TV, os horizontes ampliam-se ainda mais, por isso o futuro da ensino a distância com o advento da TV Digital tem sido visto como bastante promissor pelos profissionais da área. Canais dedicados a educação como a TV Escola (WAISMAN, 2006) já investem em pesquisa e inovações na área, com a produção de guias de programação, material de apoio ao professor, acesso a material didático audiovisual sob demanda. Com um canal de retorno é possível desenvolver cursos a distância em que se pode acompanhar os alunos.

\section{T-Advertising}

A T-Advertising, publicidade interativa na TV Digital, combina a força visual e emocional da televisão como meio de comunicação de massa com a capacidade interativa e dirigida. Ao desenvolverem campanhas mais direcionadas, possibilita aos anunciantes envolver os telespectadores e gerar feedback em tempo real, criando um novo "espaço" no meio televisivo e permitindo reforçar atributos dos produtos. As campanhas podem ser dirigidas ao público-alvo usando dados demográficos de bases de Customer Relationship Management (CRM) como Experian e Claritas. As métricas chegam ao nível do set-top box individual, sendo muito mais precisas que índices como os do Instituto Brasileiro de Opinião Pública e Estatística (IBOPE). 


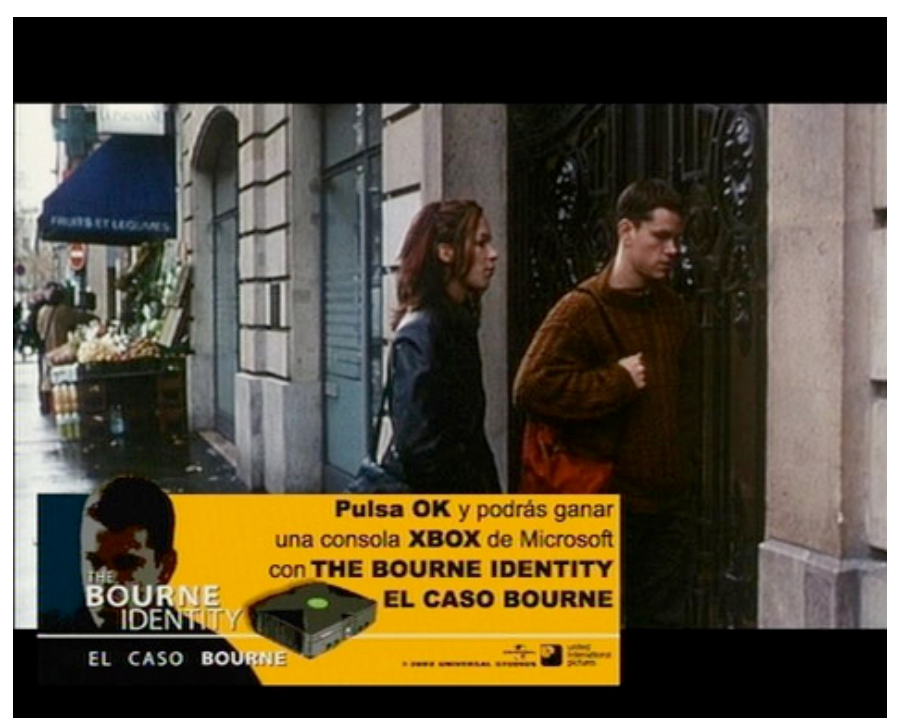

Fig. 3.15: Campanha de publicidade interativa "Caso Bourne" veículada na Espanha Fonte: www.broadbandbananas.com

\section{Outros serviços interativos}

Estes são apenas alguns exemplos, existe uma gama enorme de serviços sendo desenvolvidos para a TV Digital, como por exemplo os portais de governo eletrônico em que o cidadão acessa serviços como previdência social, saúde, administração municipal e assim por diante. Os set-top boxes podem ser utilizados como plataformas para games ou acesso à internet, incorporando browsers adaptados para a visualização a distância. Outros serviços de utilidade pública explorados na TV Digital são previsão do tempo, trânsito, partidas e chegadas em aeroportos.

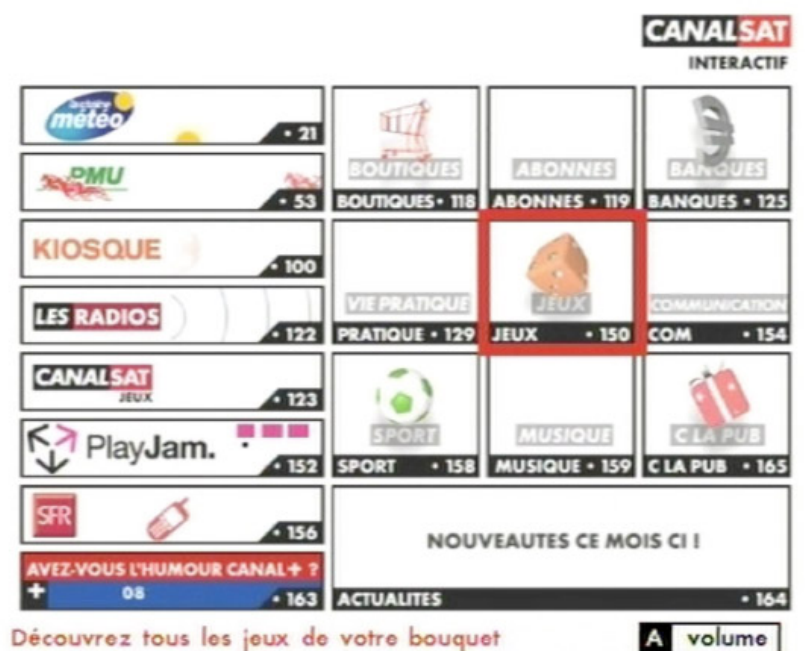

Fig. 3.16: Portal de serviços do Canal SAT - Canal + Technologies Fonte: www.broadbandabanas.com 


\section{Pay-per-view e DVR}

Atualmente a compra dos serviços de pay-per-view, ou seja, assistir a um filme ou programa de TV sob demanda, é geralmente realizada por meio de uma central telefônica. Com a TV Digital, é possível selecionar e assistir a esses programas oferecidos mediante o pagamento de uma taxa adicional diretamente da TV utilizando um menu, desde que exista um canal de retorno. O Digital Vídeo Recorder (DVR) ou Personal Vídeo Recorder (PVR) permite a gravação de programas em um Hard Drive (HD), disco rígido residente no STB; com ele se pode gravar programas gratuitamente, assinar serviços que selecionam a programação e em alguns casos editar os comerciais, como ocorre com TIVO nos EUA. Podem-se adquirir filmes sob demanda, como no caso do pay-per-view, e armazená-los por um tempo determinado sem estar limitado à janela de exibição do programa.

\subsection{Novos rumos da TV Digital}

\subsubsection{Convergência das mídias e dispositivos audiovisuais}

Existem diversas formas de assistir TV Digital, dividindo-se em dispositivos que através da combinação de hardware e software irão definir esta experiência; com a convergência dos meios de comunicação, essas tecnologias são os elementos construtivos da experiência de uma nova TV. Independentemente do hardware, que pode ser configurado de diversas formas, com a digitalização crescente dessas plataformas o software passa a ser a forma de conduzir esta experiência mudando drasticamente os hábitos do telespectador.

Ao definir-se o conteúdo da TV, é importante compreender a mídia, que em transformação acaba tendo sua configuração eventualmente definida pelo próprio conteúdo. Tal complexidade acaba sendo incompreensível para muitos telespectadores acostumados a apenas ligar a TV. Neste cenário temos os seguintes elementos construtivos deste sistema:

Receptores e conexão - Recebe o sinal de TV Digital terrestre ou via uma rede.

Terminais de Acesso - Processa e converte o sinal e as informações digitais.

Dispositivos de comando - Permite interagir e dar instruções ao terminal de acesso. 
Monitores - Através deles vemos as imagens e ouvimos os sons; podem ter diversas resoluções de tela, desde a diminuta de um celular até uma projeção.

Com a TV Analógica nos acostumamos a com a ideia de adquirir e utilizar uma solução integrada com o monitor; o aparelho receptor inclui dentro de uma "caixa" um monitor, um receptor e os circuitos eletrônicos que transformam os sinais possibilitando a experiência de assistir TV. Com o advento da TV a cabo, a introdução dos videogames e mesmo com os primeiros computadores passamos a estender a funcionalidade dos aparelhos de TV através dos STBs e outros aparelhos que poderiam ser conectados ao computador. DVDs e home theaters passam a amplificar essa experiência, tornando a instalação e utilização desses sistemas cada vez mais complexas.

Com a digitalização, muitos desses dispositivos são na verdade pequenos computadores dedicados a uma função específica. A TV Digital sendo implantada procura manter esse paradigma, em parte por pressão dos provedores de conteúdo (leia-se emissoras de TV), que tem medo de perder seu público que cativou dentro de sistemas fechados e proprietários desenvolvidos em aliança com a indústria eletrônica. Em contrapartida, a indústria de computação, que teve esse paradigma quebrado (Microsoft - IBM) já no início de sua implantação, embora não opere de forma menos monopolista que a indústria do entretenimento, desenvolve equipamentos que têm sua funcionalidade definida pelo usuário e que por limitações tecnológicas até recentemente não teve um papel na indústria do audiovisual.

No entanto, nos últimos anos, os avanços têm sido tantos que se torna quase impossível distinguir (exceto por questões políticas e legislativas) uma indústria da outra. Mesmo a TV Digital, baseada no processamento de informação binária e envolta em um pacote que era apresentado ao público nos mesmos moldes do paradigma anterior, tem tido dificuldades de implantação talvez pelo fato de seu modelo ser obsoleto, embora a tecnologia que incorpore não seja.

Um receptor de TV Digital é essencialmente um microcomputador dedicado, e o seu sistema utiliza algoritmos de compressão não muito diferentes daqueles usados pelos serviços de vídeo na internet; mesmo a modulação e transmissão da TV não está tão distante dos métodos multimídia. Por isso não é de surpreender que serviços como Hulu, NetFlix e Google 
TV não venham eventualmente a substituir a TV como conhecemos. Além disso, como se pode ver nesses mesmos serviços, os provedores de conteúdo e a forma de produzir conteúdo ainda exigem uma indústria e profissionais específicos, mas a forma de distribuição pode transformar-se radicalmente.

Um dos principais aspectos dessa transformação é o que chamamos de User Generated Content. Neste caso, o espectador passa a gerar conteúdo ou no mínimo ser um programador, e possivelmente uma das maiores transformações que veremos na TV Digital seja neste sentido, como ocorreu na mídia impressa, que sofreu transformações radicais com o advento da editoração eletrônica, culminando com uma revolução na forma de distribuição de texto com a internet. A indústria musical segue as transformações, inicialmente com o Napster; com a facilidade de baixar músicas, não muito mais tarde a transformação se radicaliza com as possibilidades introduzidas pelo MySpace.

Portanto, os receptores de TV Digital, embora teoricamente capacitados para atender demandas semelhantes às que ocorrem na mídia impressa e sonora, podem perder espaço para as soluções apresentadas pela indústria da computação, que neste sentido é muito mais dinâmica embora muito menos sedutora.
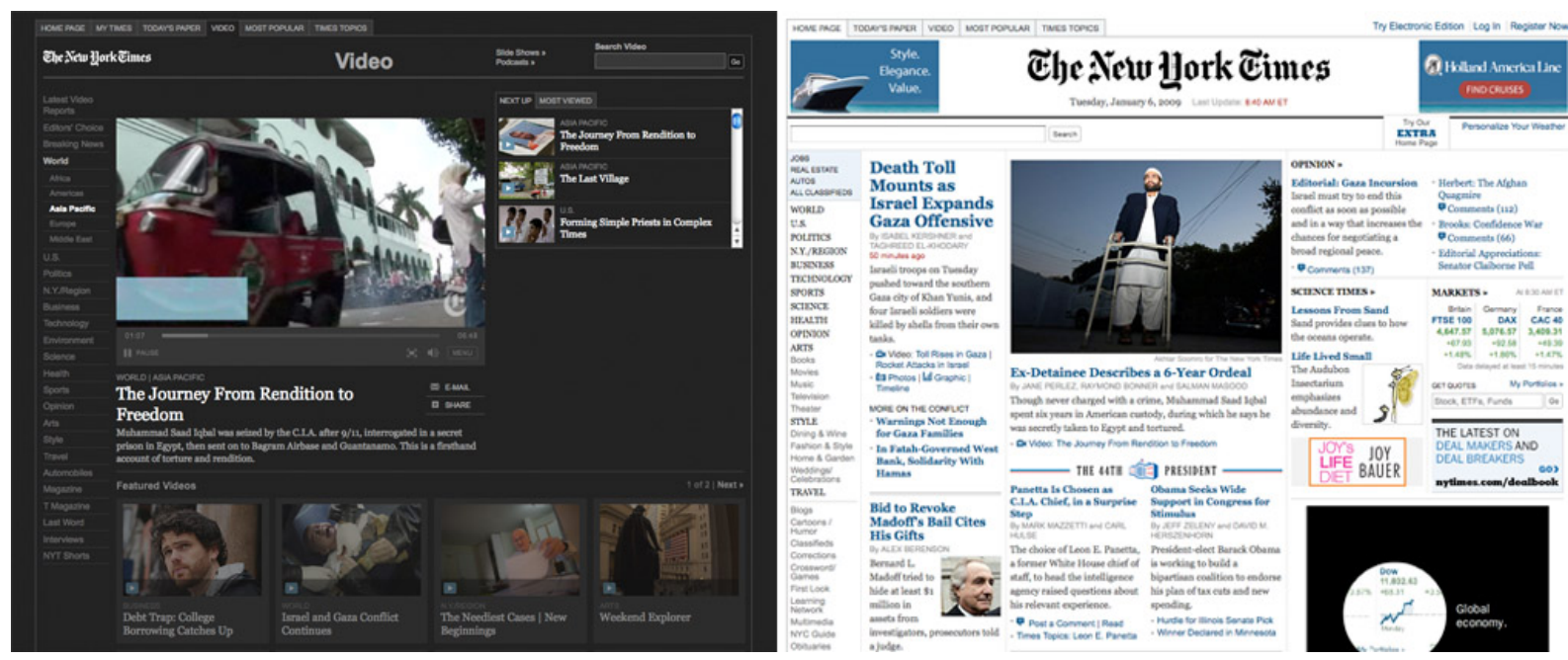

Fig. 3.17: Página de vídeos do site do New York Times, tradicional jornal dos Estados Unidos, inova ao integrar reportagens em vídeo com matérias escritas, criando uma experiência multimídia de seu jornalismo.

Fonte: www.nyt.com 


\subsubsection{Novos serviços e dispositivos}

Em setembro de 2005, a revista Wired publicou uma matéria de capa, "The all-youcan eat TV of tomorrow", em que Thomas Goetz entrevista o comediante Jon Stewart, apresentador do programa "The Daily Show", e o seu produtor executivo Ben Karlin, com a chamada: "Reinventando a televisão". A estratégia do programa é distribuí-lo concomitantemente na TV e na internet; eles acreditam que o formato pode ser consumido em "várias destilações, na hora, no lugar e no aparelho de sua escolha" (STEWART, 2005). Segundo Karlin, o modelo em que os programas da TV aberta eram o "santo graal" acabou, “hoje o público não julga a qualidade de um programa porque tem o logotipo da NBC estampado nele". Essa entrevista ocorreu cinco anos atrás, desde então as possibilidades de se assistir TV no computador ou através de outros dispositivos se multiplicaram. Ainda não é tão fácil configurar um sistema alternativo para se assistir TV, mas hoje é possível assistir à TV aberta no computador e no celular, baixar programas da TV a cabo da internet e assisti-los na TV. Diversos aparelhos e serviços que têm sido lançados com esse propósito, como Peer to Peer TV (PTPTV), Streaming de Vídeo na internet, IPTV, TV no celular e smartphones serão apresentados nesta seção, onde identifico três tendências:

1. Internet na TV - Widgets, Web, Download e Streaming

2. TV na Internet - Streaming Video

3. TV em dispositivos móveis - DTV e Streaming

\section{"Sofa Wars" - Web video na TV}

O New York Times publicou uma série de reportagens no segundo semestre de 2010 intitulada "The Sofa Wars" ${ }^{65}$. Em uma das matérias (RICHTEL;STELTER, 2010), referem-se à discussão do cord-cutting, um termo que significa cancelar a TV paga convencional (cabo e satélite) e trocar por programação on-line. No entanto, parece que a tendência não tem sido tão devastadora como previsto, e um dos motivos é a dificuldade de os usuários configurarem seus sistemas, mas aparentemente a razão principal é a dificuldade de se conseguir on-line os shows favoritos. No momento alguns destes shows, como True Blood da HBO, estão

\footnotetext{
${ }^{65}$ In the Living Room, Hooked on Pay TV MATT RICHTEL and BRIAN STELTER Published: August 23, 2010 e Crowded Field for Bringing Web Video to TVs By JENNA WORTHAM Published: August 23, 2010 http://www.nytimes.com/2010/08/23/technology/23startup.html Acesso em 13/12/2010
} 
disponíveis on-line, mas somente para assinantes do serviço de TV a cabo, o que demonstra a intenção das programadoras em dificultar o acesso à programação por meios não convencionais de distribuição. Segundo os jornalistas, analistas tem se espantado com o fato de como a internet conseguiu desafiar todas as grandes mídias como música, jornais e livros, mas ainda tem dificuldades em competir com a TV.

No entanto, as empresas de tecnologia têm introduzido alternativas como set-top boxes conectadas à internet IESTBs (Internet Enabled Set-Top Boxes) e IETVs (Internet Enabled TVs), aparelhos de TV que pode ser conectados diretamente na internet, facilitando assistir filmes e programas de TV da internet na sala em uma TV de tela plana. A indústria eletrônica tem utilizado o termo connected $T V$ ou $T V$ conectada para definir este novo nicho da indústria que tem causado reações adversas das redes de TV tanto nos EUA como na Europa. Um artigo no site ZDNet da França relata a inquietação das TVs europeias como TF1, France Télévisions, Arte, Canal+, le groupe M6, Direct 8, TMC, NT1, LCP, BFM, iTélé, Gulli et DirectStar, que assinaram um acordo onde declaram: "as modalidades de exibição dos conteúdos e serviços em rede nos aparelhos de TV e outros dispositivos de vídeo conectados" são uma ameaça as redes TV e demandam "que se respeite a integridade do sinal das redes de TV signatárias do acordo afim de manter o controle editorial total e exclusivo sobre os conteúdos e serviços exibidos ou derivados da programação" ${ }^{\circ 6}$ o objetivo é frear a influência do Google e seus consórcios que já sofreram um bloqueio das grandes redes norteamericanas ABC, CBS e NBC (CHICHEPORTICHE, 2010).

Segundo um artigo de Adriana Whitely ${ }^{67}$ (2010), do grupo de consultoria Farncombe, essas declarações das emissoras de TV europeias agravam-se com a notícia publicada pela agência de notícias Reuters de que a Microsoft está negociando com redes de TV pagas, para oferecer seu conteúdo na console de games Xbox, passando a competir com a Google TV, NetFlix e Apple. Ao estabelecer o que chamam de "operadora de TV a cabo virtual", a

\footnotetext{
${ }^{66}$ Tradução minha de: "Les modalités d'affichage des contenus et services en ligne sur les téléviseurs et autres matériels vidéo connectés"...""le respect de l'intégrité du signal de chacune des chaînes signataires afin que les éditeurs puissent continuer à exercer un contrôle total et exclusif sur les contenus et services affichés en surimpression ou autour de leurs programmes", em: TV connectées : les chaînes de TV veulent garder le contrôle par Olivier Chicheportiche, ZDNet France. Publié le 23 novembre 2010 http://www.zdnet.fr/actualites/tv-connectees-les-chaines-de-tv-veulent-garder-le-controle-39756299.htm

67 "Microsoft working on over-the-top virtual platform: another 'topware"”? November 30, 2010 by Adriana Whiteley. Disponível em: <http://www.connectedtv.eu/microsoft-working-on-over-the-top-virtual-platformanother-topware-326/>. Acesso em 20/01/2011.
} 
Microsoft passa a competir diretamente com a Google TV com seu "topware", que são especificações de middleware que podem ser utilizadas em diversos dispositivos para a recepção de conteúdo "over the top content" $(\mathrm{OTT})^{68}$, ou seja, de agregação de conteúdo feita de cima para baixo.
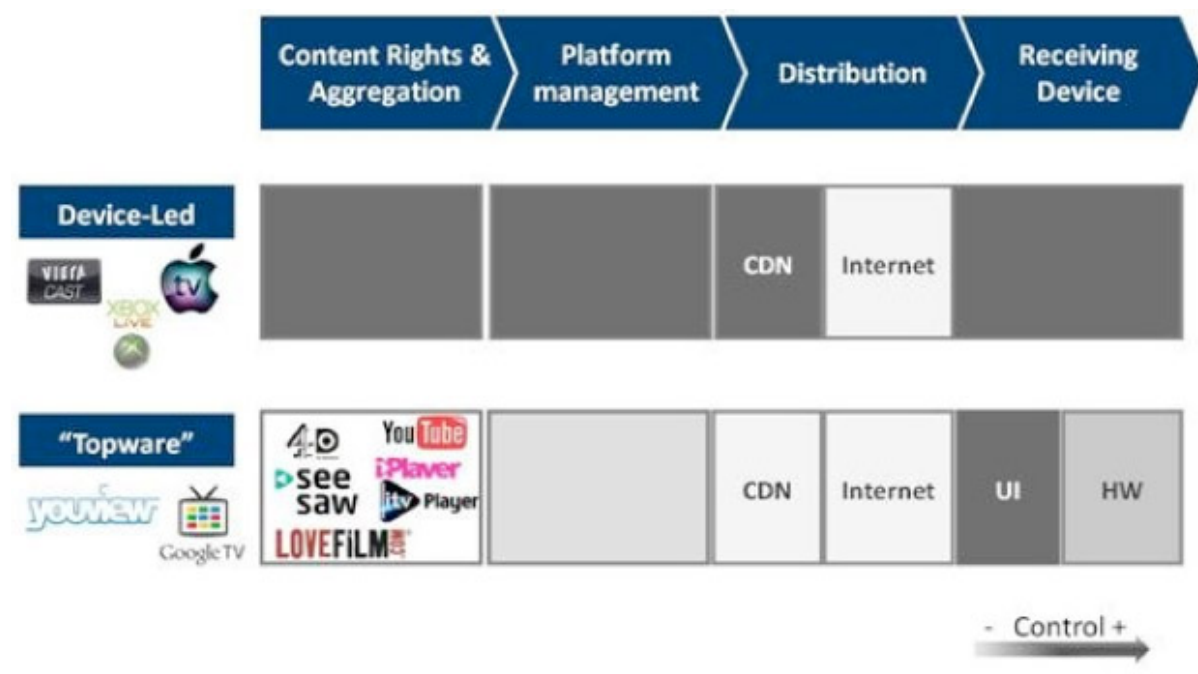

Fig. 3.18: Esquema comparando a distribuição de TV na internet utilizando over-the-top middleware e TVs conectadas cujo middleware é dependente do dispositivo. Fonte: http://www.connectedtv.eu/wp-content/uploads/2010/11/topware.jpg

Observem a importância de definir a interface do usuário neste tipo de solução topware

Mark Glaser, "anfitrião" do site Media Shift" ${ }^{69}$, da PBS, rede de TV pública norteamericana, publicou em janeiro de 2010 o guia "Your Guide to Cutting the Cord to Cable TV", onde descreve diversas alternativas de cortar a TV a cabo ou satélite e receber TV online. A revista Wired de setembro de 2010 também publica um artigo sobre o mesmo tópico onde apresenta diversos set-ups para receber TV Digital gratuitamente, incluindo HDTV terrestre.

As soluções compreendem:

- Hardware dedicado como a Apple TV, conversores de TV Digital, Boxee Box, sistemas híbridos como o Sezmi, que traz conteúdo tanto da TV Digital aberta como

\footnotetext{
${ }^{68} \mathrm{http}: / / \mathrm{www} . c o n n e c t e d t v . e u / w p-c o n t e n t / u p l o a d s / 2010 / 11 /$ topware.jpg

${ }^{69}$ Your Guide to Cutting the Cord to Cable TV, Mark Glaser, January 8, 2010

http://www.pbs.org/mediashift/2010/01/your-guide-to-cutting-the-cord-to-cable-tv008.html
} 
da internet, e "simbióticos", que fazem o streaming de filmes de services como Netflix (WORTHAM, 2010).

- Softwares como Boxee e Kylo facilitam a utilização de um computador conectado em uma TV com uma interface apropriada para visualização e comando a distância.

- Serviços como NetFlix, Hulu, YouTube, Amazon on Demand, iTunes e BitTorrents, de onde se pode adquirir ou baixar filmes e vídeos para assistir no computador ou em TVs conectadas.

Essas soluções no entanto ainda são fortemente centradas nos EUA, a maior parte do conteúdo disponível no iTunes, NetFLix e Hulu não são acessíveis de IPs localizados em outros países, mas nada garante que não haja mudanças na políticas de direitos em prática atualmente.

\subsubsection{Hardware}

Algumas soluções de hardware como o Apple TV combinam a distribuição vertical do conteúdo exclusivo, como é o caso do iTunes, e a possibilidade de acessar vídeos da internet de serviços como YouTube e Pandora. Outros aparelhos simplificam o processo de conectar um computador à TV, mas é possível configurar e conectar um PC a uma TV para assistir aos mesmos programas.

\section{Apple TV}

Em setembro de 2010, a Apple lançou a nova versão da Apple TV, um novo aparelho que permite assistir filmes adquiridos por meio do serviço iTunes da Apple. O aparelho lançado nos EUA cabe na palma de uma mão, possui uma saída HDMI, a fonte interna, uma saída de áudio digital (ótico), ethernet e Wi-Fi. 


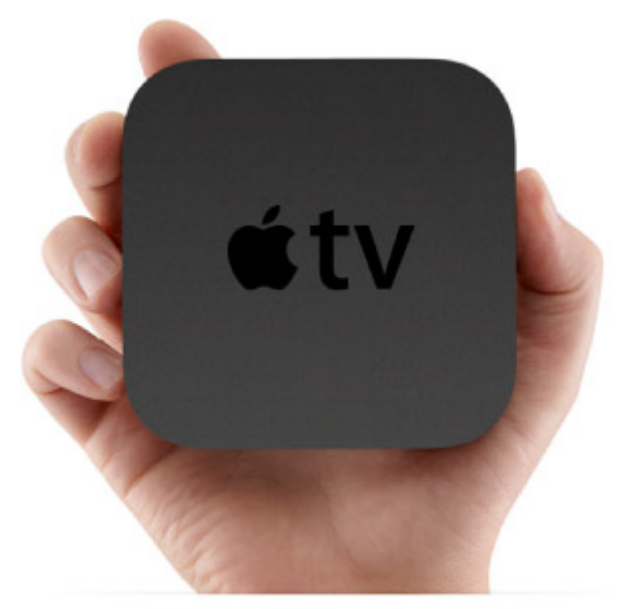

Fig. 3.19: Escala de um aparelho Apple TV Fonte: www .apple.com

Os usuários da Apple TV poderão alugar filmes recém-lançados em alta-definiç̧ão por US\$5, ao mesmo tempo em que são lançados em DVD. Será possível alugar programas de TV da rede norte-americana ABC e FOX por US\$1; segundo a revista Wired, os assinantes do serviço Netflix poderão realizar o streaming de vídeos da Netflix via Apple TV, e também poderão utilizar o aparelho para navegar e assistir vídeos no YouTube e baixar conteúdo postado pelo serviço MobileMe da Apple (TWEENEY, 2010).

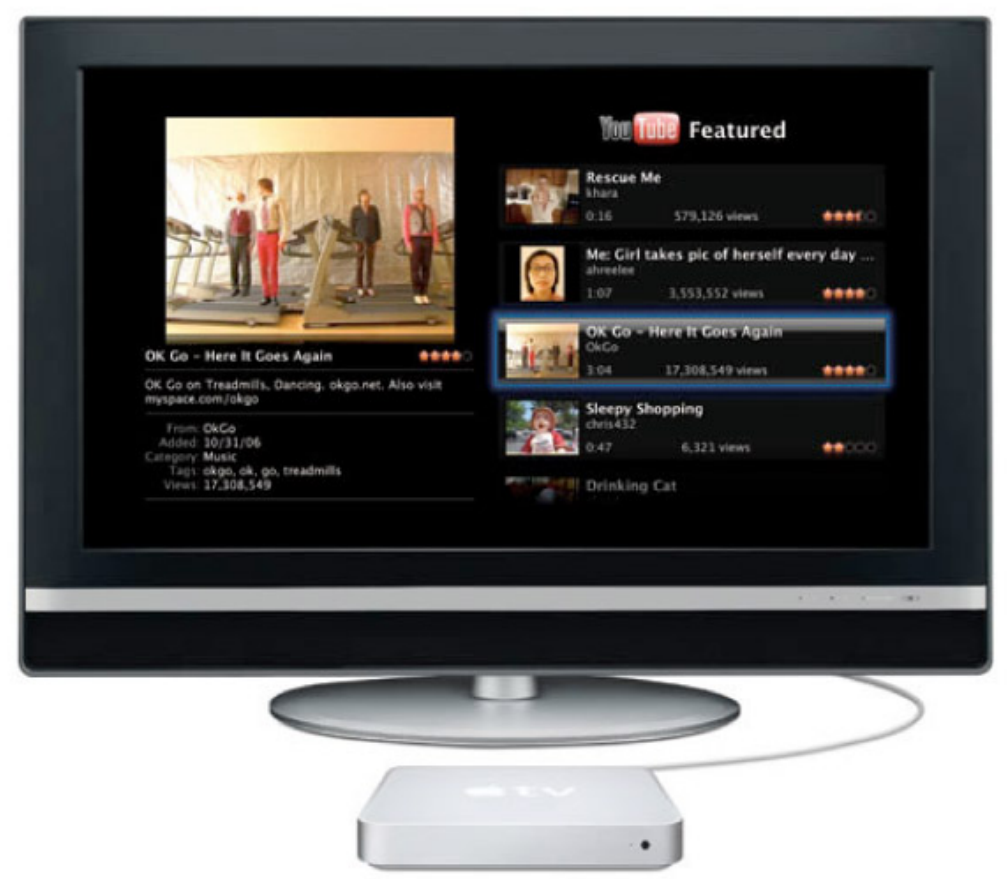

Fig. 3.20: Menu do YouTube na Apple TV

Fonte: www .apple.com 
Com esse lançamento, vemos que Apple busca oferecer uma proprietária, mas sabe que os consumidores querem poder assistir vídeos de diversas fontes na internet.

\begin{abstract}
A Apple se junta a um grupo que disputa um mercado com outras empresas que buscam reinventar a televisão na era digital. Netflix e Hulu têm oferecido streaming vídeo de filmes e programas de TV com algum sucesso por mais de um anto. E a Google está trabalhando em um set-top Box que deverá ofuscar os limites entre a TV e a internet, se comenta que o YouTube planeja alugar filmes mainstream e a Amazon está planejando seu próprio serviço de streaming vídeo à la Netflix. ${ }^{70}$ (TWEENEY, 2010).
\end{abstract}

A maior competição enfrentada pela Apple são as empresas de TV a cabo e emissoras de TV que têm conseguido restringir o acesso aos seus programas de TV e não parecem ter grandes motivos para oferecer o seu conteúdo para essas iniciativas na internet (WIRED, 2010). No mesmo artigo, cita o comentário de Andrew Eisner, a diretora da empresa de comércio eletrônico Retrevo.com, especializada em eletrônicos, de que a Apple TV é uma solução que busca a conveniência, mas se querem dominar o mercado deveriam ter uma estratégia que atingisse múltiplas plataformas. Esta fraqueza não é exclusiva da Apple, no mercado norte-americano as soluções de diversos fabricantes são verticais, tornando o mercado ainda mais fragmentado: "No momento existe um vácuo de sistemas operacionais para TV e infelizmente para os consumidores, os fabricantes de TV estão preenchendo-o com ofertas proprietárias" (EISNER apud TWEENEY, 2010) ${ }^{71}$. Eisner acredita que, assim como a Apple deve atingir outras plataformas, a televisão deve abrir-se para a internet:

A Apple precisa ganhar controle da terceira tela ou seja a tela da TV, após as telas de smartphones e computadores, e a indústria da TV deve se distanciar de ambientes fechados e permitir que suas TVs conectadas funcionem como todos os apps e conteúdo streaming pelo qual os consumidores tem se atraído. (EISNER apud TWEENEY, 2010) ${ }^{72}$.

\footnotetext{
70 “Apple Takes Aim at Cable With Tiny New Apple TV”, Dylan F. Tweney, Wired Magazine, September 1, 2010. "Apple joins an increasingly crowded and risky scrum of companies trying to reinvent television for the internet age. Netflix and Hulu both have been offering streaming video playback of movies and TV shows, with some success, for over a year. Google is working on a set-top box that would blur the line between TV and internet fare, YouTube is said to be planning mainstream film rentals and Amazon is rumored to be planning its own Netflix-like video streaming service”.

71 "A TV OS vacuum exists at the moment and unfortunately for consumers, TV manufacturers appear to be filling it with their own proprietary offerings", Eisner wrote recently." (TWEENEY, 2010).

72 “Apple needs to gain control of the third screen or TV screen, after smartphone screens and computer screens, and the TV industry needs to move away from closed environments and let their connected TVs work with all the apps and streaming content that consumers are finding so appealing." (EISNER apud WIRED, 2010).
} 


\section{Boxee Box}

Boxee Box é um produto da empresa D-link, e funciona tanto como ponto de acesso Wi-Fi como uma central de entretenimento, permitindo acessar, armazenar e apresentar vídeos, música, fotos, utilizando o software boxee em um aparelho de TV.

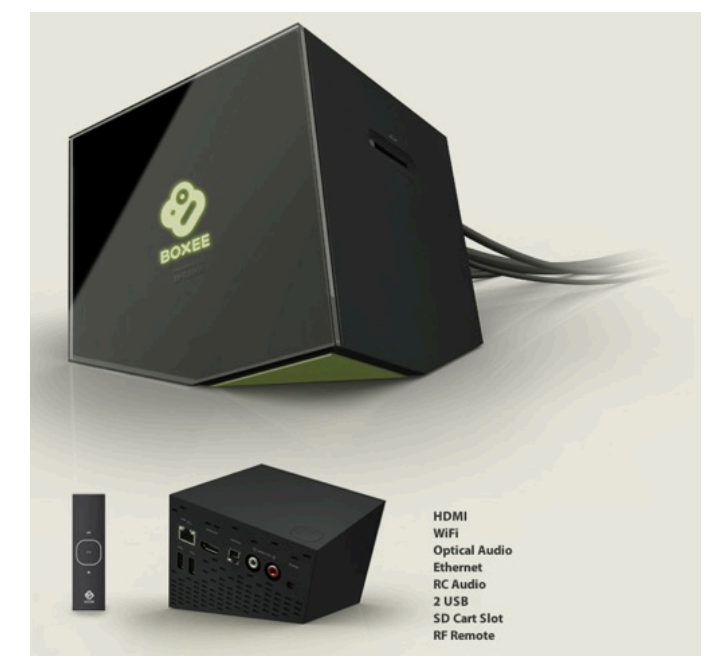

Fig. 3.21: D-Link Boxee Box

Fonte: www.dlink.com

\section{Sling Box}

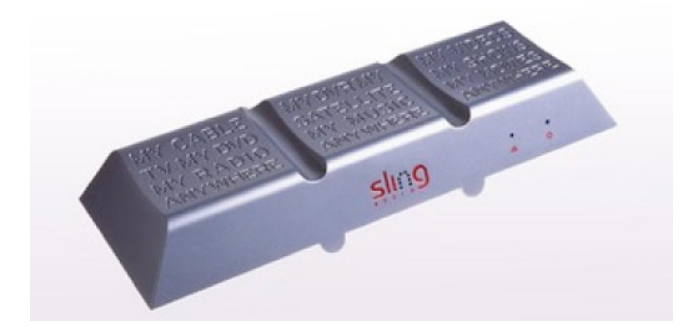

Fig. 3.22: Slingbox

Fonte: www.wired.com

O Slingbox utiliza uma rede doméstica (Wi-Fi ou Ethernet) para fazer o streaming de mídia de um PC que tenha o software SlingPlayer instalado; desta forma, o conteúdo armazenado ou disponível em diversos dispositivos em uma mesma casa podem ser assistidos em outros. Por exemplo um filme que foi baixado em um PC no quarto pode ser assistido na TV da sala. A mídia a ser compartilhada em uma residência pode incluir, além de vídeo, fotos e música ${ }^{73}$.

\footnotetext{
${ }^{73}$ http://www.wired.com/gadgetlab/2005/10/review_sling_me/\#ixzz149UEGwPS
} 


\section{Roku}

Roku é uma solução de IPTV que não depende de uma operadora, a proposta é que o consumidor compre o hardware que permite gravar vídeos digitais e faça parcerias com sites de vídeo na internet.

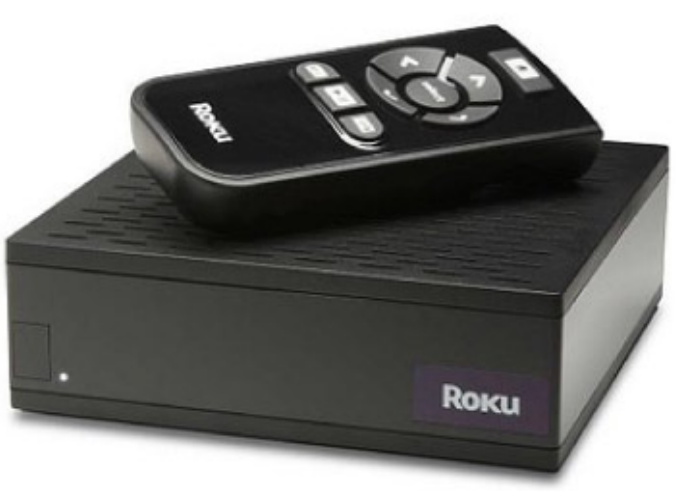

Fig. 3.23: Set-top Box e controle remoto Roku

Fonte: www.roku.com

\subsubsection{Serviços e Software}

Diversos softwares e serviços oferecem formas de se assistirem programas de TV no computador diretamente da internet, outros provêm uma interface para a visualização do conteúdo em uma TV conectada a um PC comandada por um controle remoto.

\section{You Tube}

Em 2006, a Google investiu US1,65 bilhões para adquirir o web site de vídeos YouTube, o que causou um furor na época, quando poucos compreendiam por que investir tanto dinheiro em um site em que os usuários postavam vídeos de seus bebês dançando. A estratégia da Google ia bem além do que se via na época; em 2006, a indústria de publicidade na televisão representava US\$67 bilhões $^{74}$ e já demonstrava sinais de que estava quebrando, primeiramente pela perda de audiência para novas formas de entretenimento eletrônico como videogames e a internet. Depois disso, a indústria de publicidade sentiu-se ameaçada pela possibilidade de os telespectadores assistirem os programas de TV sem interrupção comercial

\footnotetext{
${ }^{74}$ Wired 14.12 Dezembro de 2006, Tou Tube vs Boob Tube, by Bob Garfield p. 224
} 
utilizando o TIVO. Em 2010, não só o YouTube se consolidou como o serviço de distribuição de vídeos na internet, mas as agências de publicidade passaram a usar o meio para veicular uma nova modalidade de comerciais que são os virais, vídeos que simulam vídeos gerados por usuários que são "espalhados” pela web. Se por um lado o YouTube cresceu através de vídeos caseiros postados pelos seus usuários, não demorou para produtoras passarem a produzir filmes especificamente para essa plataforma, como o caso da "Lonely Girl 15", em que Jéssica Rose interpreta uma adolescente entediada em casa expondo seu cotidiano ao mundo. Essa simulação da realidade chegou a ser vista por 500 mil “telespectadores”.

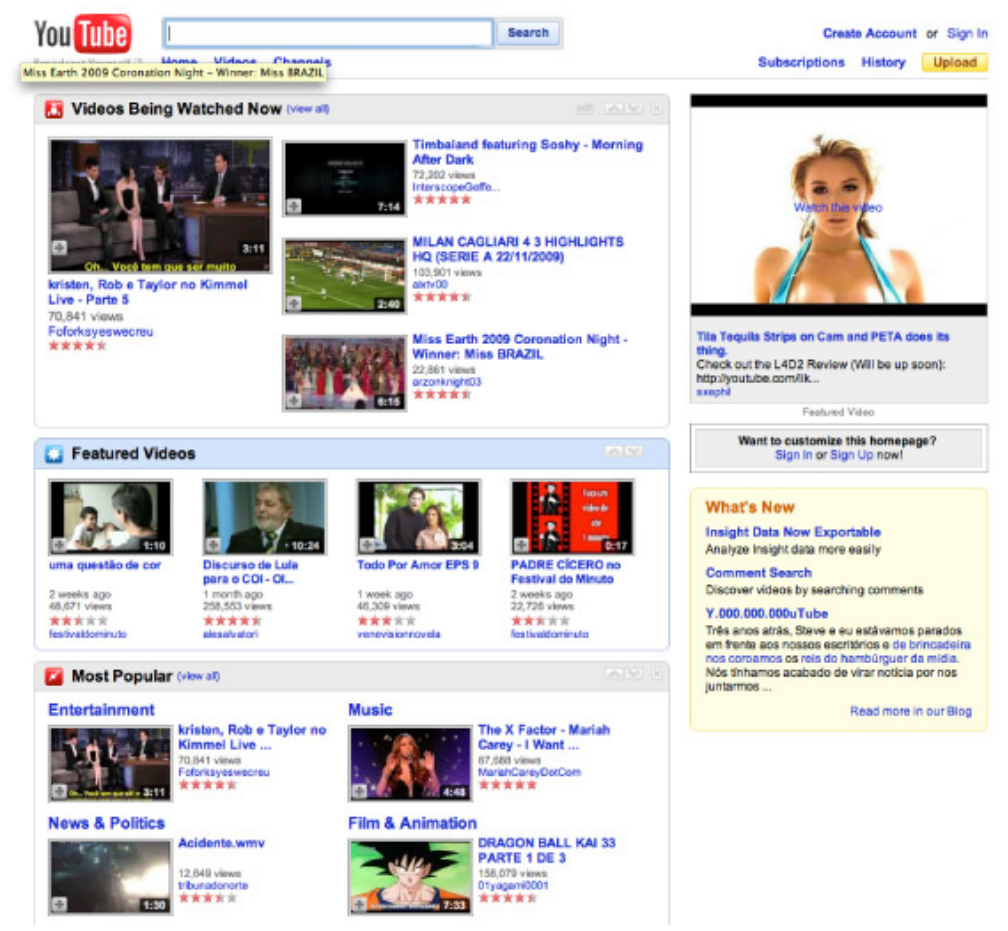

Fig. 3.24: Página do site You Tube

Fonte: www.youtube.com

Sites como a Atom Films e Pseudo Networks prometeram trazer a TV para a internet, mas foi o YouTube que tomou a dianteira ao encontrar no codec do Flash a solução para criar uma plataforma de vídeo na web. Desse modo, qualquer que fosse o formato de vídeo enviado para o site, ele era recomprimido de modo que pudesse ser assitido na grande maioria dos browsers para a web, ajustando a qualidade para se assistir o vídeo em tempo real, mesmo em conexões mais lentas. Hoje já é possível assistir a vídeos no YouTube em alta definição e a Google, que adquiriu o serviço, passa a incorporar o conteúdo em sua mais recente incursão na indústria da TV, a Google TV. 


\section{Google TV}

A Google, em parceria com empresas como Sony, Intel, Logitech, Dish Networks, Adobe e Best Buy, anunciou em 2010 o lançamento da Google TV, um serviço que busca unir a capacidade de busca da Google, o acervo de vídeos do YouTube e de outros provedores de conteúdo com plataformas de hardware que podem ser integradas com aparelhos de TV.

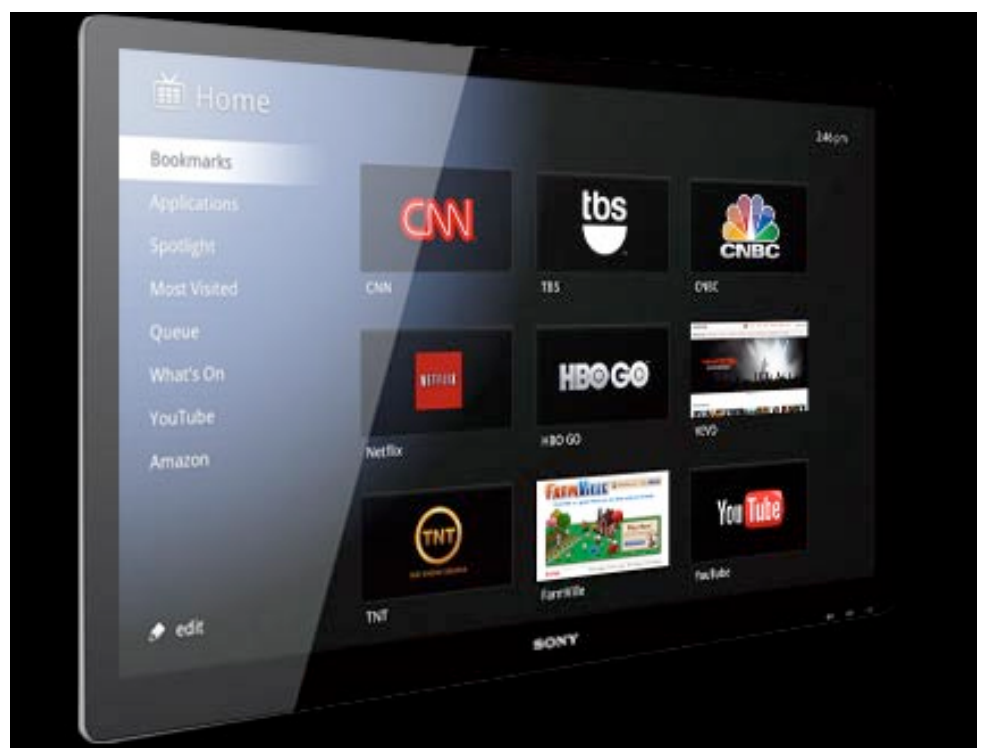

Fig. 3.25: Menu prinicipal da Google TV

Fonte:http://readwriteweb.com.br/

Na edição de 25/05/2010 do newsletter Interactive TV Today, publicado pela Tracy Swedlow da ITVT, saiu uma entrevista com Ellen Dudar da Fourthwall Media, assim como um artigo de sua autoria intitulado "Google TV: Why It Will Fail"75, em que apresenta uma análise bastante negativa da Google TV. Ellen acredita que vários dos motivos que a Google apresenta como responsáveis pelo fracasso da adoção de novas tecnologias como a Microsoft Web TV que pretendem integrar a TV com a internet são na verdade os mesmos motivos pelos quais a Google TV está fadada a fracasssar. Um deles é o fato de que a Google TV é uma plataforma para assinantes de TV Digital que "vive fora do ecossistema do conteúdo e da publicidade na TV e é mais uma peça a ser conectado ao set-top box". Portanto estamos falando da necessidade da compra de equipamento adicional que deve necessariamente rodar Android, neste caso não é tão diferente do iTunes da Apple que Eric Schmidt, CEO da Google, apresenta como uma solução fechada e proprietária e que no entanto não é uma

\footnotetext{
75 http://itvt.com/story/6820/google-launches-google-tv

“GoogleTV:Why It Will Fail”, Ellen Dudar, 25/05/10 Forthwall Media
} 
solução fracassada.

Dudar conclui que quando Silicon Valley fala o mundo escuta antecipando qual será a grande novidade, mas a verdade é que a indústria da TV é enorme e complexa em termos de gastos com publicidade e licenciamento de programas; ao contrário da internet, que gosta de des-intermediação e eficiência, a TV opera de modo oposto e muito mais regulamentado. Não é fácil criar um programa de sucesso na TV e os executivos da TV sabem disso, mas quando ocorre o fascínio ainda é muito maior do que a internet. Google desenvolveu um excelente mecanismo de busca e lida com informação com maestria em diversas áreas com imagens, mapas, vídeos, mas juntar essa capacidade com uma plataforma de hardware e um sistema operacional está longe de ser algo que irá revolucionar a TV (DUDAR, 2010). Concordo com a Ms Dubar que o produto que a Google apresentou tem poucas chances de decolar.

\section{Hulu}

Hulu é um serviço on-line que oferece programas de TV, filmes e vídeos no endereço www.hulu.com e através de outros sites. Por enquanto o serviço só está disponível nos EUA devido a limitações de licenciamento de direitos dos vídeos, mas segundo o site há planos de expandir o serviço para outros países. A empresa, com escritórios em Los Angeles, Nova York, Chicago e Beijing, foi fundada em março de 2007 e é administrada por uma equipe independente. Seus investidores além da própria equipe da Hulu são a NBC Universal, News Corp., The Walt Disney Company, Providence Equity Partners.

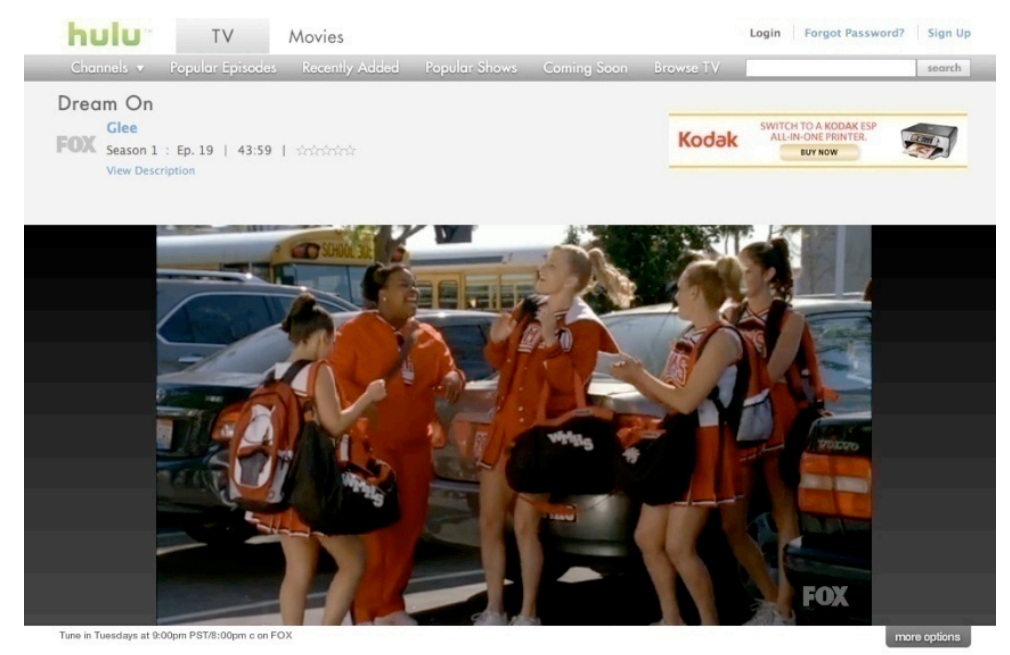

Fig. 3.26: Glee - Série de TV da FOX no site de vídeos Hulu Fonte: www.hulu.com 


\section{Yahoo Connected TV}

A Yahoo tem tido bastante sucesso com sua estratégia de realizar parcerias com fabricantes de aparelhos de TV Digital e desenvolvedores de software no sentido de criar widgets para TVs conectadas ${ }^{76}$. O serviço "Yahoo Connected TV Widgets" foi lançado em 2009, sendo disponibilizado em aparelhos de HDTV com conexão à internet de fabricantes como Sony, Vizio, Samsung e LG, de modo que os widgets estarão presentes nos aparelhos dos principais fabricantes de LCD do mundo. Embora a Yahoo tenha um catálogo de conteúdo bem menor que a Google TV e a Apple e também compita com a Microsoft XBox e Boxee Box, seus aplicativos têm sido bem aceitos pelos consumidores desde o início devido ao fato de funcionarem, estarem integrados em aparelhos de diversos fabricantes e possibilitarem utilizar na TV serviços estabelecidos como Flicker, eBay, twitter e Facebook. Uma outra vantagem é que os widgets da Yahoo são bastante leves e funcionam em aparelhos menos sofisticados do que os necessários para rodar o Google (CATACCHIO, 2010) ${ }^{77}$.

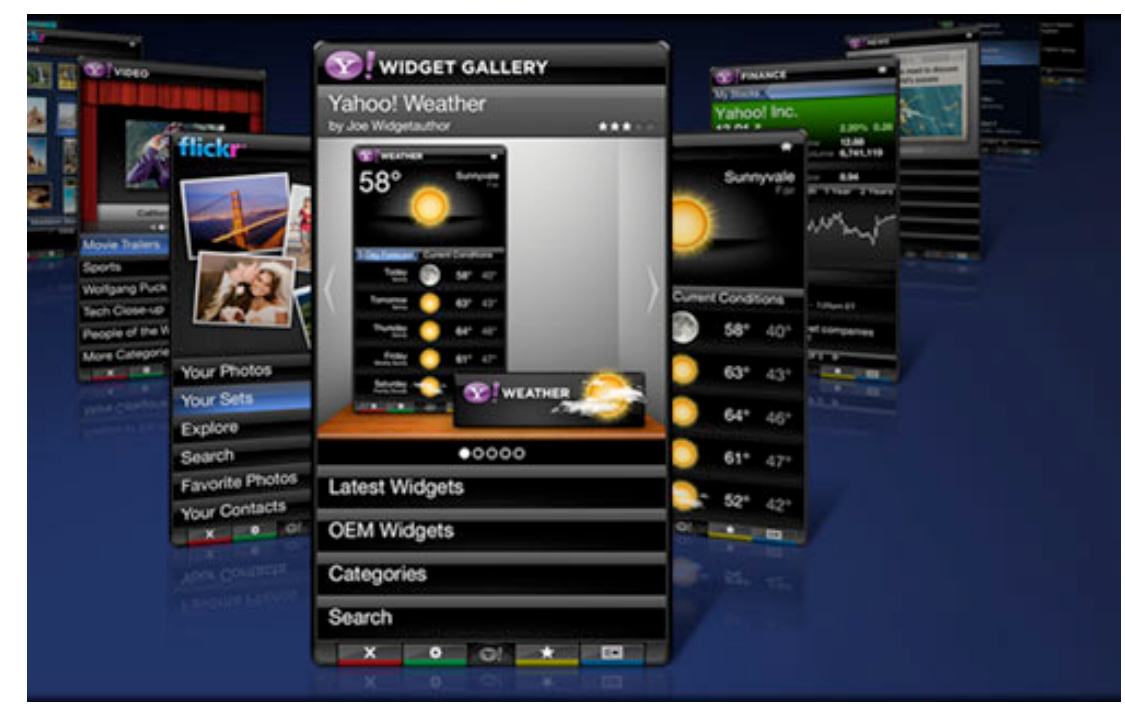

Fig. 3.27: Yahoo Widgets para IETV

Fonte: www.yahoo.com

\footnotetext{
${ }^{76} \mathrm{http}: / /$ comunicadores.info/2009/01/09/connected-tv-yahoo-cria-widgets-para-tv/ http://www.pcworld.com/article/186232/yahoo_connected_tv_moves_beyond_the_tv.html Yahoo Connected TV Moves Beyond the TV By Mark Sullivan, PCWorld Jan 7, 2010 12:22 PM

77 Yahoo Widgets come to more Sony TVs, Internet TV competition getting really interesting. Posted on Jun 16th, 2010 by Chad Catacchio. http://thenextweb.com/socialmedia/2010/06/16/yahoo-widgets-come-to-sony-tvsinternet-tv-competition-getting-really-interesting/
} 


\section{Amazon TV}

A Amazon.com oferece um serviço de distribuição de vídeos sob demanda: a Amazon Video on Demand ${ }^{78}$. O serviço disponível nos EUA possibilita a compra on-line e download dos vídeos diretamente para o computador ou em aparelhos compatíveis fabricados por parceiros como Panasonic, Roku, Samsung, Sony Tivo e Vizio. A proposta de certa forma é similar ao serviço da NetFlix, uma das maiores locadoras de vídeo on-line, e demonstra claramente que a Amazon está posicionando-se para competir neste segmento do mercado audiovisual.

\section{Portais de TV - Streaming Vídeo}

Dentre uma variedade de sites que oferecem streaming de vídeo na internet, um que aparentemente é bastante popular nos EUA é o Channel Chooser, que se posiciona como um portal de TV gratuita na internet. Nele é possível assistir a uma variedade de canais de TV ao vivo na internet. Como os codecs de vídeo podem variar de canal para canal, nem sempre é possível assistir aos vídeos; por exemplo, ao tentar assistir a um dos programas que utilizava o Microsoft Silverlight, fui direcionado ao site da Microsoft que sinalizava estar indisponível instalar o plugin. O site da Microsoft caiu, e consequentemente eu acabei desistindo de assistir o vídeo. Problemas como esse retardaram a utilização de vídeo na internet; ao padronizar a compressão de vídeo em seu servidor, o YouTube encontrou uma forma de garantir a reprodução de vídeo para uma gama de computadores, o que sem dúvida contribuiu para seu sucesso.

Sites como o Gagzgang e o World Wide Internet TV têm uma seleção bem mais globalizada que o Channel Chooser. Esses dois portais direcionados ao público da Índia e do Paquistão têm uma interface bem precária, e além de redirecionar links de streaming video disponilizados por emissoras de televisão oferecem alguns canais caseiros: a retransmissão caseira de canais de TV aberta e a cabo realizada por entusiastas que captam o sinal utilizando uma câmera e fazem seu próprio streaming.

\footnotetext{
${ }^{78} \mathrm{http}: / /$ www .amazon.com/gp/video/ontv/start
} 


\section{Sites de Emissoras (Internet TV)}

As emissoras de TV têm disponibilizado partes de sua progamação em seus websites há alguns anos. Em muitos casos o conteúdo é limitado, servindo como forma de promover as séries de TV e possibilitar rever capítulos anteriores de novelas, como no site da globo.com, mas cada vez mais episódios e séries completas estão sendo oferecidas via web pelas emissoras.

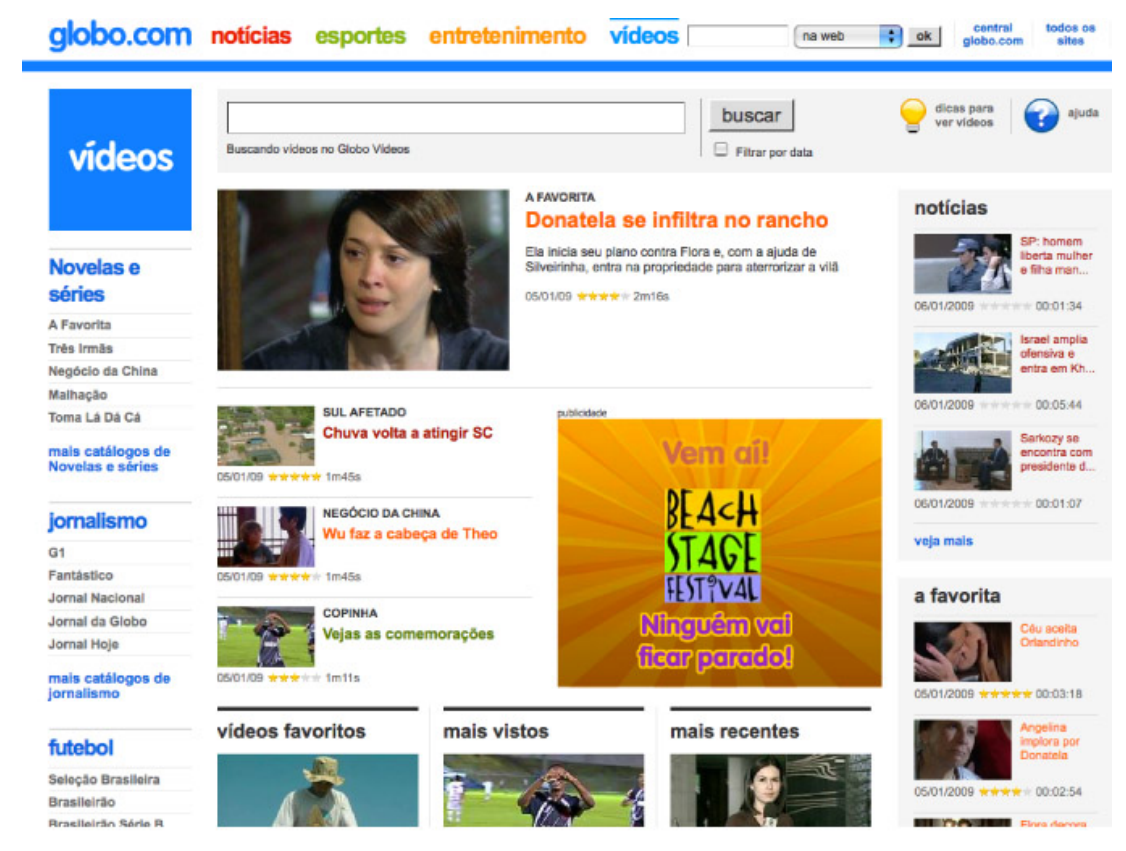

Fig. 3.28: Página de vídeos da globo.com onde é possível assistir aos capítulos anteriores das novelas da Rede Globo

Fonte: www.globo.com

Com a melhoria da qualidade de vídeo na internet, o crescimento do YouTube e novos serviços que facilitam assistir programas de TV na internet, as emissoras passaram a ser cada vez mais restritivas em relação ao conteúdo disponível na internet, restringindo o acesso em outros países ou limitando-o a assinantes de TV paga, como no caso da HBO-GO. A entrada da Google no mercado de TV tem sido considerada uma ameaça pelos executivos de TV, que têm manifestado a preocupação de que a distribuição da TV via internet ameace o modelo de negócios baseado em publicidade. A possibilidade de assisitir aos programas da TV num PC reduzirão a receita da TV com publicidade, fazendo com que as grandes redes de TV norteamericanas, como ABC, CBS, FOX e NBC bloqueiem os usuários do Google TV de assistirem programas disponíveis nos sites da emissora que por enquanto ainda poderão ser 
assistidos em um PC (RABIL; KING, 2010) ${ }^{79}$. Em contrapartida, a Time Warner, que é proprietária do canal por assinatura HBO, e as redes de TV a cabo TNT e TBS têm permitido o acesso a sua programação via Google TV.

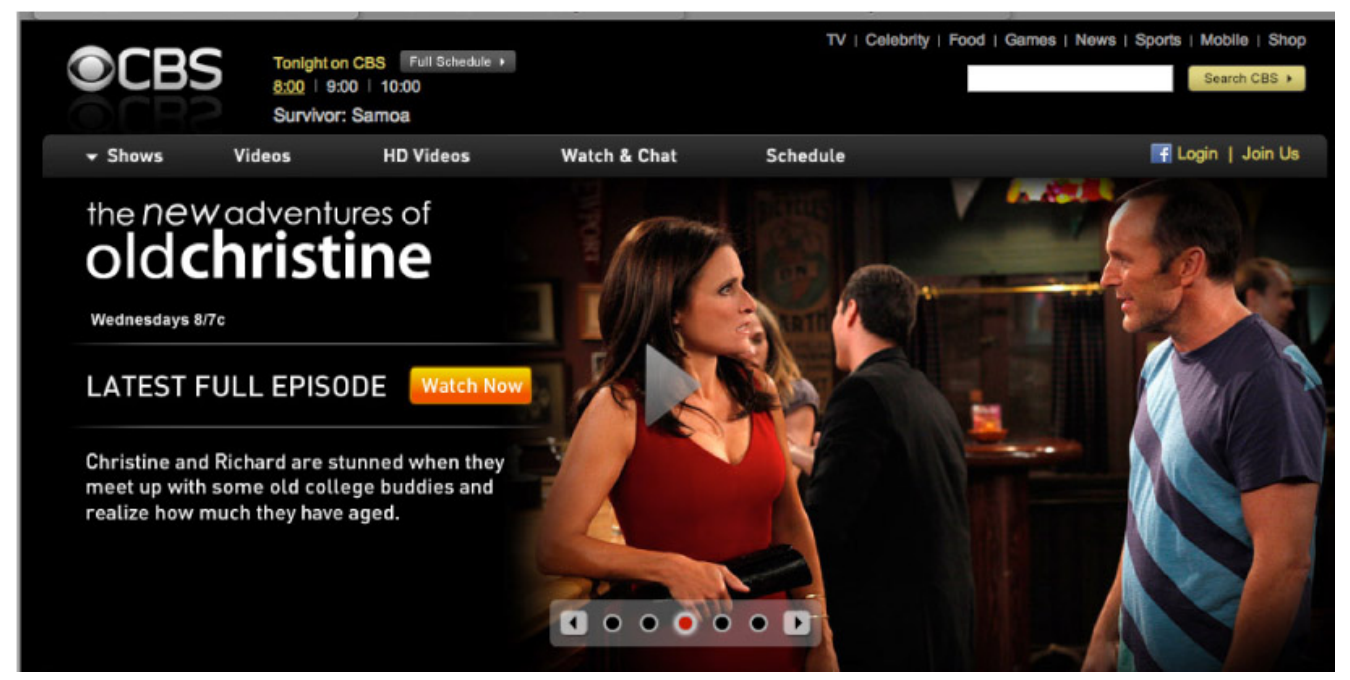

Fig. 3.29: No site da CBS o espaço dos vídeos ocupa boa parte da tela Fonte: www.cbs.com

\subsubsection{Redes Sociais e TV Digital}

\section{Social TV}

A revista Technology Review, do MIT, de maio de 2010, destaca a "Social TV" como uma das 10 principais tecnologias de ponta da atualidade. TV Social é a TV integrada com sites de relacionamento como Facebook e Orkut, Chat e User Generated Content (conteúdo gerado pelo usuário) e não deve ser confundida com TV social ou TV com objetivo de viabilizar e difundir ações sociais (ALBERONE, 2010).

\footnotetext{
${ }^{79}$ Google Bid for TV Dominance Meets Reality as CBS, Fox Bar Shows 2010-12-17 05:00:01.7 GMT By Sarah Rabil and Ian King Bloomberg Newswire
} 


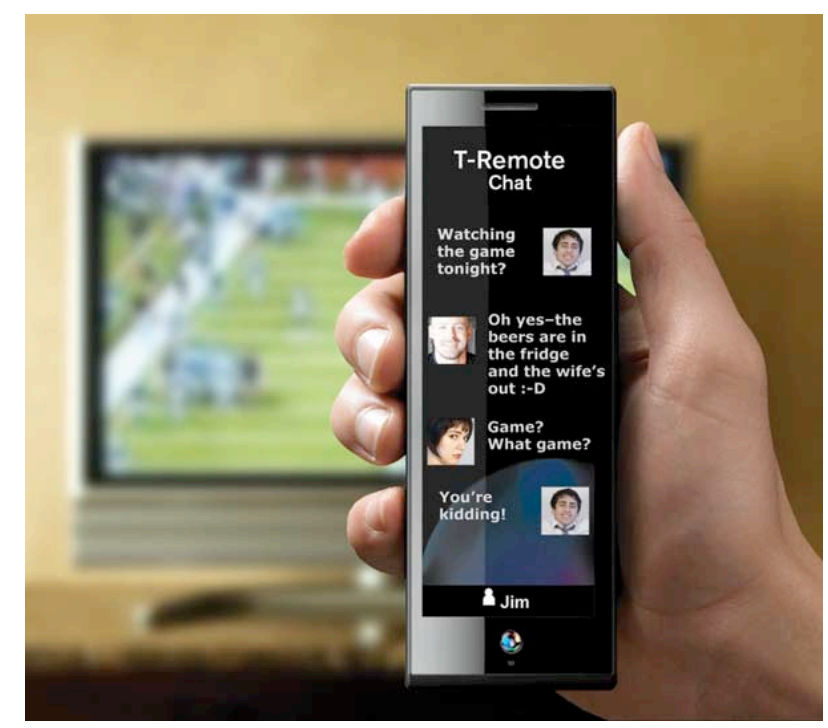

Fig. 3.30: Protótipo de Interação com a Social TV Fonte: www.mit.edu

Marie-José Montpetit, pesquisadora do Research Lab for Electronics do MIT, oferece uma disciplina no MAS, Programa de Mestrado Artes e Ciências do MIT, em que discute "como a tecnologia digital está transformando a forma como a TV se encaixa na sociedade" o foco está nos aspectos do comportamento social dos telespectadores.

Segundo a ementa do curso, "os avanços tecnológicos têm criado uma cisão entre a TV e a sua função como centro social”. A TV foi planejada inicialmente para ser assistida por milhões de pessoas simultaneamente, mas hoje com a internet é possível criar conteúdo para um público cada vez mais segmentado. Entretanto, segundo Petit, as pessoas ainda veem a TV socialmente e há novas formas de realizar os aspectos sociais da TV na internet em sites como o Facebook, que associa pessoas que têm interesses comuns, em oposição a ter que criar uma programação que agrade a vários.

\section{Life Casting}

Recentemente surgiram diversas plataformas de Lifecasting na internet. Entre as mais populares estão Ustream, Justin TV e Livestream, serviços que abrem a possibilidade de qualquer usuário cadastrado montar um canal na internet e transmitir a sua própria programação ao vivo utilizando a webcam de seu computador pessoal. Nos anos 1990,

\footnotetext{
${ }^{80}$ http://courses.media.mit.edu/2010spring/mas960/
} 
surgiram os primeiros canais de TV ao vivo na internet, como o Pseudo.com, que na época era transmitido de um loft do Soho em Nova York. Canais como esse abriram espaço para novas “personalidades" na TV mas em razão das limitações tecnológicas da época mal chegaram ao alcance dos canais de acesso público na TV a cabo. Hoje não só a tecnologia de compressão de vídeo e o acesso à internet banda larga têm viabilizado o streaming de vídeo na internet, qualquer usuário cadastrado pode montar seu programa porque as ferramentas e a infraestrutura são muito mais acessíveis. Por falar em acessibilidade, recentemente eu baixei um app do Justin.tv para o iPhone, o que transforma o celular instantaneamente em uma unidade remota de transmissão de TV.

\subsubsection{Integração com dispositivos móveis}

Como havíamos visto, o padrão SBDTV prevê a recepção da TV em dispositivos móveis como celulares, integrados em GPS, entre outros. No mercado brasileiro, por ocasião da Copa do Mundo de 2010, fabricantes de celulares como a Samsung, LG e Nokia lançaram aparelhos com receptor integrado ${ }^{81}$.
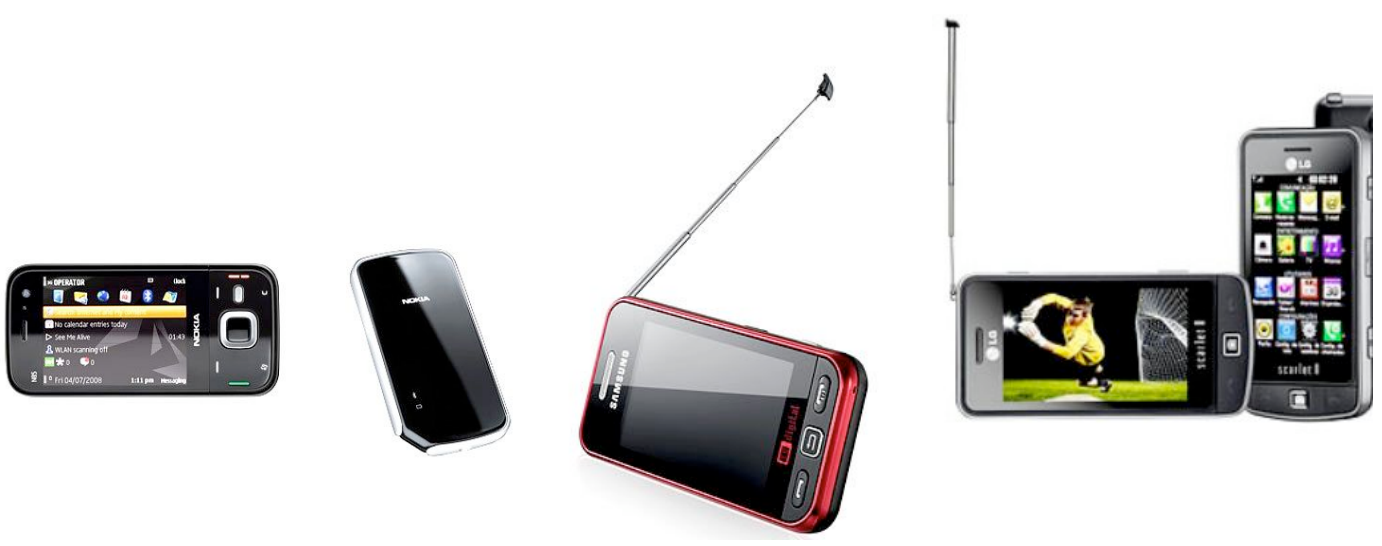

Fig. 3.31: Celulares com TV: Nokia Operator, Samsung Star TV e LG Scarlet II Fonte: http://tecnologia.terra.com.br

\footnotetext{
81 "Veja os celulares com TV Digital já disponíveis no Brasil”. http://tecnologia.terra.com.br/interna/0,,OI4386104-EI4796,00-

Veja+os+celulares+com+TV+digital+ja+disponiveis+no+Brasil.html. Acesso em: 18 de abril de 2010.
} 
Além de permitir a recepção gratuita do sinal da TV Digital, a implementação do middleware Ginga-NCL nesses aparelhos permite ao usuário acessar aplicações interativas terrestres nos aparelhos celulares (CRUZ; MORENO; SOARES, 2008). Uma outra pesquisa desenvolvida no Brasil demonstra que independentemente do conteúdo televisivo é possível utilizar o middleware Ginga- NCL e o Ginga-J para controlar controlar dispositivos domésticos (OLIVEIRA; BARBOSA; SILVA; TAVARES, 2009). O laboratório Telemídia da PUC-Rio está desenvolvendo um aplicativo para iPhone/iPod touch que complementará Ginga em interatividade com televisão digital ${ }^{82}$. Segundo a revista Mac Magazine, que entrevistou o pesquisador Bruno Seabra Nogueira Mendonça Lima, a integração das duas plataformas permite que a interatividade ocorra em diversas telas e não seja necessariamente compartilhada com outros que estejam assistindo juntos à TV na mesma sala.

Com esta tecnologia, o Bruno levanta a possibilidade de termos o seguinte cenário: um jogo de futebol está passando na televisão e um lance polêmico acontece (um pênalti não marcado, por exemplo). Através da edição ao vivo, a emissora pode mandar uma aplicação interativa (tira-teima), mas você não está assistindo sozinho ao jogo, ou somente a você interessa ver o tira-teima. Então, através do iPhone, pode-se ativar a interatividade e a aplicação é disparada somente no aparelho. Desta maneira, a pessoa não atrapalha os outros que estiverem assistindo ao jogo, mas ainda assim tem acesso ao tirateima (quantas vezes quiser).”(FISCHMANN, 2010)

Além de receber o sinal da TV Digital em um celular, dispositivos portáteis como smartphones, iPhones, Ipads e tablets como o Samsung Galaxy ao estarem conectados a redes de telefonia celular de alta velocidade como a 3-G ou a internet via uma conexão Wi-Fi podem ser utilizados para assistir vídeos e filmes disponíveis na internet em serviços como YouTube, Vimeo e Netflix. Se esses dispositivos forem equipados com uma câmera, é possível utilizá-los como uma "unidade remota" de TV através de aplicativos desenvolvidos por serviços como Justin TV e UStream, permitindo a transmissão de vídeos diretamente de

\footnotetext{
82 “Telemídia desenvolve aplicativo para iPhone/iPod touch que complementará Ginga em interatividade com televisão digital”, por Rafael Fischmann http://macmagazine.com.br/2009/04/10/telemidia-desenvolveaplicativo-para-iphoneipod-touch-que-complementara-ginga-em-interatividade-com-televisao-digital/,
}

10/4/2009. Acesso em: 17/12/2010.

http://macmagazine.com.br/2009/04/10/telemidia-desenvolve-aplicativo-para-iphoneipod-touch-quecomplementara-ginga-em-interatividade-com-televisao-digital/ 
um celular para outros usuários dos serviços que podem ser visualizados em aparelhos celulares, em um PC ou em uma TV conectada à internet.

A Yahoo desenvolveu em parceria com a TV Guide um EPG para iPhones e iPads; o guia, que funciona a partir de um aplicativo que pode ser instalado nesses aparelhos, permite consultar a programação dos canais de TV nos EUA.
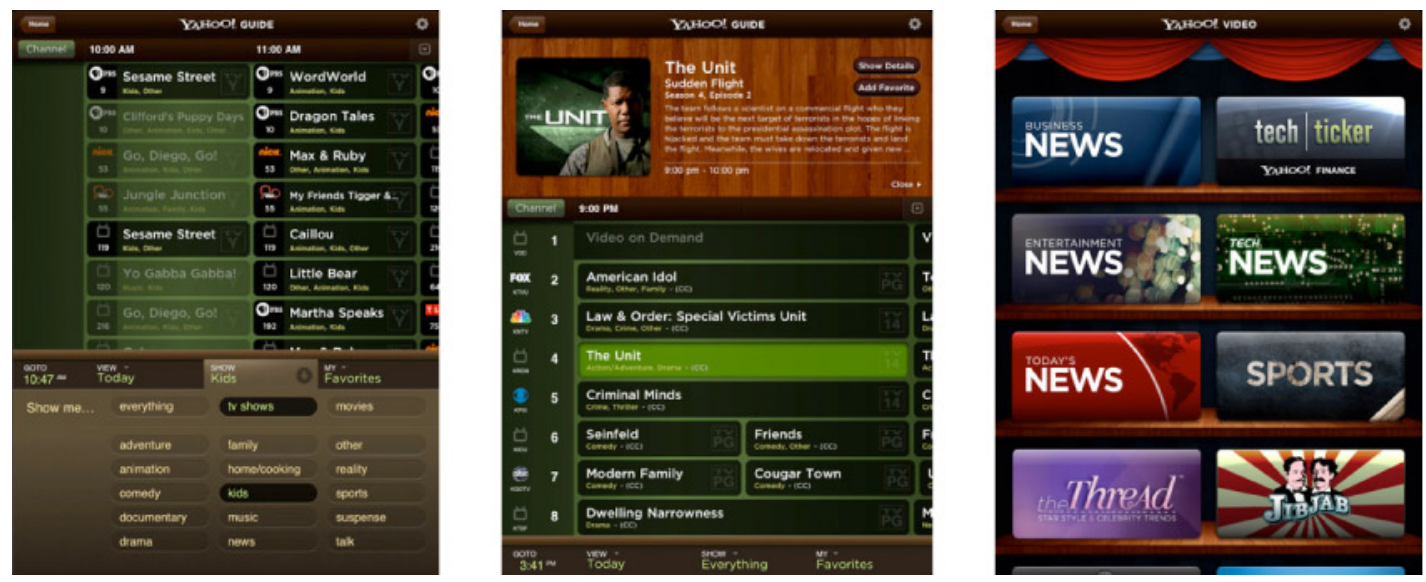

3.32: EPG da Yahoo Entertainment Fonte: www.yahoo.com

No Brasil a empresa de software Fingertips, de São Paulo, oferece gratuitamente no AppStore da Apple um guia de programação que utiliza a mesma base de dados dos guias de programação da TV a cabo. O aplicativo, ao ser instalado no celular, acessa uma página na web que é atualizada com a programação dos canais de TV.
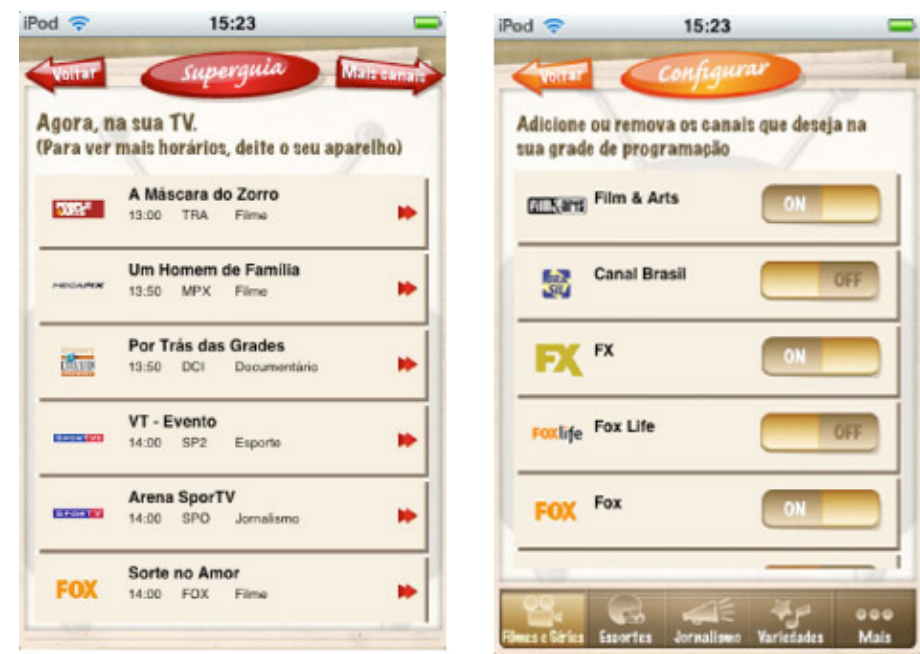

Fig. 3.33: Telas do Superguia Fingertips para o iPhone

Fonte: http://itunes.apple.com/br/app/superguia-tv/id294296789?mt=8. Acesso em: 17/5/2010 


\section{AT\&T - Uverse}

A AT\&T oferece nos EUA o serviço de IPTV Uverse ${ }^{83}$; em agosto de 2010, a empresa lançou um aplicativo móvel que permite aos assinantes de seu serviço gravarem e assistirem programas de TV em um iPhone, estendendo a experiência da TV para um dispositivo móvel. A interface do aplicativo assemelha-se aos EPGs como o da Yahoo e Fingertips, no entanto a integração com o STB e o fluxo permitem que o usuário troque o canal selecionando o programa diretamente na interface do guia ou assista ao vídeo no dispositivo portátil via uma conexão Wi-Fi com o STB.
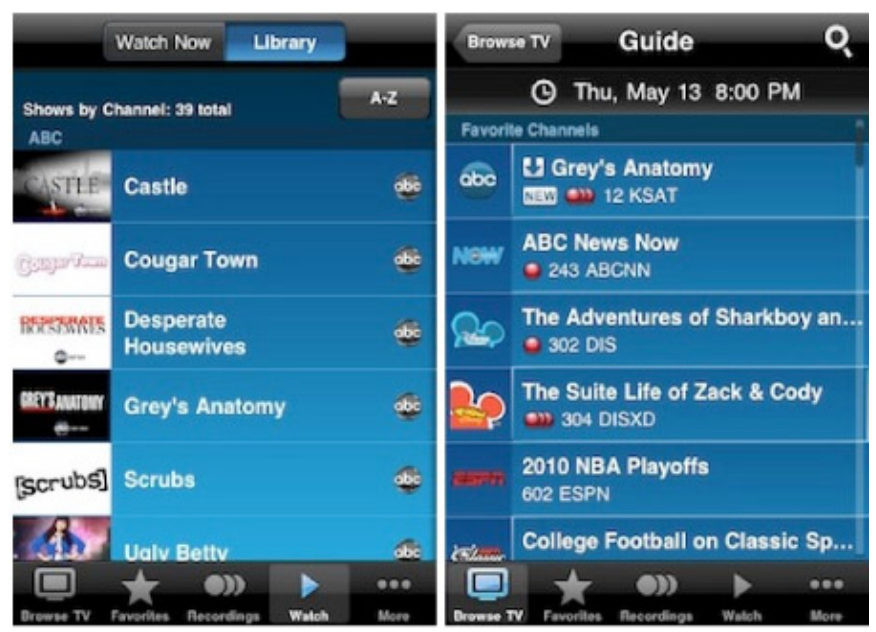

Fig. 3.34: Telas do EPG da Uverse para o iPad

Fonte: www.apple.com

\subsection{Design de Interfaces para TV Digital Interativa}

\subsubsection{Design para TVDI - Disciplinas convergentes}

Assim como ocorreu em outras áreas quando da introdução de novas tecnologias, em um primeiro momento as necessidades estritamente funcionais e da engenharia de um novo invento se sobrepõem às necessidades humanas. No caso da TV Digital, algumas áreas específicas já haviam sido estabelecidas, como o Design Industrial, envolvendo o projeto dos

\footnotetext{
${ }^{83}$ www.att.com/u-verse
} 
aparelhos de TV, dos controles remotos; a seguir, se introduziu o campo do design para a TV, responsável pela identidade das emissoras de TV tanto na tela como na mídia impressa, e mais recentemente o campo de design de interfaces que as emissoras de TV passaram a incorporar em seus departamentos de arte ao projetarem sites. Os estúdios de cinema e produtoras de programas de TV também entram em contato como esse campo do Design ao criar DVDs de seus produtos, os quais necessitam de no mínimo uma interface de navegação.

Percebemos que no momento da introdução da TVDI os produtores de conteúdo já estão em contato com as diversas especialidades que compõem o design para TVDI, especialmente a área de design de DVDs, cujo tipo de interação é muito próxima à do design para TV interativa. O que ocorre no entanto é que essas áreas de design atuam de modo isolado: Design do Produto TV, inclusive a parte de interfaces que são utilizadas pelos serviços de TV a cabo, não tem nenhuma relação com os produtores de conteúdo audiovisual e as emissoras. O Design para a TV, especificamente, já é fragmentado por si só; ainda hoje os designers que atuam na área de "promo", ou chamadas, nem sempre têm contato com os produtores dos programas ou com o departamento de programação das emissoras de TV. E a área de Design de Interfaces, ainda na sua infância, está isolada em departamentos responsáveis pela presença on-line de uma emissora e, no caso de DVDs, é comum serem terceirizados.

O Design para a TVDI apresenta-se como uma oportunidade de se integrarem esses diversos campos do Design. Na BBC, já vemos que existe um esforço neste sentido com o Red Button Initiative, o manual publicado pela $\mathrm{BBC}{ }^{84}$ detalhando as diretrizes de Design para ITV da emissora. Ele começa estabelecendo critérios de design que se referem à identidade da emissora, depois fala sobre especificidades do design para a tela de uma TV e por fim irá tratar do design para interatividade no que se refere à tela e ao controle remoto. Um dos motivos de a BBC estabelecer essa iniciativa é o fato de que muitos programas de TV são feitos por produtoras independentes, e no caso a BBC não só está procupada que esses programas mantenham a identidade visual do canal mas também que garantam a compatibilidade e usabilidade desses programas interativos com os sistemas de TV Digital pelos quais serão distribuídos.

\footnotetext{
${ }^{84}$ BBC Enhanced TV Formats January 2004 (C) British Broadcasting Corporation 2004 Author: Catrin Rees http://www.bbc.co.uk/commissioning/tv/network/pdf/formats_jan_2004.pdf
} 
Nos EUA essa tarefa torna-se ainda mais complexa, pois não há um padrão de design para programas de TV Digital interativa, mas diversas plataformas como a Open TV e Liberate. O desafio torna-se ainda maior aos considerar a questão da distribuição internacional de programas de TV Interativa. Ao contrário da Web, onde se estabeleceu a linguagem HTML como padrão mundial, no caso da TV não há um padrão compatível internacionalmente para a interatividade. Uma das possibilidades é o desenvolvimento de aplicativos em uma plataforma como Flash, que roda no middleware utilizado em vários sistemas de TV Digital ${ }^{85}$.

Os aplicativos interativos da TV Digital são acessados por meio de uma interface gráfica e de um controle remoto. Ao se adicionarem novas funções aos controles remotos, que foram concebidos originalmente com o objetivo de mudar de canal e ajustar o volume, estes tornaram-se dispositivos bastante complexos. A navegação da TV com controle remoto por muitas vezes se torna difícil, pois o usuário não tem uma relação de posição direta com os objetos na tela como é possível na manipulação direta com a qual nos acostumamos ao utilizarmos um mouse. A maioria dos controles remotos atuais permite somente um tipo de navegação bastante limitada, similar à dos menus de DVDs. Neste tipo de navegação o cursor somente transita de um campo para outro, o que acaba definindo um tipo de navegação bastante "hierárquico", limitando as possibilidades de interação.

O que vemos de modo geral é similar ao que o ocorria com os computadores quando as interfaces gráficas ainda estavam na sua infância. Por exemplo o Lynx, um dos primeiros browsers de websites, só permitia a navegação tabulada; com a introdução de browsers gráficos como o Netscape tornou-se muito mais fácil a navegação em websites que ficaram mais ricos em mídia, passando a incorporar imagens, fotos, sons e mais recentemente vídeos, fato que foi determinante para a popularização da web. Os computadores pessoais e games incorporaram diversos avanços nas interfaces gráficas, introduzindo novas formas de navegação, no entanto essas inovações ainda não foram agregadas aos aplicativos de TV expandida encontrados em alguns sistemas de TV Digital.

A literatura específica sobre design para TVDI é bastante limitada; encontram-se apenas algumas dissertações sobre o assunto, a maioria se concentrando no aspecto da usabilidade, como a dos brasileiros Thais Waisman (2006), Gil Barros (2006), Lauro Teixeira

\footnotetext{
${ }^{85}$ Macromedia ${ }^{\circledR}$ Flash for iTV CDK, By Tonya Grochoske, SpinTV, March 2002 http://www.macromedia.com/support/general/ts/documents/feedback.htm acesso em 2004
} 
(2008), Christian Brackman (2010) e do português Valter de Mattos (2005). Chorianopoulos (2006) apresenta uma perspectiva do comportamento do usuário do ponto de vista dos estudos da comunicação. Sobre design de interfaces gráficas, temos a dissertação de mestrado da norte-americana Karyn Lu (2005), da brasileira Andréa Brazil (2007), a dissertação de Rosana Vaz (2008) sobre o design televisual inclui um capítulo sobre design para TVDI. Mais adiante nesta seção irei analisar alguns desses trabalhos. Um autor que não trata especificamente do design para TVDI, e sim de design para a convergência das mídias de modo geral, é Steve Curran (2003), que será analisado a seguir.

\subsubsection{Design de Interfaces Gráficas - GUI}

O desenvolvimento de novos serviços interativos e aplicativos para a TV Digital pressupõe a utilização de interfaces predominantemente gráficas, especialmente interfaces que utilizam textos. A navegação, através de interfaces gráficas na TV, encontra condições diferentes das encontradas em um computador pessoal:

- A TV é assistida a uma distância maior do que um usuário de microcomputador;

- Assistir TV é muitas vezes uma experiência coletiva, enquanto o computador é utilizado primariamente de forma individual;

- A escolha de opções de menu, ou o input (entrada de dados) pelo usuário, é realizada por meio de um controle remoto ou teclado sem fio.

É importante ressaltar que a imagem dos tubos dos televisores analógicos é baixa (525 linhas horizontais), um fator que limita a legibilidade de textos na tela; essa limitação deve ser levada em consideração especialmente ao se desenvolverem aplicativos para TV Digital que utilizam texto extensivamente, pois esses aplicativos serão utilizados no início por pessoas que ainda não possúem um aparelho de TV Digital, mas que irão acessar o serviço digital através de uma caixa conversora acoplada a um monitor de TV analógico. 


\section{Design para a Convergência}

Steve Curran (2003), no seu livro Convergence Design, apresenta alguns dos mais importantes exemplos de design de interfaces e conteúdo para TV interativa, dispositivos móveis e banda larga desenvolvidos até sua publicação. O livro é rico em ilustrações e traz exemplos e depoimentos dos principais estúdios de Design atuantes no campo como: R/Greenberg, H-Design, Agency.com, Artifact, BBC Interactive, The American Film Institute entre outros.

Steve Curran define o design de mídia interativa como uma língua viva, e considera o design das mídias interativas como obras abertas, em estado de constante mudança, mas que ainda estão na sua infância: "Enquanto as tecnologias da interatividade evoluem em uma velocidade estonteante, a gramática desta linguagem visual evolui muito mais lentamente." (CURRAN, 2003).

Um dos projetos mais interessantes publicados no livro é a interface para a plataforma de TVDI da Sony desenvolvida pela H-Design de Dale Herigstad (hoje Schematic). A proposta era desenvolver uma estrutura de navegação em TVDI que funcionasse no ambiente da TV; a solução foi a navegação em camadas tridimensionais.

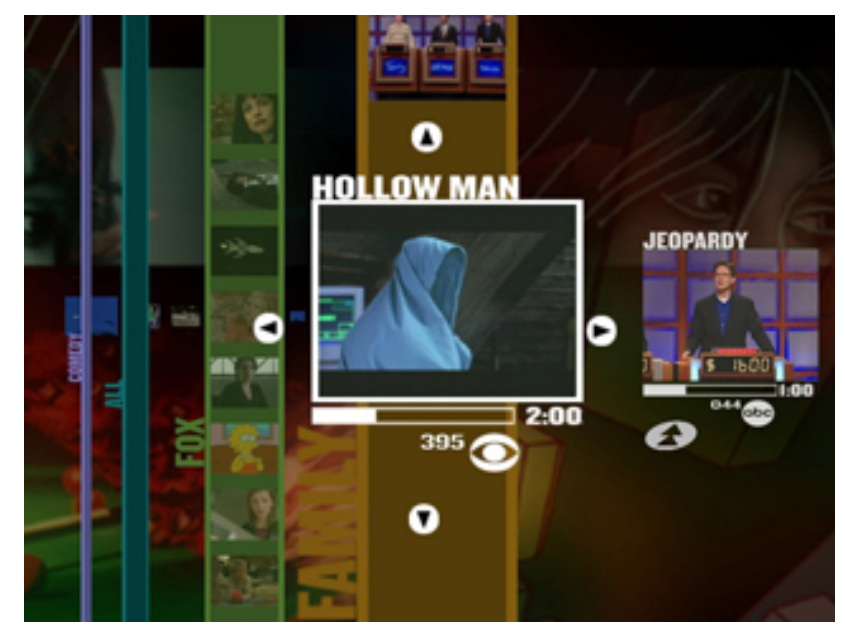

Fig. 3.35: H-Design e Sony Research Labs US Surf-Space Fonte: Convergence Design (CURRAN, 2003)

Outros exemplos interessantes apresentados em Convergence são as interfaces desenvolvidas pela BBC Interactive para o torneio de Tênis de Wimbledon, pelas quais é 
possível obter Stats - informações sobre as partidas, jogadores etc. No livro também encontramos exemplos da BBC, que desenvolveu uma interface para jogos de futebol e de empresas como a Spiderdance e Artifact, que criam interfaces para TV Digital para serem visualizadas em múltiplas telas onde parte da interatividade se desenrola em um computador conectado à internet, solução bastante comum nos EUA em virtude das deficiências da especificação interativa do padrão ATSC.

\section{Dale Herigstad - H-Design}

Em março de 2004, Dale Herigstad, um dos principais designers gráficos atuantes no campo de iTV nos EUA, participou com Josh Bernoff, analista da Forrester Research, de um encontro realizado no MIT em Cambridge, Massachussets ${ }^{86}$. Nesse evento, discutiram como a introdução do gravador digital de vídeo (DVR) está alterando a forma de as pessoas assistirem TV, e como essa nova interface altera a percepção do meio TV e quais os novos modelos de interatividade na TV sendo pesquisados em laboratórios nos EUA.

Dale acredita que a TV é essencialmente uma "coleção de telas ricas em mídia controladas pelo telespectador" e este, quando deparado com uma opção de centenas de canais de TV, precisa de novas ferramentas e interfaces para navegar neste universo. Herigstad apresentou um protótipo para o Sony Surfspace (mencionado anteriormente neste trabalho) e outros projetos aonde busca explorar "subespaços" do conteúdo. Seu trabalho busca manter o aspecto do entretenimento associado à experiência de assistir TV e procura explorar novas possibilidades de linguagem como a dos games. Na interface da versão interativa que desenvolveu para a minissérie Battlestar Galactica (2003), utilizou a plataforma do Microsoft X-Box; nesse programa, o telespectador podia participar da sequência de batalha jogando enquanto os eventos se desenrolavam na TV ao fundo. A performance do jogador relacionava-se com os acontecimentos da história. Ao integrar elementos de games, Herigstad diz buscar criar ambientes imersivos.

\footnotetext{
${ }^{86}$ Dale Herigstad no MIT Communications Fórum - 11/03/2004 - Bartos Theater, MIT Cambridge. Disponível em:<http://web.mit.edu/comm-forum/forums/interactive_television.html>.Acesso em: 20/11/2009
} 


\section{Karyn Y. Lu - Interaction Design Principles for Interactive Television}

Embora se concentrando nos aspectos técnicos do design para TVDI, a dissertação de mestrado apresentada por Karyn Lu no Georgia Institute of Technology em 2005 detalha extensivamente e com bastante precisão o estado da arte das interfaces gráficas para TV Digital nos EUA, mas apresenta poucas soluções inovadoras. Uma observação bastante relevante que $\mathrm{Lu}$ (2005) faz é a de que, embora a TV esteja presente de forma ubíqua nos EUA, os consumidores norte-americanos estão cada vez mais a utilizando simultaneamente com outras mídias como o e-mail, telefones celulares e blogs.

Em sua dissertação, Karyn Lu (2005) cita um estudo do Media Center do American Press Institute (SIMM IV, 2004 apud LU, 2005) que relata que o uso corrente e intenso de mídias simultâneas (multitasking em inglês) está definindo os conteúdos emergentes sendo consumidos pelo que denominam geração “C”. Nesta geração, a TV aparece como uma forma de mídia comumente pareada com outras opções mediáticas, e o estudo em questão apresenta os cinco maiores comportamentos da geração "C" que envolvem o uso simultâneo de diversas mídias:

"Ler email enquanto se assiste TV - praticado regularmente por 73,9\% dos consumidores.

- Ler o jornal enquanto se assiste TV - praticado regularmente por $64,5 \%$ dos consumidores.

- Assistir TV enquanto se lê correspondência - praticado regularmente por $62,9 \%$ dos consumidores.

- Acessar a internet enquanto se assiste TV - praticado regularmente por $62.9 \%$ dos consumidores.

- Ler uma revista enquanto se assiste TV - praticado regularmente por 59.2\% dos consumidores."

Em outro capítulo de sua dissertação, Lu chama atenção para o fato de que na última década os participantes de uma das mais importantes conferências sobre fatores humanos na computação, a SIG CHI (Computer Human Interaction Special Interest Group) ${ }^{87}$, têm demonstrado um crescente interesse no desenvolvimento de interfaces para TV Digital

\footnotetext{
${ }^{87}$ Grupo de interesse especial em interação homem-máquina da Association for Computing Machinery (ACM) nos EUA.A mais importante associação de pesquisadores em computação e cibernética nos EUA.
} 
interativa, fato evidenciado pela quantidade de artigos e palestras apresentadas sobre o assunto nessas conferências, como "When TVs are Computers are TVs" (MOUNTFORD ET AL., 1992, apud LU, 2005), "Interactive Television: A New Challenge for HCI” (TEASLEY; LUND; BENNETT, 1996, apud LU, 2005), "Dual Device User Interface Design: PDAs and Interactive Television” (ROBERTSON ET AL., 1996, apud LU, 2005).

Segundo Lu, na conferência CHI de 1998, Dale Herigstad, diretor de criação da Schematic, Inc, apresentou um workshop intitulado "Designing User Interfaces for Television," em que levantou as seguintes questões relativas ao design de interfaces para TV Interativa:

“. Como os monitores de TV diferem dos monitores de alta resolução utilizados por computadores?

- Quais a cores, fontes e formas que devo utilizar no design para iTV?

- Como controles remotos infra-vermelhos e teclados sem fio diferem dos comandos utilizado em computadores?

- Como projetar para apontar, selecionar, navegar e inserir dados utilizando um controle remoto?

· É possível adaptar um interface de um programa de computador para a TV?

- As capacidades e percepção dos telespectadores diferem da dos usuários de computadores?

- Como testar a usabilidade da interface gráfica de um computador?"

Essas questões, todas relevantes na prática do designer na TV interativa, tem sido confrontado no dia a dia da prática desses profissionais e são consideradas na proposta que apresento mais adiante neste trabalho.

Uma observação importante levantada na tese de Lu é a de que os telespectadores tem se distanciado gradativamente de um modelo "reclinado" ("lean back") de assistir TV para um modelo mais ativo, ou seja, "inclinado para frente" ("lean forward). Em comparação, cita um estudo da Statistical Research, Inc. (2001) intitulado "How People Use Interactive Television", que relata que $72 \%$ dos consumidores norte-americanos estão interessados em interagir com programas de TV. Em outra passagem, diz que Suzanne Stefanac, da RespondTV, acredita que o maior empecilho para o crescimento da iTV nos EUA é um padrão claro e consistente de interação. 


\section{BBC Design Guidelines}

A BBC Interactive, sob a direção de Vibeke Hansen, produziu um manual que define as regras de design de programas de TV interativa para a rede de TV BBC: Designing for interactive television v 1.0 (2005) está disponível no site da BBC e é direcionado aos produtores independentes de conteúdo interativo na TV. O manual estabelece os princípios básicos de design para TV e as normas específicas de design de interfaces para conteúdo interativo na TV Digital.

O documento vem da iniciativa $B B C$ Comissioning, que tem como objetivo padronizar e fomentar a produção de conteúdo independente para a BBC. Esse manual, embora tenha também como objetivo manter a identidade de marca da BBC, é uma referência bastante útil, podendo ser utilizada por designers de ITV em geral. O manual abrange não só a TV interativa mas a produção de quaisquer conteúdos que possam ser distribuídos pelos canais digitais da BBCi.

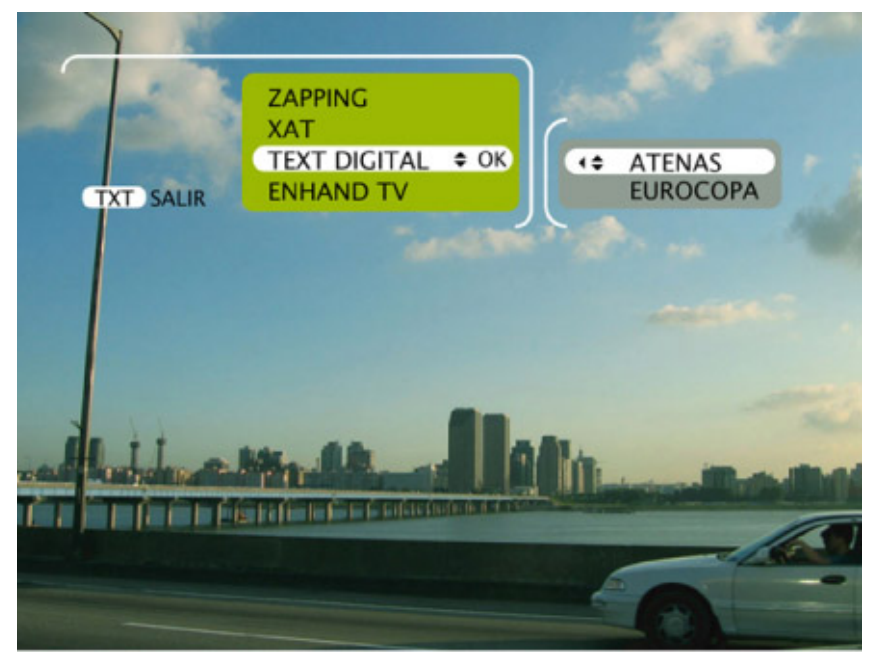

Fig.3.36: Menu de sistema com opções de fonte em um STB da NDS Fonte: www.nds.com

\subsubsection{Novas Direções em Design para TVDI}

A convergência da TV Digital com outras mídias digitais e redes de comunicação tem aberto caminho para novas formas de interatividade que não estão limitadas às restrições impostas pelos padrões de TV Digital. A TV conectada, que será analisada mais adiante neste capítulo, permite realizar na TV formas de interação antes limitada ao computador, como a possibilidade de múltiplas janelas sobrepostas que podem ser rearranjadas pelo usuário. 
Plataformas de distribuição digital para IETV, Internet Enabled TV (TV com conectividade à internet), como o YahooTV e Google TV têm realizado alianças com fabricantes de aparelhos de TV e tem utilizado "Widgets", pequenos aplicativos que podem ser acessados na TV. A Apple TV e Boxee, entre outros, têm desenvolvido equipamentos que conectados a uma TV permitem assistir vídeos, filmes e programas de TV disponíveis via internet, sob demanda, que podem ser vistos quando o espectador quiser.

Em todos os casos, embora haja uma liberdade maior no design das interfaces para estas plataformas que são mais próximas de computadores, existe a prioridade do vídeo que traz questões como a obstrução da tela por itens de menu, que interfere na experiência do telespectador ao assistir um programa, e a distância deste da tela, o que determina a necessidade de que os elementos da interface sejam legíveis a distância e o controle destes seja realizado por um controle remoto ou outro método de comando da interface a distância.

Tendo em vista a convergência das mídias digitais e sem se concentrar especificamente na tela da TV como suporte, e sim pelo contrário, ao considerar a utilização de múltiplas telas e dispositivos, destaco duas pesquisas na área, uma desenvolvida em universidades na Inglaterra e outra na divisão de Pesquisa de Desenvolvimento da Adobe, empresa de software norte-americana. Exemplos de Widgets utilizados comercialmente também são apresentados.

\section{Dual Screen Interface - Proposta de Interfaces de TVDI em Duas Telas}

No estudo Making Interactive TV Easier To Use: Interface Design for a Second Screen Approach (2007), realizado conjuntamente por Leon Cruickshank, Emmanuel Sekleves e Roger Whitham da Brunel University em Uxbridge e Annet Tehill e Kaoruko Kondo da Westminster University, em Harrow, ambas instituições do Reino Unido, os pesquisadores desenvolveram um modelo de navegação da TV interativa em que utilizam duas telas. Essa proposta veio como resposta aos resultados de pesquisas que apontam haver pouco interesse nos aspectos interativos da televisão digital na Inglaterra, sendo que nesse país a interatividade na TV já está disponível em um grande número de serviços e em 2012 se encerra o processo de digitalização da TV. 


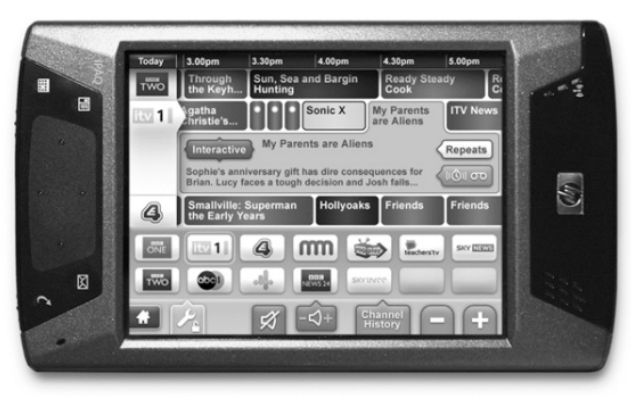

Fig. 3.37: Exemplo da interface de um EPG em um PDA

Fonte: Cruickshank; Sekleves; Roger Whitham, 2007

Nessa pesquisa, foram testados dois protótipos, o primeiro utilizando um laptop e o outro um palmtop; o objetivo era proporcionar uma forma de interação mais adequada do que aquela fornecida pelo controle remoto. Após realizarem os testes, os autores concluem que os sujeitos analisados preferem esse tipo de interatividade com a TV do que aquela proporcionada pelo controle remoto. No entanto, o laptop e o palmtop (PDA) ainda não seriam a solução ideal, não só devido a algumas limitações da interface e dificuldades encontradas no uso da tela touch-screen do PDA, mas também pela percepção de que esse tipo de dispositivo teria um custo alto; sugerem, assim, desenvolver futuramente o protótipo utilizando um celular.

\section{Adobe Nitro TV}

Nitro TV é um projeto Beta da Adobe integrando widgets na TV Digital. No site www.adobe.com/inspire, há um vídeo intitulado "Experiences that scale across devices" onde Matt Snow e Ali Ivmark, gerentes de Design da Experiência no escritório Adobe Systems em San Francisco, falam como aplicativos pode ser "scaled" em diversos dispositivos, computador desktop, laptops e TVs. Eles referem-se à plataforma Nitro da Adobe, que tem como objetivo desenhar, desenvolver e distribuir aplicativos em Flash para múltiplas telas. $\mathrm{O}$ widget é um aplicativo leve com uma única função escrito em Flash e pode ser compartilhado e utilizado em diversas plataformas com a web, em um celular e na TV. Segundo Matt Snow, há diversas maneiras de conectar-se e receber conteúdo, e cita o

\footnotetext{
${ }^{88}$ In Inspire A publication from the Adobe Experience Design Team https://xd.adobe.com/\#/videos/video/144
} 
exemplo da Sony, que distribuiu o filme Hanckok para TVs conectadas à internet antes de lançar a versão em Blu Ray. Ainda conforme o autor, "os dispositivos não estão convergindo", por isso a tendência dos consumidores de mídia de utilizarem diversos dispositivos para se conectarem, já que "as pessoas querem ir de uma tela para outra". Segundo Ivy, o espaço dos widgets é extremamente fragmentado e $80 \%$ dos widgets para a web são criados em flash e podem ser viralmente distribuídos e compartilhados.

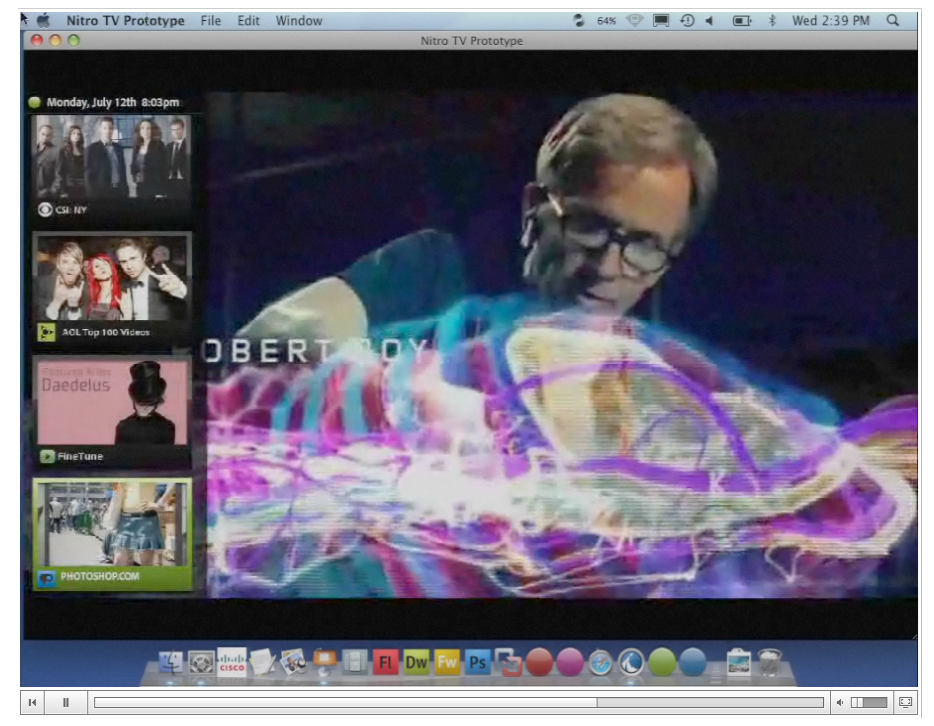

Fig. 3.38: Widgets Adobe Nitro Fonte: www adobe.com

Acima vemos diversos widgets minimizados, em um deles pode-se pesquisar a programação do canal CBS, em outro assistir a vídeos postados na AOL, escutar músicas ou utilizar uma versão para web do programa Adobe Photoshop. Na próxima tela, podemos ver o widget da AOL expandido, no exemplo é possível pesquisar os 100 vídeos mais vistos no AOL enquanto se assiste a um filme na CBS. 


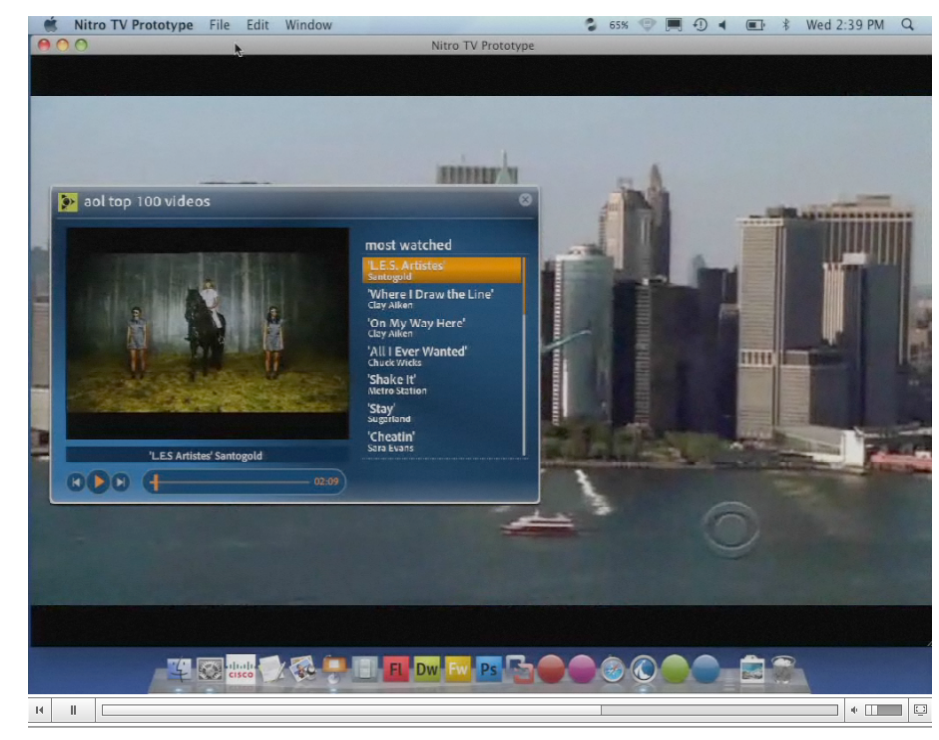

Fig. 3.39: Widget da AOL - Adobe Nitro Fonte: www.adobe.com

\section{Widgets para TV Conectada}

Fabricantes da indústria eletrônica como a Samsung, Sony e LG estão oferecendo widgets nos novos aparelhos de TV conectados, e realizando parcerias com empresas de internet, canais de TV, provedores de conteúdo para desenvolverem widgets para seus aparelhos. No site Digitaltrends.com, um artigo apresenta o exemplo do widget do Weather Channel, que permite acessar a previsão do tempo, e da CNBC, que possibilita interagir com as cotações e os gráficos da bolsa de valores. É uma forma de interatividade com programas de TV que não depende de um sistema de TV Digital, facilitando assim o acesso à informação diretamente da internet, exibindo-a na TV com a ajuda do chipset e do software do próprio aparelho de $\mathrm{TV}^{89}$.

A Yahoo oferece um kit de desenvolvimento para o Yahoo! Widget Engine Platform no site http://connectedtv.yahoo.com/developer/, para o desenvolvimento de widgets para utilização em aparelhos de parceiros como a Samsung, Sony, LG, Vizio e Toshiba. No site da Yahoo há exemplos de widgets para serviços e sites como Flickr, Facebook, eBay, Twitter entre outros que podem ser utilizados enquanto se assiste TV.

\footnotetext{
89 "Do integrated television widgets create a new revenue channel for manufacturers" ,Digital Trends, Da redação, 02/03/2010. Disponível em: <http://www.digitaltrends.com/home-theater/are-tv-widgets-a-newrevenue-channel $>$.
} 

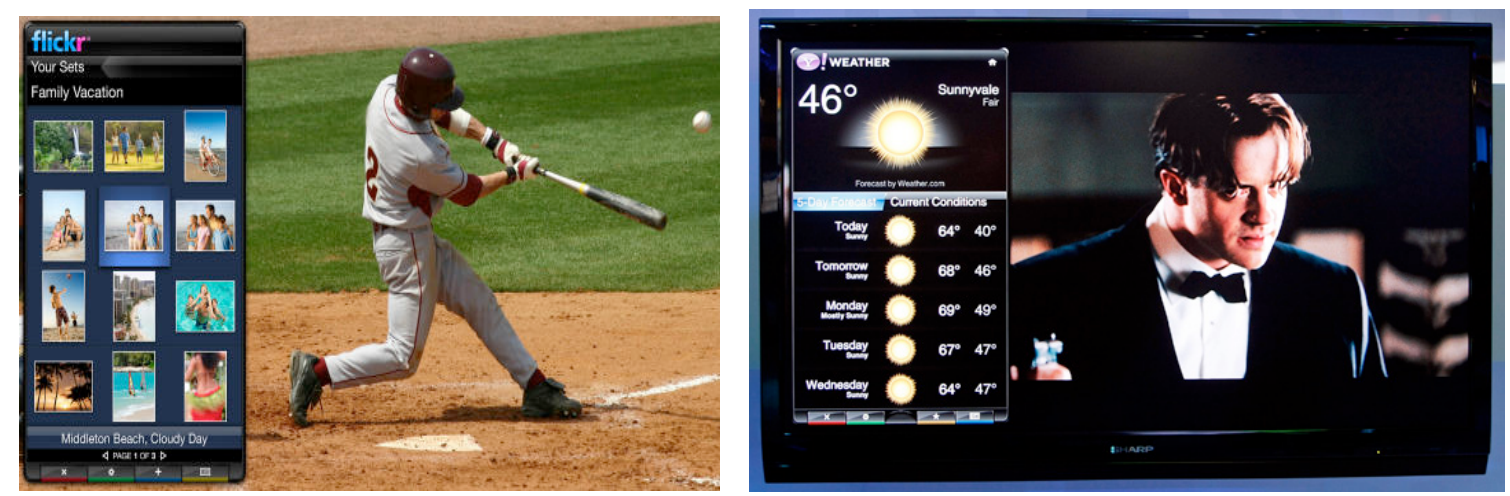

Fig. 3.40: Yahoo Widgets para o Flickr e Previsão do tempo

Fonte: www.yahoo.com

\subsubsection{Controles Remotos}

O design de interfaces gráficas para TV Digital tem até recentemente se baseado na utilização de um controle remoto como forma de comando do usuário, permitindo navegar as telas da interface e realizar a seleção de itens de menu. Um dos primeiros controles remotos para a TV foi introduzido pela Zenith em 1956, o Zenith Space Command, inventado por Robert Adler (FARHI, 2007).

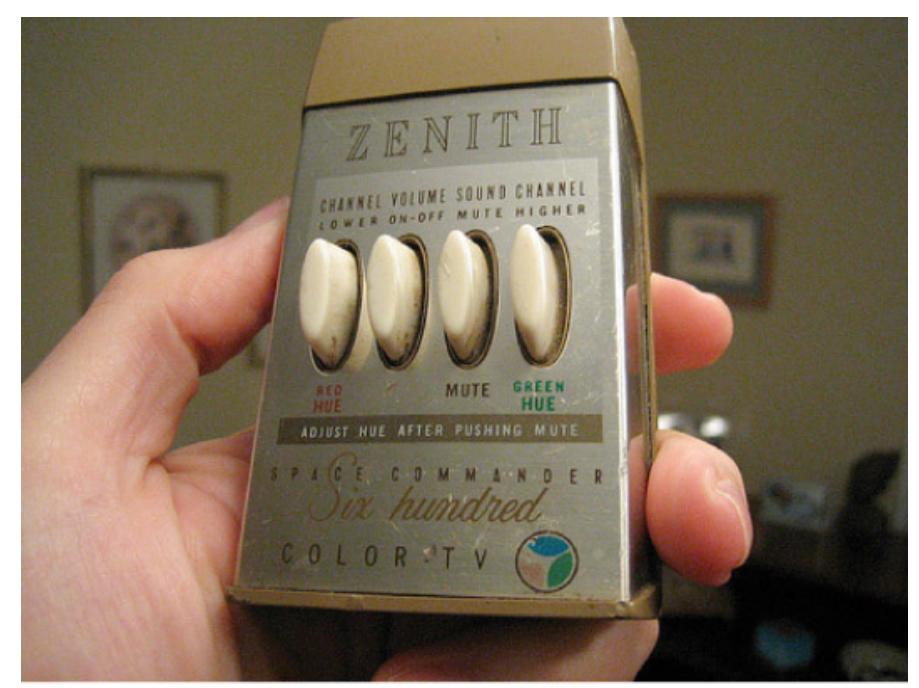

Fig. 3.41: Controle Remoto - Zenith Space Commander Fonte: Wikipedia

O controle remoto inicialmente tinha basicamente duas funções: mudar de canal e ajustar o 
volume, mas com o passar dos anos veio incorporar diversas funcionalidades que o tornaram cada vez mais complexo. Com a introdução de novos aparelhos conectados à TV, como videogames, caixas conversoras de TV a cabo, DVDs etc., o telespectador confronta-se com a necessidade de utilizar diversos controles para assistir TV, o que o leva à frustração diante da inconsistência e complexidade de interoperabilidade dos dispositivos (NORMAN, 2001). Com o intuito de resolver essa questão, diversos fabricantes têm desenvolvido "controles universais" que podem ser programados para controlar diversos aparelhos.
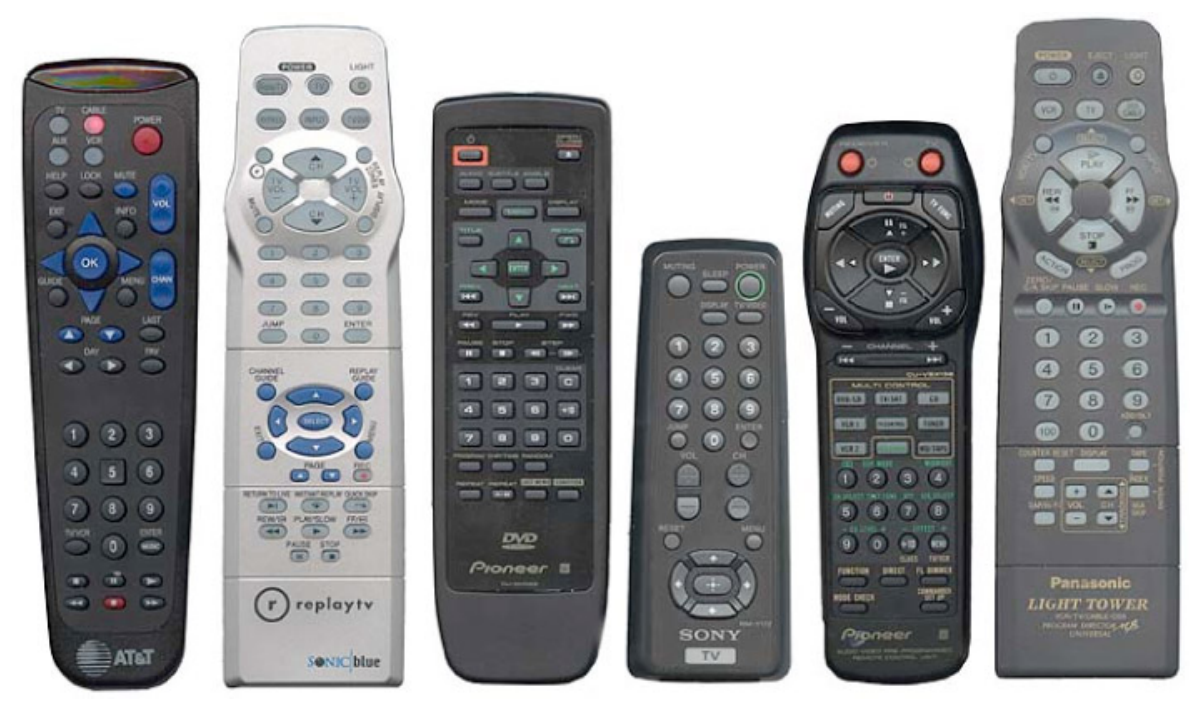

Fig. 3.42: Os seis controles remotos necessários para operar o Home Theater de Norman Fonte www.useit.com

A maioria dos controles remotos utiliza um diodo infravermelho para transmissão dos sinais, o que requer que o aparelho a ser controlado esteja no campo de visão do controle. Novos dispositivos como o controle remoto da Apple utilizam uma rede de Wi-Fi para a transmissão de sinais do controle, de modo que se pode controlar um dispositivo sem que este esteja no campo de visão do controle. Empresas de automação residencial têm desenvolvido controles remotos que permitem controlar diversos aparelhos em uma casa de outra localização. Fabricantes de videogames como a Nintendo e a Sony têm introduzido controles que respondem ao movimento do usuário como o Wii-Mote e sensores que percebem gestos.

Nos últimos anos, smartphones e outros dispositivos móveis podem utilizar software que 
permite carregar códigos de controles remotos que lhes permitem controlar aparelhos de TV, DVDs, media centers de PCs, home theaters e outros. Esta funcionalidade se dá através de menus e o teclado do telefone celular ou uma interface touch-screen desses dispositivos. A seguir são apresentados exemplos destes novos controles.

\subsubsection{Controles Infravermelho em celulares}

\section{Celulares Symbian - Novii}

NoviiRemote é um software que permite controlar aparelhos como TV, DVD, conversor de TV a cabo de um smartphone que utiliza o sistema operacional Symbian. O programa funciona enviando sinais infravermelhos salvos em arquivos denominados codebases que têm a informação de cada aparelho a ser controlado. NoviiRemote não é um programa que aprende os códigos de cada aparelho, portanto é necessário que o usuário carregue o código específico de cada aparelho (www.novii.tv,2009). Como existem diversos celulares que utilizam o sistema operacional symbian que possuem um emissor de sinais infravermelhos, é possível instalar o programa e utilizá-lo como controle remoto.

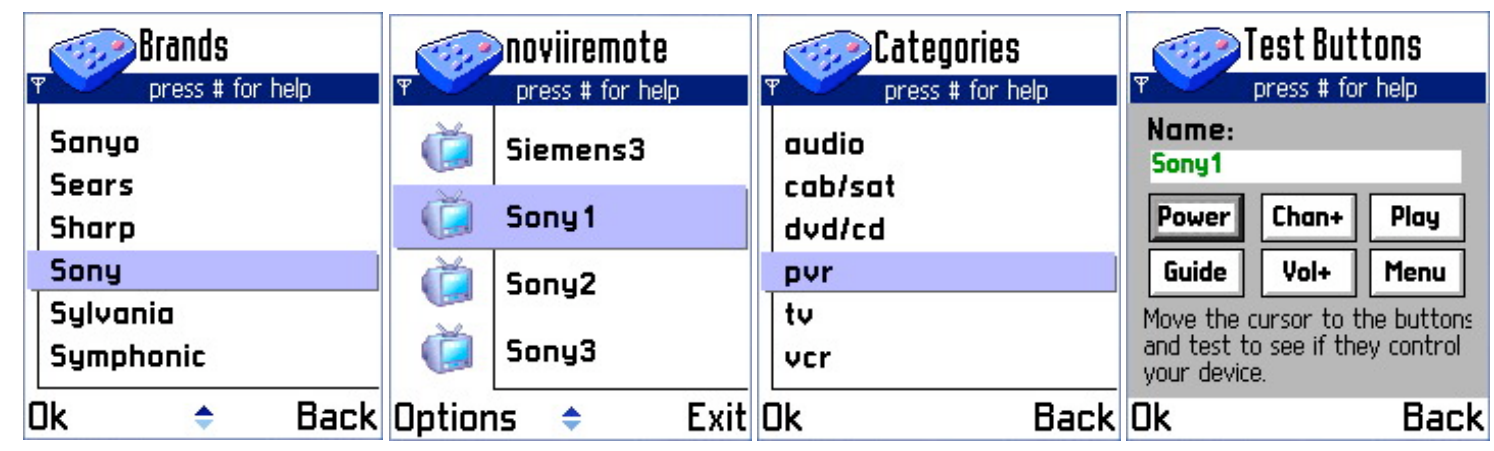

Fig. 3.43: Menus do software de controle remoto NoviiRemote para celulares Symbian Fonte: www.novii.tv

A desvantagem é que esses celulares dependem da navegação através de teclas do cursor para acessar os diversos itens de menus. Celulares Android e iPhones lançados recentemente com tela touch-screen podem emular as teclas de um controle remoto permitindo que o usuário tecle diretamente nos botões; no entanto, esses celulares não possuem um emissor de infravermelho, portanto não podem controlar a maioria dos aparelhos de TV, a não ser que sejam equipados com um acessório para tal fim. 


\section{Android Remote}

Assim como o iPhone, os celulares com o sistema operacional Android atualmente disponíveis no mercado não possuem um emissor de sinais infravermelho, de modo que não é possível utilizá-los como um controle remoto universal para mudar os canais de uma TV. Existem diversos aplicativos para o Android que permitem utilizá-lo como um controle remoto de dispositivos como o home theater em um PC, TIVO, Boxxee e outros como o STB da operadora de TV a cabo Norte American Verizon, que lançou um controle remoto Wi-Fi para a plataforma Android, disponível para os assinantes do FIOS $^{90}$ em seu serviço de TV por assinatura em banda IPTV.

Aplicativos para smartphones como o Android podem se transformar em excelentes controles remotos universais, mas para isso é necessário que os fabricantes dos aparelhos coloquem transmissores de sinais infravermelhos nos celulares ou que os fabricantes de settop boxes sigam o exemplo da TIVO e da Verizon equipando as caixas com conectividade Wi-Fi (BUSKIRK, 2010).

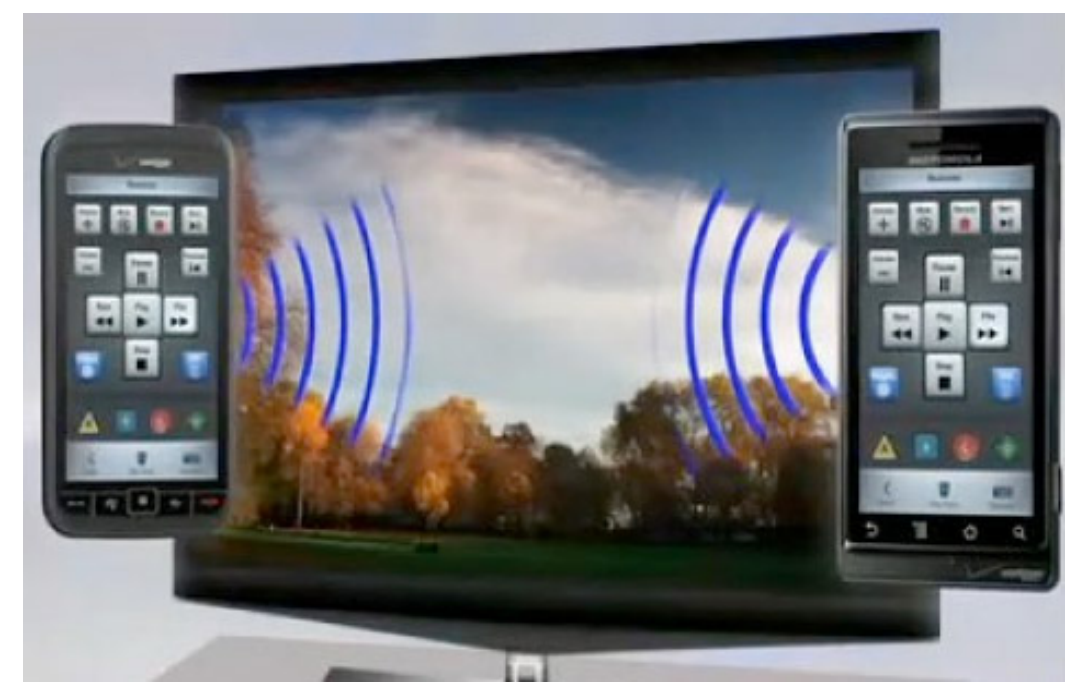

Fig. 3.44: Controle Remoto Fios para celulares Android Symbian Fonte: www.wired.com

${ }^{90} \mathrm{http}: / /$ www.wired.com/epicenter/2010/02/verizon-fios-adds-remote-control-by-android-phones-iphone-ownersjealous/\#ixzz149Rw82ZJ 


\section{Apps para iPhone e IPod Touch}

\section{Controle Remoto Infravermelho para iPhones}

Iphones e consequentemente o iPod touch e iPad podem ser utilizados como um controle remoto universal desde que sejam equipados com um acessório infravermelho e um aplicativo que permita essa funcionalidade. Diversos desenvolvedores oferecem tais produtos, veremos exemplos de alguns produtos disponíveis no mercado no momento.

\section{Re Remote}

O Re Remote é um controle remoto universal para iPhone and iPod Touch, ele funciona utilizando um transmissor infravermelho que pode ser acoplado ao i-phone ou i-pod; o app disponível via i-tunes inclui uma série de códigos para a maioria dos equipamentos audiovisuais no mercado.
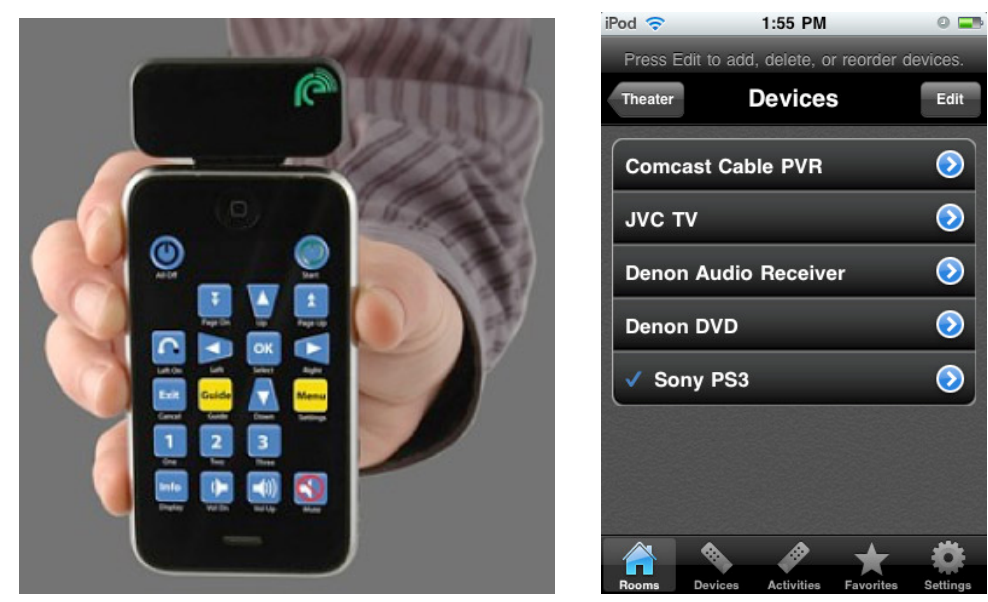

Fig. 3.45: Controle Remoto Re para iPhone e iPod Touch Fonte: www.newkinetix.com

\section{L5}

A L5, empresa de Fort Lauderdale, Florida, desenvolveu um acessório infravermelho e um aplicativo para iPhones que permitem programar os códigos de diversos controles remotos disponíveis no mercado do controle que se pretende substituir "ensinando" o iPhone através do envio de código diretamente do controle para o iPhone. O acessório começou a ser vendido em maio de 2010 por \$US50. 


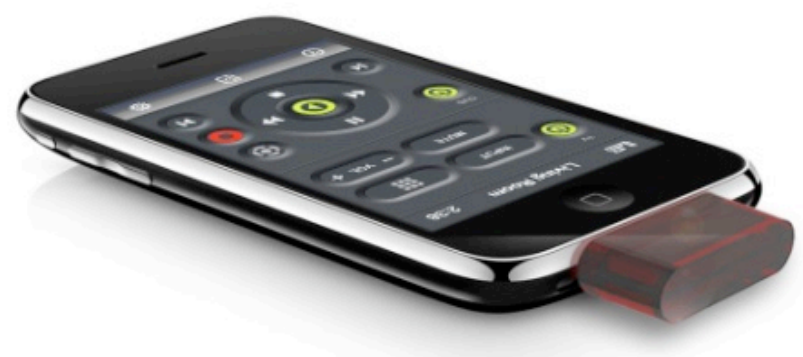

Fig. 3.46: iPhone com acessório L5 Remote.

fFnte: www.L5Technology.com.

\subsubsection{Controles Remotos Wi-Fi}

\section{Apple Remote}

Apple Remote é um app para o iPhone e iPod Touch que controla a biblioteca do iTunes via Wi-Fi. Além de funcionar de modo similar ao controle que acompanha os computadores da Apple com uma interface bastante reduzida navegar em quatro eixos e selecionar itens, o controle também reproduz parte da interface do iTunes para o iPhone, onde é possível visualizar e selecionar itens da biblioteca como músicas e vídeo diretamente na tela do aparelho portátil. Em novembro de 2010, a Apple lançou uma nova versão do seu controle remoto, compatível também com o iPad e com inovações na interface que incluem controles por gestos.
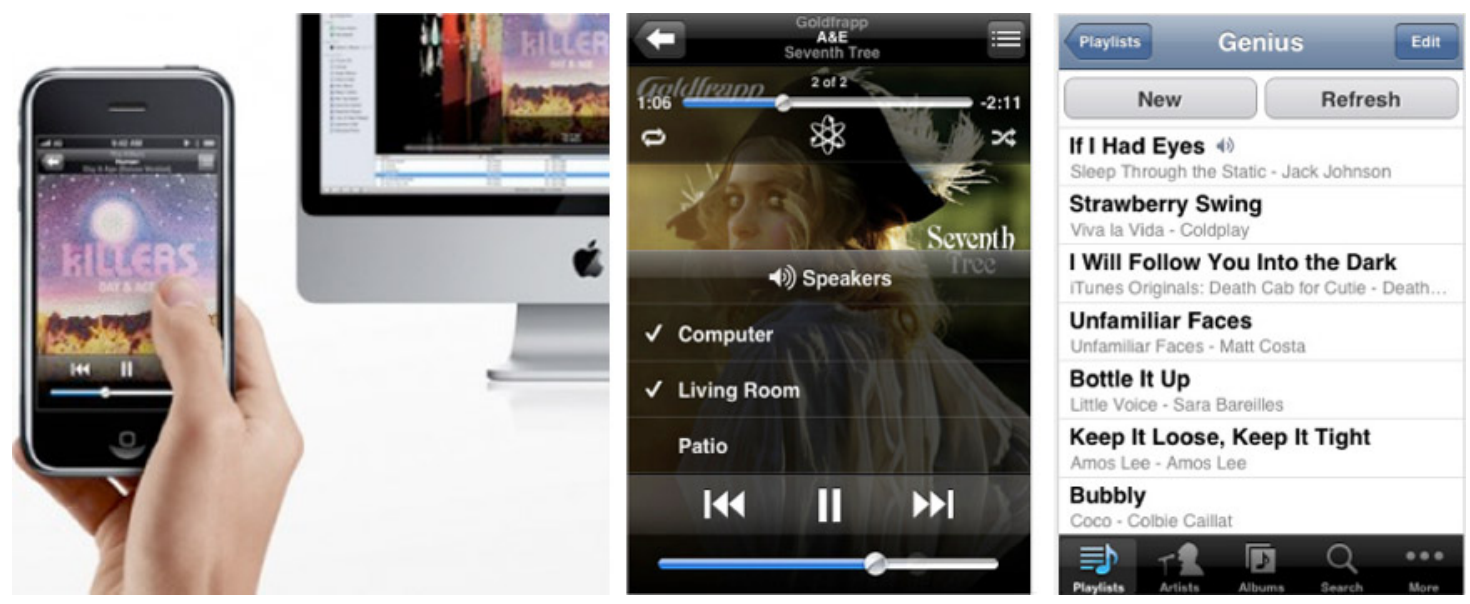

Fig. 3.47: Controlador do player no Iphone. Fonte: www.apple.com

\section{RedEye}

O sistema de controle remoto RedEye system (http://redeyeremote.com/) transforma o 
iPhone e o iPod em um controle remoto que permite controlar diversos aparelhos eletrônicos. O sistema RedEye utiliza um software gratuito que instalado no iPhone se comunica com um dispositivo RedEye através de uma rede sem fio doméstica; esse dispositivo, por sua vez, controla os aparelhos enviando sinais infravermelhos diretamente. Foi desenvolvido pela empresa norte-americana ThinkFlood, Inc. (http://thinkflood.com). O RedEye mini permite controlar a TV diretamente do controle remoto através de um acessório infravermelho conectado ao plug de áudio do iPhone ou iPod.
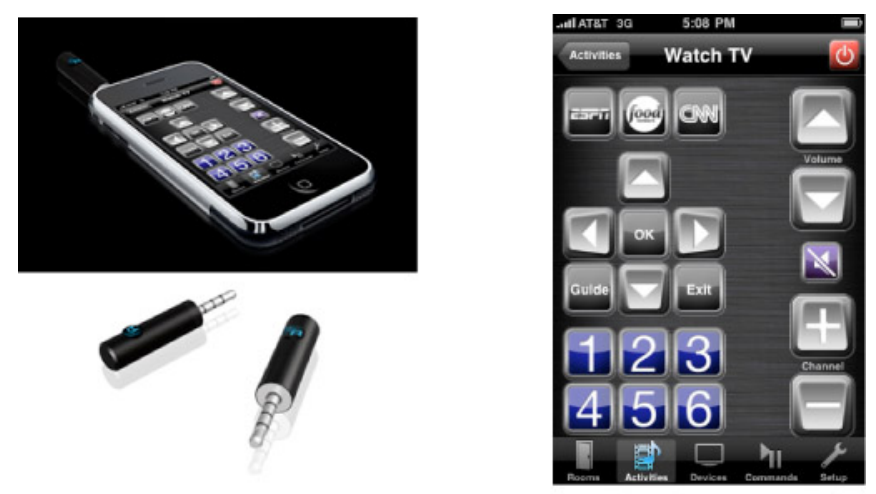

Fig. 3.48: Iphone com acessório RedEye, emulando controle remoto em tela touch screen. Fonte: www.thinkflood.com

\section{Verizon FIOS iPhone}

A Verizon, que originalmente ofereceu um aplicativo que possibilitava aos assinantes de seu serviço de IPTV Fios TV transformar um celular Android em um controle remoto, expandiu o produto para a plataforma Apple. O aplicativo permite controlar o DVR do STB do serviço e irá possibilitar o streaming de vídeo diretamente para a tela do iPad, funcionalidade que deverá ser expandida para tablets de outros fabricantes como o Samsung Galaxy ${ }^{91}$.

\footnotetext{
${ }^{91}$ Verizon's FiOS Remote app expands to iPhone. Disponível em: http://www.electronista.com/articles/10/10/19/verizon.fios.remote.hits.ios.and due.for.tablets/ acesso em 10/02/2011
} 

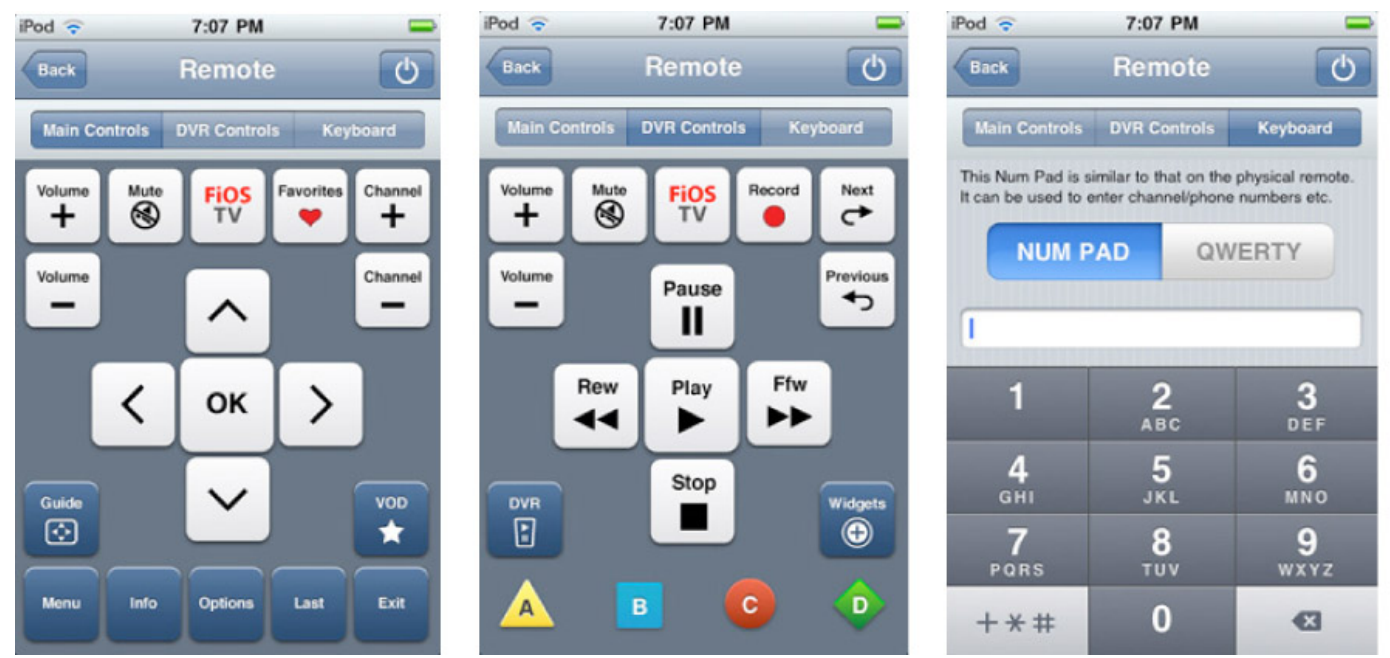

Fig. 3.49: Menus emulando controle remoto do STB da Verizon Fios em um iPhone Fonte: www.apple.com

\section{Sling Player}

O Sling Player é um aplicativo para o iPhone que permite utilizá-lo para controlar um set-top box de TV a cabo ou um aparelho de TV. Isso é possível através do Slingbox: um aparelho que recebe os comandos do iPhone via uma conexão Wi-Fi e os converte para sinais infravermelhos compatíveis com o aparelho de TV, PVR ou STB a serem controlados. A memória do Sling Player leva alguns segundos para fazer a conversão dos sinais, o que torna esta solução seja um pouco lenta92 (BUSKIRK, 2009).
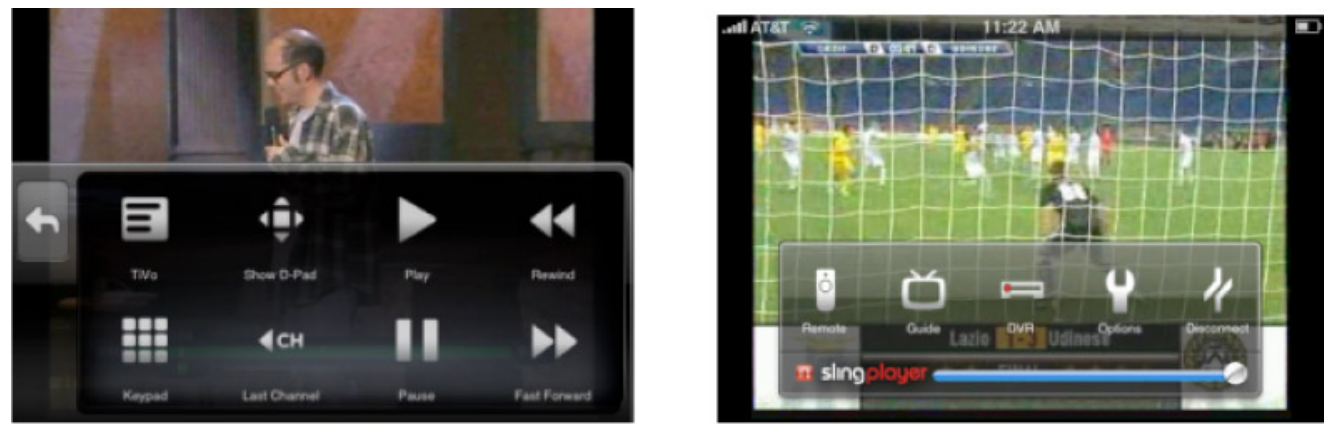

Fig. 3.50: SlingPlayer iPhone App

Fonte: www.wired.com

${ }^{92} \mathrm{http} / / /$ www.wired.com/epicenter/2009/05/slingplayer-iphone-app-crippled-by-apple-att/\#ixzz149WPYYTV SlingPlayer iPhone App Crippled by Apple, AT\&T By Eliot Van Buskirk Email Author

May 13, 2009 Revista Wired 


\subsubsection{Controles Remotos Universais}

Uma evolução encontrada nos controles remotos universais é a utilização de telas, que minimizam o número de botões necessários para comandar diversos aparelhos e trazem a possibilidade de personalizar as funções através de menus gráficos. As empresas norteamericanas Logitech e Harmony são dois dos principais fabricantes destes dispositivos.

\section{Logitech}

Logitech Harmony 1100 é um controle remoto universal touchscreen com um custo bastante elevado, aproximadamente US\$500, que utiliza transmissão infravermelha ou RF. Pode ser programado via internet ou através de um software instalado em um $\mathrm{PC}^{93}$.

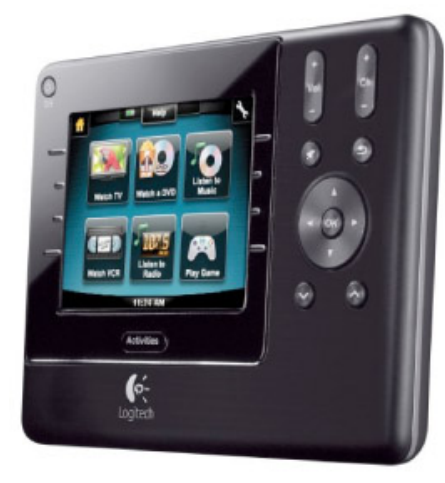

Fig. 3.51: Controle Remoto Logitech Harmony 1100 Fonte:.slashgear.com

\section{Monster}

A empresa norte-americana introduziu seu controle MCC AVL200's na CES 2010 em Las Vegas, e de acordo com o fabricante ele já vem pré-programado com códigos de milhares de fabricantes. Este controle ainda utiliza diversos botões "físicos" como o seu antecessor ${ }^{94}$.

\footnotetext{
${ }^{93} \mathrm{http} / /$ www .slashgear.com/logitech-harmony-1100-universal-touchscreen-remote-on-sale-0633282/

${ }^{94}$ http://www.monstercable.com/press/pdf/2010/Monster\%20CES\%202010\%20MCC\%20AVL200.pdf
} 


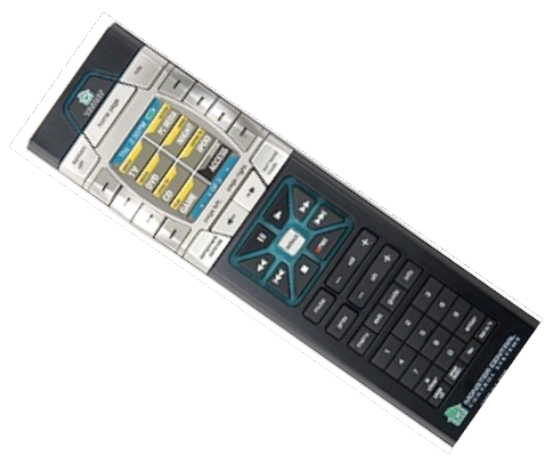

Fig. 3.52: Controle remoto MCC AVL300 da Monster Cable Fonte: www.cnet.com

O modelo AVL300 do mesmo fabricante utiliza uma versão modificada do software Harmony da Logitech e incorpora um transmissor infravermelho e $\mathrm{RF}^{95}$.

\subsubsection{Controles por gestos}

Novas tecnologias resultantes de pesquisas em design de interfaces, as quais veremos com mais detalhes no capítulo 3, estão sendo incorporadas em controles remotos introduzidos no mercado de videogames que permitem utilizar gestos e movimento para controlar videogames e outros aparelhos de entretenimento eletrônico. O mais conhecido é o controle remoto do videogame Wii, da Nintendo. Já a Sony introduziu em 2010 o Move Motion Controller para o seu console Playstation e a Microsoft lançou, em novembro de 2010, o controle Kinect para a plataforma XBox. Embora estes controles sejam projetados primordialmente para videogames, eles são capazes de controlar outras funcionalidades que podem ser visualizadas nas TVs conectadas a estes games, como navegar na internet e assistir vídeos.

\section{Nintendo Wii}

O Wii Remote é o controle remoto do console de games Nintendo Wii ${ }^{96}$. Ele capta os movimentos realizados pelo jogador utilizando três acelerômetros e uma câmera de

\footnotetext{
${ }^{95}$ http://reviews.cnet.com/remote-controls/monster-cable-home-theater/4505-7900_7-31748154.html
} 
infravermelho, além de possuir um pequeno alto-falante e produzir vibrações que dão um retorno tátil e sonoro para o usuário, assim como um retorno visual (feedback) que se apresenta na tela.
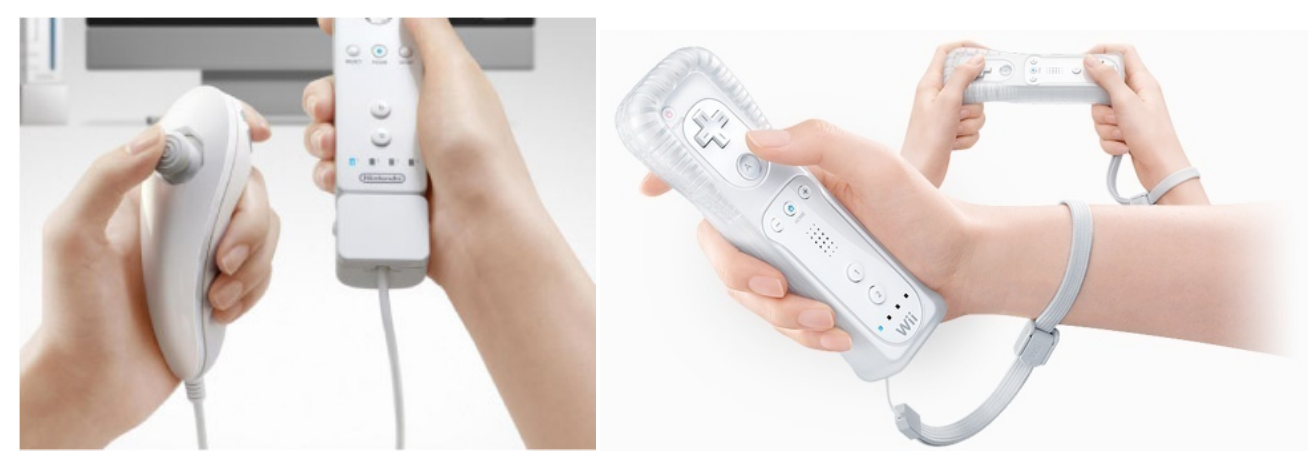

Fig. 3.53: Controle remoto Wii Remote Fonte: www.nintendo.com

O Wii Remote é uma inovação não só no controle de videogames, como também abre novas possibilidades na interação com a TV, permitindo navegar a web usando o browser Opera adaptado para visualização na tela de uma TV convencional. Um exemplo deste tipo de aplicação é o canal Looking Local, que oferece informações como: serviços públicos, empregos, trânsito na Inglaterra ${ }^{97}$. Esses serviços, antes disponíveis em plataformas de DTH como Sky e Virgin, agora estão disponíveis na plataforma Nintendo Wii.
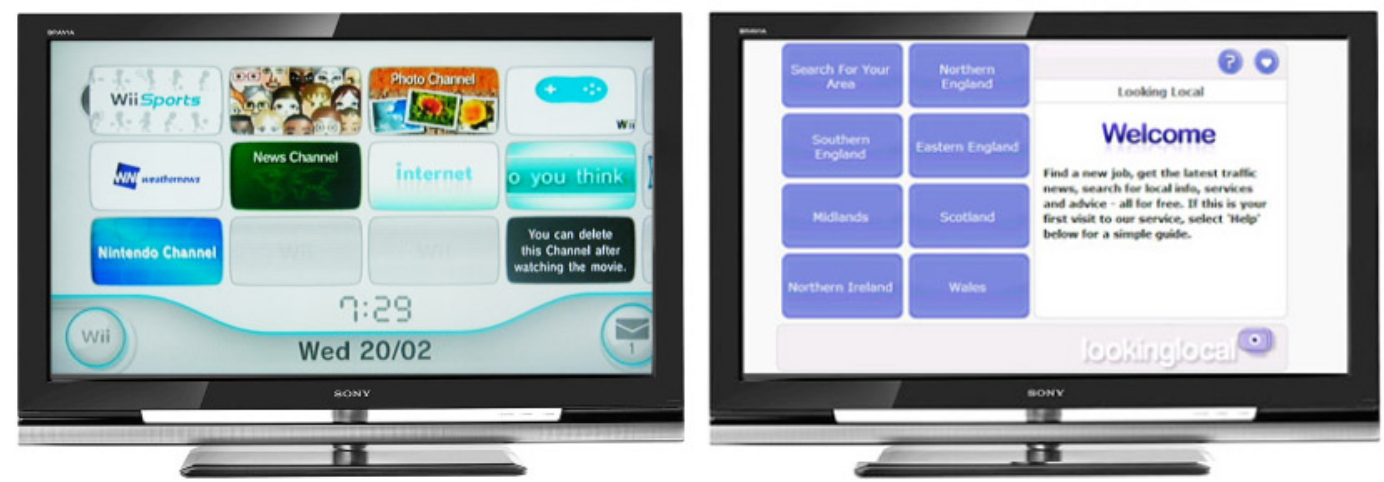

Fig. 3.54: Menus do Looking Local no Wii Internet Channel Fonte: http://lookinglocal.gov.uk/

\footnotetext{
${ }^{96} \mathrm{http}: / /$ www.nintendo.com/wii/console/controllers

${ }^{97} \mathrm{http}$ ///lookinglocal.gov.uk/wiki/display/pub/Looking+Local+is+now+available+on+the+Nintendo+Wii
} 
Uma das aplicações do controle remoto do Wii apresentadas pela Looking Local no seu site ${ }^{98}$ é a utilização de widgets para seus canais de informação. No site há exemplos de como se pode utilizar um widget do Twitter com o controle remoto do Wii ou mesmo um controle remoto convencional.

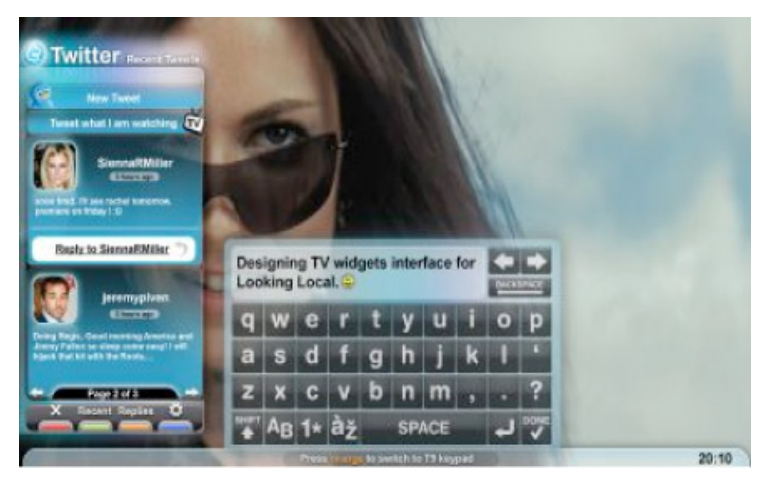

Fig. 3.55: Widget do Twitter para Looking Local Fonte: http://lookinglocal.gov.uk

\section{Microsoft Natal}

A Microsoft introduziu, em novembro de 2010, o Kinect for Xbox 360. Originalmente conhecido como Project Natal, o acessório pretende possibilitar uma experiência de "gaming" e entretenimento que não requer a utilização de um controle remoto ${ }^{99}$. Utilizando um periférico para o console Xbox 360 similar a uma webcam, o Kinect permite aos usuários controlar e interagir através de uma interface "natural" que utiliza gestos e comandos de voz sem a necessidade de tocar em um controle remoto.
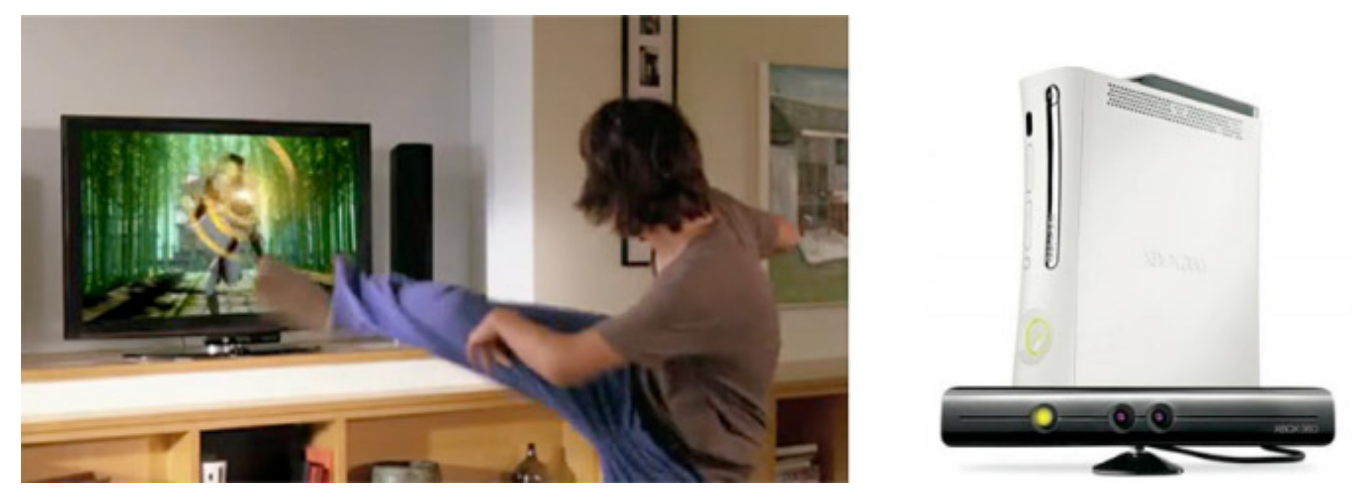

Fig. 3.56: Microsoft Project Natal/Kinect

Fonte: www.platformnation.com

\footnotetext{
${ }^{98} \mathrm{http}: / /$ lookinglocal.gov.uk/wiki/display/pub/Widget+Interfaces

${ }^{99} \mathrm{http}: / / \mathrm{www}$.gizmodo.com.br/conteudo/o-que-e-o-kinect-para-xbox-360
} 


\section{Sony PS3 Motion Controller}

A Sony introduziu um sistema de controle de games para a plataforma PS3 que consiste na câmera PlayStation Eye e o controle sensível a movimentos, o PlayStation Move, permitindo que jogadores participem dos jogos como se estivessem dentro do jogo. Segundo press release da Sony de março de 2010, o controle PlayStation Move possui um giroscópio de três eixos e um acelerômetro de três eixos, assim como um sensor de campo magnético terrestre e uma esfera colorida cuja localização é detectada pela câmera PlayStation Eye. Este sistema permite ao usuário realizar movimentos sutis e rápidos como pintar com um pincel ou jogar tênis, interagir através de comandos de botões no controle e ter sua imagem capturada pela câmera, possibilitando uma experiência de realidade virtual ${ }^{100}$.

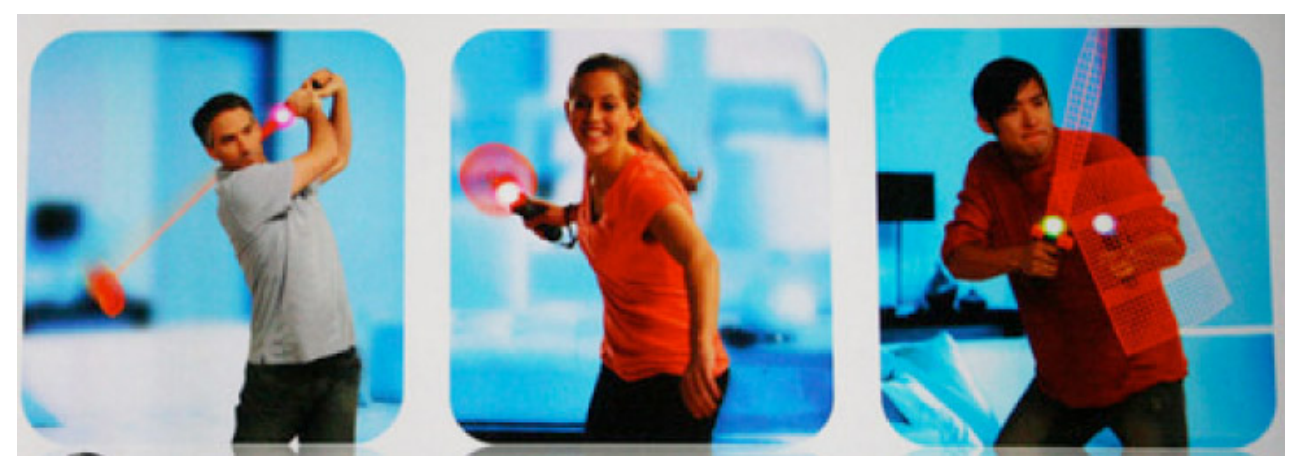

Fig. 3.57: Play Station Motion Controller

Fonte: http://gizmodo.com/tag/motioncontroller

\section{Hillcrest Research}

Um artigo no site Telephony Online (WILSON, 2009) apresenta uma proposta de um mouse desenvolvido pela Hillcrest Research que opera em "espaço livre" como o controle do Nintendo Wii (inclusive há um processo de quebra de patente da Hillcrest contra a Nintendo). Este "mouse" facilitaria a navegação de aplicativos interativos na TV Digital e talvez aumentasse o interesse por tais facilidades. Em contrapartida, o artigo mostra a opinião do executivo Joe Ambeault, diretor de desenvolvimento de produto da empresa Verizon (operadora de TV a cabo nos EUA), de que as pesquisas realizadas pela empresa junto a sua base de assinantes concluem que a longo prazo há espaço para o invento, mas por enquanto ainda é cedo e muita tecnologia pode intimidar os assinantes.

\footnotetext{
${ }^{100} \mathrm{http} / /$ gizmodo.com/5490508/sony-motion-controller-is-called-playstation-move-launches-fall-2010-hands-on
} 


\subsubsection{Usabilidade em TVDI}

\section{Interfaces do usuário da TV Digital do ponto de vista da comunicação}

Konstantinos Chorianopoulos, professor da Universidade de Atenas, no artigo "User Interface Evaluation of Interactive TV: A Media Studies Perspective" (2006), ressalta a importância dos aspectos afetivos da interface homem-máquina, principalmente em um ambiente ou situação em que o público que espera ser entretido está em uma posição reclinada "lay back", como no caso da TV. Acredita que devemos levar em conta aspectos como engajamento, envolvimento, hedonismo e prazer ao projetar interfaces para TV interativa. Seu artigo tem bastante influência das ideias de Donald Norman, especialmente as do livro Emotional Design (2004).

Segundo Chorianopoulos, a experiência do entretenimento que temos ao assistir TV interativa revela três tipos de resposta emocional (atitude, atividade e afeto) correspondentes aos três níveis do "modelo afetivo" de Norman (2004). O público da TV espera muito mais do que apenas facilidade de uso (como no caso de um caixa eletrônico); o autor afirma que "o telespectador recebe informação e tem a expectativa de ser entretido em uma postura 'reclinada' e através de uma linguagem carregada de emoções”. Ele relata que, em relação aos resultados das pesquisas referentes a aplicativos para ITV, a satisfação dos usuários não condiz com as métricas de eficiência comumente utilizadas em estudos de usabilidade de software: em alguns estudos, os aplicativos mais eficientes não eram os favoritos e sim os que geravam alguma forma de satisfação, mesmo para isso fosse preciso "clicar" desnecessariamente.

\section{Consistência da Interface na TV Digital Interativa}

Gil Barros (2009), em sua dissertação de mestrado apresentada à Escola Politécnica da Universidade de São Paulo em 2006, apresenta os princípios básicos da usabilidade nas interfaces de TV Digital, concentrando-se na questão de consistência entre plataformas, comparando diversos sistemas utilizados por operadoras de TV a cabo e satélite e detalhando funções das facilidades interativas disponíveis atualmente. No resumo de sua tese, coloca a questão: 
Esta dissertação investiga a questão da consistência da interface com o usuário para a TV interativa, considerando seus aspectos teóricos e de implementação. Para tanto investigamos na literatura de Interfaces HumanoComputador a questão da consistência e suas abordagens. Considerando que a consistência é uma característica relativa a um modelo, buscamos identificar modelos de interfaces de TV interativa que sejam exemplos de boas práticas a serem seguidas. (BARROS, 2006).

Na sua dissertação, Barros apresenta um estudo da interface gráfica da Direct TV, TVA, NET e SKY e recomenda desenhar as interfaces a partir de um controle remoto utilizando um grupo mínimo de teclas. $\mathrm{O}$ autor apresenta um excelente levantamento dos diversos tipos de controle em que compara as diversas funcionalidades disponíveis em cada plataforma. Sugere que uma interface de uma mesma plataforma poderia utilizar diversos controles mas não necessariamente mapeados da mesma maneira, o que me parece também passível de gerar outros problemas de consistência.

O trabalho de Gil Barros define muito bem os diversos modelos de navegação, propondo modelos consistentes de navegação de EPG. Porém a interatividade na TV deve permear todos os aspectos da experiência televisiva na era digital desde a funcionalidade do aparelho aos set-top boxes e EPGs. O que vemos é a repetição do mesmo modelo funcional, validado originalmente em formas lógicas de catalogação, em sua maioria hierárquica. Será que esse encaminhamento não limita o valor de entretenimento da mídia televisiva? (CHORIANOPOULOUS, 2006)

Barros está correto no sentido de que é desta forma que se organiza a TV Digital: de maneira simples, pois um dos princípios da TV como tecnologia é que ela deve ser simples e não deve falhar, basta ligar o aparelho, mudar de canais e pronto, quanto ao sinal ele não deve cair, falhar etc. Ao passo que, ao utilizarmos computadores, o mesmo não é verdade, este falha, requer upgrades e loops intermináveis são aceitáveis. 


\section{Usabilidade em Serviços Educacionais em ambiente de TV Digital}

Thais Waisman foi pesquisadora da Escola do Futuro da USP, onde desenvolveu projetos de educação em TV Digital interativa; o foco de suas pesquisas tem sido a "usabilidade" da TV Digital interativa para a educação. Tive a oportunidade de trabalhar com ela pessoalmente ao desenvolver interfaces para três projetos da Escola do Futuro em 2004 e 2005: um protótipo de EPG para a TV Escola Digital, a interface de programas educativos interativos para o CPqD e um piloto de TV Digital para o Instituto Genius de Manaus (a sua tese, assim como a de Andréia Brazil analisam essa experiência).
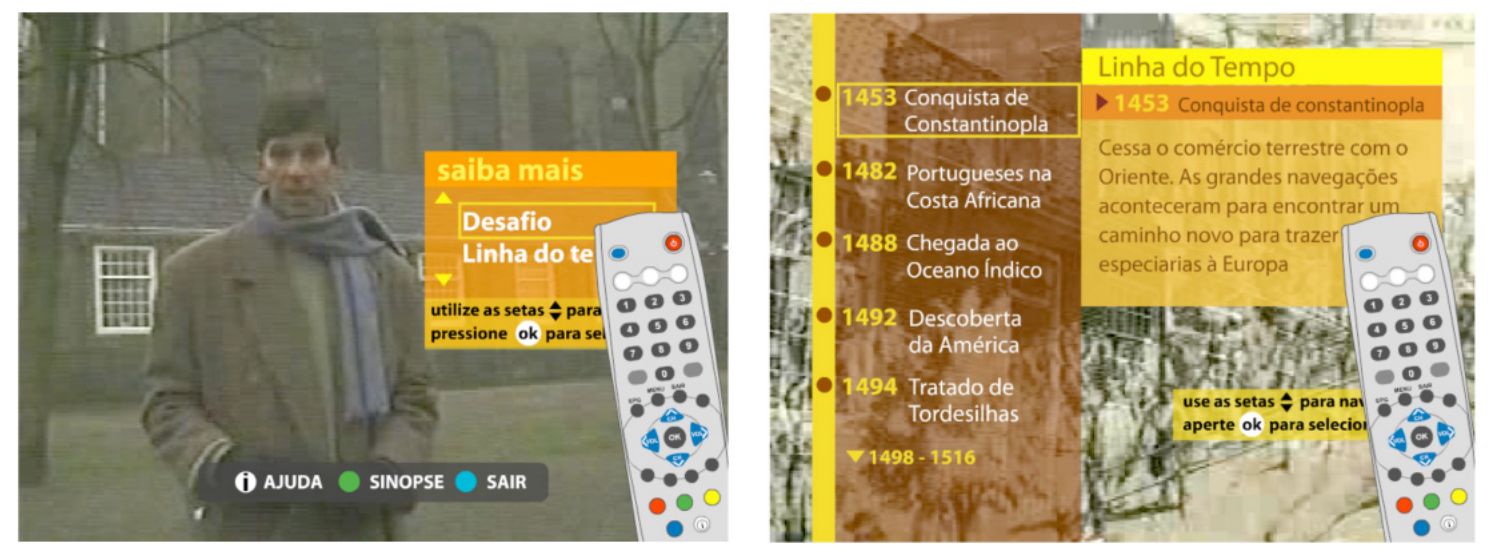

Fig. 3.58: Interface de programa educativo interativo - CPQD

Fonte: Escola do Futuro da USP

Em sua tese de doutorado apresentada à Escola de Comunicações e Artes da Universidade de São Paulo em 2006, Thais descreve os princípios da usabilidade e heurística, principalmente centrada na engenharia da usabilidade de Jakob Nielsen (2000), mostrando o universo da TV Digital, de um ponto de vista da cognição e do aprendizado. Depois apresenta exemplos de um dos projetos que desenvolvemos juntos e os testes realizados junto aos usuários, e sugere algumas regras baseadas nas conclusão desses estudos, em sua maioria de ordem prática e imediata. Em sua conclusão, apresenta várias dificuldades enfrentadas pela educação a distância e aponta justificativas para a realização de estudos de usabilidade principalmente de ordem econômica. O trabalho serve como importante referência prática para os profissionais de usabilidade no Brasil e para quem irá produzir programas interativos educativos, principalmente por ser de autoria de uma profissional ativa no mercado de TVDI no Brasil. 


\section{Usabilidade na Web e Usabilidade na Televisão Interativa}

Na dissertação de mestrado em Tecnologia Multimídia de Valter de Matos apresentada na Universidade Lusófona de Humanidade e Tecnologia e na Faculdade de Engenharia da Universidade do Porto em 2005, intitulada "Usabilidade na web e usabilidade na televisão interactiva", Matos questiona se as regras de usabilidade da web podem ser portadas às plataformas de televisão interativa, e se é possível utilizar a heurística de usabilidade de páginas web ao universo da TV interativa. A sua resposta é que é "possível e desejável a aplicação destas regras à TVi, se as especificidades do novo meio forem tomadas em consideração".

No entanto, como sugere Chorianopoulos (2006), devemos questionar a aplicação das regras de usabilidade da web à TV interativa, já que as expectativas de um telespectador são bem diferentes das de um usuário de computadores. A TV é um meio originalmente passivo e embora como nota o próprio Matos (2005), o telespectador venha tornando-se progressivamente ativo, há várias expectativas imbuídas no meio TV. Na minha opinião, apenas a convergência apontada na dissertação não seria justificativa para usar as regras de usabilidade da web na TV, muito menos ao sugerir que simplesmente podemos adequá-las ao novo meio.

\subsubsection{Processo de produção de software para a TVDI}

Com a incorporação do software no processo de produção de programas interativos para a TV Digital, emerge a necessidade de se estabelecerem processos que integrem o desenvolvimento de software com práticas já estabelecidas pelos produtores de conteúdo audiovisual. Duas importantes referências (já citadas) propõem-se a delimitar esse processo, uma delas é Gawlinsky (2003) e a outra é o Red Button Iniciative da BBC, que tem como objetivo unificar a entrega de conteúdos interativos por produtoras independentes; ambas as fontes são dirigidas primordialmente à plataforma MHP.

Uma tentativa de sistematizar esses processos dentro dos métodos de produção adotados no Brasil com a ocasião da introdução do SBTVD é o artigo "Processos de software 
para a TV interativa" 101 (FILGUEIRAS et al., 2007), em que se discute como aspectos como gerenciamento de projeto, confiabilidade, portabilidade e eficiência podem ser adotados no processo de produção de programas interativos, contribuindo para a qualidade desses programas, os prazos de produção e a integração dos processos de produção.

\section{Etapas do Design no desenvolvimento de programas interativos}

Apresento aqui como as etapas utilizadas no processo de desenvolvimento de software, web sites, programas de TV são articuladas no desenvolvimento de programas para a TV Digital interativa.

\section{a) Software}

Como vimos anteriormente, Preece et al. (2005) identificam quatro atividades principais no design de interação, como aplicativos para computadores, celulares, games, produtos e serviços digitais. Elas podem ser representadas esquematicamente como as seguintes etapas:

\section{Necessidades e Requisitos $>$ Designs Alternativos $>$ Construir Versões Alternativas $>$ Avaliação}

Nesta abordagem, as etapas do processo podem ser aplicadas a diversos modelos de ciclos de vida, desde o clássico aos ágeis, incorporando as iterações necessárias no percurso. Note-se que o esquema de Preece já prevê as iterações ao especificar designs e versões "alternativas". A vantagem deste método é que ele pode ser adaptado a diversas tecnologias e culturas (meios?).

\section{b) Web Sites}

Lynda Weinnman (2000) em Designing Web Graphics 3, publicado em um período de amadurecimento do design para a web, quando designers gráficos começaram a participar do

\footnotetext{
101 O autor colaborou com os pesquisadores do LSI - Laboratório de Sistemas Digitais e da Escola de Comunicações e Artes da USP na elaboração desse artigo.
} 
processo de desenvolvimento de websites como um todo, em vez de meramente preparar elementos gráficos para a programação, propõe o seguinte modelo:

\section{Estratégia > Storyboards e Sketches $>$ Fluxograma, Estrutura e Navegação > Autoração}

Notem que neste modelo (WEINNMAN, 2000) não há a previsão de testes com os usuários, provavelmente porque os sites no período eram programados na linguagem declarativa HTML, em que não havia a necessidade de debugging ${ }^{102}$, o que mais tarde se tornou necessário com a incorporação de aplicações em JAVA e Flash nos websites. No entanto, a simplicidade da linguagem HTML não descarta a importância das iterações com clientes e usuários. A evolução da internet para uma plataforma onde há uma gama de serviços digitais (ANDERSON, 2010) torna cada vez mais importante a incorporação dos processos iterativos no desenvolvimento de aplicativos para a internet.

\section{c) TVDI}

Gawlinksy (2003, p. 142) propõe um processo de produção para a TV Digital interativa que integra os estágios de produção de um programa de televisão (desenvolvimento, pré-produção, produção, pós-produção e transmissão) com aqueles utilizados no desenvolvimento de software, podendo ser resumido na seguinte sequência:

\section{Desenvolvimento $>$ Especificação $>$ Produção e Testes $>$ Lançamento e operação}

Na administração de projetos para TVDI de acordo com este esquema, Gawlinsky sugere que se opte entre o modelo Cascata ou o modelo RAD, mas assim como Weinnman (2000) faz poucas referências sobre as iterações durante o processo, especialmente no que se refere ao usuário.

Gawlinski usou, para sua proposta, os processos de desenvolvimento de software tradicionais, especificamente o ciclo cascata e incremental. Infelizmente, Gawlinski partiu de processos sabidamente inadequados para o desenvolvimento de sistemas interativos. (FILGUEIRAS et al., 2007).

102 "Debugging é o processo de encontrar e reduzir defeitos num aplicativo de software ou mesmo em hardware. Erros de software incluem aqueles que previnem o programa de ser executado e aqueles que produzem um resultado inesperado." Fonte: Wikipedia 


\subsection{Conclusão do Capítulo}

Assim como o design de websites evoluiu ao se libertar das restrições impostas pelas estruturas de organização e a limitação das linguagens de programação usadas inicialmente no desenvolvimento de websites, com a convergência das mídias digitais o mesmo deverá ocorrer no design de interação para programas interativos na TV Digital. Inicialmente o designer de websites sequer tinha opções de fontes tipográficas e a possibilidade de posicionar imagens e textos nos layouts da forma que achasse mais conveniente. Já com a introdução do CSS (Cascading Style Sheets) e de programas de autoração como o Dreamweaver e Go- Live, designers gráficos passaram a poder realizar layouts com a mesma liberdade que tinham na mídia impressa. O mesmo ocorreu nas emissoras de televisão nos anos 1970, com a introdução dos geradores de caracteres eletrônicos e sistemas de computação gráfica, quando a operação era realizada inicialmente por técnicos sem capacitação em design gráfico (SCHLITTLER, 2009).

No caso da TV Digital, como a importância do design televisual já está consolidada na indústria do audiovisual, o incremento de resolução decorrente da produção em alta definição vem contribuir para o campo. O que vemos é o envolvimento destes designers em uma nova disciplina que requer a compreensão dos processos de produção de programas que utilizam a interatividade. Esses processos ainda estão sendo introduzidos na organização das produtoras de programas e emissoras de televisão e no estágio atual encontram não somente as restrições impostas pela tecnologia e as ferramentas da autoração disponíveis, como o Cardinal Studio utilizado no sistema MHP e a ferramenta Composer NCL para o sistema Ginga, como possuem interfaces poucos amigáveis de modo que a utilização destas ainda tem permanecido dentro dos departamentos de engenharia ou empresas especializadas. Ademais, os processos empregados na produção de programas interativos não chegam a acompanhar os avanços da indústria de software, como vimos no modelo apresentado por Gawlinsky (2003).

\section{No próximo capítulo}

Como veremos no próximo capítulo, a convergência das mídias digitais abre novas perspectivas para o desenvolvimento de conteúdo audiovisual para a TV Digital na medida em que elas dialogam com novas mídias que encontram suporte na internet e redes de celulares e poderão ser utilizadas em uma gama de dispositivos como celulares, games e 
computadores. Neste cenário, os processos do design de interação que enfatizam a experiência do usuário e não se encontram sob o paradigma de sistemas dedicados ou proprietários são os mais adequados ao desenvolvimento de produtos e conteúdos para as novas mídias.

Esta convergência deve levar em conta também a evolução das interfaces de comunicação entre o usuário e a TV do futuro, considerando a imersão baseada na multiprojeção de imagens estreoscópicas e na eventual resposta táctil. (ZUFFO, 2001).

Acredito que o quadro de referência teórico, a prática, os processos de desenvolvimento e as pesquisas que têm sido aplicados ao design de interação apresentados neste capítulo abrem novas perspectivas no design de interfaces para a TV Digital em um cenário de convergência.

"Perhaps in the future we will finally give up the illusion of applications engineeering and design as being to separate things." (LAUREL, 1990, p. xiii) 
Capítulo 4

\section{Design para Mídias Convergentes - Interação e Identidade}

"Neste cenário o design de interfaces para TVDI deve facilitar o diálogo entre as mídias".

\section{Introdução}

A digitalização das tecnologias de produção das mídias audiovisuais e a distribuição digital dessas mídias tem transformado a maneira como as recebemos e percebemos, abrindo espaço para novos formatos e linguagens. As redes globais de comunicação possibilitam que indivíduos compartilhem conteúdo gerado pelos próprios usuários, invertendo a lógica da indústria de comunicação de massa de modo que o receptor também passe a ser transmissor.

As antigas mídias permanecem e passam a conviver com as novas mídias, mas com a digitalização todas são compostas da mesma substância: códigos binários processados e distribuídos em rede. Com isso a identidade das mídias passa a ser definida pela experiência do usuário e pelo design das interfaces das plataformas computacionais onde as mídias passam a existir. Esta identidade é essencialmente representação, como no teatro.

Em um cenário de digitalização e convergência das mídias, a mídia deixa de ser definida por sua materialidade e passa a ser marcada pela experiência que se realiza através das interfaces entre o usuário, a mídia e os dispositivos digitais. Assim como as outras mídias, a TV Digital pode ser definida por essa experiência e seus códigos. Ao projetar interfaces que facilitam a usabilidade e a interatividade com a TV Digital, o designer deve levar em conta este novo paradigma.

Nesta nova experiência, as mídias dialogam, há uma ubiquidade de dispositivos inteligentes e surgem novos formatos de conteúdo audiovisual. É necessário que o designer, ao atuar no Design de Interfaces em um cenário de convergência da TV Digital com outras mídias, compreenda esse diálogo, as transformações dele decorrentes e como elas alteram as expectativas dos usuários. Deste modo é possível inovar e propor caminhos que facilitem o diálogo e a interação do homem com as mídias convergentes de forma transparente e simples. 


\subsection{Digitalização das mídias e dispositivos}

\subsubsection{Produção e distribuição de mídias não lineares}

A digitalização atinge quase todas as mídias contemporâneas, da produção à distribuição. Nas mídias audiovisuais, sinais analógicos representando sons e imagens são convertidos em códigos digitais, de modo que sejam representados em um formato binário. Quanto mais alta a amostragem (sampling) durante a digitalização de um sinal analógico, mais fiel ao original será a codificação digital, ou seja, terá maior resolução (NOLL, 1988). Uma vez que um sinal está digitalizado, ele pode ser replicado sem que haja perda de qualidade. Na comunicação digital, não existem cópias e sim clones, tornando-se impossível distinguir entre o original e a cópia, pois são idênticos. Já no processo de duplicação das mídias analógicas, pode ocorrer a introdução de ruídos e consequentemente a cópia difere do original. O mesmo pode ocorrer na transmissão analógica, em que a interferência de ruídos no sinal altera como este é percebido pelo receptor.

A produção audiovisual engloba a captação, edição e distribuição de imagens. Esse ciclo de produção pode ser parcial ou totalmente digital. A captação digital de filmes de longa-metragem é uma prática bastante recente e ainda se discute se a qualidade da imagem analógica obtida em película com uma câmera de $35 \mathrm{~mm}$ seria superior à das câmeras de HDTV com alta definição (McSTAY, 2009). Aspectos subjetivos da percepção da imagem e amostragem de cores, introdução de ruído na película também pesam nesta discussão.

No cinema como na televisão, entretanto, a edição de imagens utilizando ferramentas digitais tornou-se uma prática comum, substituindo a moviola e as ilhas eletrônicas. A edição digital possibilita o que chamamos de edição não linear, em que arquivos de vídeo digital (ou digitalizados a partir de uma matriz analógica) são manipulados utilizando softwares que referenciam os arquivos de mídia e permitem montar "sequências" visualizadas e reorganizadas de diversas maneiras.

Processo similar ocorreu com a introdução de processadores de texto, que não só substituíram as máquinas de escrever, mas também possibilitaram recursos de linguagem, já que através de "links" hipertextuais um autor pode conectar partes do texto, abrindo caminhos 
narrativos (LANDOW, 1992). Com as possibilidades de comunicação advindas da hipertextualidade e das redes digitais, é de esperar que as mídias audiovisuais sofram transformações radicais.

Steven Johnson, em seu livro Interface Culture (1999), aponta como as novas formas de linguagem possíveis com o advento da hipertextualidade tiveram um impacto muito maior para os usuários da web do que a tecnologia propriamente dita:

Pergunte a qualquer usuário da Web se ele se recorda do que o atraiu pela primeira vez ao ciberespaço: você provavelmente não irá ouvir descrições rapsódicas de animações gráficas girando, ou um clipe sonoro agudo e distorcido. Não, o momento de eureca para a maioria de nós veio pela primeira vez quando, ao clicarmos em um link, nos encontramos atravessando o planeta. A liberdade e a imediatez daquele movimento... foi genuinamente diferente de tudo o que veio antes...

O que nos deparamos neste primeiro encontro foi algo profundo ocorrendo ao nível da linguagem. O link é a primeira forma significativa de pontuação a emergir nos últimos séculos, mas é apenas uma dica do que virá. Hipertexto, na verdade, sugere uma gramática de possibilidades inteiramente nova, uma nova forma de escrever e contar histórias." ${ }^{103}$ (JOHNSON, 1999, p. 110).

As redes digitais de comunicação abrem caminhos na distribuição de conteúdo audiovisual. Nas redes digitais, a comunicação não se dá mais exclusivamente ponto a ponto, ou do transmissor para o receptor, deixando de ser síncrona, e permitindo um diálogo entre o receptor e o transmissor. Na rede todos participam, com vídeos, imagens e comentários. Esse é um dos aspectos mais interessantes da interatividade possível na TV Digital, aquela advinda da colaboração dos usuários da rede; uma interatividade que abre caminhos para novas formas de linguagem e novos formatos audiovisuais.

${ }^{103}$ Tradução minha do texto original em inglês:

\footnotetext{
"Ask any Web user to recall what first lured him into cyberspace; you're not likely to hear rhapsodic descriptions of a twirling animated graphic or a thin, distorted sound clip. No, the eureka moment for most of us came when we first clicked on a link, and found ourselves jettisoned across the planet. The freedom and immediacy of that movement ... was genuinely unlike anything before it....

What we glimpsed in that first encounter was something profound happening at the level of language. The link is the first significant new form of punctuation to emerge in centuries, but it is only a hint of things to come. Hypertext, in fact, suggests a whole new grammar of possibilities, a new way of writing and telling stories”.
} 
A distribuição digital de conteúdo audiovisual têm colocado em xeque as mídias estabelecidas: redes de dados de alta velocidade e técnicas de compressão de arquivos de vídeo permitem realizar o download ${ }^{104}$ de filmes disponíveis na internet que, ao serem arquivados no hard-disk de um computador ou em um set-top box de TV a cabo, nos libertam da grade de programação televisiva. A mesma tecnologia pode ser aplicada para gravar programas TV e assisti-los posteriormente em um horário diferente do programado.

Quando a empresa norte-americana TIVO lançou um aparelho que combinava um Personal Video Recorder (PVR) ${ }^{105}$ com um serviço que recomendava, selecionava e gravava programas de TV de acordo com um perfil personalizado para cada telespectador e eliminava os comerciais na hora de exibi-los, a indústria de publicidade norte-americana entrou em pânico. Esta crise da publicidade é relatada no artigo "The Future of the 30-Second Spot", publicado na revista de domingo do jornal The New York Times em 2005, onde se anunciava o fim do formato comercial de 30 segundos para a TV e o da publicidade como conhecíamos até então (MANLY, 2005). O serviço da TIVO em si não acabou com o comercial como previsto, mas o avanço das diversas tecnologias que permitem assistir vídeo sob demanda na internet tem impactado a audiência da televisão e gradativamente reduzido a importância do comercial de 30 segundos, fazendo com que as agências de publicidade buscassem alternativas como os vídeos "virais", distribuídos na internet e nas redes sociais. Henry Jenkins e pesquisadores do Consórcio para Cultura Convergente do MIT sugerem que esses formatos mutáveis distorcem os interesses dos produtores de conteúdo e dos publicitários, em sua “viagem" nessa cultura participatória (JENKINS; LI; KRAUSKOPF, 2008).

As inovações tecnológicas não têm impactado apenas a indústria de comunicação de massa; a indústria de games, por sua vez, tem se consolidado e passa a competir com a indústria de cinema ${ }^{106}$ (LYONS, 2009). Um grande número de domicílios tem consoles de

\footnotetext{
104 Tem-se utilizado a expressão "baixar” como tradução do termo “download”, que significa descarregar arquivos remotamente de servidores conectados à internet para um computador pessoal. "Upload” é a designação processo inverso, ou seja, quando um utilizador transfere arquivos de um computador pessoal para um servidor na internet.

${ }^{105}$ PVR, Personal Video Recorder, também conhecido como DVR - Digital Video Recorder é uma combinação de um disco rígido e software em um STB ou outro dispositivo conectado a uma TV, que permite gravar programas de TV para se assistir posteriormente, ou gravar um programa enquanto o assiste, permitindo retroceder e pausar o programa.

${ }^{106}$ Segundo Margaret Lyons, na matéria “Videogames vs. Movies: A leader emerges... and we applaud!?”, publicado em 21/5/2009 no site da revista Entertainment Weekly, uma pesquisa de mercado realizada
} 
games conectados ao aparelho de TV, adicionando mais uma opção de entretenimento eletrônico que, ao cativar os mais jovens por horas na frente da tela, tem desviado o interesse destes da programação da TV convencional.

\subsubsection{A música como precursora do audiovisual}

Com a introdução do CD (Digital Compact Disc), a indústria musical digitalizou seus produtos. No início, a distribuição dos CDs ainda estava baseada em produtos físicos - CDs distribuídos em lojas, que, embora não tivessem mais dois lados como os álbuns de vinil, ainda eram concebidos como obras integrais, compostas por uma sequência de faixas, capa e encarte, passando a ser vistos como "substitutos" digitais do álbum Long Play. Com o avanço de técnicas de compressão de arquivos sonoros, mais especificamente o formato MP3, e a possibilidade de distribuição via internet, o meio físico deixa de ser uma condição para a distribuição da produção musical, fato que vem transformar o "business" da indústria fonográfica. Esse fato é evidenciado pelo declínio das vendas de CDs: somente entre os anos de 2000 a 2005, nos EUA declinaram 25\% (HURLEY, 2006, p.16), número que corresponde ao período anterior da consolidação do serviço iTunes da Apple. O fechamento das lojas de discos da rede varejista Tower Records é emblemático dessa situação.

Não só a distribuição se transformou, mas o modo de se consumir música mudou radicalmente. Com a tecnologia digital, é possível remixar álbuns, reorganizando a sequência planejada de uma obra musical, ou criar playlists, facilitando a compilação pelo ouvinte de músicas de diversos compositores, intérpretes e estilos, promovendo formas cada vez mais personalizadas de se escutar música. As transformações decorrentes da digitalização da música têm consequências que vão além da introdução de meios alternativos de distribuição e recepção musical, e seu impacto atinge a produção musical atual. Sites como o MySpace permitem que músicos e bandas distribuam sua produção sem depender das grandes gravadoras; de modo similar a redes sociais como Facebook, o MySpace possibilita atingir diretamente o público de um gênero musical, o que neste universo de produção musical cada vez mais segmentado tem sido um dos desafios das gravadoras.

recentemente nos EUA revela que $63 \%$ dos norte-americanos jogaram um videogame nos últimos seis meses, ultrapassando os $53 \%$ que foram assistir a um filme no cinema, no mesmo período. Disponível em:<http://popwatch.ew.com/2009/05/21/more-people-pla/>. Acesso em: 20/11/2010. 


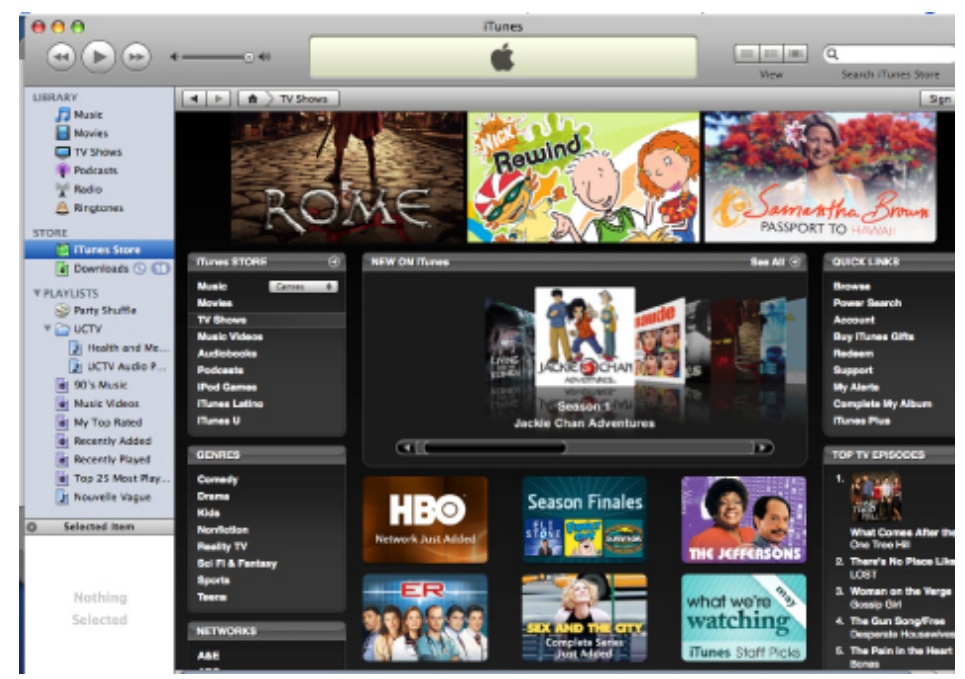

Fig. 4.1: Interface do Programa iTunes Fonte: www.apple.com

O iTunes é a central da plataforma de mídia digital da Apple, um sistema que inclui o Apple TV (IPTV), ITunes store, iPhones e iPods, formando uma solução total de comercialização, distribuição e recepção de mídia audiovisual.

Assim como ocorreu com o processo de digitalização da música, o avanço das técnicas de compressão de vídeo e o crescente acesso doméstico a redes de banda larga têm viabilizado a distribuição de filmes e vídeos na internet por serviços como Apple iTunes e NetFlix. Em razão desses avanços tecnológicos e da mudança de comportamento do público, acredito ser inevitável que a indústria do audiovisual sofra as mesmas transformações pelas quais passou a indústria fonográfica.

Neste cenário, a métrica dos formatos fragmenta-se: há pulverização de unidades. O You Tube, por exemplo, é constituído de múltiplos elementos audiovisuais, muitos gerados pelos próprios usuários e que são consumidos de forma diferente da TV tradicional. Não só muda a forma de assistirmos e consumirmos conteúdo audiovisual, como esta passa a dialogar com outras mídias. Ao lermos uma notícia no site de um jornal, podemos clicar em um link e começar a assistir um vídeo sobre a notícia. Esse vídeo pode ter referências geográficas que podemos explorar em sites como o Google Maps, que por sua vez pode indicar outros vídeos relacionados ao mesmo local. Por exemplo, um desses vídeos pode estar hiperlinkado a um trecho de um livro que cita um lugar, e ao explorarmos este local virtualmente no Google Maps podemos começar a assistir a um filme que foi rodado nessa mesma locação. Inversamente, quando vemos um filme, é possível parar e buscar informações sobre um ator ou um local, ou ainda, durante um jogo de futebol, visitar o estádio ou pesquisar estatísticas e 
escalações dos times. Filmes podem ser interativos, ao associarem a contribuição dos usuários de redes de computadores a narrativas não lineares. Novos gêneros de programação podem surgir a partir do advento da autoria coletiva, como já tem sido indicado pelo sucesso dos reality shows.

\section{Novas formas de produção de conteúdo}

Até os anos 1970, o conteúdo audiovisual era gerado principalmente por emissoras de TV ou estúdios de cinema. Nos anos 1980, vemos as portas abrindo-se para a produção independente (MACHADO, 2003). Hoje, com a facilidade de acesso às ferramentas de produção, se abre a possibilidade de indivíduos serem provedores de conteúdo audiovisual. Processo similar ocorreu na indústria da computação quando a Microsoft passou a vender o sistema operacional desatrelado do hardware da IBM, o que não só abriu caminho para o surgimento da indústria de software, mas com a evolução das redes globais de computadores desencadeou uma revolução com a introdução do software livre e a possibilidade de desenvolvimento de aplicativos em rede de forma coletiva. Hoje, redes sociais como Orkut e Facebook e o crescimento do interesse por conteúdo gerado por usuários (User Generated Content) competem com as mídias estabelecidas (KLYM; MONTPETIT, 2008).

\subsection{Identidade das Mídias}

\subsubsection{Especificidade dos aparelhos midiáticos}

Com a digitalização, a forma como percebemos e utilizamos as mídias tem se transformado. No universo analógico, as mídias eram análogas ao meio material utilizado por uma dada mídia, portanto os aparatos físicos que possibilitavam a comunicação possuíam uma função específica e determinada por sua materialidade. Assim sendo, um televisor servia para assistir TV, um rádio para escutar programas de rádio, uma câmera para captar imagens e um telefone para conversar com outras pessoas. Nas mídias digitais, já não há mais a necessidade dessa especificidade: um telefone pode tirar fotos, jogamos games em um 
aparelho de TV e assistimos programas de TV no computador onde trabalhamos.

Vivemos um período de transição, pois ainda estamos acostumados com a ideia de que adquirimos dispositivos midiáticos para fins específicos: um aparelho de TV Digital é projetado para assistir TV, mas também pode ser utilizado para outras funções como controlar a biblioteca de música em uma casa ou acessar a internet. O mesmo caso ocorre com o telefone celular, que pode servir como agenda, relógio despertador, máquina fotográfica e uma infinidade de funções, como se fosse um canivete suíço digital. Só que no canivete suíço existe uma fisicalidade para cada função expressa em sua forma. Nos dispositivos digitais, a funcionalidade está destacada da materialidade do objeto, o que só é possível através da representação.

\subsubsection{Materialidade das mídias}

A digitalização das mídias faz com que haja a perda da materialidade das mídias, o que pode acarretar a perda de identidade destas, que antes era definida por aspectos físicos e palpáveis. Anteriormente à convergência das mídias digitais, as mídias trafegavam individualmente por canais discretos e eram recebidas por dispositivos dedicados a uma mídia específica. Com a digitalização, a "descrição" vem da codificação e decodificação, gerando novas mídias mas não necessariamente substituindo as mídias estabelecidas. As mídias analógicas tinham sua identidade definida pela sua materialidade, e assim como os noticiários eletrônicos e digitais não substituíram os jornais impressos mas passaram a conviver com eles, o cenário de convergência das mídias digitais provavelmente não acarretará a morte das mídias eletrônicas como a TV e o Rádio.

No entanto, as mídias eletrônicas têm sua materialidade definida pelo aparelho receptor e não pelo substrato em si, como ocorre na fotografia, no cinema e nos livros. A digitalização das mídias eletrônicas nos faz questionar a definição da identidade individual de cada mídia, pois a materialidade destas passa a ser substituída por códigos binários, cuja única materialidade são os processadores onde residem e são distribuídos. Neste novo ambiente, a identidade deve consolidar-se através da representação baseada em metáforas, códigos visuais e culturais que têm origem na herança analógica de cada mídia.

As mídias do entretenimento: TV, web, celular e games podem ser compreendidas como linhas independentes que ao convergirem perderam a autonomia e caminham para um 
diálogo. As novas mídias digitais como a internet, HDTV, smartphones e games, podem ser vistas com uma única substância. Na prática, esses aparelhos são constituídos de microprocessadores, monitores (output), sensores e mecanismos de controle (input devices) e conectividade a redes de computadores. A funcionalidade e a particularidade de cada mídia são definidas por software e interfaces, ou seja, por uma série de códigos de informação e representação - processos lógicos que permitem realizar tarefas e metáforas ou narrativas que nos permitem interagir com a mídia. O software permite esta multifuncionalidade, e enquanto os aspectos materiais dos aparelhos de comunicação são essencialmente os mesmos (processador + monitor + input) para diversas mídias, esta versatilidade não vem sem um custo para o usuário.

Se observarmos o ambiente onde assistimos TV, em muitos casos iremos encontrar diversos controles remotos que permitem operar o equipamento através do mapeamento físico das funções eletrônicas em botões nesses controles, mas esta pletora de controles não dialoga entre si; o controle remoto universal surgiu como tentativa de resolver esse problema, mas acabou não tendo sucesso. Como as mídias tendem a dialogar entre si, estão sendo desenvolvidas interfaces do usuário e controles que visam facilitar a interação do usuário com diversas mídias.

\subsubsection{Representação e metáforas da TV}

As interfaces desenvolvidas atualmente para aplicativos da TV Digital interativa são dedicadas a dispositivos ou objetos específicos e não têm a versatilidade do mouse ou do teclado alfanumérico de um celular, que servem para múltiplos dispositivos. Com a digitalização, a fisicalidade dos objetos deixa de ter uma especificidade funcional, como no caso do disco dedicado a focar a imagem na câmera fotográfica. Na máquina fotográfica digital, o disco regulador pode servir tanto para focar como, ao ser acionado em outro "modo", para ajustar o obturador da câmera.

O design de um produto digital incorpora a representação e as metáforas. Para isso, um primeiro passo é esquecer o dispositivo e pensar no objetivo, ou seja, a tarefa que se quer realizar. Por exemplo, ao dizer que queremos assistir TV, é necessário ligar o aparelho e sintonizar um canal; essa tarefa é um pouco diferente daquela realizada quando nos propomos a assistir um DVD, mas em termos operacionais a sequência de comandos é similar em ambos 
os casos. Como decorrência dessa operação, ao ligarmos o aparelho de TV para vermos um filme que está passando em determinado horário em um canal de filmes na TV a cabo, acreditamos haver uma distinção entre assistir a um filme na TV e não um DVD, embora a experiência como espectador seja essencialmente a mesma. Mas se esse filme estivesse disponível sob demanda em um serviço de pay-per-view, substituindo a mídia física do DVD, não fazemos a mesma distinção entre assistir a um filme na TV ou em DVD.

Quando vamos ao cinema, dizemos que fomos assistir a um "filme", há uma conotação de que o que se viu era a projeção de uma película, ou seja, um substrato que roda e é projetado na frente dos nossos olhos. Se a projeção for digital, essa película deixou de existir, mas não deixamos de ir ao cinema, nem de assistir a um filme. Neste caso, o filme como suporte ou mídia deixa de existir, mas a história, a narrativa, as imagens e os sons permanecem. A materialidade referenciada da mídia se esvai, enquanto o contexto social, eventual e sensorial permanece, pois, mesmo com a digitalização da mídia cinematográfica, ainda há uma diferença entre ir ao cinema e assistir a um filme e ver o mesmo filme em casa projetado em um home theater com características bastante próximas de uma diminuta sala de projeção de um cinema multiplex ${ }^{107}$.

A TV digital passa por processo similar: é possível receber a transmissão de um canal de TV no computador e assistir ao Jornal Nacional no PC, mas há uma percepção de que nesse momento não estamos assistimos TV, mas sim vendo a TV no computador. Na essência, é uma questão de apresentação ou "enquadramento", como ocorre com embalagens de produtos de consumo. Como acabamos de ver, embora um receptor de TV Digital se assemelhe a um computador e um monitor conectado a uma rede de dados,ainda há diferenças determinadas por aspectos físicos do aparelho receptor.

Com a digitalização, concretiza-se o fato de que a TV passa a ser um monitor, cujo receptor é um computador genérico ao invés de um circuito dedicado a uma função, e esse computador possui software (middleware), possibilitando realizar a tarefa de "assistir TV". Este "receptor", quando conectado a redes, também pode se comunicar bidirecionalmente permitindo a interatividade. O mesmo hardware e software de um aparelho de TV que recebem e decodificam sinais de TV Digital podem ser reconfigurados para acessar serviços

\footnotetext{
107 "Multiplex" é como se tem denominado os cinemas com múltiplas salas, muitas vezes resultado da conversão de uma grande sala de projeção em pequenas salas. Não se deve confundir com a forma de transmissão de vários fluxos de vídeo na TV Digital.
} 
de vídeo sob demanda na internet como o Net FlixHulu, TIVO. Inversamente, é possível utilizar um PC para assistir vídeos, em tempo real ou sob demanda, seja das emissoras, ao instalar-se uma placa receptora de TV Digital no PC, ou diretamente da internet. Esse mesmo computador pode gravar a transmissão, realizando-se assim o time shifting da programação televisiva e permitindo-se que um programa seja visto na hora em que se quiser, mudando radicalmente nosso relacionamento com a grade de programação de uma emissora. Serviços na internet como o You Tube estão revolucionando a maneira como o público tem assistido vídeos, permitindo aos usuários postar suas próprias produções, remixar programas de TV, resgatar vídeos do passado, mudando a autoria e pondo em xeque a indústria de produção e distribuição audiovisual. Em 2010, vídeos passaram a representar $51 \%$ do tráfego total de dados na internet nos EUA, ao passo que em 1995 representavam uma parcela próxima a zero (ODLYZKO, 2010, p.120).

\subsubsection{Identidade das mídias}

Ao deixarmos de associar o conteúdo audiovisual a uma mídia específica, uma questão que vem à tona é como manter a identidade dos produtores de conteúdo quando ele deixa de ter controle dos canais onde sua produção será distribuída. Com o estabelecimento da TV a cabo nos anos 1990 nos EUA, tornou-se cada vez mais importante que os canais de TV tivessem uma identidade visual forte de modo que se diferenciassem entre centenas de canais que surgiam. As redes de TV como NBC, CBS e ABC, que detinham $91 \%$ da audiência em 1979 (HOINEFF, 1991, p. 40), viram seus índices de audiência cair exponencialmente com a competição dos canais de TV a cabo. Estas buscavam estabelecer-se em nichos, com uma programação cada vez mais segmentada, desenvolvendo sua identidade com o objetivo de atingir seu público específico. Emissoras como a MTV passaram a trabalhar conceitualmente com a marca, de forma que o manual de identidade se torna abstrato - uma "consciência coletiva" de valores e atributos de uma marca que passa a definir um espaço, um segmento da mídia. Por exemplo, a moda define espaços nas cidades: ao vestir-se de uma determinada forma, cada indivíduo participa do espaço urbano de acordo com os signos embutidos na sua aparência. As interfaces gráficas têm este atributo e limitação; ao mudar a aparência de um site ou programa de TV,ele é posicionado em outro espaço social e cultural.

A importância da identidade visual encontrada pelos canais de TV transpõe-se para a 
internet, onde os desafios são cada vez maiores - com um click pode-se abandonar o site e estar em outro canal. A diversidade de programação encontrada na TV a cabo e a facilidade de mudar de canal ao utilizar-se um controle remoto passam a ser um desafio para as emissoras. Os canais de TV não são mais fixos no "dial", cada sistema pode organizar os canais de sua maneira, de modo que o canal 5 na transmissão terrestre pode passar a ser o canal 23 em um sistema de TV a cabo. Outro desafio que surge com a TV a cabo, além da necessidade de reter um telespectador que passa a "zapear" incessantemente entre canais, é o de se identificar instantaneamente quando o telespectador passa por um canal. Como resposta a esse problema, a MTV, ao lançar nos anos 1990 um novo canal de música, o VH1, introduziu o que apelidaram de "bug": a utilização do logotipo do canal como se fosse uma marca d'água sobreposta ao vídeo.

O termo "bug", que tem sua origem na percepção de que esta marca era como se fosse um inseto que pousou na tela de TV e ficava incomodando ${ }^{108}$ o telespectador, reflete a rejeição à prática encontrada no início, mas que hoje tem sido adotada por quase todos os canais de TV. Hoje, como os vídeos das emissoras de TV podem ser copiados e postados em lugares diferentes na internet, a aplicação dessa identificação tem importância renovada, sendo utilizada como recurso de marcar a autoria dos vídeos. Da mesma forma como fazendeiros marcam o gado $^{109}$ para que sejam reconhecidos caso pastem em outras propriedades, os proprietários dos direitos de imagem de conteúdo audiovisual "marcam" seus vídeos para que sejam identificados na internet.

A convergência das mídias traz desafios não só para a identidade dos produtores de conteúdo como os que surgiram com a TV a cabo e continuaram com a web; ela traz também a questão da identidade das mídias em si, que passam a perder a identidade que era definida pela sua materialidade: um jornal era identificado como tal por ser impresso em papel jornal, uma revista por ser encadernada de uma determinada forma, um vídeo pelo formato do cassete (U-Matic, VHS ou Betamax), um filme pela bitola da película (Super 8, 35mm ou $16 \mathrm{~mm})$ e assim por diante. Uma opção é representar mídias analógicas através de ícones e símbolos que representem seu legado analógico, mas tal prática tem suas limitações ao

\footnotetext{
108 A expressão "bugging" em inglês significa: importunar, incomodar.

109 O termo "Branding" tem sua origem nessa prática dos fazendeiros de marcar o gado com um ferro moldado no formato de suas iniciais.
} 
considerar-se a introdução de novas mídias como as que unem a TV com redes sociais.
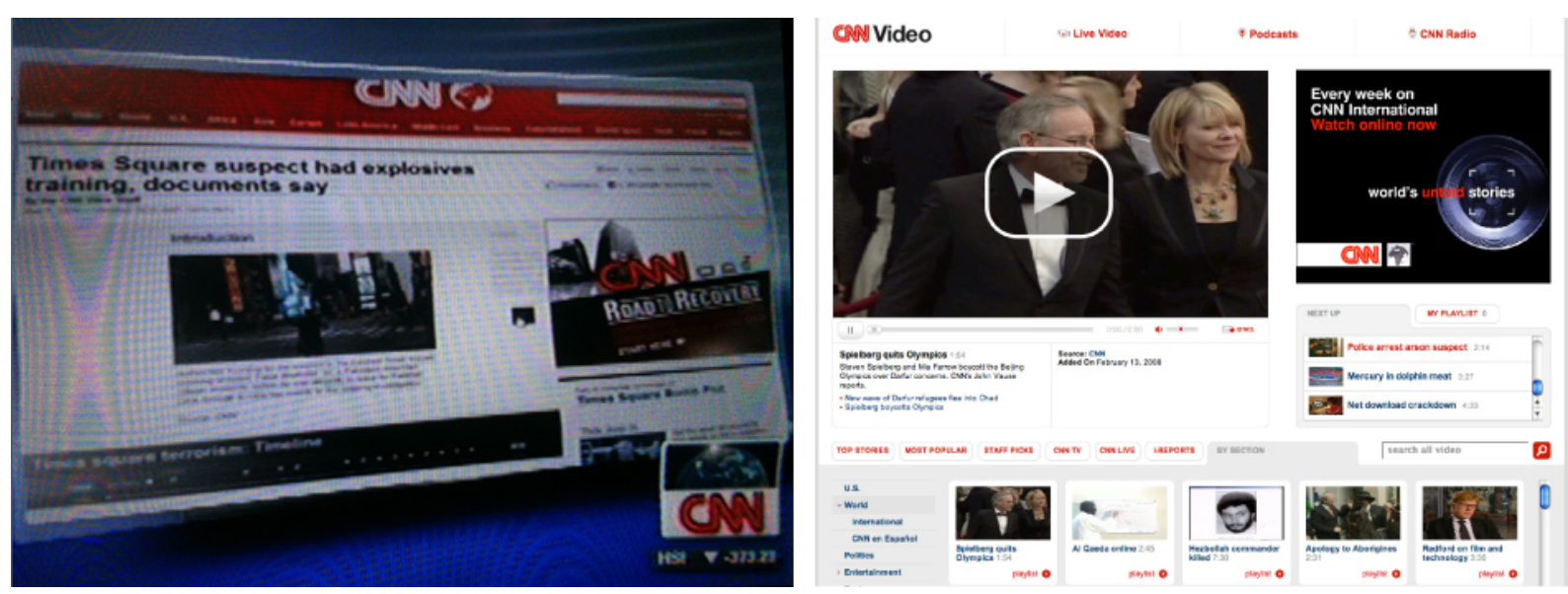

Fig. 4.2: Frame da transmissão da rede de TV CNN e do website CNN.com

A rede de TV CNN destaca notícias do site www.cnn.com, enquanto o site da CNN disponibiliza a transmissão de TV ao vivo e possibilita buscar vídeos ou procurar notícias por editorias.

Fonte: www.cnn.com

As novas mídias resultantes da convergência digital, ou "remediadas", ainda estão em fase de maturação, e portanto poucas possuem referências que podem ser incorporadas em sua identidade. Serviços como You Tube e Facebook deixam de ser simplesmente sites na web e se transformam em plataformas na web; por enquanto suas interfaces ainda seguem os padrões de navegação de um site e utilizam players que simulam os controles de um DVD ou um videocassete, permitindo que o usuário assista a um vídeo. Mas com o tempo a relação que o usuário faz entre tocar um vídeo e um aparelho originalmente dedicado a este fim deixa de ter importância, pois essas referências ficam cada vez mais abstratas. Serviços que permitem assistir a vídeos ou compartilhar imagens passam a ser oferecidos em novos dispositivos, como telefones celulares, smartphones, a navegação e a interface passam a ser diferentes da web, definindo mídias que tendem a buscar uma identidade.

\subsection{Definindo a experiência de assistir a TV}

O que é assistir TV? Uma postura, uma situação? Ao tratar-se da identidade das mídias audiovisuais, é crucial definir a experiência de se assistir TV. Podemos considerá-la uma atividade relacionada ao conteúdo e à tecnologia empregada. O conteúdo são os gêneros de programação que encontramos; a tecnologia, a forma de comunicação audiovisual a 
distância (do grego tele -"distante" e do latim visione -"visão"). O televisor capta as ondas eletromagnéticas e as converte em imagens e sons; já a TV Digital decodifica imagens e sons modulados que são convertidos em bytes, sequências binárias que representam essa informação e que por meio de um tradutor é remodulada, produzindo imagens em um monitor e sons em um alto-falante.

Com a digitalização, os "dispositivos midiáticos" deixam de ter importância. Temos que nos basear em representação e metáforas. No caso da TV, uma forma de resolver este problema é esquecer o aparelho e pensar no objetivo, ou na ação que se pretende realizar (NORMAN, 2010). Retomemos o exemplo apresentado anteriormente, quando distinguimos entre assistir a um filme na TV acessado por diferentes mídias - TV a cabo, DVD - e sob demanda na internet. Nos três casos, verificamos que o telespectador, ao assistir ao mesmo filme em uma tela (monitor) a qual denomina TV, cujos sons e imagens são codificados pelo mesmo algoritmo de compressão (por exemplo MPEG), realiza uma distinção desta atividade em função da mídia de distribuição do filme, ou seja, o aparelho de reprodução da mídia conectada à TV: STB, no caso da TV a cabo, aparelho de DVD e um computador, no caso do filme baixado da internet.

No entanto, caso o usuário não tenha realizado as conexões físicas desses aparelhos com a TV, a mídia só é evidenciada pelo fato de comandá-la por um controle remoto e menus criados especificamente para cada mídia (assumindo que o disco do DVD já estava inserido no leitor ótico). Isso nos leva a concluir que a distinção entre as três possíveis formas de se consumir um mesmo conteúdo audiovisual é definida muito mais pela interface entre o usuário e a mídia do que pelos aspectos físicos de cada mídia. Assumindo que hipoteticamente se pode criar uma interface com uma identidade consistente para um suposto "menu" que permitiria escolher as cenas ou configurar o áudio desse mesmo filme (por exemplo, TV Digital Interativa, IPTV e DVD), e que os dispositivos de reprodução estivessem todos incorporados em um mesmo aparelho, a mídia em si deixa de ter uma identidade dependente de suas características materiais e permanecem apenas os aspectos representacionais. O que resta então para o espectador, neste caso, é a experiência de assistir a TV ou especificamente a um filme na TV. 


\subsubsection{HDTV e percepção de resolução (Killer application da TV Digital?)}

No processo de definição do padrão de TV Digital nos EUA, os broadcasters ${ }^{110}$ defendiam que o "Killer Application" da TV Digital seria a High Definition Television HDTV, a TV de altadefinição. Essa posição era favorável aos interesses das emissoras afiliadas à NAB, pois justificavam os custos da implantação e as favorecia na competição com as operadoras de TV a cabo e empresas de telecomunicações que entravam no mercado de TV(DIZARD, 2000).

Em 1993, Negroponte inicia sua coluna no primeiro número da revista Wired com a seguinte afirmação: “A TV de Alta Definição é claramente irrelevante. Quando você olha para a TV, você se pergunta. O que está errado ? A resolução da imagem?Claro que não. O que está errada é a programação."111 (NEGROPONTE, 1993)

Ao reler essa coluna quase vinte anos depois, vemos que HDTV não foi justificativa suficiente para os norte-americanos trocarem seus aparelhos de TV analógicos por digitais; em 2009, ano em que todas as emissoras cessaram suas transmissões analógicas, uma grande parcela dos lares norte-americanos não havia feito a transição. Um dos motivos é que grande parte dos lares contrata serviços de TV por assinatura via cabo ou satélite, e mesmo que os set-top boxes sejam digitais eles possuem saídas analógicas, permitindo que os telespectadores continuassem usando monitores analógicos. Para aqueles que não compraram um novo televisor digital, o governo ofereceu cupons que podiam ser trocados por conversores da TV Digital (ATSC) para aparelhos analógicos (FCC, 2008).

A Copa do Mundo de 2010 foi a primeira em que os brasileiros puderam assistir aos jogos em alta definição; embora consumidores já tivessem comprado TVs de LCD ou plasma, muitos nunca haviam visto imagens de alta definição em seus aparelhos. Os que viram se impressionaram com a qualidade da imagem, mas é discutível se isso é razão suficiente para trocar de aparelho; fatores como a menor profundidade da tela, menor peso do aparelho

\footnotetext{
${ }^{110}$ As principais redes de TV nos EUA. ABC, CBS e NBC e suas emissoras afiliadas, estão representadas pela NAB National Association of Broadcasters, o termo Broadcasters, quando utilizado no âmbito da TV, refere-se a este grupo e o lobby que representam em termos de legislação da telecomunicações e rádiodifusão nos EUA.

111 Tradução do autor do texto original em inglês: "High-definition television is clearly irrelevant. When you look at television, ask yourself: What's wrong with it? Picture resolution? Of course not. What's wrong is the programming. “
} 
também pesam na decisão de troca.

A questão da percepção da resolução em pixels pelos telespectadores tem sido foco de estudos, como um publicado na revista New Scientist (JOOR; BEEKHUIZEN;VAN DE WIJNGAERT; BAAREN, 2009); nele, pesquisadores compararam as impressões de vários telespectadores ao assistir vídeo de qualidade standard e de alta resolução em um mesmo monitor de HDTV. O estudo conclui que muitos dos sujeitos não perceberam a diferença de qualidade da imagem. Esses resultados reforçam as projeções de Negroponte (1993) quando afirma que "HDTV é irrelevante".

No Brasil, durante o processo de especificação do SBTVD, as redes de TV defendiam a TV de alta definição (HDTV) pelos mesmos motivos que os broadcasters norte-americanos, entre eles o ganho de espectro (CRUZ, 2008). O governo, por sua vez, defendia que a TV deveria ser um instrumento de inclusão digital; consequentemente, essa discussão proporcionou ganhos para o SBTVD, que não só contempla HDTV, mas a transmissão para dispositivos móveis, comunicação com outras plataformas e a interatividade em uma plataforma aberta (Ginga). Uma das promessas da TV Digital no Brasil sempre foi a interatividade, mas sua implementação ainda engatinha. Negroponte (1993) sugere que, para que a TV Digital suceda, ela deve inovar em sua programação, e essa inovação vem do fato de a TV ser digital. É com base nessa premissa que devemos pensar a interatividade e o design de interfaces para a TV Digital, no entanto, a implementação da interatividade em TVDI ainda está pautada em paradigmas ultrapassados, como será discutido mais adiante neste capítulo.

É necessário inovar em programação, novas formas de "entrega" e personalização de conteúdo. Tudo isto pode ser derivado do fato de ser digital. O noticiário das $18 \mathrm{~h} 00$ poderá não só ser "entregue" quando você quiser, mas poderá ser editado por você e acessado aleatoriamente por você. Se o telespectador quer assistir a um filme antigo do Humphrey Bogart às 20h17, a empresa de telefonia irá providenciar isto através de um par de fios de cobre. Eventualmente, ao assistir a um jogo de beisebol, será possível fazê-lo de qualquer assento do estádio, ou desta maneira da perspectiva da bola de beisebol. Isto será uma grande mudança. ${ }^{112}$ (NEGROPONTE, 1993)

112 Tradução minha do original em inglês:

"What is needed is innovation in programming, new kinds of delivery, and personalization of content. All of this can be derived from being digital. The six-o'clock news can be not only delivered when you want it, but it also can be edited for you and randomly accessed by you. If the viewer wants an old Humphrey Bogart movie at 8:17 pm, the telephone company will provide it over its twisted-pair copper lines. Eventually, when you watch a baseball game, you will be able to do so from any seat in the stadium or, for that matter, from the perspective of the baseball. That would be a big change." 
O que Negroponte propõe é uma realidade hoje, mas a forma de realizá-la ainda é muito fragmentada e complexa; os serviços de vídeo sob demanda funcionam bem em plataformas dedicadas como Apple TV. Serviços como o Hulu demonstram que isso está mudando, e que já é possível assistir vídeo sob demanda na internet com qualidade bastante razoável; não é $\mathrm{HD}$, mas, como foi dito, dada a opção de se personalizar o conteúdo, a resolução menor do vídeo pode ser irrelevante para o telespectador. No entanto, devem-se considerar as dificuldades encontradas pelos usuários ao realizar conexões físicas dos aparelhos conectados à sua TV, dificuldade que encontramos desde que começamos a conectar aparelhos de videogame e videocassete à televisão. Uma das grandes dificuldades é navegar em menus incompreensíveis para muitos usuários e que são necessários para acessar novas funcionalidades incorporadas nos aparelhos. Funções como programar canais favoritos ou agendar a gravação de um programa acabam sendo abandonadas pelo consumidor, que termina optando por somente realizar as funções mais básicas como mudar de canal e aumentar o volume.

Muitas vezes o consumidor, ao comprar um aparelho de HDTV, não se dá conta de que na realidade ele está adquirindo um monitor que pode ser conectado a diversos serviços digitais, como a internet, TV a cabo, via satélite, consoles de videogames, DVDs e Blu-Ray. No caso de o aparelho não possuir um receptor de TV Digital incorporado, podemos especular que o telespectador opte por receber o sinal de outras fontes, em vez de receber a transmissão de HDTV das emissoras de TV Aberta. Podemos assumir que esse aparelho, que foi adquirido com o propósito de servir como um aparelho de TV de Alta Definição, acaba sendo muito mais utilizado para assistir à programação da TV Analógica, conteúdo acessado da internet e outras formas de entretenimento que mesmo em baixa resolução passam a competir com a programação da TV Digital.

\subsubsection{Social VS Individual}

Essa multiplicidade de usos dos monitores de HDTV aponta para a entrada do computador na sala de estar - o centro social de uma residência, assim como nos bares e em outros espaços públicos. Não que isso já não esteja ocorrendo com a presença crescente de 
dispositivos inteligentes móveis, laptops, tablets, smartphones e games portáteis nesses espaços. No entanto, esses dispositivos são de uso individual, já a TV é uma mídia com a qual nos relacionamos em grupo $^{113}$; quando o computador passa a ser utilizado coletivamente, há a necessidade de interfaces adequadas para essa interação, o que não é o caso dos sistemas operacionais dos PCs e celulares, cujo modelo de interação é inadequada para esse tipo de utilização pois focam no indivíduo, mesmo que esteja conectado a outros virtualmente através de redes de comunicação.

Em relação aos aspectos da interação de grupos de indivíduos com computadores, videogames que utilizam múltiplos controles remotos, permitindo que vários jogadores interajam na mesma tela, podem indicar um caminho a ser considerado ao se desenvolverem interfaces para múltiplos usuários em um ambiente com um único aparelho de TV Digital. Um outro aspecto do qual não podemos nos esquecer é a relação com o prazer que buscamos ao utilizar e assistir mídias eletrônicas como a TV e videogames. As interfaces para interagir com a TV Digital não só devem considerar as possibilidades advindas dos avanços tecnológicos e a inclusão de múltiplos usuários, como também que a essência da TV é entretenimento e não deve assemelhar-se ou tornar-se um trabalho.

\subsubsection{Novo paradigma da TVDI}

Até recentemente, os parâmetros utilizados nos requisitos de projetos de interfaces gráficas para a Televisão Digital Interativa - TVDI ${ }^{114}$ supunham que no Brasil o modo de produzir programas de TV Interativos para o Sistema Brasileiro de TV Digital (SBTVD) seria muito próximo daqueles apresentados por Gawlinsky (2003) em seu livro Interactive Television Production, obra que tem sido adotada por produtores e designers ao desenvolverem programas de TV Interativa para a plataforma $\mathrm{MHP}^{115}$.Esses mesmos parâmetros definiram inicialmente o escopo desta pesquisa, ao propor o desenvolvimento de

\footnotetext{
${ }^{113}$ Embora também se possa assistir TV individualmente e em muitos lares existam aparelhos em diversos cômodos, a TV tem um caráter coletivo nas famílias brasileiras.

${ }^{114}$ Como por exemplo o RFP (Request for Proposals) do CPqD para o consórcio TAR do SBTVD. Participei como designer de interfaces para TVDI junto à Escola do Futuro da USP, onde a obra de Gawlinky (2003) foi adotada como principal referência.

115 MHP é a especificação multimídia do DVB, padrão europeu de TV Digital, para a qual desde o final dos anos 1990 tem-se produzido uma gama de programas interativos como os apresentados no capítulo 3.
} 
interfaces gráficas para a TV Digital em um momento em que se estava definindo o SBTVD. Com a consolidação do You Tube e a introdução de novos serviços de TV via internet como o GoogleTV e Hulu.com, os parâmetros que guiavam o desenvolvimento de programas interativos para a TV Digital passaram a representar limitações a estes projetos, que não levavam em consideração que hoje a experiência de assistir TV não está necessariamente associada a um equipamento receptor projetado especificamente para esse fim.

$\mathrm{O}$ atual paradigma da interatividade na TV- interfaces sobrepostas à programação e manipuladas por um controle remoto - não tem despertado o interesse pela interatividade prevista na TV Digital. Este desinteresse pela interatividade na TV não será em parte uma limitação do dispositivo de controle? O celular é bem mais limitado em sua operacionalidade, o que no entanto não impediu o desenvolvimento de formas interativas em plataformas móveis, aspecto que consequentemente acabou despertando o interesse da indústria em adotar pesquisas de ponta no campo do design de interfaces, como a incorporação da manipulação direta na interface do iPhone da Apple.

\subsubsection{Novos paradigmas tecnológicos}

Os novos monitores de HDTV de alta definição e progressive scan estão cada vez mais próximos e chegam a superar a resolução dos monitores de computadores pessoais PCs. Como foi apresentado anteriormente, com a digitalização da TV os STBs passaram a ser microprocessados e, em alguns casos, equipados com Hard Drives - HDs, discos rígidos que com sua capacidade de armazenamento de vídeo permitem incorporar a funcionalidade de Digital Video Recorder (DVR) nos STBs. Desde 2009, estão sendo lançados Internet Enabled Set-Top Boxes (IESTBs) e Internet Enabled TVs (IETV), possibilitando o acesso à internet diretamente da TV, e se considerarmos outras formas de conectividade como Bluetooth, USB e Wi-Fi, temos um sistema muito próximo do computador pessoal, que permite personalizar a configuração do sistema. Segundo Negroponte (1993), "Ao se transferir a inteligência de um sistema de TV do transmissor para o receptor, a diferença entre uma TV e um Computador Pessoal passa a ser negligenciável". ${ }^{116}$

\footnotetext{
116 Tradução minha para o original em inglês: "As intelligence in the television system moves from the transmitter to the receiver, the difference between a TV and a personal computer will become negligible." (NEGROPONTE, 1993)
} 
Neste cenário tecnológico se estabelece um novo paradigma da TV Digital, no qual se define a experiência de se "assistir TV" pela atitude do telespectador, em vez do hardware utilizado para "assistir TV". Este novo paradigma deve nortear os requisitos em um projeto de design de interfaces que permita a interatividade do telespectador com a TV Digital e não as especificações de um determinado sistema, que pode tornar-se obsoleto em pouco tempo. $\mathrm{O}$ design deve ter como objetivo a experiência da interatividade e o que podemos fazer diante de uma TV no contexto da convergência das mídias, e não resolver graficamente telas de menus de navegação cuja funcionalidade é imposta por uma tecnologia que foi definida por interesses contrários à convergência das mídias.

No paradigma anterior, em que a TV era atrelada a um hardware - um equipamento eletrônico construído para um fim específico -, assumia-se que o aspecto interativo seria secundário à atividade de se assistir TV. Mesmo que houvesse interatividade, não se questionava se o usuário estava assistindo TV ou usando um computador, pois se assumia que a atividade principal era a de assistir, já que ela é definida pelo aparelho. No paradigma atual, ao receber a transmissão da TV Digital terrestre em um PC, pode-se assumir que o usuário está "acessando" a TV em um PC. No entanto, se o mesmo computador estiver conectado de forma "transparente" a um monitor de TV e se o usuário utilizar um controle remoto para mudar os canais, é bastante provável que esse usuário tenha a percepção que está assistindo TV em vez de achar que está "vendo a TV em um computador".

Existem hoje no mercado norte-americano soluções que tornam essa proposição possível, como o programa Boxee, que consolida em uma interface gráfica arquivos de mídia, IPTV e serviços web, minimizando os aspectos "computacionais" do PC e criando um "ambiente" de entretenimento que permite acessar os arquivos de mídia no PC (SWEDLOW, 2010), streaming de programas de TV via web e realizar o download de filmes disponíveis na internet através de serviços como o NetFlix ${ }^{117}$.No entanto, uma das principais dificuldades encontradas na prática ao utilizar uma solução como essa é a necessidade de configuração por parte do usuário, inibindo o uso dessa solução por um grande número de usuários que tem menos facilidade ou paciência para lidar com as complexidades impostas por uma tecnologia pouco "amigável” (user friendly).

\footnotetext{
${ }^{117}$ Mais informações sobre este serviço e parcerias podem ser encontradas no site do fabricante: $<$ http://www.netflix.com>, acesso em: 5/7/2010.
} 
Os sistemas de TV Digital como SBTVD, ATSC, DVB (DTV, 2008) assumem que a plataforma televisiva deve ser robusta e simples, as aplicações interativas rodam sobre um middleware, permitindo uma padronização do hardware e minimizando os "glitches", pequenos conflitos e erros gerados pelo sistema operacional ou software (GORIUNOVA; SHULGIN, 2006). Essas falhas momentâneas, comuns nos softwares de computadores, acabam sendo aceitas pelos usuários como um aspecto intrínseco da tecnologia digital. A ideia do middleware é a de preservar as características dos aparelhos eletrônicos que até recentemente não estavam sujeitos a esse tipo de falhas durante sua operação. Do ponto de vista do telespectador, espera-se uma experiência bastante objetiva em relação à utilização do equipamento onde se assiste um programa de TV: deve-se buscar que haja um mínimo de configurações para se utilizar o sistema, o usuário deve poder ligar a TV, mudar de canal e ajustar o volume de uma forma simples e direta. No novo paradigma, corre-se o risco de esses glitches serem constantes, frustrando o espectador.

No paradigma anterior, com a introdução do set-top box como parte integrante do sistema, e a decorrente necessidade de realizar tarefas como selecionar a entrada de vídeo, utilizar múltiplos controles remotos e conectar cabos entre diversos aparelhos, o telespectador depara-se com uma situação razoavelmente complexa para realizar uma tarefa tão simples quanto assistir a um programa de TV. No novo paradigma, o sistema torna-se ainda mais complexo. O designer de interfaces deve compreender que seu papel passa ser também o de um facilitador dessa experiência.

O SBTVD, da forma como foi estabelecido, e seu middleware Ginga parecem suficientemente abertos para incorporar essas mudanças, como vemos através de pesquisas que permitem utilizar o Ginga em dispositivos móveis (CRUZ; MORENO; SOARES, 2008). Não sabemos exatamente quais serão as mudanças que podem ocorrer ou deixar de ocorrer devido às forças que dominam o mercado, onde por um lado temos a indústria do audiovisual com as emissoras e produtoras e de outro temos a indústria da computação e software. Entre elas temos as empresas de telefonia, operadoras de TV a cabo e satélite provendo novas possibilidades de acesso ao conteúdo audiovisual.

\subsubsection{O diálogo das mídias}

Neste cenário de convergência, onde as grandes mídias dialogam, o design de 
interfaces é fundamental como facilitador deste diálogo. Para que isto ocorra, é necessário que o designer compreenda as transformações tecnológicas e incorpore no projeto as mudanças de paradigmas que vêm com essas transformações. As expectativas dos telespectadores em relação às mídias também mudam neste cenário, pois passam a ser usuários podendo participar ativamente em uma rede de comunicação. Nas redes com as quais os usuários já têm contato através do celular, games e internet, já se está criando o hábito da interação com as mídias por meio de interfaces bastante complexas. O design de interfaces para TV Digital deve não apenas facilitar o acesso à tecnologia, contribuindo para a usabilidade da TV, mas permitir a interatividade do telespectador como participante do processo. Para isso, deve olhar para inovações nas interfaces das outras mídias e propor caminhos, já que, para que não haja ruído nesse diálogo, essas interfaces devem ser transparentes e simples, de modo que cumpram seu papel sem interferir na mídia e no diálogo.

\subsection{Controles e interfaces}

No início da história da TV, fabricantes de aparelhos receptores de TV nos EUA como a RCA e Dumont também produziam programas de TV. Uma matéria na revista Business Week especulava que a Dumont passou a produzir programas como forma de incentivar a venda de seus aparelhos. A empresa acabou fechando as suas portas em 1955 diante da competição das emissoras de rádiocomo a RCA, NBC e CBS, que eventualmente se estabeleceram como as três redes de TV que dominaram o mercado televisivo nos EUA por décadas (AUTER; BOYD, 1995). Embora o controle remoto já existisse desde os anos 1950, a sua invenção na época não parece ter tido um impacto significativo na competição das três redes, que disputavam entre si a frequência de VHF (canais 2 a 13). O grande impacto do controle remoto ocorreu nos anos 1980 e 1990, com o advento da TV a cabo, que, ao oferecer centenas de canais, promoveu uma transformação radical nos hábitos dos telespectadores.

Esse período de crescimento da TV a cabo coincide com a popularização do videocassete, dos videogames e com a introdução dos computadores pessoais para uso doméstico, que em grande parte foi propulsionada pela facilidade de operação promovida pelas interfaces gráficas e o mouse. O controle remoto como dispositivo de comando que permite a troca de canais e o ajuste de volume cumpria sua função no contexto da TV a cabo, 
mas passa a ser bastante limitada a outras atividades que começam a ser realizadas na TV como a operação de videogames que dependiam de controles projetados especificamente para os jogos. A introdução, nos anos 1990, de novas plataformas que permitiam a interatividade na TV, como a WebTV da Microsoft, dependia da utilização de novas formas de comando como um teclado sem fio para acesso a e-mail.

Com a oferta da indústria da telefonia celular de uma gama de possibilidades de interação em uma plataforma miniaturizada, há uma aceitação pelo usuário da hibridização do uso do teclado telefônico como forma de comando e entrada de dados através utilização das teclas do telefone e de sua equivalência alfanumérica, como é o caso de sua utilização para o envio de mensagens SMS, jogos, acesso a serviços de dados e a operação de funções introduzidas nos aparelhos celulares como fotos, agenda, despertador etc. Poderia prever-se que a hibridização do uso das funções das teclas do controle remoto passasse a ser aceita como decorrência da prática encontrada no uso dos celulares.

No entanto, o controle remoto torna-se cada vez mais limitado para desempenhar o comando das funções advindas da extensão da capacidade da TV ao convergir com novas plataformas de entretenimento. Um dos motivos talvez seja a necessidade de se utilizarem controles simples na TV, em razão de a natureza da atividade ser passiva, mesmo que as tarefas que se propõe realizar na TV passem a ser cada vez mais complexas. O que ocorre é justamente o inverso: os controles remotos tornam-se gradativamente mais complexos, não há padronização como nos teclados dos celulares, as informações dos menus apresentadas na tela são de difícil navegação. Essa situação não é condizente com a atividade do telespectador, que tem a expectativa de ligar a TV, reclinar no sofá, assistir TV, um video ou jogar um game. Esse talvez seja um dos maiores dilemas da indústria neste momento e um grande desafio para os designers.

\subsubsection{Design e plataformas abertas - dispositivos midiáticos híbridos}

Até recentemente, os meios de recepção de mídias analógicas requeriam conteúdos específicos para cada dispositivo, mais que isso, esses dispositivos eram projetados para realizar uma função específica, por exemplo, uma TV era projetada para receber e exibir programas de TV, um telefone somente possibilitava realizar conversas telefônicas, um cinema permitia projetar filmes, um jornal para ler notícias, o correio para mandar cartas e 
assim por diante. A troca de informação e a difusão de ideias dava-se por canais específicos e a mensagem era codificada da forma mais eficiente para cada meio de comunicação.

Hoje, os dispositivos de recepção mediática têm suas funções mutáveis por software, cuja operação na maioria dos casos ocorre através de interfaces gráficas projetadas por designers que não estão envolvidos nem com a especificação do software pelos engenheiros, nem com o designer de produto que resolve as linhas externas de um aparelho midiático como uma TV. Esses designers raramente se envolvem com a relação do usuário e a tecnologia, muito menos com um aspecto importante na utilização do produto que estão projetando: o conteúdo midiático. Os programas, softwares e games são o objetivo final da utilização de um aparelho de mídia eletrônica e definem a experiência da utilização por parte dos usuários.

O processo de produção de conteúdo audiovisual e interativo envolve engenheiros, programadores, roteiristas e designers, mas na maioria dos casos não há uma integração dos participantes do desenvolvimento de conteúdo com os desenvolvedores das plataformas onde serão mediados esses conteúdos. Por exemplo, no caso da produção de programas de TV, vemos o designer gráfico e o cenógrafo desenvolverem uma ambientação para esse conteúdo através de vinhetas, tipografia, grafismos e cenários. Com esses elementos o designer cria a identidade de um programa ou canal de TV, com a interatividade surgem novos aspectos do design que fazem parte do produto como a identidade de um canal no EPG e os menus de navegação de um aplicativo para celular relacionado ao programa de TV; o conjunto desses elementos passa a constituir o design total do produto TV.

Até recentemente, o envolvimento de um designer com o conteúdo de uma mídia eletrônica estava refém da tecnologia implantada e servindo usualmente à narrativa, portanto raramente era possível interferir na tecnologia. Nas artes plásticas, vemos um pioneirismo neste sentido na obra do artista coreano Nam June Paik (MARTIN, 2006) que, ao colocar ímãs em um aparelho de TV, distorce as imagens na tela e mais tarde utiliza sintetizadores para interferir na imagem transmitida. A arquitetura, ao dominar a tecnologia da construção, passa a poder interferir no espaço construído de modo que expresse ideias e conceitos, desafiando os materiais e a natureza.

A partir do momento em que o software define a função do hardware e as mídias estão digitalizadas, o designer ganha um novo papel que vai além dos aspectos formais do objeto, seja ele bidimensional ou tridimensional, estanque ou sujeito a alterações temporais. Bill Moggridge (2007), designer e sócio do estúdio de design IDEO, relata em seu livro Designing 
Interactions que, após completar o projeto de um dos primeiros computadores laptop, ele teve a chance de utilizar o produto pronto pela primeira vez. Nesse momento, ele percebeu que existia uma outra dimensão do produto que transcendia o design, a ergonomia e a funcionalidade do produto, uma dimensão totalmente virtual: ele referia-se ao sistema operacional do laptop e aos programas que rodavam nele, os quais possibilitavam realizar diversas tarefas independentes daquelas incorporadas ao objeto que haviam desenvolvido. A interface gráfica e os softwares instalados possibilitavam uma experiência que transcendia a forma do objeto e permitia múltiplas funcionalidades.

\title{
4.4.2 Narrativas e metáforas, o design de dispositivos mediáticos
}

Hoje não basta mais o designer de um produto interferir e solucionar a forma de um objeto com base na função deste; um telefone celular pode ser em alguns instantes uma câmera fotográfica e noutros um tocador de música. O designer passa a estar envolvido em uma narrativa, na qual se possibilita ao usuário ter uma experiência com um objeto, com o objetivo de se realizar algo. Por isso, o designer tem um papel semelhante ao de um arquiteto, no sentido em que deve buscar resolver sistemas complexos e apresentá-los de modo familiar e compreensível ao usuário. Este, por um lado, deseja que a tecnologia seja transparente, ou seja, que ela não interfira na sua utilização. Nós vivemos e utilizamos nossas casas sem ter que nos preocupar com os métodos empregados em sua construção, mas por outro lado devemos "compreendê-la" de modo que sejamos capazes de manter e transformar nosso espaço construído.

No caso das novas tecnologias baseadas no "binômio" hardware/software, existe uma curva de aprendizado para se utilizar uma função específica. Por mais intuitiva que a interface de um celular seja, dificilmente conseguimos utilizar a câmera fotográfica que está embutida nele sem que leiamos alguma instrução; em comparação, para utilizar uma câmera instamatic, bastava girar uma manivela e apertar um botão para tirar uma foto. Para exemplificar, vejamos que funcionalidade da câmera em um celular pressupõe uma narrativa e diálogos entre o equipamento e o usuário, como este:

\author{
(desbloquear) \\ - O que você quer fazer? \\ - Tirar uma foto
}


O desenho de uma máquina fotográfica reflex surge no canto superior da tela.

Você demora para tomar uma ação e a câmera diz:

- Esperando.

Ao pressionar uma tecla, surge na tela a pergunta:

- Continuar? Ajuda? Sair?

Você decide continuar e o celular pergunta:

- Definir como papel de parede? Renomear a imagem? Definir como imagem de chamada de um contato?

Você responde:

- Designar a contato.

- Qual contato?

Você muda de ideia e aparece uma figura representando um envelope, uma seta sobre um globo e uma lata de lixo, você escolhe a lata de lixo e a câmera pergunta:

- Excluir?

Você responde:

- Sim.

Neste momento, você se despede da máquina fotográfica, que desaparece dizendo: -Bye, bye.

O celular antes de adormecer aproveita para lhe dizer:

-São 19:44, não há nenhuma mensagem nova no seu telefone, mas no seu Gmail existem três "cartas" eletrônicas.

A tela do celular escurece e a imagem de um envelope com o numero 3 estampado fica piscando ocasionalmente.

Como vemos nessa narrativa, uma sequência de ações e diálogos possibilita ao usuário utilizar o celular como uma máquina fotográfica, enviar a foto para alguém ou mesmo guardála na sua agenda telefônica para lembrar de um amigo. Nesse caso, o usuário decidiu jogar a imagem no lixo e ignorou a chegada de e-mails na caixa postal, mesmo assim o celular irá continuar avisando-o que ele não foi abrir sua caixa de correio.

Esse exemplo ajuda a explicitar como uma narrativa define um produto que está dentro de um sistema complexo. Para que esse sistema seja compreensível, ele depende da representação de ações conhecidas e que fazem parte de nossa cultura. Com isso criamos repertórios que nos permitem realizar ações; os designers utilizam o repertório para transformar a tecnologia, ou melhor, o código/software em um produto, nesse caso uma câmera. No caso, o usuário recebeu três e-mails representados por um envelope; o que 
ocorreria se em determinada cultura ou mesmo no futuro envelopes deixassem de representar a forma de enviar mensagens de texto a distância?

\subsubsection{Software e cultura}

Como um designer resolverá a funcionalidade de um produto se os códigos de outra cultura não permitirem a compreensão de uma narrativa? Ou mesmo o que irá acontecer se na nossa cultura perdermos nossa herança histórica? Na narrativa que acabo de descrever, utilizava-se a imagem de uma máquina fotográfica para representar que naquele momento se estava tirando uma foto; em outro momento, apareceu um envelope onde poderíamos colocar a foto para enviá-la a alguém. O que nos faz levantar a seguinte questão: será que uma criança que não conhece uma máquina fotográfica não sabe que está utilizando uma máquina fotográfica no celular? Aparentemente ela é curiosa o suficiente para prosseguir na narrativa e apertar um "botão" (que também pode ser virtual) e "tirar uma foto"; então essa criança irá associar essa ação que resulta em uma imagem estática a um ícone que se assemelha a uma câmera fotográfica dos anos 1960 que quem sabe um dia irá conhecer em uma feira de antiguidades.

Vejamos que software requer narrativas, de modo que ele venha a interferir em nossa realidade. Estes pequenos scripts armazenados no software traduzem diversas funções, e eles são os módulos através dos quais um designer pode construir um programa e um programa pode substituir um objeto, como um despertador, uma câmera ou um gravador. No caso da $\mathrm{TV}$, que é um objeto que possibilita receber narrativas por excelência, uma das primeiras perguntas é: o telespectador quer interferir nestas narrativas e em qual nível?

O telespectador que passivamente assiste a um programa TV se deixa não só levar pela narrativa, mas permite que o meio "defina" sua imaginação. Assim como no cinema, a TV "define" o mundo desta narrativa, nela os personagens têm cara, cor e entonação, os ambientes têm forma, luz e se caracterizam como espaço. Ao passo que em um livro e mesmo no teatro, ainda há muito espaço a ser construído pela imaginação. No entanto, para chegar a este espaço passivo e se submeter a uma narrativa, o espectador teve que tomar certas decisões como ligar a TV, escolher um canal, posicionar-se em uma sala e assumir uma atitude, seja uma que exige uma atenção parcial como a de quem assiste ao telejornal no fundo enquanto realiza outra tarefa, ou coletivamente com amigos ou em família ao assistir à 
novela ou a um jogo de futebol.

A TV de modo geral é uma atividade social: o espectador pode ser passivo em relação à mídia, mas ele é ativo em seu espaço real ao interagir com outros espectadores. Esta interação pode ser síncrona, ao torcer e fazer comentários durante um jogo de futebol, ou assíncrona, ao comentar um capítulo de novela ou seriado após a sua exibição. No caso do cinema, uma das diferenças dos aspectos sociais da TV é que, embora a sala de exibição seja coletiva, a experiência é individual, pois há uma imersão total do espectador.

Com as novas mídias digitais, a distinção entre o consumo dessas formas de entretenimento passa a ser definida muito mais pelo tipo de experiência e a relação espacial com a mídia do que com a tecnologia de exibição ou o dispositivo em si. Ou seja: ao escurecer uma sala e ficar em silêncio durante 120 minutos, pode-se assumir que se está assistindo a um filme, seja em um cinema, na sala de estar ou em um avião. Ao assistir a um jogo de futebol, seja em um telão como o de um cinema, no celular ou no ônibus, se está assistindo TV. E finalmente, quando duas pessoas conversam utilizando vídeo no Skype, através do computador que está conectado ao mesmo cabo que serve para receber TV, se está realizando uma conversa telefônica, mas se uma destas pessoas utiliza a mesma webcam usada para conversar no Skype e grava vídeos descrevendo seu cotidiano e os "posta" no justin.tv ou u-stream, ele está transmitindo um programa de TV.

Portanto, hoje, para se diferenciar entre ver TV, utilizar um computador e assistir a um filme é muito mais importante entender a atitude e postura do usuário/espectador ou mesmo o ambiente que ele cria do que o equipamento e a tecnologia utilizada. A tecnologia para essas diversas formas mediáticas são hoje essencialmente as mesmas desde os primórdios do cinema e da TV: um monitor, ou seja, um display onde se pode exibir as imagens e altofalantes para reprodução do som, câmera e microfone que permitem captar sons e imagens, um processador/computador, ou seja, um mecanismo que possibilite codificar, decodificar e armazenar essas informações e um método de conexão permitindo receber e transmitir as informações. 


\subsection{Design como facilitador do diálogo entre as mídias}

Como vimos, a forma de se produzir TV mudou, seus conteúdos mudaram, consequentemente o design para a TV digital deve incorporar essas mudanças. Se considerarmos que assistir TV é uma experiência que se realiza independentemente de o dispositivo ser dedicado a esse fim, a maneira de facilitar essa experiência pode assumir formas diferentes das que estamos acostumados. Essa experiência pode ser interativa, o que requer que o design de uma interface entre a máquina e o homem deva não só facilitar a interação com a máquina, mas permitir o diálogo do telespectador/usuário com a mídia e seus dispositivos, promovendo o diálogo entre as mídias. Recapitulando, o designer que projeta interfaces para a TV Digital interativa deve levar em conta:

- A convergência da TV com outras mídias como a internet, celular e games.

- A ubiquidade dos dispositivos inteligentes.

- Os novos formatos de conteúdo e novas linguagens audiovisuais.

\subsubsection{Design e convergência}

A TV, ao incorporar processadores e software em seus aparelhos e convergir com as novas mídias digitais, passa a ser uma mídia que oferece:

a) comunicação bidirecional como a encontrada nos celulares, e-mail e chats;

b) novas funcionalidades que permitem realizar tarefas, acessar serviços interativos e

c) múltiplas experiências audiovisuais: televisão, cinema, vídeo sob demanda e videogames.

Como havia apresentado, a possibilidade de a TV oferecer essas diversas modalidades de entretenimento e serviços advém da funcionalidade de o hardware ser mutável por software. Esse software é comandado e interpretado pelo usuário ou telespectador por interfaces que são representadas primordialmente na tela da TV e conduzidas por um ou diversos controles remotos. O design dessas interfaces herda inicialmente as pesquisas já praticadas pela indústria de softwares utilizados em computadores, aparelhos eletrônicos e nos videogames. Com o amadurecimento dessa mídia convergente, essas interfaces podem tornarse mais adequadas à utilização das novas funcionalidades em uma situação que conceituamos 
como a "experiência de assistir TV".

Em lugar de mimetizar as interfaces e os procedimentos utilizados para realizar uma chamada telefônica em um celular ou enviar e-mails de um computador, o papel do designer não deve ser unicamente de adaptar essas interfaces para a visualização em uma tela de TV ou serem operadas por um controle remoto. O designer deve ter uma visão "total”, ao buscar desenvolver uma interface que permita ao usuário realizar essas funções de modo que haja uma harmonia e não interfira na atividade principal que é assistir TV.

Por exemplo, no caso de uma conversa, seja ela textual ou por voz, pode-se conceber integrá-la de algum modo com o programa de TV que um dos participantes da conversa está assistindo, assim a outra parte envolvida na conversa poderá acompanhar ou mesmo interagir com o programa que está sendo transmitido. Já que ocorrem diversas formas de comunicação simultâneas, ao envolver os diversos participantes, pode-se reduzir o ruído pois ambas as partes podem referenciar diversas mídias, trazendo-as para dentro do diálogo. O You Tube permite aos usuários postar comentários sobre os vídeos, estabelecendo-se um diálogo ao referenciar um determinado vídeo que só tem sentido neste contexto.

O desafio é fazer com que este tipo de "diálogo", que surge nas interfaces de serviços na internet como o Skype ou Messenger e que foram projetadas para serem utilizadas individualmente em computadores, seja transposto para o universo da Televisão. Uma solução que tem sido apresentada são os widgets como os da Yahoo $\mathrm{TV}^{118}$, pequenos aplicativos sobrepostos à imagem da TV. Em sua implementação atual, esses widgets, como o do Skype, ainda não integram o conteúdo da TV que está sendo exibido em uma das telas na comunicação com o usuário remoto.

\subsubsection{Design e dispositivos móveis}

A utilização de dispositivos móveis inteligentes concomitante com a TV é uma das formas como a experiência televisiva pode ser enriquecida; eles podem ser considerados um meio de extensão da mídia televisiva. Isso já é uma realidade se pensarmos que podemos enviar torpedos de um celular que terão um impacto no desenrolar dos acontecimentos de um

\footnotetext{
${ }^{118}$ No capítulo 2, descrevemos mais detalhadamente os widgets e como se relacionam com a estratégia da Yahoo de penetração no mercado de TV Digital.
} 
reality show. Um laptop pode ser utilizado para acessar um site e buscar informações sobre os atores, diretores de um determinado filme em sites na internet; canais de notícias como a CNN oferecem em seu site mais detalhes sobre uma matéria sendo exibida na TV, a Globo.com disponibiliza capítulos anteriores das novelas que podem ser consultados enquanto se assiste ao capítulo atual.

No paradigma da interatividade previsto nos sistemas de DTV, esperava-se que o acesso a esses serviços e informações fosse integrado à TV Digital e feito por meio do STB, utilizando o mesmo fluxo de dados do programa de TV. E enquanto se discute que essas formas de interatividade não "decolaram" como o esperado, frustrando a expectativa que a interatividade iria propulsionar o interesse pela TV Digital, atividades como essas, ditas interativas, já estão sendo realizadas pelo telespectador em dispositivos móveis concomitantemente com a TV. Ao invés de se buscar integrar essas tarefas na plataforma da TV Digital, o design pode buscar soluções que facilitem utilizar diversas plataformas em múltiplas telas e dispositivos que dialoguem entre si.

\subsubsection{Design e novas linguagens}

Novas linguagens como as narrativas não lineares e Alternate Reality Games (ARG), advindas da cultura de rede, dos videogames e da videoarte, têm contribuído para enriquecer a experiência televisiva em um cenário de convergência. Neste contexto, é importante lembrar que a TV é uma experiência de entretenimento, enquanto o computador ainda é percebido como uma ferramenta e associado ao trabalho. Dispositivos digitais como celulares, tablets, mp3 players podem ter diversas funções, entre elas jogos e vídeos, mas nem todos os usos são associados ao entretenimento. O uso destes é primordialmente individual, e ao serem conectados a uma rede permitem interagir com outras pessoas. A TV e seus periféricos como games e DVD players participam do ambiente social, da sala de estar, da cozinha, no bar, no ônibus e são "consumidos" socialmente em grupos. Enquanto se desenvolvem linguagens apropriadas para esses novos dispositivos e mesmo para a web, há uma grande carência de conteúdo interativo que explore as novas possibilidades oferecidas pela hipertextualidade na TV Digital e que atenda às expectativas de entretenimento desta mídia.

O design de interfaces para TV Digital hoje deve obrigatoriamente incorporar essas considerações muitas vezes ausentes na especificação um programa interativo ou aplicativo, 
que acabam transpondo o modelo de um aplicativo para o computador ou adaptando games desenvolvidos para consoles. O designer, ao compreender essas transformações e ter algum domínio dessas novas tecnologias, poderá estar capacitado para propor novos produtos e não somente reagir às demandas da indústria. Desenvolver interfaces para TV Digital não se limita a diagramar e resolver visualmente a navegação de um Guia Eletrônico de Programação (EPG) ou solucionar os menus interativos de um programa.

Um designer atuando na TV Digital deixa de ser somente um comunicador visual que resolve os desafios trazidos por produtores e executivos de TV. Ele deve ser pró-ativo, propondo novas ideias, e sua capacidade de unir, manipular imagens utilizando novas tecnologias e narrativas interativas é essencial para o desenvolvimento de novas formas de assistir e interagir com a TV. Pioneiros do design para cinema e televisão como Saul Bass e Harry Marks não só dominavam a linguagem visual mas também compreendiam a importância do movimento. Designers de interfaces gráficas passaram a ter que dominar software e aprender princípios de usabilidade. Os futuros designers digitais irão atuar na totalidade do design de produtos inseridos em sistemas cada vez mais complexos.

\subsubsection{TV como teatro}

Designers têm se preocupado em projetar objetos, transformando materiais, por mais de um século, desde a revolução industrial, e seu papel tem se tornado cada vez mais importante na sociedade atual. O designer gráfico, no entanto, tem se dedicado ao longo dos tempos à comunicação visual propriamente, mas raramente também atua como um inventor de produtos. Há uma intersecção entre a experimentação da linguagem das novas mídias, design de interfaces gráficas, design de programas de computadores, design de sites ricos em mídias audiovisuais e design em movimento (motion graphics) que irá definir os caminhos do design para a TV Digital. Embora a televisão também tenha se segmentado de forma extrema com o advento da TV a cabo, pensar o design para a TV Digital pode ser extremamente limitado porque os padrões estabelecidos para o meio são bastante rígidos e restritivos, em oposição à flexibilidade e modularidade encontradas na indústria de computação.

O designer, embora deva conhecer as normas em vigor, não deve restringir-se aos parâmetros estabelecidos. Como ponto de partida, pode pensar em modelos de interação e criar experiências. Quando Brenda Laurel (1993), em seu livro Computers as Theater, sugere 
que o designer de interfaces deva encarar o "computador como uma mídia e não apenas uma ferramenta", o mesmo pode ser aplicado à TV Digital, pois ela é em essência um computador, e este não é apenas um objeto que realiza certas funções como uma batedeira, ou mesmo diversas funções como um canivete suíço, o computador é um espaço de comunicação, de interação e simulação. As soluções apresentadas pelos designers devem de modo transparente e natural promover o diálogo entre as mídias, os usuários e as máquinas através de interfaces. Essas interfaces requerem controles que facilitem a interação entre as mídias, ao consolidar o comando e as linguagens de diversas mídias. 
Capítulo 5

\section{Estudo de caso - TV Digital e a Copa do Mundo 2010}

"Partindo de um exemplo de conteúdo distribuído em diversas mídias, podese demonstrar a contribuição do design de interfaces para a TV Digital em um cenário de convergência".

\subsection{Justificativa do caso específico}

\subsubsection{Estudo de Caso: Copa do Mundo - FIFA}

Neste capítulo, realizo um levantamento do conteúdo midiático e das inovações tecnológicas correlatas que ocorreram na Copa do Mundo da FIFA de 2010. Este levantamento será utilizado em um projeto de design de interação que tem como objetivo sintetizar na prática o resultado desta pesquisa. Tecnologias emergentes no campo da TV Digital, avanços no design de interfaces que potencialmente irão amadurecer em 2014.

A Copa do Mundo da FIFA é um dos eventos de maior IBOPE da TV no Brasil e no mundo, atingindo telespectadores de diversas faixas etárias. Segundo a FIFA, a expectativa era de que 30 bilhões de pessoas assistissem à Copa em 2010 ${ }^{119}$. Um dos motivos da escolha deste estudo de caso é a possibilidade de dentro dele poder explorar vários gêneros televisivos: esporte, jornalismo, documentário, infantil. Outro motivo é o fato de que essa mesma diversidade de conteúdo requer uma gama de recursos técnicos: transmissão ao vivo, bancos de dados, gravação de programas. Essas ramificações e o fato de o gênero esportivo

\footnotetext{
119 “Audiência da Copa do Mundo pela TV deve ser recorde”, Da redação do diariodepernambuco.com.br 13/06/2010. Disponível em:

$<\mathrm{http}: / /$ www.diariodepernambuco.com.br/viver/nota.asp?materia=20100613174615\&assunto=148\&onde=Viver >. Acesso em: 20/11/2010.
} 
instigar a participação do público abrem diversas perspectivas para a interatividade na TV Digital, trazendo consigo novos desafios no desenvolvimento de interfaces gráficas.

\subsubsection{Copa de 2010 e convergência}

Em 2010, o Brasil assistiu à Copa do Mundo na TV em Alta Definição, ou ao menos uma parcela da população teve essa oportunidade, já que era possível receber o sinal HD da transmissão digital da Rede Globo e Bandeirantes nas principais cidades do Brasil. No segmento de TV por assinatura, as operadoras de TV a cabo e DTH empenharam-se em vender pacotes de programação em HDTV. Segundo a projeção de Lourival Kiçula, presidente da Associação Nacional de Fabricantes de Produtos Eletroeletrônicos (ELETROS), 2010 seria o primeiro ano em que o volume vendido das TVs planas superaria o de TVs de tubo. Em 2009, as TVs planas representaram 45\% e as de TVs de tubo 55\% (MING, 2010) ${ }^{120}$. A ELETROS estimava que 11 milhões de brasileiros trocassem de TV em 2010, sendo que mais de metade dessas vendas representariam TVs de tela plana e que boa parte delas seriam Full HD; é de esperar, portanto, que os consumidores se sintam impulsionados a receber o sinal HDTV de modo a fazer valer seu investimento nos novos aparelhos.

No entanto, o consumidor ainda se encontra bastante confuso acerca do que é TV Digital e como receber o sinal HDTV. Por falta de informação ou influenciados pela propaganda das operadoras de TV a cabo, poucos sabem que podem receber o sinal de alta definição simplesmente conectando um aparelho de TV equipado com um receptor digital a uma simples antena de UHF, ou mesmo adquirir um conversor de TV Digital, possibilitando receber gratuitamente o sinal HD transmitido pelas emissoras de TV aberta.

Os torcedores da Copa que assistiram à transmissão em HDTV pela primeira vez viram os jogos com um nível de detalhes e uma qualidade de imagem nunca vistos antes em suas TVs. Mas a surpresa para os assinantes de TV a cabo que adquiriram pacotes de HDTV para a Copa foi o "delay"121 na transmissão: enquanto os torcedores que assistiam aos jogos em TVs convencionais comemoravam os gols, quem assistia em HD via cabo via o gol com atraso de alguns segundos, o que deixou a muitos perplexos. O que poucos compreendiam é

\footnotetext{
${ }^{120}$ MING, Celso. "O mercado de TVs e a Copa”. O Estado de S.Paulo, São Paulo, 12 jun. 2010. Caderno de Economia.

121 "Delay" é o termo técnico que representa o atraso de um receptor ao receber um sinal transmitido ao vivo.
} 
que o sinal de TV Digital HD terrestre não tinha este delay, que era causado pela retransmissão desse mesmo sinal pelas operadoras de TV acabo.

Ethevaldo Siqueira, colunista de tecnologia do jornal $O$ Estado de S. Paulo, em seu blog ${ }^{122}$ dizia estar em "lua de mel com a cobertura da Copa do Mundo da África em alta definição", não só devido à qualidade de imagem mas pelo prazer obtido pela experiência.

Minha experiência como telespectador nunca foi tão prazerosa. Em primeiro lugar, porque as tomadas de imagens, os novos ângulos, a multiplicidade de câmeras utilizadas nesta copa superam tudo que tivemos no passado. As imagens em câmera lenta nos replays são de uma nitidez impressionante. E mostram detalhes jamais percebidos na TV analógica. (SIQUEIRA, 2010).

Uma matéria intitulada "Na TV uma copa revolucionária", publicada no Estado de São Paulo ${ }^{123}$, apresenta as principais novidades da transmissão televisiva da FIFA para a Copa de 2010: além da transmissão em alta definição e a primeira transmissão de alguns jogos da copa em 3-D, na Copa de 2010 havia quarenta câmeras espalhadas pelo campo, inclusive uma "câmera aranha" fazendo tomadas aéreas dos jogos. Os replays em câmera lenta e a nitidez de detalhes vistos em alta definição tornaram-se motivo de polêmica em relação à arbitragem dos jogos, pois os telespectadores passaram a ter "super olhos", vendo aspectos dos lances que os árbitros não conseguiam acompanhar. Estes ângulos eram controlados pela transmissão da FIFA, que acabou optando por não transmitir os lances mais polêmicos, mas com a possibilidade de interatividade e recepção de múltiplos ângulos na TV Digital. Talvez esta atitude não seja possível em 2014.

Em sua apresentação "TV Digital por assinatura via satélite: A transição para HDTV” realizada no Simpósio Internacional de TV Digital, organizado pelo Instituto de Estudos da Televisão (IETV) no Rio de Janeiro em $2005^{124}$, Ricardo Miranda, então presidente da Sky Brasil, aponta como a Copa do Mundo tem marcado a história da TV: em 1954, com a estreia

\footnotetext{
122 "Curtindo a copa numa super TV”, blog de Ethevaldo Siqueira, 14 de junho de 2010. Disponível em: $<$ http://www .ethevaldo.com.br/Generic.aspx?pid=2735>. Acesso em: 23/8/10.

123 "Na TV uma copa revolucionária”, publicada no jornal O Estado de S. Paulo, 24 de junho de 2010. Disponível em:

< http://www.estadao.com.br/estadaodehoje/20100624/not_imp571256,0.php> . Acesso em: 14/1/2011.

124 Anotações minhas como ouvinte do Simpósio Internacional de TV Digital, IETV, Rio de Janeiro, 2005. A programação do evento está disponível em:

< http://www.ietv.org.br/v3/index.php?sub=eventos\&eventos=87>. Acesso em: 14/1/2011.
} 
da transmissão direta pela televisão em preto e branco, em 1970 a primeira transmissão em cores para todo o Brasil ao vivo via Embratel e em 2006 Ricardo previa a transmissão em HDTV, o que ocorreu mas teve alcance bastante limitado. Assim, foi 2010 que ficou na história como ano da Copa em HDTV no Brasil.

Uma série de outras novidades nas mídias também marcaram a Copa de 2010: jogos puderam ser acompanhados por TVs digitais móveis em celulares e automóveis ou mesmo pequenos aparelhos portáteis, ou ainda em web sites que publicavam cada lance em tempo real. Técnicas de "tracking" permitiam localizar a posição da bola a cada instante da partida, fornecendo dados para a execução de gráficos detalhados. As estatísticas dos jogadores de cada partida disponíveis na internet podiam ser correlacionadas com outras informações, álbuns de figurinha digitalizaram-se, os lances e os replays conhecidos por tira-teima reconstruídos em 3-D puderam ser revistos de diversos ângulos. Torcedores acompanhavam os jogos recebendo informações em seus celulares, onde versões digitais das tabelas de jogos se preenchiam automaticamente.

A Copa do Mundo de 2010 não só serviu como vitrine, onde as emissoras demonstraram o alto nível de detalhes das imagens na transmissão em HDTV, como também introduziu novidades na transmissão como: câmeras posicionadas em ângulos, diferentes enriquecendo a experiência do telespectador; testes de transmissão em 3-D e TV Digital interativa utilizando o middleware Ginga (DTV, 2010) ${ }^{125}$. Complementando as inovações na TV, aplicativos para celulares e internet foram distribuídos por provedores de conteúdo como a Globo, UOL e Abril. Vejamos que estes representam indústrias antes distintas como TV, internet e editoração, no entanto hoje todas elas distribuem conteúdo eletrônico unindo vídeo e interatividade. Na prática, houve uma pequena utilização destes serviços como os oferecidos pela NET, o App de iPad da Globo e o celular com Ginga da LG, mas essas inovações abrem uma janela para o futuro da TV na próxima Copa.

\footnotetext{
125 “TV digital: produção de conteúdo interativo ganha impulso neste semestre” Fonte: Tele Síntese Análise, publicado na seção de Notícias do Site DTV-Forum SBTVD. Disponível em:

< http://www.dtv.org.br/index.php/tv-digital-producao-de-conteudo-interativo-ganha-impulso-neste-semestre/>. Acesso em 14/01/2011
} 


\subsubsection{Novo comportamento do Telespectador}

Nos anos 1980 e 1990, com o crescimento da TV a cabo nos EUA, vimos centenas de novos canais de TV a cabo entrando no ar, que passaram a ser retransmitidos mundialmente via satélite e oferecidos para operadoras de TV a cabo (MSO) em outros países. No Brasil, a globalização da programação, a oferta de programação de TV cada vez mais segmentada e variada e o controle remoto foram responsáveis pela adoção pelo telespectador brasileiro do comportamento referido como Channel Surfing, termo introduzido pelo Wall Street Journal em 1986 (JENKINS, 2007) ${ }^{126}$. Estes telespectadores que mudam constantemente de canal são conhecidos como zappers e têm sido motivo de preocupação para programadores e anunciantes. Como já comentado em capítulo anterior, o canal de TV a cabo norte-americano VH1 introduziu, no início dos anos 1990, o "bug”, uma marca d'água sobreposta ao vídeo, esta forma de se identificar visualmente para telespectadores que trocam incessantemente de canal, acabou sendo adotado por quase todos os canais de TV, e hoje passa a ter uma importância renovada com o fato dos programas de TV serem "postados" na internet em serviços como o You Tube.

Com o crescimento da internet, o telespectador de TV também tem sua atenção cada vez mais dividida com outras fontes de informação e entretenimento. Principalmente as gerações mais jovens, que têm consumido diversas mídias simultaneamente, fenômeno conhecido como multi-tasking. Segundo um levantamento da Kaiser Family Foundation, realizado em 2005, nos EUA, as crianças norte-americanas continuavam passando 6,5 horas por dia usando mídias eletrônicas, mas passaram a consumir 8,5 horas de mídia por dia (WALLIS, 2006) ${ }^{127}$.

\footnotetext{
126 "Convergence Culture, Where Old and New Media Collide”, Henry Jenkins, NYU Press, 2007, Disponível em: <http://www.convergenceculture.org/weblog/white_papers/>. Acesso em 25/11/2010

127 WALLIS, Claudia.“The Multitasking Generation”, revista Time, 19/3/2006. Disponível em: <http://www.time.com/time/magazine/article/0,9171,1174696,00.html>. Acesso em: 11/12/2010.
} 


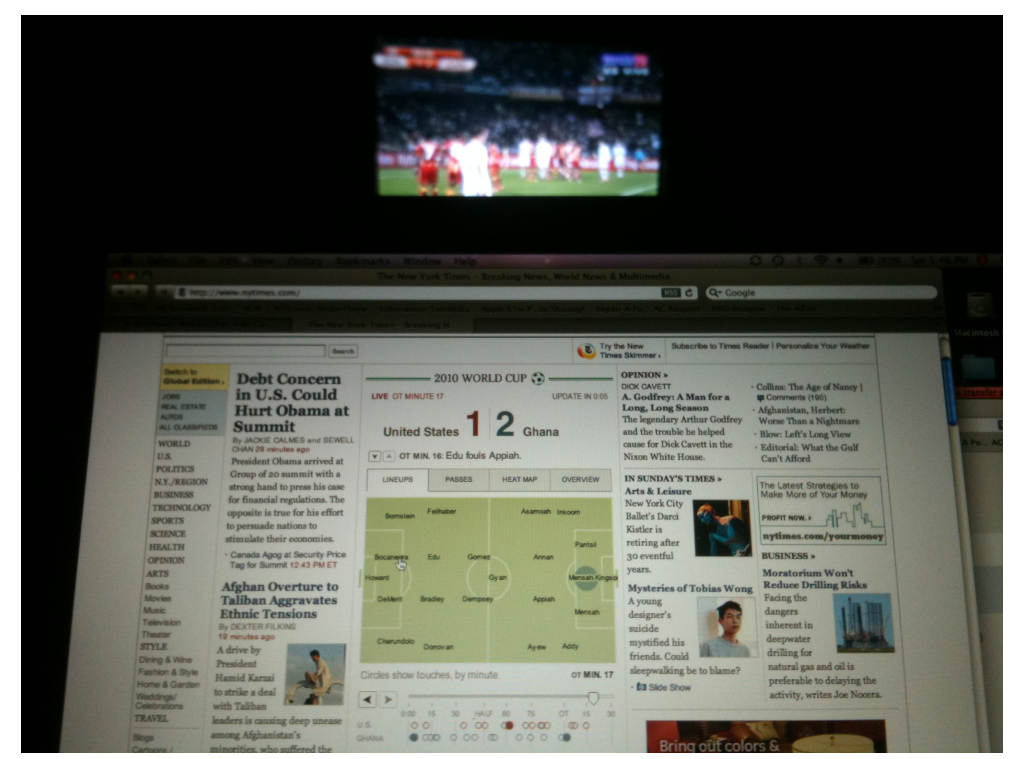

Fig. 5.1: Transmissão do jogo da copa no canal Sport TV enquanto espectador acompanha lances e passes no site do New York Times.

Fonte: Fotografia do autor.

Assistir TV e realizar outra tarefa simultaneamente não é mais privilégio das gerações mais jovens; cada vez mais nossa sociedade tem realizado tarefas simultaneamente em diferentes mídias. A ubiquidade de dispositivos eletrônicos conectados à internet tem acelerado a possibilidade de realizar múltiplas tarefas. Aparelhos de TV que podem ser conectados à internet irão favorecer ainda mais a possibilidade de utilizar outros serviços ou acessar conteúdo da internet diretamente de um aparelho de TV. Redes sociais como Facebook e Orkut têm se tornado pervasivas e "viciantes"; este novo comportamento associado ao zapping e multi-tasking, que já se estabeleceram na nossa cultura nos anos 1980 e 1990, estão definindo um novo telespectador da TV Digital bastante diferente daquele do período em que se começou a definir modelos de TV Digital.

A TV também deixa de ser o ponto central da sala de estar, competindo com outras mídias como a internet e videogames, ao mesmo tempo em que ela pode ser sintonizada em outros espaços e dispositivos: no celular, no automóvel, no transporte público. A TV portátil foi introduzida há algumas décadas, mas a digitalização traz com a ela a possibilidade de uma TV verdadeiramente móvel, que pode acompanhar-nos em cada espaço sem interrupções. 


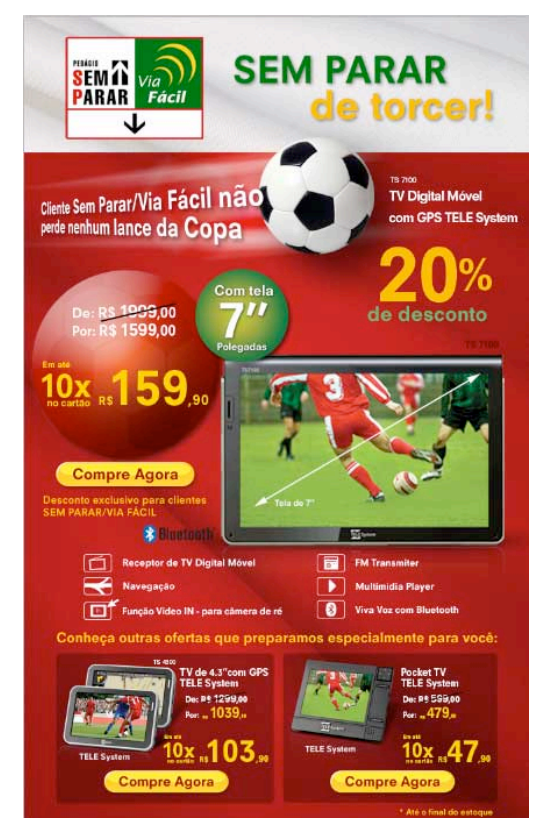

Fig. 5.2: Anúncio de TV portátil integrada a um GPS veicular. Fonte: Sem Parar - Via Fácil

Não só as questões espaciais definidas por novos dispositivos têm transformado o comportamento do telespectador nos últimos anos, a temporalidade da TV tem passado por transformações. Nos anos 1970 foi introduzido o replay de lances durante os jogos de futebol, inserido em uma elipse temporal, mas ainda sob o controle da emissora. Com a introdução da TV sob demanda, utilizando serviços como TIVO ou STBs equipados com PVRs, é possível gravar um programa e assistir em um horário diferente. A introdução do VHS teve inicialmente esse objetivo, mas acabou definindo-se como uma mídia de distribuição de locação de vídeos. Estas novas tecnologias têm facilitado o que se chama de "Time Shifted TV”, permitindo que o telespectador crie sua própria grade de programação, personalizando o horário de seus programas preferidos.

Serviços como Hulu, Apple TV, Sezmi, introduzidos recentemente, estão catalisando ainda mais essas transformações e consequentemente o comportamento do telespectador, o que não necessariamente torna a TV convencional obsoleta, e sim mais uma opção. Mantendo particularidades da mídia analógica, ela é "re-midiada". Portanto o design de interfaces para TV Digital deve resolver como o telespectador se relaciona com essas diversas mídias.

Ao realizar um levantamento do mesmo conteúdo em diversas mídias, no caso, a Copa do Mundo, definimos os elementos a serem equacionados na interface de uma TV Digital que converge com outras mídias. Não esqueçamos que, mesmo com a mudança do 
comportamento do telespectador, a TV ainda mantém as características de uma experiência passiva, ou seja, a do espectador, que busca o entretenimento, resultando em uma atitude diferente de quando está trabalhando em um computador. A TV tem uma tradição de simplicidade em sua utilização, no entanto as inovações advindas da introdução da TV Digital podem ser bastante complexas, potencialmente intimidando os telespectadores.

Um exemplo foi a oferta pela operadora de telefonia celular Vivo do aparelho LGGM600, que incorpora um receptor de TV Digital e prometia um aplicativo interativo para a Copa do Mundo de 2010. No entanto, o software (baseado no middleware Ginga) que possibilitava essa interatividade não vinha pré-instalado, o que de imediato já desestimulou seu uso. Este é o caso de algumas das inovações que serão relatadas neste capítulo.

\subsubsection{Classificação de Conteúdo Mediático}

Para fins deste estudo, realizo um levantamento de tipos de conteúdos mediáticos relacionados à Copa do Mundo sem necessariamente atrelá-los a uma mídia específica. A seguir levanto exemplos de conteúdo da Copa de 2010 em várias mídias e por fim analiso como essas mídias podem ser veiculadas por diversos meios. Em um cenário de convergência das mídias, o conteúdo digital pode trafegar por diversas mídias; para que isso aconteça, o conteúdo deve ser "adaptado" para uma mídia específica sem que necessariamente seja "reescrito", ou seja, a interface deve apresentar o mesmo conteúdo em diversas plataformas. Por exemplo, um banco de dados com estatísticas de um time pode ser apresentado em um site na internet, sobreposto a um jogo na TV ou disponibilizado em um app para celular. Daí a importância da integração de repositórios de informação com interfaces que permitem ao usuário manipular os dados. O conteúdo específico é definido pela tecnologia e pela mídia a ser utilizada ou incorporada no projeto; a equação tecnologia-mídia define as possibilidades deste novo meio e não seria seguro assumir que um precede ou define o outro.

Para a realização da proposta, foi feito um levantamento do "universo tecnológico" que pode estar especificado no SBTVD, ou novas tendências e pesquisas que estão sendo ou podem vir a ser adotadas pela TV Digital, e do "universo mediático" veiculado na TV analógica ou disponível em outras plataformas digitais convergentes com a TV. Portanto, a pesquisa na qual este conteúdo irá inserir-se deve considerar a tecnologia não só como ferramenta mas como "conteúdo", uma vez que diversas dessas tecnologias são baseadas em 
"software" e podem (discutivelmente) ser consideradas obras ou "material consumível" pela base de usuários que inclui os telespectadores, internautas e assinantes de telefonia celular que poderão utilizar os serviços de diversas formas dependendo de como acessam e interagem com essas tecnologias.

\subsection{Levantamento de conteúdo em diversas mídias - Copa de 2010}

Um evento como a Copa do Mundo tem sua cobertura realizada por e em diversas mídias, que são consumidas em paralelo ou complementam umas às outras. Esta sobreposição de mídias traz consigo o conceito de "re-mediação", termo cunhado por Richard Grusin como uma forma de compreender o reaproveitamento das mídias dentro da lógica de "imidiação" e "hipermidiação". Essa lógica torna-se clara na "Re-medição, quando apagamos uma mídia no ato de multiplicá-la" (BOLTER; GRUSIN, 2000). Ao assistir a um jogo de futebol na televisão, um dos objetivos é nos sentir o mais próximo possível do evento, idealmente eliminando as mídias, ou seja, reduzindo a mediação do evento. No caso do futebol, a mídia televisiva tem prevalecido por ser a mais apta a realizar essa mediação.

No entanto, com a convergência, mídias como o jornalismo impresso, ao incorporar a comunicação audiovisual e transpor-se para o meio eletrônico, obtêm na internet o sincronismo do rádio. Um dos desafios do design da interface de um jornal digital, além de resolver a usabilidade e a navegabilidade, é manter a identidade de cada mídia. Neste estudo busco dentro do possível levantar cada mídia de modo independente para consequentemente propor sua "trans-midiação", ao representá-la em uma interface.

\subsubsection{Mídia Impressa}

Com a introdução dos meios eletrônicos de informação, a mídia impressa tem um aspecto mais informativo do que noticioso. Jornais e revistas passam a ter uma importância maior como fonte de informação sobre a programação de eventos, tabelas de campeonatos, escalação de times e comentários sobre os jogos, técnicos e jogadores. A mídia impressa tem um papel importante como complemento do evento ao vivo, seja ele "midiado" ou presenciado in loco. Com a digitalização, essas informações podem ser transmitidas junto com o sinal audiovisual na internet e na TV digital, mesmo que a última ainda não seja o 
suporte ideal para sua visualização. Por isso consultar o horário do jogo em uma revista em vez de utilizar o guia eletrônico da TV ainda é uma prática comum.

\subsubsection{Jornais}

Os principais jornais do Brasil editaram cadernos especiais de esportes durante a Copa do Mundo de 2010, nos quais havia tabelas dos jogos, informações sobre os times, estádios, partidas, comentários, entre outros. A infografia apresentada nos jornais tem a vantagem da alta resolução da mídia impressa comparada com a mídia eletrônica, permitindo criar gráficos bastante detalhados e que podem ser "lidos" sem a limitação de tempo imposta pela televisão. Mas em contrapartida não tem as possibilidades da animação da TV nem a interatividade dos meios digitais.

Seguem alguns exemplos de gráficos publicados em jornais:

\section{O Estado de S. Paulo}

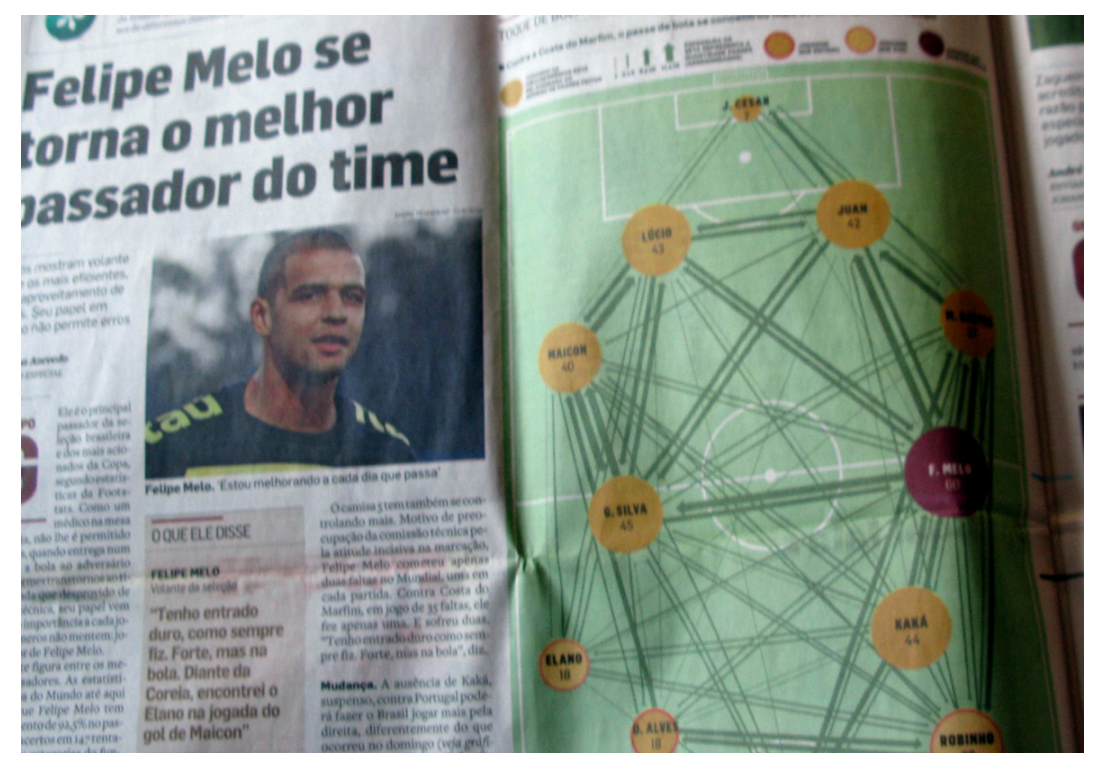

Fig. 5.3: Caderno Especial Copa 2010 do jornal O Estado de São Paulo Fonte: O Estado de São Paulo- 24/6/2010

O infográfico desta matéria destaca a posição do jogador Felipe Melo em diversos lances contra a Costa do Marfim. Na versão impressa, há uma interatividade do leitor com a informação diferente da versão digital. No papel, ainda é possível concentrar um número maior de informações em uma única imagem e o leitor não tem limitações temporais impostas 
pela mídia, já um gráfico digital utiliza camadas de informação ou animação para compensar sua inferioridade nesse aspecto, o que acaba resultando em uma visão fragmentada.

\section{Folha de S. Paulo}

O jornal Folha de S.Paulo publicou o caderno especial "Copa 2010" no dia 6 de junho de 2010. Na capa temos um texto sobre as origens do futebol, em que citações do futebolista Tostão são destacadas como se fossem hiperlinks, indicando a página do caderno onde há um assunto relacionado. A proposta é claramente influenciada pela linguagem hipermídia, sendo "re-midiada" para a mídia impressa; esse processo inverso gera uma forma diferente de ler o jornal. Os infográficos do caderno que facilitam a visualização são adequados à leitura no papel e, ao utilizarem diversas camadas de informação, indicam influências da mídia digital.

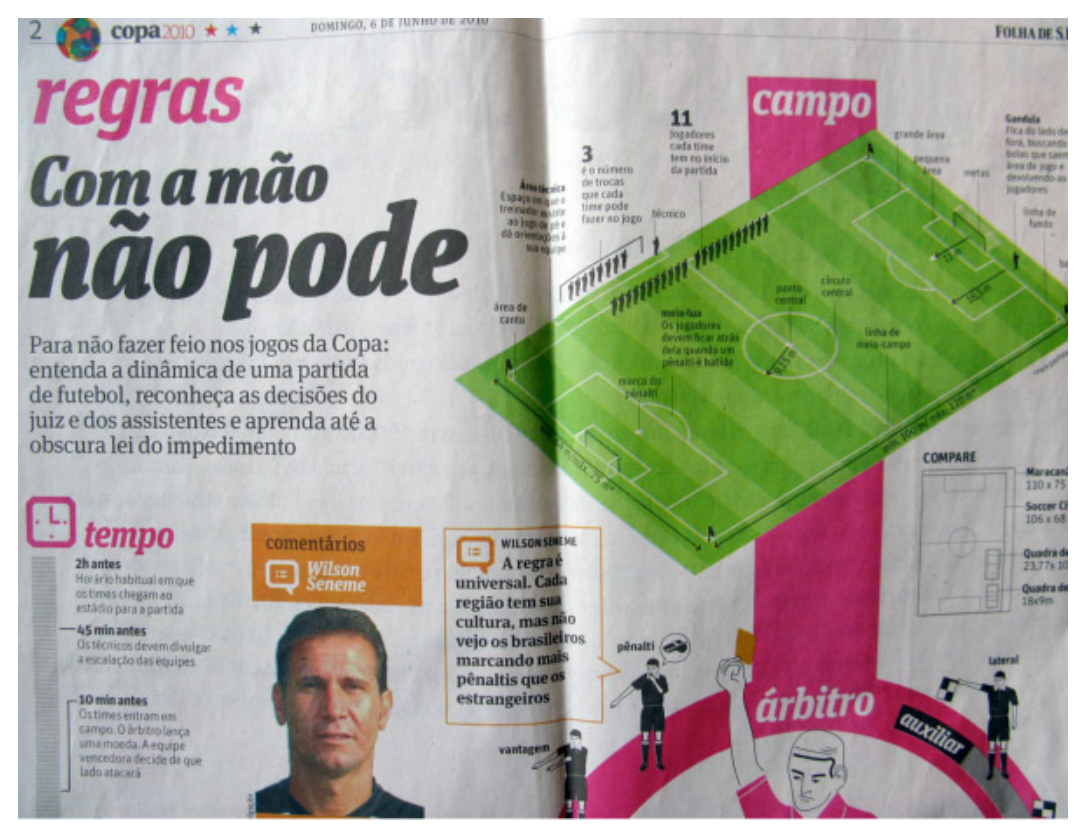

Fig. 5.4: Regras - Caderno Copa 2010 - Folha de São Paulo

Fonte: Folha de S.Paulo- 6/6/2010

Nesta outra forma de visualizar a tabela da Copa na Folha de S.Paulo, as seleções têm destaques diferentes conforme a "força" de cada uma delas: 


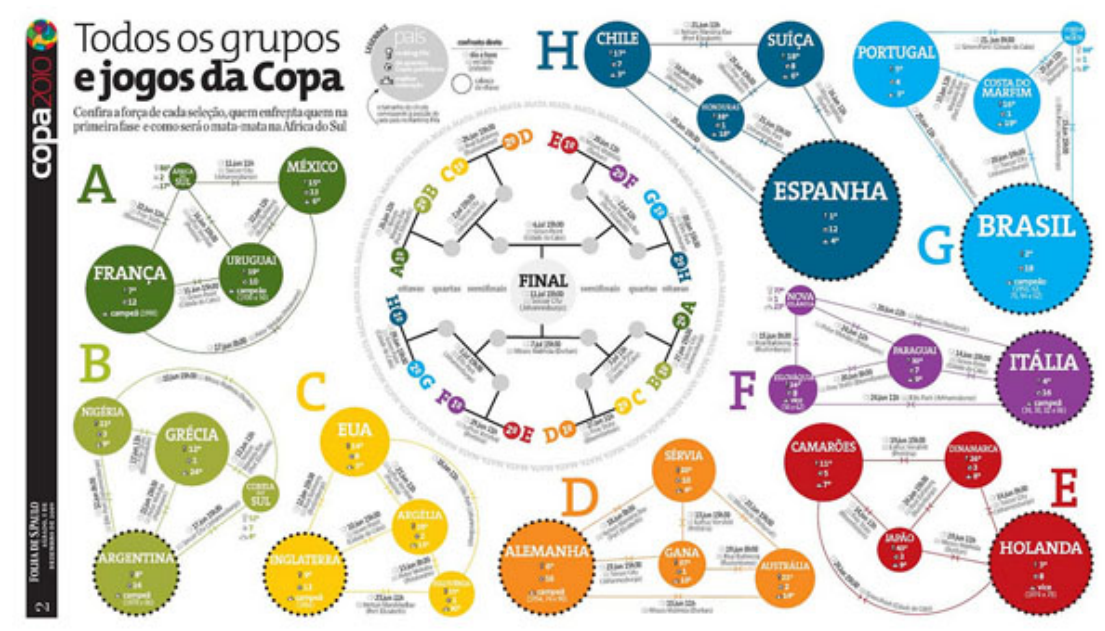

Fig. 5.5: Infográfico Caderno Copa 2010 - Folha de São Paulo Fonte: Folha de São Paulo- 06/06/2010

\section{Destak}

O jornal Destak, de distribuição gratuita na cidade de São Paulo, publicou um caderno especial no dia 11 de junho de 2010. O caderno traz tabelas, informações sobre cada seleção, estádios, entre outros, mas com uma diagramação bastante tradicional. Um aspecto que diferencia esta publicação é que ao lado de cada página temos informações relacionadas com a Copa mas fora do contexto, por exemplo, ao falar do Uruguai, há uma nota sobre o fato de o Uruguai ser o primeiro país da América Latina a legalizar o casamento homossexual, ou tratando da seleção da Nova Zelândia, o jornal nos informa que diversas cenas do filme "O Senhor dos Anéis" foram gravadas naquele país. São uma espécie de hiper-link off-line, que em uma versão digital poderia levar o leitor para uma outra página ou mídia.

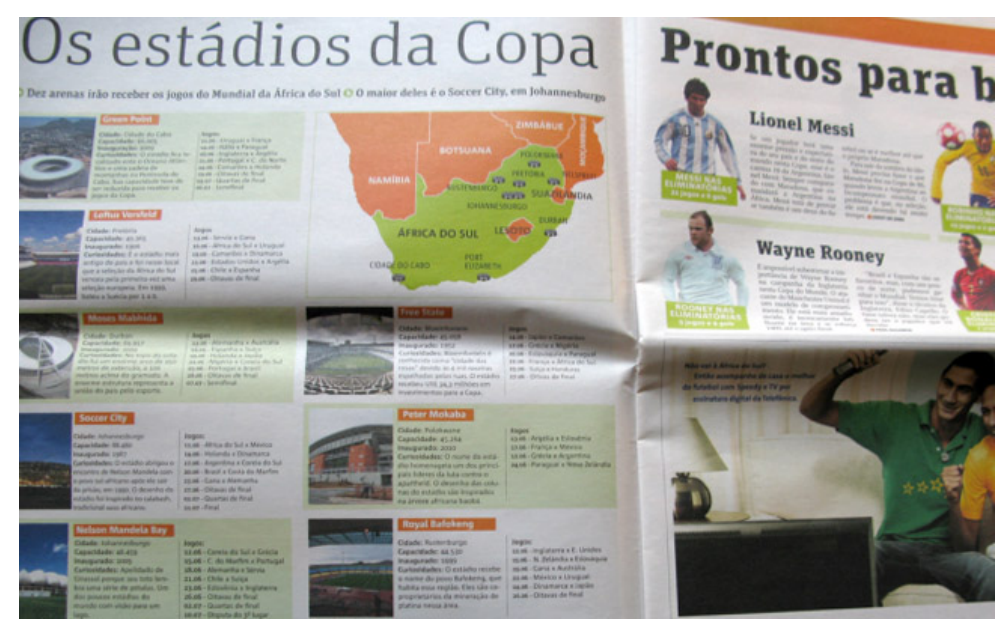

Fig. 5.6: “Os Estádios da Copa”, jornal Destak Fonte: Destak, São Paulo. 11/06/2010 


\section{MTV na Rua}

A MTV, canal de TV a cabo que se popularizou com a exibição de videoclipes de música e hoje passou a ter uma programação variada dirigida a um público jovem, tem se expandido em mídias como a internet e revistas, integrando-os com sua programação. Durante a Copa de 2010, o canal distribuiu gratuitamente o jornal em formato tabloide MTV na Rua 3$D$ junto com uns óculos que permitia visualizar as imagens impressas em três dimensões. Esse é um esforço de marketing, aliando a mídia impressa a inovações tecnológicas das mídias eletrônicas (3-D), que tem ganhado interesse recente, por manter a presença da marca junto ao seu público-alvo em um momento em que este se distancia de seu veículo principal.

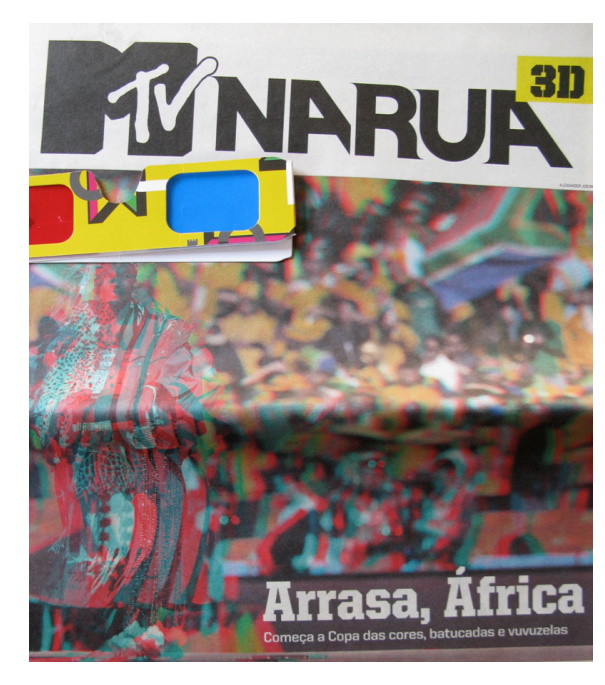

Fig. 5.7: Jornal 3-D, MTV na Rua

\subsubsection{Revistas}

\section{Revista Veja}

Na capa da revista Veja de 2 de junho de 2010, temos a imagem de uma bola de futebol sobreposta por uma QR Code (Quick Response Code) na sua capa. Dentro da revista, em um encarte especial da Copa do Mundo, diversas matérias linkavam para o site da revista (veja.com.br), onde o leitor poderia ler o QR Code com sua webcam, dispensando a necessidade de digitar o endereço eletrônico. Na matéria on-line o leitor encontrava conteúdo expandido, como jogos e "brincadeiras" interativas. 


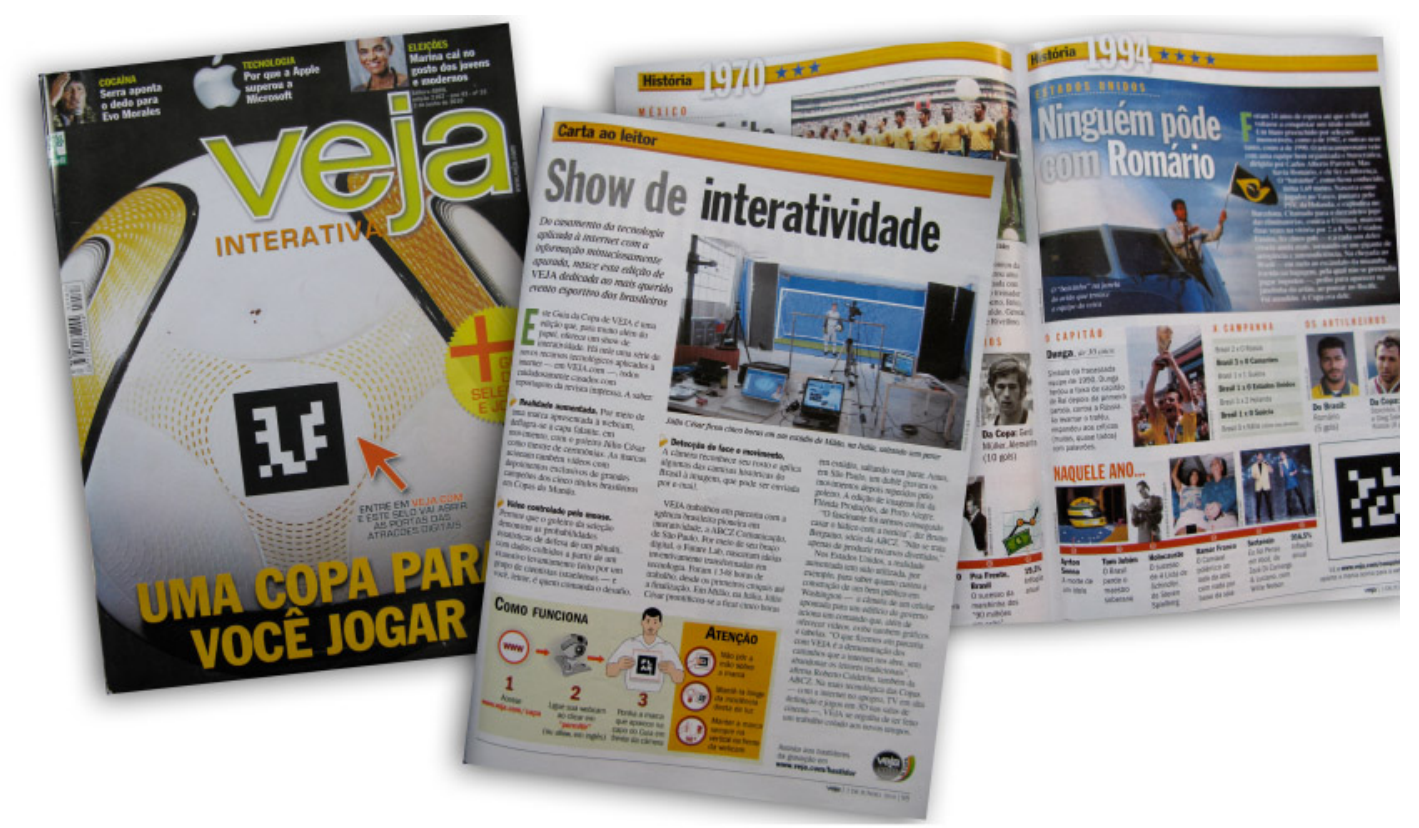

Fig. 5.8: Revista Veja "Interativa" Edição Especial da Copa do Mundo 2010

Nesta forma de relacionamento entre a mídia impressa e a mídia digital ocorrem duas coisas: uma é que existe uma quantidade maior de informação do que é viável publicar na edição impressa, mas o conteúdo já está nas mãos do veículo; ao disponibilizá-lo na internet, a revista mantém a fidelidade do seu público em seu canal de comunicação e abre uma ponte entre as mídias A outra é que, ao disponibilizar o conteúdo digital, a editora busca recriar a mídia em um formato "inovador" ou próprio desta nova mídia, o que em princípio é uma proposta interessante, mas que na prática deixa de ser, pois se encontram jogos de melhor qualidade produzidos por empresas especializadas no assunto. No final se cai no clichê da novidade. O que faria mais sentido seria compartilhar ou licenciar esse conteúdo para desenvolvedores de conteúdo digital que dominam a tecnologia mas não têm um acervo de conteúdo.

A revista Placar, tradicional publicação direcionada ao público esportivo, publica guias para diversos campeonatos. Com um projeto gráfico bem resolvido, o guia da Copa de 2010 traz informações sobre os jogos e seleções em um formato de fácil acesso e leitura, aproveitando ao máximo as vantagens da mídia impressa. Ao estabelecer sua reputação nesse nicho, essa publicação tem o potencial de ser uma marca que serve como referência e provedora de conteúdo para desenvolvedores de conteúdo digital para a Copa do Mundo. 


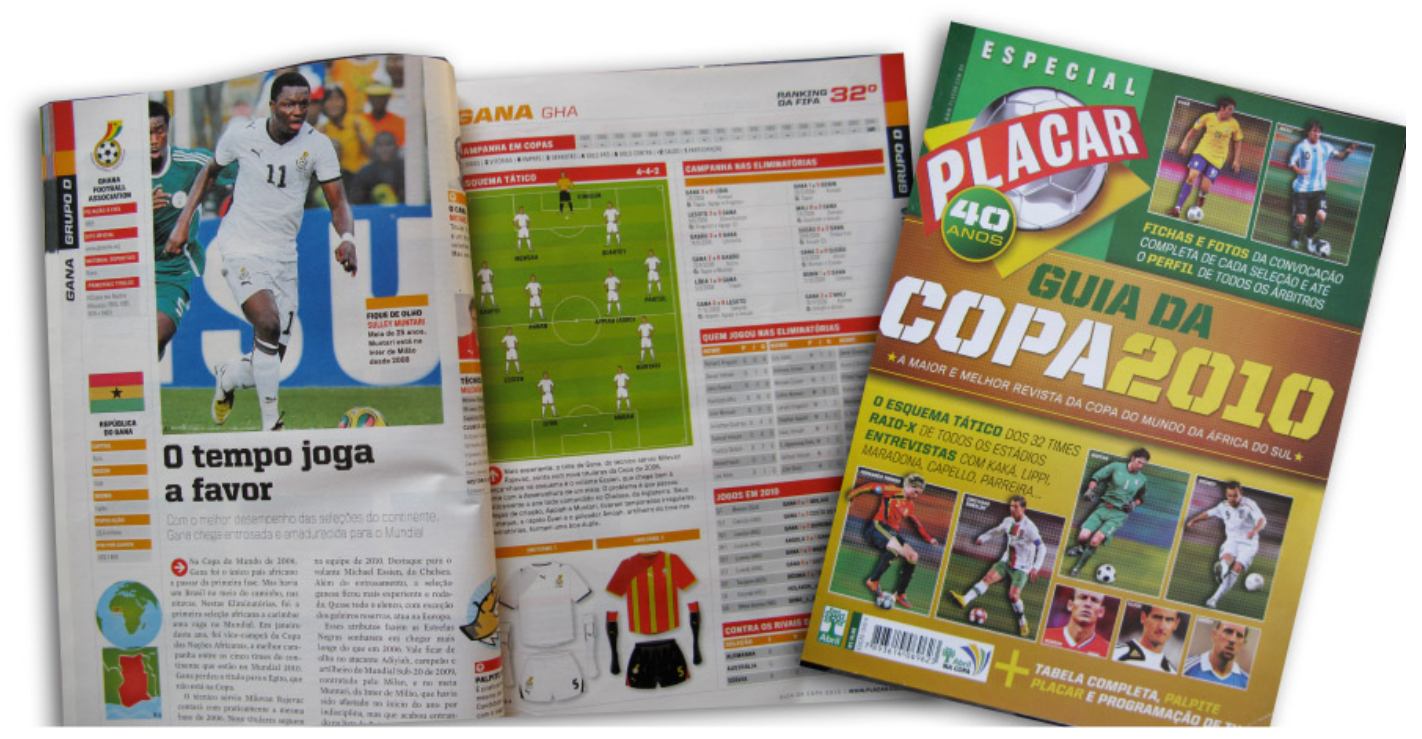

Fig. 5.9: Revista Placar - Edição Especial da Copa do Mundo 2010

\subsubsection{Televisão e Rádio}

\subsubsection{Televisão}

Os jogos da Copa do Mundo 2010 foram transmitidos em HDTV ao vivo no Brasil pela Rede Globo e Rede Bandeirantes na TV aberta e pelos canais de TV aberta ESPN e Sport TV, que recebem a transmissão oficial dos jogos da FIFA e inserem imagens adicionais produzidas pelos canais, locução e comentários de seus apresentadores e comentaristas, gráficos de cada emissora.

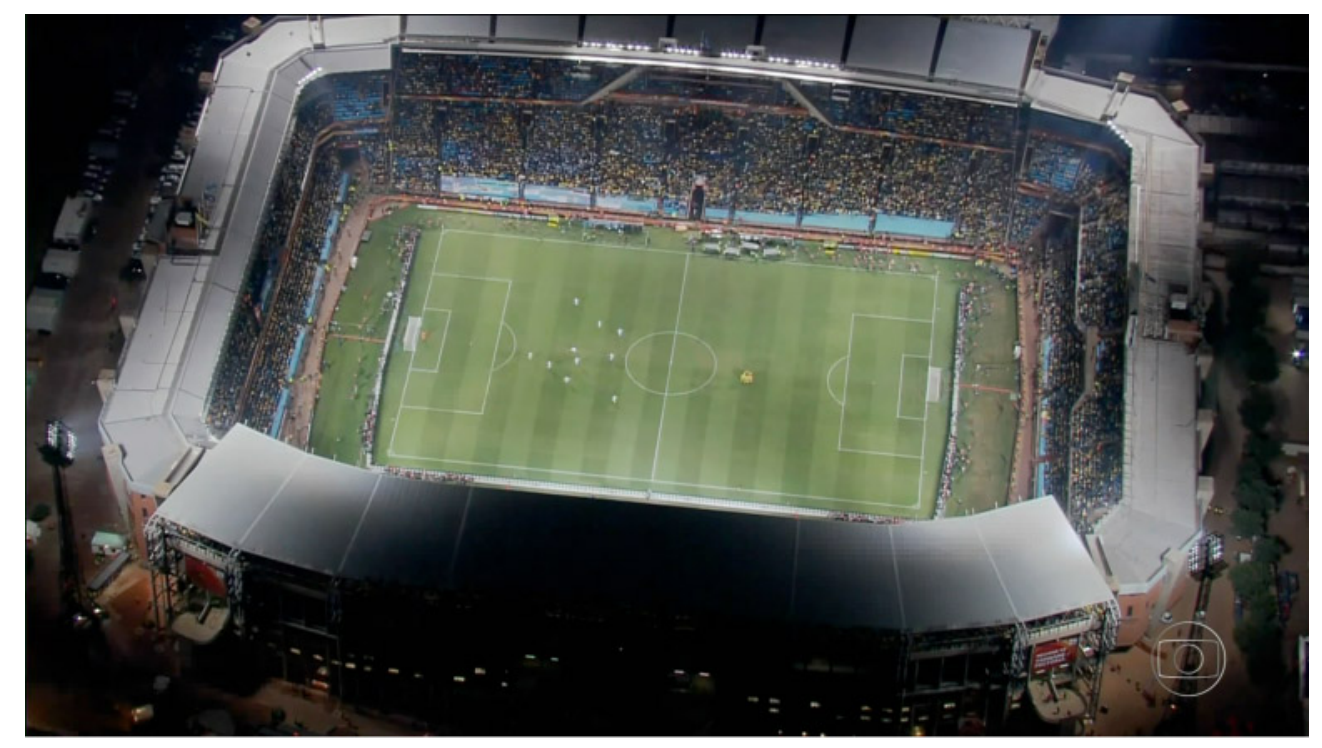

Fig. 5.10: Transmissão da Copa do Mundo 2010 em HDTV na Rede Globo 
Além dessa personalização, as emissoras inserem sobre as imagens conteúdos que identificam o canal, como gráficos, placar e alguns "features" extras, como o Tira-Teima da Globo. Esse ano a Globo e a Bandeirantes realizaram alguns testes de interatividade utilizando Ginga, além de disponibilizaram conteúdo em seus web sites e a aplicativos para celulares.

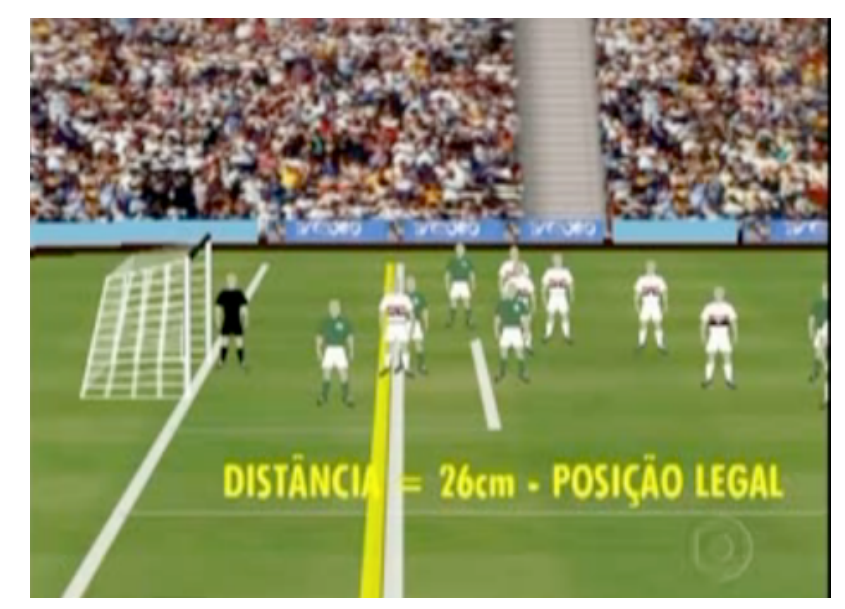

Fig. 5.11: Tira-Teima da Rede Globo

Além da personalização das emissoras, as operadoras de TV a cabo têm a capacidade de inserir gráficos utilizando o STB conectado à TV do assinante. Esse recurso aparentemente não foi utilizado, pois na maioria dos casos a informação disponível era a padrão dos EPGs, e em muitos casos desatualizados ou com informações bastante genéricas que não chegavam a incluir dados sobre as partidas que estavam sendo transmitidas.
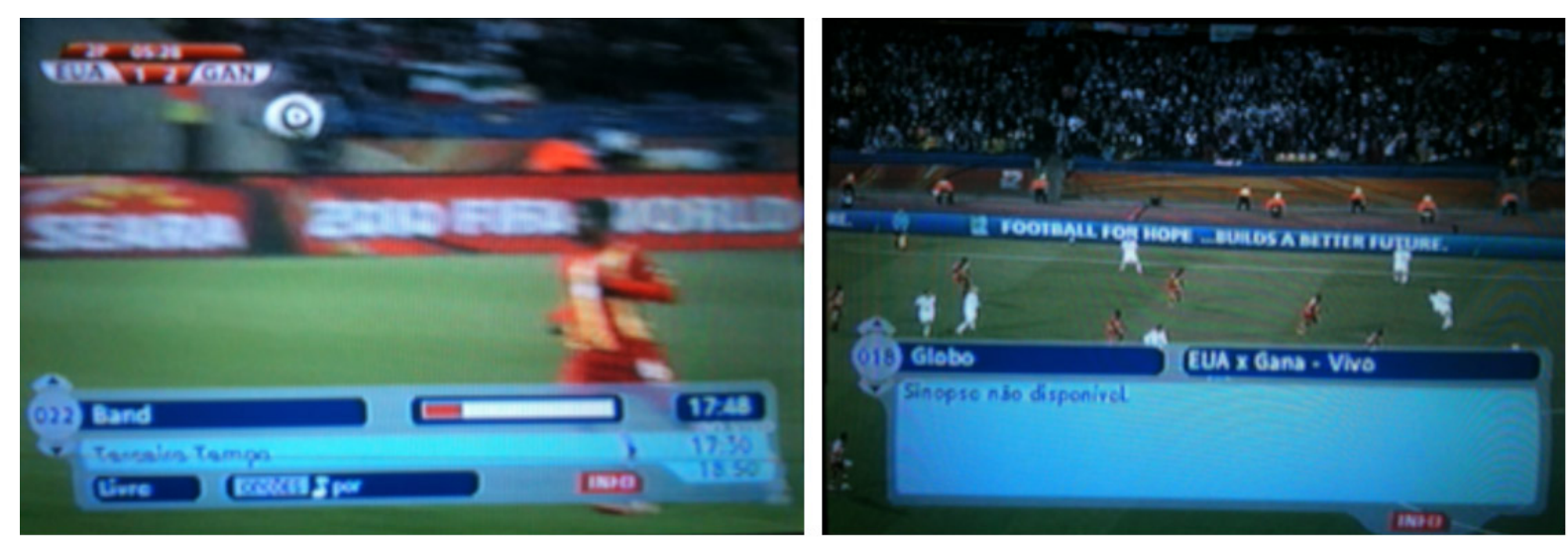

Fig. 5.12: Informação disponível no EPG da operadora de TV a cabo NET durante a transmissão da Band do jogo EUA e Gana e Sinopse da Rede Globo na Net durante a transmissão do mesmo jogo.

Os dados que alimentam os EPGs poderiam ser enriquecidos, por exemplo, extraindose dados dos sites das emissoras ou de outros provedores de conteúdo. 

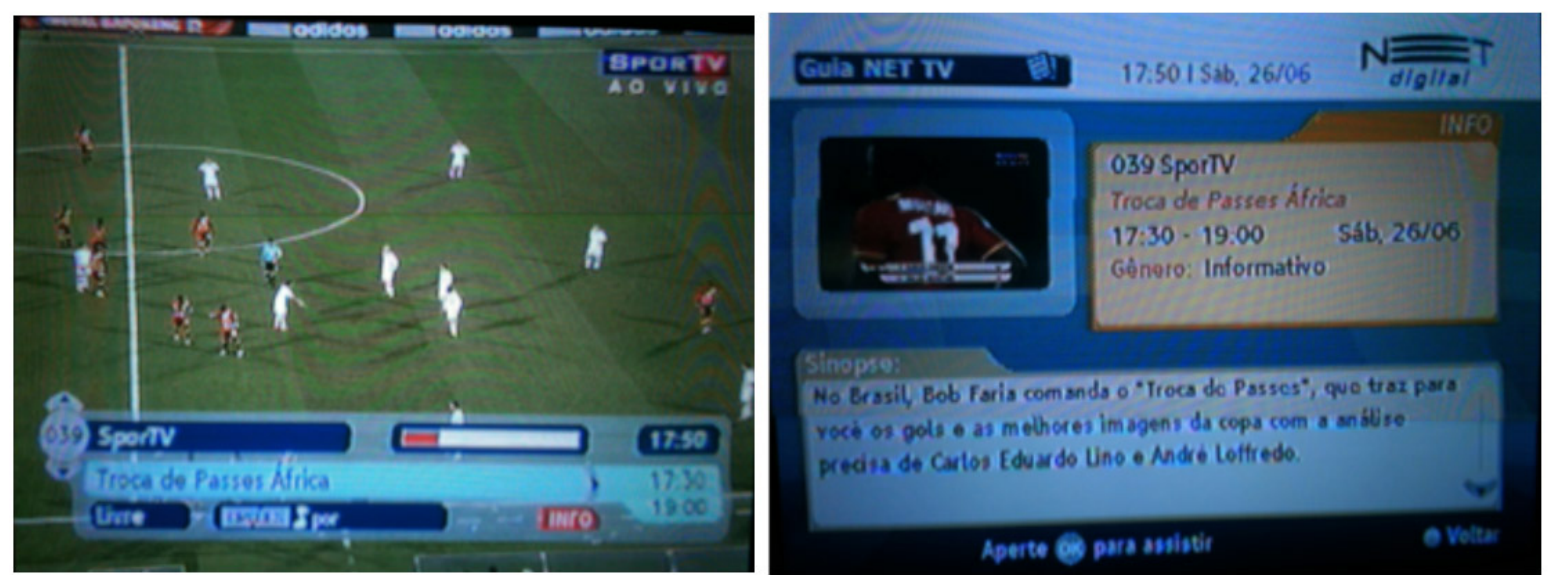

Fig. 5.13: Miniguia e sinopse do EPG da NET informando a transmissão do Sport TV em Standard Definition.

\section{Ginga na Globo Copa 2010}

Em "fóruns" especializados como o site da revista Home Theater, usuários de aparelhos de TV Digital com receptor integrado relatam terem tido sucesso com o aplicativo interativo para da Copa do Mundo desenvolvido em Ginga pela Rede Globo, a maioria utilizando o modelo LH45 da LG com middleware Ginga (ou aplicativo DTVi, como passou a ser chamado pelos fabricantes) instalado no próprio aparelho. Há relatos de que o modelo 32 EX45 da Sony também era capaz de rodar o aplicativo ${ }^{128}$.

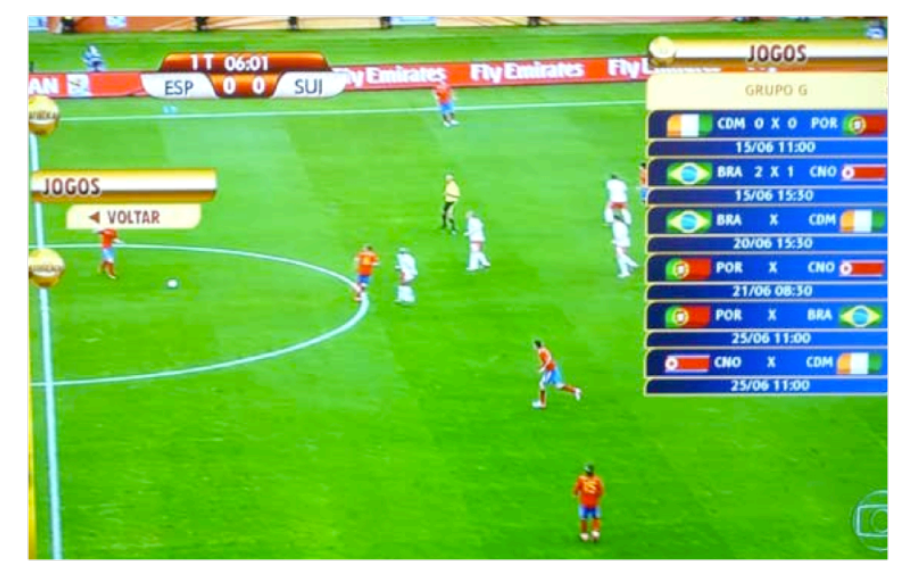

Fig. 5.14: Interatividade com Ginga na Copa do Mundo disponível na TV LH45 da LG. Fonte: planetech.uol.com.br

128 "Vídeo: interatividade (Ginga) na Copa do Mundo", Planet Tech, 16/6/2010. Disponível em: $<$ http://planetech.uol.com.br/2010/06/16/video-interatividade-ginga-na-copa-do-mundo-2/>. Acesso em: $16 / 1 / 2011$ 
A Rede Bandeirantes também ofereceu um aplicativo em Ginga desenvolvido em parceria com a TQTVD ${ }^{129}$, mas há poucos relatos de telespectadores que acessaram o aplicativo na Copa de 2010.

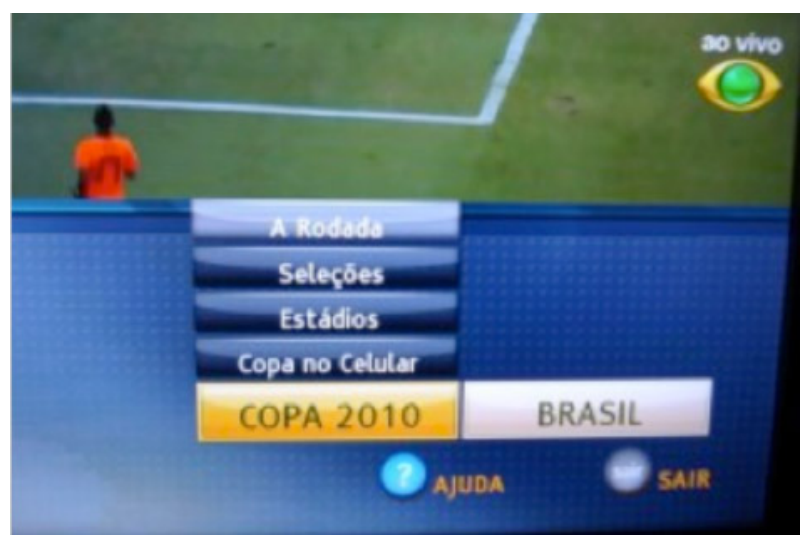

Fig. 5.15: Detalhe da aplicação da Band para Copa 2010 desenvolvida pela BRAVA iTV e TQTVD

Fonte: Bravaitv.com.br

\subsubsection{Programas Gravados}

Por ocasião da Copa de 2010, vimos o lançamento da coleção de documentários “Copa do Mundo FIFA - 1930-2006” pela editora Abril, que é composta por 15 DVDs com os documentários originais da FIFA sobre cada torneio. Canais de TV a cabo reprisaram imagens e lances de copas anteriores em matérias editadas por ocasião do evento. Existe um vasto acervo audiovisual da Copa do Mundo, arquivado pelas emissoras e disponível na internet, muitas vezes remixado por internautas. Esse material poderá ser facilmente acessado em uma TV conectada à internet.

\subsubsection{3 Áudio e Rádio}

Um das grandes diferenças entre a transmissão de TV e de rádio na Copa do Mundo é o estilo de locução, sendo que no rádio ele pode deve ter mais descrições visuais de modo a compensar a inexistência da imagem. Nos estádios, é comum vermos torcedores escutando a locução no rádio enquanto assiste ao jogo ao vivo. Na transmissão televisiva, o comentarista é

\footnotetext{
129 " [Bê-a-Bá] TV com acesso à Internet. Isto é Ginga?” Bruno Ledesma, BRAVAiTV Blog da Interatividade, 29/09/2010, Disponível em:

<http://www.bravaitv.com.br/blog/index.php/page/2/?tag=tv-digital> Acesso em 16/01/2011
} 
um dos principais motivos da escolha de um canal pelo público, já que no caso da Copa do Mundo as imagens são virtualmente as mesmas. Com a convergência das mídias, abre-se a possibilidade de se escutar a locução de uma mídia enquanto se vê a imagem de outra.

\subsubsection{Internet}

O crescimento do uso da internet como meio de acesso a informações sobre a Copa do Mundo torna-se evidente ao vermos a importância dada ao evento pelos principais web sites e portais de internet no Brasil e no mundo. Irei analisar aqui como foi a cobertura do evento nos portais brasileiros Universo Online e Globo.com, no site do Jornal New York Times, no site de duas revistas brasileiras da editora Abril: Veja Online e Placar e no site do jornal O Estado de S. Paulo.

\section{New York Times}

$\mathrm{Na}$ home page do NYT (www.nyt.com), infográficos interativos permitiam acompanhar as partidas da Copa do Mundo de 2010. Nos exemplos a seguir, do jogo EUA x Gana, foi possível acompanhar (minuto a minuto) a escalação, passes, "heat map" (uma representação gráfica da área mais ativa no jogo). Entre outras funcionalidades, destaca-se uma linha do tempo permitindo percorrer temporalmente a partida interagindo com os infográficos.

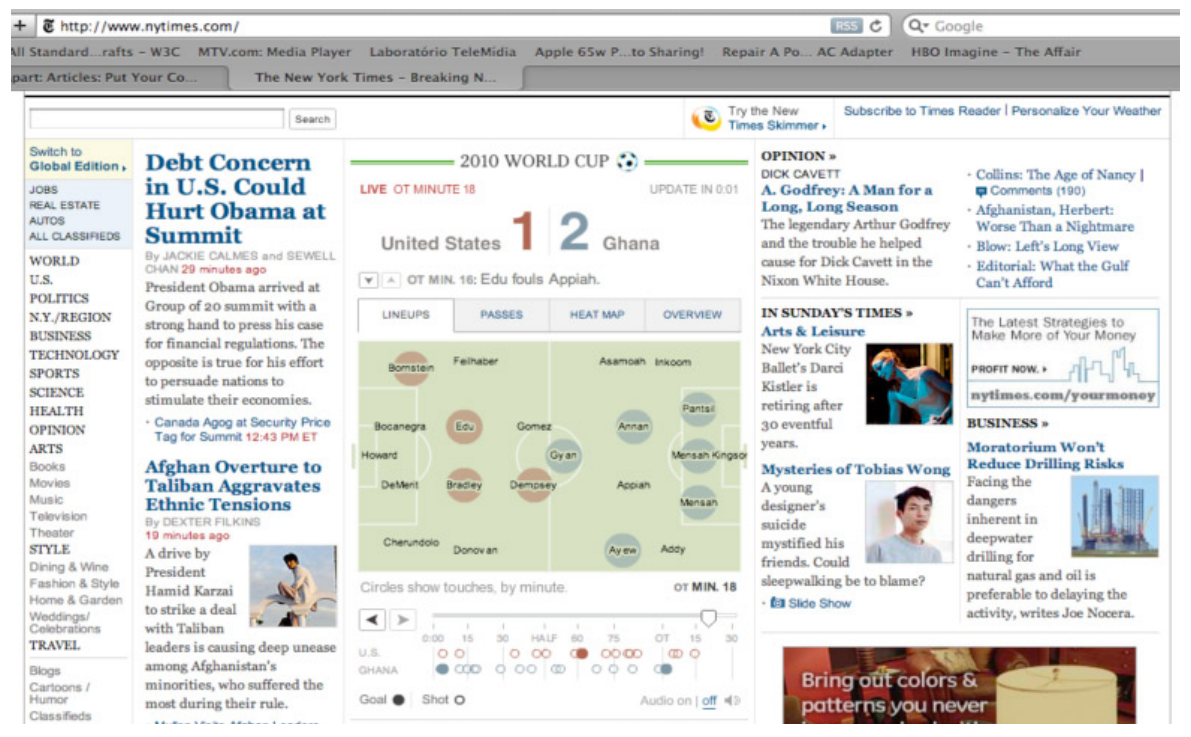

Fig. 5.16: Home page do site New York Times durante o jogo EUA vs. Gana Fonte: www.nyt.com 
Este tipo infografia originada nos jornais pode ser vista como uma nova forma de narração do jogo, que só pode existir com as mídias digitais; independentemente de outras mídias, pode ser "linkada" a outras fontes na internet.
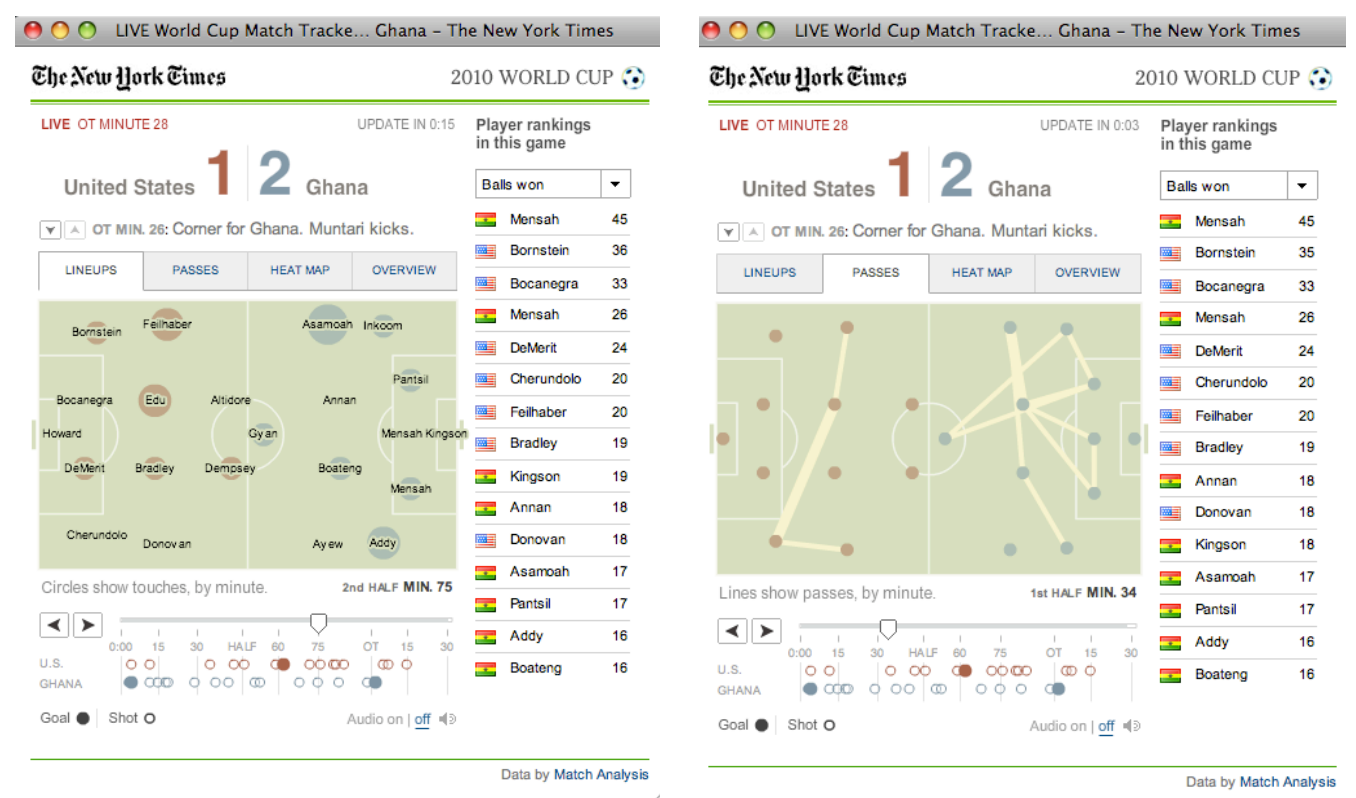

Fig. 5.17: Infográfico Interativo - Escalação e lances - EUA vs. Gana Copa 2010 Fonte: www.nyt.com

A capacidade do usuário de visualizar os lances de momentos distintos do jogo torna o infográfico mais limpo visualmente do que na mídia impressa (como no exemplo do jornal $O$ Estado de S. Paulo), pois é possível visualizá-los individualmente sem a necessidade de sobreposição. Este tipo de gráfico pode no futuro ser integrado com a imagem de satélite do estádio, uma cobertura em vista aérea do jogo e a linha de tempo pode servir para acessar vídeos do jogo minuto a minuto.

A empresa Match Analysis (www.matchanalysis.com), que forneceu os dados para os gráficos do New York Times, também oferece dados e informações em tempo real para emissoras, treinadores e comentaristas. Os analistas da empresa recebem o sinal de vídeo via satélite ou via internet e registram cada lance sincronizando os dados com o vídeo da partida, que trafegam por um banco de dados ficando disponíveis para ser utilizados por terceiros. 


\section{Universo Online - UOL}

A UOL (www.uol.com.br), dedicou um espaço de destaque em sua home page para a Copa do Mundo, onde era possível acompanhar o evento em "tempo real". Nele havia um "box" com o placar das partidas e menus que direcionavam diretamente a páginas do site desenvolvidas exclusivamente para a Copa de 2010. Nessa área do site, infográficos permitiam acompanhar os lances dos jogos minuto a minuto, consultar tabelas interativas e informações sobre os times e jogadores.

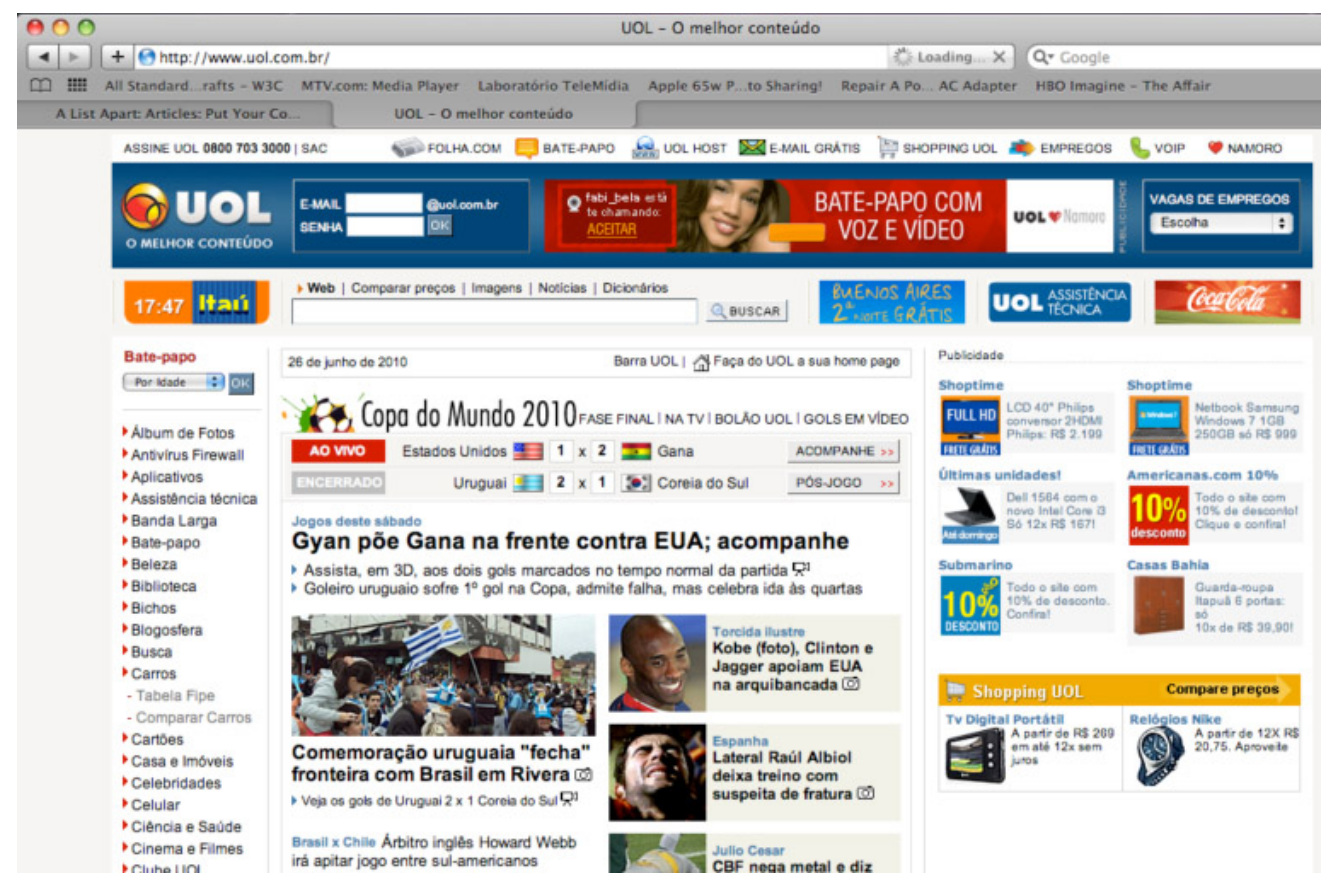

Fig. 5.18: Home page da UOL durante o jogo EUA vs. Gana Fonte: www.uol.com.br

No site infográficos como "Os Bons Moços de Dunga" permitiam acompanhar "Um dia na vida" dos principais "pilares" da seleção. A parte histórica é extensa, com curiosidades, estatísticas e depoimentos. Entre outras sessões do site de destam-se um guia da Africa do Sul, informações sobre os estádios, fotos e notícias.

Um aspecto interessante do site do UOL é a incorporação de um aplicativo de chat dentro da página, permitindo que os visitantes da página fizessem comentários durante a partida. 


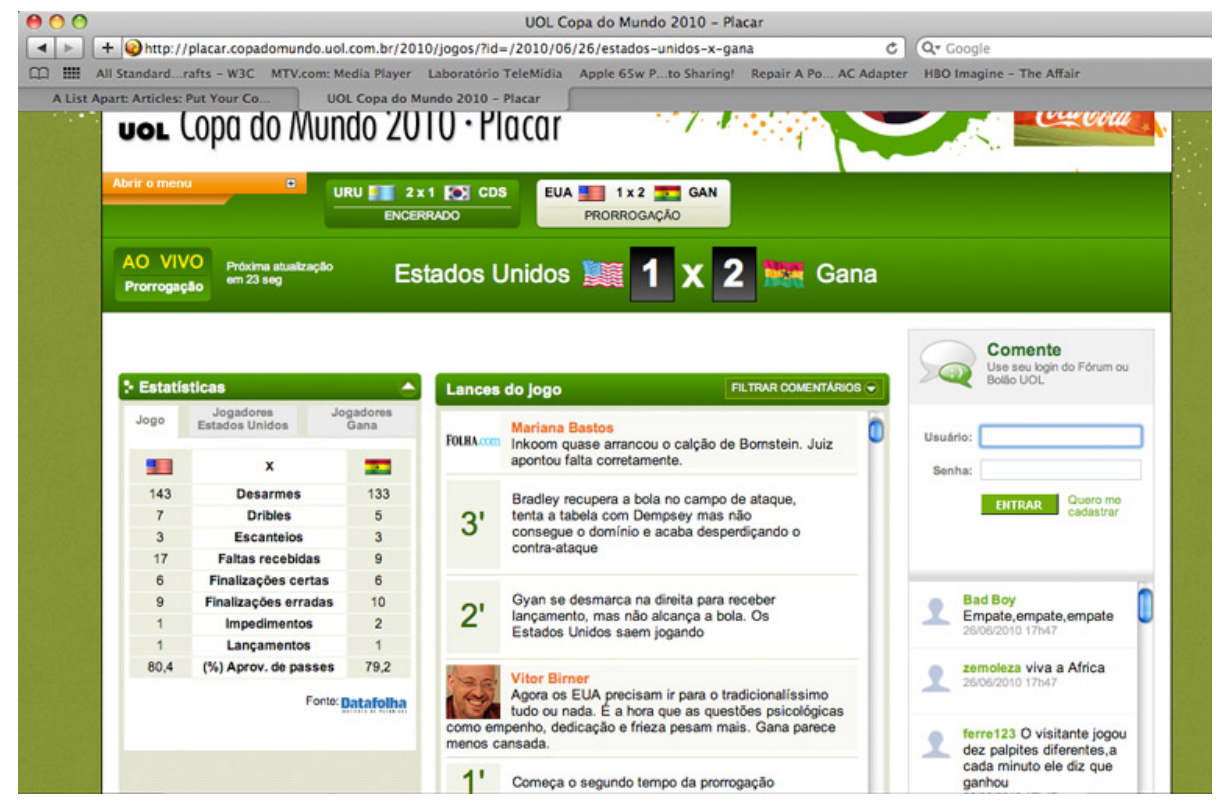

Fig. 5.19: Lances e estatísticas do jogo EUA x Gana no site da UOL Fonte: www.uol.com.br

Outra inovação bastante interessante no site da UOL foi a reconstituição dos gols da Copa em modelagem 3-D, que puderam ser visualizados em diversos ângulos utilizando o aplicativo UOL Unity Player.

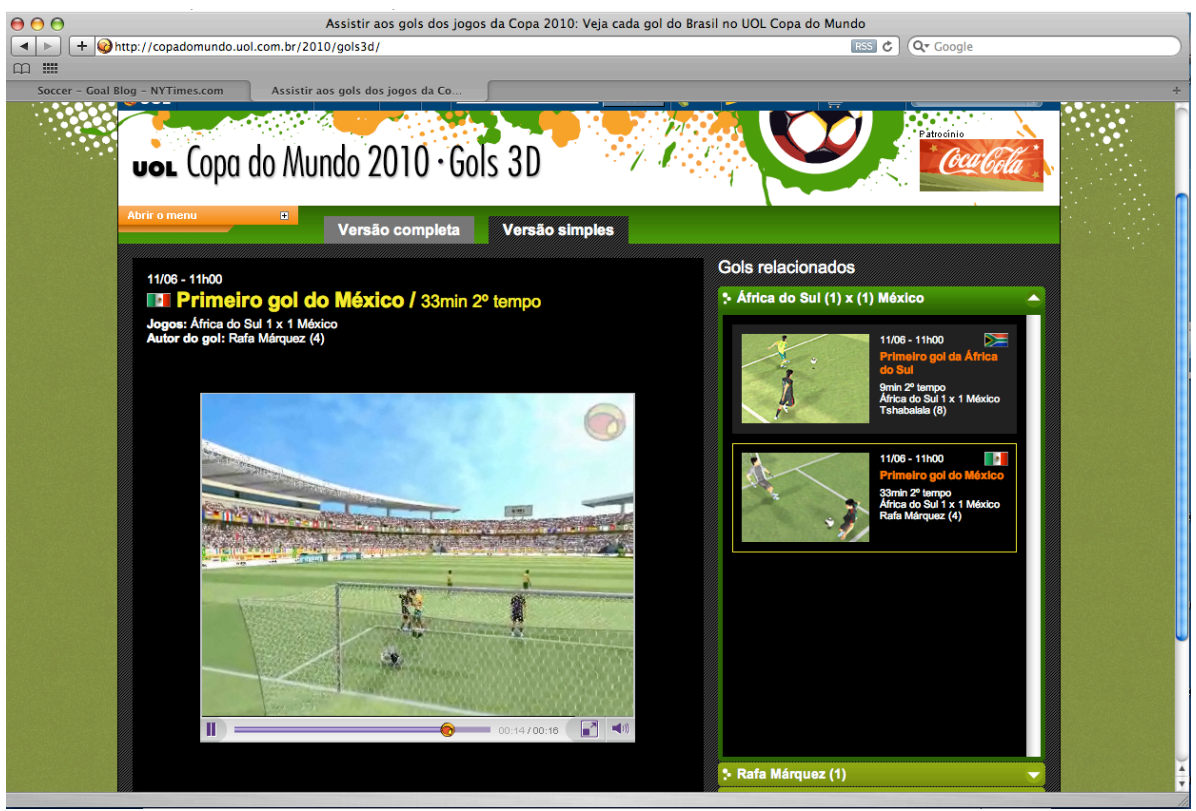

Fig. 5.20: UOL Copa do Mundo 2010 - Gols 3-D

Fonte: www.uol.com.br 
A UOL também ofereceu aos visitantes do site a possibilidade de receber notícias da Copa no celular através de mensagens de texto SMS, expandido seu conteúdo para a plataforma móvel.

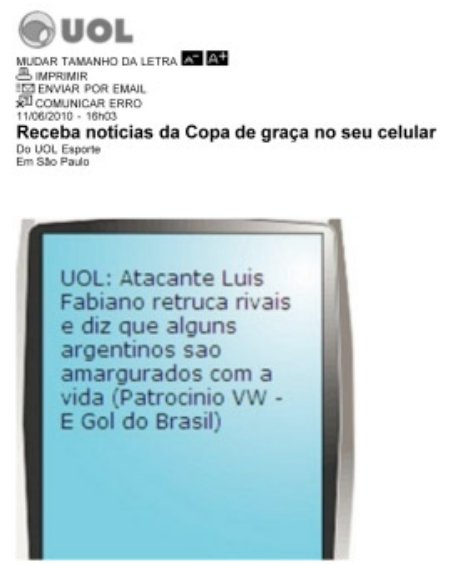

Fig. 5.21:. Aplicativo de notícias da Copa para celular do UOL

Fonte: www.uol.com.br

\section{Estadão.com.br}

Na versão online do jornal $O$ Estado de S. Paulo, foi possível acompanhar a evolução dos jogos em tempo real, no entanto a parte dedicada aos jogos ficou bastante a dever em relação à versão impressa.

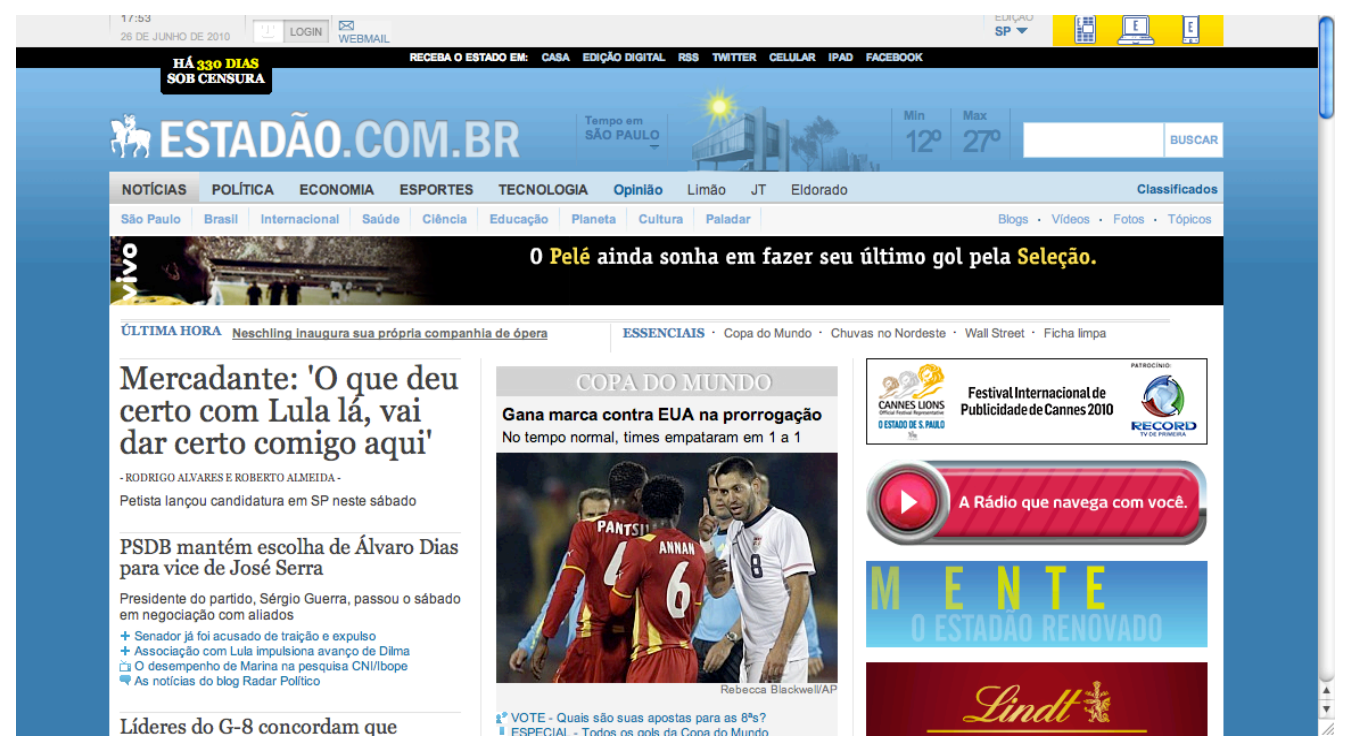

Fig. 5.22: Home page do Estadao.com.br durante o jogo EUA e Gana na Copa de 2010

Fonte: www.estadao.com.br 


\section{Placar}

O site da revista Placar, especializada em futebol, tem sessões bem organizadas e de fácil navegação. A formatação do site para a Copa do Mundo é o mesmo utilizado para outros campeonatos, com as subsessões matérias, entrevistas, galeria de fotos, notícias, podcast, tabelas e vídeos. O podcast tem um formato semelhante ao de notícias, apresentando gravações de seus comentaristas analisando as partidas e o campeonato. Os vídeos do site são referenciados de servidores externos ao site, como o YouTube.

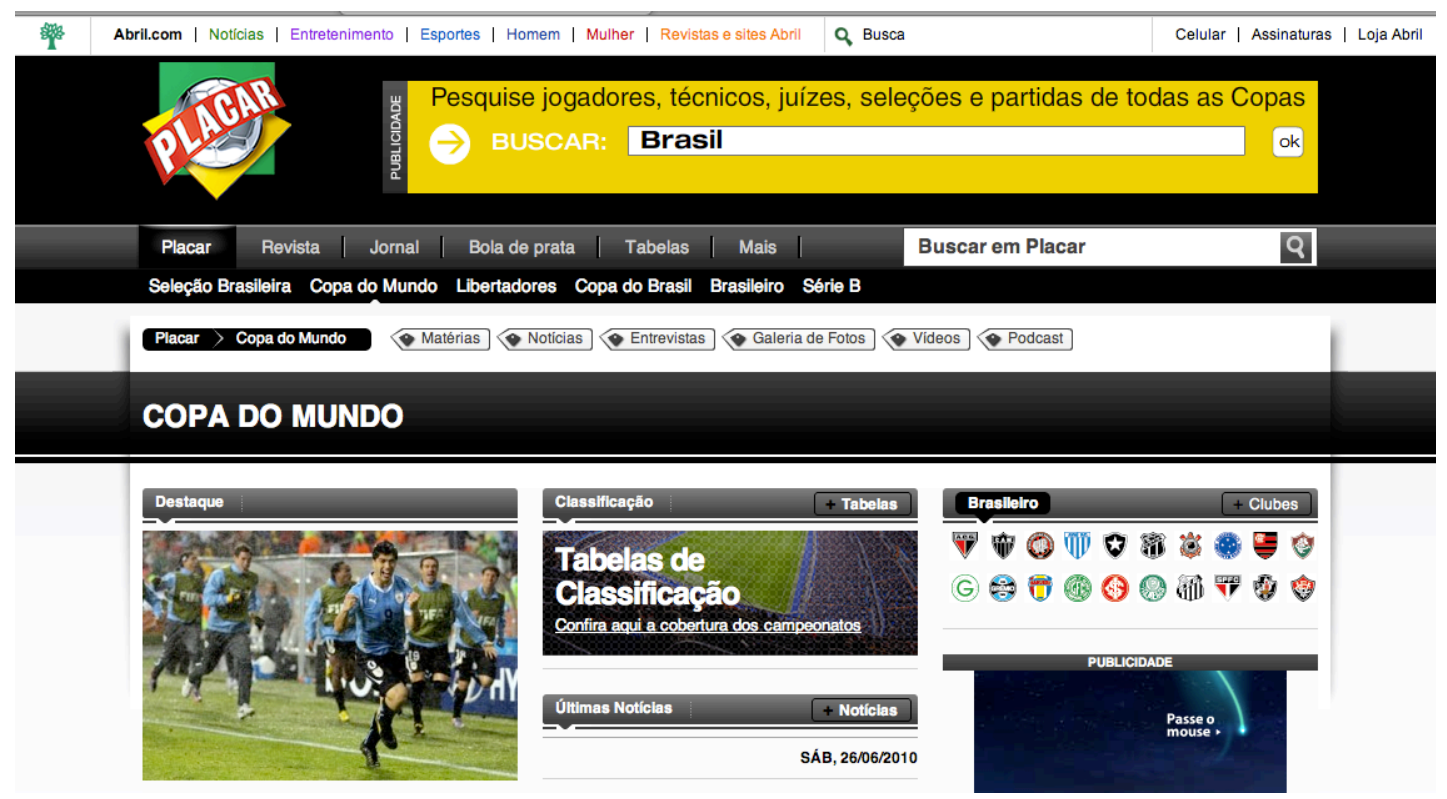

Fig. 5.23: Home page da Placar Online durante a Copa de 2010

Fonte: www.placar.abril.com.br

\section{Globoesporte.com}

A área de esportes do portal Globo.com teve várias páginas dedicadas à Copa do Mundo em 2010. O evento esteve presente em toda a hierarquia do site, com chamadas na home direcionando às páginas de esportes, onde se encontrava um conteúdo bastante rico em vídeos e imagens dos jogos. As tabelas e informações sobre times e jogos eram bastante completas e de fácil navegação. Na sessão de vídeos, segmentos dos jogos estavam disponíveis para streaming com excelente resolução. Durante os jogos era possível rever os lances que acabavam de acontecer em uma partida, uma linha de tempo permitia a navegação destes, descritos e indexados temporalmente. No projeto de interface que apresento no 
próximo capítulo, sugiro "re-midiar" esse aspecto do site adequando sua navegação para um celular com a possibilidade de ver os vídeos em tela cheia na TV.
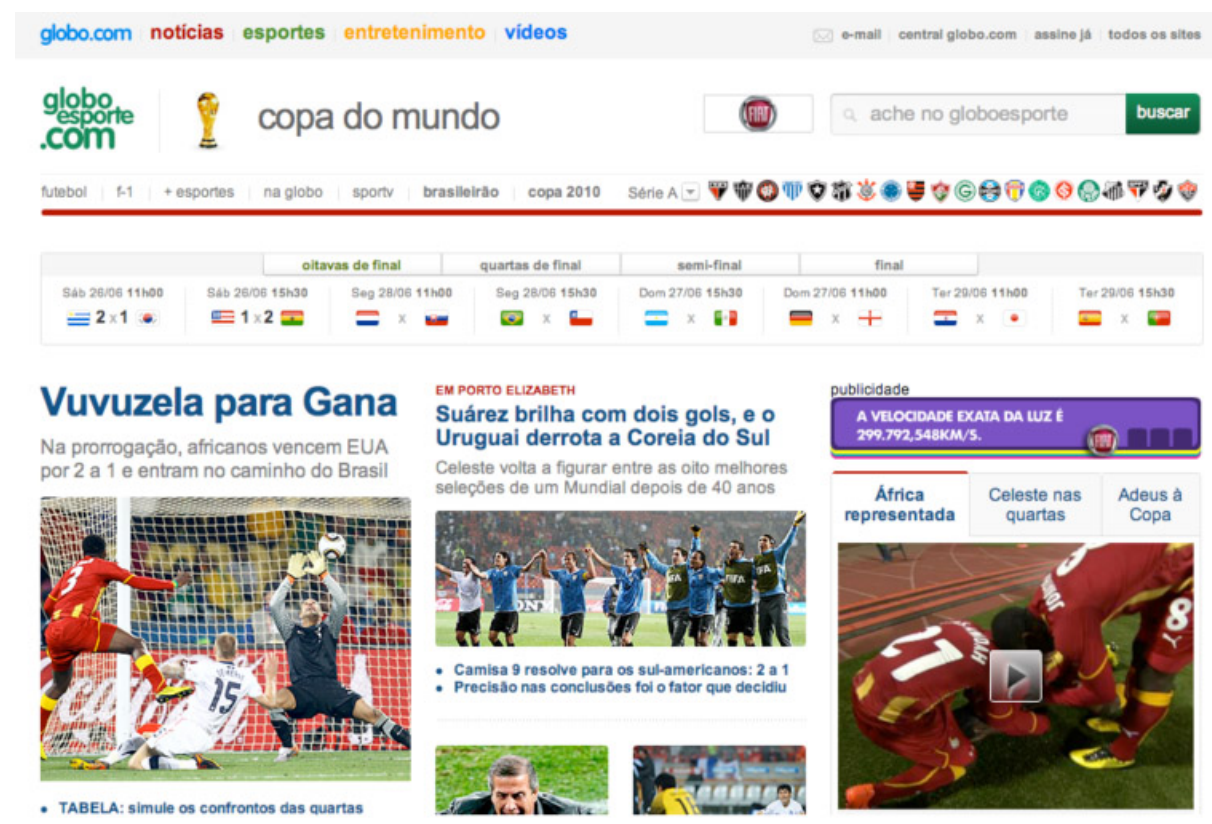

Fig. 5.24: Página principal do Globoesporte.com durante a Copa de 2010

Fonte: www.globoesporte.com

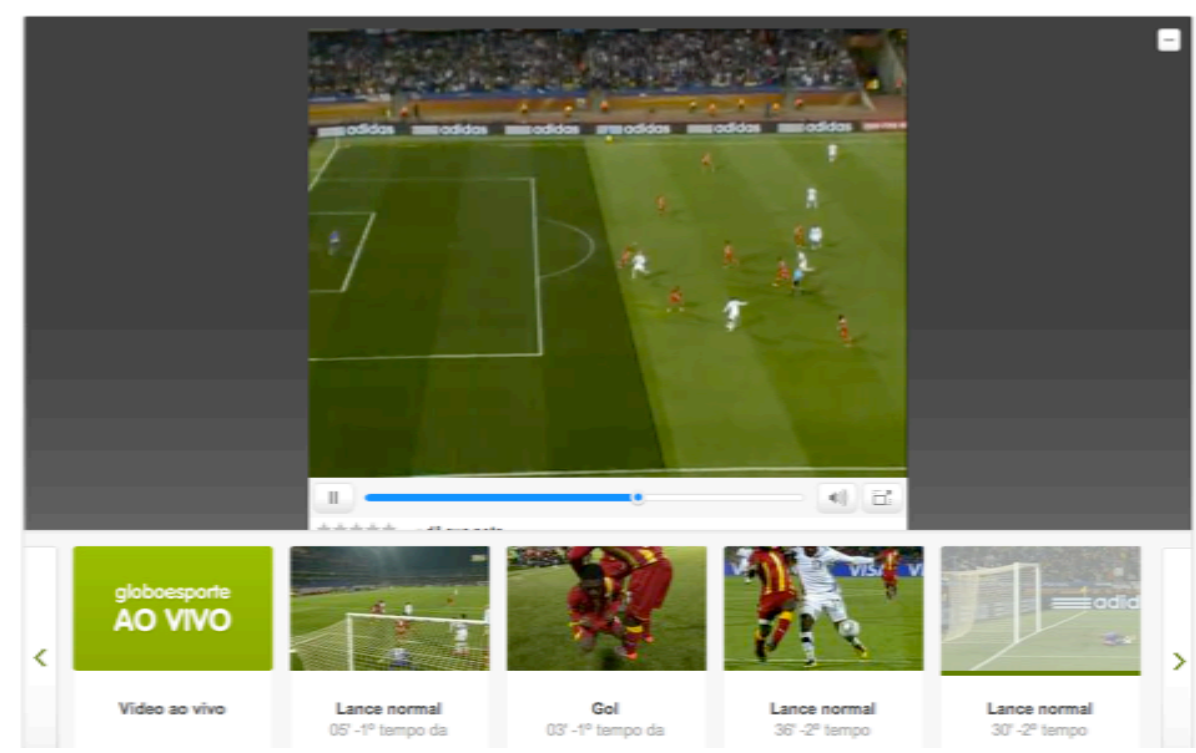

Fig. 5.25: Página de lances em tempo real no Globoesporte.com, EUA vs. Gana, Copa de 2010 Fonte: www.globoesporte.com

\section{Veja Interativa}

A revista Veja desenvolveu um site integrado a uma edição especial impressa da revista da Copa de 2010. Ao acessar o site com a revista em mãos, o leitor apontava a imagem 
de um QR code para sua webcam, direcionando o conteúdo interativo complementar à matéria impressa.

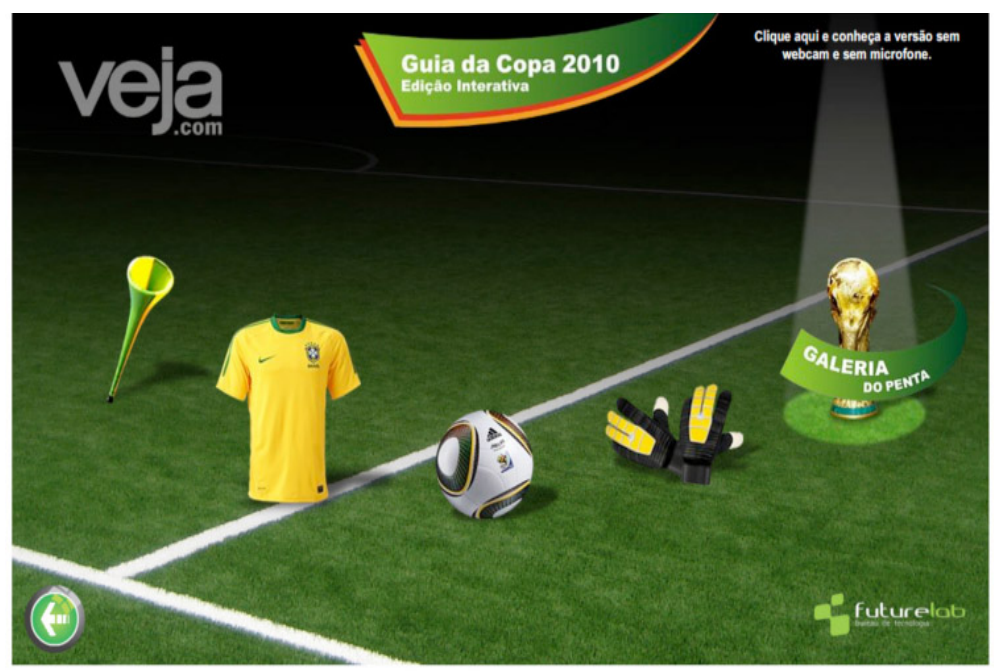

Fig. 5.26: Página principal da versão interativa da revista Veja na Copa de 2010 Fonte: www.veja.com.br

Este conteúdo consistia em diversas "brincadeiras". Em uma era possível captar a imagem do usuário e sobrepô-la a um game em que se simulavam chutes a gol, noutra se podia “assoprar" em uma vuvuzela (corneta tipíca das torcidas de futebol na África do Sul).

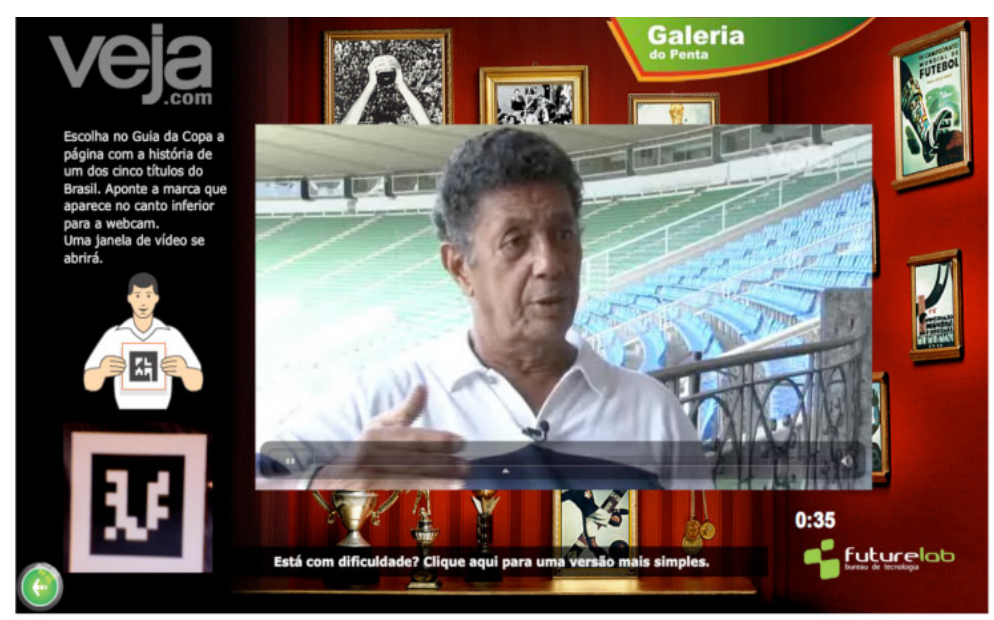

Fig. 5.27: "Galeria do Penta" na versão interativa da revista Veja na Copa de 2010 Fonte: www.veja.com.br

$\mathrm{Na}$ "Galeria do Penta", ao clicar nos quadros na parede de uma sala, era possível assistir a vídeos representados pelas imagens. 


\subsubsection{Telefones Celulares}

Impulsionadas pela demanda dos telespectadores, as operadoras de telefonia celular e fabricantes de aparelhos lançaram em 2010 diversos modelos de celulares com receptores de TV Digital, entre eles o ZTE N290 ${ }^{130}$, o Star TV da Samsung ${ }^{131}$ e o LG- GM600; para o último foi desenvolvido um aplicativo interativo em Ginga que analisarei a seguir. A recepção da TV Digital no celular é gratuita, pois o aparelho não utiliza a rede da operadora de telefonia para receber o sinal digital da TV aberta, no entanto as operadoras veem a oportunidade de cobrança ao oferecer serviços e aplicativos interativos através de suas redes de dados.

Diversos aplicativos que foram desenvolvidos para a Copa do Mundo de 2010 na plataforma iPhone serão analisados neste capítulo. No momento, o celular iPhone da Apple não possui um receptor de TV Digital, mas é possível adquirir um acessório, o UTV Tivizen $^{132}$, que conectado a um iPhone ou a um iPad permite receber a transmissão da TV Digital em ISDB. Mesmo sem acesso à TV Digital utilizando o iPhone, este grande número de aplicativos para a plataforma demonstra que existe um interesse do usuário em utilizar diversos dispositivos, preferindo utilizar aquele cuja interface é mais apropriada para um determinado uso. Por exemplo, no caso do aparelho da LG, a interatividade disponível no aplicativo Ginga era facilmente superada pelos aplicativos do iPhone.

\subsubsection{Telefone Celular com TV Digital e Ginga}

A LG lançou em 2010 um celular com receptor de TV Digital interativa. A interatividade é possível no celular através do middleware Ginga; o aparelho utiliza a sigla DTVi em vez de mencionar a linguagem Ginga. A Globo desenvolveu um aplicativo para a Copa do Mundo e outras emissoras devem estar desenvolvendo aplicativos para a plataforma. Segundo Raymundo Barros, diretor de engenharia da TV Globo, em entrevista para Ana Paula Lobo da UOL ${ }^{133}$, a Globo estabeleceu uma parceria com a LG para desenvolvimento de

\footnotetext{
${ }^{130} \mathrm{http}: / / \mathrm{www} . v i v o b l o g . c o m . b r / z t e-n 290-c o m-t v-d i g i t a l . h t m l$

${ }^{131} \mathrm{http}: / / \mathrm{www}$.baixaki.com.br/info/3605-analise-samsung-star-tv.htm

${ }^{132} \mathrm{http}$ ://www.blog.jaldomir.com.br/index.php?option=com_content\&view=article\&id=166:receptor-de-tvdigital-para-iphoneipodipad\&catid=39: novidades\&Itemid $=\overline{55}$

133 “TV Digital: LG lança primeiro celular com Ginga no Brasil “ Ana Paula Lobo Convergência Digital :UOL 01/06/2010, Disponível em:
} 
aplicativos em Ginga para o terminal, e a emissora desenvolveu nove aplicativos com Ginga tanto para terminais móveis como para aparelhos fixos, sendo que o da Copa do Mundo, o LG TV Phone GM600 para celulares, será adaptado para o Campeonato Brasileiro e para os Estaduais.

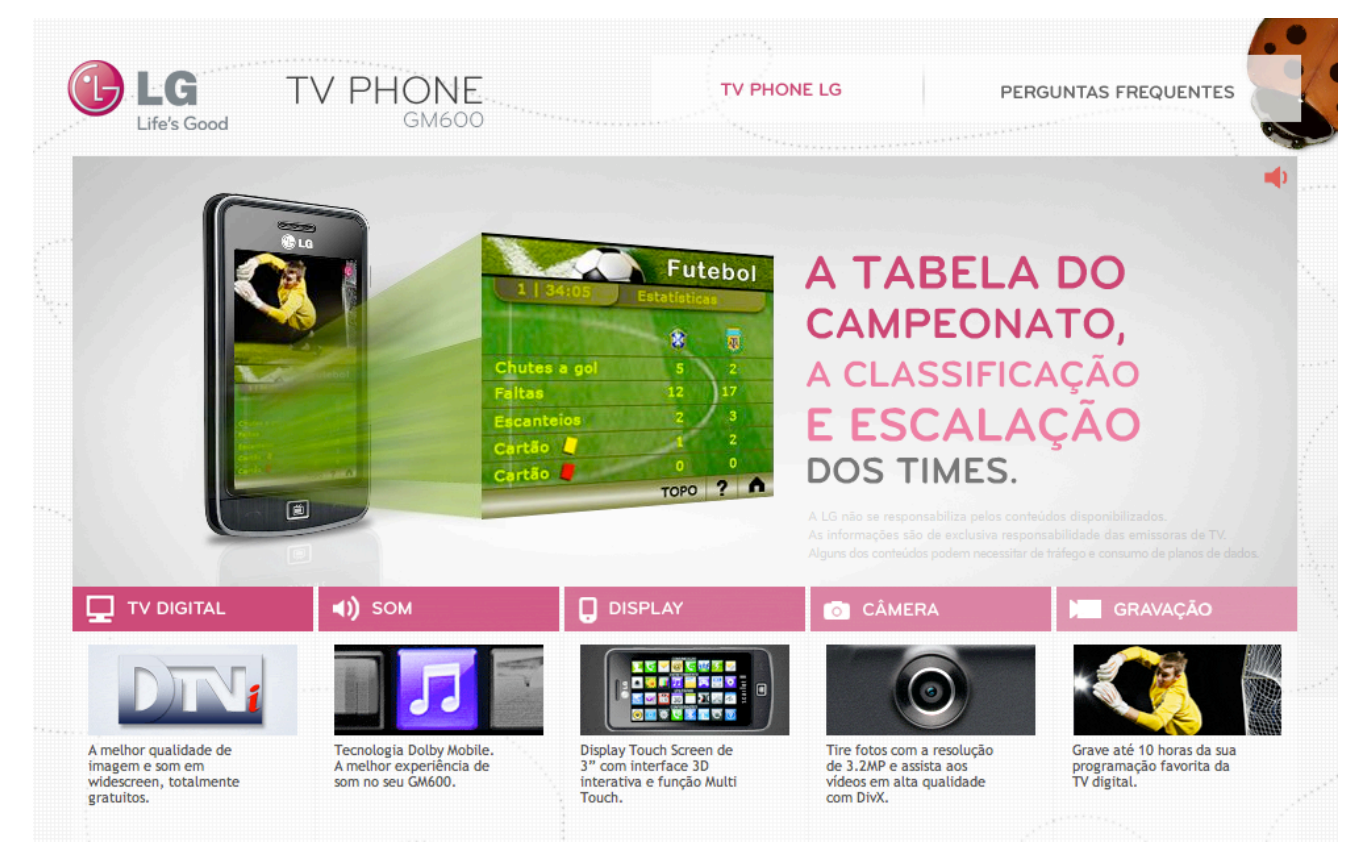

Fig. 5.28: Anúncio no site da LG do celular GM600 com TV Digital e Ginga Fonte: www.lge.com.br

Segundo Rodrigo Ayres, gerente de produto de celular da LG Eletronics (na mesma matéria), "A expectativa da fabricante coreana é que, em 2014, 30 milhões de usuários do serviço celular tenham o terminal com TV Digital. Hoje, esse índice é de 1,5\%, podendo chegar, segundo a empresa, a $5 \%$ até o final do ano."

Realizei testes com o aparelho da LG sem sucesso devido à dificuldade de instalação do software: o aparelho não vem com a atualização de software que permite utilizar o aplicativo interativo para a TV, o usuário deve baixar o programa no website do fabricante, mas antes disso deve atualizar o sistema operacional do aparelho celular. As instruções de como realizar esse procedimento são bastante imprecisas, e uma vez que consegue acessar o software de atualização, o usuário deve realizar um procedimento um tanto complexo, que 
consiste em conectar o celular via USB ao computador e posteriormente retirar a bateria. Mesmo assim o instalador da atualização não foi capaz de instalar o programa, depois de diversas tentativas em vários PCs e com a assistência de outros usuários, foi realizada uma tentativa de instalar o programa no Laboratório de Mídias Audiovisuais (LMA) do Departamento de Cinema, Rádio e Televisão (CTR) ECA USP, acompanhado do técnico responsável do laboratório, o qual também não conseguiu instalar o programa.

Assim sendo, chegamos à conclusão de que não basta que a interface de um programa seja utilizável, a pré-instalação deste é crucial, a necessidade de instalação e atualização de software é uma das características da indústria da computação que deve ser resolvida na convergência de computadores com a TV, pois o telespectador da TV espera simplesmente poder ligar a TV e assistir à programação.

\subsubsection{Aplicativos para iPhone}

É possível instalar aplicativos para o iPhone, iPod Touch e iPad através da "App Store" da Apple diretamente do celular, seja utilizando uma conexão 3-G ou uma rede de WiFi. A instalação desses aplicativos é bastante simples, requerendo apenas que o usuário tenha uma conta na loja e selecione o botão "instalar". Se por um lado o usuário é refém da estratégia da Apple de concentrar em sua loja virtual iTunes a distribuição de aplicativos, por outro há a garantia de que os aplicativos da plataforma atendam a determinados requisitos mínimos de qualidade e funcionalidade.

Identifiquei e analisei diversos aplicativos desenvolvidos para a Copa do Mundo de 2010 na plataforma iPhone, tanto por desenvolvedores brasileiros como de outros países. Vejamos alguns exemplos:

\section{Central Copa - TV Globo}

O aplicativo Central Copa da TV Globo permite ao usuário obter diversas informações complementares aos jogos. O app está organizado em grupos, onde se acessa a informação de cada seleção, e pode-se também acessar informações dos jogos diretamente através de cada grupo. Algumas outras funcionalidades do programa são: 
-Notícias com fotos e textos, com resultados dos jogos e comentários; a atualização destas continuou ativa mesmo após o término da Copa de 2010.

-Integração com o Google Earth, permitindo, ao clicar em um time, acessar um mapa indicando a localização da sede de um time.

-Tabela de jogos atualizada automaticamente.
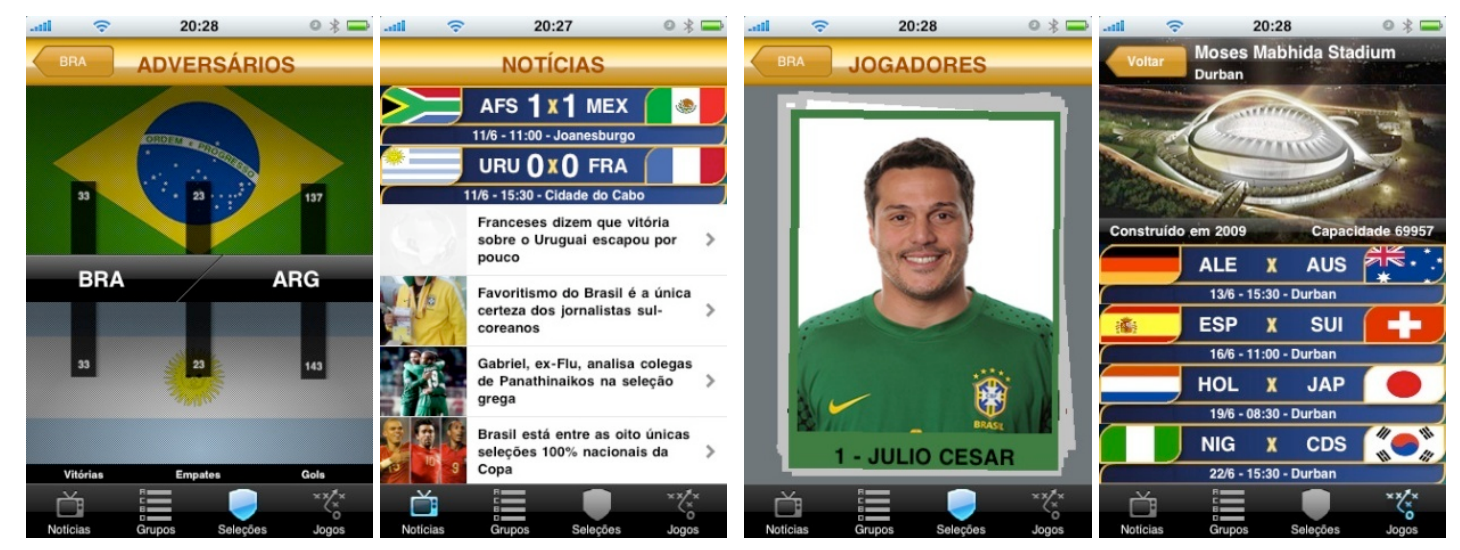

Fig, 5.29: Aplicativo Central Copa da TV Globo para iPhones

Fonte: www.apple.com/itunes/

O aplicativo é bastante robusto, aparentemente exibe as mesmas informações disponíveis no aplicativo DTVi que a Globo desenvolveu para receptores de TV Digital. No entanto, a manipulação direta da interface possível no iPhone torna esta versão muito mais funcional do que a versão para DTV. Uma integração dessa plataforma (ou similares como Android) com receptores de TV Digital parece ser um caminho bastante interessante a ser explorado na Copa de 2014.

\section{Copa do Mundo 2010 - Finger Tips}

O Aplicativo "Copa do Mundo 2010" da Finger Tips, empresa paulistana especializada em desenvolver aplicativos para iPhone, apresenta funcionalidade similar à de outros Apps desenvolvidos para a Copa: sendo organizado em grupos, apresentando notícias minuto a minuto, tabelas de jogos e informações das seleções e história. No entanto, talvez por não haver uma parceria do desenvolvedor com provedores de conteúdo como emissoras de TV ou jornais e notícias, as informações e imagens disponíveis acabam não sendo muito ricas. Há também inconsistências na interface, que deve ser utilizada em alguns momentos na posição vertical e em outros, na posição horizontal. 

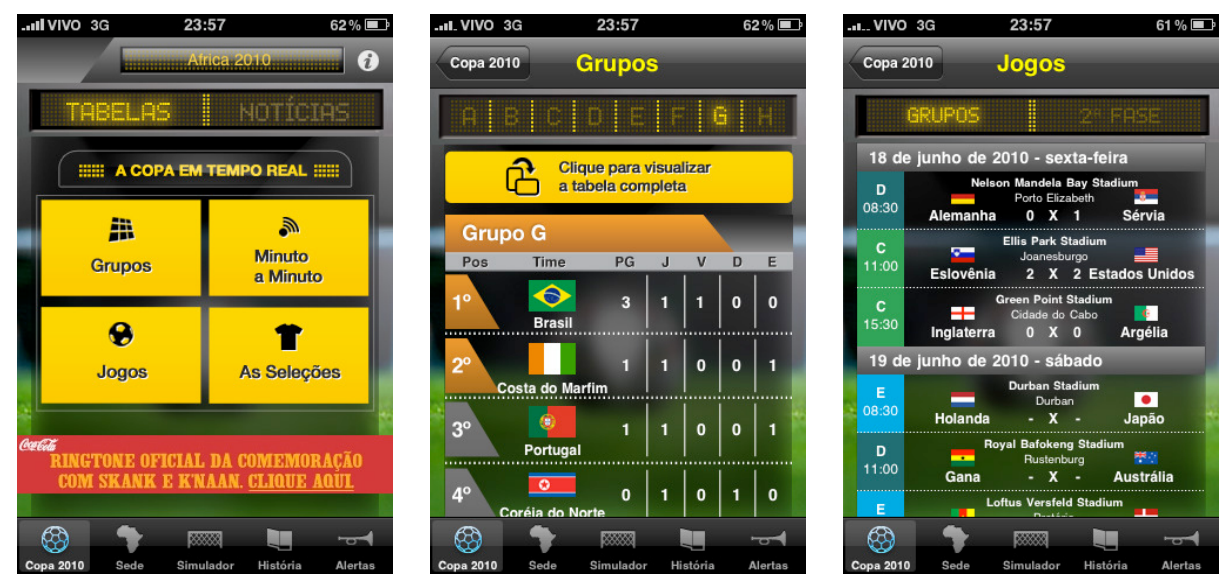

Fig. 5.30: Copa do Mundo 2010 - Finger Tips

Fonte: www.apple.com/itunes/

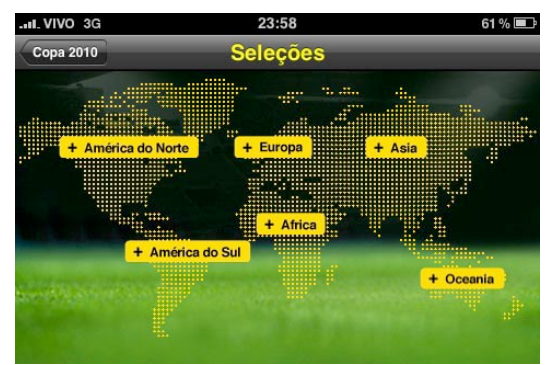

Fig. 5.31: Menu horizontal do aplicativo Copa do Mundo 2010 - Finger Tips

Fonte: www.apple.com/itunes/

Uma funcionalidade bastante interessante do aplicativo é a possibilidade de receber alertas "PUSH" dos gols das partidas da copa; os alertas textuais acompanhados de um aviso sonoro aparecem em tempo real no celular mesmo quando o aplicativo não está sendo utilizado.

\section{South África - Mubaloo}

O aplicativo gratuito South Africa Tracker $2010^{134}$ bateu recordes de download na app store da Apple. Assim como nos dois anteriores, as informações são acessadas por grupos, há informações sobre os estádios e há filtros por país; sua funcionalidade é principalmente a de uma tabela. Uma das particularidades do aplicativo é a de poder conectar-se com o Facebook, mas o aplicativo é lento e trava ocasionalmente. 

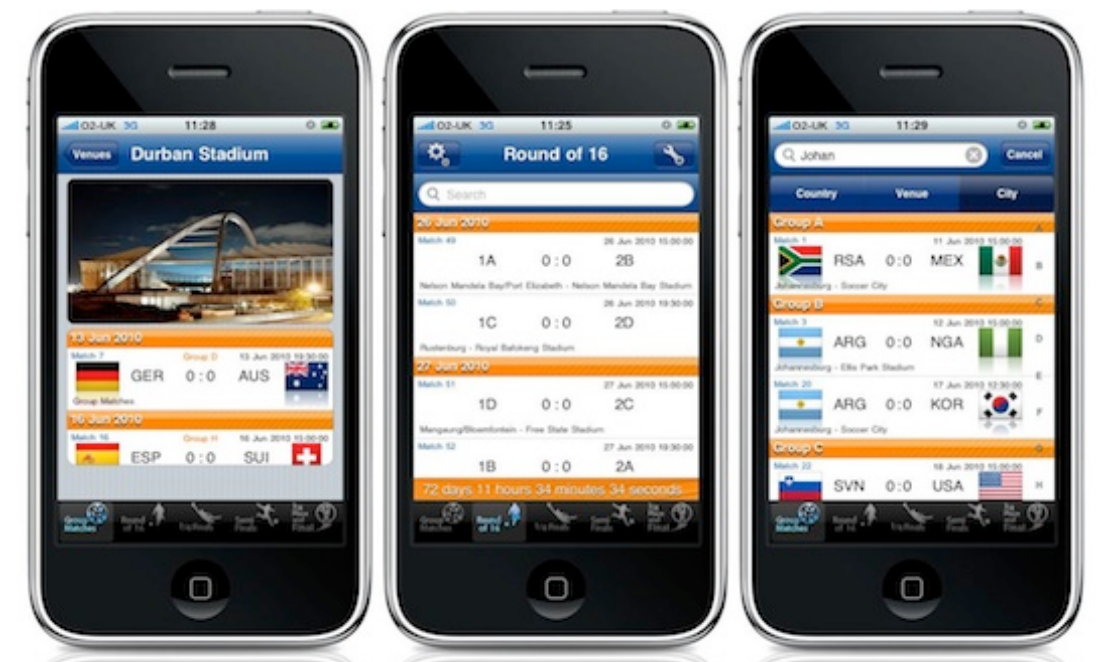

Fig. 5.32: South Africa Tracker 2010 - Mubaloo Fonte: www.apple.com/itunes/

\section{Placar UOL}

O app Placar UOL cobre diversos campeonatos como o Brasileirão, Série B, Libertadores e campeonatos internacionais como os da Inglaterra e França. Nele podemos acessar a tabela dos jogos e classificação, mas há pouca informação sobre os times.
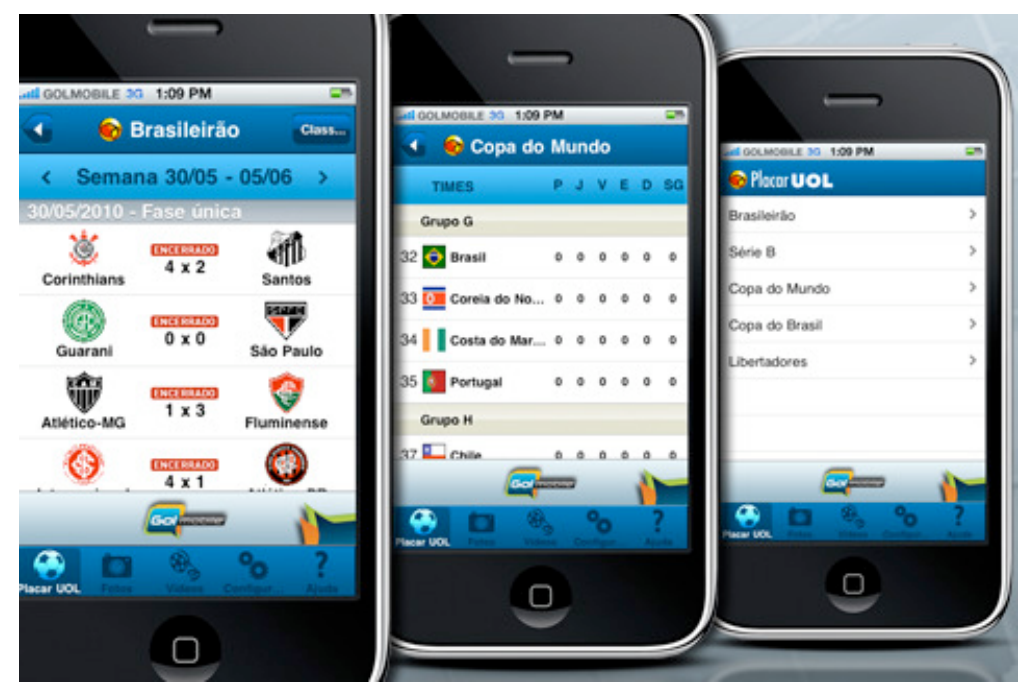

Fig. 5.33: App Placar UOL para iPhone Fonte: www.apple.com/itunes/

\section{Live Score}

O site Livescore.com disponibiliza os resultados e tabelas de jogosdo mundo inteiro, principalmente futebol, mas também inclui as categorias: Copa do Mundo, Futebol, Hockey, 
Basquete, Criquete e Tênis, e os dados estão otimizados para serem acessados por celulares via wap e um aplicativo para iPhone.
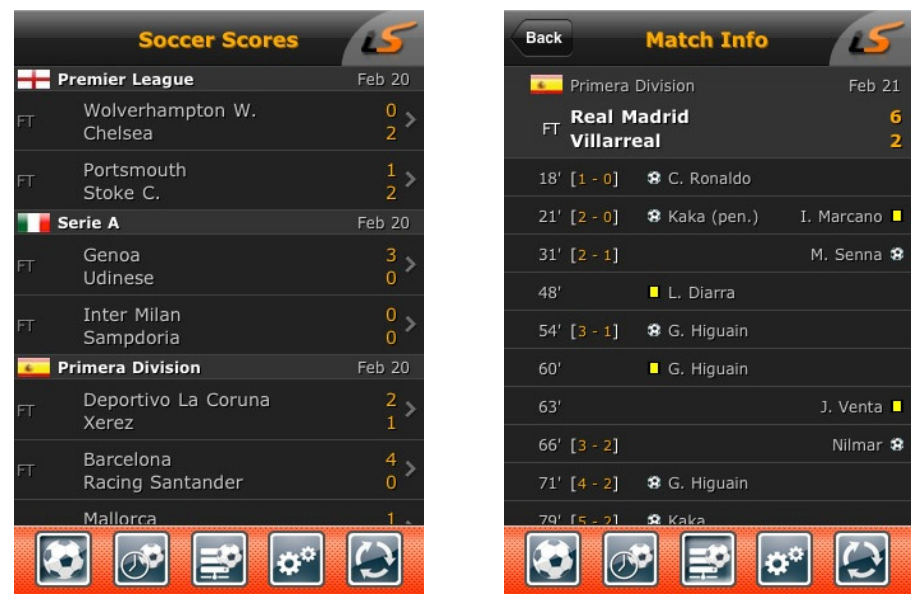

Fig. X: App do site livescore.com para iPhone Fonte: www .apple.com/itunes/

\subsection{Novas tendências para a Copa de 2014}

Identifiquei três tendências da TV Digital para a Copa de 2014: TV social, integração com dispositivos portáteis e TV conectada. Essas tendências serão analisadas individualmente a seguir. Pensadas conjuntamente como soluções tecnológicas condutoras dos conteúdos midiáticos que acabo de levantar, podem definir um modelo de convergência da experiência televisiva para o qual podemos projetar interfaces. No próximo capítulo, apresento um projeto que, ao levar em consideração este novo cenário, propõe um design de interfaces que busca facilitar esta experiência.

Em entrevista à rádio $\mathrm{CBN}$ em 28 de setembro de $2010^{135}$, Ethevaldo Siqueira faz a seguinte previsão para a transmissão da Copa do Mundo de 2014: "A cobertura de televisão da Copa de 2014 será muito mais sofisticada do que todas as anteriores. Pela primeira vez, teremos a associação de três avanços: TV digital, TV de alta definição e TV tridimensional.” Indagado se estes avanços não serão privilégio de uma minoria dos telespectadores brasileiros, Siqueira afirma que não, ao fazer a seguinte previsão para 2014: “A TV digital

\footnotetext{
135 “A TV na Copa de 2014”, transcrição de entrevista de Ethevaldo Siqueira concedida a Heródoto Barbero, na Rádio CBN em 28/9/2010. Disponível em:

<http://www.ethevaldo.com.br/Generic.aspx?pid=3324>. Acesso em: 15/1/2011.
} 
deverá estar presente em quase 50\% dos domicílios. A alta definição em pelo menos $40 \%$ dos lares. E a TV 3D em 15 a 20\%, o que significará algo próximo de 12 milhões de residências”. Ele acredita que, além da transmissão para os domicílios, existe a possibilidade de cinemas, bares e outros locais públicos realizarem projeções 3D, atraindo "centenas de torcedores, para assistirem juntos às partidas da Copa, com supertelões e todos os avanços tecnológicos”.

Como vimos, há uma tendência de a Copa de 2014 ser recebida em diversas plataformas: celulares, computadores e laptops, TV Digital em resolução standard e HDTV e em 3-D. No entanto, algumas dessas plataformas são mais adequadas para a recepção individual e o brasileiro tende a assistir aos jogos da Copa em grupos de amigos. Por isso Siqueira sugere que possa haver um interesse em investimento na projeção da transmissão dos jogos para um público maior, como no caso de um cinema 3-D. Este aspecto "social" da TV no Brasil deve adquirir outra dimensão ao ser associado ao crescimento de dispositivos conectados à internet, possibilitando novas formas de interatividade com o público.

\subsubsection{TV Social}

A introdução das TVs conectadas à internet e com widgets como o do Facebook e Twitter pode alavancar o que Marie-José Montpetit denomina "Social TV". Segundo um artigo na revista Technology Review do MIT $^{136}$, a cientista dessa instituição tem desenvolvido sua pesquisa com o intuito de combinar redes sociais à experiência passiva da televisão. Seu objetivo é fazer com que a TV seja algo que pessoas de diversos lugares possam compartilhar e conversar e tornar mais fácil encontrar programas para assistir (BULEKELEY, 2010).

Ricardo Ogliari, em seu blog ${ }^{137}$ www.mobilidadetudo.com, recomenda o artigo "Será que estamos preparados para a TV social mudar a forma como assistimos à televisão?",de Maurilio Alberone, que começa com a seguinte nota: “O termo TV Social utilizado neste artigo refere-se exclusivamente à integração da televisão com redes sociais, sendo diferente

\footnotetext{
${ }^{136}$ BULKELEY, William M., “TR10: Social TV - Relying on relationships to rebuild TV audiences”, em 10 Emerging Technologies 2010 Mit Technology Review, May/June 2010. Disponível em: <http://www.technologyreview.com/communications/25084/>. Acesso em: 14/1/2011.

${ }^{137}$ Blog de Ricardo Ogliari "Mobilidade é tudo". Disponível em: $<$ http://www.mobilidadetudo.com/2010/05/estamos-preparados-para-a-tv-social.html>. Acesso em: 14/1/2010.
} 
do outro uso para o mesmo termo, que referencia serviços de inclusão social pelo ambiente da TV.” (ALBERONE, 2010)

Segundo Alberone, o business dos aplicativos para TV será dominado pelas emissoras de TV:

Porém, dentro do modelo de negócios atual da TV digital interativa brasileira, as aplicações serão distribuídas em sua maioria pelas emissoras de TV. No máximo, os fabricantes disponibilizarão alguns aplicativos embarcados em seus set-top boxes.

Infelizmente, as grandes emissoras de TV ainda possuem suas receitas baseadas na audiência das massas. E mais uma atração (ou distração) para o telespectador sobre o seu conteúdo pode afetar o modelo de pseudo-hipnose que garante seus anunciantes. Eles ainda são muito ortodoxos e não trocam audiência por mobilização facilmente, apesar de reconhecerem a tendência. Imagine ainda se você puder compartilhar uma crítica com um determinado programa ao vivo no próprio ambiente da TV. Isso ainda parece inconcebível em um modelo tradicional de informação unidirecional. Uma coisa é você criticar algo pelo twitter, outra é xingar o narrador de futebol e isso ser compartilhado com milhares de pessoas na mesma tela onde assistem o jogo. Com isso, as emissoras vão tender a moderar as informações compartilhadas nessas aplicações. E assim o enfraquecimento desse modelo parece óbvio.

Em contrapartida, a proliferação dos widgets em TVs conectadas à internet pode abrir um canal de compartilhamento independente do controle emissoras e que ocorre sobreposta à mesma tela. O brasileiro de modo geral é bastante sociável, buscando interações em grupo, sejam reais ou virtuais. A interatividade local com a TV aparentemente não desperta tanto o interesse como as redes sociais. A possibilidade de cada pessoa ter sua própria TV na mesma casa em parte reduz as brigas pelo controle remoto ou discussões sobre o que assistir, assim como o fato de cada indivíduo poder ter seu celular para se comunicar com os amigos fora de casa. No Brasil, ainda há uma dominância de programas com grande audiência, que centralizam a família, como as novelas, os programas de domingo e os jogos de futebol. Recentemente os mais jovens tem se isolado desse ambiente, preferindo o chat no MSN ou Orkut. A integração destes com a socialização da TV na sala é um desafio a ser considerado.

No caso do futebol, especificamente em relação à Copa do Mundo, há uma unanimidade em relação à escolha do programa. Neste caso há inclusive um esforço de organização para se assistir ao jogo em grupo, transformando-se em um "subevento". Neste evento, além de torcer junto e o grupo comentar sobre os lances do jogo, existem também decisões técnicas em relação ao "equipamento" que passam a ser decididas em grupo, como: 
em qual canal assistir ao jogo, talvez porque uns prefiram um narrador a outro; discute-se o nível do volume e o ajuste das cores, pois uns gostam do gramado bem verde enquanto outros gostam de ver as cores menos vibrantes.

Algumas tecnologias da TV Digital que oferecem opções da forma de visualização de um programa, como a escolha do ângulo da câmera ou a seleção de trilhas sonoras diferentes, criam novas decisões a serem tomadas em grupo. As interfaces para essas funções, se acessadas por um controle remoto individual, não contribuem para essa experiência em grupo, por isso ao se desenvolverem aplicativos integrando diversas plataformas é importante levantar quais aspectos têm uso individual e quais serão realizados em grupo. Por exemplo, a escolha do ângulo de câmera deve ter algum feedback para o grupo e não ser pré-visualizado apenas pelo indivíduo que está com o controle remoto.

Segundo Gianluigi Cuccureddu, em um artigo ${ }^{138}$ no site www.appmarket.tv, o crescimento das Redes Sociais Baseadas em Eventos (ESBNs) traz elementos oriundos de redes de localização como Four Square e Gowalla e tem o potencial de difundir a TV social para os telespectadores de massa. Conforme o autor, eventos de grande audiência como o Grammy Awards, a entrega do Oscar, o Globo de Ouro e a final da Copa do Mundo ainda agregam um número enorme de telespectadores (CUCCUREDDU, 2010). Mas enquanto as redes baseadas em localização são um importante agregador para usuários de celulares e têm implicações em termos de conteúdo, despertando o interesse da publicidade pela possibilidade de direcionar anúncios a um público-alvo bastante específico, "a televisão é a força que impulsiona as redes baseadas em eventos" (CUCCUREDDU, 2010). Além disso, ao associarse à força dos eventos televisivos, as redes sociais já estabelecidas realizando essa experiência, em duas telas há uma possibilidade muito maior de sucesso da TV social do que está ocorrendo com o crescimento da Web TV (CUCCUREDDU, 2010). O autor cita a pesquisa de Montpetit que conclui que a utilização de múltiplas telas diminui a irritação dos usuários ao utilizar a tela da TV para texto, obscurecendo a imagem do programa na tela.

Gerd Leonhard, professor visitante da Fundação Dom Cabral em São Paulo e Belo Horizonte, autodenomina-se Futurista Cultural, em uma apresentação intitulada "Social

\footnotetext{
${ }^{138}$ CUCCUREDDU, Gianluigi, “Can Event-Based Social Networks further diffuse Social TV?”, App Market TV ,22/7/2010. Disponível em: <http://www .appmarket.tv/opinion/469--can-event-based-social-networks-further-diffuse-social-tv.html>. Acesso em: 14/1/2011
} 
Media and the Future of Football” para Associação Pan-Europeia de Futebol ${ }^{139}$. Leonhard afirma que "O futebol (e outros negócios esportivos) deve abraçar a web como a plataforma onde atingirá diretamente seu público alvo - em paralelo aos acordos de transmissão tradicionais na TV, ajudando os jogadores a se conectarem diretamente com seus fãs e seguidores". A TV está convergindo com a internet, e neste processo de convergência as redes de comunicação digital passam a ter tanta importância quanto as redes de TV. Isso é de extrema importância para os times de futebol, pois as relações entre os times e os torcedores passam a ter que considerar os aspectos "sociais" das redes de comunicação, em que pode haver novos relacionamentos entre os fãs e os times e os jogadores, que não eram possíveis com o modelo de comunicação de massa das emissoras de TV (LEONHARD, 2010).

\subsubsection{Multiplataforma - Dispositivos Portáteis}

O site IT Web $^{140}$ publicou uma série de reportagens sobre as tendências tecnologia da informação e telecomunicações para a Copa de 2014. Em uma das reportagens, intitulada "A Copa Multiplataforma", além do crescimento de inovações como TV 3-D e HDTV já vistas na Copa de 2010, prevê-se o crescimento de torcedores assistindo à Copa em celulares e notebooks, o que irá transformar a forma como o público assiste ao jogo; por exemplo, um flagrante captado em baixa resolução por um celular de um torcedor pode ter mais importância do que aquela captada por uma câmera de alta definição das emissoras de TV (PAVONI JUNIOR, 2009). Segundo o diretor da divisão de jornalismo da Central Globo de Engenharia, José Manoel Marino: “A Copa de 2014 incentivará a criação de conteúdo multiplataforma e, para isto, é fundamental o uso de sistemas que suportem fluxos de trabalho flexíveis, baseados em tráfego de arquivos sobre redes de dados de alta velocidade" (MARINO apud PAVONI JUNIOR, 2009).

\footnotetext{
${ }^{139}$ LEONHARD, Gerd, "Social Media and the Future of Football”, Media Futurist.com, 12/3/2010. Disponível em:

<http://www.mediafuturist.com/2010/03/social-media-and-the-future-of-football-slideshow.html>.Acesso em: 15/1/2011.

140 “2014: a Copa multiplataforma”, por Gilberto Pavoni Junior I especial para IT Web, 18/8/2009. Disponível em:

<http://www.itweb.com.br/noticias/index $\cdot a s p ? \operatorname{cod}=60132>$. Acesso em: 15/1/2011.
} 


\section{Ubiquidade dos Dispositivos Portáteis}

Segundo um balanço divulgado em fevereiro de 2010 pela Agência Nacional de Telecomunicações (ANATEL) ${ }^{141}$, o número total de celulares no Brasil chegou a 175,6 milhões no mês de janeiro e o número de celulares de terceira geração $(3 \mathrm{G})$ e de modems para acesso à banda larga móvel chegou a 12,18 milhões. Ou seja, atualmente existe praticamente um celular para cada habitante do Brasil, sendo que a parcela dos que têm acesso à internet rapidamente chega a $10 \%$ dos aparelhos. Isso mostra que não é inviável pensar que no Brasil daqui a alguns anos exista uma parcela significativa de smartphones que possam ser utilizados para interagir com a televisão. Acrescente-se a isso o fato de que novos celulares com receptores de SBTVD-T estão entrando no mercado com preços cada vez mais acessíveis. Segundo dados do IBGE, em 2009, 95,7\% das residências no Brasil possuíam pelo menos um aparelho de $\mathrm{TV}^{142}$, sendo que o celular passa a ser uma nova foram de receber informações ao estar conectado à internet e receber o sinal de TV. Assim, podemos concluir que nos próximos anos os brasileiros estarão recebendo informações em diversas mídias.

\subsubsection{TV Conectada}

Em se tratando de acesso à televisão através de computadores pessoais, um artigo da mesma série sobre a infraestrutura de telecomunicações na Copa de 2014 publicado pelo site Itweb, prevê que

A Copa de 2014 deve ser assistida pela quase totalidade dos 2 bilhões de PCs que o mundo terá nessa época, segundo dados do Gartner. Os netbooks terão vendas dobradas a cada ano. Junte-se a isso a provável "internet das coisas", evidenciada em estudos sobre como será a casa conectada em 2014, da ABI Research, que aponta que muitos eletrodomésticos serão computadores com acesso à net.

\footnotetext{
${ }^{141}$ MARQUES, Gerusa “Número de celulares no Brasil chega a 175,6 milhões”, O Estado de S. Paulo, Economia, 22 de fevereiro de 2010. Disponível em:

<http://economia.estadao.com.br/noticias/not_5884.htm>. Acesso em: 1/6/2010.

${ }^{142}$ JUNIOR, Cirilo; LAGE, Janaina, “Cresce o número de domicílios com DVD, TV e máquina de lavar, diz IBGE”, Folha.com. Disponível em:

<http://www1 folha.uol.com.br/mercado/795265-cresce-o-numero-de-domicilios-com-dvd-tv-e-maquina-delavar-diz-ibge.shtml>.Acesso em: 15/1/2011.
} 
O que é o caso da TV conectada, em que uma TV equipada com um chip e conexões, ao permitir acessar dados e vídeos na internet, poderá exibir os jogos da Copa e conteúdo correlato, sem receber o sinal da transmissão terrestre de TV, ou de provedores de TV por assinatura por cabo ou via satélite. A conectividade de diversos dispositivos não só altera certos aspectos da funcionalidade dos aparelhos de TV mas também abre possibilidades de se utilizarem outros como celulares, computadores e tablets para a recepção e o compartilhamento de conteúdo ${ }^{143}$.

\section{No próximo capítulo}

A partir deste levantamento, as considerações sobre os avanços da tecnologia da TV Digital, o cenário de convergência das mídias e as novas tendências no design de interfaces gráficas, pretendo demonstrar como o design em um cenário de convergência das mídias poderá facilitar a interação do homem com a experiência televisiva na Copa 2014.

\footnotetext{
143 “Cinco tendências de TI e telecom para a Copa de 2014”, por Gilberto Pavoni Junior I especial para IT Web, 28/7/2009. Disponível em:

<http://www.itweb.com.br/noticias/index.asp?cod=59506>. Acesso em: 17/1/2011
} 
Capítulo 6

\section{Projeto de Interfaces - TV Digital na Copa do Mundo 2014}

"Uma solução é a integração de dispositivos móveis inteligentes com a TV Digital".

\subsection{Apresentação}

\section{Design de interação em múltiplas telas}

Neste capítulo, apresento a interface gráfica de um projeto de design de interação, que busca integrar dispositivos móveis inteligentes (celulares, smartphones, tablets) com a TV Digital. A proposta tem como objetivo responder de forma prática as questões levantadas nos capítulos anteriores. Avanços recentes na tecnologia da TV Digital e da internet levaram às seguintes constatações:

1. A TV Digital está convergindo com outras mídias através de computadores conectados à internet.

2. Há uma ubiquidade de dispositivos digitais interconectados em nosso cotidiano.

3. Cresce o volume de vídeos e filmes acessados na internet.

4. Tornou-se viável a utilização de dispositivos inteligentes portáteis (smartphones, tablets controladores de videogames) como forma de comando e interação com a TV.

5. Serviços como Facebook, Skype, Flicker estão migrando da internet para outros dispositivos como celulares e games e TVs.

6. É viável utilizar telefones celulares como canal de retorno na interatividade com a TV Digital terrestre.

Tendo este cenário em mente, um projeto de design de interação entre o homem e a TV Digital deve facilitar o acesso do usuário ao conteúdo midiático e permitir o controle de 
diversos dispositivos, contribuindo para a convergência de diversas mídias. Tomando como ponto de partida tendências identificadas na Copa do Mundo da FIFA de 2010 (descritas no capítulo anterior), a solução visa integrar diversas mídias dentro de um sistema, viabilizando o compartilhamento de mídias criadas originalmente em uma plataforma para outra plataforma diferente, de modo que não seja necessário produzir versões específicas para cada uma delas.

A popularização do uso de celulares (Serviço Móvel Pessoal - SMP) no Brasil e mais recentemente dos smartphones justifica a viabilidade da adoção de um modelo de interação com a TV Digital na Copa de 2014 integrando as duas tecnologias.

Durante a copa de 2010, ao assistir aos jogos em HDTV em casa, era possível tanto receber o mesmo sinal de TV Digital em celulares e computadores quanto consultar tabelas, obter estatísticas detalhadas, ler e ouvir comentários e acompanhar as partidas em sites e portais na internet. Além do estádio e da TV, a experiência coletiva do torcedor de futebol permeou redes sociais como Facebook, tornando-se um espaço virtual de interação e compartilhamento de opiniões, imagens e vídeos. Este projeto de interface gráfica propõe a utilização de múltiplas telas, sendo a principal um monitor conectado à TV Digital e a secundária, um dispositivo portátil como um celular ou um tablet, que teria diversas funções, entre elas:

a) Controle remoto com tela touch-screen que permite a manipulação direta da interface, e tem a vantagem adicional de não "poluir" a tela principal. Esta tela também poderá servir como:

b) Tela secundária, permitindo visualizar outros ângulos de câmera, trechos de outros programas, vídeos e conteúdo digital relacionado ao programa sendo exibido na TV.

c) Canal de retorno permitindo interatividade bidirecional na TV Digital terrestre.

Um dos motivos da escolha da Copa do Mundo como exemplo neste projeto é o fato de um único evento gerar diversos conteúdos que, digitalizados, poderão ser distribuídos em diversas mídias. No paradigma atual, mesmo com a digitalização dos processos de produção, ainda é necessário gerar versões específicas para o formato de distribuição de cada mídia (Fig. $6.1)$. 


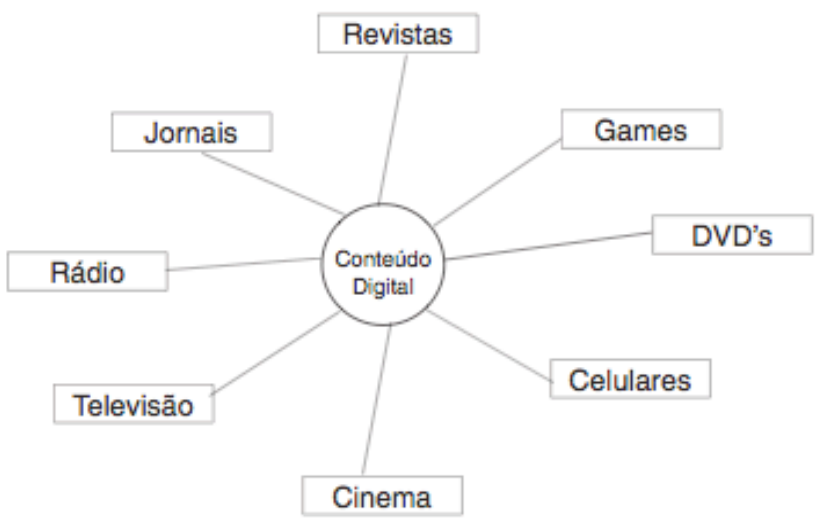

Fig. 6.1: Conteúdos adaptados para diversos formatos.

Já com a distribuição digital das mídias e a hibridização dos dispositivos de recepção, o mesmo conteúdo, quando arquivado em um formato digital compatível, poderá ser acessado em diversas plataformas. Neste cenário, a interface tem a tarefa de interpretar o conteúdo e representá-lo da forma mais adequada ao aparato receptor.

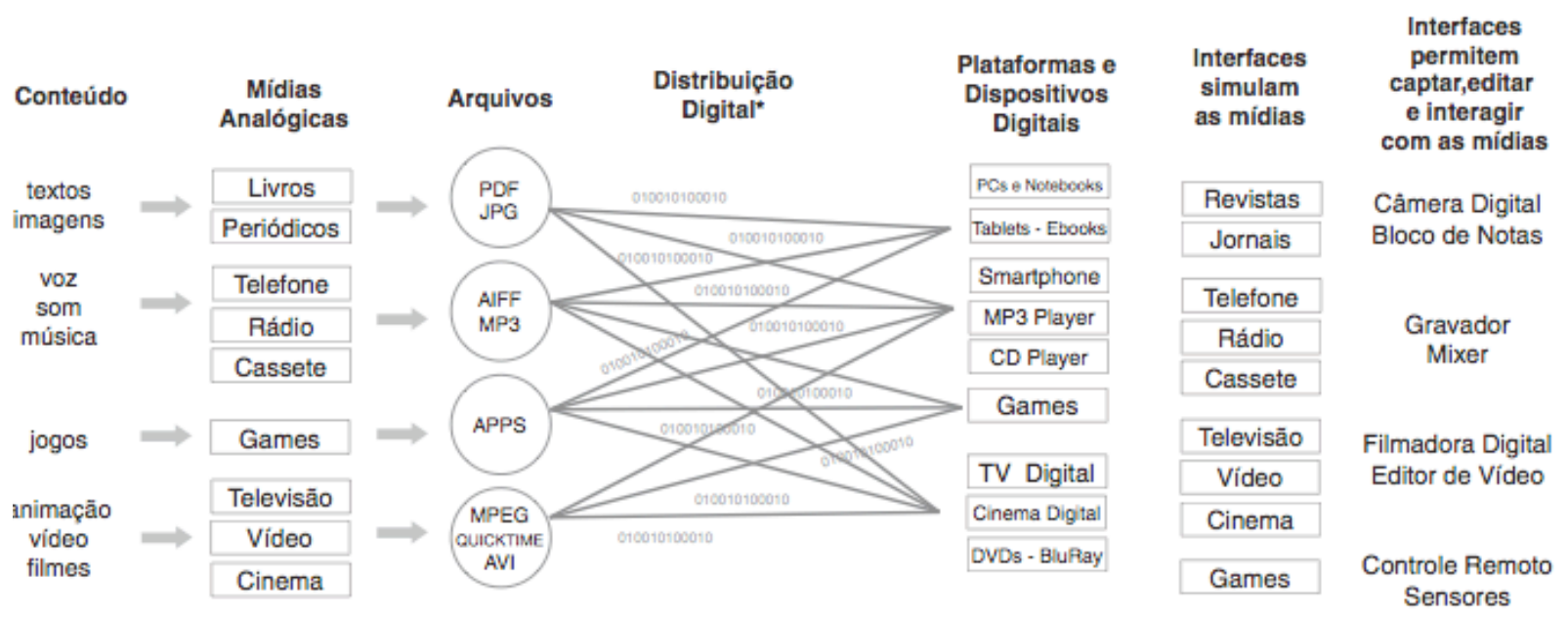

Fig 6.2: Distribuição de conteúdo digital em múltiplas plataformas.

O diagrama acima (Fig. 6.2) exemplifica como a digitalização dos conteúdos midiáticos possibilita sua distribuição em plataformas digitais híbridas, nas quais a interface representa a mídia associada ao conteúdo.

As redes de computadores permitem a distribuição de conteúdo digital sem que seja necessário o transporte e manuseio de mídias físicas como CDs, DVDs e cartões de memória. 
A interface tem a função de representar esta desmaterialização de uma forma compreensível ao usuário. Em um sistema como o iTunes, um mesmo usuário pode acessar sua biblioteca de mídia em dispositivos, locais e servidores remotos. Nestes, se houver uma perda de conexão com a rede, o usuário não poderá utilizar seus arquivos. O usuário ainda encontra dificuldade em lidar com diferentes entradas (inputs) do sinal audiovisual em um monitor, principalmente quando essa tarefa for realizada com múltiplos controles remotos (NIELSEN, 2004). Mesmo as interfaces de sistemas inteligentes que detectam o sinal de entrada ainda dependem do cabeamento correto do sistema, que quando conectado a uma mídia física as identificam.

\section{*Distribuição Digital}

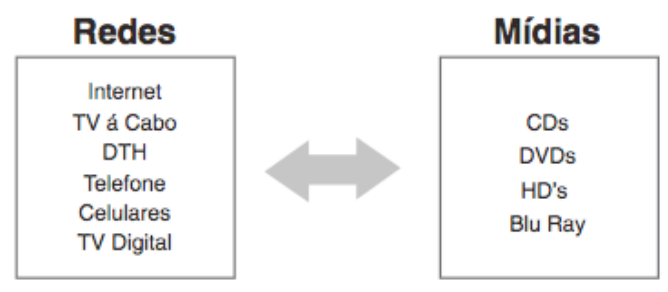

Fig 6.3: Redes e mídias físicas para a distribuição de conteúdo digital.

O esquema acima (Fig. 6.3) representa diversas possibilidades de distribuição digital de conteúdo audiovisual. A interface do sistema deve permitir que o usuário possa acessar arquivos de mídias físicas como DVDs e cartões de memória ou conteúdo remoto disponível nas redes de distribuição digital como a internet e TV Digital.

\subsection{Requisitos de projeto}

Quanto à problemática levantada anteriormente por este trabalho, os requisitos de projeto propostos contemplam-na adequadamente, como se pode verificar abaixo:

1. Seguir diretrizes de design de interfaces (iPhone), de produtos cuja usabilidade já vem sendo testada com aceitação crescente dos usuários.

2. Verificada a dificuldade de utilização dos controles remotos tradicionais (Norman, 2001), a interface oferece uma opção na qual se pode manipular a informação diretamente na tela.

3. A adoção de um dispositivo conectado à internet (celular, tablet) representa uma solução de interação com a TV Digital que inclui um canal de retorno para interatividade total. 
O design de interface resultante desses requisitos propõe uma solução formal que pode servir de modelo para o desenvolvimento de um protótipo que possibilitará uma série de testes, essenciais para a complementação desta pesquisa.

\section{Aplicativos e serviços}

O projeto demonstra a viabilidade da integração de dispositivos portáteis inteligentes com a TV Digital, através do desenvolvimento da interface gráfica de um sistema que facilite o uso de aplicativos e serviços na TV Digital como:

- Guia Eletrônico de Programação (EPG) - Acesso a programação e informações

- Integração do EPG com funcionalidades do controle remoto

- Multicâmera - Controle de vários ângulos televisivos

- PVR - Gravação de programas, replay, freeze, timeshift

- IPTV - Acesso a programação complementar disponível na internet como documentários e jogos anteriores, possibilidade de visualização simultânea

- Tabelas, estatísticas e dados diretamente relacionados ao programa sendo transmitido

- Aplicativos complementares ao evento, como simuladores, realidade aumentada, games e redes sociais

- Conteúdo gerado por usuários relacionados ao evento.

- Social TV, chat, integração com redes sociais como Facebook, Twitter e Orkut.

- Google Maps

Alguns desses serviços são acessíveis ora utilizando um hardware específico (DVR, Apple TV), ora via internet. 


\section{Conteúdo}

Embora exista uma variedade de "conteúdos" digitais da Copa disponíveis em diversas mídias, muitos só podem ser decodificados pelo usuário de um sistema proprietário ou por assinatura. A configuração da comunicação entre diversos dispositivos é uma tarefa difícil para a maioria dos telespectadores e o design de interfaces pode facilitar esta tarefa, popularizando o uso da TV como suporte de conteúdo audiovisual de diversas mídias. Com a digitalização, os “conteúdos" independem de sua mídia original, por isso, tendo em vista a definição de um universo de conteúdo para a TV Digital, ao invés da classificação usual por duração e formatos de mídia (35mm, DV, Beta, DAT, etc), proponho esta "Classificação Material da Copa do Mundo".

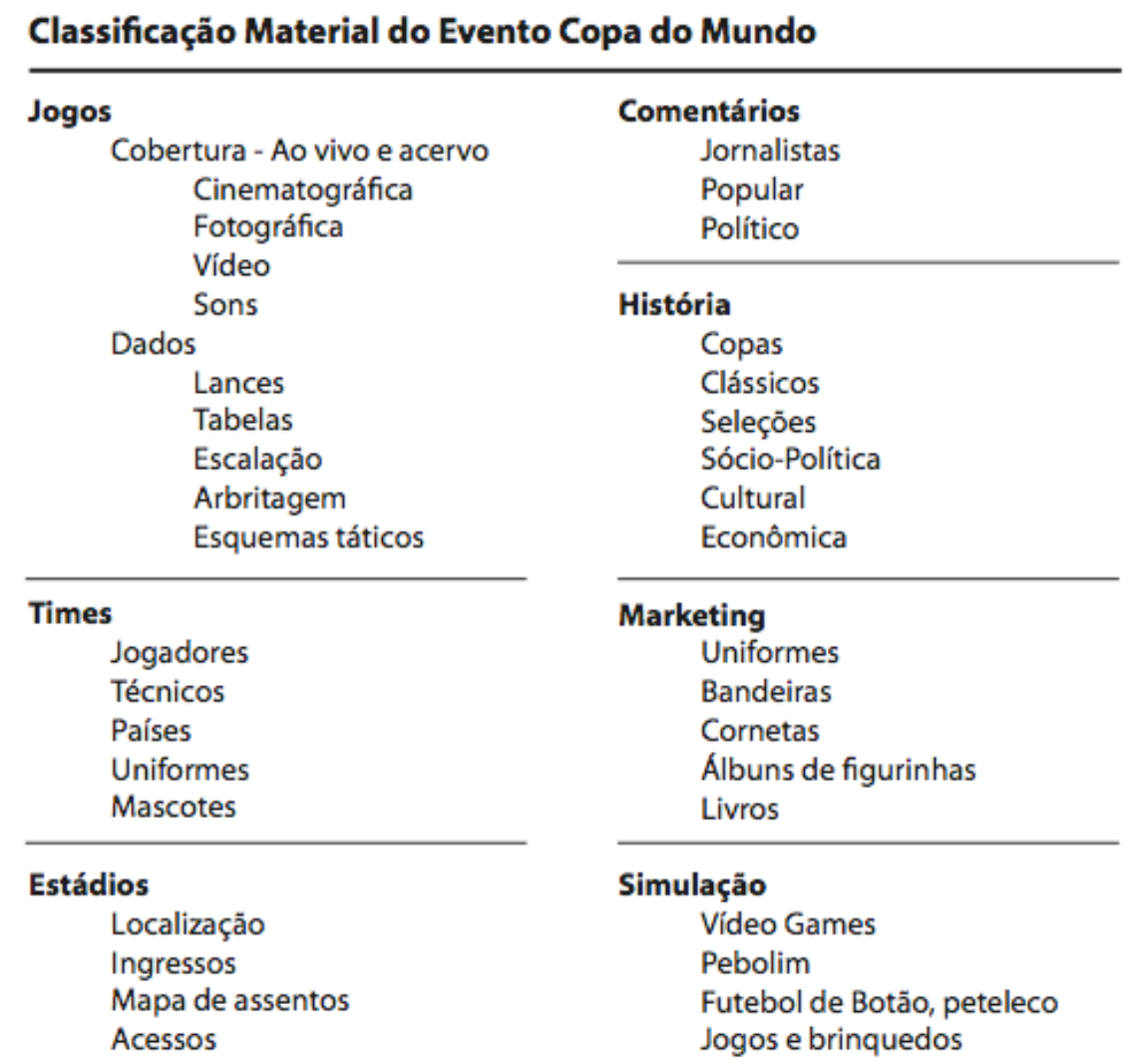

Tabela 6.4: Classificação “material” da Copa do Mundo FIFA.

Esta classificação tem como objetivo definir os diversos elementos que podem ser considerados conteúdo que tem origem na Copa do Mundo como evento, o que inclui tanto o registro mediático, como aspectos históricos e culturais relacionados ao futebol: os times, as torcidas e os locais onde os jogos estejam sendo realizados. Por exemplo, "Jogos" refere-se ao evento em si, podendo ser descrito verbalmente, registrado em vídeo assumindo a materialidade do seu suporte, ou modelado virtualmente em 3-D deixando de existir no 
mundo real. Como os registros midiáticos podem ser "re-midiados" no processo de digitalização, ao classificar os "materiais" buscando sua forma mais elementar é possível gerar um repertório de conhecimento, imagens, informações e sons independente de seu suporte. Deste modo é possível ter um panorama do conteúdo relacionado ao evento Copa do Mundo que pode trafegar entre diversas plataformas.

O esquema seguinte (Fig. 6.5) demonstra como "eventos" representados por "conteúdos" podem ser distribuídos em diversas mídias, culminando em uma experiência virtual.

\section{Evento Real Conteúdo Mídias Experiência virtual}

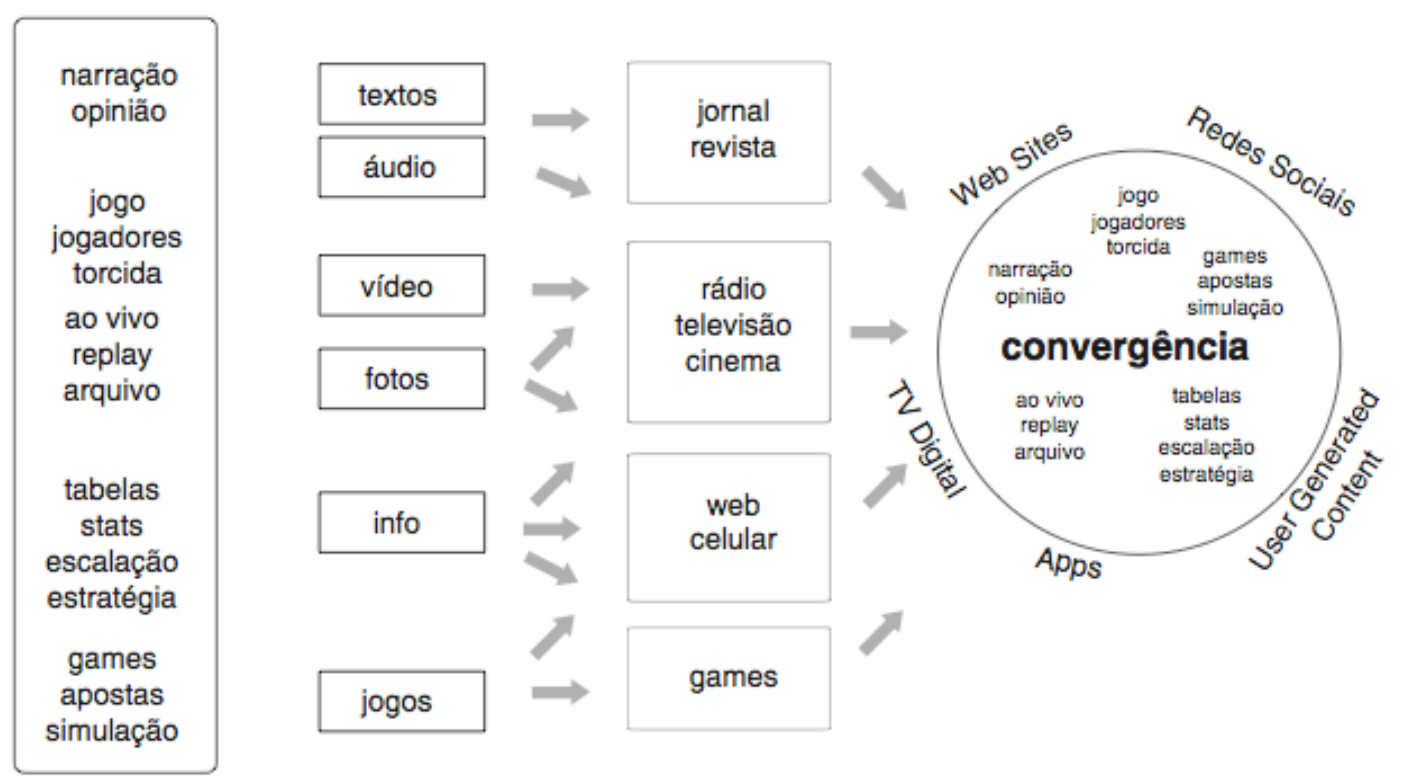

Fig. 6.5: Convergência como representação virtual de um evento esportivo

\subsection{Esquematização do sistema}

No caso da Copa do Mundo, cada partida pode ser considerada um "evento" a ser transmitido (midiado). Na convergência digital, arquivos gerados na captação audiovisual podem ser distribuídos por diversos canais de comunicação (TV, internet, celular). Essa captação pode ser "oficial" quando realizada pelas emissoras ou gerada por usuários a partir de aparelhos portáteis conectados a redes (microtransmissão). Alem da captação de sons imagens, o evento gera outros conteúdos como estatísticas, comentários etc. Estes podem ser 
originados nas emissoras ou por terceiros. Em ambos os casos pode haver apropriação de imagens, ou seja, um canal de TV pode transmitir imagens captadas por um torcedor ou um torcedor pode publicar um link referenciando um vídeo da emissora em uma rede social e promover uma discussão ou uma série de comentários a respeito. A ilustração seguinte representa o "universo" de conteúdo digital de um jogo de futebol (TV ao vivo, internet) e como estes se relacionam com o evento no estádio.

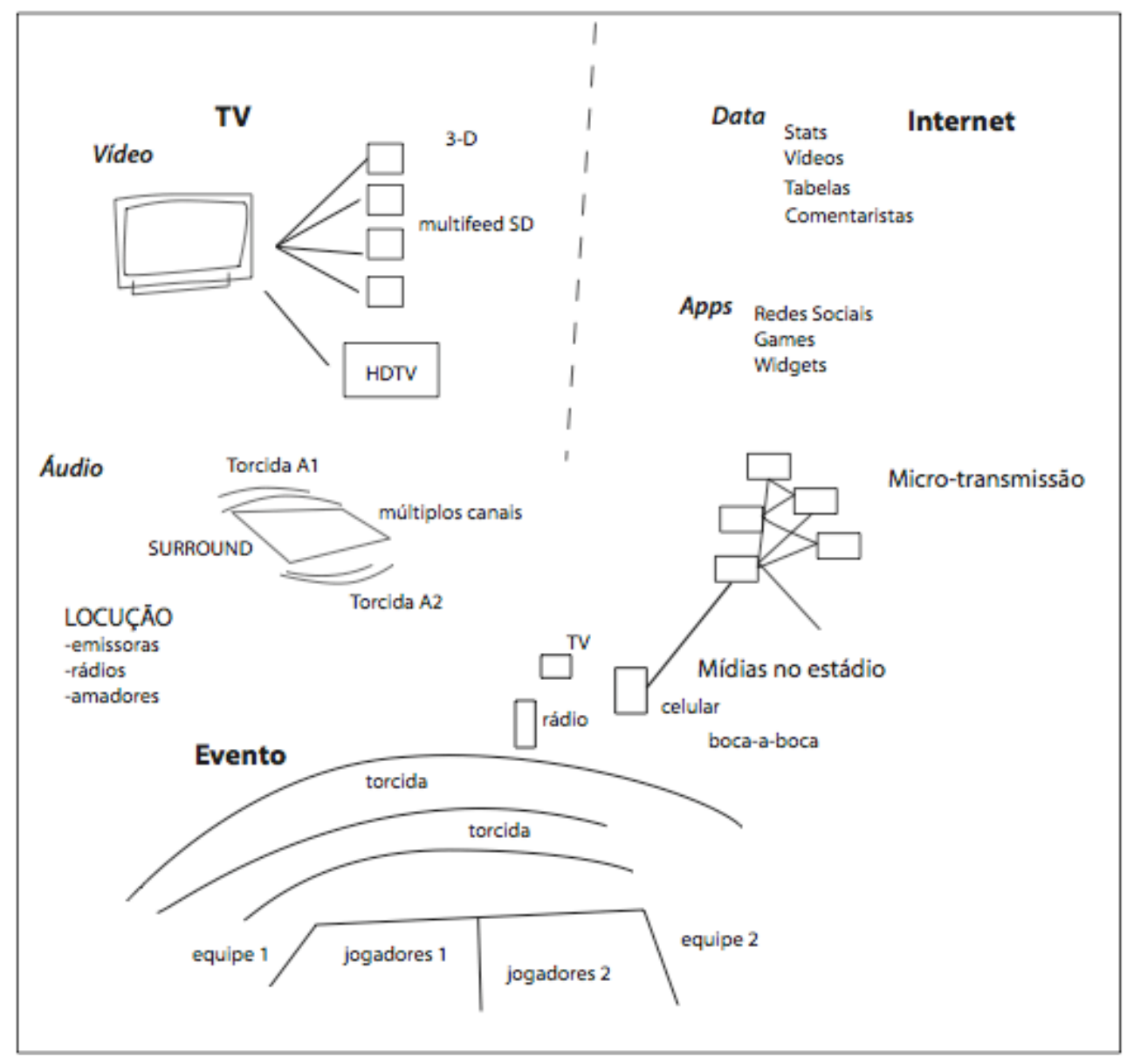

Fig. 6.6: Universo de conteúdo de um jogo de futebol ao vivo

Uma vez definido o universo de conteúdo, desenvolvi um esquema (Fig. 6.6) ilustrando como as diversas plataformas e sistemas se inter-relacionam. Vemos que há várias conexões possíveis entre os dispositivos, o que promove o compartilhamento de conteúdo. Neste caso, a TV é uma tela central capaz de receber tanto o sinal das emissoras e de operadoras de TV por assinatura através de um receptor ou set-top box e receber conteúdo da internet quando conectado diretamente à rede ou dispositivos móveis inteligentes quanto também permitir aos usuários publicarem seu próprio conteúdo, alimentando o sistema. 


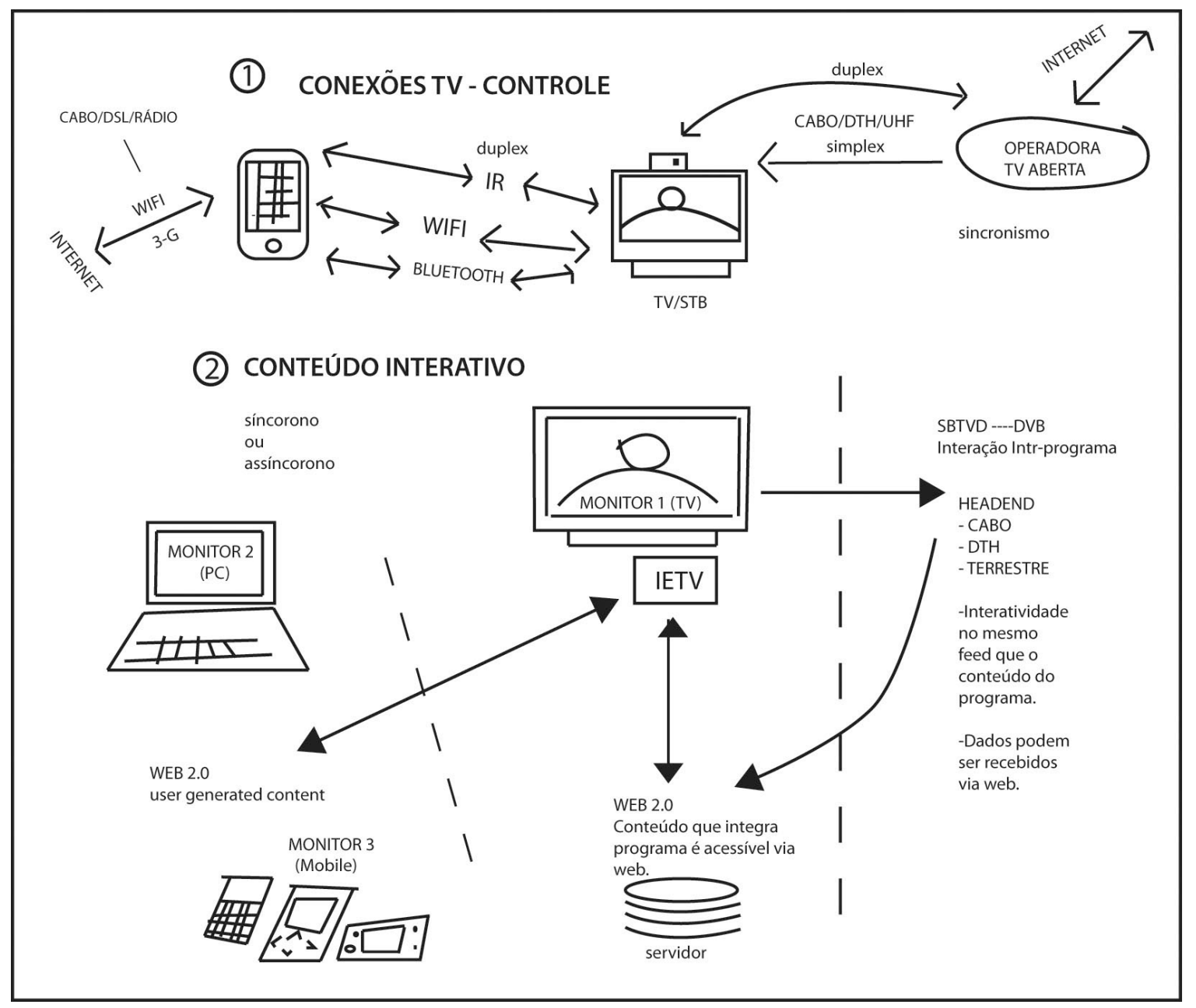

Fig. 6.7: Conexões TV - Controle

O esquema acima corresponde às conexões entre controle remoto e fontes de conteúdo.

\subsection{Definição do partido projetual}

Depois de levar em conta o universo de conteúdo da Copa do Mundo de 2010 que favorecesse a integração entre diversas plataformas de distribuição, o próximo passo foi situar o usuário no centro deste sistema. A ilustração a seguir representa as diversas escalas de recepção midiática em que o telespectador ou usuário pode inserir-se: individual, coletiva ou em rede. 


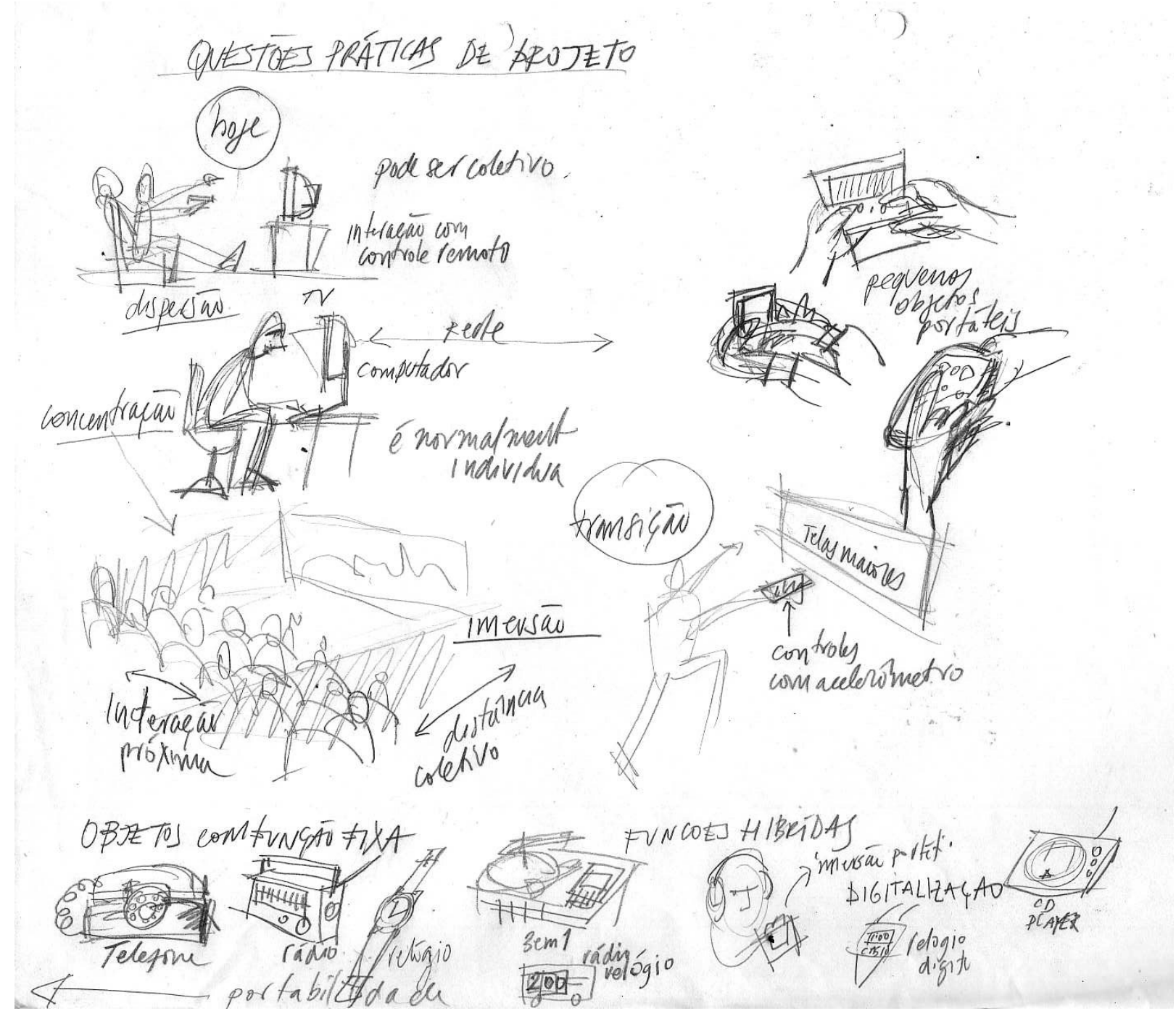

Fig.6.8: -"Questões Práticas de Projeto"

Ao constatar que vivemos um período de transição no qual são usados dispositivos dedicados a cada escala, que ao se tornarem híbridos adquirem múltiplas funcionalidades e podem ser conectados entre si, cheguei à conclusão de que a experiência de interação do usuário com a TV Digital deveria ser independente do dispositivo e de sua tela. Aparelhos de TV, celulares e tablets quando conectados entre si acessam o mesmo conteúdo. As telas podem ser categorizadas em pequenas (celulares), médias (tablets e laptops) e grandes (monitores LCD, plasma). 


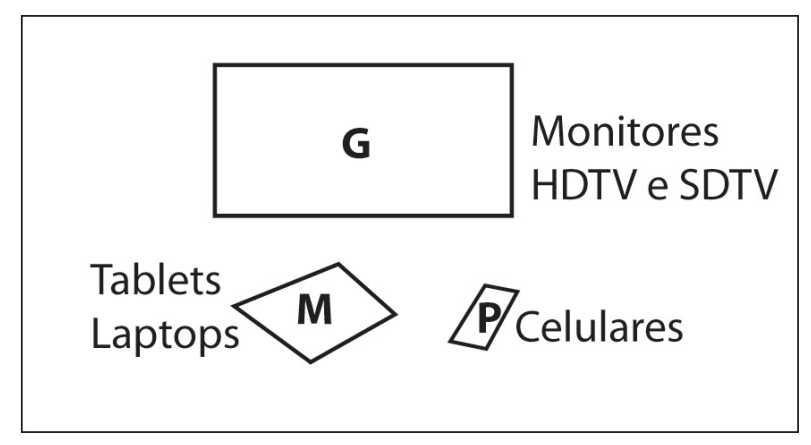

Fig. 6.9: Escala relativa das telas de plataformas digitais

Para determinar a escala mais apropriada, considerei a atividade realizada e o número de pessoas interagindo. Uma família assiste a um jogo de futebol em uma TV de LCD, enquanto um indivíduo busca informações sobre determinado jogador em um tablet. Caso ele queira compartilhar essa informação com o resto do grupo, ele poderá enviar a informação do seu aparelho para a TV principal.

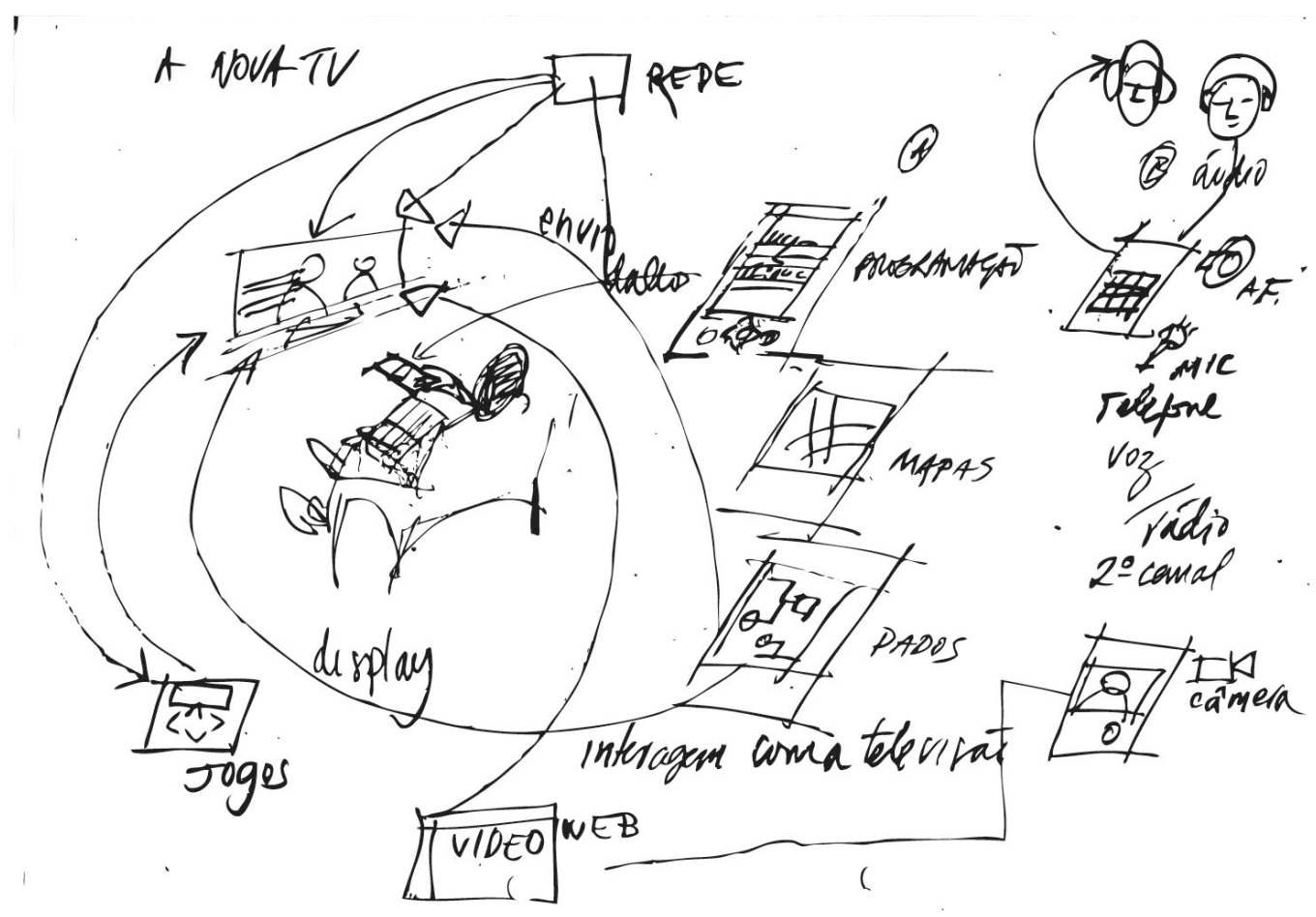

Fig. 6.10: "A Nova TV" 
O exemplo da figura anterior (fig. 6.10) esquematiza a situação de um usuário de telas interconectadas, que através de um dispositivo portátil pode controlar o aparelho de TV, pesquisar a grade de programação e acessar mapas e dados na internet. É possível transferir a informação visualizada no dispositivo, enviar para a TV e obter o conteúdo através da rede apropriada. No caso de este usuário optar por um celular ou tablet conectado à internet (Wi-Fi ou 3-G), este tem a função de canal de retorno para interatividade com um aplicativo da TV Digital, posta comentários em uma rede social ou realiza o streaming de um vídeo relacionado ao programa.

O próximo passo foi definir como seria a navegação em um sistema como este. Inicialmente procurei definir fluxogramas que englobassem as atividades e um dos problemas encontrados foi a tendência para definir a estrutura em um sistema rígido organizado em forma de árvore com diversas ramificações. Esse tipo de organização é inviável em uma solução aberta como a que está sendo proposta, pois a diversidade de fontes e dispositivos envolvidos adicionam novas variáveis e tornam a arquitetura do sistema desnecessariamente complexa.

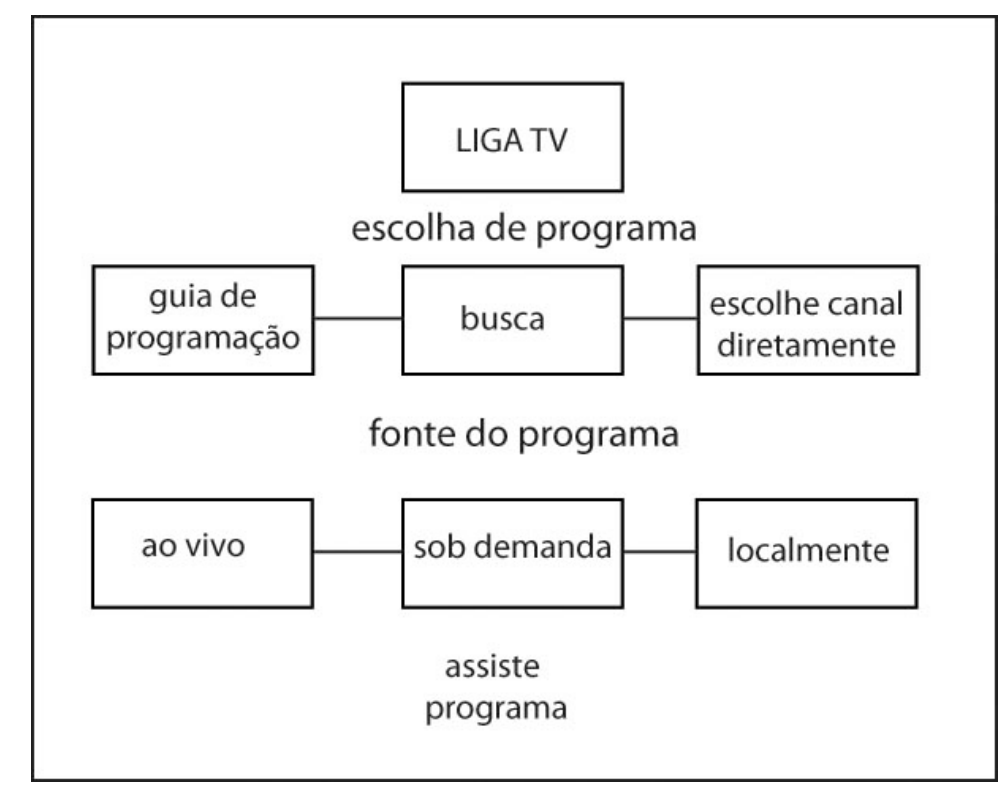

Fig. 6.11: Fluxograma de escolha de programação.

No mesmo sistema podemos ter vários aparelhos que acessam o conteúdo de diversas fontes. Os sistemas atuais utilizam menus representando opções como as da tabela seguinte: 


\begin{tabular}{lll}
\hline FONTE & CONEXÃo & MÍDIA/TRANSMISSÃo \\
\hline GAME & LOCAL/REDE & CD/MEMORY CARD/WI-FI \\
PLAYER & LOCAL/REDE LOCAL & DVD/BLU-RAY/HD/WI-FI \\
TV ABERTA & RECEPTOR & ISDB-T/PAL-M \\
TV- DTH/CABO & REDE DEDICADA & CABO/SATÉLITE \\
IPTV & INTERNET DEDICADA & DSL/CABLE MODEM \\
WEB & INTERNET & WI-FI/3-G/DSL/CABLE MODEM \\
APPS & INTERNET/local & WI-FI/3-G/DSL/CABLE MODEM \\
\hline
\end{tabular}

Tabela 6.1: Menu de Seleção de Fontes em um sistema de TV Digital

Em vez de propor um menu onde o usuário escolhe qual mídia alimentará a tela, optei por definir sequências operacionais para cada atividade, denominando-as "narrativas interativas". São sequências que têm como objetivo realizar tarefas sem a necessidade de configurar o sistema. No caso, a interface está centrada no conteúdo, independentemente da plataforma onde reside. Deste modo, se o usuário está interessado em um programa específico, não importa se vem da TV aberta, da internet ou satélite; todas as mídias integradas ao sistema serão acessadas e por consequência os conteúdos relacionados.

O usuário acessa a programação da TV em um celular ou tablet, que por estar conectado à internet possibilita buscar tanto os horários de transmissão como informações adicionais. O dispositivo portátil permite controlar a TV e os periféricos, assim como receber e enviar sinais digitais.

No caso específico deste projeto, propus uma sequência em que o usuário de um aplicativo instalado em um smartphone controla a TV e os periféricos, acessa a internet, escuta podcasts e assiste vídeos em múltiplas telas. $\mathrm{Na}$ interface do aplicativo sempre estão presentes um menu onde se pode escolher entre TV, vídeos, games, web e aplicativos. A possibilidade de mudar canais e ajustar o áudio sempre está disponível, assim como o seu uso para navegação e seleção de itens de menu na tela principal. 


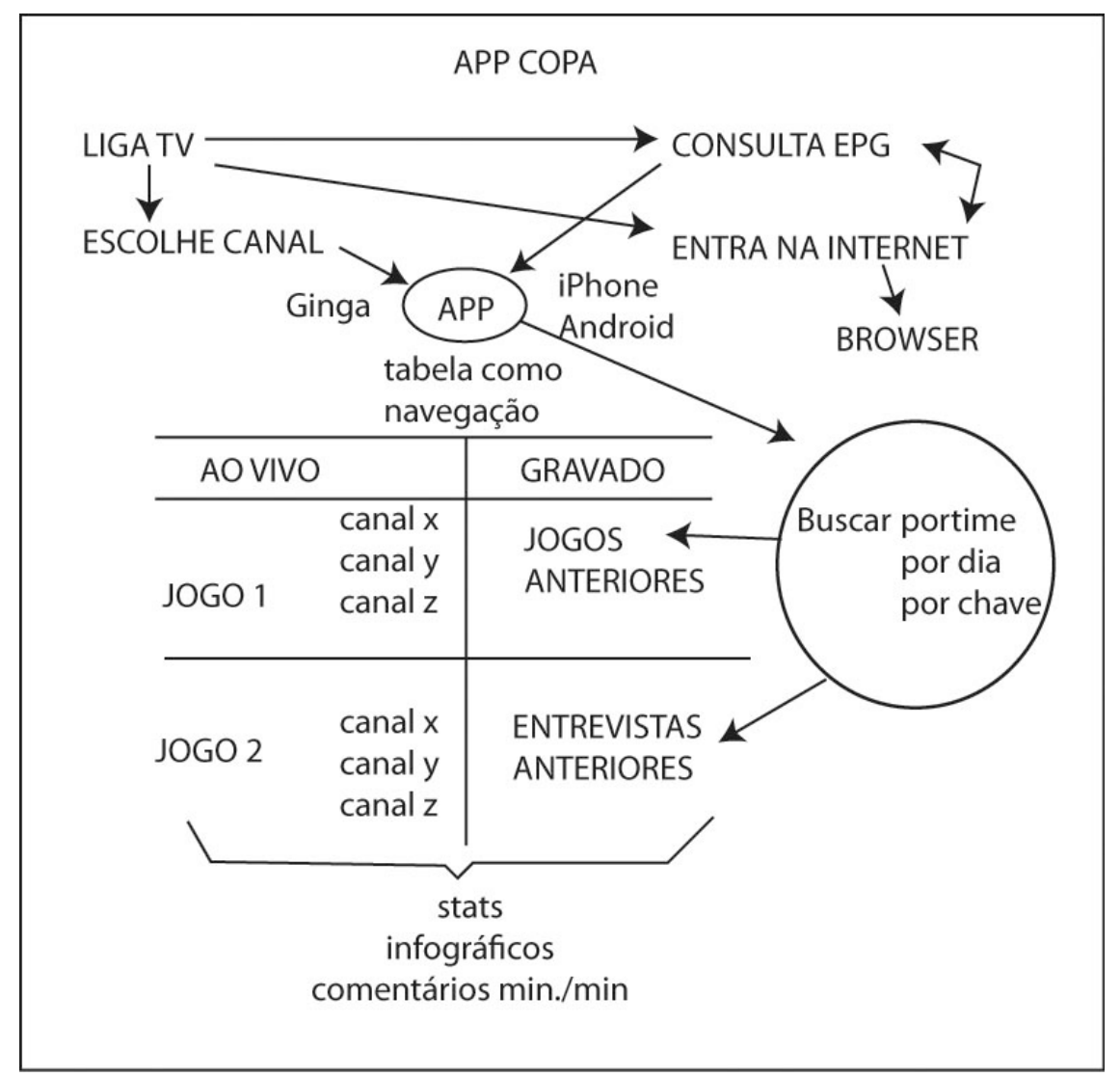

Fig. 6.12: Gráfico representando o fluxo de uma sequência operacional

$\mathrm{Na}$ sequência representada no gráfico anterior, o usuário (ou telespectador) de um smartphone (iPhone, Android etc.) escolhe um canal e começa a assistir a um jogo da Copa na TV. Enquanto faz isso, ele tem acesso a todos os conteúdos relacionados com a partida como: opções de áudio, ângulos de câmera, transmissão de outros canais, entrevistas, comentários, replays e ao acessar a internet pode agregar chats, redes sociais, vídeos em streaming e aplicativos relacionados ao evento. Esse conjunto de conteúdos expande a experiência da TV.

Como forma de explicitar a proposta, parti para o projeto de telas representativas de momentos dessa experiência que posteriormente possam ser programadas em um protótipo funcional da interface (o prosseguimento desta pesquisa). Este protótipo teria a seguinte configuração de hardware:

- Monitor de TV (HDTV ou SD)

- STB ou receptor de TV Digital

- Smartphone ou tablet (controle da TV via RF ou Wi-Fi) 
O canal de retorno pode dar-se através de:

- TV conectada à internet

- Smartphone ou tablet com acesso à internet (3-G ou Wi-Fi)

A partir do levantamento apresentado nos capítulos anteriores, foi extraído o conteúdo interativo e a ser utilizado no utilizado no projeto, sendo este:

\author{
-Transmissão de TV Digital - FIFA (HDTV e Multicâmera e móvel). \\ -Áudio alternativo: locução, plateia, podcasts (CBN, Band, Globo, iTunes) \\ -Websites e serviços na internet (UOL, New York Times, Facebook, Twitter). \\ -Programação de TV Digital Interativa (Ginga). \\ -Aplicativos para iPhone - Apps (Placar, Guia TV, ReRemote, Skype) \\ -Streaming Vídeo e IPTV (YouTube, Justin.tv, GoogleTV)
}

Como prova de conceito, tomei a decisão de projetar a interface de um dispositivo móvel para um celular iPhone da plataforma Apple. Este irá interagir com um STB conectado a uma TV HDTV full definition (1080p). Havíamos visto nos capítulos anteriores que há uma gama de aplicativos (apps) para o iPhone que permitem controlar um aparelho de TV e periféricos, assim como outros desenvolvidos especificamente para a Copa do Mundo. Além disso, ao conectar-se à internet é possível acessar outros serviços e sites como Facebook, Skype e portais de informação, complementando a experiência.

Um dos motivos da escolha da plataforma Apple foi a facilidade de acesso à documentação com as diretrizes de design para o iPhone, que é de fácil compreensão por um designer leigo em programação. Segundo o vídeo "iPhone User Interface Design" (APPLE, 2010), disponível no site da Apple, ao iniciar-se o projeto de um app para o iPhone, o primeiro passo é explicitar sua função em uma única sentença. O objetivo desse exercício é fazer com que seu aplicativo seja condizente com a simplicidade do iPhone. Tendo isso em mente, o "application statement" deste aplicativo é:

Criar uma interface que facilite a convergência da TV Digital com a telefonia celular. 


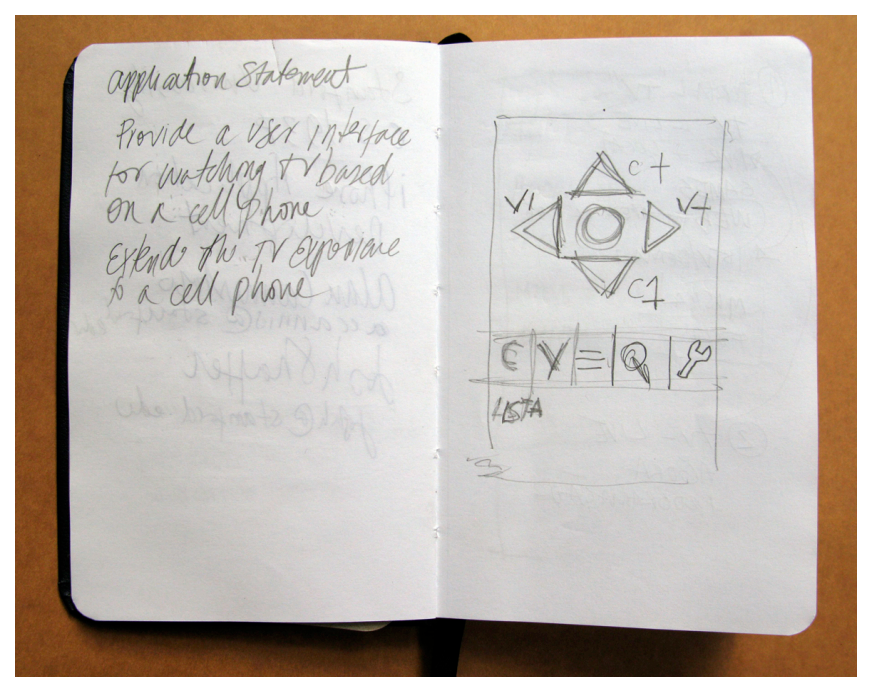

Fig. 6.13: Concepção inicial do controle em um celular

Segundo a publicação iPhone Human Interface Guidelines (APPLE, 2010), o design de uma interface de aplicativos para iPhone deve levar em conta:

-Tela compacta

-Uma tela é vista de cada vez

-Manter menus de ajuda (help) ao mínimo

-Utilizar metáforas

-Manipulação direta

-Feedback

-Controle do usuário

-Integridade estética

-Obviedade

-Expressar informações sucintamente

-Os alvos devem ser do tamanho dos dedos

O guia recomenda que inicialmente se desenhem todas as telas no papel antes de proceder à execução da arte final no computador, e sugere criar gabaritos para ajudar a manter a consistência e as proporções dos elementos básicos que constituem a interface. Sendo estes: 
- Barra de status (do telefone)

- Barra de navegação

- Barra de ferramentas

- Tab bar (funciona como um relê modal)

Levando em consideração os guidelines da Apple, gerei layouts das telas necessárias para se realizarem as atividades da sequência proposta. A imagem seguinte apresenta o gabarito de cartão que confeccionei para auxiliar nos esboços da tela e das barras de navegação:

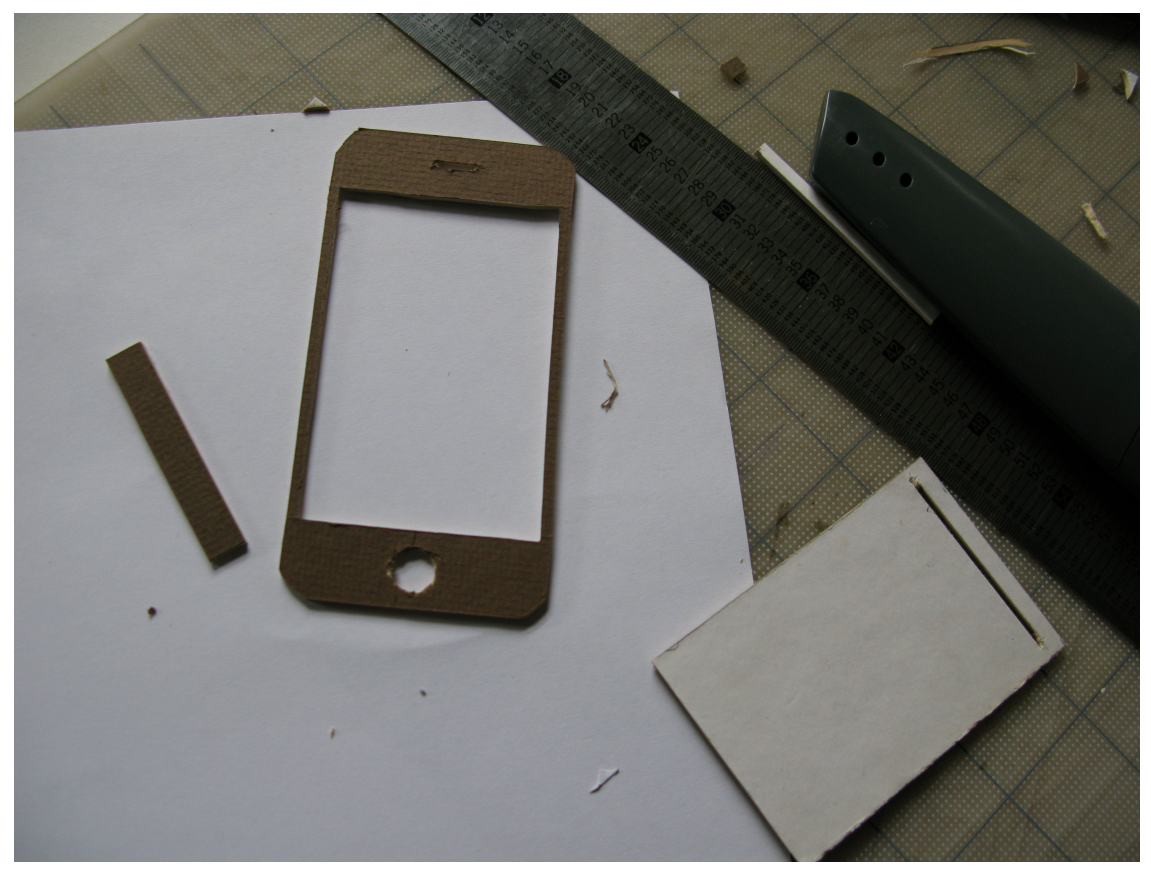

Fig. 6.14: Gabarito para desenho de interface do iPhone

Em seguida, transpus os layouts das telas do celular relacionando-os com a interface que seria visualizada na tela da televisão, produzindo assim um storyboard das diversas situações que representam a sequência dos principais passos necessários na utilização do aplicativo. Na próxima seção, reproduzo exemplos de alguns croquis e storyboards que foram produzidos para o projeto. 


\subsection{Croquis e storyboards}

Com o objetivo de demonstrar as possibilidades deste modelo de interação, foi definida a seguinte sequência de operações:

1. Ligar TV (tela principal) utilizando o celular.

2. Mudar de canal.

3. Procurar um programa no guia.

4. Acessar o guia no celular.

5. Transpor o guia do celular para a tela.

6. Navegar no guia.

7. Escolher programa.

8. Ver câmeras em outros ângulos no celular.

8. Mudar a câmera na tela principal.

9. Escolher um áudio alternativo.

10. Acessar estatísticas dos passes em um site na internet.

11. Visualizar os passes sobrepostos graficamente sobre o vídeo.

12. Buscar e pré-visualizar lances anteriores no celular.

13. Replay dos lances na tela principal.

14. Comentar sobre o jogo em uma rede social.

15. Apontar para o jogador e obter informações.

Durante a execução dos croquis das telas para o iPhone, questões de interoperabilidade com o monitor principal tornaram-se evidentes. Para resolvê-las, produzi storyboards que relacionassem a interface do dispositivo móvel com a da TV. 


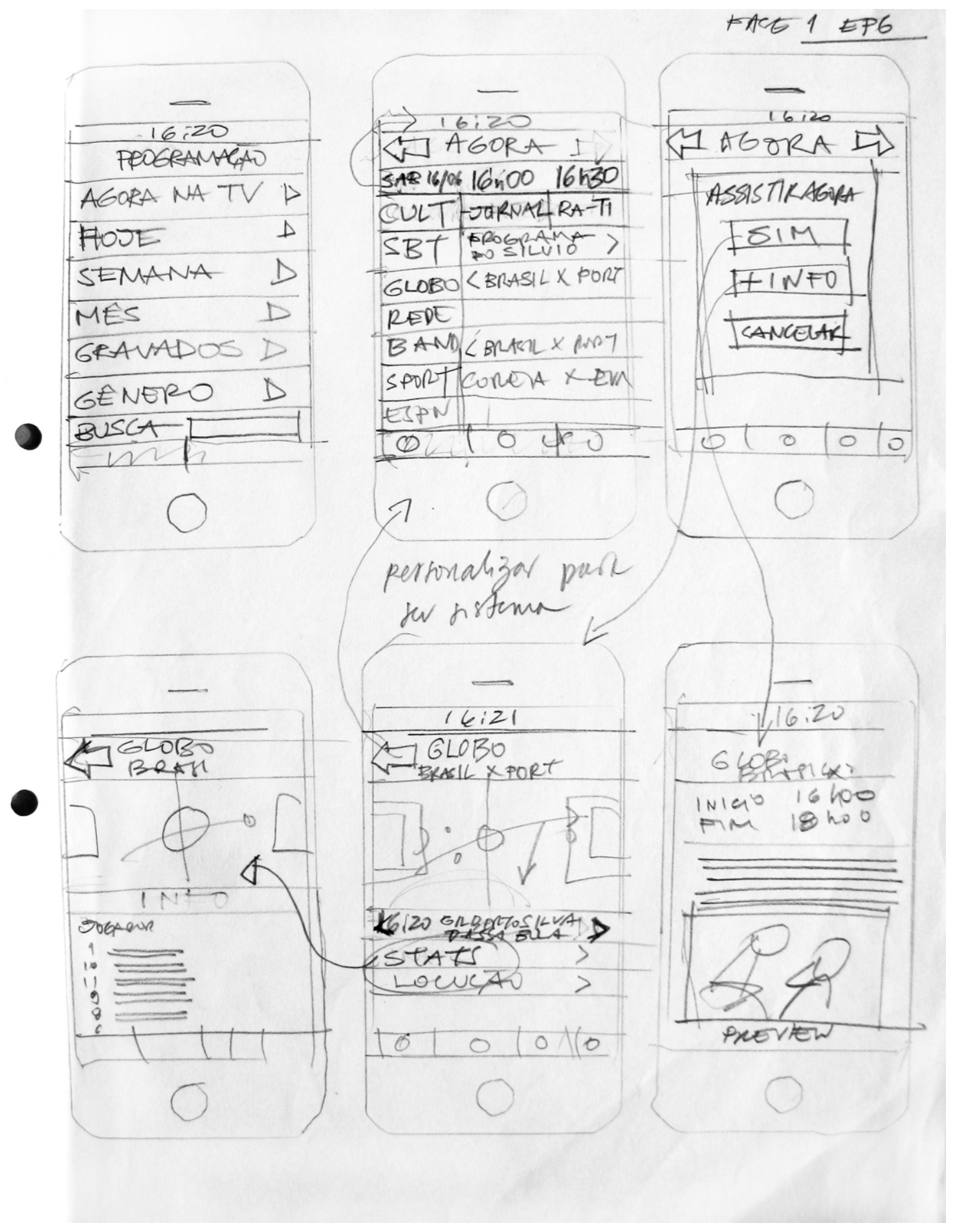

Fig. 6.15: Croquis representando layouts da interface de um EPG no iPhone 
292

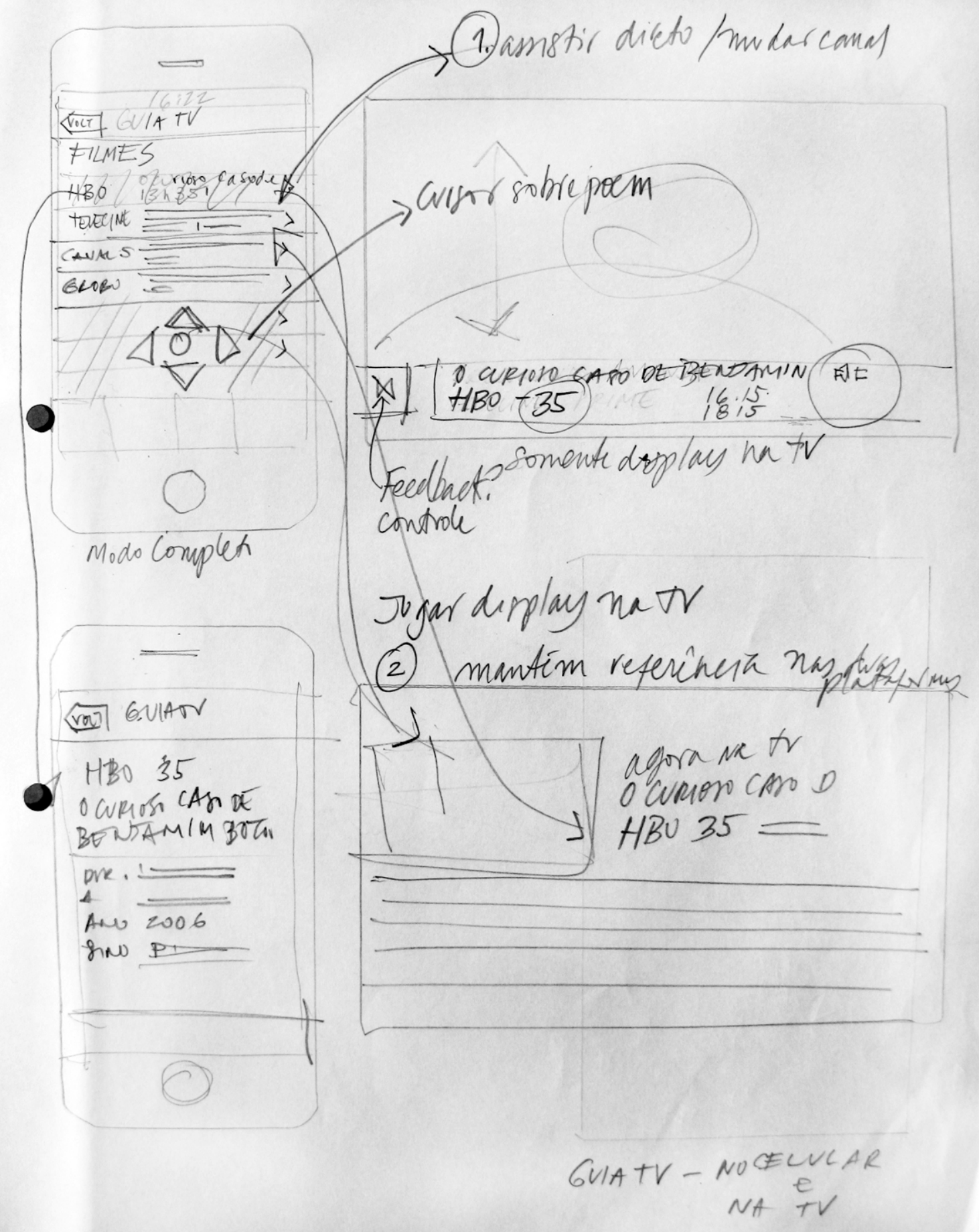

Fig. 6.16: Storyboard de interação do controle remoto com a TV Digital no modo EPG. 


\subsection{Layouts da Interface para Celular e TVDI}

Definidas as telas nos croquis, iniciei a execução de layouts da interface adequada à resolução das telas da TV e do celular: 1920 x 1280 pixels para o monitor de HDTV e 480by-320 para a tela do iPhone modelo 3GS. Os layouts foram produzidos no programa Adobe Illustrator, separando os elementos da interface em layers, que quando combinados entre si permitiram gerar diversas instâncias da interação.

Foram criados layouts representativos das interações do usuário com o celular, assim como o resultado dessa interação na interface exibida na tela da TV. Para fins de demonstração, o layout da tela do celular foi sobreposto ao layout da interface para um monitor HDTV. Posteriormente esse layout pode ser adaptado a monitores em resolução SDTV para fins de compatibilidade com a base de aparelhos implantada.

\subsubsection{Controle Remoto}

O controle remoto proposto é um aplicativo para o iPhone. Existem no momento diversas soluções comerciais que permitem utilizar smartphones (Symbian, Android e iPhone) como controle remoto para aparelhos de TV. Uma das opções é através da conexão Wi-Fi com um STB, como é o caso do Boxee Box da empresa norte-americana D-Link e do aplicativo Apple Remote para iTunes e Apple TV. Outra é a instalação de um acessório transmissor infravermelho, como é caso do L5 Remote e Re Remote, ambos direcionados para a plataforma iPhone e iPod da Apple. Embora a proposta siga as diretrizes de design de interfaces do iPhone, ela pode ser implementada utilizando qualquer uma dessas configurações.

Uma das premissas do projeto é que o controle facilite as operações básicas necessárias para assistir TV, sem a necessidade de se navegar através de diversos menus. A tela inicial do aplicativo é um controle remoto para televisão que permite trocar canais, ajustar o volume e escolher outras fontes de conteúdo. Na Fig. 6.17 a interface do controle está sobreposta à tela da $\mathrm{TV}$, onde na parte inferior se visualizam as informações do programa referente ao canal selecionado no controle remoto. 


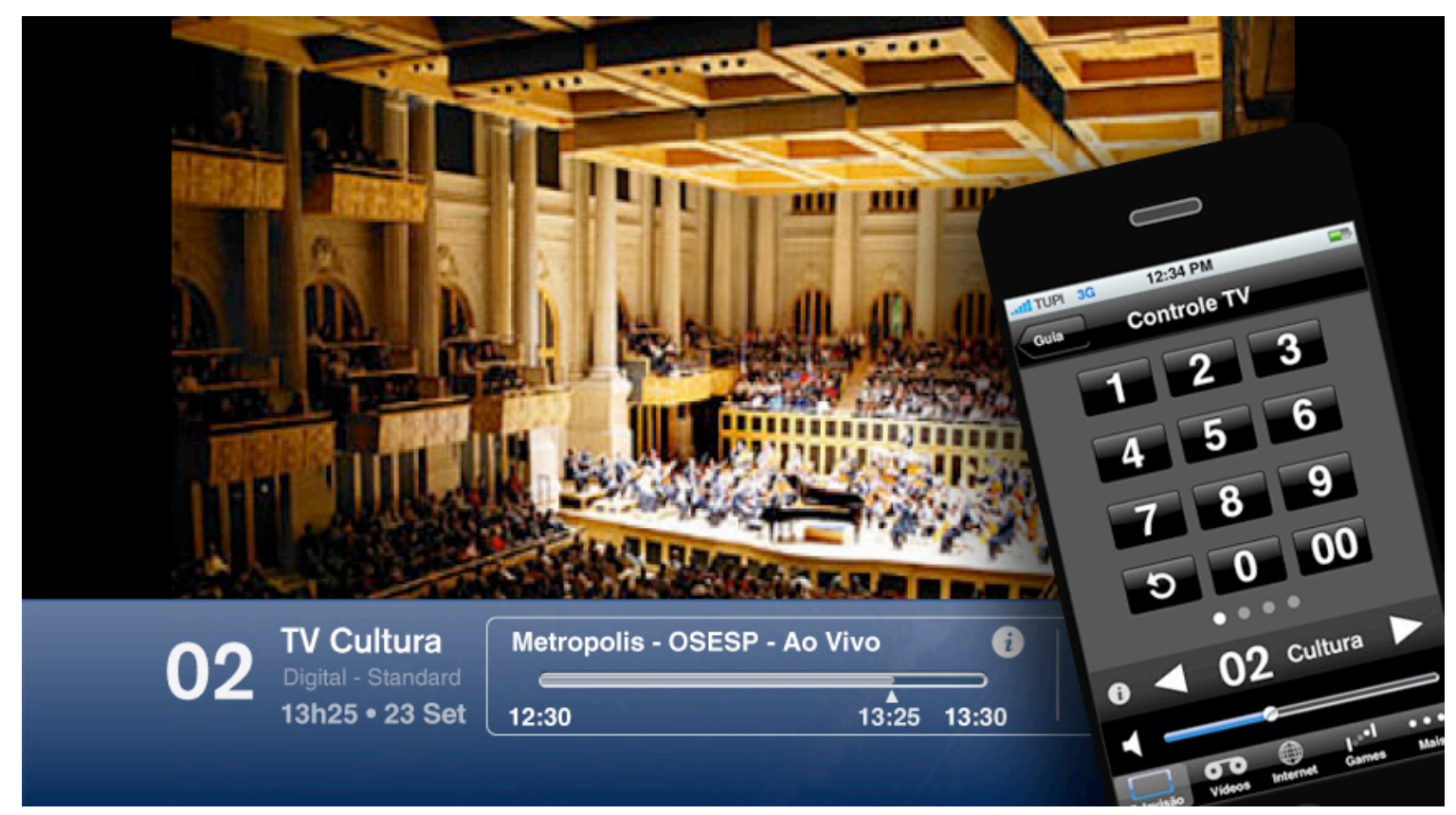

Fig. 6.17: Aplicativo de controle remoto para TV Digital.

O controle também permite a navegação na tela através de um cursor ou com gestos (possível devido ao acelerômetro embutido no dispositivo). Na figura seguinte (Fig. 6.18), vemos um exemplo da tela com o cursor servindo como controle para programas interativos que utilizam as teclas coloridas conforme o padrão DVB- MHP.

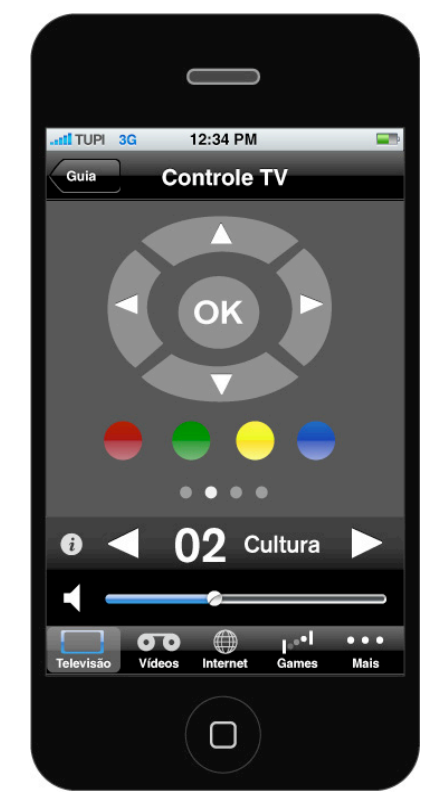

Fig. 6.18: Tela como cursor e teclas de atalho no controle remoto. 
Em todas as telas do controle remoto é sempre possível ajustar o volume, mudar de canal e acessar o guia de programação. O usuário também pode escolher entre diversas fontes de conteúdo: televisão, vídeo, internet, games e outras opções que poderão ser personalizadas. Essas fontes podem ser originadas de aparelhos conectados à TV como um DVD ou um STB, dispositivos móveis e computadores conectados a uma rede doméstica sem fio. Com o objetivo de reduzir ao mínimo a necessidade da leitura de instruções e visando manter a simplicidade do sistema, a interface proposta prescinde de menus de ajuda.

\subsubsection{Guia Eletrônico de Programação - EPG}

Um dos principais aplicativos residentes no middleware de aparelhos de TV Digital é o Guia Eletrônico de Programação (EPG). Nele é possível consultar a grade de programação atual e futura, assim como obter sinopses detalhadas dos programas. Ao consultar o EPG em um monitor de TV, podem-se visualizar as informações do programa na parte inferior da tela, com o mínimo de interferência no vídeo. Caso se queira visualizar uma grade semanal, é necessário ocupar a tela inteira com as informações, de modo que o telespectador não perca a referência do programa que está assistindo; é comum sobrepor uma imagem reduzida do programa ao guia.

Smartphones disponíveis no mercado atualmente contam com telas cuja resolução permite a visualização de gráficos e textos com boa qualidade; se utilizados como controle remoto, suas telas são perfeitamente capazes de servir como suporte para um EPG. No capítulo 5, foram analisados EPGs desenvolvidos para celulares como o app para iPhone "Guia TV" da empresa Finger Tips de São Paulo e Yahoo TV Guide para iPhone e iPad. Sistemas operacionais multi-tasking tornam potencialmente viável a incorporação de programas como estes ao controle remoto proposto.

O que vemos nos exemplos seguintes é a representação de um EPG genérico, projetado apenas para demonstração da integração com o controle remoto. O modo miniguia permite visualizar as informações do programa em uma barra na parte inferior da tela, onde é possível obter feedback de algumas operações realizadas no controle e das características da transmissão do sinal digital, tais como canal, hora local, resolução de imagem (SDTV ou HDTV), opções de áudio e vídeo. Uma caixa gráfica destina-se à exibição do título, hora de início e término do programa, e inclui uma barra que representa o tempo transcorrido e pode 
servir como interface de avanço e retrocesso em STBs equipados com um PVR, permitindo assistir trechos e programas pré-gravados.

Na tela seguinte (Fig. 6.19), vemos o EPG sendo utilizado no celular enquanto o miniguia representa a informação relativa ao controle remoto. Se o usuário desejar assistir a um programa que acaba de consultar no EPG do celular, ao selecioná-lo pode mudar o canal na TV e o miniguia atualiza-se com o novo programa e permanece na tela por tempo determinado. Caso queira visualizar novamente o miniguia, o usuário pode acessá-lo selecionando a tecla " $i$ " no controle. Se pressionar novamente essa tecla, a sinopse do programa será exibida.

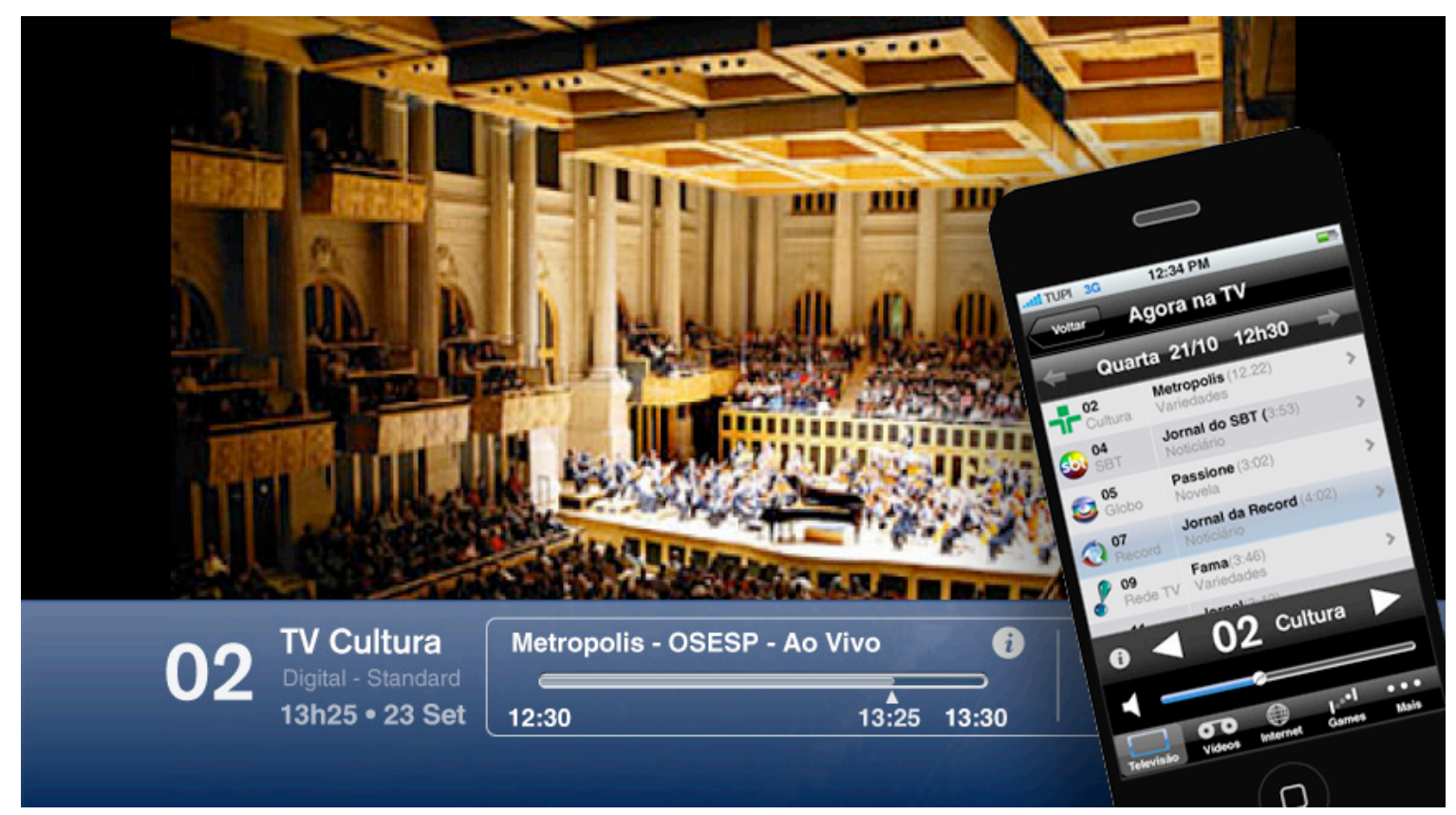

Fig. 6.19: Guia de programação para TV Digital em um iPhone.

A tela anterior (Fig. 6.19) representa o EPG ativo de forma resumida no celular. Neste exemplo, o telespectador obtém informações na tela do celular sem necessidade de interromper a programação na tela principal. Opcionalmente o guia de programação pode ser transposto para a tela da TV, permitindo um layout mais detalhado que pode ser visto por outras pessoas no mesmo ambiente, como vemos nos dois exemplos seguintes: 


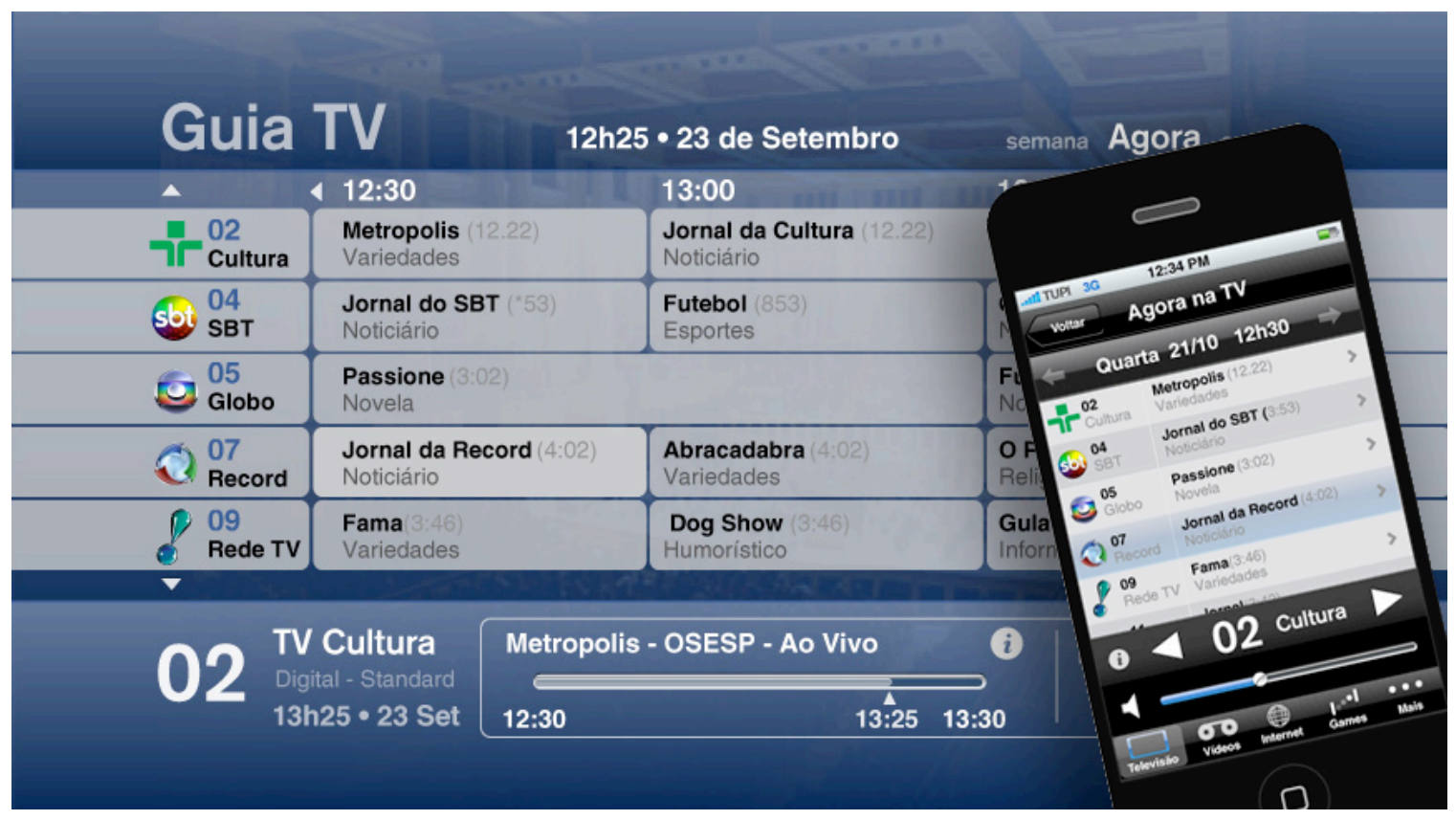

Fig. 6.20: Integração de guia de programação para TV Digital em um iPhone com um EPG.

Tanto na TV como no celular, ao selecionar um programa no guia, uma caixa de diálogo oferece a opção de assisti-lo ou obter mais informações. O usuário do celular pode pré-visualizar um programa no dispositivo portátil de modo que não interrompa o programa que está sendo exibido na tela principal.

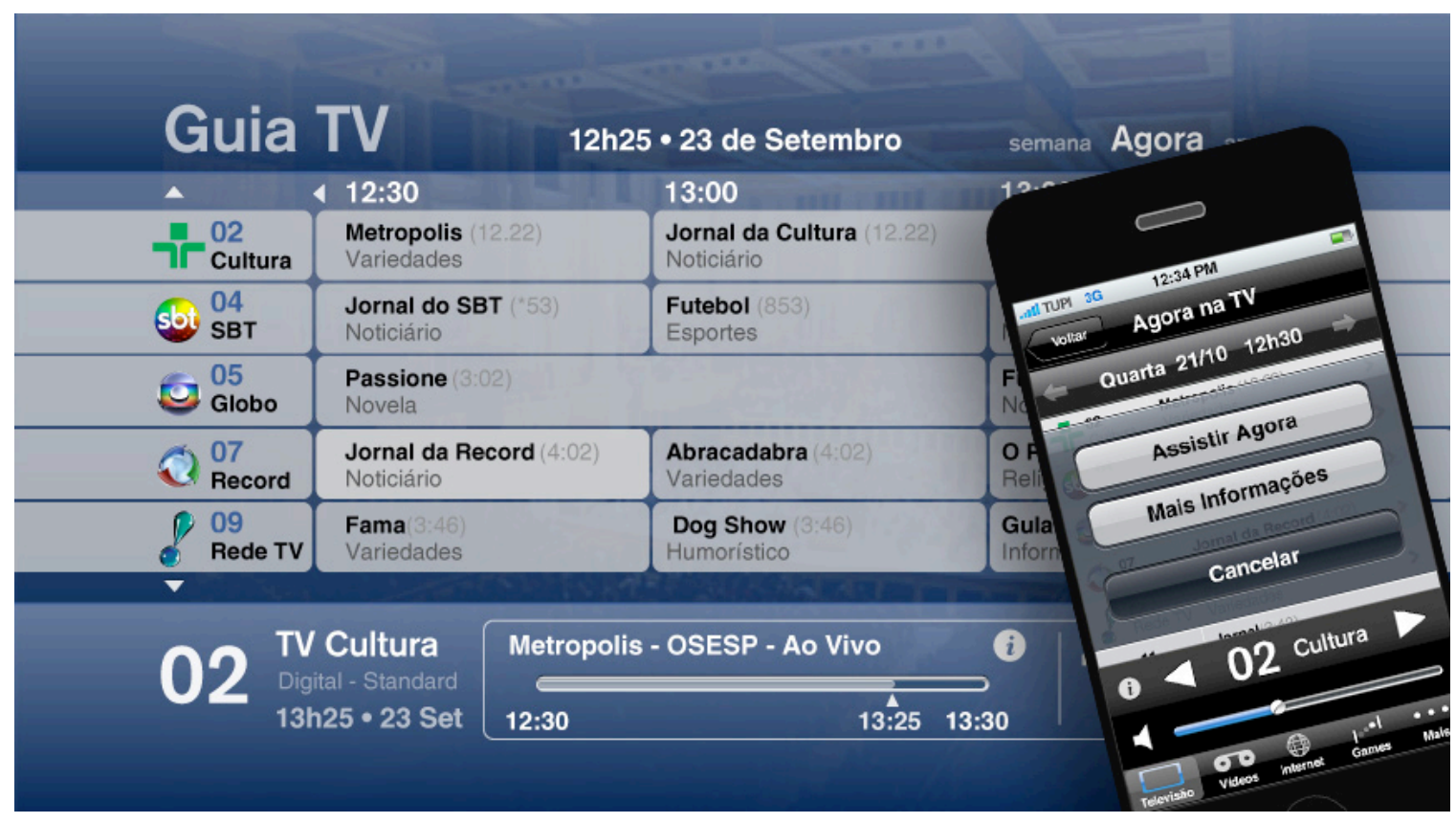

Fig. 6.21: Tela de diálogo da interface de um EPG em um iPhone. 


\subsubsection{Aplicativos para a Copa do Mundo de Futebol}

No capítulo anterior, foram analisados diversos aplicativos do iPhone para a Copa do Mundo de 2010 e a presença do evento em web sites do Brasil e do mundo. Nas próximas telas, propõe-se a integração destes com a TV Digital utilizando o iPhone como interface. Os aplicativos podem residir no aparelho móvel ou em um STB de TV Digital.

Uma das características da TV Digital é a possibilidade de transmissão de múltiplas câmeras em um programa. O controle pode servir como uma "mesa de corte" onde o telespectador pode pré-visualizar e selecionar diversos ângulos enquanto assiste a outro na TV. No caso da transmissão da Copa do Mundo da FIFA, há uma variedade de ângulos que poderão ser personalizados pelo telespectador.

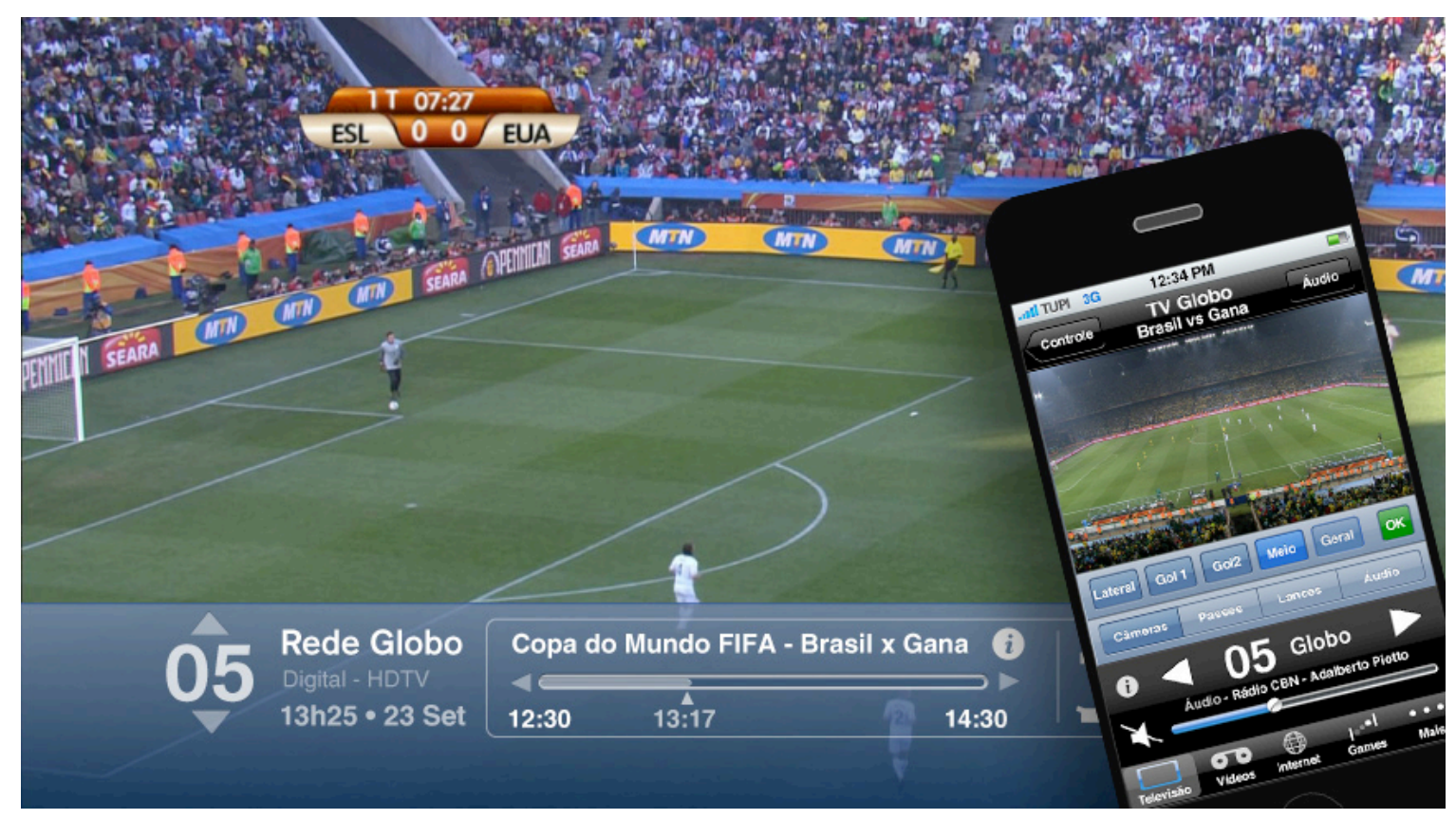

Fig. 6.22: Tela de escolha de ângulos em uma transmissão multicâmera.

Com a disponibilidade de diversos canais de áudio na TV Digital e rádios em streaming na internet, o celular permite "sintonizar" canais secundários. Estes podem ser escutados individualmente no aparelho utilizando fones de ouvido ou substituir o áudio principal no aparelho de TV. 


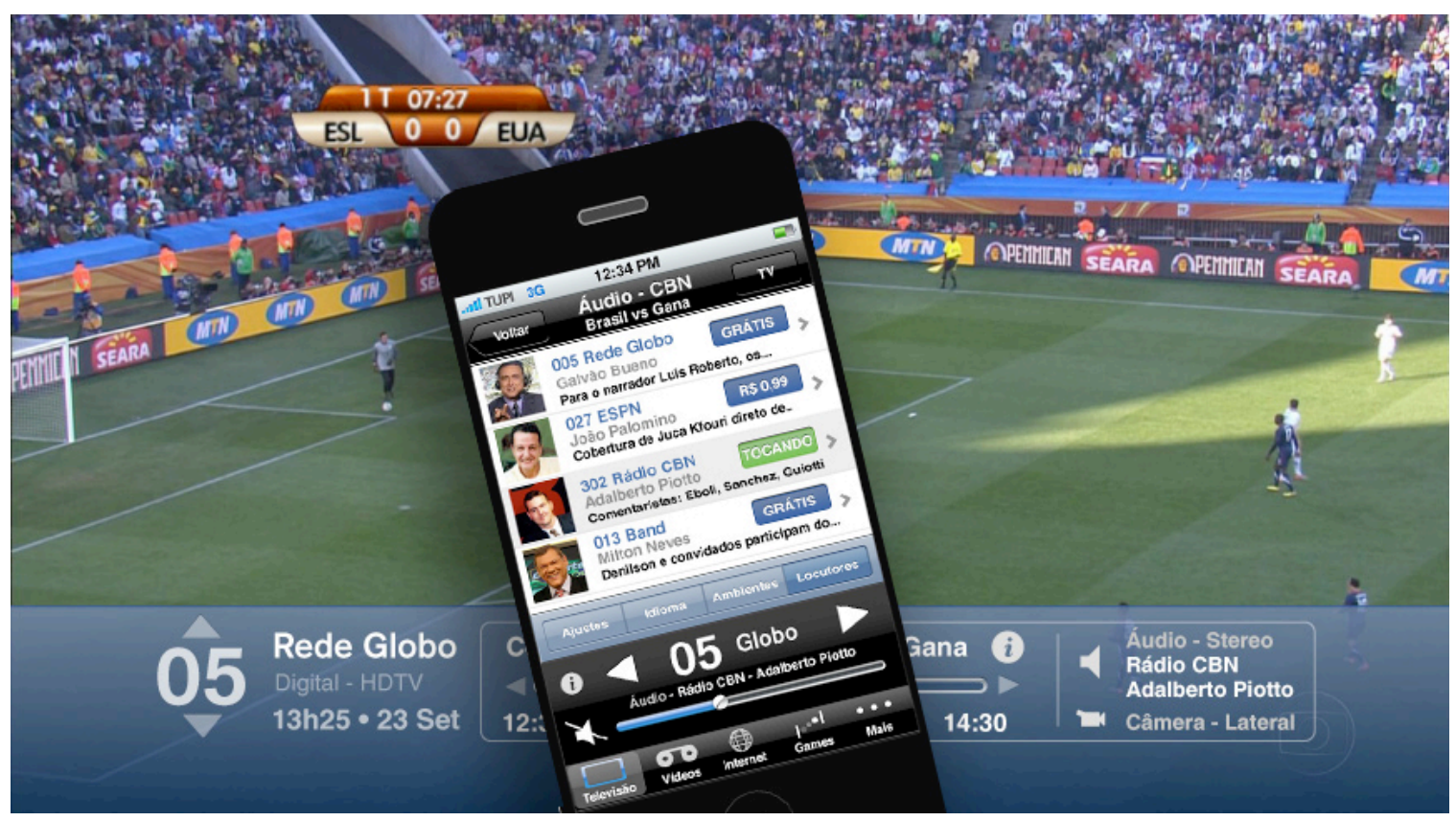

Fig. 6.23: Tela de opções de áudio.

Infográficos interativos no web site do New York Times possibilitaram rever os passes realizados durante os jogos da Copa de 2010. Ao integrar este aplicativo no iPhone, é possível transpor estas informações para a tela principal, como no seguinte exemplo:

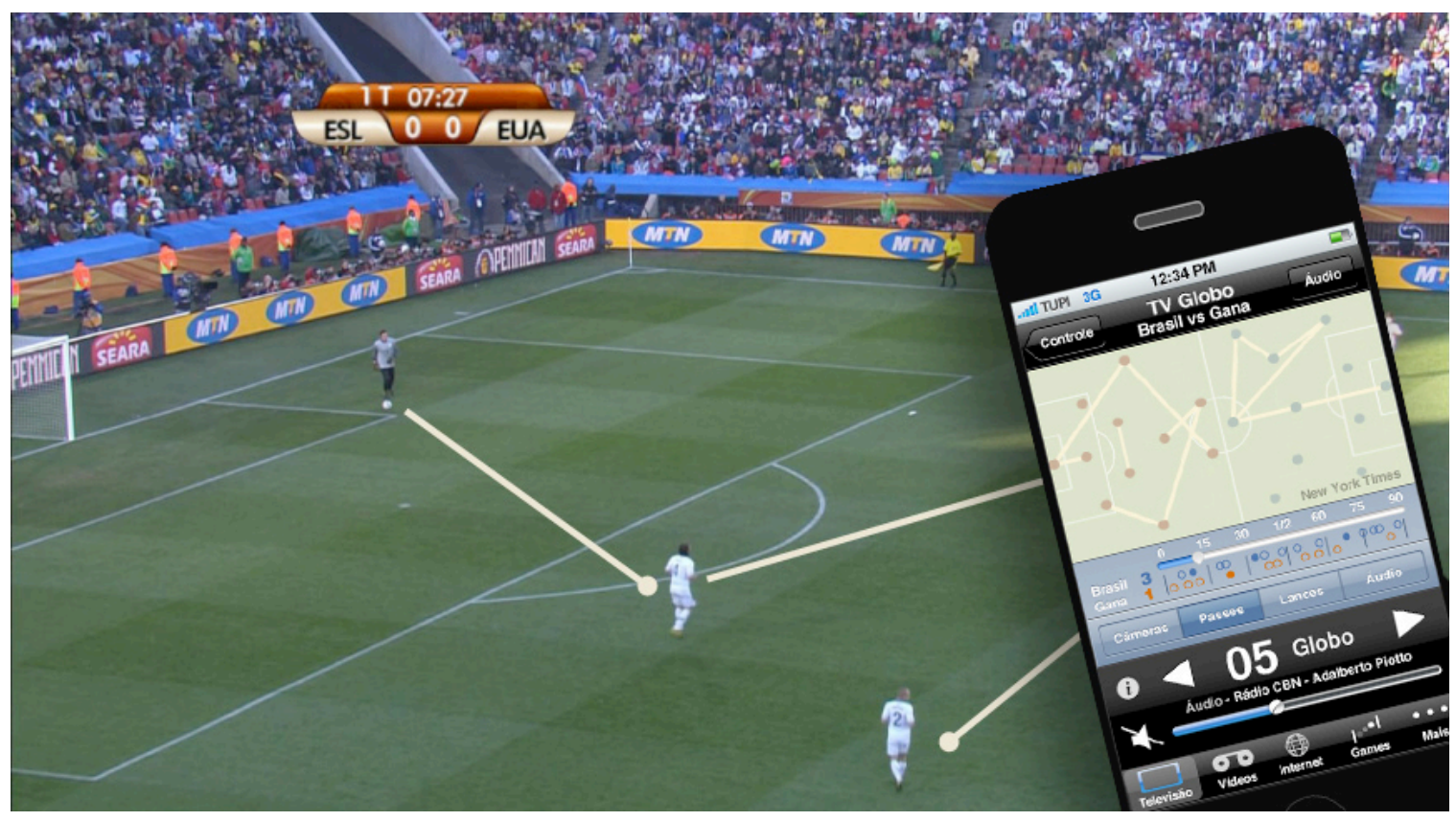

Fig. 6.24: Menu que permite visualizar passes durante uma partida na Copa do Mundo. 


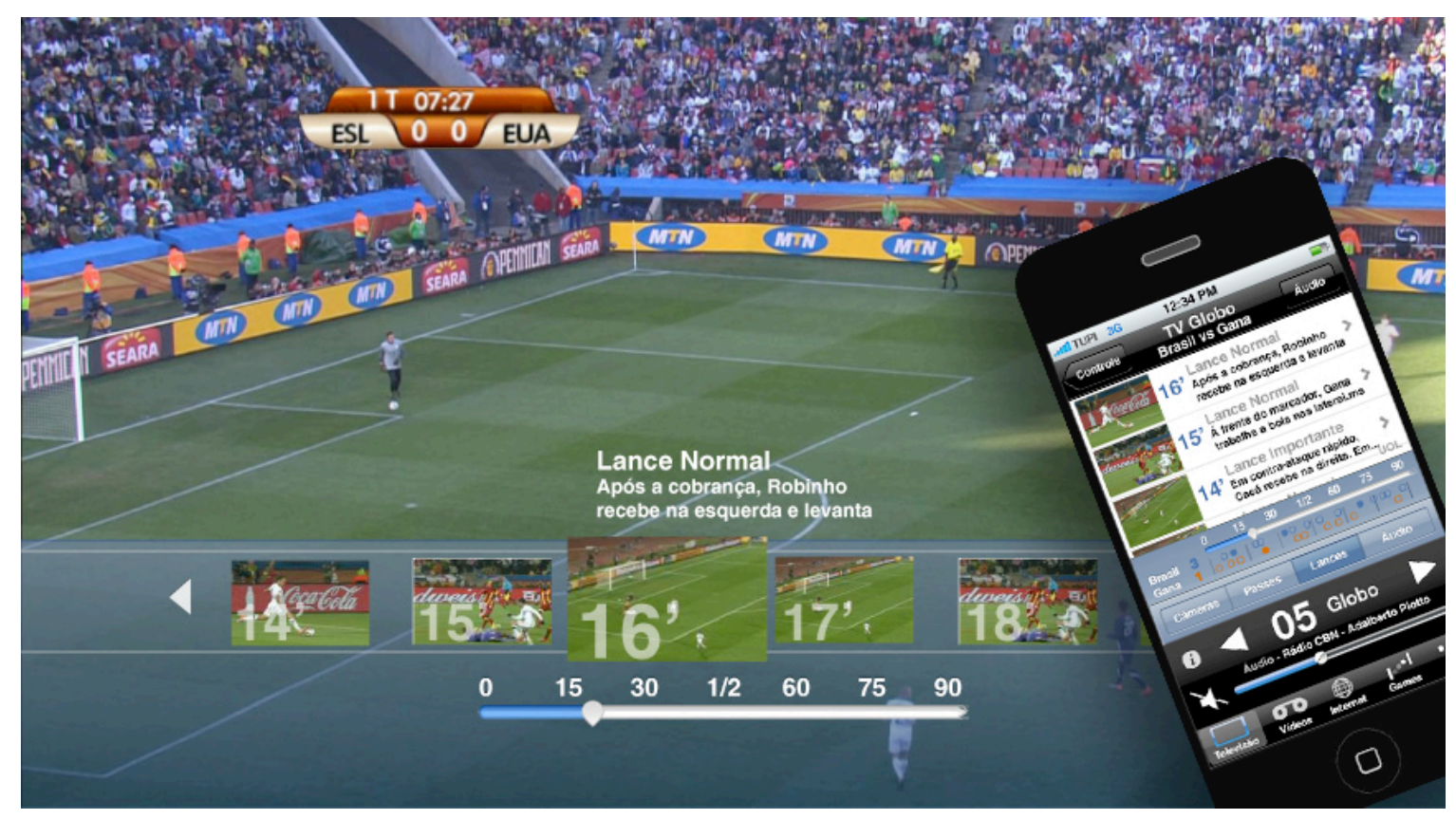

Fig. 6.25: Tela de visualização de lances durante uma partida de futebol.

$\mathrm{Na}$ imagem anterior, vemos uma outra proposta de integração com a web. Ela é baseada em uma página do site www.globo.com que permite rever os lances dos jogos da Copa do Mundo. Os lances arquivados a cada minuto são acompanhados por uma descrição textual. Nesta interface é possível pré-visualizar o lance no celular e vê-lo em tela cheia na TV. Isto pode ocorrer de diversas maneiras: Streaming de vídeo da internet, MPEG Vídeo enviado na camada de dados da TV Digital ou acesso a vídeo gravado e indexado em um PVR.

$\mathrm{Na}$ imagem seguinte, vemos a interação do telespectador com um aplicativo de TV social. Do lado esquerdo da tela, temos a versão para o celular e do lado direito vemos o widget para TV conectada que pode ser sincronizado ao celular de modo que outros telespectadores presentes no mesmo ambiente possam compartilhar o mesmo conteúdo. Esse widget também pode ser controlado pelo celular utilizando sua função de controle remoto. Neste exemplo, um usuário compartilha através de uma rede social um vídeo captado em seu aparelho celular, tornando este conteúdo visível aos outros usuários da rede simultaneamente à transmissão do jogo na TV. 


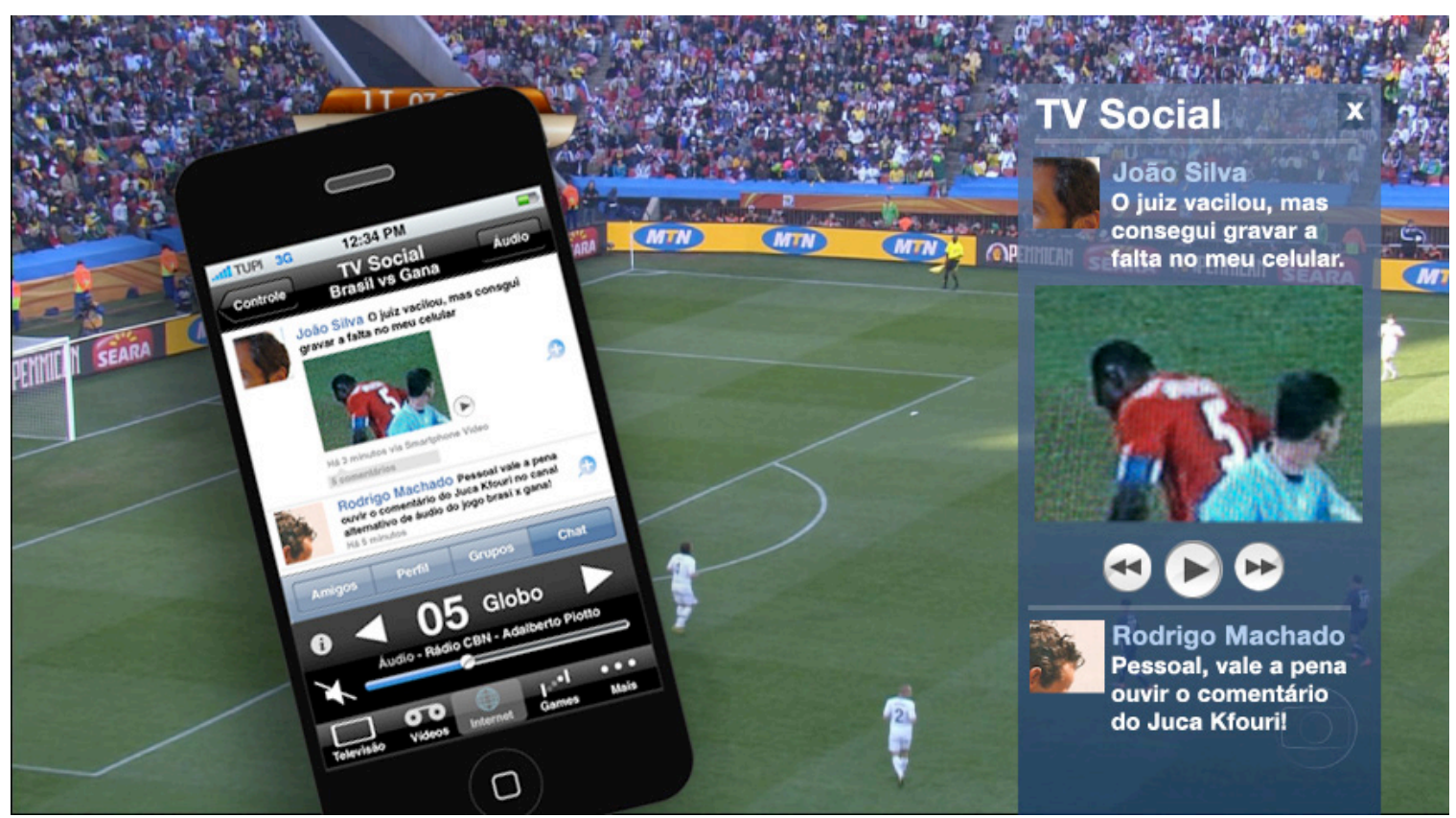

Fig. 6.26: Aplicativo de Rede Social para Celular sincronizado com widget de TV Social para TV Conectada.

As estatísticas referentes às partidas e aos jogadores são ocasionalmente exibidas pela emissora de TV. A interatividade permite ao telespectador acessá-las sob demanda.

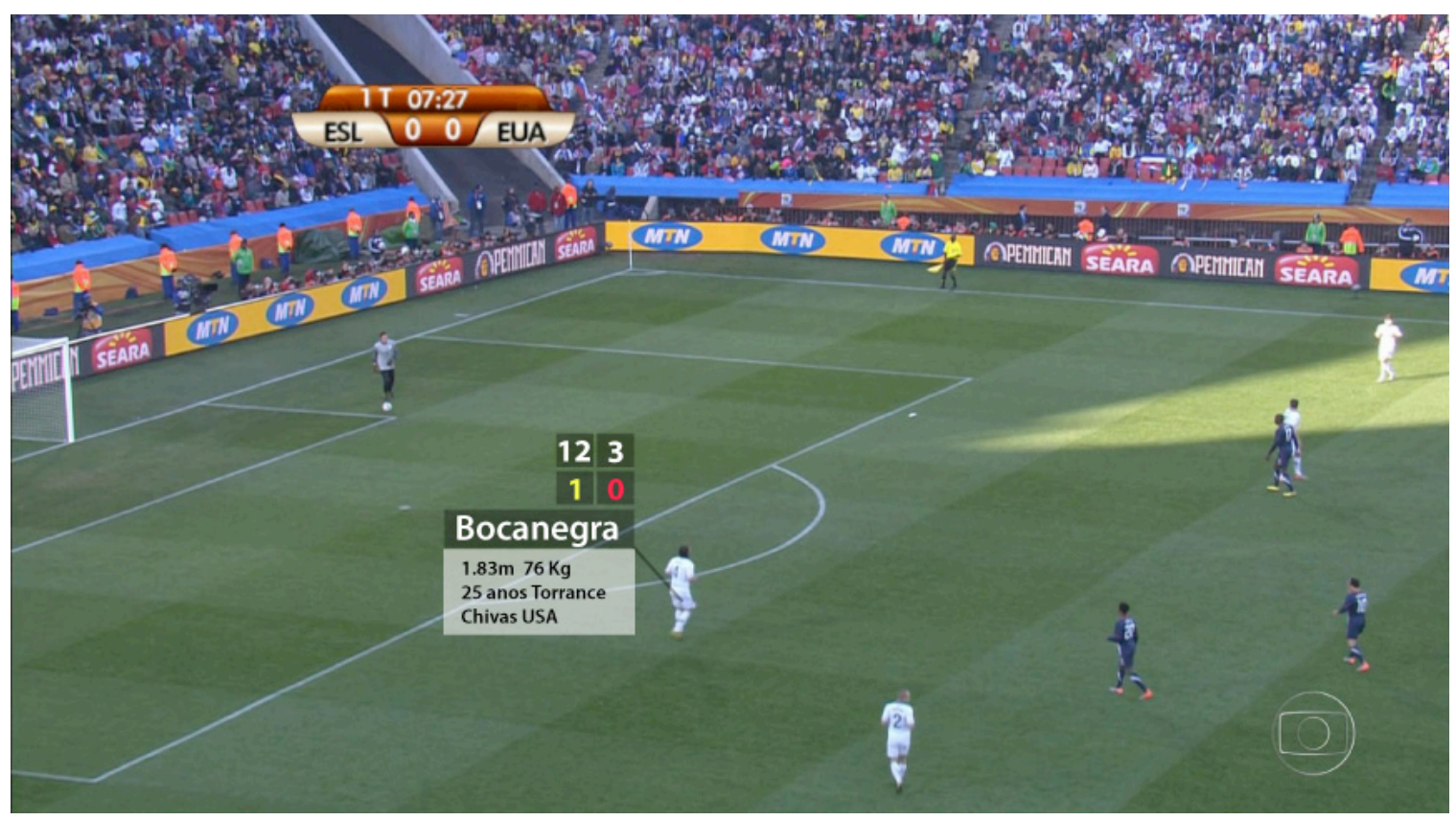

Fig. 6.27: Sobreposição na tela das informações de um jogador cuja posição é determinada por tracking ótico.

A imagem anterior representa a proposta de utilização um controle com acelerômetro e sensor de posição. Cruzando informações dos jogadores obtidas em bancos de dados acessíveis via internet e determinando a posição dos jogadores por um programa de tracking, 
a interface permite que o usuário aponte o controle para o jogador na tela e as informações relacionadas a ele sejam sobrepostas à imagem.

Esse tipo de interação pode ser enriquecida pela integração da TV Digital com plataformas de games como Nintendo Wii, Sony Playstation com Motion Controller e Microsoft XBox com Kinect, que apresentam soluções de interfaces baseadas em gestos, resultado de pesquisas no campo do design de interação como as Interfaces Naturais do Usuário (NUI), como visto no capítulo 2. Como os games são utilizados nos mesmos monitores em que assistimos TV, é provável que esse tipo de interação seja incorporada na interatividade com a TV Digital.

\subsection{Conclusão do capítulo}

As telas apresentadas representam apenas uma amostra do que é possível realizar ao gerar interfaces agregando conteúdo da internet com a TV Digital, com o objetivo de:

- Definir um partido de projeto que atenda às demandas da convergência da TV Digital com as tecnologias da informação e a ubiquidade de dispositivos móveis inteligentes.

- Levar em consideração as características técnicas do sistema de TV Digital implantado no Brasil e incorporar a estas aplicativos residentes em telefones celulares inteligentes (smartphones).

- Demonstrar como o telespectador da Copa do Mundo de 2014 poderá acessar diversas mídias digitais simultaneamente à transmissão da TV Digital.

- Apresentar uma solução de interatividade que incorpore um canal de retorno ao conectar a TV à internet via 3-G, DSL, CATV ou Wi-Fi.

- Incorporar tendências observadas em aplicativos e serviços interativos disponíveis na internet durante na Copa de 2010 e que podem migrar para a TV Digital até 2014, já que atualmente têm sido utilizados simultaneamente com a TV.

No capítulo anterior, havia identificado três tendências da TV Digital que podem concretizar-se na transmissão da Copa do Mundo de 2014: 
1 - TV social: a associação da TV Digital com redes sociais como Orkut e Facebook.

2 - TV multiplataforma: integração TV Digital com celulares e dispositivos inteligentes portáteis.

3 - TV conectada: acesso à internet e serviços como Google TV, Yahoo Widgets e AppleTV.

O projeto da interface deste sistema evidencia estas tendências e demonstra como o design pode contribuir na criação de um produto digital quando este é subsidiado pelo conhecimento obtido com pesquisa de tecnologias e linguagens.

Ao projetar interfaces gráficas para a TV Digital e um smartphone conectado a esta, foi possível representar um modelo hipotético de Design de Interação agregando conteúdo da internet com a TV Digital. As telas apresentadas no projeto representam uma amostra do que é possível realizar neste modelo. Uma das principais metas do projeto foi demonstrar o papel do design no processo de desenvolvimento de software e na concepção de sistemas digitais.

A representação gráfica pode sintetizar diversas funcionalidades de um serviço ou produto digital, servindo como um protótipo que possa ser utilizado como prova de conceito. Isso não significa que não seja necessário programar protótipos funcionais cuja usabilidade possa ser testada por usuários, mas pode ser oportuno não exigir testes funcionais de um novo produto digital prematuramente, particularmente quando a produção deste for limitada à capacidade de programação disponível. Verificada a viabilidade teórica de desenvolvimento de um novo produto, pode ser vantajoso demonstrá-lo em primeira instância através da representação visual e textual, como ocorre na aprovação de projetos arquitetônicos.

Uma vez definido este modelo, seu prosseguimento natural seria montar um protótipo funcional a partir desse projeto, que poderá ser programado em um smartphone e dialogar com o middleware Ginga quando instalado em um receptor compatível com o Sistema Brasileiro de TV Digital. Considero também a possibilidade de agregar outros aplicativos e serviços digitais desenvolvidos para a Copa do Mundo de 2010, descritos no capítulo anterior, mas não representados neste projeto. 
Capítulo

Conclusão "Desta forma o design poder facilitar a experiência da TVDI em um cenário
de convergência".

\subsection{0 que aprendemos}

A introdução da TV Digital no Brasil ocorre simultaneamente com a convergência da mídias digitais, o que provoca no público certa dificuldade em distingui-la de outras formas de distribuição de conteúdo audiovisual. Embora a plataforma da TV Digital seja distinta da internet, creio que as especificações do SBTVD são suficientemente abertas para viabilizar a fusão com outras plataformas conectadas à internet e consolidar a convergência. Na prática, mudanças como essas tardam a ocorrer por força de interesses comerciais e políticos mas (possivelmente) acabam concretizando-se devido a demandas dos usuários.

Avanços no campo do design de interação como as interfaces gráficas do usuário impulsionaram o uso de computadores pessoais e consequentemente o acesso à internet. Recentemente interfaces tangíveis e melhor resolução das telas dos celulares equipados com microprocessadores (smartphones) têm popularizado o uso destes em atividades antes restritas a computadores.

A digitalização impulsionou a utilização de mídias audiovisuais em sistemas e serviços digitais interativos, dando lugar a plataformas híbridas. Esta multifuncionalidade faz com que a distinção entre as mídias fique a cargo de interfaces simuladoras das mídias analógicas.

Neste cenário, um dos grandes desafios dos produtores de conteúdo é a indexação da produção (ou mídia) audiovisual, facilitando sua busca e organização na miríade de dispositivos de recepção midiática que permeiam nosso ambiente. A programação televisiva 
atual é dominada por um modelo de distribuição vertical controlado por grandes grupos de mídia, que se encarregam de sua indexação e organização, tendo como consequência a redundância das fontes de conteúdo.

O paradigma (de convergência) televisivo proposto neste trabalho pressupõe o compartilhamento do conteúdo pelos usuários. Neste modelo, os produtos audiovisuais podem residir em repositórios de mídia na internet. Esta tendência ressalta a importância de mecanismos de busca, despertando o interesse de empresas como Google e Yahoo em competir com as mídias estabelecidas,

\subsection{Considerações sobre o projeto}

Ao unir três plataformas distintas: TV, internet e celular, tendo como objetivo resolver questões operacionais, a interface proposta permite o encontro de atitudes distintas do usuário: assistir (TV), compartilhar (internet), ao mesmo tempo em que conversar (celular). Esta versatilidade resulta em uma experiência inédita catalisadora de uma nova mídia. Redes sociais são um exemplo concreto disto; nelas temos essas três modalidades inclusas na interface da tela do computador, apropriadas a uma utilização ainda predominante individual. Um dos desafios do projeto foi incorporar o aspecto coletivo da recepção da TV, as relações rizomáticas da internet e a mobilidade do celular.

Na ausência do desenvolvimento de um protótipo passível de ser testado por usuários, as conclusões a respeito do projeto desenvolvido são especulativas. O valor do modelo de interação resultante está na identificação de questões acerca do papel do design na interação do homem com a TV Digital. A viabilidade técnica deste modelo, embora hipotética, tem base no conhecimento adquirido com o levantamento da tecnologia da TV Digital e de pesquisas em interação homem-computador.

Adotou-se uma postura de demonstrar as interações possíveis do usuário com a mídia, explicitando a hipótese de que é possível integrar dispositivos móveis com a TV, como um catalisador da interatividade na TV Digital ao convergir com a internet. Neste caso, o design tem o papel de síntese da tecnologia, linguagem e mídia que se expressa em um projeto de interface. 


\subsection{O papel do designer na TV Digital}

Uma das caracteristícas primordiais da televisão é o entretenimento, distinguindo-a das plataformas computacionais. Com a convergência, computadores deixam de ser associados unicamente a atividades produtivas, adquirindo o status de uma nova mídia. A TV Digital é essencialmente um computador cuja identidade como mídia é determinada pela interface do usuário, o que enfatiza o papel do design em definir espaços midiáticos.

Os dispositivos digitais e suas interfaces são aspectos visíveis da convergência alimentados por novos formatos de conteúdo em que a linguagem é resultado de inovações tecnológicas. User-generated-content, life-casting, mash-ups e remixes compõem um repertório de conteúdo digital que tira a atenção dos telespectadores. Redes sociais, serviços de localização geográficas e identificação, quando combinados com bases de dados, mapas e repositórios de vídeos, abrem possibilidades narrativas que transcendem o espaço cênico clássico adotado pelo cinema e pela televisão.

Enquanto a produção de programas interativos para TV Digital não se libertar dos paradigmas atuais, há pouco futuro para a TV Digital interativa, confrontada com o dinamismo das mídias emergentes. Assim como o cinema e a televisão incorporaram a dramatização teatral em novos suportes, games e redes sociais aglutinam a produção audiovisual em plataformas concebidas para serem interativas. Colocando-as em posição "vantajosa" com relação à TV Expandida, na qual a interatividade não costuma integrar a produção de um programa de TV.

Do mesmo modo que o surgimento da fotografia não substituiu a pintura, filmes e minisséries continuarão a existir, portanto o surgimento de novas mídias não torna obsoletas as mídias anteriores.

Nos anos 1970 e 1980, a operação de equipamentos gráficos nos estúdios de TV era realizada por técnicos sem formação em design visual. Nos anos 1990, a TV a cabo passou a competir com as redes de TV aberta trazendo a necessidade de aprimorar a sua identidade, tendo como consequência o amadurecimento do Design Televisual. Fato similar ocorreu com a web, onde o layout das páginas visualizadas nos primeiros browsers era limitado a poucas opções encontradas na linguagem HTML, mas com a introdução dos Cascading Style Sheets (CSS) designers gráficos passaram a atuar no projeto de páginas da internet, trazendo consigo o refinamento da mídia impressa. 
O design de interação para TV Digital é uma atividade multidisciplinar, e exige a capacitação dos profissionais em diversas disciplinas: Design de Produto (Desenho Industrial), Design da Experiência do Usuário (UX), Design de Interfaces Gráficas, nas técnicas de animação e nos processos de produção de software e programas de TV.

No início, designers atuantes no campo da televisão tiveram que dominar a arte do movimento, depois designers de interfaces passaram a ter que compreender o processo de produção de software e sua usabilidade. Futuros designers digitais terão que versar em programação, prosa e emoção. O domínio da programação permite que o designer não seja refém das convenções do software utilizado na criação, ou seja, ao escrever seu próprio código, o designer pode manipular diretamente a informação sem intervenção do ponto de vista de outro programador. A interação entre o homem e os computadores pressupõe um diálogo, seja textual ou visual, o que requer a capacidade de se elaborar um discurso. Assumindo que a TV é associada ao entretenimento, soluções meramente funcionais são descabidas em um contexto em que se buscam emoções e prazer. 


\section{Referências}

ABRAMS, Janet. Muriel Cooper's Visible Wisdom. ID Magazine, September-October, 1994.

ALBERONE, Maurilio. Será que estamos preparados para a TV social mudar a forma como assistimos à televisão? Site imasters.com.br, 13 maio de 2010.

Disponível em:

<http://imasters.com.br/artigo/16850/tvdigital/sera_que_estamos_preparados_para_a_tv_socia 1_mudar_a_forma_como_assistimos_a_televisao/>. Acesso em: 14/01/2011.

ALENCAR, Marcelo S. Televisão digital. São Paulo: Érica, 2007.

ALMAS, Almir Antonio Rosa. Televisão Digital Terrestre: sistemas, padrões e modelos. Tese (Doutorado) - Pontifícia Universidade Católica de São Paulo, São Paulo, 2005 (Orientador: Arlindo Ribeiro Machado Neto).

ANDERSON, Chris; WOLFF Michael. The Web Is Dead. Long Live the Internet. Wired Magazine, September 2010. Disponível em:

<http://www.wired.com/magazine/2010/08/ff_webrip/all/1>. Acesso em: 30/11/2010.

APPLE. iPhone Human Interface Guidelines, 2010. Disponível em:

$<$ http://developer.apple.com/library/ios/\#documentation/userexperience/conceptual/mobilehig /Introduction/Introduction.html>. Acesso em: 23/12/2010.

APPLE. iPhone User Interface Design, 2010. Disponível em:

$<$ http://developer.apple.com/library/ios/\#documentation/userexperience/conceptual/mobilehig /Introduction/Introduction.html>. Acesso em: 23/12/2010.

APPLE. iPhone Human Interface Guidelines -User Experience. Apple Inc., Cupertino, 2010.

APPLE. iPhone User Interface Design (iPhone Development Essential Videos). Apple Inc., Cupertino, 2010.

AUTER, Philip. J.; BOYD, Douglas A. Dumont. The Original Fourth Television Network. Journal of Popular Culture, Ohio, 1995.

BARROS, Gil. Com quantos chapéus se faz um arquiteto?. In: $3^{\circ}$ EBAI - Encontro Brasileiro de Arquitetura de Informação, 2009. Disponível em:

$<$ http://www.congressoebai.org/index.php/2009/com-quantos-chapeus-se-faz-umarquiteto/10>. Acesso em: 29/11/2010.

BARROS, Gil. A Consistência da interface com o usuário para a TV interativa. Dissertação (Mestrado) - Departamento de Engenharia de Sistemas Eletrônicos, Escola Politécnica da Universidade de São Paulo, São Paulo, 2006 (Orientador: Prof. Dr. Marcelo Knörich Zuffo).

BARTHES, Roland. S/Z. Paris: Seuil, 1970. 
BAUDRILLARD, Jean. O sistema dos objetos. São Paulo: Perspectiva, 1973.

BECKER, Valdecir. Plano de Comunicação do SBTVD. Brasília, MC, 2005.

Disponível em:

$<$ http://sbtvd.cpqd.com.br/cmp_tvdigital/divulgacao/anexos/57_124_SBTVD_Release_12de.p df>. Acesso em: 20/11/2009.

BECKER, Valdecir; MORAES, Áureo. A necessidade da inovação no conteúdo televisivo digital: uma proposta de comercial para TV interativa.

Disponível em: <http://www.tvdi.inf.br/upload/artigos/a-scpdi_03.pdf>. Acesso em: 16 maio 2010.

BENEDIKT, Michael, Cyberspace: First Steps. Cambridge: MIT Press, 1991.

BOLTER, Jay David; GRUSIN, Richard. Remediation: Understanding New Media. Cambridge: MIT Press, 2000.

BRENNAND, Edna; LEMOS, Guido. Televisão Digital Interativva: reflexões, sistemas e padrões. São Paulo: Ed. Mackenzie, 2007.

BRUNNER, Jerome. Towards a Theory of Instruction. Cambridge: Belkapp Press, 1966.

BULKELEY, William M. TR10: Social TV - Relying on relationships to rebuild TV audiences. 10 Emerging Technologies 2010 MIT Technology Review, may/june 2010. Disponível em: <http://www.technologyreview.com/communications/25084/>. Acesso em: 14/01/2011.

BURROUGHS, William. The Cut-Up Method of Bryan Gysin, Sterling Lord, 1978 (in WARDRIP-FRUIN, Nick; MONTFORT, Noah (Ed.).The New Media Reader. Cambridge, MIT Press, 2003).

BUSH, Vannevar. As We May Think. The Atlantic Monthly, p. 101-108, July 1945.

CAPANEMA, Rafael, Ainda protótipos, TVs 3D chegam mais perto das casas. Folha de S.Paulo, 14/01/2010. Disponível em:

<http://www1.folha.uol.com.br/folha/informatica/ult124u489871.shtml>Acesso em: $16 / 02 / 2010$.

CARUSO, Denise. Debate over advanced TV gives the F.C.C. a chance to be assertive. New York Times, New York, June 17, 1996.

Disponível em: <http://www.nytimes.com/1996/06/17/business/technology-digitalcommerce-debate-over-advanced-tv-gives-fcc-chance-be.html?src=pm $>$.

Acesso em: 17/02/2011.

CHUNG, Johnny Lee. In search of a Natural Gesture. Journal, XRDS: Crossroads, The ACM Magazine for Students, The Future of Interaction, Vol 16 Issue 4, Summer 2010, New York, ACM, 2010

CHORIANOPOULOS, Konstantinos; SPINELLIS, Diomidis. User Interface Evaluation of 
Interactive TV: A Media Studies Perspective, Universal Access in the Information Society, Volume 5, Issue 2, July 2006, pp. 209-218, 2006.

COOPER, Muriel. Computers and Design. Design Quarterly, v. 142, 1989.

COTTON, Bob; OLIVIER, Richard. Understanding Hypermedia. London: Phaidon, 1993.

CRUICKSHANK, Leon; SEKLEVES, Emmanuel T.; WHITHAM, Roger; HILL, Annette; KONDO, Kaoruko. Making Interactive Tv Easier To Use: Interface Design For A Second Screen Approach. Uxbridge; Harrow, UK: Brunel University, Westminster University, 2007.

CRUZ, Renato. TV digital no Brasil: tecnologia versus política. São Paulo: Senac, 2008.

CRUZ, Vítor Medina; MORENO, Marcio Ferreira;SOARES, Luiz Fernando Gomes.GingaNCL: implementação de referência para dispositivos portáteis. Pontifícia Universidade Católica, Rio de Janeiro, 2008. Disponível em: <ftp://ftp.telemidia.pucrio.br/ lfgs/docs/conferencepapers/2008_10_vitor.pdf>. Acesso em: 20 maio 2010.

CUCCUREDDU, Gianluigi. Can Event-Based Social Networks further diffuse Social TV? App Market TV, 22/07/2010.

Disponível em: <http://www.appmarket.tv/opinion/469--can-event-based-social-networksfurther-diffuse-social-tv.html>. Acesso em: 14/01/2011.

CURRAN, Steve. Convergence Design. Boston: Rockport, 2003.

DIZARD, Wilson. A nova mídia, a comunicação de massa na era da informação. Rio de Janeiro: Zahar,2000.

DELEUZE, Gilles. Mille Plateaux. Paris: Les Editions de Minuit, 1976.

DTV. Site Oficial da TV Digital Brasileira, 2008. Disponível em:

$<\mathrm{http}$ ://ttv.org.br/materias.asp?menuid=3\&id=11>. Acesso em: 24 nov. 2009.

DTV. TV digital: produção de conteúdo interativo ganha impulso neste semestre. Fonte: Tele Síntese Análise, publicado na seção de Notícias do Site DTV-Forum SBTVD.

Disponível em: < http://www.dtv.org.br/index.php/tv-digital-producao-de-conteudointerativo-ganha-impulso-neste-semestre/>. Acesso em: 14/01/2011.

DVB PROJECT 2010. Open Middleware for Interactive TV, DVB Fact Sheet - May 2010. Multimedia Home Platform. Disponível em:

$<$ http://www.dvb.org/technology/fact_sheets/DVB-MHP_Factsheet.pdf>.

ENGELBART, Douglas C. Augmenting Human Intellect: A Conceptual Framework (1962). In: PACKER, Randall; JORDAN, Ken (Eds.). Multimedia: From Wagner to Virtual Reality, Norton, 2002.

FARHI, Paul. The Inventor Who Deserves a Sitting Ovation. Washington Post, Saturday, February 17, 2007. Disponível em:

<http://www.washingtonpost.com/wpdyn/content/article/2007/02/16/AR2007021602102.html $>$. 
FCC - FEDERAL COMMUNICATIONS COMMISSION. DTV is coming, Consumer Facts, 1/3/2008. Disponível em: <www.dtv.gov>.Acesso em: 21 nov. 2010.

FEITOSA, Deisy Fernanda; ALVES, Kellyanne Carvalho; NUNES FILHO, Pedro.

Conceitos de interatividade e aplicabilidades na TV digital. In: NUNES, Pedro (Org.). Mídias digitais \& interatividade. João Pessoa: Editora Universitária da UFPB, 2009.

FERNANDES, Jorge, LEMOS, Guido, SILVEIRA, Gledson Elias. Introdução à Televisão Digital Interativa: arquitetura, protocolos, padrões e práticas. Minicurso apresentado na XXIII Jornada de Atualização em Informática do XXIV Congresso da Sociedade Brasileira de Computação. JAI-SBC - 2004. Disponível em: <http://www.cic.unb.br/ jhcf/MyBooks>.

FILGUEIRAS, L. V. L. ; ALMAS, Almir; SCHLITTLER, João Paulo; OLIVEIRA NETO, João Soares de; GIANNOTTO, Eduardo; BARROS, Gil; ZUFFO, Marcelo Knorich.

Processos de software para televisão digital interativa. In: FÓRUM DE OPORTUNIDADES EM TELEVISÃO DigitAL INTERATIVA, 4., 2006, Poços de Caldas. Anais... Poços de Caldas: Pontifícia Universidade Católica de Minas Gerais, 2006.

GAWLINSKI, Mark. Interactive Television Production. London: Focal Press, 2003.

GIBSON, William. Neuromancer. Vancouver, 1983.

GLASER, Marc. Your Guide to Cutting the Cord to Cable TV. PBS Media Shift, Boston, 08/01/2010.

Disponível em: <http://www.pbs.org/mediashift/2010/01/your-guide-to-cutting-the-cord-tocable-tv008.html>. Acesso em: 13/10/2010.

GORIUNOVA, Olga; SHULGIN, Alexei. Glitch. Software Studies / A lexicon. Ed. Fuller Matthew. Cambridge: MIT Press, 2006.

GREFÉ, Richard. (FORM+ Content+ Context +Time) = Experience Design. Gain - AIGA Jornal for the Network Economy, New York, AIGA, v. 1, n. 1, 2000.

HANSEN, Vibeke. Designing for interactive television v. 1.0. BBCi \& Interactive tv programmes. London: BBC, 2005.

HOINEFF, Nelson. TV em expansão. Rio de Janeiro: Record, 1991.

HOUAISS, Antônio; VILLAR, Mauro de Salles. Dicionário Houaiss da língua portuguesa. Rio de Janeiro: Objetiva, 2009.

HUDGINS-BONAFIELD, Christy. Attack Of The $\$ 500$ Killer Network Computers, Time-

Warner Cable's Full Service Network, in The H-Report, December 15, 1995.

Disponível em: <http://www.networkcomputing.com/616/616tw.html>. Acesso em: $17 / 11 / 2010$.

HURLEY, Shonagh. The Music Industry and The Internet: A Study. Thesis (for the Masters of Multimedia) - University of Dublin, Ireland, 2006. 
JAMESON, Frederic. Post modernism or The Cultural Logic of Late Capitalism. Verso, 1991.

JENKINS, Henry. Convergence Culture, Where Old and New Media Collide. NYU Press, 2007. Disponível em: <http://www.convergenceculture.org/weblog/white_papers/>. Acesso em: 25/11/2010.

JENKINS, Henry; LI, Xiachang; KRAUSKOPF, Domb. If it doesn't spread it's dead. White Paper, Convergence Culture Consortium, MIT, 2008.

JOHNSON, Steven R. Interface Culture. New York: Basic Books, 1999.

JOHNSON, Steven. Cultura da Interface. Rio de Janeiro: Zahar, 2001.

JOOR, Dirkjan; BEEKHUIZEN, Wilco; VAN DE WIJNGAERT, Lidwien; BAAREN, Eva. The Emperor's Clothes in High Resolution: An Experimental Study of the Framing Effect and the Diffusion of HDTV.Computers in Entertainment (CIE) - SPECIAL ISSUE: TV and Video Entertainment Environments archive, Utrecht University e Twente University, v. 7, n. 3, article 40, set. 2009.

JORDÀ, Sergi; JULIÀ, Carles F.; GALLARDO. Daniel, Interactive Surfaces and Tangibles. Journal, XRDS: Crossroads, The ACM Magazine for Students, The Future of Interaction, Vol 16 Issue 4, Summer 2010, New York, ACM, 2010.

JOVANELI, Rogerio. 3D na TV aberta, INFO Online (26/02/2010), Info.abril.com.br. Disponível em: <http://info.abril.com.br/noticias/mercado/redetv-realiza-primeiratransmissao-ao-vivo-18052010-15.shl>. Acesso em: 26/05/2010.

KARAMCHEDU, Raj. Does China Have the Best Digital Television Standard on the Planet? May 2009.

Disponível em: <http://spectrum.ieee.org/consumer-electronics/standards/does-china-havethe-best-digital-television-standard-on-the-planet/2>. Acesso em: 10/01/2010.

KAVANAGH, Eric. The Future Of Television: When Will The Gates To High-Definition TV Swing Open? New Orleans, November 18th, 1996.

Disponível em: <http://www.mobiusmedia.com/FutureTV.htm>. Acesso em: 14/11/2010.

KAY, Alan. User Interface - A Personal View. In: LAUREL, Brenda (Org.). The Art of Human Computer Interface Design. Addison Wesley, 1990.

KLYM, Natalie; MONTPETIT, Marie José. Innovation at the Edge: Social TV and Beyond.MIT CFP -VCDWG Working Papers. MIT Technology Review, 2008. Disponível em: $<$ http://www.technologyreview.com/communications/25084/?a=f>. Acesso em: 19 abr. 2010 .

KRUGER, Myron, Texto de apresentação da exposição Touchware, Siggraph,1998. Disponível em: <http://www.siggraph.org/artdesign/gallery/S98/pione/pione3/krueger.html>. Acesso em: 23/12/2010. 
KNEMEYER, Dirk; SVOBODA, Eric (2007). User Experience - UX, em InteractionDesign.org. Disponível em:

$<$ http://www.interactiondesign.org/encyclopedia/user_experience_or_ux.html>.

Acesso em: 29/11/2010.

LANDOW, George.Hypertext: The Convergence of Contemporary Critical Theory and Technology. Baltimore: John Hopkins, 1992.

LANDOW, George; DELANY, Paul. Hypertext, Hypermedia and Literary Studies: The State of the Art. Boston, Hypermedia and Literary Studies, MIT, 1991.

LAUREL, Brenda. Computers as Theatre. New York: Addison-Wesley, 1993.

LAUREL, Brenda (Org.). The Art of Human Computer Interface Design. Addison Wesley, 1990.

LEAL, Fred. 3D na TV a cabo. Estadao.com.br, 18 de fevereiro de 2010, Caderno Link. Disponível em: <http://blogs.estadao.com.br/link/3d-na-tv-a-cabo/>. Acesso em: 18/05/2010.

LEMOS, André. Anjos interativos e retribalização do mundo. Sobre interatividade e interfaces digitais, 1997.

Disponível em: <http://www.facom.ufba.br/ciberpesquisa/lemos/interativo.pdf>. Acesso em:

22/12/2010.

LEONHARD, Gerd. Social Media and the Future of Football. Media Futurist.com, 12/03/2010. Disponível em: <http://www.mediafuturist.com/2010/03/social-media-and-thefuture-of-football-slideshow.html >. Acesso em: 15/01/2011.

LÉVY, Pierre. The Art and Architecture of Cyberspace, Collective Intelligence. New York: Plenum, 1997.

LU, Karyn Y. Interaction Design Principles For Interactive Television. Dissertação (Mestrado) - Georgia Institute of Technology, 2005.

LYONS, Margaret.Videogames vs. Movies:A leader emerges...and we applaud!?Entertainment Weekly, 21/5/2009. Disponível em:

<http://popwatch.ew.com/2009/05/21/more-people-pla/>. Acesso em: 20 nov. 2010.

MACHADO, Arlindo. (Org.). Made in Brasil: três décadas do vídeo brasileiro. São Paulo: Itaú Cultural, 2003.

MAEDA, John. Design by numbers. Cambridge: MIT Press, 1999.

MAEDA, John. Laws of Simplicity. Cambridge: MIT Press, 2006.

MANLY, Lorne.The Future of the 30-Second Spot. New York Times Magazine, 27/3/2005.

MARTIN, Sylvia. Video Art. Colonia: Taschen, 2006.

MATOS, Valter. Usabilidade na Web e usabilidade na Televisão Interactiva. Dissertação 
(Mestrado) - Universidade Lusófona de Humanidade e Tecnologia, Porto, 2005.

McLUHAN, Marshall. Understanding Media: The Extensions of Man. New York: McGrawHill, 1964 (reedição MIT Press, 1994).

McSTAY, Daniel. Challenges of Contemporary Cinematography.Dissertação (Mestrado)University of Westminster, 2009.

MING, Celso. O mercado de TVs e a Copa. O Estado de S. Paulo, 12 de junho de 2010, Caderno de Economia.

MITCHELL, William J. City of Bits: Space, Place and the Infobahn. Cambridge: MIT Press, 1995.

MOGGRIDGE, Bill. Designing Interactions. Cambridge: MIT Press, 2007.

MONTEZ, Carlos; BECKER, Valdecir. TV Digital Interativa: conceitos e tecnologias. In: WEBMIDIA E LA-WEB 2004 - Joint Conference. Ribeirão Preto, SP, outubro de 2004.

MONTEZ, Carlos; BECKER, Valdecir. TV Digital Interativa: conceitos, desafios e perspectivas para o Brasil. Florianópolis: Ed. da UFSC, 2005.

MOREIRA, A. M.; CASTRO, I. C. A. Metodologias de Desenvolvimento: Um Comparativo entre Extreme Programming e Rational Unified Process. CienteFico, Faculdade Rui Barbosa, v. I, 2007.

MORRIS, Steven; SMITH-CHAIGNEAU, Anthony. Interactive TV Standards: A Guide to Mhp, Ocap, and JavaTV. London: Focal Press, 2005.

MURRAY, Janet. Hamlet on the Holodeck: The Future of Narrative in Cyberspace.

Cambridge: MIT Press, 1997.

NEGRI, Antonio; HARDT, Michael. Empire. Cambridge: Harvard University Press, 2000.

NEGROPONTE, Nicholas. HDTV:What's wrong with this picture.Wired, Premiere Issue, $\mathrm{p}$. $112,1993$.

NELSON, Ted. Computer Lib. 1976 (Edição independente do autor).

NELSON, Ted. Literary Machines. Califórnia: Mindful Press, 1981.

NELSON, Theodor. The Right Way to Think About Software Design In: LAUREL, Brenda (Org.). The Art of Human Computer Interface Design. Addison Wesley, 1990.

NIELSEN, Jakob. Heuristic evaluation. In: NIELSEN, J.; MACK, R.L. (Eds.). Usability Inspection Methods. New York: John Wiley \& Sons, 1994.

NIELSEN, Jakob. Projetando Websites. Rio de Janeiro: Elsevier, 2000.

NIELSEN, Jakob. Remote Control Anarchy, Jakob Nielsen’s Alertbox, June 7, 2004. 
Disponível em: <http://www.useit.com/alertbox/20040607.html>.

NIELSEN, J.; MOLICH, R. Heuristic evaluation of user interfaces. Proc. ACM CHI'90 Conf. (Seattle, WA, 1-5 April), p. 249-256, 1990.

NOLL, A. Michael. Introduction to telecommunication electronics. Massachussets: Artech House, 1988.

NORMAN, Donald A. The Design of Everyday Things. London: The MIT Press, 2000. (original: NORMAN, Donald A. The Psychology of Everyday Things. New York: Basic Books, 1988)

NORMAN, Donald A. The Perils of Home Theater. Artigo. Jnd.org, 2001. Disponível em: $<$ http://www.jnd.org/dn.mss/the_perils_of_h.html>. Acesso em 20/02/2011

NORMAN, Donald A. Emotional design: why we love (or hate) everyday things. Basic Books, 2004.

NORMAN, Donald A. Natural User Interfaces are Not Natural. Interactions, v. XVII. p. 6, May/Jun 2010.

NORMAN, Don; NIELSEN, Jakob. Gestural Interfaces: A Step Back in Usability. Interactions, ACM, v. XVII, n. 5, Sept.-Oct. 2010.

NOVAK, Marcos. Liquid Architectures for Cyberspace. In: BENEDIKT, Michael.

Cyberspace: First Steps. Cambridge: MIT Press, 1991.

NUNES, Pedro (Org.). Mídias Digitais \& interatividade. João Pessoa, Editora Universitária da UFPB, 2009.

ODLYZKO, Andrew.Long live the Internet. Infografia, Revista Wired, set. 2010.

OLIVEIRA, Bruno Dias de; BARBOSA, Hildegard Paulino; SILVA, Julio César Ferreira; TAVARES, Tatiana Aires. Uma casa no controle da TV: Desenvolvimento de um Programa para TV Digital para Controle de Dispositivos Domésticos. Artigo apresentado no Interaction '09 I South America (IXDSA), 2009.

OLIVEIRA, Cícero Carlos de; CARVALHO, Lincoln Almendra; JÚNIOR, Rufino da Silva Ribeiro. Tv Digital: Panorama Internacional e Perspectivas para o Brasil. Monografia - UNB, Brasília, 2006 (orientador: Prof. Jacir Bordim).

Disponível em: <http://www.cic.unb.br/ bordim/TD/Arquivos/G01_Monografia.pdf >. Acesso em: 04/04/2010.

PACKER, Randall; JORDAN, Ken (Eds.). Multimedia: From Wagner to Virtual Reality. Norton, 2002.

PAPERT, Seymour. Mindstorms: Children, Computers, and Powerful Ideas. New York: Basic Books, 1980.

PAVONI JUNIOR, Gilberto. 2014: a Copa multiplataforma. IT Web, 18/08/2009. Disponível em: <http://www.itweb.com.br/noticias/index.asp?cod=60132>. Acesso em: 15/01/2011. 
PECK, Evan; CHAUNCEY, Krysta ; GIROUARD, Audrey; GULOTTA, Rebecca; LALOOSES, Francine ; TREACY, Erin Solovey; WEAVER, Doug; JACOB, Robert. From brains to bytes. Journal, XRDS: Crossroads, The ACM Magazine for Students, The Future of Interaction, Vol 16 Issue 4, Summer 2010, New York, ACM, 2010.

PEREIRA, Lívia Cirne de Azevedo; BEZERRA, Ed. Pôrto. Televisão digital: do Japão ao Brasil. Culturas Midiáticas, UFPB, ano I, n. 1, jul./dez. 2008.

PINHEIRO, Mauro. Do design de Interface ao design da experiência. Revista Design em Foco, Salvador, v. IV, n. 2, jun.-dez.2007.

PREECE, Jennifer; ROGERS, Yvonne; SHARP, Helen. Design de Interação: além da interação homem-computador. Porto Alegre: Bookman, 2005.

PRIMO, ALEX. Interação mediada por computador. Porto Alegre, Sulina, 2008.

ROYO, Javier. Design Digital. São Paulo: Rosari, 2008.

SCHLITTLER-SILVA, J. P. A. O designer e a TV no Brasil: anos 1970 e anos 1980. In: CONGRESSO INTERNACIONAL DO DESIGN DA INFORMAÇÃO, 4.,2009. Rio de Janeiro. Pesquisa cientifíca em design da informação, p. 523-528.

SHNEIDERMAN, Ben. Direct manipulation: a step beyond programming languages. IEEE Computer, 16(8), p. 57-69, August 1983.

SILVA, Sivaldo Pereira da. TV Digital, democracia e interatividade. In: NUNES, Pedro (Org.), Mídias Digitais \& interatividade. João Pessoa: Editora Universitária da UFPB, 2009.

SIQUEIRA, Ethevaldo. Curtindo a Copa numa super TV. Blog de Ethevaldo Siqueira, 14 de junho de 2010. Disponível em: <http://www .ethevaldo.com.br/Generic.aspx?pid=2735>. Acesso em: 23/08/10.

SOARES, Luiz Fernando G.; BARBOSA, Simone D. J. Programando em NCL 3.0: desenvolvimento de aplicações para o middleware Ginga. Rio de Janeiro: Campus, 2009.

SONG, Jian. The Latest Development of Chinese Terrestrial DTV Standard. DTMB DTV Technology R\&D Center, Tsinghua University.

Disponível em: <http://www.modibec.org/download/Events/2008/CHNE/Day\%202-D42\%20Song\%20Jian-DTMB_Latest_Development20081027.pdf>. Acesso em: 10/01/2010.

SOUZA, Engo Anivaldo Matias; DANTAS, Marcos; TEIXEIRA, Miguel. Cartilha da TV Digital. Minas Gerais, CREA-SENGE, 2007.

SWEDLOW, Tracy. Boxee Launches New Version Of Its Mlb.Tv Application: Interactive Television Today, 2010. Disponível em:<http://www.itvt.com/story/6614/boxee-launchesnew-version-its-mlbtv-application>. Acesso em: 10 mar. 2010.

TAN, Desney; MORRIS, Dan; SAPONAS, T.Scott. Interfaces on the Go. Journal, XRDS: Crossroads, The ACM Magazine for Students, The Future of Interaction, Vol 16 Issue 4, Summer 2010, New York, ACM, 2010. 
TEIXEIRA, Lauro Henrique de Paiva. Televisão digital: interação e usabilidade.

Dissertação (Mestado) - Faculdade de Arquitetura, Artes e Comunicação,Universidade

Estadual Paulista, Bauru, 2008 (Orientadora: Ana Sílvia Lopes Davi Médola).

TWENEY, Dylan F. Apple Takes Aim at Cable With Tiny New Apple TV. Wired Magazine, September 2010.

VARNELIS, Kazys. Networked Publics. Cambridge: MIT Press, 2008.

VATAVU, Radu-Daniel; PENTIUC, Stefan-Gheorghe; CHAILLOU, Christophe. On Natural Gestures for Interacting in Virtual Environments, Advances in Electrical and Computer Engineering, Suceava, Romania, volume 5 (12), n. 2/2005, p. 72-79, ISSN 1582-7445.

WAISMAN, Thais. Usabilidade em serviços educacionais em ambiente de TV Digital. Tese (Doutorado)- Escola de Comunicações e Artes, Universidade de São Paulo, 2006.(Orientador: Prof. Dr. Fredric Michael Litto)

WALLIS. The Multitasking Generation. Revista Time, 19/3/2006. Disponível em: <http://www.time.com/time/magazine/article/0,9171,1174696,00.html>. Acesso em: $11 / 12 / 2010$.

WARDRIP-FRUIN, Nick; MONTFORT, Noah (Eds.). The New Media Reader. Cambridge: MIT Press, 2003.

WEINMAN, Lynda. Designing Web Graphics 3. New Riders, 2000.

WILSON, Carol. Does interactive TV need a new interface? Telephony Online. March 2009. Disponível em: <http://telephonyonline.com/residential_services/news/interactive-tv-userinterface-0330/index.html $>$. Acesso em 22/02/2011

YOUNGBLOOD, Gene. Expanded Cinema. Introd. R. Buckminster Fuller. New York: Dutton, 1970.

ZIMERMANN, Filipe. Canal de Retorno em TV Digital -Técnicas e abordagens para a efetivação da interatividade televisiva. Monografia -Departamento de Informática e Estatística, Universidade Federal de Santa Catarina (UFSC), Florianópolis, 2007 (orientador: Mario Antonio Ribeiro).

ZUFFO, Marcelo K. A Convergência da realidade virtual e internet avançada em novos paradigmas de TV Digital Interativa. Tese (Livre-Docência) - Escola Politécnica da Universidade de São Paulo, 2001. 


\section{Links}

Apple - iOS Reference Library

http://developer.apple.com/library/ios/navigation/

b4dtv - Blog for digital TV

http://b4dtv.blogspot.com/2009/01/ferramentas-de-acessibilidade-para-tv.html

Broadband Bananas

http://www.broadbandbananas.com/

Connected TV

http://www.connectedtv.eu/

DTV - Site Oficial da TV Digital Brasileira

http://dtv.org.br/

Especificações técnicas do padrão ISDB-TB - Wikipedia

http://pt.wikipedia.org/wiki/Televisão_digital_no_Brasil

Fórum SBTVD

http://www.forumsbtvd.org.br/

Ginga - Portal do Software Público Brasileiro

http://www.softwarepublico.gov.br/ver-comunidade?community_id=1101545

Ginga - Digital TV Middleware Specification

http://www.ginga.org.br

Google TV

http://www.google.com/tv/

Grupo de Pesquisa da TV Digital Interativa (GPTVDi)

Universidade Católica de Pelotas

www.tvdi.inf.br

Interactive TV Today - Tracy Swedlow

http://www.itvt.com/

International Telecommunications Union (ITU) - IPTV Focus Group (FG IPTV)

http://www.itu.int/ITU-T/IPTV/

iPhone SDK

xcode_3.2.2_and_iphone_sdk_3.2_final.dmg

http://developer.apple.com/library/ios/navigation/

Laboratório Telemídia - PUC - RIO

http://www.telemidia.puc-rio.br/pt/index.html 
MIT Media Lab

http://www.media.mit.edu/

MIT Technology Review

http://www.technologyreview.com/communications/25084/?a=f

Revista New Scientist

http://www.newscientist.com

Telephony Online

http://telephonyonline.com

TVDI - Interatividade e Usabilidade para TV Digital (www.tvdi.inf.br)

http://groups.google.com/group/tvinterativa/

TV Digital Interativa - por Regis Alvim Junot

http://www.via.multimidia.nom.br/tvdi.htm

TV Digital - Social

http://tvdigitalsocial.blogspot.com/

Valdecir Becker - iMasters UOL

http://imasters.uol.com.br/artigo/14324/tvdigital/programando_em_ncl_30/

Acesso em: 19/11/2009

Yahoo! Connected TV

http://connectedtv.yahoo.com 